\title{
MINERAL COMMODITY SUMMARIES 2021
}

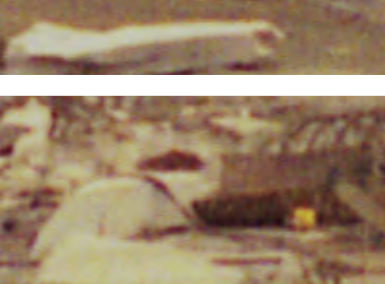

Abrasives

Aluminum

Antimony

Arsenic

Asbestos

Barite

Bauxite

Beryllium

Bismuth

Boron

Bromine

Cadmium

Cement

Cesium

Chromium

Clays

Cobalt

Copper

Diamond

Diatomite

Feldspar
Fluorspar

Gallitum

Garnet

Gemstones

Germanium

Gold

Graphite

Gypsum

Hafnium

Helium

Indium

lodine

Iron and Steel

Iron Ore

Iron Oxide Pigments

Kyanite

Lead

Lime

Lithium

Magnesium

Manganese

$x^{-14}$
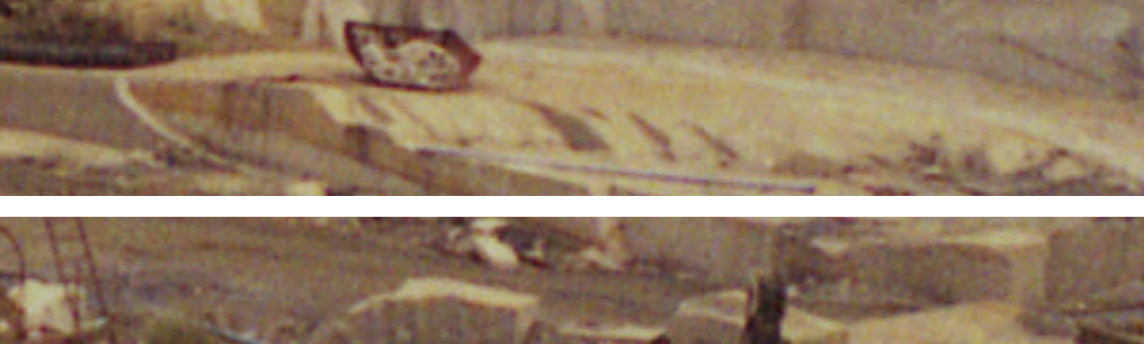

$x^{2}$
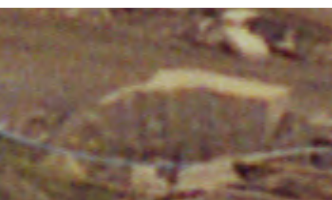

Mercury

Mica

Molybdenum

Nickel

Niobium

Nitrogen

Palladium

Peat

Perlite

Phosphate Rock

Platinum

Potash

Pumice

Quartz Crystal

Rare Earths

Rhenium

Rubidium

Salt

Sand and Gravel

Scandium

Selenium s.t.

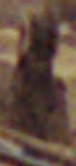

\section{Stilicon}

Silver

Soda Ash

Stone

Strontium

Sulfur

Talc

Tantalum

Tellurium

Thallium

Thorium

Tin

Iitanium

Tungsten

Vánadium

Vermiculite

Wollastonite

Yttrium

Zeolites

Zinc

Zirconium

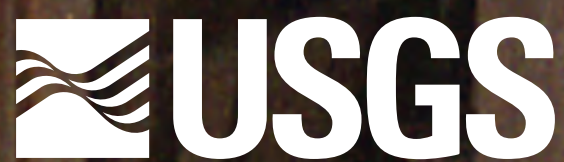


Cover: Photograph of Fletcher Granite Co.'s Chelmsford Grey Quarry in Westford, MA, taken in about 2000. This quarry has been in continual operation since $\mathbf{1 8 8 1}$ and is the source of the company's Chelmsford Grey product. Over the years, granite from this quarry has been used in numerous building and civil engineering projects. According to the company, Chelmsford Grey granite was used for the Thurgood Marshall Federal Judiciary Building and the National Cathedral, both in Washington, DC. Photograph by Thomas P. Dolley, U.S. Geological Survey. 


\section{MINERAL COMMODITY SUMMARIES 2021}

$\begin{array}{llll}\text { Abrasives } & \text { Fluorspar } & \text { Mercury } & \text { Silicon } \\ \text { Aluminum } & \text { Gallium } & \text { Mica } & \text { Silver } \\ \text { Antimony } & \text { Garnet } & \text { Molybdenum } & \text { Soda Ash } \\ \text { Arsenic } & \text { Gemstones } & \text { Nickel } & \text { Stone } \\ \text { Asbestos } & \text { Germanium } & \text { Niobium } & \text { Strontium } \\ \text { Barite } & \text { Gold } & \text { Nitrogen } & \text { Sulfur } \\ \text { Bauxite } & \text { Graphite } & \text { Palladium } & \text { Talc } \\ \text { Beryllium } & \text { Gypsum } & \text { Peat } & \text { Tantalum } \\ \text { Bismuth } & \text { Hafnium } & \text { Perlite } & \text { Tellurium } \\ \text { Boron } & \text { Helium } & \text { Phosphate Rock } & \text { Thallium } \\ \text { Bromine } & \text { Indium } & \text { Platinum } & \text { Thorium } \\ \text { Cadmium } & \text { Iodine } & \text { Potash } & \text { Tin } \\ \text { Cement } & \text { Iron and Steel } & \text { Pumice } & \text { Titanium } \\ \text { Cesium } & \text { Iron Ore } & \text { Quartz Crystal } & \text { Tungsten } \\ \text { Chromium } & \text { Iron Oxide Pigments } & \text { Rare Earths } & \text { Vanadium } \\ \text { Clays } & \text { Kyanite } & \text { Rhenium } & \text { Vermiculite } \\ \text { Cobalt } & \text { Lead } & \text { Rubidium } & \text { Wollastonite } \\ \text { Copper } & \text { Lime } & \text { Salt } & \text { Yttrium } \\ \text { Diamond } & \text { Lithium } & \text { Sand and Gravel } & \text { Zeolites } \\ \text { Diatomite } & \text { Magnesium } & \text { Scandium } & \text { Zinc } \\ \text { Feldspar } & \text { Manganese } & \text { Selenium } & \text { Zirconium }\end{array}$




\section{U.S. Geological Survey, Reston, Virginia: 2021}

Manuscript approved for publication January 29, 2021.

For more information on the USGS - the Federal source for science about the Earth, its natural and living resources, natural hazards, and the environmentvisit https://www.usgs.gov or call 1-888-ASK-USGS.

For an overview of USGS information products, including maps, imagery, and publications, visit https://store.usgs.gov/.

For sale by the Superintendent of Documents, U.S. Government Publishing Office

P.0. Box 979050, St. Louis, MO 63197-9000

Phone: (866) 512-1800 (toll-free); (202) 512-1800 (Washington, DC, area)

Fax: (202) 512-2104

Internet: https://bookstore.gpo.gov

Email: ContactCenter@gpo.gov

Any use of trade, product, or firm names is for descriptive purposes only and does not imply endorsement by the U.S. Government.

Although this report is in the public domain, permission must be secured from the individual copyright owners to reproduce any copyrighted material contained within this report.

\section{Suggested citation:}

U.S. Geological Survey, 2021, Mineral commodity summaries 2021: U.S. Geological Survey, 200 p., https://doi.org/10.3133/mcs2021.

ISBN 978-1-4113-4398-6 
CONTENTS

\section{General:}

Introduction

Figure 1-The Role of Nonfuel Minerals in the U.S Economy.

Significant Events, Trends, and Issues.

Figure 2-2020 U.S. Net Import Reliance

Figure 3-Major Import Sources of Nonfuel Mineral Commodities in 2020

Table 1-U.S. Mineral Industry Trends

Table 2-U.S. Mineral-Related Economic Trends .......... 9

Table 3-Value of Nonfuel Mineral Production in the United States in 2020

Figure 4-Value of Nonfuel Minerals Produced in 2020, by State

.. 10

\section{Mineral Commodities:}

Abrasives (Manufactured) ........................................ 18

Aluminum .......................................................... 20

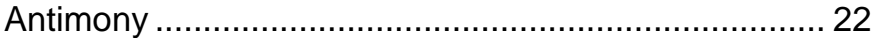

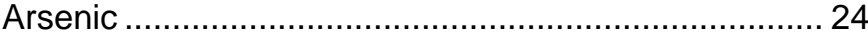

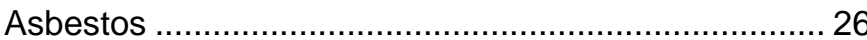

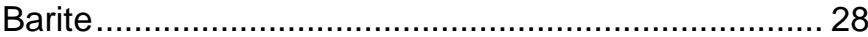

Bauxite and Alumina ................................................ 30

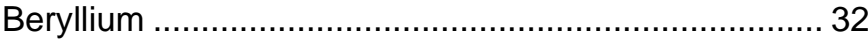

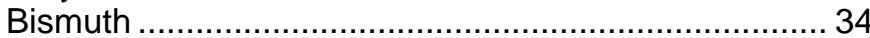

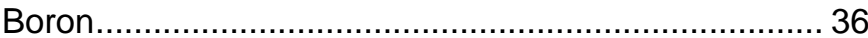

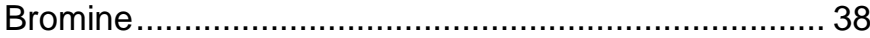

Cadmium ......................................................... 40

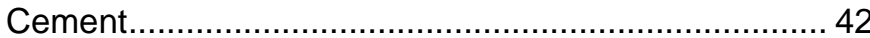

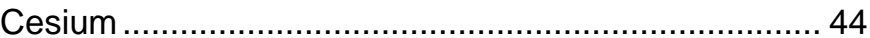

Chromium..................................................... 46

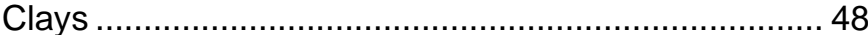

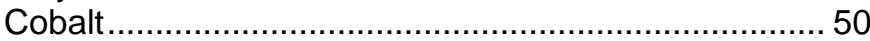

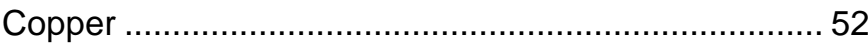

Diamond (Industrial) ............................................... 54

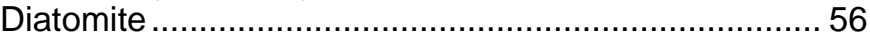

Feldspar and Nepheline Syenite.................................... 58

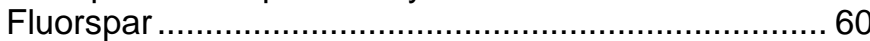

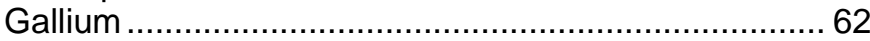

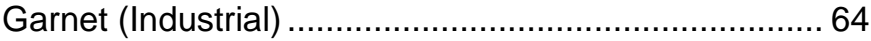

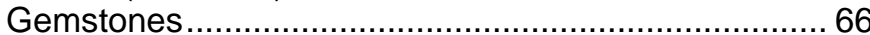

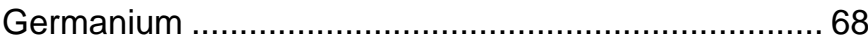

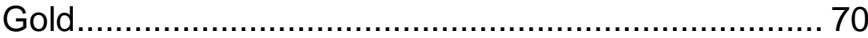

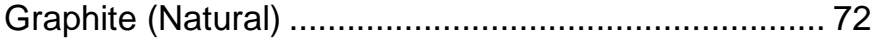

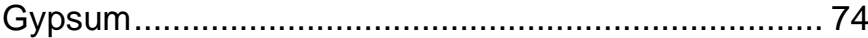

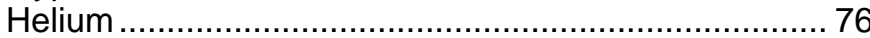

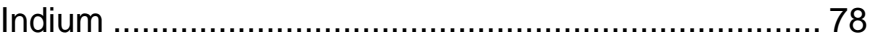

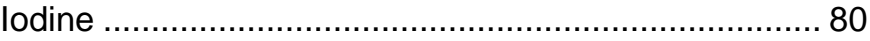

Iron and Steel.................................................. 82

Iron and Steel Scrap ................................................ 84

Iron and Steel Slag ................................................... 86

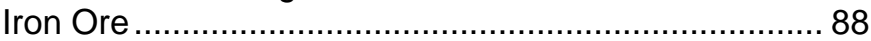

Iron Oxide Pigments .............................................. 90

Kyanite and Related Minerals ....................................... 92

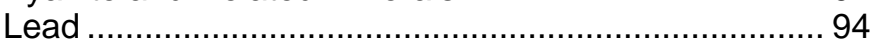

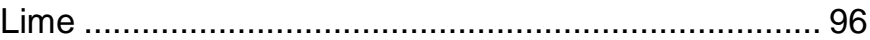

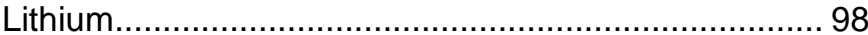

Magnesium Compounds ........................................... 100

Magnesium Metal.................................................... 102

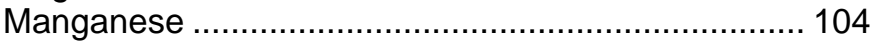

Figure 5-Value of Metals and Metallic Minerals

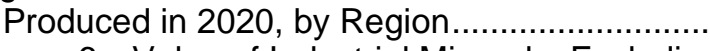

Figure 6-Value of Industrial Minerals, Excluding Natural Aggregates, Produced in 2020, by Region .. 14

Figure 7-Value of Crushed Stone Produced in 2020, by State.

Figure 8-Value of Construction Sand and Gravel Produced in 2020, by State....................................16

Appendix A-Abbreviations and Units of Measure ....194 Appendix B-Definitions of Selected Terms Used in This Report......................................................... 194 Appendix C-Reserves and Resources....................195 Appendix D—Country Specialists Directory ...............199

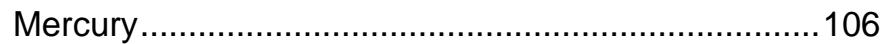

Mica (Natural) ……......................................... 108

Molybdenum ……................................................ 110

Nickel ................................................................... 112

Niobium (Columbium) ................................................ 114

Nitrogen (Fixed)_Ammonia .....................................116

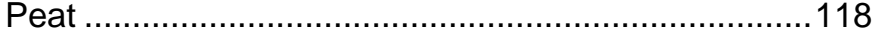

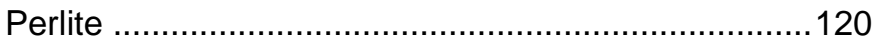

Phosphate Rock ..................................................122

Platinum-Group Metals.............................................124

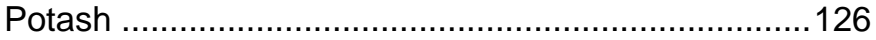

Pumice and Pumicite.................................................128

Quartz Crystal (Industrial) ..................................... 130

Rare Earths ........................................................... 132

Rhenium ...................................................... 134

Rubidium ................................................... 136

Salt .................................................................... 138

Sand and Gravel (Construction) ...............................140

Sand and Gravel (Industrial) ...................................142

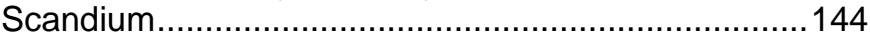

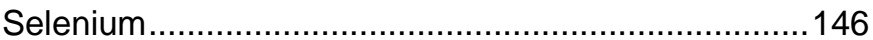

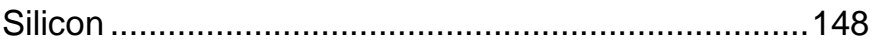

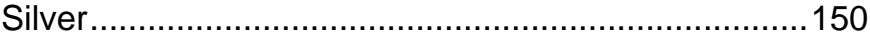

Soda Ash ..................................................... 152

Stone (Crushed) …............................................ 154

Stone (Dimension) .................................................... 156

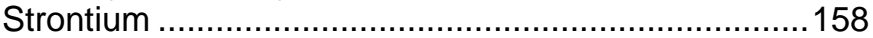

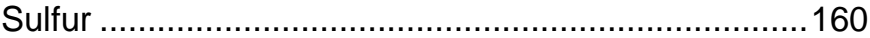

Talc and Pyrophyllite ............................................... 162

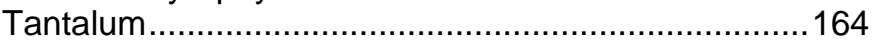

Tellurium .............................................................. 166

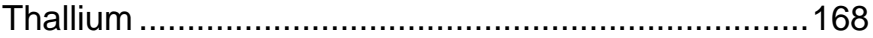

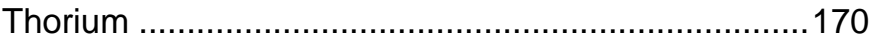

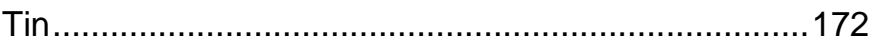

Titanium and Titanium Dioxide ..................................174

Titanium Mineral Concentrates ................................176

Tungsten........................................................ 178

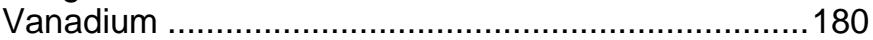

Vermiculite ....................................................... 182

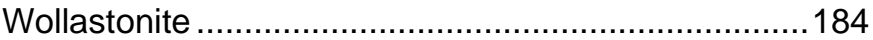

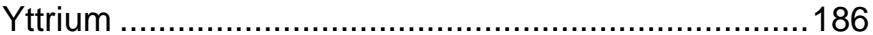

Zeolites (Natural) .................................................188

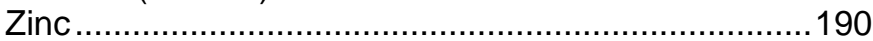

Zirconium and Hafnium ..........................................192 


\section{INSTANT INFORMATION}

Information about the U.S. Geological Survey, its programs, staff, and products is available from the internet at https://www.usgs.gov or by calling (888) ASK-USGS [(888) 275-8747].

This publication has been prepared by the National Minerals Information Center. Information about the Center and its products is available from the internet at https://www.usgs.gov/centers/nmic or by writing to Director, National Minerals Information Center, 988 National Center, Reston, VA 20192.

\section{KEY PUBLICATIONS}

Minerals Yearbook-These annual publications review the mineral industries of the United States and of more than 180 other countries. They contain statistical data on minerals and materials and include information on economic and technical trends and developments and are available at https://www.usgs.gov/centers/nmic/publications. The three volumes that make up the Minerals Yearbook are volume I, Metals and Minerals; volume II, Area Reports-Domestic; and volume III, Area Reports-International.

Mineral Commodity Summaries-Published on an annual basis, this report is the earliest Government publication to furnish estimates covering nonfuel mineral industry data and is available at https://www.usgs.gov/centers/nmic/mineral-commodity-summaries. Data sheets contain information on the domestic industry structure, Government programs, tariffs, and 5-year salient statistics for more than 90 individual minerals and materials.

Mineral Industry Surveys-These periodic statistical and economic reports are designed to provide timely statistical data on production, shipments, stocks, and consumption of significant mineral commodities and are available at https://www.usgs.gov/centers/nmic/mineral-industry-surveys. The surveys are issued monthly, quarterly, or at other regular intervals.

Materials Flow Studies-These publications describe the flow of minerals and materials from extraction to ultimate disposition to help better understand the economy, manage the use of natural resources, and protect the environment and are available at https://www.usgs.gov/centers/nmic/materials-flow.

Recycling Reports-These studies illustrate the recycling of metal commodities and identify recycling trends and are available at https://www.usgs.gov/centers/nmic/recycling-statistics-and-information.

Historical Statistics for Mineral and Material Commodities in the United States (Data Series 140)_This report provides a compilation of statistics on production, trade, and use of approximately 90 mineral commodities since as far back as 1900 and is available at https://www.usgs.gov/centers/nmic/historical-statistics-mineral-and-materialcommodities-united-states.

\section{WHERE TO OBTAIN PUBLICATIONS}

- Mineral Commodity Summaries and the Minerals Yearbook are sold by the U.S. Government Publishing Office. Orders are accepted over the internet at https://bookstore.gpo.gov, by email at ContactCenter@gpo.gov, by telephone toll free (866) 512-1800; Washington, DC, area (202) 512-1800, by fax (202) 512-2104, or through the mail (P.O. Box 979050, St. Louis, MO 63197-9000).

- All current and many past publications are available as downloadable Portable Document Format (PDF) files through https://www.usgs.gov/centers/nmic. 


\section{INTRODUCTION}

Each mineral commodity chapter of the 2021 edition of the U.S. Geological Survey (USGS) Mineral Commodity Summaries (MCS) includes information on events, trends, and issues for each mineral commodity as well as discussions and tabular presentations on domestic industry structure, Government programs, tariffs, 5-year salient statistics, and world production and resources. The MCS is the earliest comprehensive source of 2020 mineral production data for the world. More than 90 individual minerals and materials are covered by 2-page synopses.

For mineral commodities for which there is a Government stockpile, detailed information concerning the stockpile status is included in the 2-page synopsis.

Abbreviations and units of measure and definitions of selected terms used in the report are in Appendix $A$ and Appendix B, respectively. Reserves and resources information is in Appendix C, which includes "Part A-Resource and Reserve Classification for Minerals" and "Part B-Sources of Reserves Data." A directory of USGS minerals information country specialists and their responsibilities is in Appendix D.

The USGS continually strives to improve the value of its publications to users. Constructive comments and suggestions by readers of the MCS 2021 are welcomed. 
Figure 1.-The Role of Nonfuel Minerals in the U.S. Economy

(Estimated values in 2020)

\section{Net Exports of Mineral \\ Raw Materials \\ Gold, Soda Ash, Zinc \\ concentrates, and so forth \\ Exports: $\quad \$ 8.1$ billion \\ Imports: $\quad \$ 4.1$ billion \\ Net exports: $\$ 4.0$ billion}

\section{Domestic Mineral Raw Materials From Mining \\ Copper ores, Iron Ore, Sand and Gravel, Stone, and so forth \\ Value: $\$ 82.3$ billion}

\section{Metals and Mineral Products Recycled Domestically \\ Aluminum, Glass, Steel, and so forth \\ Value of old scrap: $\$ 28.0$ billion}

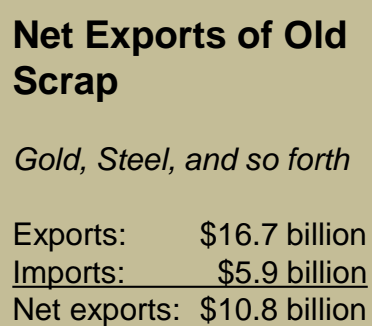

\section{Mineral Materials}

Processed Domestically

Aluminum, Brick, Cement,

Copper, Fertilizers, Steel, and

so forth

Value of shipments:

$\$ 710$ billion

\section{Net Imports of \\ Processed Mineral \\ Materials \\ Imports: $\quad \$ 177$ billion \\ Exports: $\quad \$ 79$ billion \\ Net imports: $\$ 98$ billion}

Metals, Chemicals, and so forth

\section{U.S. Economy}

Gross Domestic Product: $\$ 20,933$ billion

Sources: U.S. Geological Survey and the U.S. Department of Commerce.

${ }^{1}$ Major consuming industries of processed mineral materials are construction, durable goods manufacturers, and some nondurable goods manufacturers. The value of shipments for processed mineral materials cannot be directly related to gross domestic product. 


\section{SIGNIFICANT EVENTS, TRENDS, AND ISSUES}

In 2020, the estimated total value of nonfuel mineral production in the United States was $\$ 82.3$ billion, a decrease of $2 \%$ from the revised total of $\$ 83.7$ billion in 2019. The estimated value of metals production increased by $3 \%$ to $\$ 27.7$ billion. Increased prices for precious metals, such as gold, which reached a record-high price of $\$ 2,060$ per troy ounce in August, contributed to the increased value of metal production. The total value of industrial minerals production was $\$ 54.6$ billion, a $4 \%$ decrease from that of 2019 . Of this total, $\$ 27.0$ billion was construction aggregates production (construction sand and gravel and crushed stone). Crushed stone was the leading nonfuel mineral commodity in 2020 with a production value of $\$ 17.8$ billion and accounted for $22 \%$ of the total value of U.S. nonfuel mineral production.

Decreases in consumption of nonfuel mineral commodities in commercial construction, oil and gas production, steel production, and automotive and transportation industry were attributed to the financial impacts of the global COVID-19 pandemic. For the metals sector, the aluminum, iron ore, steel, and titanium industries were particularly affected by reduced demand from manufacturing. For the industrial minerals sector, the largest decreases in production were in barite and industrial sand and gravel, commodities that are closely tied to the performance of the natural gas and oil welldrilling industry. In general, mines were not subject to COVID-19-related stay-at-home orders because they were deemed critical industries, but decreased demand from downstream industries resulted in reduced production at some operations.

In 2020, additional import duties were put in place for certain products that were derivatives of aluminum and steel articles, and the additional duties continued for most countries as a result of the U.S. Department of Commerce findings in 2018 of harm to national security under section 232 of the Trade Expansion Act of 1962 (19 U.S.C. §1862, as amended). As of December 2020, aluminum and derivative product imports from all countries except Argentina, Australia, Canada, and Mexico remained subject to a $10 \%$ ad valorem tariff, and steel and derivative product imports from all countries except Argentina, Australia, Brazil, Canada, the Republic of Korea, and Mexico remained subject to a $25 \%$ ad valorem tariff.

Under section 301(b) of the Trade Act of 1974 (19 U.S.C. §2411, as amended), in August 2020, the Office of the United States Trade Representative (USTR) published additional ad valorem duty rates on approximately $\$ 7.5$ billion of imported items from specified European countries related to the Large Civil Aircraft dispute (85 FR 50866). In November, the European Union imposed additional duties on approximately $\$ 4$ billion of imports from the United States. Most of the listed items were aircraft, agricultural items and spirits.

The additional $25 \%$ ad valorem duty for products imported from China (Lists 1, 2, and 3) and the 7.5\% ad valorem duty for products imported from China (List 4) imposed under section 301(b) of the Trade Act of 1974, (19 U.S.C. $\$ 2411$, as amended) by the USTR continued in 2020. Likewise, China imposed additional import duties for certain items originating in the United States. The United States imposed an additional tariff on approximately $\$ 309$ billion of imports from China. China imposed additional tariffs on approximately $\$ 77$ billion of imports from the United States.

Actions to achieve the goals and objectives of Executive Order 13817, "A Federal Strategy to Ensure Secure and Reliable Supplies of Critical Minerals," issued in December 2017, continued in 2020. As outlined in a report issued by the U.S. Department of Commerce, a strategy was developed to reduce the Nation's reliance on critical minerals; an assessment of progress toward developing critical minerals recycling and reprocessing technologies and technological alternatives to critical minerals; options for accessing and developing critical minerals through investment and trade with our allies and partners; a plan to improve the topographic, geologic, and geophysical mapping of the United States and make the resulting data and metadata electronically accessible, to the extent permitted by law and subject to appropriate limitations for purposes of privacy and security, to support private sector mineral exploration of critical minerals; and recommendations to streamline permitting and review processes related to developing leases; enhancing access to critical mineral resources; and increasing discovery, production, and domestic refining of critical minerals.

In February 2020, the U.S. Geological Survey (USGS) published a new methodology to evaluate the global supply of and U.S. demand for 52 mineral commodities for the years 2007 to 2016 . It identified 23 mineral commodities, including aluminum, antimony, bismuth, cobalt, gallium, germanium, indium, niobium, platinumgroup metals, rare-earth elements, tantalum, titanium, and tungsten, as posing the greatest supply risk for the U.S. manufacturing sector (Nassar and others, 2020).

On September 30, 2020, Executive Order 13953, "Addressing the Threat to the Domestic Supply Chain Reliance on Critical Minerals from Foreign Adversaries and Supporting the Domestic Mining and Processing Industries," was issued to address the national emergency described. Several actions by Federal agencies were ordered including tasking the Secretary of the Interior, in consultation with the Secretary of the Treasury, the Secretary of Defense, the Secretary of Commerce, and the heads of other agencies, as appropriate, to investigate the Nation's reliance on critical minerals.

On December 7, 2020, Open-File Report 2020-1127, "Investigation of U.S. Foreign Reliance on Critical Minerals-U.S. Geological Survey Technical Input Document in Response to Executive Order No. 13953 issued September 30, 2020," was published by the USGS. The report identified and categorized the main sources of U.S. mineral commodity imports according to 
existing security of supply agreements with the United States and the U.S. Department of Commerce's list of nonmarket economies; quantified the concentration of import sources; identified net import reliance considerations, trends, and technical options salient for each mineral commodity; highlighted factors that may obscure the true net import reliance; and provided a general framework for evaluating strategies that may help reduce U.S. net import reliance.

On November 17, 2020, the U.S. Department of Defense announced contracts and agreements with rare-earthelement producers under the authorities of title III of the Defense Production Act. These agreements were put in place to support and strengthen the domestic rare earth supply chain in response to the Presidential Determinations, signed on July 22, 2019, pursuant to section 303 of the Defense Production Act of 1950, as amended (50 U.S.C. $\$ 4501$ et seq.).

As shown in figure 1, minerals remained fundamental to the U.S. economy, contributing to the real gross domestic product at several levels, including mining, processing, and manufacturing finished products. The estimated value of nonfuel minerals produced at mines in the United States in 2020 was $\$ 82.3$ billion. The value of net exports of mineral raw materials increased to $\$ 4.0$ billion from $\$ 3.7$ billion in 2019 . Domestically recycled products totaled $\$ 28$ billion, and iron and steel scrap contributed $\$ 9$ billion to that total. Domestic raw materials and domestically recycled materials were used to produce mineral materials worth $\$ 710$ billion. These mineral materials as well as imports of processed mineral materials, which increased by $83 \%$ in 2020 , were, in turn, consumed by downstream industries creating an estimated value of $\$ 3.03$ trillion in 2020 , a $3 \%$ decrease from that in 2019.

Figure 2 illustrates the reliance of the United States on foreign sources for raw and processed mineral materials. In 2020, imports made up more than one-half of the U.S. apparent consumption for 46 nonfuel mineral commodities, and the United States was $100 \%$ net import reliant for 17 of those. Of the 35 minerals or mineral material groups identified as "critical minerals" published in the Federal Register on May 18, 2018 (83 FR 23295), 14 of the 17 mineral commodities with $100 \%$ net import reliance were listed as critical minerals, and 14 additional critical mineral commodities had a net import reliance greater than $50 \%$ of apparent consumption.

Figure 3 shows the countries from which the majority of these mineral commodities were imported and the number of mineral commodities for which each highlighted country was a leading supplier. China, followed by Canada, supplied the largest number of nonfuel mineral commodities.

The estimated value of U.S. metal mine production in 2020 was $\$ 27.7$ billion, 3\% higher than the revised value of 2019 (table 1). Principal contributors to the total value of metal mine production in 2020 were gold $(38 \%)$, copper $(27 \%)$, iron ore (15\%), and zinc $(6 \%)$. The estimated value of U.S. industrial minerals production in 2020, including construction aggregates, was $\$ 54.6$ billion, about $4 \%$ less than the revised value of 2019 (table 1). The value of industrial minerals production in 2020 was dominated by crushed stone, $32 \%$; cement (masonry and portland), $20 \%$; construction sand and gravel, 17\%; and industrial sand and gravel, $6 \%$.

In 2020, U.S. production of 12 mineral commodities was valued at more than $\$ 1$ billion each. These commodities were, in decreasing order of value, crushed stone, gold, cement, construction sand and gravel, copper, iron ore, industrial sand and gravel, salt, lime, phosphate rock, zinc, and soda ash.

In 2020, 12 States each produced more than $\$ 2$ billion worth of nonfuel mineral commodities. These States were, in descending order of production value, Nevada, Arizona, Texas, California, Minnesota, Florida, Alaska, Utah, Missouri, Michigan, Wyoming, and Georgia (table 3, fig. 4).

The Defense Logistics Agency Strategic Materials (DLA Strategic Materials) is responsible for the operational oversight of the National Defense Stockpile (NDS) of strategic and critical materials. Managing the security, environmentally sound stewardship, and ensuring the readiness of all NDS stocks is the mission of DLA Strategic Materials. The NDS currently contains 48 unique commodities stored at 12 locations within the continental United States. In fiscal year 2020,

approximately $\$ 9.2$ million of new stocks were acquired and $\$ 56.85$ million of excess materials were sold.

Revenue from the Stockpile Sales Program fund the operation of the NDS and the acquisition of new stocks. As of September 30,2020, the NDS inventory had a fair market value of $\$ 887.9$ million. For reporting purposes, NDS stocks are categorized as held in reserve or available for sale. The majority of stocks are held in reserve. Additional detailed information can be found in the "Government Stockpile" sections in the mineral commodity chapters that follow. Under the authority of the Defense Production Act of 1950 (Pub. L. 81-774), the USGS advises the DLA Strategic Materials on acquisitions and disposals of NDS mineral materials.

\section{Reference Cited}

Nassar, N.T., Brainard, Jamie, Gulley, Andrew, Manley, Ross, Matos, Grecia, Lederer, Graham, Bird, L.R., Pineault, David, Alonso, Elisa, Gambogi, Joseph, and Fortier, S.M., 2020, Evaluating the mineral commodity supply risk of the U.S. manufacturing sector: Science Advances, v. 6, no. 8, February 21, 11 p. (Accessed January 28, 2021, at https://doi.org/10.1126/ sciadv.aay8647.) 


\section{Figure 2.-2020 U.S. Net Import Reliance ${ }^{1}$}

Commodity

ARSENIC, all forms

ASBESTOS

CESIUM

FLUORSPAR

GALLIUM

GRAPHITE (NATURAL)

INDIUM

MANGANESE

MICA (NATURAL), sheet

NEPHELINE SYENITE

NIOBIUM (COLUMBIUM)

RARE EARTHS, ${ }^{3}$ compounds and metal

RUBIDIUM

SCANDIUM

STRONTIUM

TANTALUM

YTTRIUM

GEMSTONES

VANADIUM

TELLURIUM

BISMUTH

POTASH

TITANIUM MINERAL CONCENTRATES

DIAMOND (INDUSTRIAL), stones

ZINC, refined

ANTIMONY, metal and oxide

SILVER

PLATINUM

STONE (DIMENSION)

COBALT

PEAT

RHENIUM

ABRASIVES, crude fused aluminum oxide

ABRASIVES, crude silicon carbide

BARITE

BAUXITE

IRON OXIDE PIGMENTS, natural and synthetic

CHROMIUM

TIN, refined

MAGNESIUM COMPOUNDS

GOLD

GERMANIUM

IODINE

LITHIUM

TITANIUM, sponge

TUNGSTEN

NICKEL

CADMIUM

MAGNESIUM METAL

SELENIUM

ALUMINA

GARNET (INDUISTRIAL)

DIAMOND (INDUSTRIAL), dust, grit, and powder

PALLADIUM

SILICON, metal and ferrosilicon

COPPER, refined

MICA (NATURAL), scrap and flake

PERLITE

SALT

BROMINE

ZIRCONIUM, ores and concentrates

LEAD, refined

VERMICULITE

\section{Percent}

$$
100
$$

100

100

100

100

$$
100
$$

$$
\begin{aligned}
& 100 \\
& 100 \\
& 100
\end{aligned}
$$
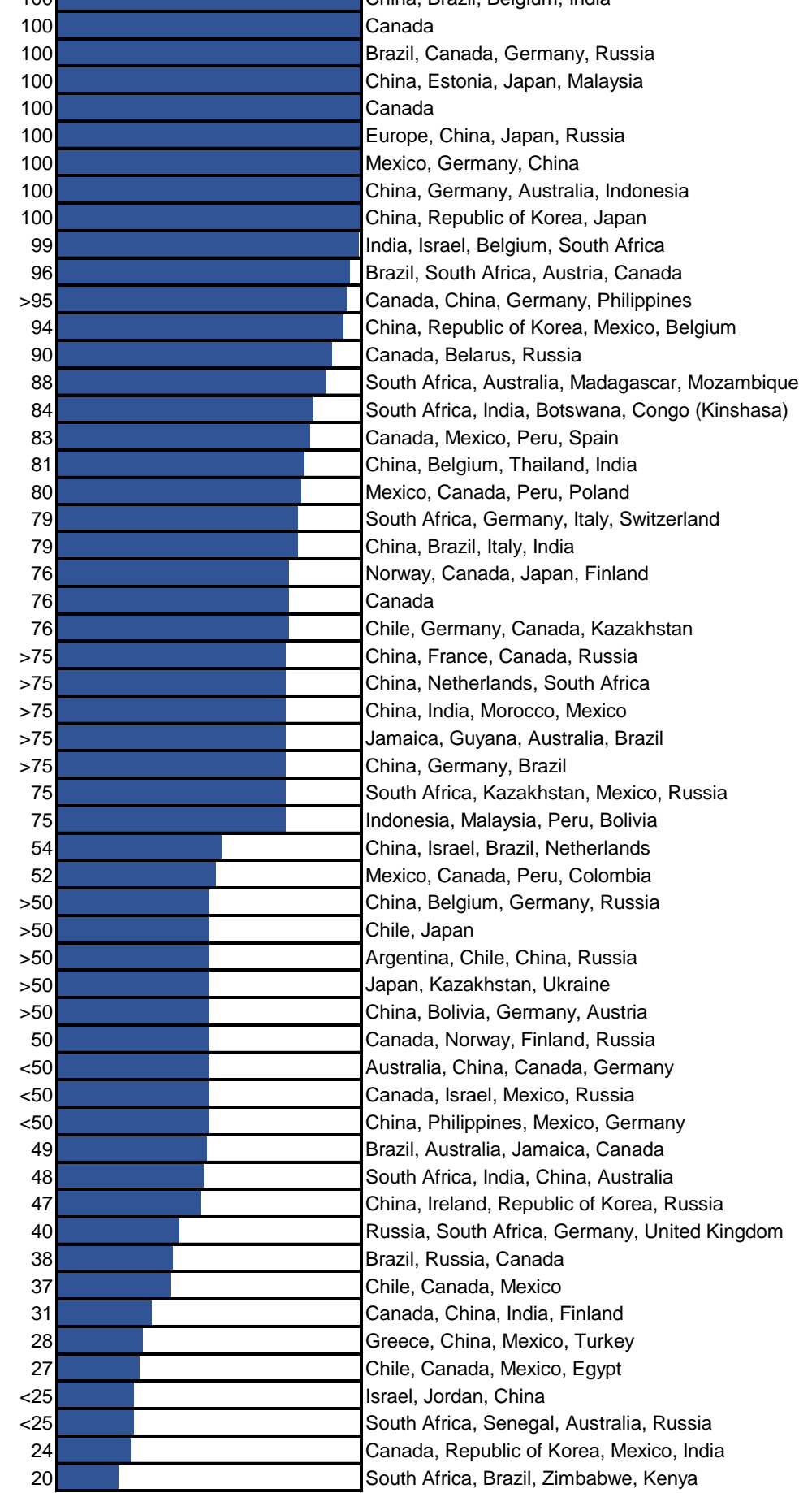

Canad, Japan, Finland

Chile, Germany, Canada, Kazakhstan

China, France, Canada, Russia

China, Netherlands, South Africa

China, India, Morocco, Mexico

Jamaica, Guyana, Australia, Brazil

China, Germany, Brazil

South Africa, Kazakhstan, Mexico, Russia

Indonesia, Malaysia, Peru, Bolivia

China, Israel, Brazil, Netherlands

Mexico, Canada, Peru, Colombia

China, Belgium, Germany, Russia

Chile, Japan

Argentina, Chile, China, Russia

Japan, Kazakhstan, Ukraine

China, Bolivia, Germany, Austria

Canada, Norway, Finland, Russia

Australia, China, Canada, Germany

Canada, Israel, Mexico, Russia

China, Philippines, Mexico, Germany

Brazil, Australia, Jamaica, Canada

South Africa, India, China, Australia

China, Ireland, Republic of Korea, Russia

Russia, South Africa, Germany, United Kingdom

Brazil, Russia, Canada

Chile, Canada, Mexico

Canada, China, India, Finland

Greece, China, Mexico, Turkey

Chile, Canada, Mexico, Egypt

Israel, Jordan, China

South Africa, Senegal, Australia, Russia

Canada, Republic of Korea, Mexico, India

South Africa, Brazil, Zimbabwe, Kenya

${ }^{1}$ Not all mineral commodities covered in this publication are listed here. Those not shown include mineral commodities for which the United States is a net exporter (boron; clays; diatomite; helium; iron and steel scrap; iron ore; kyanite; molybdenum concentrates; sand and gravel, industrial; soda ash; titanium dioxide pigment; wollastonite; zeolites; and zinc concentrates) or less than $20 \%$ net import reliant (abrasives, metallic; aluminum; beryllium; cement; feldspar; gypsum; iron and steel; iron and steel slag; lime; nitrogen (fixed)-ammonia; phosphate rock; pumice; sand and gravel, construction; stone, crushed; sulfur; and talc and pyrophyllite). For some mineral commodities (hafnium; mercury; quartz crystal, industrial; thallium; and thorium), not enough information is available to calculate the exact percentage of import reliance.

${ }^{2}$ Listed in descending order of import share.

${ }^{3}$ Data include lanthanides. 
Figure 3.-Major Import Sources of Nonfuel Mineral Commodities for which the United States was greater than 50\% Net Import Reliant in 2020

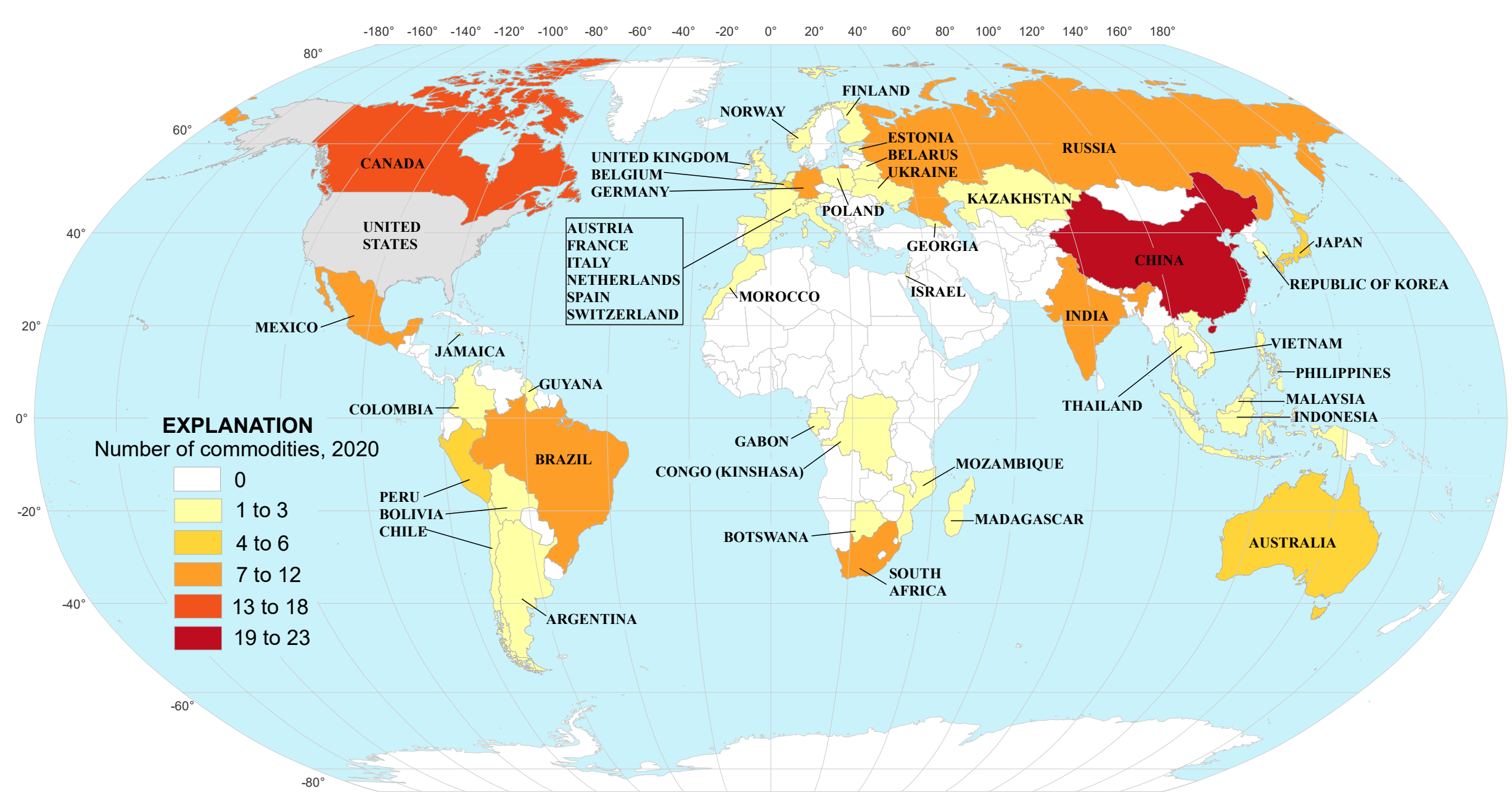

Source: U.S. Geological Survey 
Table 1.-U.S. Mineral Industry Trends

Total mine production (million dollars):

Metals

Industrial minerals

Coal

Employment (thousands of workers):

Coal mining, all employees

Nonfuel mineral mining, all employees

Chemicals and allied products, production workers

Stone, clay, and glass products, production workers

Primary metal industries, production workers

Average weekly earnings of workers (dollars):

Coal mining, all employees

Chemicals and allied products, production workers

Stone, clay, and glass products, production workers

Primary metal industries, production workers

\begin{tabular}{rrrrr}
$\underline{\mathbf{2 0 1 6}}$ & $\underline{\mathbf{2 0 1 7}}$ & $\underline{\mathbf{2 0 1 8}}$ & $\underline{\mathbf{2 0 1 9}}$ & $\underline{\underline{\mathbf{2 0 2 0}}}$ \\
23,700 & 26,800 & 28,200 & 26,900 & 27,700 \\
47,700 & 52,600 & 56,100 & 56,900 & 54,600 \\
22,300 & 26,100 & 27,200 & 25,500 & 18,800 \\
& & & & \\
51 & 52 & 52 & 52 & 46 \\
130 & 134 & 140 & 140 & 136 \\
516 & 525 & 546 & 558 & 533 \\
306 & 305 & 311 & 315 & 301 \\
293 & 292 & 295 & 300 & 268 \\
& & & & \\
1,441 & 1,486 & 1,546 & 1,617 & 1,510 \\
950 & 1,010 & 1,072 & 1,067 & 1,060 \\
851 & 873 & 945 & 968 & 978 \\
1,002 & 995 & 1,036 & 1,025 & 1,010 \\
\hline
\end{tabular}

eEstimated.

Sources: U.S. Geological Survey, U.S. Department of Energy, and U.S. Department of Labor.

Table 2.-U.S. Mineral-Related Economic Trends

\begin{tabular}{|c|c|c|c|c|c|}
\hline Gross domestic product (billion dollars) & $\begin{array}{r}\mathbf{2 0 1 6} \\
18,745\end{array}$ & $\frac{\mathbf{2 0 1 7}}{19,543}$ & $\begin{array}{r}\mathbf{2 0 1 8} \\
20,612\end{array}$ & $\frac{\mathbf{2 0 1 9}}{21,433}$ & $\frac{\mathbf{2 0 2 0 ^ { e }}}{20,933}$ \\
\hline \multicolumn{6}{|l|}{ Industrial production $(2012=100)$ : } \\
\hline Total index: & 102 & 104 & 109 & 109 & 101 \\
\hline Manufacturing: & 101 & 103 & 106 & 106 & 98 \\
\hline Nonmetallic mineral products & 111 & 115 & 120 & 119 & 114 \\
\hline Primary metals: & 93 & 94 & 98 & 97 & 82 \\
\hline Iron and steel & 87 & 92 & 97 & 97 & 80 \\
\hline Aluminum & 106 & 103 & 107 & 107 & 97 \\
\hline Nonferrous metals (except aluminum) & 95 & 91 & 91 & 88 & 75 \\
\hline Chemicals & 95 & 97 & 100 & 101 & 97 \\
\hline Mining: & 103 & 110 & 124 & 133 & 119 \\
\hline Coal & 70 & 75 & 74 & 69 & 52 \\
\hline Oil and gas extraction & 129 & 135 & 156 & 173 & 165 \\
\hline Metals & 100 & 98 & 93 & 93 & 93 \\
\hline Nonmetallic minerals & 114 & 118 & 119 & 123 & 122 \\
\hline \multicolumn{6}{|l|}{ Capacity utilization (percent): } \\
\hline Total industry: & 75 & 76 & 79 & 78 & 72 \\
\hline Mining: & 78 & 84 & 90 & 90 & 81 \\
\hline Metals & 75 & 71 & 69 & 69 & 68 \\
\hline Nonmetallic minerals & 87 & 88 & 88 & 90 & 89 \\
\hline Housing starts (thousands) & 1,177 & 1,207 & 1,248 & 1,295 & 1,370 \\
\hline Light vehicle sales (thousands) & 17,465 & 17,136 & 17,214 & 16,953 & 14,200 \\
\hline Highway construction, value, put in place (billion dollars) & 94 & 90 & 91 & 98 & 100 \\
\hline
\end{tabular}

Sources: U.S. Department of Commerce and Federal Reserve Board. 


\section{Table 3.- Value of Nonfuel Mineral Production in the United States and Principal Nonfuel Minerals Produced in $2020^{\mathrm{p}, 1}$}

\begin{tabular}{|c|c|c|c|c|}
\hline State & $\begin{array}{c}\text { Value } \\
\text { (millions) }\end{array}$ & Rank $^{2}$ & $\begin{array}{l}\text { Percent of } \\
\text { U.S. total }\end{array}$ & Principal nonfuel mineral commodities ${ }^{4}$ \\
\hline Alabama & $\$ 1,580$ & 18 & 1.92 & $\begin{array}{l}\text { Cement (portland), lime, sand and gravel (construction), sand } \\
\text { and gravel (industrial), stone (crushed). }\end{array}$ \\
\hline Alaska & 3,160 & 7 & 3.83 & Gold, lead, sand and gravel (construction), silver, zinc. \\
\hline Arizona & 7,030 & 2 & 8.54 & $\begin{array}{l}\text { Cement (portland), copper, molybdenum concentrates, sand } \\
\text { and gravel (construction), stone (crushed). }\end{array}$ \\
\hline Arkansas & 869 & 29 & 1.06 & $\begin{array}{l}\text { Bromine, cement (portland), sand and gravel (construction), } \\
\text { sand and gravel (industrial), stone (crushed). }\end{array}$ \\
\hline California & 4,680 & 4 & 5.68 & $\begin{array}{l}\text { Boron minerals, cement (portland), gold, sand and gravel } \\
\text { (construction), stone (crushed). }\end{array}$ \\
\hline Colorado & 1,620 & 17 & 1.96 & $\begin{array}{l}\text { Cement (portland), gold, molybdenum concentrates, sand and } \\
\text { gravel (construction), stone (crushed). }\end{array}$ \\
\hline Connecticut $^{5}$ & 190 & 43 & 0.23 & $\begin{array}{l}\text { Clay (common clay), sand and gravel (construction), stone } \\
\text { (crushed), stone (dimension). }\end{array}$ \\
\hline Delaware $^{5}$ & 23 & 50 & 0.03 & $\begin{array}{l}\text { Magnesium compounds, sand and gravel (construction), stone } \\
\text { (crushed). }\end{array}$ \\
\hline Florida & 3,520 & 6 & 4.27 & $\begin{array}{l}\text { Cement (masonry and portland), phosphate rock, sand and } \\
\text { gravel (construction), stone (crushed). }\end{array}$ \\
\hline Georgia & 2,020 & 12 & 2.45 & $\begin{array}{l}\text { Cement (portland), clay (kaolin), sand and gravel (construction), } \\
\text { sand and gravel (industrial), stone (crushed). }\end{array}$ \\
\hline Hawaii & 128 & 45 & 0.16 & Sand and gravel (construction), stone (crushed). \\
\hline Idaho $^{5}$ & 247 & 35 & 0.30 & $\begin{array}{l}\text { Lead, phosphate rock, sand and gravel (construction), silver, } \\
\text { stone (crushed). }\end{array}$ \\
\hline Illinois ${ }^{5}$ & 1,100 & 23 & 1.34 & $\begin{array}{l}\text { Cement (portland), sand and gravel (construction), sand and } \\
\text { gravel (industrial), silica (tripoli), stone (crushed). }\end{array}$ \\
\hline Indiana ${ }^{5}$ & 695 & 24 & 0.84 & $\begin{array}{l}\text { Cement (portland), lime, sand and gravel (construction), stone } \\
\text { (crushed), stone (dimension). }\end{array}$ \\
\hline lowa ${ }^{5}$ & 727 & 28 & 0.88 & $\begin{array}{l}\text { Cement (portland), lime, sand and gravel (construction), sand } \\
\text { and gravel (industrial), stone (crushed). }\end{array}$ \\
\hline Kansas $^{5}$ & 1,250 & 20 & 1.52 & $\begin{array}{l}\text { Cement (portland), helium (Grade-A), salt, sand and gravel } \\
\text { (construction), stone (crushed). }\end{array}$ \\
\hline Kentucky ${ }^{5}$ & 566 & 30 & 0.69 & $\begin{array}{l}\text { Cement (portland), clay (common clay), lime, sand and gravel } \\
\text { (construction), stone (crushed). }\end{array}$ \\
\hline Louisiana $^{5}$ & 656 & 33 & 0.80 & $\begin{array}{l}\text { Clay (common clay), salt, sand and gravel (construction), sand } \\
\text { and gravel (industrial), stone (crushed). }\end{array}$ \\
\hline Maine ${ }^{5}$ & 148 & 44 & 0.18 & $\begin{array}{l}\text { Cement (portland), peat, sand and gravel (construction), stone } \\
\text { (crushed), stone (dimension). }\end{array}$ \\
\hline Maryland 5 & 429 & 32 & 0.52 & $\begin{array}{l}\text { Cement (masonry and portland), sand and gravel (construction), } \\
\text { stone (crushed), stone (dimension). }\end{array}$ \\
\hline Massachusetts ${ }^{5}$ & 267 & 42 & 0.32 & $\begin{array}{l}\text { Clay (common clay), lime, sand and gravel (construction), stone } \\
\text { (crushed), stone (dimension). }\end{array}$ \\
\hline Michigan & 2,630 & 10 & 3.20 & $\begin{array}{l}\text { Cement (portland), iron ore, salt, sand and gravel (construction), } \\
\text { stone (crushed). }\end{array}$ \\
\hline Minnesota $^{5}$ & 4,090 & 5 & 4.96 & $\begin{array}{l}\text { Iron ore, sand and gravel (construction), sand and gravel } \\
\text { (industrial), stone (crushed), stone (dimension). }\end{array}$ \\
\hline Mississippi ${ }^{5}$ & 286 & 41 & 0.35 & $\begin{array}{l}\text { Clay (bentonite and montmorillonite), sand and gravel } \\
\text { (construction), sand and gravel (industrial), stone (crushed). }\end{array}$ \\
\hline Missouri & 3,030 & 9 & 3.68 & $\begin{array}{l}\text { Cement (portland), lead, lime, sand and gravel (industrial), stone } \\
\text { (crushed). }\end{array}$ \\
\hline Montana & 1,680 & 16 & 2.04 & $\begin{array}{l}\text { Copper, molybdenum concentrates, palladium, platinum, sand } \\
\text { and gravel (construction). }\end{array}$ \\
\hline
\end{tabular}

See footnotes at end of table. 


\section{Table 3.- Value of Nonfuel Mineral Production in the United States and Principal Nonfuel Minerals Produced in $2020^{\mathrm{p}}, 1$-Continued}

\begin{tabular}{|c|c|c|c|c|}
\hline State & $\begin{array}{c}\text { Value } \\
\text { (millions) }\end{array}$ & Rank $^{2}$ & $\begin{array}{l}\text { Percent of } \\
\text { U.S. total }\end{array}$ & Principal nonfuel mineral commodities ${ }^{4}$ \\
\hline Nebraska $^{5}$ & $\$ 215$ & 38 & 0.26 & $\begin{array}{l}\text { Cement (portland), lime, sand and gravel (construction), sand } \\
\text { and gravel (industrial), stone (crushed). }\end{array}$ \\
\hline Nevada & 9,140 & 1 & 11.10 & Copper, diatomite, gold, lime, silver. \\
\hline New Hampshire & 110 & 47 & 0.13 & $\begin{array}{l}\text { Sand and gravel (construction), stone (crushed), stone } \\
\text { (dimension). }\end{array}$ \\
\hline New Jersey & 345 & 40 & 0.42 & $\begin{array}{l}\text { Sand and gravel (construction), sand and gravel (industrial), } \\
\text { stone (crushed). }\end{array}$ \\
\hline New Mexico & 864 & 31 & 1.05 & $\begin{array}{l}\text { Cement (portland), copper, potash, sand and gravel } \\
\text { (construction), stone (crushed). }\end{array}$ \\
\hline New York & 1,690 & 15 & 2.05 & $\begin{array}{l}\text { Cement (portland), salt, sand and gravel (construction), stone } \\
\text { (crushed), zinc. }\end{array}$ \\
\hline North Carolina 5 & 1,150 & 19 & 1.39 & $\begin{array}{l}\text { Clay (common clay), phosphate rock, sand and gravel } \\
\text { (construction), sand and gravel (industrial), stone (crushed). }\end{array}$ \\
\hline North Dakota ${ }^{5}$ & 74 & 48 & 0.09 & $\begin{array}{l}\text { Clay (common clay), lime, sand and gravel (construction), stone } \\
\text { (crushed). }\end{array}$ \\
\hline Ohio $^{5}$ & 1,340 & 13 & 1.63 & $\begin{array}{l}\text { Cement (portland), lime, salt, sand and gravel (construction), } \\
\text { stone (crushed). }\end{array}$ \\
\hline Oklahoma & 1,040 & 27 & 1.26 & $\begin{array}{l}\text { Cement (portland), iodine, sand and gravel (construction), sand } \\
\text { and gravel (industrial), stone (crushed). }\end{array}$ \\
\hline Oregon & 513 & 36 & 0.62 & $\begin{array}{l}\text { Cement (portland), diatomite, perlite (crude), sand and gravel } \\
\text { (construction), stone (crushed). }\end{array}$ \\
\hline Pennsylvania 5 & 1,750 & 14 & 2.13 & $\begin{array}{l}\text { Cement (portland), lime, sand and gravel (construction), sand } \\
\text { and gravel (industrial), stone (crushed). }\end{array}$ \\
\hline Rhode Island 5 & 48 & 49 & 0.06 & $\begin{array}{l}\text { Sand and gravel (construction), sand and gravel (industrial), } \\
\text { stone (crushed). }\end{array}$ \\
\hline South Carolina ${ }^{5}$ & 895 & 25 & 1.09 & $\begin{array}{l}\text { Cement (masonry and portland), gold, sand and gravel } \\
\text { (construction), stone (crushed). }\end{array}$ \\
\hline South Dakota & 449 & 37 & 0.54 & $\begin{array}{l}\text { Cement (portland), gold, lime, sand and gravel (construction), } \\
\text { stone (crushed). }\end{array}$ \\
\hline Tennessee & 1,330 & 22 & 1.61 & $\begin{array}{l}\text { Cement (portland), sand and gravel (construction), sand and } \\
\text { gravel (industrial), stone (crushed), zinc. }\end{array}$ \\
\hline Texas & 6,090 & 3 & 7.40 & $\begin{array}{l}\text { Cement (portland), lime, sand and gravel (construction), sand } \\
\text { and gravel (industrial), stone (crushed). }\end{array}$ \\
\hline Utah & 3,150 & 8 & 3.82 & $\begin{array}{l}\text { Cement (portland), copper, gold, molybdenum concentrates, } \\
\text { sand and gravel (construction). }\end{array}$ \\
\hline Vermont ${ }^{5}$ & 119 & 46 & 0.14 & $\begin{array}{l}\text { Sand and gravel (construction), stone (crushed), stone } \\
\text { (dimension), talc (crude). }\end{array}$ \\
\hline Virginia & 1,370 & 21 & 1.67 & $\begin{array}{l}\text { Cement (portland), kyanite, lime, sand and gravel (construction), } \\
\text { stone (crushed). }\end{array}$ \\
\hline Washington & 630 & 34 & 0.77 & $\begin{array}{l}\text { Cement (portland), diatomite, sand and gravel (construction), } \\
\text { sand and gravel (industrial), stone (crushed). }\end{array}$ \\
\hline West Virginia $^{5}$ & 164 & 39 & 0.20 & $\begin{array}{l}\text { Cement (masonry and portland), lime, sand and gravel } \\
\text { (industrial), stone (crushed). }\end{array}$ \\
\hline Wisconsin ${ }^{5}$ & 1,020 & 26 & 1.24 & $\begin{array}{l}\text { Lime, sand and gravel (construction), sand and gravel } \\
\text { (industrial), stone (crushed), stone (dimension). }\end{array}$ \\
\hline Wyoming & 2,440 & 11 & 2.97 & $\begin{array}{l}\text { Cement (portland), clay (bentonite), helium (Grade-A), sand and } \\
\text { gravel (construction), soda ash. }\end{array}$ \\
\hline $\begin{array}{l}\text { Undistributed } \\
\text { Total }\end{array}$ & $\frac{3,780}{82,300}$ & $\frac{X X}{X X}$ & $\frac{4.61}{100.00}$ & \\
\hline
\end{tabular}

pPreliminary. XX Not applicable.

${ }^{1}$ Table includes data available through December 2020. Data are rounded to no more than three significant digits; may not add to totals shown.

${ }^{2}$ Rank based on total, unadjusted State values.

${ }^{3}$ Percent of U.S. total calculated to two decimal places.

${ }^{4}$ Listed in alphabetical order.

${ }^{5}$ Partial total; excludes values that must be withheld to avoid disclosing company proprietary data, which are included with "Undistributed." 


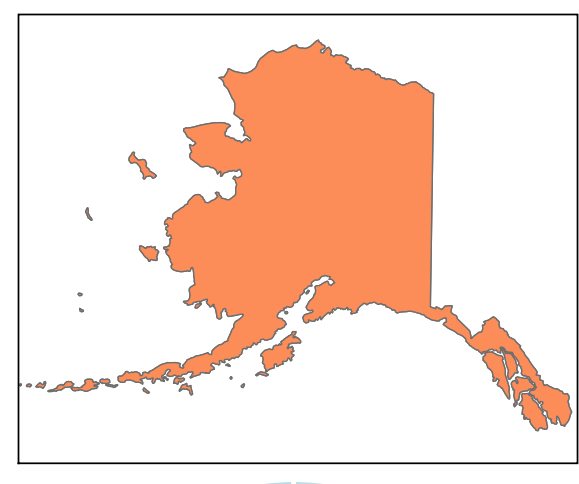

Figure 4.- Value of Nonfuel Minerals Produced in 2020, by State

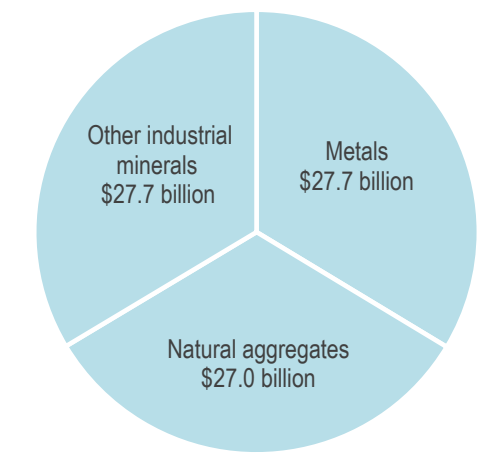

U.S. total: $\$ 82.4$ billion
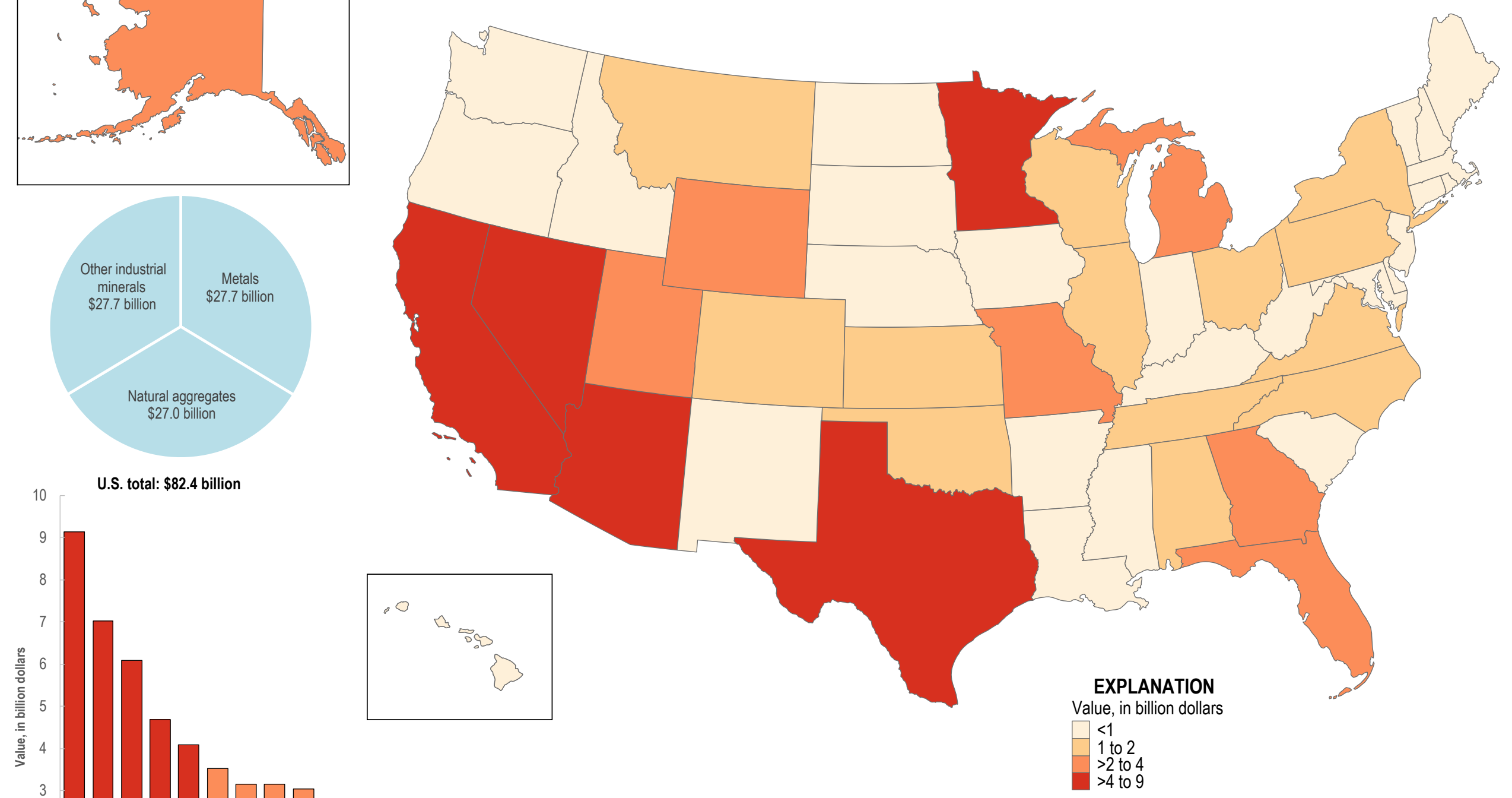

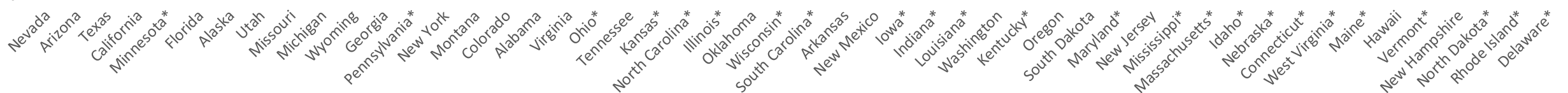

*Partial total; excludes values that must be withheld to avoid disclosing company proprietary data, which are included with "Undistributed" in table 3. 
Figure 5.-Value of Metals and Metallic Minerals Produced in 2020, by Region

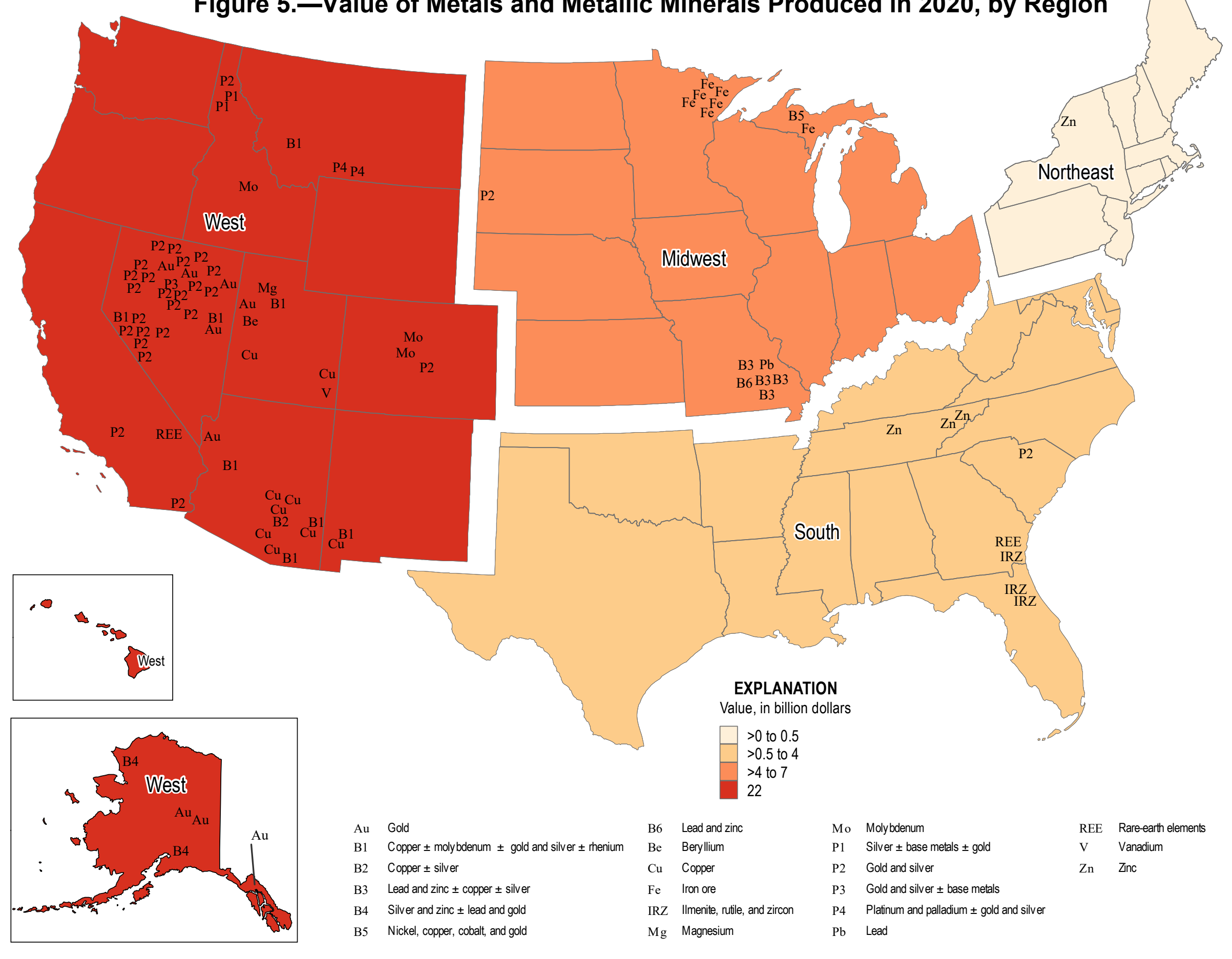




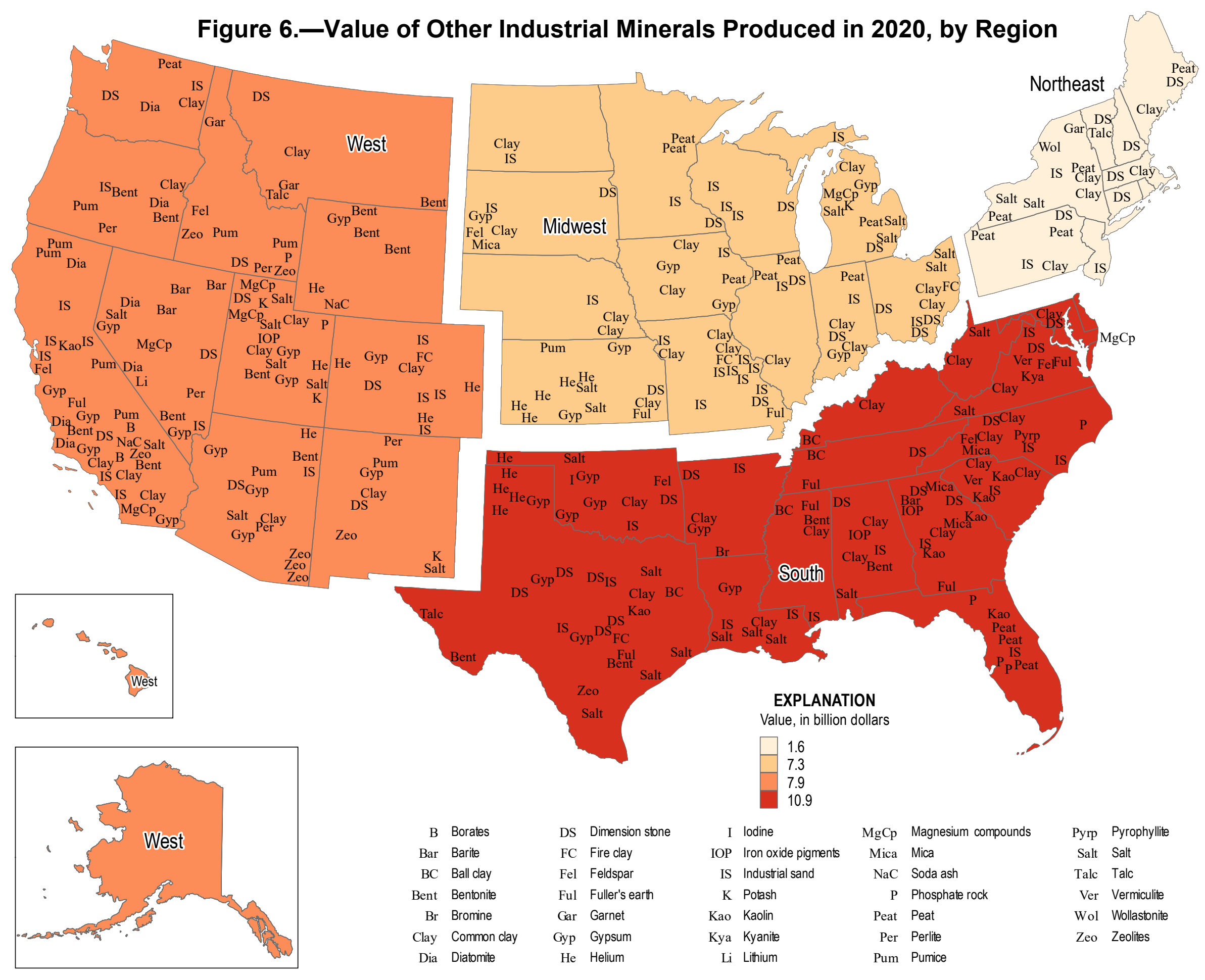




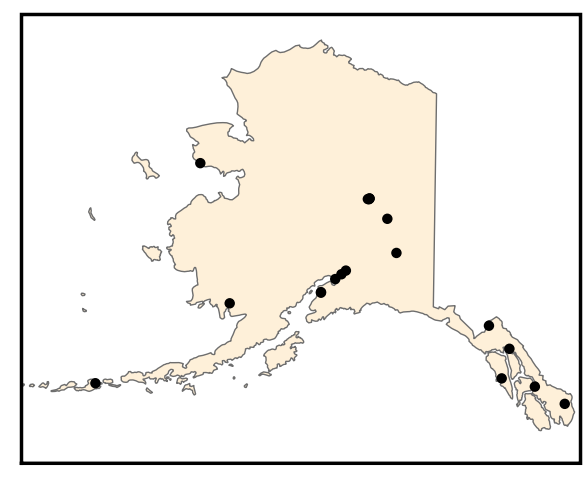

Figure 7.-Value of Crushed Stone Produced in 2020, by State

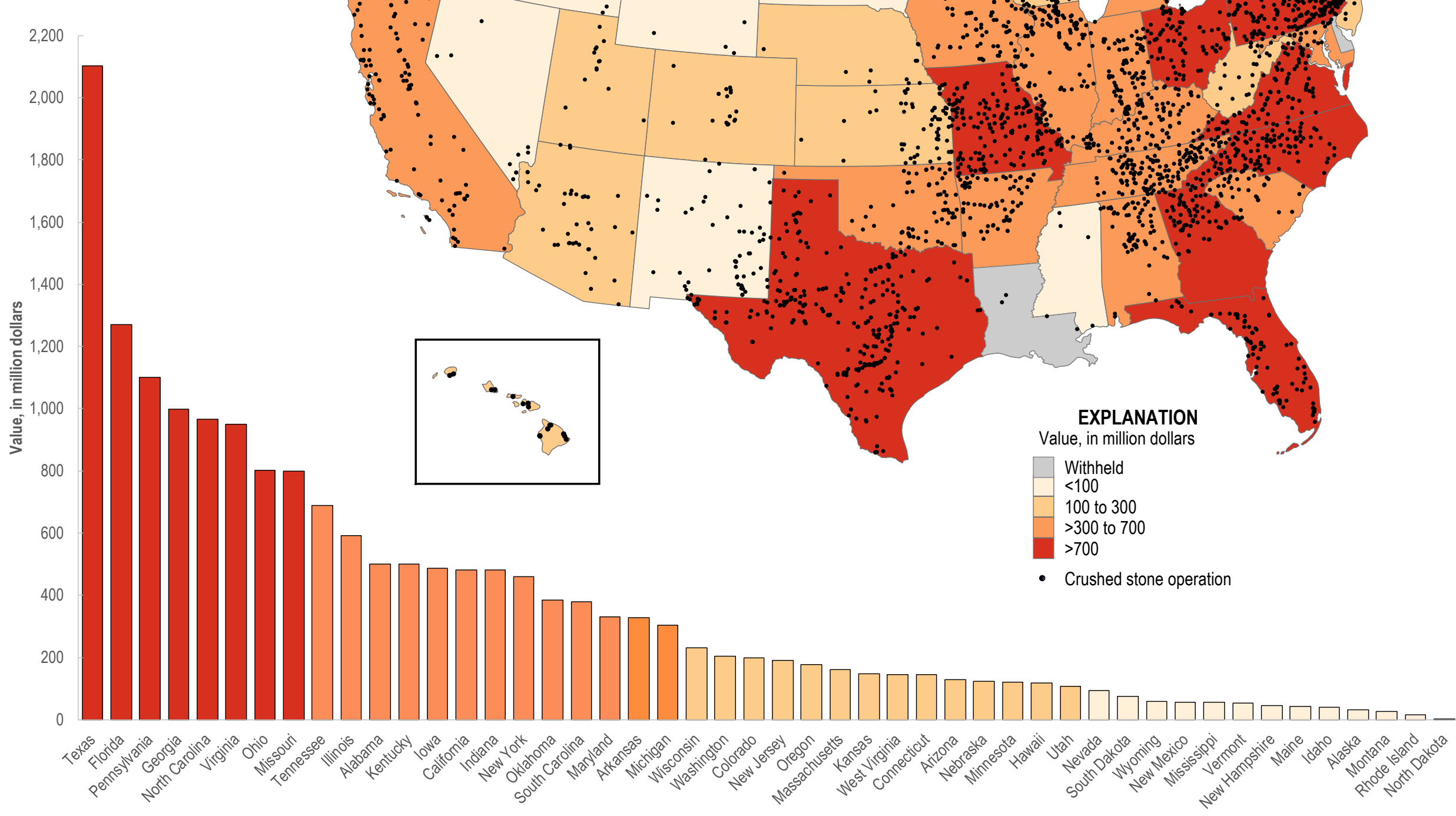




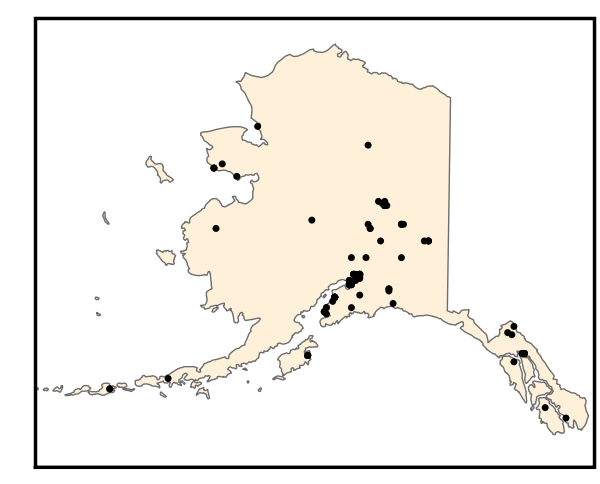

Figure 8.-Value of Construction Sand and Gravel Produced in 2020, by State

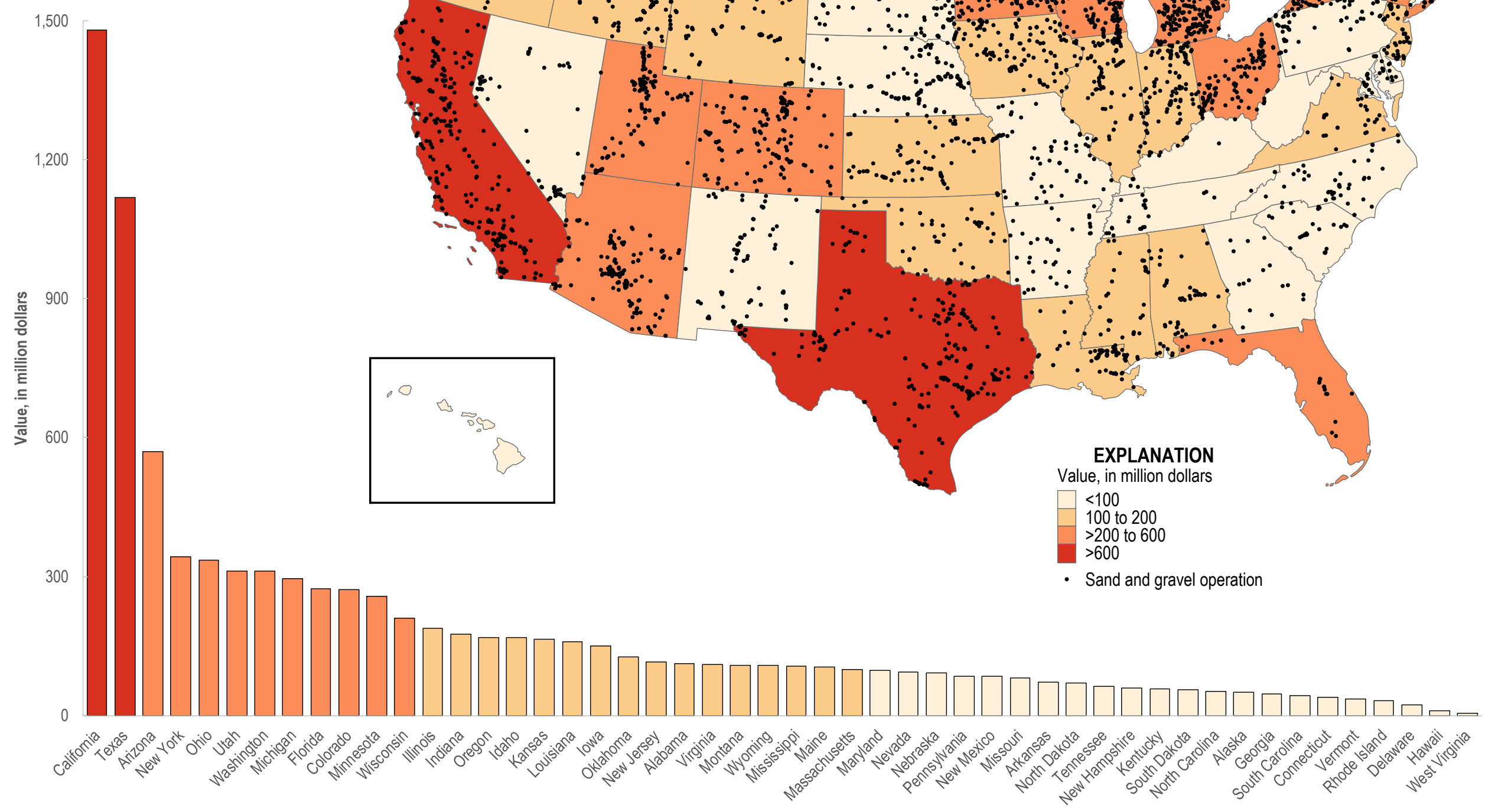


(THIS PAGE INTENTIONALLY LEFT BLANK) 


\section{ABRASIVES (MANUFACTURED)}

(Fused aluminum oxide, silicon carbide, and metallic abrasives)

(Data in metric tons unless otherwise noted)

Domestic Production and Use: Fused aluminum oxide was produced by two companies at three plants in the United States and Canada. Production of crude fused aluminum oxide had an estimated value of $\$ 1.7$ million. Silicon carbide was produced by two companies at two plants in the United States. Production of crude silicon carbide had an estimated value of about $\$ 26$ million. Metallic abrasives were produced by 11 companies in eight States. Production of metallic abrasives had an estimated value of about $\$ 120$ million. Bonded and coated abrasive products accounted for most abrasive uses of fused aluminum oxide and silicon carbide. Metallic abrasives are used primarily for steel shot and grit and cut wire shot, which are used for sandblasting, peening, and stonecutting applications.

\section{Salient Statistics_United States:}

Production:

Fused aluminum oxide, crude ${ }^{1,2}$

Silicon carbide ${ }^{2}$

Metallic abrasives

Shipments, metallic abrasives

Imports for consumption:

Fused aluminum oxide

Silicon carbide

Metallic abrasives

Exports:

Fused aluminum oxide

Silicon carbide

Metallic abrasives

Consumption, apparent:

Fused aluminum oxide ${ }^{3}$

Silicon carbide 4

Metallic abrasives 5

Price, average value of imports, dollars per ton:

Fused aluminum oxide, regular

Fused aluminum oxide, high-purity

Silicon carbide, crude

Metallic abrasives

Net import reliance ${ }^{6}$ as a percentage of apparent

consumption:

Fused aluminum oxide

Silicon carbide

Metallic abrasives

$\begin{array}{rrrrr}\underline{\mathbf{2 0 1 6}} & \underline{\mathbf{2 0 1 7}} & \underline{\mathbf{2 0 1 8}} & \underline{\mathbf{2 0 1 9}} & \underline{\mathbf{2 0 2 0}} \\ 10,000 & 10,000 & 10,000 & 10,000 & 10,000 \\ 35,000 & 35,000 & 35,000 & 35,000 & 35,000 \\ 188,000 & 179,000 & 180,000 & 177,000 & 180,000 \\ 204,000 & 197,000 & 196,000 & 195,000 & 190,000 \\ & & & & \\ 155,000 & 206,000 & 192,000 & 184,000 & 130,000 \\ 116,000 & 137,000 & 146,000 & 131,000 & 130,000 \\ 54,100 & 29,600 & 29,900 & 27,900 & 25,000 \\ & & & & \\ 14,300 & 15,500 & 20,100 & 18,400 & 14,000 \\ 6,820 & 6,100 & 10,100 & 11,500 & 9,300 \\ 28,600 & 31,000 & 33,600 & 31,200 & 24,000 \\ & & & & \\ 141,000 & 191,000 & 172,000 & 166,000 & 120,000 \\ 144,000 & 166,000 & 171,000 & 155,000 & 160,000 \\ 230,000 & 196,000 & 192,000 & 192,000 & 190,000 \\ & & & & \\ 418 & 489 & 692 & 716 & 670 \\ 1,360 & 1,220 & 1,290 & 1,250 & 1,200 \\ 452 & 479 & 670 & 701 & 600 \\ 543 & 1,020 & 1,180 & 1,310 & 1,200 \\ & & & & \\ >75 & >75 & >75 & >75 & >75 \\ >75 & >75 & >75 & >75 & >75 \\ 11 & \mathrm{E} & \mathrm{E} & \mathrm{E} & 1\end{array}$

Recycling: Up to $30 \%$ of fused aluminum oxide may be recycled, and about $5 \%$ of silicon carbide is recycled.

Import Sources (2016-19): Fused aluminum oxide, crude: China, 86\%; France, 7\%; Canada, 2\%; and other, 5\%. Fused aluminum oxide, grain: Canada, 19\%; Brazil, 18\%; Austria, 17\%; Germany, 12\%; and other, 34\%. Silicon carbide, crude: China, 85\%; Netherlands, 7\%; South Africa, 5\%; and other, 3\%. Silicon carbide, grain: China, 48\%; Brazil, 21\%; Russia, 9\%; Norway, 6\%; and other, 16\%. Metallic abrasives: Canada, 26\%; Sweden, 19\%; China, 15\%; Germany, 10\%; and other, 30\%.

\section{Tariff: Item}

Artificial corundum, crude

White, pink, ruby artificial corundum, greater than $97.5 \%$ aluminum oxide, grain

Artificial corundum, not elsewhere specified or included, fused aluminum oxide, grain

Silicon carbide, crude

Silicon carbide, grain

Iron, pig iron, or steel granules
Number

2818.10.1000

2818.10.2010

2818.10.2090

2849.20.1000

2849.20.2000

7205.10 .0000
Normal Trade Relations

12-31-20

Free.

$1.3 \%$ ad val.

$1.3 \%$ ad val.

Free.

$0.5 \%$ ad val.

Free.

Prepared by Lori E. Apodaca [(703) 648-7724, lapodaca@usgs.gov] 
Depletion Allowance: None.

\section{Government Stockpile: None.}

Events, Trends, and Issues: In 2020, China was the world's leading producer of abrasive fused aluminum oxide and abrasive silicon carbide. Imports, especially from China where operating costs were lower, continued to challenge abrasives producers in the United States and Canada. In recent years, imports of abrasives from Hong Kong have also increased. Foreign competition is expected to persist and continue to limit production in North America. The average unit value of imports had increased every year since 2016 for regular fused aluminum oxide and crude silicon carbide but decreased in 2020. The average unit values of imports of regular fused aluminum oxide and crude silicon carbide during the first 6 months of 2020 were $6 \%$ and $16 \%$ lower, respectively, than those in 2019 and $3 \%$ and $5 \%$ higher, respectively, than those in 2018.

Abrasives consumption in the United States is greatly influenced by activity in the manufacturing sectors, particularly the aerospace, automotive, furniture, housing, and steel industries. Steel grit can be reclaimed and used multiple times. The use of reclaimed metallic abrasives increased, at least in part, owing to rising surcharges on scrap and waste disposal and increasing prices for new material.

In 2020, the abrasives manufacturing industry was considered part of the critical manufacturing sector by the U.S. Department of Homeland Security. The COVID-19 pandemic "stay-at-home" orders issued in March 2020 did not affect the abrasives manufacturing industry, and these plants maintained full operations. However, imports and exports for fused aluminum oxide decreased by $29 \%$ and $24 \%$, respectively, from those in 2019.

\section{World Production Capacity:}

United States
Argentina
Australia
Austria
Brazil
China
France
Germany
India
Japan
Mexico
Norway
Venezuela
Other countries
$\quad$ World total (rounded)

\begin{tabular}{rr} 
Fused aluminum oxide \\
$\mathbf{2 0 1 9}$ \\
60,000 & $\underline{\mathbf{2 0 2 0}}$ \\
- & 60,000 \\
50,000 & - \\
60,000 & 50,000 \\
50,000 & 60,000 \\
800,000 & 50,000 \\
40,000 & 800,000 \\
80,000 & 40,000 \\
40,000 & 80,000 \\
15,000 & 40,000 \\
- & 15,000 \\
- & - \\
- & - \\
80,000 & - \\
\hline $1,300,000$ & 80,000 \\
\hline $1,300,000$
\end{tabular}

\begin{tabular}{rr}
\multicolumn{2}{c}{ Silicon carbide } \\
2019 & $\underline{\mathbf{2 0 2 0}}$ \\
40,000 & 40,000 \\
5,000 & 5,000 \\
- & - \\
- & - \\
40,000 & 40,000 \\
450,000 & 450,000 \\
20,000 & 20,000 \\
35,000 & 35,000 \\
5,000 & 5,000 \\
60,000 & 60,000 \\
45,000 & 45,000 \\
80,000 & 80,000 \\
30,000 & 30,000 \\
190,000 & 190,000 \\
\hline $1,000,000$ & $1,000,000$
\end{tabular}

World Resources: ${ }^{7}$ Although domestic resources of raw materials for the production of fused aluminum oxide are rather limited, adequate resources are available in the Western Hemisphere. Domestic resources are more than adequate for the production of silicon carbide.

Substitutes: Natural and manufactured abrasives, such as garnet, emery, or metallic abrasives, can be substituted for fused aluminum oxide and silicon carbide in various applications.

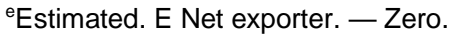

${ }^{1}$ Production data for aluminum oxide are combined production data from the United States and Canada to avoid disclosing company proprietary data.

${ }^{2}$ Rounded to the nearest 5,000 tons to avoid disclosing company proprietary data.

${ }^{3}$ Defined as imports - exports because production includes data from Canada; actual consumption is higher than that shown.

${ }^{4}$ Defined as production + imports - exports.

${ }^{5}$ Defined as shipments + imports - exports.

${ }^{6}$ Defined as imports - exports.

${ }^{7}$ See Appendix $\mathrm{C}$ for resource and reserve definitions and information concerning data sources.
} 


\section{ALUMINUM ${ }^{1}$}

(Data in thousand metric tons unless otherwise noted)

Domestic Production and Use: In 2020, three companies operated seven primary aluminum smelters in six States. Two smelters operated at full capacity and four smelters operated at reduced capacity throughout the year. One smelter operated at reduced capacity until it was idled in July. One other smelter remained on standby throughout the year. Domestic smelters were operating at about $49 \%$ of capacity of 1.79 million tons per year at yearend 2020 . Production decreased by $8 \%$ after increasing in 2019 . Based on published prices, the value of primary aluminum production was about $\$ 1.98$ billion, $17 \%$ less than the value in 2019 . The average annual U.S. market price declined by about $11 \%$ from that in 2019 . Transportation applications accounted for $40 \%$ of domestic consumption; in descending order of consumption, the remainder was used in packaging, $21 \%$; building, $14 \%$; electrical, $8 \%$; consumer durables, 7\%; machinery, 7\%; and other, $3 \%$.

\begin{tabular}{|c|c|c|c|c|c|}
\hline Salient Statistics-United States: & $\underline{2016}$ & $\underline{2017}$ & $\underline{2018}$ & $\underline{2019}$ & $\underline{2020^{\circ}}$ \\
\hline \multicolumn{6}{|l|}{ Production: } \\
\hline Primary & 818 & 741 & 891 & 1,093 & 1,000 \\
\hline Secondary (from old scrap) & 1,570 & 1,590 & 1,570 & 1,540 & 1,500 \\
\hline Secondary (from new scrap) & 2,010 & 2,050 & 2,140 & 1,920 & 1,700 \\
\hline \multicolumn{6}{|l|}{ Imports for consumption: } \\
\hline Crude and semimanufactures & 5,410 & 6,220 & 5,550 & 5,210 & 3,200 \\
\hline Scrap & 609 & 700 & 695 & 596 & 530 \\
\hline \multicolumn{6}{|l|}{ Exports: } \\
\hline Crude and semimanufactures & 1,470 & 1,330 & 1,310 & 1,090 & 880 \\
\hline Scrap & 1,350 & 1,570 & 1,760 & 1,860 & 2,000 \\
\hline Consumption, apparent ${ }^{2}$ & 5,090 & 5,680 & 4,900 & 4,940 & 2,870 \\
\hline Supply, apparent ${ }^{3}$ & 7,100 & 7,730 & 7,040 & 6,860 & 4,570 \\
\hline Price, ingot, average U.S. market (spot), cents per pound & 80.4 & 98.3 & 114.7 & 99.5 & 89 \\
\hline \multicolumn{6}{|l|}{ Stocks, yearend: } \\
\hline Aluminum industry & 1,400 & 1,470 & 1,570 & 1,600 & 1,400 \\
\hline London Metal Exchange (LME), U.S. warehouses ${ }^{4}$ & 362 & 254 & 186 & 120 & 250 \\
\hline Employment, number 5 & 31,900 & 31,700 & 31,600 & 32,900 & 31,900 \\
\hline \multirow{2}{*}{$\begin{array}{l}\text { Net import reliance }{ }^{6} \text { as a percentage of } \\
\text { apparent consumption }\end{array}$} & 53 & 59 & 5 & 47 & 13 \\
\hline & & & & & 10 \\
\hline
\end{tabular}

Recycling: In 2020, aluminum recovered from purchased scrap in the United States was about 3.2 million tons, of which about $53 \%$ came from new (manufacturing) scrap and $47 \%$ from old scrap (discarded aluminum products). Aluminum recovered from old scrap was equivalent to about $51 \%$ of apparent consumption.

Import Sources (2016-19): Canada, 50\%; the United Arab Emirates, 10\%; Russia 9\%; China, 5\%; and other, 26\%.

Tariff: Item

Aluminum, not alloyed: Unwrought (in coils) Unwrought (other than aluminum alloys)

Aluminum alloys, unwrought (billet)

Aluminum scrap:

Used beverage container scrap

Industrial process scrap
Number

7601.10 .3000

7601.10 .6000

7601.20 .9045

7602.00 .0030

7602.00 .0091
Normal Trade Relations 12-31-20

$2.6 \%$ ad val.

Free.

Free.

Free.

Free.

Depletion Allowance: Not applicable. ${ }^{1}$

Government Stockpile: None.

Events, Trends, and Issues: Starting in March, many aluminum consumers shut down or reduced production in response to the COVID-19 pandemic. Several manufacturers in the aerospace and automotive industries shut down production facilities citing local government orders, agreements negotiated between the companies and the unions representing employees, or decreased demand by retail consumers. Several extruders, rolling mills, and secondary smelters decreased output or shut down in response to the COVID-19 pandemic. By July, most of the shutdowns ended as safety measures were implemented. Consumption of aluminum for containers and packaging remained steady as bars and restaurants were ordered closed by many local authorities, resulting in increased demand for beverages in aluminum cans. Rolling mills and secondary smelters that produce can sheet increased imports of 


\section{ALUMINUM}

used beverage cans to make up for decreased supply from domestic can redemption centers that were closed in most States. Primary aluminum smelters were exempted from the lockdown orders.

In March, a 252,000-ton-per-year smelter in Hawesville, KY, completed restarting one potline with 50,000 tons per year of capacity after scheduled maintenance work. The restart of another 50,000-ton-per-year potline at the Hawesville smelter was delayed because of economic conditions after maintenance work was completed. In July, a 279,000-ton-per-year smelter in Ferndale, WA, shut down four of its five potlines, citing high power prices and low aluminum prices. The rest of its capacity was shut down previously.

On January 24, the President of the United States imposed a 10\% tariff on imported products made with aluminum. In March 2018, a 10\% tariff was imposed on imports of aluminum but concerns had been raised that domestic manufacturers were having to pay more for aluminum and that competitors were able to import finished products without having to pay a tariff on the aluminum contained in finished products. Aluminum imports from all countries except Argentina, Australia, Canada, and Mexico remained subject to the $10 \%$ ad valorem tariff as of early December. The 10\% tariffs were imposed under authority of section 232 of the Trade Expansion Act of 1962.

In March, the U.S. Department of Commerce initiated a countervailing duty investigation of imports of common alloy aluminum sheet from 18 countries. The U.S. International Trade Commission initiated an antidumping investigation on the same products from four countries. On August 10, the U.S. Department of Commerce issued its preliminary determination of the countervailing duty investigation and set preliminary subsidy rates, with a final determination expected by early 2021. The U.S. International Trade Commission was expected to issue its final determination in February 2021. In June, the U.S. Department of Commerce issued its preliminary determination of the countervailing duty investigation of foil imports from China and set preliminary subsidy rates.

World Smelter Production and Capacity: Capacity data for China and Russia were revised based on Government and company data.

\begin{tabular}{lrrrr} 
& \multicolumn{2}{c}{ Production } & \multicolumn{2}{c}{ Yearend capacity } \\
United States & $\mathbf{2 0 1 9}$ & $\mathbf{2 0 2 0 ^ { \mathbf { e } }}$ & $\underline{\mathbf{2 0 1 9}}$ & $\mathbf{2 0 2 \mathbf { e } ^ { \mathbf { e } }}$ \\
Australia & 1,093 & $\underline{1,000}$ & 1,790 & 1,790 \\
Bahrain & 1,570 & 1,600 & 1,720 & 1,720 \\
Canada & 1,370 & 1,500 & 1,540 & 1,540 \\
China & 2,850 & 3,100 & 3,270 & 3,270 \\
Iceland & 35,000 & 37,000 & 41,300 & 43,000 \\
India & 845 & 840 & 890 & 890 \\
Norway & 3,640 & 3,600 & 4,060 & 4,060 \\
Russia & 1,400 & 1,400 & 1,430 & 1,430 \\
United Arab Emirates & 3,640 & 3,600 & 4,020 & 4,020 \\
Other countries & 2,600 & 2,600 & 2,700 & 2,700 \\
$\quad$ World total (rounded) & 9,200 & $\underline{9,000}$ & $\underline{12,200}$ & 12,300 \\
\hline
\end{tabular}

World Resources: ${ }^{7}$ Global resources of bauxite are estimated to be between 55 billion and 75 billion tons and are sufficient to meet world demand for metal well into the future. ${ }^{1}$

Substitutes: Composites can substitute for aluminum in aircraft fuselages and wings. Glass, paper, plastics, and steel can substitute for aluminum in packaging. Composites, magnesium, steel, and titanium can substitute for aluminum in ground transportation uses. Composites, steel, vinyl, and wood can substitute for aluminum in construction. Copper can replace aluminum in electrical and heat-exchange applications.

\footnotetext{
eEstimated.

${ }^{1}$ See also Bauxite and Alumina.

${ }^{2}$ Defined as domestic primary metal production + recovery from old aluminum scrap + net import reliance; excludes imported scrap.

${ }^{3}$ Defined as domestic primary metal production + recovery from all aluminum scrap + net import reliance; excludes imported scrap.

${ }^{4}$ Includes aluminum alloy. Starting with 2019, also includes off-warrant stocks of primary and alloyed aluminum; estimated for 2019.

${ }^{5}$ Alumina and aluminum production workers (North American Industry Classification System-3313). Source: U.S. Department of Labor, Bureau of Labor Statistics.

${ }^{6}$ Defined as imports - exports + adjustments for industry stock changes; excludes imported scrap.

${ }^{7}$ See Appendix $\mathrm{C}$ for resource and reserve definitions and information concerning data sources.
} 


\section{ANTIMONY}

(Data in metric tons of antimony content unless otherwise noted)

Domestic Production and Use: In 2020, no marketable antimony was mined in the United States. A mine in Nevada that had extracted about 800 tons of stibnite ore from 2013 through 2014 was placed on care-and-maintenance status in 2015 and had no reported production in 2020. Primary antimony metal and oxide were produced by one company in Montana using imported feedstock. Secondary antimony production was derived mostly from antimonial lead recovered from spent lead-acid batteries. The estimated value of secondary antimony produced in 2020, based on the average New York dealer price for antimony, was about $\$ 35$ million. Recycling supplied about 18\% of estimated domestic consumption, and the remainder came mostly from imports. The value of antimony consumption in 2020, based on the average New York dealer price, was about \$193 million. In the United States, the leading uses of antimony were as follows: flame retardants, 42\%; metal products, including antimonial lead and ammunition, 36\%; and nonmetal products, including ceramics and glass and rubber products, $22 \%$.

\begin{tabular}{|c|c|c|c|c|c|}
\hline Salient Statistics-United States: & $\underline{2016}$ & $\underline{2017}$ & $\underline{2018}$ & $\underline{2019}$ & $\underline{2020^{e}}$ \\
\hline Production: & & & & & \\
\hline Mine (recoverable antimony) & - & - & - & - & - \\
\hline Smelter: & & & & & \\
\hline Primary & 664 & 621 & 331 & 377 & 260 \\
\hline Secondary & 3,810 & 4,370 & 4,090 & 4,140 & 4,000 \\
\hline Imports for consumption: & & & & & \\
\hline Ore and concentrates & 119 & 61 & 96 & 121 & 130 \\
\hline Oxide & 16,100 & 17,800 & 19,200 & 17,300 & 14,000 \\
\hline Unwrought, powder & 7,110 & 6,810 & 6,320 & 6,670 & 5,500 \\
\hline Waste and scrap $^{1}$ & 41 & 16 & 202 & 17 & 8 \\
\hline Exports: & & & & & \\
\hline Ore and concentrates ${ }^{1}$ & 12 & 46 & 38 & 9 & 8 \\
\hline Oxide & 1,330 & 1,600 & 1,750 & 1,570 & 1,400 \\
\hline Unwrought, powder & 446 & 643 & 497 & 370 & 290 \\
\hline Waste and scrap ${ }^{1}$ & 177 & 11 & 9 & 14 & 14 \\
\hline Consumption, apparent ${ }^{2}$ & 25,900 & 27,400 & 27,700 & 26,400 & 22,000 \\
\hline Price, metal, average, dollars per pound ${ }^{3}$ & 3.35 & 3.98 & 3.88 & 3.90 & 3.98 \\
\hline Employment, plant, numbere & 27 & 27 & 27 & 27 & 27 \\
\hline Net import reliance ${ }^{4}$ as a percentage of & & & & & \\
\hline t consump & 83 & 82 & 84 & 83 & 81 \\
\hline
\end{tabular}

Recycling: The bulk of secondary antimony is recovered at secondary lead smelters as antimonial lead, most of which was generated by, and then consumed by, the lead-acid battery industry.

Import Sources (2016-19): Ore and concentrates: Italy, 55\%; China, 31\%; India, 7\%; Mexico, 4\%; and other, 3\%. Oxide: China, 69\%; Belgium, 10\%; Bolivia and Thailand, 6\% each; and other, 9\%. Unwrought metal and powder: China, 46\%; India, 20\%; Vietnam, 11\%; the United Kingdom, 6\%; and other, 17\%. Total metal and oxide: China, 63\%; Belgium, $7 \%$; Thailand, 6\%; India, 5\%; and other, $19 \%$.

Tariff: Item

Ore and concentrates

Antimony oxide

Antimony and articles thereof:

Unwrought antimony; powder

Waste and scrap

Other
Number

2617.10.0000

2825.80 .0000

8110.10 .0000

8110.20 .0000

8110.90 .0000
Normal Trade Relations 12-31-20

Free.

Free.

Free.

Free.

Free.

Depletion Allowance: $22 \%$ (domestic), 14\% (foreign).

Government Stockpile: ${ }^{5}$

\begin{tabular}{lccccc} 
& \multicolumn{2}{c}{ FY 2020 } & \multicolumn{2}{c}{ FY 2021 } \\
Inventory & Potential & Potential & Potential & Potential \\
Material & as of 9-30-20 & acquisitions & disposals & acquisitions & disposals \\
Antimony & 90.16 & 1,100 & - & 1,100 & -
\end{tabular}

Prepared by Kateryna Klochko [(703) 648-4977, kklochko@usgs.gov] 


\section{ANTIMONY}

Events, Trends, and Issues: China continued to be the leading global antimony producer in 2020 and accounted for more than $52 \%$ of global mine production. Owing to the global COVID-19 pandemic and the consequent very tight supply of antimony raw materials, operations at China's refineries were constrained. According to China's customs data, China imported 30\% less of antimony ore and concentrates from January through August 2020 than for the same period of 2019. This caused a supply shortage of antimony ingots on the market and the antimony price increased to about $\$ 4.00$ per pound in 2020 . In 2020 , China imported $83 \%$ less unwrought antimony than in the previous year. Exports of China's unwrought antimony and antimony oxide fell by $24 \%$ and $12 \%$, respectively.

World Mine Production and Reserves: Reserves for Canada and Kyrgyzstan were revised based on Government and industry reports.

\begin{tabular}{|c|c|c|c|}
\hline & \multicolumn{2}{|c|}{ Mine production } & Reserves $^{6}$ \\
\hline United States & & - & 760,000 \\
\hline Australia & 2,030 & 2,000 & 8140,000 \\
\hline Bolivia & 3,000 & 3,000 & 310,000 \\
\hline Burma & 6,000 & 6,000 & NA \\
\hline Canada & 1 & 1 & 78,000 \\
\hline China & 89,000 & 80,000 & 480,000 \\
\hline Ecuador & 1 & 1 & NA \\
\hline Guatemala & 25 & 25 & NA \\
\hline Iran & 500 & 500 & NA \\
\hline Kazakhstan & 300 & 300 & NA \\
\hline Kyrgyzstan & - & - & 260,000 \\
\hline Laos & 140 & 100 & NA \\
\hline Mexico & 300 & 300 & 18,000 \\
\hline Pakistan & - & - & 26,000 \\
\hline Russia (recoverable) & 30,000 & 30,000 & 350,000 \\
\hline Tajikistan & 28,000 & 28,000 & 50,000 \\
\hline Turkey & 2,400 & 2,000 & 100,000 \\
\hline Vietnam & 310 & 300 & NA \\
\hline World total (rounded) & $\overline{162,000}$ & $\overline{153,000}$ & $1,900,000$ \\
\hline
\end{tabular}

World Resources: ${ }^{6}$ U.S. resources of antimony are mainly in Alaska, Idaho, Montana, and Nevada. Principal identified world resources are in Australia, Bolivia, China, Mexico, Russia, South Africa, and Tajikistan. Additional antimony resources may occur in Mississippi Valley-type lead deposits in the Eastern United States.

Substitutes: Selected organic compounds and hydrated aluminum oxide are substitutes as flame retardants. Chromium, tin, titanium, zinc, and zirconium compounds substitute for antimony chemicals in enamels, paint, and pigments. Combinations of calcium, copper, selenium, sulfur, and tin are substitutes for alloys in lead-acid batteries.

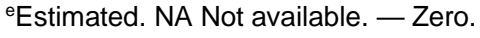

${ }^{1}$ Gross weight.

${ }^{2}$ Defined as primary production + secondary production from old scrap + imports of antimony in oxide and unwrought metal, powder - exports of antimony in oxide and unwrought metal, powder + adjustments for Government stock changes.

${ }^{3} \mathrm{New}$ York dealer price for $99.65 \%$ metal, cost, insurance, freight U.S. ports. Source: S\&P Global Platts Metals Week.

${ }^{4}$ Defined as imports of antimony in oxide and unwrought metal, powder - exports of antimony in oxide and unwrought metal, powder + adjustments for Government stock changes.

${ }^{5}$ See Appendix $B$ for definitions.

${ }^{6}$ See Appendix $C$ for resource and reserve definitions and information concerning data sources.

${ }^{7}$ Company-reported probable reserves for the Stibnite Gold Project in Idaho.

${ }^{8}$ For Australia, Joint Ore Reserves Committee-compliant reserves were 64,600 tons.
} 


\section{ARSENIC}

(Data in metric tons of arsenic content ${ }^{1}$ unless otherwise noted)

Domestic Production and Use: Arsenic trioxide and primary arsenic metal have not been produced in the United States since 1985. The principal use for arsenic trioxide was for the production of arsenic acid used in the formulation of chromated copper arsenide (CCA) preservatives for the pressure treating of lumber used primarily in nonresidential applications. Three companies produced CCA preservatives in the United States in 2020. The grids in lead-acid storage batteries were strengthened by the addition of arsenic metal. Arsenic metal also was used as an antifriction additive for bearings, to harden lead shot, and in clip-on wheel weights. Arsenic compounds were used in herbicides and insecticides. High-purity arsenic (99.9999\%) metal was used to produce gallium-arsenide (GaAs) semiconductors for solar cells, space research, and telecommunications. Arsenic also was used for germaniumarsenide-selenide specialty optical materials. Indium-gallium-arsenide (InGaAs) was used for short-wave infrared technology. The value of arsenic compounds and metal imported domestically in 2020 was estimated to be about $\$ 9.3$ million. Given that arsenic metal has not been produced domestically since 1985 , it is likely that only a small portion of the material reported by the U.S. Census Bureau as arsenic exports was pure arsenic metal, and most of the material that has been reported under this category reflects the gross weight of alloys, compounds, residues, scrap, and waste containing arsenic. Therefore, the estimated consumption reported under salient U.S. statistics reflects only imports of arsenic products.

Salient Statistics_United States:

Imports for consumption:

Arsenic metal

Compounds

Exports, all forms of arsenic (gross weight)

Consumption, estimated, all forms of arsenic ${ }^{2}$

Price, average value of imports (free alongside ship), ${ }^{3}$ dollars per kilogram:

Arsenic metal (China)

Trioxide (China)

Trioxide (Morocco)

Net import reliance 4 as a percentage of estimated consumption, all forms of arsenic

$\begin{array}{rrrrr}\underline{\mathbf{2 0 1 6}} & \underline{\mathbf{2 0 1 7}} & \underline{\mathbf{2 0 1 8}} & \underline{\mathbf{2 0 1 9}} & \underline{\mathbf{2 0 2 0}} \\ \mathbf{7 9 3} & 942 & 929 & 391 & 500 \\ 5,320 & 5,980 & 5,540 & 7,090 & 10,000 \\ 1,760 & 698 & 107 & 56 & 20 \\ 6,120 & 6,920 & 6,470 & 7,480 & 10,500 \\ & & & & \\ 1.89 & 1.56 & 1.43 & 1.92 & 1.70 \\ 0.46 & 0.45 & 0.44 & 0.46 & 0.42 \\ 0.68 & 0.68 & 0.75 & 0.78 & 0.83 \\ 100 & 100 & 100 & 100 & 100\end{array}$

Recycling: Arsenic metal was contained in new scrap recycled during GaAs semiconductor manufacturing. Arseniccontaining process water was internally recycled at wood treatment plants where CCA was used. Although scrap electronic circuit boards, relays, and switches may contain arsenic, no arsenic was known to have been recovered during the recycling process to recover other contained metals. No arsenic was recovered domestically from arseniccontaining residues and dusts generated at nonferrous smelters in the United States.

Import Sources (2016-19): Arsenic metal: China, 91\%; Japan, 5\%; Hong Kong, 3\%; and other, 1\%. Arsenic trioxide: China, 55\%; Morocco, 41\%; Belgium, 2\%; and other, 2\%. All forms of arsenic: China, 58\%; Morocco, 38\%; Belgium, $2 \%$; and other, $2 \%$.

Tariff: Item

Arsenic metal

Arsenic acid

Arsenic trioxide

Arsenic sulfide
Number

2804.80.0000

2811.19.1000

2811.29.1000

2813.90.1000
Normal Trade Relations

12-31-20

Free.

$2.3 \%$ ad val.

Free.

Free.

Depletion Allowance: $14 \%$ (domestic and foreign).

Government Stockpile: None. 


\section{ARSENIC}

Events, Trends, and Issues: China and Morocco continued to be the leading global producers of arsenic trioxide, accounting for about $90 \%$ of estimated world production and supplying almost all of United States imports of arsenic trioxide in 2020. China was the leading world producer of arsenic metal and, with Hong Kong, supplied about $94 \%$ of United States arsenic metal imports in 2020.

High-purity (99.9999\%) arsenic metal was used to produce GaAs, indium-arsenide, and InGaAs semiconductors that were used in biomedical, communications, computer, electronics, and photovoltaic applications. In 2020, the market value of global high-purity arsenic metal was about $\$ 200$ million. Almost one-half of global GaAs wafer production took place in China. See the Gallium chapter for additional details.

\section{World Production and Reserves (gross weight):}

\begin{tabular}{lrr} 
& \multicolumn{2}{c}{$\begin{array}{c}\text { Productione, } \\
\text { (arsenic }\end{array}$} \\
United Statexide) \\
Belgium & $\underline{\mathbf{2 0 1 9}}$ & $\underline{\mathbf{2 0 2 0}}$ \\
Bolivia & 1,000 & 1,000 \\
China & 120 & 100 \\
Iran & 24,000 & 24,000 \\
Japan & 110 & - \\
Morocco & 45 & 40 \\
Russia & 5,500 & 5,500 \\
$\quad$ World total (rounded) & 1,500 & 1,500 \\
\hline
\end{tabular}

Reserves $^{6}$

World reserves data are unavailable but are thought to be more than 20 times world production.

World Resources: ${ }^{6}$ Arsenic may be obtained from copper, gold, and lead smelter flue dust, as well as from roasting arsenopyrite, the most abundant ore mineral of arsenic. Arsenic has been recovered from orpiment and realgar in China, Peru, and the Philippines and from copper-gold ores in Chile, and arsenic was associated with gold occurrences in Canada. Orpiment and realgar from gold mines in Sichuan Province, China, were stockpiled for later recovery of arsenic. Arsenic also may be recovered from enargite, a copper mineral. Arsenic trioxide was produced at the hydrometallurgical complex of Guemassa, near Marrakech, Morocco, from cobalt-arsenide ore from the Bou-Azzer Mine.

Substitutes: Substitutes for CCA in wood treatment include alkaline copper quaternary, ammoniacal copper quaternary, ammoniacal copper zinc arsenate, alkaline copper quaternary boron-based preservatives, copper azole, copper citrate, and copper naphthenate. Treated wood substitutes include concrete, plastic composite material, plasticized wood scrap, or steel. Silicon-based complementary metal-oxide semiconductor power amplifiers compete with GaAs power amplifiers in midtier third generation cellular handsets. Indium phosphide components can be substituted for GaAs-based infrared laser diodes in some specific-wavelength applications, and helium-neon lasers compete with $\mathrm{GaAs}$ in visible laser diode applications. Silicon is the principal competitor with GaAs in solar-cell applications. In many defense-related applications, GaAs-based integrated circuits are used because of their unique properties, and no effective substitutes exist for GaAs in these applications. In heterojunction bipolar transistors, GaAs is being replaced in some applications by silicon-germanium.

\footnotetext{
eEstimated. - Zero.

${ }^{1}$ Arsenic content of arsenic metal is $100 \%$; arsenic content of arsenic compounds is $77.7 \%$ for arsenic acids, $60.7 \%$ for arsenic sulfides, and $75.71 \%$ for arsenic trioxide.

${ }^{2}$ Estimated to be the same as imports.

${ }^{3}$ Calculated from U.S. Census Bureau import data.

${ }^{4}$ Defined as imports.

${ }^{5}$ Includes calculated arsenic trioxide equivalent of output of elemental arsenic compounds other than arsenic trioxide; inclusion of such materials would not duplicate reported arsenic trioxide production. Chile, Mexico, and Peru were thought to be significant producers of commercial-grade arsenic trioxide but have reported no production in recent years.

${ }^{6}$ See Appendix $\mathrm{C}$ for resource and reserve definitions and information concerning data sources.
} 


\section{ASBESTOS}

(Data in metric tons unless otherwise noted)

Domestic Production and Use: The last U.S. producer of asbestos ceased operations in 2002 as a result of the decline in domestic and international asbestos markets associated with health and liability issues. The United States has since been wholly dependent on imports to meet manufacturing needs. All of the asbestos fiber currently imported into and used within the United States consists of chrysotile. In 2020, domestic consumption of chrysotile was estimated to be 450 tons, and all imports originated from Brazil, based on data available through July. The chloralkali industry, which uses chrysotile to manufacture nonreactive semipermeable diaphragms that prevent chlorine generated at the anode of an electrolytic cell from reacting with sodium hydroxide generated at the cathode, has accounted for $100 \%$ of asbestos consumption since at least 2016. In addition to chrysotile, a small, but unknown, quantity of asbestos is imported annually within manufactured products, including brake blocks for use in the oil industry, rubber sheets for gaskets used to create a chemical-containment seal in the production of titanium dioxide, certain other types of preformed gaskets, and some vehicle friction products.

\section{Salient Statistics-United States:} Imports for consumption ${ }^{1}$ Exports $^{3}$

Consumption, estimated ${ }^{4}$

Price, average U.S. customs value, dollars per ton

Net import reliance ${ }^{5}$ as a percentage of

estimated consumption

$\begin{array}{rrrrr}\frac{\mathbf{2 0 1 6}}{747} & \frac{\mathbf{2 0 1 7}}{332} & \frac{\mathbf{2 0 1 8}}{681} & \frac{\mathbf{2 0 1 9}}{172} & \frac{\mathbf{2 0 2 0}}{2300} \\ \frac{-1}{770} & -520 & - & - & - \\ 1,910 & 1,870 & 1,670 & 1,570 & 2,000 \\ 100 & 100 & 100 & 100 & 100\end{array}$

Recycling: None.

Import Sources (2016-19): Brazil, 86\%; and Russia, 14\%.

Tariff: Item

Crocidolite

Amosite

Chrysotile:

Crudes

Milled fibers, group 3 grades

Milled fibers, group 4 and 5 grades

Other

Other, asbestos
Number

2524.10.0000

2524.90.0010

2524.90.0030

2524.90 .0040

2524.90.0045

2524.90.0055

2524.90.0060
Normal Trade Relations

12-31-20

Free.

Free.

Free.

Free.

Free.

Free.

Free.

Depletion Allowance: 22\% (domestic), 10\% (foreign).

Government Stockpile: None.

Events, Trends, and Issues: Consumption of asbestos fiber in the United States has decreased during the past several decades, falling from a record high of 803,000 tons in 1973 to less than 800 tons in each year since 2016 . This decline has taken place as a result of health and liability issues associated with asbestos use, leading to the displacement of asbestos from traditional domestic markets by substitutes, alternative materials, and new technology. The chloralkali industry is the only remaining domestic consumer of asbestos in mineral form. Asbestos diaphragms are used in at least 11 chloralkali plants in the United States and account for about one-third of domestic chlorine production.

The Frank R. Lautenberg Chemical Safety for the 21st Century Act, which amended the Toxic Substances Control Act of 1976 (TSCA), was signed into law in 2016. The legislation granted the U.S. Environmental Protection Agency (EPA) greater authority to evaluate the hazards posed by new chemicals as well as those already in the marketplace. In 2020, the EPA issued the final risk evaluation report for chrysotile. The agency determined that the disposal, processing, and (or) use of chrysotile in the chloralkali industry and in all chrysotile-containing manufactured products that are currently imported into the United States (oil industry brake blocks, sheet and other gaskets, and some vehicle friction products) present unreasonable risks to human health. As required by the TSCA, the EPA will propose and finalize actions to address these risks by yearend 2022. The new regulations could include limitations or prohibitions on the disposal, distribution in commerce, manufacture, processing, or use of chrysotile. ${ }^{6}$ 
Estimated worldwide consumption of asbestos fiber decreased from approximately 2 million tons in 2010 to roughly 1 million tons per year in the past several years. Asbestos-cement products, such as corrugated roofing tiles, pipes, and wall panels, are expected to continue to be the leading global market for asbestos.

In Brazil, a comprehensive national ban on asbestos was enacted in November 2017. A judicial injunction allowed the only asbestos producer in the country to continue operating until February 2019, when production ceased. In July 2019, the government of the State of Goias passed a law that authorized the extraction of asbestos in the State for export purposes; ore processing was restarted in February 2020. The Supreme Federal Court of Brazil was expected to issue a ruling on the constitutionality of the Goias law but had not done so as of September 2020.

At the former King Mine in Mashava, Zimbabwe, asbestos production from old tailings commenced in 2019, and dewatering of the mining shafts was completed in March 2020. The company was in the process of selling real estate assets to fund the restart of mining operations and working to dewater an additional asbestos mine in Zvishvane. At full capacity, the King Mine was expected to produce 75,000 tons per year of asbestos.

\section{World Mine Production and Reserves:}

\begin{tabular}{lrrr} 
& \multicolumn{2}{c}{ Mine production } & Reserves $^{\mathbf{e}}$ \\
United States & $\underline{\mathbf{2 0 1 9}}$ & $\underline{\mathbf{2 0 2 0}}$ & Small \\
Brazil & 15,000 & 60,000 & $11,000,000$ \\
China & 150,000 & 100,000 & $95,000,000$ \\
Kazakhstan & 8211,000 & 210,000 & Large \\
Russia & 790,000 & 790,000 & $110,000,000$ \\
Zimbabwe & $\frac{2,500}{\text { Large }}$ \\
$\quad$ World total (rounded) & $\frac{8,000}{1,170,000}$ & $\frac{1,200,000}{\text { Large }}$
\end{tabular}

World Resources: ${ }^{7}$ Reliable evaluations of global asbestos resources have not been published recently, and available information was insufficient to make accurate estimates for many countries. However, world resources are large and more than adequate to meet anticipated demand in the foreseeable future. Resources in the United States are composed mostly of short-fiber asbestos for which use in asbestos-based products is more limited than long-fiber asbestos.

Substitutes: Numerous materials substitute for asbestos. Substitutes include calcium silicate, carbon fiber, cellulose fiber, ceramic fiber, glass fiber, steel fiber, wollastonite, and several organic fibers, such as aramid, polyethylene, polypropylene, and polytetrafluoroethylene. Several nonfibrous minerals or rocks, such as perlite, serpentine, silica, and talc, are also considered to be possible asbestos substitutes for products in which the reinforcement properties of fibers are not required. Membrane cells and mercury cells are alternatives to asbestos diaphragms used in the chloralkali industry.

\footnotetext{
eEstimated. - Zero.

${ }^{1}$ Imports of asbestos minerals (chrysotile). Additional imports were reported by the U.S. Census Bureau in some years, but existing asbestos bans and bill of lading information from a commercial trade database suggest that some shipments were misclassified.

${ }^{2}$ According to the U.S. Census Bureau, imports of chrysotile totaled 138 tons through July. Final 2020 imports may differ significantly from the provided estimate because chrysotile imports typically do not follow a predictable pattern throughout the year.

${ }^{3}$ Exports of asbestos reported by the U.S. Census Bureau were 587 tons in 2016, 143 tons in 2017, 235 tons in 2018, 2 tons in 2019 , and 0 tons through July in 2020. These shipments likely consisted of materials misclassified as asbestos, reexports, and (or) waste products because the United States no longer mines asbestos.

${ }^{4}$ To account for year-to-year fluctuations in asbestos imports owing to cycles of companies replenishing and drawing down stockpiles, consumption is estimated as a 5-year rolling average of imports for consumption. Information regarding the quantity of industry stocks was unavailable.

${ }^{5}$ Defined as imports - exports. The United States has been $100 \%$ import reliant since 2002 . All consumption of asbestos was from imports and a drawdown in unreported inventories.

${ }^{6}$ U.S. Environmental Protection Agency, 2020, Risk evaluation for asbestos, part I-Chrysotile asbestos: Washington, DC, EPA Document \# EPA-

740-R1-8012, December, $352 \mathrm{p}$.

${ }^{7}$ See Appendix $\mathrm{C}$ for resource and reserve definitions and information concerning data sources.

${ }^{8}$ Reported.
} 
BARITE

(Data in thousand metric tons unless otherwise noted)

Domestic Production and Use: Numerous domestic barite mining and processing facilities were idled in 2020, and only one company in Nevada mined barite. Production data were withheld to avoid disclosing company proprietary data. An estimated 1.3 million tons of barite (from domestic production and imports) was sold by crushers and grinders operating in seven States. Typically, more than $90 \%$ of the barite sold in the United States is used as a weighting agent in fluids used in the drilling of oil and natural gas wells. The majority of Nevada crude barite was ground in Nevada and then sold to companies drilling in the Central and Western United States. Because of the higher cost of rail and truck transportation compared to ocean freight, offshore drilling operations in the Gulf of Mexico and onshore drilling operations in other regions primarily used imported barite.

Barite also is used as a filler, extender, or weighting agent in products such as paints, plastics, and rubber. Some specific applications include use in automobile brake and clutch pads, automobile paint primer for metal protection and gloss, use as a weighting agent in rubber, and in the cement jacket around underwater petroleum pipelines. In the metal-casting industry, barite is part of the mold-release compounds. Because barite significantly blocks $\mathrm{x}$-ray and gamma-ray emissions, it is used as aggregate in high-density concrete for radiation shielding around x-ray units in hospitals, nuclear powerplants, and university nuclear research facilities. Ultrapure barite is used as a contrast medium in $\mathrm{x}$-ray and computed tomography examinations of the gastrointestinal tract.

\begin{tabular}{|c|c|c|c|c|c|}
\hline \multirow{2}{*}{\multicolumn{6}{|c|}{$\begin{array}{l}\text { Salient Statistics-United States: } \\
\text { Production: }\end{array}$}} \\
\hline & & & & & \\
\hline Sold or used, mine & 232 & 334 & 366 & 414 & W \\
\hline Ground and crushed 1 & 1,420 & 2,030 & 2,420 & 2,350 & 1,300 \\
\hline Imports for consumption ${ }^{2}$ & 1,260 & 2,470 & 2,460 & 2,550 & 1,500 \\
\hline Exports $^{3}$ & 78 & 116 & 67 & 38 & 38 \\
\hline Consumption, apparent (crude and ground) ${ }^{4}$ & 1,410 & 2,680 & 2,760 & 2,930 & W \\
\hline Price, average value, ground, ex-works, & & & & & \\
\hline dollars per tone & 187 & 179 & 176 & 179 & 180 \\
\hline Employment, mine and mill, number & 400 & 450 & 520 & 510 & 350 \\
\hline $\begin{array}{l}\text { Net import reliance }{ }^{5} \text { as a percentage of } \\
\text { apparent consumption }\end{array}$ & 84 & 88 & 87 & 86 & 75 \\
\hline
\end{tabular}

Recycling: None.

Import Sources (2016-19): China, 47\%; India, 20\%; Morocco, 14\%; Mexico, 12\%; and other, 7\%.

\section{Tariff: Item}

Ground barite

Crude barite

Barium compounds:

Barium oxide, hydroxide, and peroxide

Barium chloride

Barium sulfate, precipitated

Barium carbonate, precipitated

\section{Number}

2511.10.1000

2511.10 .5000

2816.40.2000

2827.39.4500

2833.27.0000

2836.60.0000
Normal Trade Relations 12-31-20

Free.

$\$ 1.25$ per metric ton.

$2 \%$ ad val.

$4.2 \%$ ad val.

$0.6 \%$ ad val.

$2.3 \%$ ad val.

Depletion Allowance: 14\% (domestic and foreign).

Government Stockpile: None. 
Events, Trends, and Issues: Domestic consumption of barite as measured by sales of ground barite decreased by an estimated $45 \%$ in 2020 . World mine production was estimated to have decreased by about $15 \%$. Decreased demand for barite mirrored global trends in oil consumption, which was adversely affected by travel restrictions owing to the global COVID-19 pandemic and reduced demand for transport fuels.

Because of barite's role in drilling for oil and gas, drilling rig counts have historically been a good barometer of barite consumption. In 2020, the total international monthly average rig count excluding the United States peaked in February at 1,334, but began to decline in March, and by the end of October had decreased by $45 \%$. Decreases in drilling activity were greatest in the United States, where the number of active rigs had already begun to decline in 2019. Between October 2019 and October 2020, the monthly average of active rigs decreased by 67\%. The largest decrease in rig activity was in the Permian Basin, where drilling activity has been concentrated in recent years. Drilling operations there are primarily supplied by imported barite ground in Texas. Sales of barite from plants in Texas were estimated to have decreased by more than $50 \%$. Only one company mined barite in Nevada in 2020 , and domestic production was estimated to have been at its lowest level since the 1930s.

The United States is typically the world's leading barite consumer, and a key trading partner for most of the world's leading barite-producing countries. Decreased U.S. imports coupled with reduced drilling activity in almost all regions likely contributed to decreased mine production in most barite-producing countries. The most notable exception was India, where decreased exports to the United States were estimated to have been offset by increased exports to the Middle East.

World Mine Production and Reserves: In response to concerns about dwindling global reserves of 4.2-specificgravity barite used by the oil and gas drilling industry, the American Petroleum Institute issued an alternate specification for 4.1-specific-gravity weighting agents in 2010. This has likely stimulated exploration and expansion of global barite resources. Estimated reserves data are included only if developed since the adoption of the 4.1-specificgravity standard. Reserves data for Iran and Pakistan were revised based on company and Government information.

United States

China

India

Iran

Kazakhstan

Laos

Mexico

Morocco

Pakistan

Russia

Turkey

Other countries World total (rounded)

\begin{tabular}{rr}
$\begin{array}{rr}\text { Mine production } \\
\text { 2019 }\end{array}$ & $\frac{\mathbf{2 0 2 0 ^ { \mathbf { e } }}}{W}$ \\
\hline 414 & $\mathrm{~W}$ \\
2,800 & 2,500 \\
2,000 & 2,000 \\
202 & 200 \\
597 & 600 \\
440 & 330 \\
384 & 280 \\
1,100 & 800 \\
110 & 110 \\
160 & 160 \\
250 & 130 \\
418 & 340 \\
\hline 8,870 & 77,500
\end{tabular}

Reserves $^{6}$
NA
36,000
51,000
100,000
85,000
$\mathrm{NA}$
$\mathrm{NA}$
$\mathrm{NA}$
40,000
12,000
35,000
30,000
390,000

World Resources: ${ }^{6}$ In the United States, identified resources of barite are estimated to be 150 million tons, and undiscovered resources contribute an additional 150 million tons. The world's barite resources in all categories are about 2 billion tons, but only about 740 million tons are identified resources. However, no known quantitative assessment of either U.S. or global barite resources has been conducted since the 1980s.

Substitutes: In the drilling mud market, alternatives to barite include celestite, ilmenite, iron ore, and synthetic hematite that is manufactured in Germany. None of these substitutes, however, has had a major impact on the barite drilling mud industry.

\footnotetext{
${ }^{e}$ Estimated. NA Not available. W Withheld to avoid disclosing company proprietary data.

${ }^{1}$ Imported and domestic barite, crushed and ground, sold or used by domestic grinding establishments.

${ }^{2}$ Includes data for the following Harmonized Tariff Schedule of the United States codes: 2511.10.1000, 2511.10.5000, and 2833.27.0000.

${ }^{3}$ Includes data for the following Schedule B codes: 2511.10.1000 and 2833.27.0000.

${ }^{4}$ Defined as sold or used by domestic mines + imports - exports.

${ }^{5}$ Defined as imports - exports.

${ }^{6}$ See Appendix $\mathrm{C}$ for resource and reserve definitions and information concerning data sources.

${ }^{7}$ Excludes U.S. production.
} 
Domestic Production and Use: In 2020, the reported quantity of bauxite consumed was estimated to be 4 million tons, slightly more than that reported in 2019 , with an estimated value of about $\$ 110$ million. About $79 \%$ of the bauxite was refined by the Bayer process for alumina or aluminum hydroxide, and the remainder went to products such as abrasives, cement, chemicals, proppants, and refractories, and as a slag adjuster in steel mills. Two domestic Bayer-process refineries with a combined alumina production capacity of 1.7 million tons per year produced an estimated 1.3 million tons in $2020,8 \%$ less than that in 2019 . About $56 \%$ of the alumina produced went to primary aluminum smelters, and the remainder went to nonmetallurgical products, such as abrasives, ceramics, chemicals, and refractories.

\section{Salient Statistics_United States:}

Bauxite:

Production, mine

Imports for consumption²

Exports $^{2}$

Stocks, industry, yearend ${ }^{2}$

Consumption:

$$
\text { Apparent }^{3}
$$

Reported

Price, average value, U.S. imports, free alongside ship (f.a.s.), dollars per ton

Net import reliance ${ }^{4}$ as a percentage of apparent consumption

Alumina:

Production, refinery ${ }^{5}$

Imports for consumption ${ }^{5}$

Exports $^{5}$

Stocks, industry, yearend ${ }^{5}$

Consumption, apparent ${ }^{3}$

Price, average value, U.S. imports (f.a.s.), dollars per ton

Net import reliance ${ }^{4}$ as a percentage of apparent consumption

$\begin{array}{rrrrr}\underline{\mathbf{2 0 1 6}} & \underline{\mathbf{2 0 1 7}} & \underline{\mathbf{2 0 1 8}} & \underline{\mathbf{2 0 1 9}} & \underline{\mathbf{2 0 2 0}} \\ \mathrm{W} & \mathrm{W} & \mathrm{W} & \mathrm{W} & \mathrm{W} \\ 6,050 & 4,360 & 3,980 & 4,310 & 3,900 \\ \mathbf{4 0} & 29 & 17 & 15 & 17 \\ 880 & 880 & 600 & 300 & 250 \\ \mathrm{~W} & \mathrm{~W} & \mathrm{~W} & \mathrm{~W} & \mathrm{~W} \\ 6,630 & 4,330 & 4,460 & 3,920 & 4,000 \\ & & & & \\ 28 & 31 & 31 & 32 & 27 \\ >75 & >75 & >75 & >75 & >75 \\ 2,360 & 1,430 & 1,570 & 1,410 & 1,300 \\ 1,140 & 1,330 & 1,530 & 1,930 & 1,300 \\ 1,330 & 481 & 288 & 200 & 130 \\ 320 & 264 & 275 & 275 & 200 \\ 2,130 & 2,340 & 2,800 & 3,140 & 2,550 \\ 362 & 486 & 592 & 472 & 370 \\ E & 38 & 44 & 55 & 49\end{array}$

Recycling: None.

Import Sources (2016-19): Bauxite:2 Jamaica, 37\%; Guyana, 21\%; Australia, 16\%; Brazil, 11\%; and other, 15\%. Alumina:5 Brazil, 47\%; Australia, 26\%; Jamaica, 12\%; Canada, 5\%; and other, 10\%.

\section{Tariff: Item}

Bauxite, calcined (refractory grade)

Bauxite, calcined (other)

Bauxite, crude dry (metallurgical grade)

Aluminum oxide (alumina)

Aluminum hydroxide
Number

2606.00 .0030

2606.00.0060

2606.00.0090

2818.20.0000

2818.30.0000
Normal Trade Relations 12-31-20

Free.

Free.

Free.

Free.

Free.

Depletion Allowance: $22 \%$ (domestic), 14\% (foreign).

Government Stockpile: None.

Events, Trends, and Issues: In 2020, two domestic alumina refineries produced alumina from imported bauxite. A 1.2-million-ton-per-year alumina refinery in Gramercy, LA, produced alumina for aluminum smelting and specialty-grade alumina. A 500,000-ton-per-year alumina refinery in Burnside, LA, produced specialty-grade alumina until it temporarily shut down in August, citing the COVID-19 pandemic for decreased demand. The average prices free alongside ship (f.a.s.) for U.S. imports for consumption of crude-dry bauxite and metallurgical-grade alumina during the first 8 months of 2020 were $\$ 27$ per ton, $16 \%$ less than that in the same period in 2019 , and $\$ 370$ per ton, $26 \%$ less than that in the same period of 2019 , respectively. 


\section{BAUXITE AND ALUMINA}

The COVID-19 pandemic was cited for decreased alumina production in China during January and February. Shortages of bauxite and caustic soda were reported at several inland alumina refineries as shipments from ports were delayed because of limited rail and truck service, but deliveries to ports were not interrputed. Alumina prices in China and other parts of the world increased owing to supply shortages and concerns about future availablity during the first quarter of the year. Coal deliveries to some refineries also slowed. Health officials in China imposed travel and work restrictions in parts of the country most affected by the COVID-19 virus to contain it, and in other regions, higher rates of absenteeism were attribuited to concerns about the virus. In March, many of the travel restrictions were lifted and alumina production restarted. Despite the temporary shutdowns, production in China increased.

In February, a 1.7-million-ton-per-year bauxite mine in Guyana shut down, citing civil unrest that interfered with mining operations and damaged mine property. The mine was a major supplier of refractory-grade bauxite. Bauxite and alumina production increased in Brazil compared with that in 2019 after the restart of capacity that was shut down for most of 2019. In August, a 9.9-million-ton-per-year bauxite mine in Brazil temporarily shut down production, citing damage to the pipeline used to transport bauxite to an alumina refinery. Routine inspection of the pipeline dicovered that it had deteriorated more than expected and it was shut down immediately for repair. The repair work was completed and the mine restarted production in October. Production from the 6.3-million-ton-per-year alumina refinery was decreased to $35 \%$ to $40 \%$ of its capacity, a rate of 2.2 to 2.5 million tons per year, until the pipeline was repaired.

World Alumina Refinery and Bauxite Mine Production and Bauxite Reserves: Reserves for Australia, Brazil, Malaysia, and Saudi Arabia were revised based on information from Government and other sources.

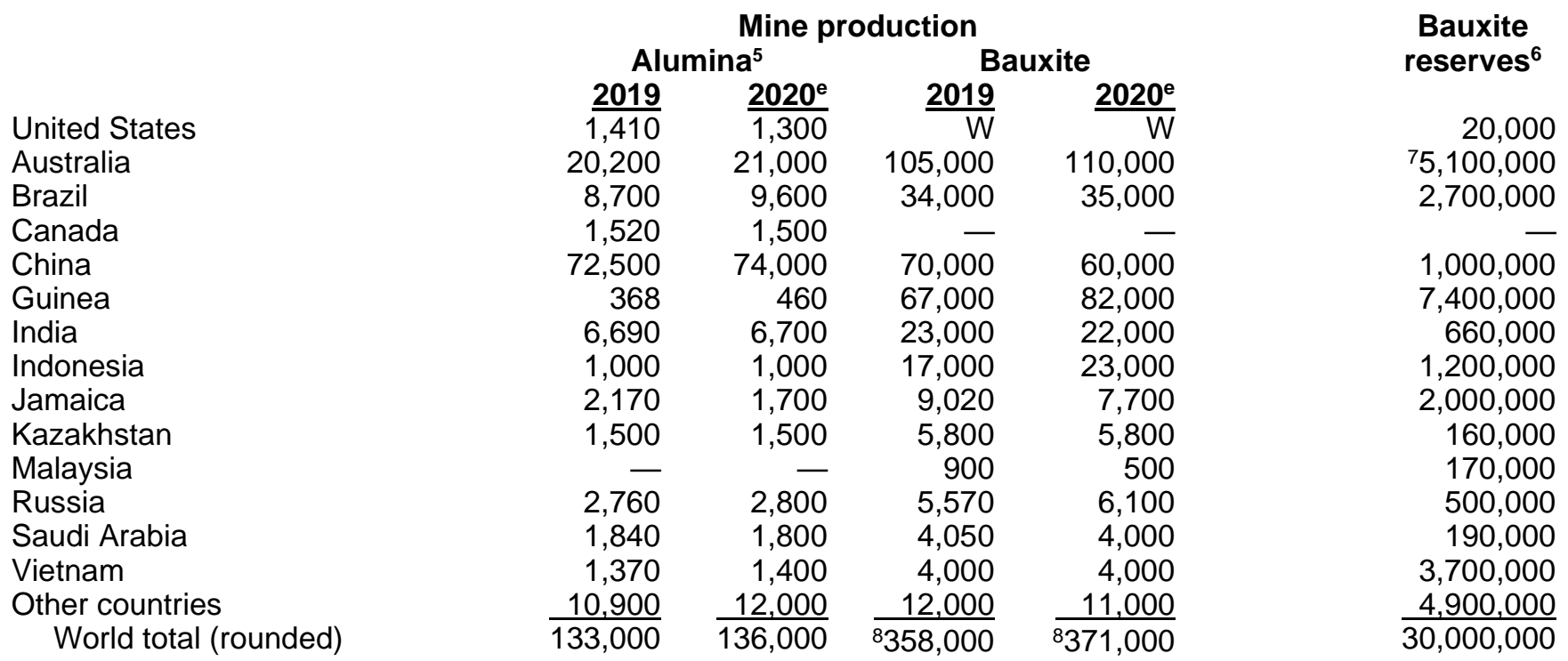

World Resources: ${ }^{6}$ Bauxite resources are estimated to be 55 billion to 75 billion tons, in Africa (32\%), Oceania (23\%), South America and the Caribbean (21\%), Asia (18\%), and elsewhere (6\%). Domestic resources of bauxite are inadequate to meet long-term U.S. demand, but the United States and most other major aluminum-producing countries have essentially inexhaustible subeconomic resources of aluminum in materials other than bauxite.

Substitutes: Bauxite is the only raw material used in the production of alumina on a commercial scale in the United States. Although currently not economically competitive with bauxite, vast resources of clay are technically feasible sources of alumina. Other raw materials, such as alunite, anorthosite, coal wastes, and oil shales, offer additional potential alumina sources. Synthetic mullite, produced from kaolin, bauxitic kaolin, kyanite, and sillimanite, substitutes for bauxite-based refractories. Silicon carbide and alumina-zirconia can substitute for abrasives but cost more.

\footnotetext{
eEstimated. E Net exporter. W Withheld to avoid disclosing company proprietary data. - Zero.

${ }^{1}$ See also Aluminum. As a general rule, 4 tons of dried bauxite is required to produce 2 tons of alumina, which, in turn, produces 1 ton of aluminum. ${ }^{2}$ Includes all forms of bauxite, expressed as dry equivalent weights.

${ }^{3}$ Defined as production + imports - exports + adjustments for industry stock changes.

${ }^{4}$ Defined as imports - exports + adjustments for industry stock changes.

${ }^{5}$ Calcined equivalent weights.

${ }^{6}$ See Appendix $C$ for resource and reserve definitions and information concerning data sources.

${ }^{7}$ For Australia, Joint Ore Reserves Committee-compliant reserves were 2.2 billion tons.

${ }^{8}$ Excludes U.S. production.
} 


\section{BERYLLIUM}

(Data in metric tons of beryllium content unless otherwise noted)

Domestic Production and Use: One company in Utah mined bertrandite ore and converted it, along with imported beryl, into beryllium hydroxide. Some of the beryllium hydroxide was shipped to the company's plant in Ohio, where it was converted into metal, oxide, and downstream beryllium-copper master alloy, and some was sold. Based on the estimated unit value for beryllium in imported beryllium-copper master alloy, beryllium apparent consumption of 170 tons was valued at about $\$ 110$ million. Based on sales revenues, approximately $24 \%$ of beryllium products were used in aerospace and defense applications; $23 \%$ in industrial components; $12 \%$ each in automotive electronics and telecommunications infrastructure; $11 \%$ in consumer electronics; $9 \%$ in energy applications; $1 \%$ in semiconductor applications; and $8 \%$ in other applications. Beryllium alloy strip and bulk products, the most common forms of processed beryllium, were used in all application areas. Most unalloyed beryllium metal and beryllium composite products were used in defense and scientific applications.

\begin{tabular}{|c|c|c|c|c|c|}
\hline Salient Statistics-United States: & $\underline{2016}$ & $\underline{2017}$ & $\underline{2018}$ & $\underline{2019}$ & $\underline{2020^{\mathrm{e}}}$ \\
\hline Production, mine shipments & $\overline{155}$ & $\overline{150}$ & $\overline{165}$ & $\overline{160}$ & $\overline{150}$ \\
\hline Imports for consumption ${ }^{1}$ & 68 & 60 & 67 & 49 & 45 \\
\hline Exports $^{2}$ & 34 & 38 & 30 & 37 & 30 \\
\hline Shipments from Government stockpile ${ }^{3}$ & 3 & 2 & - & - & 3 \\
\hline \multicolumn{6}{|l|}{ Consumption: } \\
\hline Apparent ${ }^{4}$ & 182 & 179 & 202 & 167 & 170 \\
\hline Reported, ore & 160 & 160 & 170 & 160 & 150 \\
\hline \multicolumn{6}{|l|}{ Price, annual average value, beryllium-copper master } \\
\hline alloy, ${ }^{5}$ dollars per kilogram of contained beryllium & 510 & 640 & 590 & 620 & 620 \\
\hline Stocks, ore, consumer, yearend & 35 & 30 & 30 & 35 & 35 \\
\hline \multicolumn{6}{|l|}{ Net import reliance 6 as a percentage } \\
\hline of apparent consumption & 15 & 16 & 18 & 4 & 11 \\
\hline
\end{tabular}

Recycling: Beryllium was recovered from new scrap generated during the manufacture of beryllium products and from old scrap. Detailed data on the quantities of beryllium recycled are not available but may account for as much as $20 \%$ to $25 \%$ of total beryllium consumption. The leading U.S. beryllium producer established a comprehensive recycling program for all of its beryllium products, recovering approximately $40 \%$ of the beryllium content of the new and old beryllium alloy scrap.

Import Sources (2016-19): ${ }^{1}$ Kazakhstan, 43\%; Japan, 16\%; Brazil, 12\%; Latvia, 7\%; and other, 22\%.

Tariff: Item

Beryllium ores and concentrates

Beryllium oxide and hydroxide

Beryllium-copper master alloy

Beryllium-copper plates, sheets, and strip:

Thickness of 5 millimeters $(\mathrm{mm})$ or more

Thickness of less than $5 \mathrm{~mm}$ : Width of $500 \mathrm{~mm}$ or more

Beryllium:

Width of less than $500 \mathrm{~mm}$

Unwrought, including powders

Waste and scrap

Other
Number

2617.90 .0030

2825.90.1000

7405.00 .6030

7409.90 .1030

7409.90 .5030

7409.90 .9030

8112.12 .0000

8112.13 .0000

8112.19 .0000
Normal Trade Relations

12-31-20

Free.

$3.7 \%$ ad val.

Free.

$3.0 \%$ ad val.

$1.7 \%$ ad val.

$3.0 \%$ ad val.

$8.5 \%$ ad val.

Free.

$5.5 \%$ ad val.

Depletion Allowance: 22\% (domestic), 14\% (foreign).

Government Stockpile: ${ }^{7}$ The Defense Logistics Agency Strategic Materials had a goal of retaining 47 tons of beryllium metal in the National Defense Stockpile.

$\begin{array}{lccc}\text { Material } & \begin{array}{c}\text { Inventory } \\ \text { as of 9-30-20 }\end{array} & \begin{array}{c}\text { FY 2020 } \\ \text { acquisitions }\end{array} & \begin{array}{c}\text { Potential } \\ \text { disposals }\end{array} \\ \text { Beryl ore (gross weight) } & 1 & - & - \\ \text { Metal (all types) } & 64 & - & 7 \\ \text { Structured powder } & 7 & - & -\end{array}$

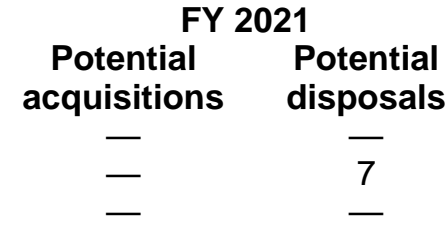

Prepared by Brian W. Jaskula [(703) 648-4908, bjaskula@usgs.gov] 
Events, Trends, and Issues: Domestic beryllium consumption in 2020 was estimated to be about $6 \%$ lower than that of 2019. Imports of beryl concentrate have decreased substantially since 2015. During the first 6 months of 2020, the leading U.S. beryllium producer reported that net sales of its beryllium alloy strip and bulk products and beryllium metal and composite products were $24 \%$ lower than those during the first 6 months of 2019. Value-added sales of beryllium products decreased primarily in the aerospace and defense, consumer electronics, energy, and telecommunications markets. The impact of the COVID-19 pandemic was reported to have been a substantial factor in the reduction of customer demand.

Because of the toxic nature of beryllium, various international, national, and State guidelines and regulations have been established regarding beryllium in air, water, and other media. Industry is required to carefully control the quantity of beryllium dust, fumes, and mists in the workplace.

\section{World Mine Production and Reserves:}

\begin{tabular}{|c|c|c|c|}
\hline & \multicolumn{2}{|c|}{ Mine production ${ }^{8,9}$} & \multirow[t]{2}{*}{ Reserves $^{10}$} \\
\hline & 2019 & $2020^{e}$ & \\
\hline United States & 160 & 150 & The United States has very little beryl that \\
\hline Brazil & e3 & 3 & can be economically hand sorted from \\
\hline China & 70 & 70 & pegmatite deposits. The Spor Mountain \\
\hline Madagascar & $e_{1}$ & 1 & area in Utah, an epithermal deposit, \\
\hline Mozambique & e15 & 15 & contains a large bertrandite resource, \\
\hline Nigeria & $e_{1}$ & 1 & which is being mined. Proven and probable \\
\hline Rwanda & $e_{1}$ & 1 & bertrandite reserves in Utah total about \\
\hline Uganda & $\overline{\overline{0}}$ & $\frac{1}{20}$ & 20,000 tons of contained beryllium. World \\
\hline World total (rounded) & $\overline{250}$ & $\overline{240}$ & beryllium reserves are not available. \\
\hline
\end{tabular}

World Resources: ${ }^{10}$ The world's identified resources of beryllium have been estimated to be more than 100,000 tons. About $60 \%$ of these resources are in the United States; by tonnage, the Spor Mountain area in Utah, the McCullough Butte area in Nevada, the Black Hills area in South Dakota, the Sierra Blanca area in Texas, the Seward Peninsula in Alaska, and the Gold Hill area in Utah account for most of the total.

Substitutes: Because the cost of beryllium is high compared with that of other materials, it is used in applications in which its properties are crucial. In some applications, certain metal matrix or organic composites, high-strength grades of aluminum, pyrolytic graphite, silicon carbide, steel, or titanium may be substituted for beryllium metal or beryllium composites. Copper alloys containing nickel and silicon, tin, titanium, or other alloying elements or phosphor bronze alloys (copper-tin-phosphorus) may be substituted for beryllium-copper alloys, but these substitutions can result in substantially reduced performance. Aluminum nitride or boron nitride may be substituted for beryllium oxide.

\footnotetext{
eEstimated. - Zero.

${ }^{1}$ Includes estimated beryllium content of imported ores and concentrates, oxide and hydroxide, unwrought metal (including powders), beryllium articles, waste and scrap, beryllium-copper master alloy, and beryllium-copper plates, sheets, and strip.

${ }^{2}$ Includes estimated beryllium content of exported unwrought metal (including powders), beryllium articles, and waste and scrap.

${ }^{3}$ Change in total inventory level from prior yearend inventory.

${ }^{4}$ Defined as production + imports - exports + adjustments for Government and industry stock changes.

${ }^{5}$ Calculated from gross weight and customs value of imports; beryllium content estimated to be $4 \%$. Rounded to two significant figures.

${ }^{6}$ Defined as imports - exports + adjustments for Government and industry stock changes.

${ }^{7}$ See Appendix $B$ for definitions.

${ }^{8}$ In addition to the countries listed, Kazakhstan and Portugal may have produced beryl ore, but available information was inadequate to make reliable estimates of output. Other nations that produced gemstone beryl ore may also have produced some industrial beryl ore.

${ }^{9}$ Based on a beryllium content of $4 \%$ from bertrandite and beryl sources.

${ }^{10}$ See Appendix $\mathrm{C}$ for resource and reserve definitions and information concerning data sources.
} 


\section{BISMUTH}

(Data in metric tons gross weight unless otherwise noted)

Domestic Production and Use: The United States ceased production of primary refined bismuth in 1997 and is highly import dependent for its supply. Bismuth is contained in some lead ores mined domestically. However, the last domestic primary lead smelter closed at yearend 2013; since then all lead concentrates have been exported for smelting.

About three-fifths of domestic bismuth consumption was for chemicals used in cosmetic, industrial, laboratory, and pharmaceutical applications. Bismuth use in pharmaceuticals included bismuth salicylate (the active ingredient in over-the-counter stomach remedies) and other compounds used to treat burns, intestinal disorders, and stomach ulcers. Bismuth is also used in the manufacture of ceramic glazes, crystalware, and pearlescent pigments.

Bismuth has a wide variety of metallurgical applications, including use as an additive to enhance metallurgical quality in the foundry industry and as a nontoxic replacement for lead in brass, free-machining steels, and solders. The use of bismuth in brass for pipe fittings, fixtures, and water meters increased after 2014 when the definition of "lead-free" under the Safe Drinking Water Act was modified to reduce the maximum lead content of "lead-free" pipes and plumbing fixtures to $0.25 \%$ from $8 \%$. The melting point of bismuth is relatively low at 271 degrees Celsius, and it is an important component of various fusible alloys, some of which have melting points below that of boiling water. These bismuth-containing alloys can be used in holding devices for grinding optical lenses, as a temporary filler to prevent damage to tubes in bending operations, as a triggering mechanism for fire sprinklers, and in other applications in which a low melting point is ideal. Bismuth-tellurium-oxide alloy film paste is used in the manufacture of semiconductor devices.

\section{Salient Statistics_United States:}

Production:

Refinery

Secondary (scrap) ${ }^{e}$

Imports for consumption, metal, alloys, and scrap

Exports, metal, alloys, and scrap

Consumption:

Apparent ${ }^{1}$

Reported

Price, average, ${ }^{2}$ dollars per pound

Stocks, yearend, consumer

Net import reliance ${ }^{3}$ as a percentage of apparent consumption

$\begin{array}{rrrrr}\underline{\mathbf{2 0 1 6}} & \underline{\mathbf{2 0 1 7}} & \underline{\mathbf{2 0 1 8}} & \underline{\mathbf{2 0 1 9}} & \underline{\mathbf{2 0 2 0 ^ { e }}} \\ \overline{-} & - & - & - & - \\ 80 & 80 & 80 & 80 & 80 \\ 2,190 & 2,820 & 2,510 & 2,300 & 2,000 \\ 431 & 392 & 653 & 636 & 670 \\ 1,780 & 2,530 & 2,080 & 1,650 & 1,400 \\ 651 & 694 & 570 & 548 & 500 \\ 4.53 & 4.93 & 4.64 & 3.19 & 2.70 \\ 513 & 489 & 346 & 443 & 500 \\ 96 & 97 & 96 & 95 & 94\end{array}$

Recycling: Bismuth-containing alloy scrap was recycled and thought to compose less than $5 \%$ of U.S. bismuth apparent consumption.

Import Sources (2016-19): China, 69\%; the Republic of Korea, 10\%; Mexico, 8\%; Belgium, 5\%; and other, 8\%.

Tariff: Item

Bismuth and articles thereof, including waste and scrap
Number

Normal Trade Relations $\underline{12-31-20}$

8106.00 .0000

Free.

Depletion Allowance: $22 \%$ (domestic), 14\% (foreign).

Government Stockpile: None. 
Events, Trends, and Issues: Bismuth prices continued a significant downward trend that began in 2014, when the annual average domestic dealer price was $\$ 11.14$ per pound. Bismuth was one of the metals held in significant quantities by the defunct Fanya Nonferrous Metals Exchange in China, which closed in 2015. In December 2019, 19,200 tons of Fanya Metal Exchange bismuth stocks were sold, which was likely the cause for the price slump at the end of that year. In 2020, it was announced that the Fanya bismuth stocks would be used internally for manufacturing, which relieved downward pricing pressures seen through the first half of 2020 , resulting in a slight increase in the third quarter.

The global COVID-19 pandemic affected the global economy and trade during the first of half of 2020; in particular, China during the first quarter and the United States in the second quarter. Economies in both countries have showed some rebound in subsequent quarters. Trade data through August 2020 were mixed when compared with the same period in 2019-while bismuth exports increased, imports for consumption decreased.

World Refinery Production and Reserves: Available information was inadequate to make reliable estimates for mine production and reserves data.

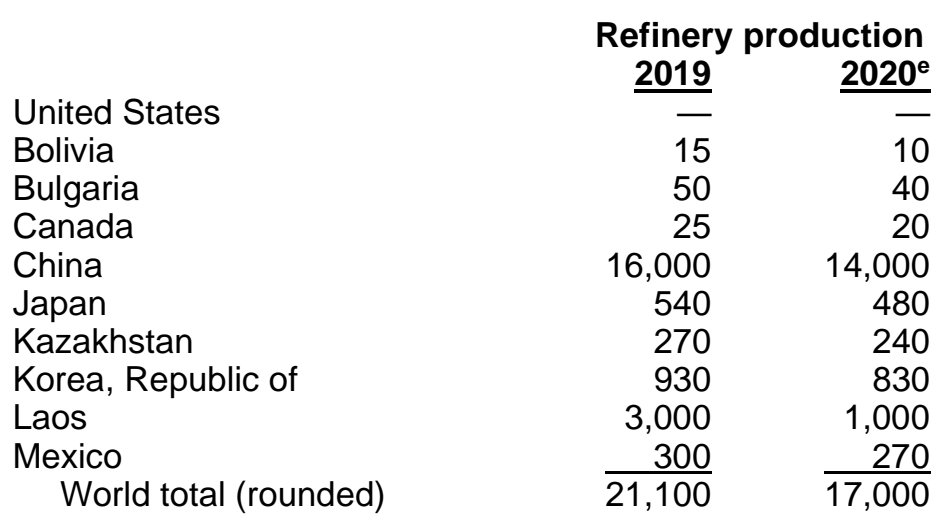

World Resources: ${ }^{4}$ World reserves of bismuth are usually estimated based on the bismuth content of lead resources because bismuth production is most often a byproduct of processing lead ores. In China and Vietnam, bismuth production is a byproduct or coproduct of tungsten and other metal ore processing. Bismuth minerals rarely occur in sufficient quantities to be mined as principal products; the Tasna Mine in Bolivia and a mine in China are the only mines where bismuth has been the primary product. The Tasna Mine has been inactive since 1996.

Substitutes: Bismuth compounds can be replaced in pharmaceutical applications by alumina, antibiotics, calcium carbonate, and magnesia. Titanium dioxide-coated mica flakes and fish-scale extracts are substitutes in pigment uses. Cadmium, indium, lead, and tin can partially replace bismuth in low-temperature solders. Resins can replace bismuth alloys for holding metal shapes during machining, and glycerine-filled glass bulbs can replace bismuth alloys in triggering devices for fire sprinklers. Free-machining alloys can contain lead, selenium, or tellurium as a replacement for bismuth. Bismuth is an environmentally friendly substitute for lead in plumbing and many other applications, including fishing weights, hunting ammunition, lubricating greases, and soldering alloys.

\footnotetext{
eEstimated. - Zero.

${ }^{1}$ Defined as secondary production + imports - exports + adjustments for industry stock changes.

${ }^{2}$ Price is based on 99.99\%-purity metal at warehouse (Rotterdam) in minimum lots of 1 ton. Source: American Metal Market (Fastmarkets AMM).

${ }^{3}$ Defined as imports - exports + adjustments for industry stock changes.

${ }^{4}$ See Appendix $C$ for resource and reserve definitions and information concerning data sources.
} 


\section{BORON}

(Data in thousand metric tons unless otherwise noted)

Domestic Production and Use: Two companies in southern California produced borates in 2020, and most of the boron products consumed in the United States were manufactured domestically. Estimated boron production decreased in 2020 compared with 2019 production levels. U.S. boron production and consumption data were withheld to avoid disclosing company proprietary data. The leading boron producer mined borate ores, which contain the minerals kernite, tincal, and ulexite, by open pit methods and operated associated compound plants. Kernite was used to produce boric acid, tincal was used to produce sodium borate, and ulexite was used as a primary ingredient in the manufacture of a variety of specialty glasses and ceramics. A second company produced borates from brines extracted through solution-mining techniques. Boron minerals and chemicals were principally consumed in the northcentral and eastern United States. In 2020, the glass and ceramics industries remained the leading domestic users of boron products, accounting for an estimated $80 \%$ of total borates consumption. Boron also was used as a component in abrasives, cleaning products, insecticides, and insulation and in the production of semiconductors.

\begin{tabular}{|c|c|c|c|c|c|}
\hline$\frac{\text { Salient Statistics_United States: }}{\text { Production }}$ & $\frac{2016}{W}$ & $\frac{2017}{W}$ & $\frac{2018}{W}$ & $\frac{2019}{W}$ & $\frac{2020^{e}}{W}$ \\
\hline \multicolumn{6}{|l|}{ Imports for consumption: } \\
\hline Refined borax & 173 & 158 & 133 & 161 & 180 \\
\hline Boric acid & 46 & 40 & 51 & 41 & 50 \\
\hline Colemanite (calcium borates) & 35 & 58 & 73 & 42 & 30 \\
\hline Ulexite (sodium borates) & 43 & 24 & 34 & 38 & 30 \\
\hline \multicolumn{6}{|l|}{ Exports: } \\
\hline Boric acid & 238 & 216 & 251 & 251 & 250 \\
\hline Refined borax & 581 & 572 & 610 & 598 & 640 \\
\hline Consumption, apparent ${ }^{1}$ & W & W & W & W & W \\
\hline \multicolumn{6}{|l|}{ Price, average value of imports, } \\
\hline cost, insurance, and freight, dollars per ton & 352 & 392 & 404 & 373 & 384 \\
\hline Employment, number & 1,340 & 1,300 & 1,350 & 1,350 & 1330 \\
\hline $\begin{array}{l}\text { Net import reliance }{ }^{2} \text { as a percentage of } \\
\text { apparent consumption }\end{array}$ & $\mathrm{E}$ & $E$ & $\mathrm{E}$ & $\mathrm{E}$ & $\mathrm{E}$ \\
\hline
\end{tabular}

Recycling: Insignificant.

Import Sources (2016-19): All forms: Turkey, 84\%; Bolivia, 8\%; Chile, 3\%; and other, 5\%.

Tariff: Item

Natural borates:

Sodium (ulexite)

Calcium (colemanite)

Boric acids

Borates, refined borax:

Anhydrous

Non-anhydrous
Number

2528.00.0005

2528.00.0010

2810.00.0000

2840.11 .0000

2840.19 .0000

\section{Normal Trade Relations} 12-31-20

Free.

Free.

$1.5 \%$ ad val.

$0.3 \%$ ad val. $0.1 \%$ ad val.

Depletion Allowance: Borax, 14\% (domestic and foreign).

Government Stockpile: None. 
Events, Trends, and Issues: Elemental boron is a metalloid with limited commercial applications. Although the term "boron" is commonly referenced, it does not occur in nature in an elemental state. Boron combines with oxygen and other elements to form boric acid, or inorganic salts called borates. Boron compounds, chiefly borates, are commercially important; therefore, boron products are priced and sold based on their boric oxide $\left(\mathrm{B}_{2} \mathrm{O}_{3}\right)$ content, varying by ore and compound and by the absence or presence of calcium and sodium. The four borate mineralscolemanite, kernite, tincal, and ulexite-account for $90 \%$ of the borate minerals used by industry worldwide. Although borates were used in more than 300 applications, more than three-quarters of world consumption was used in ceramics, detergents, fertilizers, and glass.

China, India, the Netherlands, Malaysia, and Indonesia, in decreasing order of tonnage, are the countries that imported the largest quantities of refined borates from the United States in 2020. Because China has low-grade boron reserves and demand for boron is anticipated to rise in that country, imports to China from Chile, Russia, Turkey, and the United States were expected to remain steady during the next several years.

Continued investment in new borate refineries and the continued rise in demand were expected to fuel growth in world production for the next few years. Two Australia-based mine developers confirmed that production of highquality boron products would be possible from their projects in California and Nevada. These companies have the potential to become substantial boron producers when they are fully developed. The project in California was expected to begin production in 2021, and the project in Nevada was expected to begin production in 2023.

\section{World Production and Reserves:}

United States

Argentina, crude ore

Bolivia, ulexite

Chile, ulexite

China, boric oxide equivalent

Germany, compounds

Peru, crude borates

Russia, datolite ore

Turkey, refined borates World total ${ }^{4}$

$\begin{array}{rr}\begin{array}{c}\text { Production-All forms } \\ \mathbf{2 0 1 9}\end{array} & \begin{array}{r}\mathbf{2 0 2 0 ^ { e }} \\ W\end{array} \\ \mathbf{W} & 70 \\ 200 & 200 \\ 400 & 400 \\ 250 & 250 \\ 120 & 120 \\ 111 & 110 \\ 80 & 80 \\ \frac{2,400}{X X} & \frac{2,400}{X X}\end{array}$

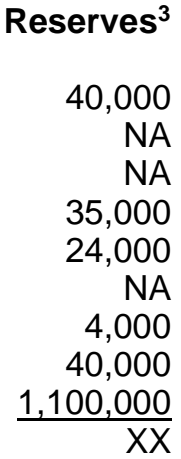

World Resources: ${ }^{3}$ Deposits of borates are associated with volcanic activity and arid climates, with the largest economically viable deposits in the Mojave Desert of the United States, the Alpide belt in southern Asia, and the Andean belt of South America. U.S. deposits consist primarily of tincal, kernite, and borates contained in brines, and to a lesser extent, ulexite and colemanite. About $70 \%$ of all deposits in Turkey are colemanite, primarily used in the production of heat-resistant glass. At current levels of consumption, world resources are adequate for the foreseeable future.

Substitutes: The substitution of other materials for boron is possible in detergents, enamels, insulation, and soaps. Sodium percarbonate can replace borates in detergents and requires lower temperatures to undergo hydrolysis, which is an environmental consideration. Some enamels can use other glass-producing substances, such as phosphates. Insulation substitutes include cellulose, foams, and mineral wools. In soaps, sodium and potassium salts of fatty acids can act as cleaning and emulsifying agents.

\footnotetext{
eEstimated. E Net exporter. NA Not available. W Withheld to avoid disclosing company proprietary data. XX Not applicable.

${ }^{1}$ Defined as production + imports - exports.

${ }^{2}$ Defined as imports - exports.

${ }^{3}$ See Appendix $\mathrm{C}$ for resource and reserve definitions and information concerning data sources.

${ }^{4}$ World totals cannot be calculated because production and reserves are not reported in a consistent manner by all countries.
} 


\section{BROMINE}

(Data in metric tons of bromine content unless otherwise noted)

Domestic Production and Use: Bromine was recovered from underground brines by two companies in Arkansas. Bromine is one of the leading mineral commodities, in terms of value, produced in Arkansas. The two bromine companies in the United States account for a large percentage of world production capacity.

The leading global applications of bromine are for the production of brominated flame retardants and intermediates and industrial uses. Bromine compounds are also used in a variety of other applications, including drilling fluids and industrial water treatment. U.S. apparent consumption of bromine in 2020 was estimated to be less than that in 2019.

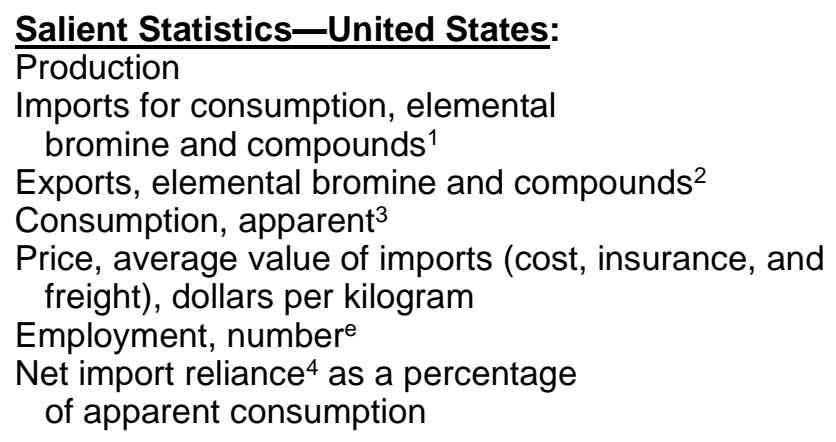

$\begin{array}{rrrrr}\frac{\mathbf{2 0 1 6}}{W} & \frac{\mathbf{2 0 1 7}}{W} & \frac{\mathbf{2 0 1 8}}{W} & \frac{\mathbf{2 0 1 9}}{W} & \frac{\mathbf{2 0 2 0}}{W} \\ 58,400 & 52,700 & 56,200 & 56,300 & 43,000 \\ 28,300 & 32,600 & 21,900 & 29,300 & 35,000 \\ W & W & W & W & W \\ 2.19 & 2.30 & 2.21 & 2.31 & 2.40 \\ 1,050 & 1,050 & 1,050 & 1,050 & 1,050 \\ <25 & <25 & <25 & <25 & <25\end{array}$

Recycling: Some bromide solutions were recycled to obtain elemental bromine and to prevent the solutions from being disposed of as hazardous waste. For example, hydrogen bromide is emitted as a byproduct in many organic reactions. This byproduct waste can be recycled with virgin bromine brines and used as a source of bromine production. Bromine contained in plastics can be incinerated as solid organic waste, and the bromine can be recovered.

Import Sources (2016-19): ${ }^{5}$ Israel, 80\%; Jordan, 11\%; China, 6\%; and other, 3\%.

Tariff: Item

Number

Bromine

Hydrobromic acid

Potassium or sodium bromide

Ammonium, calcium, or zinc bromide

Potassium bromate

Sodium bromate

Ethylene dibromide

Methyl bromide

Dibromoneopentyl glycol

Tetrabromobisphenol A

Decabromodiphenyl and octabromodiphenyl oxide
2801.30 .2000

2811.19.3000

2827.51 .0000

2827.59.2500

2829.90.0500

2829.90.2500

2903.31.0000

2903.39.1520

2905.59.3000

2908.19.2500

2909.30.0700

Normal Trade Relations
$\mathbf{1 2 - 3 1 - 2 0}$
5.5\% ad val.
Free.
Free.
Free.
Free.
Free.
5.4\% ad val.
Free.
Free.
$5.5 \%$ ad val.
$5.5 \%$ ad val.

Depletion Allowance: Brine wells, 5\% (domestic and foreign).

Government Stockpile: None. 
Events, Trends, and Issues: The United States maintained its position as one of the leading bromine producers in the world. China, Israel, and Jordan also are major producers of elemental bromine. In 2020, U.S. net imports of bromine and bromine compounds decreased compared with those in 2019. The average import value of bromine and bromine compounds increased by about $4 \%$ in 2020 compared with that in 2019. The leading source of imports of bromine and bromide compounds (gross weight) in 2020 was Israel. Together, the leading imported bromine products in terms of both gross weight and bromine content were bromides and bromide oxides of ammonium, calcium, or zinc and bromides of sodium or potassium (about 90\%). Reported exports of methyl bromide were revised for 2017 through 2019 by the U.S. Census Bureau.

Global consumption of bromine and bromine compounds decreased in 2020. Owing to the global COVID-19 pandemic, the demand for flame retardants and clear brine fluids, leading applications for bromine and bromine compounds, decreased. This decreased demand was attributed to declining consumer spending in the automotive, electronic, and construction industries (which use brominated flame retardants in their products), as well declining demand for drilling fluids by the oil- and gas-well-drilling industries, which use clear brine fluids in oil- and gas-well drilling. Although the values of U.S.-imported bromine and bromine compounds increased in 2020 compared with those in 2019 , domestic selling prices were reported to have decreased slightly.

Some bromine facilities in Shandong Province, China, restarted production in the first half of 2020 following completion of rectifications and improvements required to meet new environmental regulations initiated by the Government of China in late 2017. However, production volumes and selling prices remained low.

\section{World Production and Reserves:}

\begin{tabular}{|c|c|c|c|}
\hline \multirow{2}{*}{\multicolumn{3}{|c|}{ Production }} & \multirow[t]{2}{*}{ Reserves $^{6}$} \\
\hline & & & \\
\hline United States & $\mathrm{W}$ & W & $11,000,000$ \\
\hline Azerbaijan & - & - & 300,000 \\
\hline China & 64,000 & 63,000 & NA \\
\hline India & 10,000 & 10,000 & NA \\
\hline Israel & 180,000 & 180,000 & Large \\
\hline Japan & 20,000 & 20,000 & NA \\
\hline Jordan & 150,000 & 150,000 & Large \\
\hline Ukraine & 4,500 & 4,500 & NA \\
\hline World total (rounded) & 7429,000 & $\overline{7430,000}$ & Large \\
\hline
\end{tabular}

World Resources: ${ }^{6}$ Bromine is found principally in seawater, evaporitic (salt) lakes, and underground brines associated with petroleum deposits. The Dead Sea, in the Middle East, is estimated to contain 1 billion tons of bromine. Seawater contains about 65 parts per million bromine, or an estimated 100 trillion tons. Bromine is also recovered from seawater as a coproduct during evaporation to produce salt.

Substitutes: Chlorine and iodine may be substituted for bromine in a few chemical reactions and for sanitation purposes. There are no comparable substitutes for bromine in various oil- and gas-well completion and packer applications. Because plastics have a low ignition temperature, aluminum hydroxide, magnesium hydroxide, organic chlorine compounds, and phosphorus compounds can be substituted for bromine as fire retardants in some uses.

\footnotetext{
eEstimated. NA Not available. W Withheld to avoid disclosing company proprietary data. - Zero.

${ }^{1}$ Includes data for the Harmonized Tariff Schedule of the United States codes shown in the "Tariff" section.

${ }^{2}$ Includes data for the following Schedule B codes: 2801.30.2000, 2827.51.0000, 2827.59.0000, 2903.31.0000, and

2903.39.1520.

${ }^{3}$ Defined as production (sold or used) + imports - exports.

${ }^{4}$ Defined as imports - exports.

${ }^{5}$ Calculated using the gross weight of imports.

${ }^{6}$ See Appendix $C$ for resource and reserve definitions and information concerning data sources.

${ }^{7}$ Excludes U.S. production.
} 


\section{CADMIUM}

(Data in metric tons of cadmium content unless otherwise noted)

Domestic Production and Use: Two companies in the United States produced refined cadmium in 2020. One company, operating in Tennessee, recovered primary refined cadmium as a byproduct of zinc leaching from roasted sulfide concentrates. The other company, operating in Ohio, recovered secondary cadmium metal from spent nickel-cadmium (NiCd) batteries. Domestic production and consumption of cadmium were withheld to avoid disclosing company proprietary data. Cadmium metal and compounds are mainly consumed for alloys, coatings, NiCd batteries, pigments, and plastic stabilizers. For the past 5 years, the United States has been a net importer of unwrought cadmium metal and cadmium metal powders and a net exporter of wrought cadmium products and cadmium pigments.

\section{Salient Statistics_-United States:}

Production, refined 1

Imports for consumption:

Unwrought cadmium and powders

Wrought cadmium and other articles (gross weight)

Cadmium waste and scrap (gross weight)

Exports:

Unwrought cadmium and powders

Wrought cadmium and other articles (gross weight)

Cadmium waste and scrap (gross weight)

Consumption, reported, refined

Price, metal, annual average,$^{3}$ dollars per kilogram

Stocks, yearend, producer and distributor

Net import reliance ${ }^{4}$ as a percentage of apparent

consumption

$\begin{array}{rrrrr}\frac{2016}{W} & \frac{2017}{W} & \frac{\mathbf{2 0 1 8}}{W} & \frac{\mathbf{2 0 1 9}}{W} & \frac{\mathbf{2 0 2 0}}{W} \\ 240 & 274 & 273 & 385 & 190 \\ (2) & 2 & 1 & 20 & 3 \\ 52 & 20 & 20 & 86 & 70 \\ 157 & 223 & 41 & 32 & 6 \\ 371 & 205 & 99 & 84 & 440 \\ 12 & \left({ }^{2}\right) & (2) & 6 & (2) \\ W & W & W & W & W \\ 1.34 & 1.75 & 2.89 & 2.67 & 2.30 \\ W & W & W & W & W \\ <25 & <25 & <50 & <50 & <50\end{array}$

Recycling: Secondary cadmium is mainly recovered from spent consumer and industrial NiCd batteries. Other waste and scrap from which cadmium can be recycled includes copper-cadmium alloy scrap, some complex nonferrous alloy scrap, cadmium-containing dust from electric arc furnaces, and cadmium telluride (CdTe) solar panels.

Import Sources (2016-19): ${ }^{5}$ Australia, 23\%; China, 19\%; Canada, 17\%; Germany, 13\%; and other, 28\%.

Tariff: Item

Cadmium oxide

Cadmium sulfide

Pigments and preparations based

on cadmium compounds

Unwrought cadmium and powders

Cadmium waste and scrap

Wrought cadmium and other articles
Number

2825.90.7500

2830.90 .2000

3206.49.6010

8107.20 .0000

8107.30 .0000

8107.90 .0000

\section{Normal Trade Relations 12-31-20 Free.}

$3.1 \%$ ad val.

$3.1 \%$ ad val.

Free.

Free.

$4.4 \%$ ad val.

Depletion Allowance: 22\% (domestic), 14\% (foreign).

\section{Government Stockpile: None.}

Events, Trends, and Issues: Most of the world's primary cadmium metal was produced in Asia, and leading global producers, in descending order of production, were China and the Republic of Korea, followed by Canada and Japan with approximately equal production. A smaller amount of secondary cadmium metal was recovered from recycling $\mathrm{NiCd}$ batteries. In India, a major primary cadmium plant was under construction that would have a capacity of 2,600 tons per year. Although detailed data on the global consumption of primary cadmium were not available, NiCd battery production was thought to have continued to account for most global cadmium consumption. Other end uses for cadmium and cadmium compounds included alloys, anticorrosive coatings, pigments, polyvinyl chloride (PVC) stabilizers, and semiconductors for solar cells and for radiation-detecting imaging equipment. A new use for cadmium being developed in 2020 was for extremely precise cadmium-based optical lattice clocks; these would operate at room temperature, unlike those currently in use that required cryogenic cooling. 


\section{CADMIUM}

The average monthly cadmium price began 2020 averaging $\$ 2.63$ per kilogram in January and trended downward to about $\$ 2.08$ per kilogram in August. The decrease could be attributed to decreasing demand in India, in large part owing to the COVID-19 pandemic affecting economic activity, including a lockdown in India that extended from March 25 to May 3. As a major consumer of cadmium, India was an important driver behind cadmium prices in the spot market.

In 2020, a major United States-based CdTe thin-film solar-cell producer reached its full production rate after completing a new facility in Ohio, increasing the company's U.S. CdTe solar-cell manufacturing capacity to 1.8 gigawatts per year. A second company entered the market in 2020 with a 100-megawatt-per-year facility, also in Ohio. Innovation continued in the NiCd battery industry. A new line of compact cadmium batteries designed to compete with conventional lead-acid batteries in remote locations was introduced for manufacture in the United States. The batteries were lighter than the lead-acid batteries, had a longer expected service life of more than 20 years, and would use the existing lead-acid battery charging system, allowing a direct replacement.

\section{World Refinery Production and Reserves:}

$\begin{array}{lrr} & \text { Refinery } & \text { production } \\ \text { United States } & \mathbf{2 0 1 9}^{1} & \underline{\mathbf{2 0 2 0}^{\mathrm{e}}} \\ \text { Canada } & 1,803 & 1,800 \\ \text { China } & 8,200 & 8,200 \\ \text { Japan } & 2,000 & 1,800 \\ \text { Kazakhstan } & 1,500 & 1,500 \\ \text { Korea, Republic of } & 4,400 & 3,000 \\ \text { Mexico } & 1,395 & 1,300 \\ \text { Netherlands } & 1,100 & 1,100 \\ \text { Peru } & 772 & 700 \\ \text { Russia } & 900 & 900 \\ \text { Other countries } & 2,320 & 2,300 \\ \quad \text { World total (rounded) }{ }^{7} & 24,400 & 23,000\end{array}$

\section{Reserves $^{6}$}

Quantitative estimates of reserves are not available. The cadmium content of typical zinc ores averages about $0.03 \%$. See the Zinc chapter for zinc reserves.

World Resources: ${ }^{6}$ Cadmium is generally recovered from zinc ores and concentrates. Sphalerite, the most economically significant zinc ore mineral, commonly contains minor amounts of cadmium, which shares certain similar chemical properties with zinc and often substitutes for zinc in the sphalerite crystal lattice. The cadmium mineral greenockite is frequently associated with weathered sphalerite and wurtzite.

Substitutes: Lithium-ion and nickel-metal hydride batteries can replace NiCd batteries in many applications. Except where the surface characteristics of a coating are critical (for example, fasteners for aircraft), coatings of zinc, zinc-nickel, aluminum, or tin can be substituted for cadmium in many plating applications. Cerium sulfide is used as a replacement for cadmium pigments, mostly in plastics. Barium-zinc or calcium-zinc stabilizers can replace barium-cadmium stabilizers in flexible PVC applications. Amorphous silicon and copper-indium-gallium-selenide photovoltaic cells compete with cadmium telluride in the thin-film solar-cell market. Research efforts continued to advance new thin-film technology based on perovskite material as a potential substitute.

\footnotetext{
eEstimated. W Withheld to avoid disclosing company proprietary data.

${ }^{1}$ Cadmium metal produced as a byproduct of zinc refining plus metal from recycling.

${ }^{2}$ Less than $1 / 2$ unit.

${ }^{3}$ Average free market price for $99.95 \%$ purity in 10-ton lots; cost, insurance, and freight; global ports. Source: Metal Bulletin.

${ }^{4}$ Defined as imports of unwrought metal and metal powders - exports of unwrought metal and metal powders + adjustments for industry stock changes.

${ }^{5}$ Includes data for the following Harmonized Tariff Schedule of the United States code: 8107.20.0000.

${ }^{6}$ See Appendix $C$ for resource and reserve definitions and information concerning data sources.

${ }^{7}$ Excludes U.S. production.
} 


\section{CEMENT}

(Data in thousand metric tons unless otherwise noted)

Domestic Production and Use: In 2020, U.S. portland cement production increased slightly to an estimated 87 million tons, and masonry cement production decreased slightly to 2.3 million tons. Cement was produced at 96 plants in 34 States, and at 2 plants in Puerto Rico. Texas, Missouri, California, and Florida were, in descending order of production, the four leading cement-producing States and accounted for nearly $45 \%$ of U.S. production. Overall, the U.S. cement industry's growth continued to be constrained by closed or idle plants, underutilized capacity at others, production disruptions from plant upgrades, and relatively inexpensive imports. In 2020, shipments of cement were essentially unchanged from those of 2019 and were valued at $\$ 12.7$ billion. In 2020 , it was estimated that $70 \%$ to $75 \%$ of sales were to ready-mixed concrete producers, $10 \%$ to concrete product manufactures, $8 \%$ to $10 \%$ to contractors, and $5 \%$ to $12 \%$ to other customer types.

\section{Salient Statistics_United States: ${ }^{1}$ \\ Production: \\ Portland and masonry cement ${ }^{2}$ \\ Clinker}

Shipments to final customers, includes exports

Imports for consumption:

Hydraulic cement

Clinker

Exports of hydraulic cement and clinker

Consumption, apparent ${ }^{3}$

Price, average mill value, dollars per ton

Stocks, cement, yearend

Employment, mine and mill, numbere

Net import reliance ${ }^{4}$ as a percentage of apparent consumption

$\begin{array}{rrrrr}\underline{\mathbf{2 0 1 6}} & \underline{\mathbf{2 0 1 7}} & \underline{\mathbf{2 0 1 8}} & \underline{\mathbf{2 0 1 9}} & \underline{\underline{\mathbf{2 0 2 0}}} \\ 84,695 & 86,356 & 86,368 & { }^{\mathrm{e}} 88,000 & 89,000 \\ 75,633 & 76,678 & 77,112 & 79,000 & 79,000 \\ 95,397 & 97,935 & 99,419 & 103,000 & 103,000 \\ & & & & \\ 11,742 & 12,288 & 13,764 & 14,690 & 15,000 \\ 1,496 & 1,209 & 967 & 1,160 & 1,400 \\ 1,097 & 1,035 & 919 & 1,002 & 1,000 \\ 95,150 & 97,160 & 98,500 & \mathrm{e} 103,000 & 102,000 \\ 111 & 117 & 121 & \mathrm{e} 123 & 124 \\ 7,420 & 7,870 & 8,580 & \mathrm{e} 7,140 & 7,800 \\ 12,700 & 12,500 & 12,300 & 12,500 & 12,500 \\ & & & & \\ 13 & 13 & 14 & 14 & 15\end{array}$

Recycling: Cement is not recycled, but significant quantities of concrete are recycled for use as a construction aggregate. Cement kilns can use waste fuels, recycled cement kiln dust, and recycled raw materials such as slags and fly ash. Various secondary materials can be incorporated as supplementary cementitious materials (SCMs) in blended cements and in the cement paste in concrete.

Import Sources (2016-19): ${ }^{5}$ Canada, 33\%; Turkey, 16\%; Greece, 15\%; China, 12\%; and other, 24\%.

Tariff: Item

Cement clinker

White portland cement

Other portland cement

Aluminous cement

Other hydraulic cement
Number

2523.10.0000

2523.21.0000

2523.29.0000

2523.30.0000

2523.90.0000
Normal Trade Relations 12-31-20

Free.

Free.

Free.

Free.

Free.

Depletion Allowance: Not applicable. Certain raw materials for cement production have depletion allowances.

\section{Government Stockpile: None.}

Events, Trends, and Issues: In 2020, production of cement was temporarily idled in many countries and localities in response to national lockdowns imposed to limit the spread of the global COVID-19 pandemic. The duration of the lockdowns and the return to full production following the restart of operations, varied by geographic region.

Disruptions to construction activities corresponded with reduced cement demand, and some regions experienced increased fuel and freight costs. Additionally, several planned cement plant openings and expansions were delayed. 


\section{CEMENT}

Despite the economic disruptions owing to the COVID-19 pandemic, the value of total construction put in place in the United States increased by about $4 \%$ during the first 9 months of 2020 compared with that of the same period in 2019. Residential construction spending increased more than nonresidential construction spending. A cement plant in New York was idled in April because of decreased demand resulting from restrictions put in place to mitigate the spread of the virus. However, the U.S. cement industry has shown no prolonged or widespread negative effects from the pandemic. The leading cement-consuming States continued to be Texas, California, and Florida, in descending order by tonnage. Company merger-and-acquisition activity continued in 2020 , with the completion of the sale of a cement company in Kentucky. In 2019, one European cement company entered into an agreement to purchase a Mexican cement company's plant in Pennsylvania and the transaction was still pending regulatory approval in 2020.

Cement plant upgrades were announced at cement plants in Alabama and Texas. Several minor upgrades were ongoing at some other domestic plants, and upgrades were also announced for a few cement terminals. However, one cement company delayed work on an upgrade to one of its plants in Indiana. Another company secured its final air permit for a new cement plant in Georgia. Numerous companies made announcements aligned with the industry's commitment to sustainability, such as new product lines, renewable energy plans, decarbonization research initiatives, and other innovations. Many plants have installed emissions-reduction equipment to comply with the 2010 National Emissions Standards for Hazardous Air Pollutants (NESHAP). It remains possible that some kilns could be shut, idled, or used in a reduced capacity to comply with NESHAP, which would constrain U.S. clinker capacity.

\section{World Production and Capacity:}

United States (includes Puerto Rico)
Brazil
China
Egypt
India
Indonesia
Iran
Japan
Korea, Republic of
Russia
Turkey
Vietnam
Other countries (rounded)
$\quad$ World total (rounded)

\begin{tabular}{rr}
\multicolumn{2}{c}{ Cement productione } \\
$\mathbf{2 0 1 9}$ & $\underline{\mathbf{2 0 2 0}}$ \\
89,000 & 90,000 \\
54,000 & 57,000 \\
$2,300,000$ & $2,200,000$ \\
47,000 & 50,000 \\
340,000 & 340,000 \\
70,000 & 73,000 \\
60,000 & 60,000 \\
53,000 & 53,000 \\
50,000 & 50,000 \\
56,000 & 56,000 \\
57,000 & 66,000 \\
97,000 & 96,000 \\
880,000 & 890,000 \\
\hline $4,100,000$ & $4,100,000$
\end{tabular}

\begin{tabular}{rr}
\multicolumn{2}{c}{ Clinker capacity } \\
$\mathbf{2 0 1 9}$ & $\underline{\mathbf{2 0 2 0}}$ \\
103,000 & 103,000 \\
60,000 & 60,000 \\
$1,970,000$ & $1,970,000$ \\
48,000 & 48,000 \\
280,000 & 280,000 \\
78,000 & 78,000 \\
81,000 & 81,000 \\
53,000 & 53,000 \\
50,000 & 50,000 \\
80,000 & 80,000 \\
92,000 & 92,000 \\
90,000 & 90,000 \\
720,000 & 720,000 \\
\hline $3,700,000$ & $3,700,000$
\end{tabular}

World Resources: Although reserves at individual plants are subject to exhaustion, limestone and other cement raw materials are geologically widespread and abundant, and overall shortages are unlikely in the future.

Substitutes: Most portland cement is used to make concrete, mortars, or stuccos, and competes in the construction sector with concrete substitutes, such as aluminum, asphalt, clay brick, fiberglass, glass, gypsum (plaster), steel, stone, and wood. Certain materials, especially fly ash and ground granulated blast furnace slag, develop good hydraulic cementitious properties by reacting with lime, such as that released by the hydration of portland cement. Where readily available (including as imports), these SCMs are increasingly being used as partial substitutes for portland cement in many concrete applications and are components of finished blended cements.

\footnotetext{
eEstimated.

${ }^{1}$ Portland plus masonry cement unless otherwise noted; excludes Puerto Rico unless otherwise noted.

${ }^{2}$ Includes cement made from imported clinker.

${ }^{3}$ Defined as production of cement (including from imported clinker) + imports (excluding clinker) - exports + adjustments for stock changes.

${ }^{4}$ Defined as imports (cement and clinker) - exports.

${ }^{5} \mathrm{Hydraulic}$ cement and clinker; includes imports into Puerto Rico.
} 


\section{CESIUM}

(Data in metric tons of cesium oxide unless otherwise noted)

Domestic Production and Use: In 2020, no cesium was mined domestically, and the United States was $100 \%$ import reliant for cesium minerals. Pollucite, mainly found in association with lithium-rich, lepidolite-bearing or petalitebearing zoned granite pegmatites, is the principal cesium ore mineral. Cesium minerals are used as feedstocks to produce a variety of cesium compounds and cesium metal. The primary application for cesium, by gross weight, is in cesium formate brines used for high-pressure, high-temperature well drilling for oil and gas production and exploration. With the exception of cesium formate, cesium is used in relatively small-scale applications, using only a few grams for most applications. Owing to the lack of global availability of cesium, many applications have used mineral substitutes and the use in any particular application may no longer be viable.

Cesium metal is used in the production of cesium compounds and potentially in photoelectric cells. Cesium bromide is used in infrared detectors, optics, photoelectric cells, scintillation counters, and spectrophotometers. Cesium carbonate is used in the alkylation of organic compounds and in energy conversion devices, such as fuel cells, magneto-hydrodynamic generators, and polymer solar cells. Cesium chloride is used in analytical chemistry applications as a reagent, in high-temperature solders, as an intermediate in cesium metal production, in isopycnic centrifugation, as a radioisotope in nuclear medicine, as an insect repellent in agricultural applications, and in specialty glasses. Cesium hydroxide is used as an electrolyte in alkaline storage batteries. Cesium iodide is used in fluoroscopy equipment-Fourier-transform infrared spectrometers-as the input phosphor of x-ray image intensifier tubes, and in scintillators. Cesium nitrate is used as a colorant and oxidizer in the pyrotechnic industry, in petroleum cracking, in scintillation counters, and in x-ray phosphors. Cesium sulfates are soluble in water and are thought to be used primarily in water treatment, fuel cells, and to improve optical quality for scientific instruments.

Cesium isotopes, which are obtained as a byproduct in nuclear fission or formed from other isotopes, such as barium-131, are used in electronic, medical, metallurgical, and research applications. Cesium isotopes are used as an atomic resonance frequency standard in atomic clocks, playing a vital role in aircraft guidance systems, global positioning satellites, and internet and cellular telephone transmissions. Cesium clocks monitor the cycles of microwave radiation emitted by cesium's electrons and use these cycles as a time reference. Owing to the high accuracy of the cesium atomic clock, the international definition of 1 second is based on the cesium atom. The U.S. civilian time and frequency standard is based on a cesium fountain clock at the National Institute of Standards and Technology in Boulder, CO. The U.S. military frequency standard, the United States Naval Observatory timescale, is based on 48 weighted atomic clocks, including 25 cesium fountain clocks.

A company in Richland, WA, produced a range of cesium-131 medical products for treatment of various cancers. Cesium-137 may be used in industrial gauges, in mining and geophysical instruments, and for sterilization of food, sewage, and surgical equipment. Because of the danger posed by the radiological properties of cesium-137, efforts to find substitutes in its applications continued.

Salient Statistics_United States: Consumption, import, and export data for cesium have not been available since the late 1980s. Because cesium metal is not traded in commercial quantities, a market price is unavailable. Only a few thousand kilograms of cesium chemicals are thought to be consumed in the United States every year. The United States was 100\% import reliant for its cesium needs.

In 2020 , one company offered 1-gram ampoules of $99.8 \%$ (metal basis) cesium for $\$ 65.20$, a $3.5 \%$ increase from $\$ 63.00$ in 2019, and 99.98\% (metal basis) cesium for $\$ 84.70$, a $4.4 \%$ increase from $\$ 81.10$ in 2019 .

In 2020 , the prices for 50 grams of $99.9 \%$ (metal basis) cesium acetate, cesium bromide, cesium carbonate, cesium chloride, and cesium iodide were $\$ 120.00, \$ 72.90, \$ 104.40, \$ 107.20$, and $\$ 121.20$, respectively, with increases ranging from $1.4 \%$ to $3.6 \%$ from prices in 2019 . The price for a cesium-plasma standard solution (10,000 micrograms per milliliter) was $\$ 77.80$ for 50 milliliters and $\$ 119.00$ for 100 milliliters, and the price for 25 grams of cesium formate, $98 \%$ (metal basis), was $\$ 41.40$.

Recycling: Cesium formate brines are typically rented by oil and gas exploration clients. After completion of the well, the used cesium formate brine is returned and reprocessed for subsequent drilling operations. Cesium formate brines are recycled, recovering nearly $85 \%$ of the brines for recycling to be reprocessed for further use. 


\section{CESIUM}

Import Sources (2016-19): No reliable data have been available to determine the source of cesium ore imported by the United States since 1988. Prior to 2016, Canada was thought to be the primary supplier of cesium ore.

\section{Tariff: Item}

Alkali metals, other

Chlorides, other

Bromides, other

lodides, other

Sulfates, other

Nitrates, other

Carbonates, other

Cesium-137, other

\section{Number}

2805.19.9000

2827.39.9000

2827.59.5100

2827.60.5100

2833.29.5100

2834.29.5100

2836.99.5000

2844.40 .0021

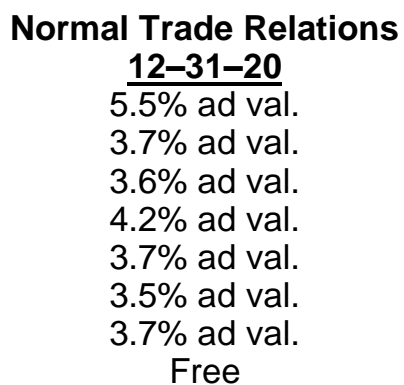

Depletion Allowance: 14\% (domestic and foreign).

Government Stockpile: None.

Events, Trends, and Issues: Domestic cesium occurrences will likely remain uneconomic unless market conditions change. No known human health issues are associated with naturally occurring cesium, and its use has minimal environmental impact. Manufactured radioactive isotopes of cesium have been known to cause adverse health effects. Certain cesium compounds may be toxic if consumed. Food that has been irradiated using the radioisotope cesium-137 has been found to be safe by the U.S. Food and Drug Administration.

During 2020, no primary cesium mine production was reported globally. Mine production of cesium from all countries, excluding China, ceased within the past two decades. Production in Namibia ceased in the early 2000s, followed by the Tanco Mine in Canada shutting down and later being sold after a mine collapse in 2015. The Bikita Mine in Zimbabwe was depleted of pollucite ore reserves in 2018, and the Sinclair Mine in Australia completed the mining and shipments of all economically recoverable pollucite ore in 2019.

A company completed an updated mineral resource estimate for the Karibib project in Namibia, reporting 8.9 million metric tons of measured and indicated resources containing $0.23 \%$ rubidium and 302 parts per million cesium. Located in the Karibib Pegmatite Belt, lithium would be the primary product, with cesium, potassium, and rubidium as potential byproducts.

World Mine Production and Reserves: ${ }^{1}$ There were no official sources for cesium production data in 2020. Cesium reserves are, therefore, estimated based on the occurrence of pollucite, a primary lithium-cesium-rubidium mineral. Most pollucite contains $5 \%$ to $32 \%$ cesium oxide. No reliable data are available to determine reserves for specific countries; however, Australia, Canada, China, Namibia, and Zimbabwe were thought to have reserves totaling less than 200,000 tons.

World Resources: ${ }^{1}$ Cesium is associated with lithium-bearing pegmatites worldwide, and cesium resources have been identified in Australia, Canada, Namibia, the United States, and Zimbabwe. In the United States, pollucite occurs in pegmatites in Alaska, Maine, and South Dakota. Lower concentrations occur in brines in Chile and China and in geothermal systems in Germany, India, and Tibet. China was thought to have cesium-rich deposits of geyserite, lepidolite, and pollucite, with concentrations highest in Yichun, Jiangxi Province, although no resource, reserve, or production estimates were available.

Substitutes: Cesium and rubidium can be used interchangeably in many applications because they have similar physical properties and atomic radii. Cesium, however, is more electropositive than rubidium, making it a preferred material for some applications. However, rubidium is mined from similar deposits, in relatively smaller quantities, as a byproduct of cesium production in pegmatites and as a byproduct of lithium production from lepidolite (hard-rock) mining and processing, making it no more readily available than cesium.

${ }^{1}$ See Appendix $\mathrm{C}$ for resource and reserve definitions and information concerning data sources. 


\section{CHROMIUM}

(Data in thousand metric tons of chromium content unless otherwise noted)

Domestic Production and Use: In 2020, the United States was expected to consume 4\% of world chromite ore production in various forms of imported materials, such as chromite ore, chromium chemicals, chromium ferroalloys, chromium metal, and stainless steel. Imported chromite ore was consumed by one chemical firm to produce chromium chemicals. Stainless-steel and heat-resisting-steel producers were the leading consumers of ferrochromium. Stainless steels and superalloys require the addition of chromium via ferrochromium or chromiumcontaining scrap. The value of chromium material consumption was expected to be about $\$ 600$ million in 2020 , as measured by the value of net imports, excluding stainless steel, and was an increase from \$304 million in 2019.

\begin{tabular}{|c|c|c|c|c|c|}
\hline Salient Statistics-United States: & $\underline{2016}$ & $\underline{2017}$ & $\underline{2018}$ & $\underline{2019}$ & $2020^{e}$ \\
\hline \multicolumn{6}{|l|}{ Production: } \\
\hline Mine & - & - & - & - & - \\
\hline Recycling ${ }^{1}$ & 156 & 156 & 143 & 142 & 130 \\
\hline Imports for consumption & 548 & 634 & 651 & 530 & 490 \\
\hline Exports & 253 & 255 & 211 & 157 & 110 \\
\hline Shipments from Government stockpile & 5 & 8 & 4 & 4 & 4 \\
\hline \multicolumn{6}{|l|}{ Consumption (includes recycling): } \\
\hline Reported & 462 & 523 & 465 & 489 & 440 \\
\hline Apparent $^{2}$ & 455 & 545 & 587 & 519 & 510 \\
\hline \multicolumn{6}{|c|}{ Price, average annual value of imports, dollars per ton: } \\
\hline Chromite ore (gross weight) & 198 & 259 & 279 & 248 & 180 \\
\hline Ferrochromium (chromium content) ${ }^{3}$ & 1,750 & 2,547 & 2,549 & 2,094 & 1,800 \\
\hline Chromium metal (gross weight) & 9,939 & 9,675 & 11,344 & 10,393 & 7,900 \\
\hline Stocks, consumer, yearend & 9 & 6 & 5 & 5 & 5 \\
\hline $\begin{array}{l}\text { Net import reliance }{ }^{4} \text { as a percentage of } \\
\text { apparent consumption }\end{array}$ & 66 & 71 & 76 & 73 & 75 \\
\hline
\end{tabular}

Recycling: In 2020, recycled chromium (contained in reported stainless steel scrap receipts) accounted for $25 \%$ of apparent consumption.

Import Sources (2016-19): Chromite (mineral): South Africa, 99\%; and Canada, 1\%. Chromium-containing scrap: 5 Canada, 50\%; Mexico, 42\%; and other, 8\%. Chromium (primary metal): 6 South Africa, 36\%; Kazakhstan, $10 \%$; Russia, 7\%; and other, 47\%. Total imports: South Africa, 39\%; Kazakhstan, 8\%; Mexico, 6\%; Russia, 6\%; and other, $41 \%$.

\section{Tariff: ${ }^{7}$ Item}

Chromium ores and concentrates:

$\mathrm{Cr}_{2} \mathrm{O}_{3}$ not more than $40 \%$

$\mathrm{Cr}_{2} \mathrm{O}_{3}$ more than $40 \%$ and less than $46 \%$

$\mathrm{Cr}_{2} \mathrm{O}_{3}$ more than or equal to $46 \%$

Chromium oxides and hydroxides:

Chromium trioxide

Other

Sodium dichromate

Potassium dichromate

Other chromates and dichromates

Carbides of chromium

Ferrochromium:

Carbon more than $4 \%$

Carbon more than 3\%

Carbon more than $0.5 \%$

Other

Ferrosilicon chromium

Chromium metal:

Unwrought, powder

Waste and scrap

Other

\section{Number}

2610.00 .0020

2610.00 .0040

2610.00.0060

2819.10.0000

2819.90.0000

2841.30.0000

2841.50 .1000

2841.50 .9100

2849.90.2000

7202.41 .0000

7202.49 .1000

7202.49 .5010

7202.49 .5090

7202.50 .0000

8112.21 .0000

8112.22 .0000

8112.29 .0000

\section{Normal Trade Relations} 12-31-20

Free.

Free.

Free.

$3.7 \%$ ad val.

$3.7 \%$ ad val.

$2.4 \%$ ad val.

$1.5 \%$ ad val.

$3.1 \%$ ad val.

$4.2 \%$ ad val.

$1.9 \%$ ad val.

$1.9 \%$ ad val.

$3.1 \%$ ad val.

$3.1 \%$ ad val.

$10 \%$ ad val.

$3 \%$ ad val.

Free.

$3 \%$ ad val.

Depletion Allowance: 22\% (domestic), 14\% (foreign).

Prepared by Ruth F. Schulte [(703) 648-4963, rschulte@usgs.gov] 


\section{Government Stockpile: ${ }^{8}$}

$\begin{array}{lccccc} & \begin{array}{c}\text { Inventory } \\ \text { In of 9-30-20 }\end{array} & \begin{array}{c}\text { Potential } \\ \text { acquisitions }\end{array} & \begin{array}{c}\text { Potential } \\ \text { disposals }\end{array} & \begin{array}{c}\text { FY 2021 } \\ \text { Potential } \\ \text { acquisitions }\end{array} & \begin{array}{c}\text { Potential } \\ \text { disposals }\end{array} \\ \begin{array}{l}\text { Material } \\ \text { Ferrochromium: }\end{array} \quad 33.9 & - & 1021.3 & - & 1021.8 \\ \quad \text { High-carbon } & 26.8 & - & - & - & - \\ \quad \text { Low-carbon } & 3.83 & - & 0.181 & - & 0.454 \\ \text { Chromium metal } & \text { as } & - & & - & \end{array}$

Events, Trends, and Issues: Chromium is consumed in the form of ferrochromium to produce stainless steel. South Africa was the leading chromite ore producer. Increased labor costs, increased costs for electricity, an unreliable supply of electricity, temporary mine closures related to the COVID-19 pandemic, and challenges related to deep level mining could affect production in South Africa in 2020.

China was the leading chromium-consuming country. China was also the leading stainless-steel- and ferrochromiumproducing country. South Africa was the second-leading country in ferrochromium production. Ferrochromium production is electrical-energy intensive, so constrained electrical power supply and rising costs for electricity in South Africa, as well as temporary closures related to the COVID-19 pandemic, could also affect ferrochromium production.

From September 2019 to September 2020, the monthly average high-carbon ferrochromium price increased by $12 \%$. Prices of chromium metal decreased by $18 \%$ in September 2020 compared with the monthly average price in September 2019 and were below the prior low in February 2007.

\section{World Mine Production and Reserves:}

\begin{tabular}{|c|c|c|}
\hline & $\begin{array}{cr}\text { Mine production } & 11 \\
2019 & 2020^{\mathrm{e}}\end{array}$ & $\begin{array}{c}\text { Reserves }^{12} \\
\text { (shipping grade) }^{13}\end{array}$ \\
\hline United States & - $=$ & 620 \\
\hline Finland & 2,415 & 13,000 \\
\hline India & 4,139 & 100,000 \\
\hline Kazakhstan & 6,700 & 230,000 \\
\hline South Africa & 16,395 & 200,000 \\
\hline Turkey & 10,000 & 26,000 \\
\hline Other countries & 5,110 & NA \\
\hline World total (rounded) & $\overline{44,800}$ & $\overline{570,000}$ \\
\hline
\end{tabular}

World Resources: $:^{12}$ World resources are greater than 12 billion tons of shipping-grade chromite, sufficient to meet conceivable demand for centuries. World chromium resources are heavily geographically concentrated (95\%) in Kazakhstan and southern Africa; United States chromium resources are mostly in the Stillwater Complex in Montana.

Substitutes: Chromium has no substitute in stainless steel, the leading end use, or in superalloys, the major strategic end use. Chromium-containing scrap can substitute for ferrochromium in some metallurgical uses.

\footnotetext{
${ }^{e}$ Estimated. NA Not available. - Zero.

${ }^{1}$ Recycling production is based on reported receipts of all types of stainless-steel scrap.

${ }^{2}$ Defined as production (from mines and recycling) + imports - exports + adjustments for Government and industry stock changes.

${ }^{3}$ Excludes ferrochromium silicon.

${ }^{4}$ Defined as imports - exports + adjustments for Government and industry stock changes.

${ }^{5}$ Includes chromium metal scrap and stainless-steel scrap.

${ }^{6}$ Includes chromium metal, ferrochromium, and stainless steel.

${ }^{7}$ In addition to the tariff items listed, certain imported chromium materials (see 26 U.S.C. sec. 4661, 4662, and 4672) are subject to excise tax.

${ }^{8}$ See Appendix $B$ for definitions.

${ }^{9}$ Units are thousand tons of material by gross weight.

${ }^{10} \mathrm{High}$-carbon and low-carbon ferrochromium, combined.

${ }^{11}$ Mine production units are thousand tons, gross weight, of marketable chromite ore.

${ }^{12}$ See Appendix $\mathrm{C}$ for resource and reserve definitions and information concerning data sources.

${ }^{13}$ Reserves units are thousand tons of shipping-grade chromite ore, which is deposit quantity and grade normalized to $45 \% \mathrm{Cr}_{2} \mathrm{O}_{3}$, except for the United States where grade is normalized to $7 \% \mathrm{Cr}_{2} \mathrm{O}_{3}$ and Finland where grade is normalized to $26 \% \mathrm{Cr}_{2} \mathrm{O}_{3}$.
} 


\section{CLAYS}

(Data in thousand metric tons unless otherwise noted)

Domestic Production and Use: Production of clays (sold or used) in the United States was estimated to be 25 million tons valued at $\$ 1.6$ billion in 2020 , with about 125 companies operating clay and shale mines in 39 States. The leading 20 firms produced approximately $64 \%$ of the U.S. tonnage and $84 \%$ of the value for all types of clay. Principal uses for specific clays were estimated to be as follows: ball clay-55\% floor and wall tile and $18 \%$ sanitaryware; bentonite-49\% pet waste absorbents and $23 \%$ drilling mud; common clay-43\% brick, $30 \%$ lightweight aggregate, and $23 \%$ cement; fire clay- $77 \%$ heavy clay and lightweight aggregates products (for example, brick, cement, and concrete) and $23 \%$ refractory products and miscellaneous uses; fuller's earth $-81 \%$ absorbents (includes oil and grease absorbents, pet waste absorbents and miscellaneous absorbents); and kaolin-49\% paper coating and filling, $10 \%$ refractory products, and $8 \%$ paint.

Exports of clay and shale were estimated have decreased by 15\% in 2020 after decreasing slightly in 2019. In 2020, the United States exported an estimated 760,000 tons of bentonite mainly for pet waste absorbent, drilling mud, foundry sand bond, and iron ore pelletizing applications, with Canada, Japan, and China being the leading destinations. About 1.9 million tons of kaolin were exported mainly as a paper coating and filler; a component in ceramic bodies; and fillers and extenders in paint, plastic, and rubber products, with China, Mexico, and Japan being the leading destinations. Lesser quantities of ball clay, fire clay, and fuller's earth were exported for ceramic, refractory, and absorbent uses, respectively.

\section{Salient Statistics_United States:}

Production (sold or used):

Ball clay

Bentonite

Common clay

Fire clay

Fuller's earth ${ }^{1}$

Kaolin

Total 1,2

Imports for consumption:

Artificially activated clays and earths

Kaolin

Other

Total ${ }^{2}$

Exports:

Artificially activated clays and earths

Ball clay

Clays, not elsewhere classified

Fire clay ${ }^{3}$

Fuller's earth

Kaolin

Total $^{2}$

Consumption, apparent ${ }^{4}$

Price, ex-works, average, dollars per ton:

Ball clay

Bentonite

Common clay

Fire clay

Fuller's earth ${ }^{1}$

Kaolin

Employment (excludes office workers), number:

Mine (may not include contract workers) Mill

Net import reliance 5 as a percentage of apparent consumption
Bentonite

\begin{tabular}{|c|c|c|c|c|}
\hline 2016 & 2017 & $\underline{2018}$ & $\underline{2019}$ & $2020^{\circ}$ \\
\hline 1,270 & 1.270 & 1,110 & 1.060 & 990 \\
\hline 4,000 & 4,430 & 4,560 & 4,490 & 4,300 \\
\hline 13,000 & 13,300 & 12,600 & 12,600 & 12,000 \\
\hline 534 & 575 & 567 & 603 & 570 \\
\hline 1,860 & 1,840 & 1,880 & 1,920 & 2,000 \\
\hline 5,200 & 5,450 & 5,350 & 5,060 & 4,600 \\
\hline$\overline{25,900}$ & $\overline{26,900}$ & $\overline{26,100}$ & $\overline{25,700}$ & $\overline{25,000}$ \\
\hline 26 & 28 & 23 & 31 & 29 \\
\hline 389 & 316 & 330 & 293 & 190 \\
\hline 57 & 86 & 68 & 66 & 32 \\
\hline$\overline{473}$ & $\overline{430}$ & $\overline{421}$ & $\overline{390}$ & $\overline{250}$ \\
\hline 143 & 147 & 149 & 138 & 130 \\
\hline 41 & 83 & 90 & 85 & 57 \\
\hline 801 & 961 & 845 & 906 & 760 \\
\hline 256 & 244 & 244 & 204 & 180 \\
\hline 184 & 225 & 250 & 194 & 180 \\
\hline 86 & 78 & 70 & 73 & 75 \\
\hline 2,290 & 2,310 & 2,390 & 2,280 & 1,900 \\
\hline$\overline{3,800}$ & $\overline{4,040}$ & $\overline{4,030}$ & $\overline{3,880}$ & $\overline{3,300}$ \\
\hline 22,600 & 23,300 & 22,500 & 22,200 & 22,000 \\
\hline 39 & 49 & 55 & 56 & 53 \\
\hline 99 & 99 & 98 & 98 & 98 \\
\hline 14 & 15 & 16 & 16 & 16 \\
\hline 13 & 13 & 12 & 14 & 14 \\
\hline 89 & 93 & 88 & 86 & 82 \\
\hline 159 & 158 & 160 & 162 & 160 \\
\hline 1,120 & 1,220 & 1,110 & 1,110 & 1,060 \\
\hline 4,440 & 4,370 & 4,310 & 4,310 & 4260 \\
\hline & E & E & E & $E$ \\
\hline
\end{tabular}

Recycling: Insignificant.

Import Sources (2016-19): All clay types combined: Brazil, 72\%; Mexico, 8\%; China, 7\%; and other, 13\%. 


\section{CLAYS}

Tariff: Item

Kaolin and other kaolinic clays, whether or not calcined

Bentonite

Fire clay

Common blue clay and other ball clays

Decolorizing earths and fuller's earth

Other clays

Chamotte or dinas earth

Activated clays and activated earths

Expanded clays and other mixtures
Number

2507.00.0000

2508.10.0000

2508.30.0000

2508.40 .0110

2508.40 .0120

2508.40 .0150

2508.70.0000

3802.90 .2000

6806.20 .0000
Normal Trade Relations

12-31-20

Free.

Free.

Free.

Free.

Free.

Free.

Free.

$2.5 \%$ ad val.

Free.

Depletion Allowance: Ball clay, bentonite, fire clay, fuller's earth, and kaolin, 14\% (domestic and foreign); clay used in the manufacture of common brick, lightweight aggregate, and sewer pipe, $7.5 \%$ (domestic and foreign); clay used in the manufacture of drain and roofing tile, flower pots, and kindred products, $5 \%$ (domestic and foreign); clay from which alumina and aluminum compounds are extracted, $22 \%$ (domestic).

Government Stockpile: None.

Events, Trends, and Issues: As in recent years, U.S. sales of clay in 2020 continued to slightly decrease. Owing to the global COVID-19 pandemic, production of all types of clays, except for fuller's earth, decreased in 2020. Housing construction decreased in the spring because of the pandemic, before rebounding during the latter part of the year. The percentage of new building construction using brick continues to decrease in favor of other materials.

World Mine Production and Reserves: ${ }^{6}$ Global reserves are large, but country-specific data were not available.

\begin{tabular}{|c|c|c|c|c|c|c|}
\hline \multirow{3}{*}{ United States } & \multicolumn{2}{|c|}{ Bentonite } & \multicolumn{2}{|c|}{ INIII provuctio } & \multicolumn{2}{|c|}{ Kaolin } \\
\hline & 2019 & $2020^{e}$ & 2019 & $2020^{e}$ & 2019 & $2020^{\circ}$ \\
\hline & $\overline{4,490}$ & $\overline{4,300}$ & $1 \longdiv { 1 , 9 2 0 }$ & $\overline{2,000}$ & $\overline{5,060}$ & $\overline{4,600}$ \\
\hline Brazil (beneficiated) & 610 & 610 & - & - & 1,700 & 1,700 \\
\hline China & 2,000 & 2,000 & - & - & 5,000 & 5,000 \\
\hline Czechia & 357 & 360 & - & - & 73,450 & 73,400 \\
\hline Germany & 395 & 390 & - & - & 5,200 & 5,200 \\
\hline Greece & 71,300 & 71,300 & 37 & 37 & - & \\
\hline India & 1,700 & 1,700 & 6 & 6 & 74,000 & 74,000 \\
\hline Iran & 360 & 360 & - & - & 790 & 790 \\
\hline Mexico & 250 & 250 & 110 & 110 & 140 & 140 \\
\hline Senegal & - & - & 117 & 120 & - & 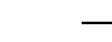 \\
\hline Spain & 160 & 160 & 626 & 620 & 7450 & 7450 \\
\hline Turkey & 1,300 & 1,300 & 20 & 27 & 1,500 & 1,500 \\
\hline Ukraine & 180 & 180 & - & - & 1,840 & 1,800 \\
\hline Uzbekistan & - & - & - & - & 4,500 & 4,500 \\
\hline Other countries & 3,150 & 3,200 & 344 & 350 & $\underline{10,700}$ & 11,000 \\
\hline World total (rounded) & $\overline{16,300}$ & $\overline{16,000}$ & $\overline{3,180}$ & $\overline{13,300}$ & $\overline{44,300}$ & $\overline{44,000}$ \\
\hline
\end{tabular}

World Resources: ${ }^{6}$ Resources of all clays are extremely large.

Substitutes: Clays compete with calcium carbonate in filler and extender applications; diatomite, organic pet litters, polymers, silica gel, and zeolites as absorbents; and various siding and roofing types in building construction.

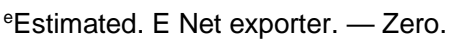

${ }^{1}$ Does not include U.S. production of attapulgite.

${ }^{2}$ Data may not add to totals shown because of independent rounding.

${ }^{3}$ Includes refractory-grade kaolin.

${ }^{4}$ Defined as production (sold or used) + imports - exports.

${ }^{5}$ Defined as imports - exports.

${ }^{6}$ See Appendix $\mathrm{C}$ for resource and reserve definitions and information concerning data sources.

${ }^{7}$ Includes production of crude ore.
} 


\section{COBALT}

(Data in metric tons of cobalt content unless otherwise noted)

Domestic Production and Use: In 2020, the nickel-copper Eagle Mine in Michigan produced cobalt-bearing nickel concentrate. In Missouri, a company produced nickel-copper-cobalt concentrate from historic mine tailings. Most U.S. cobalt supply comprised imports and secondary (scrap) materials. Approximately six companies in the United States produced cobalt chemicals. About $43 \%$ of the cobalt consumed in the United States was used in superalloys, mainly in aircraft gas turbine engines; $10 \%$ in cemented carbides for cutting and wear-resistant applications; $16 \%$ in various other metallic applications; and $31 \%$ in a variety of chemical applications. The total estimated value of cobalt consumed in 2020 was $\$ 300$ million.

\begin{tabular}{|c|c|c|c|c|c|}
\hline Salient Statistics-United States: & $\underline{2016}$ & $\underline{2017}$ & $\underline{2018}$ & $\underline{2019}$ & $\underline{2020^{e}}$ \\
\hline \multicolumn{6}{|l|}{ Production:e } \\
\hline Mine & 690 & 640 & 480 & 500 & 600 \\
\hline Secondary ${ }^{1}$ & 2,750 & 2,750 & 2,750 & 2,750 & 2,100 \\
\hline Imports for consumption & 12,800 & 11,900 & 11,900 & 13,900 & 10,000 \\
\hline Exports & 4,160 & 5,690 & 6,950 & 4,070 & 3,500 \\
\hline \multicolumn{6}{|l|}{ Consumption (includes secondary): } \\
\hline Reported & 9,010 & 9,240 & 9,290 & 9,050 & 7,300 \\
\hline Apparent ${ }^{2}$ & 11,500 & 8,950 & 7,700 & 12,500 & 8,700 \\
\hline \multicolumn{6}{|l|}{ Price, average, dollars per pound: } \\
\hline U.S. spot, cathode 3 & 12.01 & 26.97 & 37.43 & 16.95 & 16.00 \\
\hline London Metal Exchange (LME), cash & 11.57 & 25.28 & 32.94 & 14.88 & 14.00 \\
\hline \multicolumn{6}{|l|}{ Stocks, yearend: } \\
\hline Industry ${ }^{4}$ & 969 & 1,020 & 1,060 & 1,090 & 1,000 \\
\hline LME, U.S. warehouse & 195 & 160 & 130 & 102 & 80 \\
\hline $\begin{array}{l}\text { Net import reliance } 5 \text { as a percentage of } \\
\text { apparent consumption }\end{array}$ & 76 & 69 & 64 & 78 & 76 \\
\hline
\end{tabular}

Recycling: In 2020, cobalt contained in purchased scrap represented an estimated $29 \%$ of cobalt reported consumption.

Import Sources (2016-19): Cobalt contained in metal, oxide, and salts: Norway, 20\%; Canada, 14\%; Japan, 13\%; Finland, 10\%; and other, 43\%.

Tariff: Item

Cobalt ores and concentrates

Chemical compounds:

Cobalt oxides and hydroxides

Cobalt chlorides

Cobalt sulfates

Cobalt carbonates

Cobalt acetates

Unwrought cobalt, alloys

Unwrought cobalt, other

Cobalt mattes and other intermediate

products; cobalt powders

Cobalt waste and scrap

Wrought cobalt and cobalt articles
Number

2605.00.0000

2822.00.0000

2827.39.6000

2833.29.1000

2836.99.1000

2915.29.3000

8105.20 .3000

8105.20 .6000

8105.20 .9000

8105.30 .0000

8105.90 .0000
Normal Trade Relations 12-31-20

Free.

$0.1 \%$ ad val.

$4.2 \%$ ad val.

$1.4 \%$ ad val.

$4.2 \%$ ad val.

$4.2 \%$ ad val.

$4.4 \%$ ad val.

Free.

Free.

Free.

$3.7 \%$ ad val.

Depletion Allowance: 22\% (domestic), 14\% (foreign).

Government Stockpile: ${ }^{6}$ See the Lithium chapter for statistics on lithium-cobalt oxide and lithium-nickel-cobaltaluminum oxide.

\section{Material}

Cobalt

Cobalt alloys, gross weight ${ }^{7}$
FY 2020

Inventory
as of 9-30-20
302
3

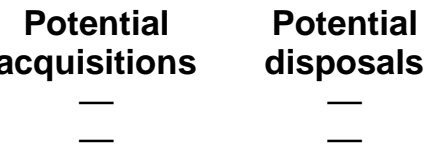

FY 2021

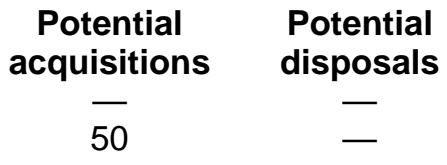


Events, Trends, and Issues: Congo (Kinshasa) continued to be the world's leading source of mined cobalt, supplying approximately $70 \%$ of world cobalt mine production. With the exception of production in Morocco and artisanally mined cobalt in Congo (Kinshasa), most cobalt is mined as a byproduct of copper or nickel. China was the world's leading producer of refined cobalt, most of which was produced from partially refined cobalt imported from Congo (Kinshasa). China was the world's leading consumer of cobalt, with more than $80 \%$ of its consumption being used by the rechargeable battery industry.

Cobalt mine and refinery production were forecast to decrease in 2020. Estimated annual average cobalt prices declined from those of 2019. Cobalt production in Madagascar was suspended to prevent the spread of COVID-19. Increased production from recently started operations in Congo (Kinshasa) was more than offset by reduced production at other operations in response to low prices and restrictions resulting from the COVID-19 pandemic.

World Mine Production and Reserves: Reserves for multiple countries were revised based on industry reports.

\begin{tabular}{|c|c|c|c|}
\hline \multicolumn{3}{|c|}{ Mine production } & \multirow[t]{2}{*}{ Reserves $^{8}$} \\
\hline & $\underline{2019}$ & $\underline{2020^{e}}$ & \\
\hline United States & $\overline{500}$ & 600 & 53,000 \\
\hline Australia & 5,740 & 5,700 & ${ }^{9} 1,400,000$ \\
\hline Canada & 3,340 & 3,200 & 220,000 \\
\hline China & 2,500 & 2,300 & 80,000 \\
\hline Congo (Kinshasa) & 100,000 & 95,000 & $3,600,000$ \\
\hline Cuba & 3,800 & 3,600 & 500,000 \\
\hline Madagascar & 3,400 & 700 & 100,000 \\
\hline Morocco & 2,300 & 1,900 & 14,000 \\
\hline Papua New Guinea & 2,910 & 2,800 & 51,000 \\
\hline Philippines & 5,100 & 4,700 & 260,000 \\
\hline Russia & 6,300 & 6,300 & 250,000 \\
\hline South Africa & 2,100 & 1,800 & 40,000 \\
\hline Other countries & 6,320 & 6,400 & 560,000 \\
\hline World total (rounded) & $\overline{144,000}$ & 140,000 & $\overline{7,100,000}$ \\
\hline
\end{tabular}

World Resources: ${ }^{8}$ Identified cobalt resources of the United States are estimated to be about 1 million tons. Most of these resources are in Minnesota, but other important occurrences are in Alaska, California, Idaho, Michigan, Missouri, Montana, Oregon, and Pennsylvania. With the exception of resources in Idaho and Missouri, any future cobalt production from these deposits would be as a byproduct of another metal. Identified world terrestrial cobalt resources are about 25 million tons. The vast majority of these resources are in sediment-hosted stratiform copper deposits in Congo (Kinshasa) and Zambia; nickel-bearing laterite deposits in Australia and nearby island countries and Cuba; and magmatic nickel-copper sulfide deposits hosted in mafic and ultramafic rocks in Australia, Canada, Russia, and the United States. More than 120 million tons of cobalt resources have been identified in manganese nodules and crusts on the floor of the Atlantic, Indian, and Pacific Oceans.

Substitutes: Depending on the application, substitution for cobalt could result in a loss in product performance or an increase in cost. The cobalt contents of lithium-ion batteries, the leading global use for cobalt, are being reduced; potential commercially available cobalt-free substitutes use iron and phosphorus. Potential substitutes in other applications include barium or strontium ferrites, neodymium-iron-boron, or nickel-iron alloys in magnets; cerium, iron, lead, manganese, or vanadium in paints; cobalt-iron-copper or iron-copper in diamond tools; copper-iron-manganese for curing unsaturated polyester resins; iron, iron-cobalt-nickel, nickel, ceramic-metallic composites (cermets), or ceramics in cutting and wear-resistant materials; nickel-based alloys or ceramics in jet engines; nickel in petroleum catalysts; rhodium in hydroformylation catalysts; and titanium-based alloys in prosthetics.

\footnotetext{
eEstimated.

${ }^{1}$ Estimated from consumption of purchased scrap.

${ }^{2}$ Defined as secondary production + imports - exports + adjustments for Government and industry stock changes for refined cobalt.

${ }^{3}$ Source S\&P Global Platts Metals Week. Cobalt cathode is refined cobalt metal produced by an electrolytic process.

${ }^{4}$ Stocks held by consumers and processors; excludes stocks held by trading companies and held for investment purposes.

${ }^{5}$ Defined as imports - exports + adjustments for Government and industry stock changes for refined cobalt.

${ }^{6}$ See Appendix B for definitions.

${ }^{7}$ Inventory is cobalt alloys; potential acquisitions are samarium-cobalt alloy; excludes potential disposals of nickel-base and aerospace alloys.

${ }^{8}$ See Appendix $\mathrm{C}$ for resource and reserve definitions and information concerning data sources.

${ }^{9}$ For Australia, Joint Ore Reserves Committee-compliant reserves were 640,000 tons.
} 


\section{COPPER}

(Data in thousand metric tons of copper content unless otherwise noted)

Domestic Production and Use: In 2020, U.S. mine production of recoverable copper decreased by $5 \%$ to an estimated 1.2 million tons and was valued at an estimated $\$ 7.5$ billion, $3 \%$ less than $\$ 7.75$ billion in 2019 . Arizona was the leading copper-producing State and accounted for an estimated $74 \%$ of domestic output, followed by, in descending order, Utah, New Mexico, Nevada, Montana, Michigan, and Missouri. Copper was recovered or processed at 25 mines (18 of which accounted for $99 \%$ of mine production), 3 smelters, 3 electrolytic refineries, and 14 electrowinning facilities. Refined copper and scrap were used at about 30 brass mills, 15 rod mills, and 500 foundries and miscellaneous consumers. Copper and copper alloy products were used in building construction, $43 \%$; electrical and electronic products, $21 \%$; transportation equipment, $19 \%$; consumer and general products, $10 \%$; and industrial machinery and equipment, $7 \% .^{1}$

\begin{tabular}{|c|c|c|c|c|c|}
\hline \multirow{2}{*}{\multicolumn{6}{|c|}{$\begin{array}{l}\text { Salient Statistics-United States: } \\
\text { Production: }\end{array}$}} \\
\hline & & & & & \\
\hline Mine, recoverable & 1,430 & 1,260 & 1,220 & 1,260 & 1,200 \\
\hline \multicolumn{6}{|l|}{ Refinery: } \\
\hline Primary (from ore) & 1,180 & 1,040 & 1,070 & 985 & 860 \\
\hline Secondary (from scrap) & 46 & 40 & 41 & 44 & 45 \\
\hline Copper recovered from old (post-consumer) scrap 2 & 149 & 146 & 149 & e150 & 150 \\
\hline \multicolumn{6}{|l|}{ Imports for consumption: } \\
\hline Ore and concentrates & $\left({ }^{3}\right)$ & 14 & 32 & 27 & 2 \\
\hline Refined & 708 & 813 & 778 & 663 & 680 \\
\hline \multicolumn{6}{|l|}{ Exports: } \\
\hline Ore and concentrates & 331 & 237 & 253 & 363 & 390 \\
\hline Refined & 134 & 94 & 190 & 125 & 40 \\
\hline \multicolumn{6}{|l|}{ Consumption: } \\
\hline Reported, refined metal & 1,800 & 1,800 & 1,820 & 1,830 & 1,700 \\
\hline Apparent, primary refined and old scrap 4 & 1,880 & 1,860 & 1,830 & 1,810 & 1,600 \\
\hline \multicolumn{6}{|l|}{ Price, annual average, cents per pound: } \\
\hline U.S. producer, cathode (COMEX + premium) & 224.9 & 285.4 & 298.7 & 279.6 & 280.0 \\
\hline COMEX, high-grade, first position & 219.7 & 280.4 & 292.6 & 272.3 & 270.0 \\
\hline London Metal Exchange, high-grade & 220.6 & 279.5 & 296.0 & 272.4 & 270.0 \\
\hline \multicolumn{6}{|l|}{ Stocks, refined, held by U.S. producers, consumers, } \\
\hline and metal exchanges, yearend & 223 & 265 & 244 & 111 & 150 \\
\hline \multirow[b]{2}{*}{$\begin{array}{l}\text { Net import reliance } 5 \text { as a percentage of } \\
\text { apparent consumption }\end{array}$} & 10.1 & 10.5 & 11.7 & 12.0 & 11.0 \\
\hline & 30 & 36 & 33 & 37 & 37 \\
\hline
\end{tabular}

Recycling: Old (post-consumer) scrap, converted to refined metal and alloys, provided an estimated 150,000 tons of copper. Purchased new (manufacturing) scrap, derived from fabricating operations, yielded an estimated 720,000 tons. Of the total copper recovered from scrap (including non-copper-base scrap), brass and wire-rod mills accounted for about $80 \%$; smelters, refiners, and ingot makers, $15 \%$; and miscellaneous chemical plants, foundries, and manufacturers, $5 \%$. Copper recovered from scrap contributed about $38 \%$ of the U.S. copper supply. ${ }^{6}$

Import Sources (2016-19): Copper content of blister and anodes: Finland, 75\%; Malaysia, 19\%; and other, 6\%. Copper content of matte, ash, and precipitates: Canada, 27\%; Mexico, 21\%; Spain, 11\%; Belgium, 10\%; and other, $31 \%$. Copper content of ore and concentrates: Mexico, $>99 \%$; and other, $<1 \%$. Copper content of scrap: Canada, 55\%; Mexico, 33\%; and other, 12\%. Refined copper: Chile, 59\%; Canada, 24\%; Mexico, 11\%; and other, $6 \%$. Refined copper accounted for $85 \%$ of all unmanufactured copper imports.

Tariff: Item

Copper ore and concentrates, copper content Unrefined copper anodes

Refined copper and alloys, unwrought

Copper wire rod

\section{Number}

2603.00.0010

7402.00 .0000

7403.00 .0000

7408.11 .0000

\section{Normal Trade Relations 12-31-20}

$1.7 \% / \mathrm{kg}$ on lead content. Free. $1.0 \%$ ad val. $1.0 \%$ or $3.0 \%$ ad val.

Depletion Allowance: $15 \%$ (domestic), 14\% (foreign).

Government Stockpile: None. 
Events, Trends, and Issues: In 2020, U.S. mine production of copper decreased by an estimated 5\%, primarily owing to reduced output from the Bingham Canyon Mine in Utah and the Chino Mine in New Mexico. At Bingham Canyon, ore grades were lower than those in 2019 because of planned pit sequencing and optimization of molybdenum production during an extended shutdown of the smelter. In April, operations at the Chino Mine were suspended after multiple workers tested positive for COVID-19; the mine was expected to restart in 2021 at about $50 \%$ of capacity. Production at the Pumpkin Hollow Mine began in December 2019, was suspended in April 2020 owing to restrictions implemented by the State of Nevada in response to the COVID-19 pandemic, and restarted in August. Output of refined copper in the United States decreased by an estimated $13 \%$ as a result of strikes, ongoing since October 2019, at a smelter in Arizona and electrolytic refinery in Texas. Refined copper production was also affected by maintenance at the smelter in Utah, which closed for several months for a complete furnace rebuild after an earthquake in March.

Global mine production of copper declined slightly to an estimated 20 million tons in 2020 from 20.4 million tons in 2019, owing primarily to COVID-19 lockdowns in April and May. These disruptions significantly affected output in Peru, the second-ranked mine producer of copper, where production through July 2020 fell by nearly 250,000 tons (23\%) from that in the same period of 2019 . Global refined copper production increased slightly to an estimated 25 million tons in 2020 from 24.5 million tons in 2019 , when output in multiple countries was affected by temporary smelter shutdowns for maintenance and upgrades.

World Mine and Refinery Production and Reserves: Reserves for multiple countries were revised based on company and Government information.

\begin{tabular}{|c|c|c|c|c|c|}
\hline & Mine $p$ & Iuction & Refinery & Iuction & Reserves $^{7}$ \\
\hline & $\underline{2019}$ & $2020^{e}$ & 2019 & $\underline{2020^{e}}$ & \\
\hline United States & $\overline{1,260}$ & $\overline{1,200}$ & $\overline{1,030}$ & 910 & 48,000 \\
\hline Australia & 934 & 870 & 426 & 380 & 888,000 \\
\hline Canada & 573 & 570 & 281 & 290 & 9,000 \\
\hline Chile & 5,790 & 5,700 & 2,270 & 2,400 & 200,000 \\
\hline China & 1,680 & 1,700 & 9,780 & 9,800 & 26,000 \\
\hline Congo (Kinshasa) & 1,290 & 1,300 & 1,080 & 1,100 & 19,000 \\
\hline Germany & - & - & 632 & 670 & 2,000 \\
\hline Japan & - & - & 1,500 & 1,600 & \\
\hline Kazakhstan & 562 & 580 & 512 & 540 & 20,000 \\
\hline Korea, Republic of & - & - & 665 & 680 & \\
\hline Mexico & 715 & 690 & 477 & 470 & 53,000 \\
\hline Peru & 2,460 & 2,200 & 308 & 330 & 92,000 \\
\hline Poland & 399 & 400 & 566 & 550 & 32,000 \\
\hline Russia & 801 & 850 & 1,050 & 1,060 & 61,000 \\
\hline Zambia & 797 & 830 & 262 & 360 & 21,000 \\
\hline Other countries & 3,100 & 3,300 & 3,640 & 3,500 & 200,000 \\
\hline World total (rounded) & $\overline{20,400}$ & $\overline{20,000}$ & $\overline{24,500}$ & $\overline{25,000}$ & $\overline{870,000}$ \\
\hline
\end{tabular}

World Resources: ${ }^{7}$ A U.S. Geological Survey study of global copper deposits indicated that, as of 2015, identified resources contained 2.1 billion tons of copper, and undiscovered resources contained an estimated 3.5 billion tons. ${ }^{9}$

Substitutes: Aluminum substitutes for copper in automobile radiators, cooling and refrigeration tube, electrical equipment, and power cable. Titanium and steel are used in heat exchangers. Optical fiber substitutes for copper in telecommunications applications, and plastics substitute for copper in drain pipe, plumbing fixtures, and water pipe.

\footnotetext{
eEstimated. - Zero.

${ }^{1}$ Distribution reported by the Copper Development Association. Some electrical components are included in each end use.

${ }^{2}$ Copper converted to refined metal and alloys by brass and wire-rod mills, foundries, refineries, and other manufacturers.

${ }^{3}$ Less than $1 / 2$ unit.

${ }^{4}$ Primary refined production + copper in old scrap converted to refined metal and alloys + refined imports - refined exports \pm refined stock changes.

${ }^{5}$ Defined as refined imports - refined exports \pm adjustments for refined copper stock changes.

${ }^{6}$ Primary refined production + copper recovered from old and new scrap + refined imports - refined exports \pm refined stock changes.

${ }^{7}$ See Appendix $\mathrm{C}$ for resource and reserve definitions and information concerning data sources.

${ }^{8}$ In Australia, Joint Ore Reserves Committee-compliant reserves were 22 million tons.

${ }^{9}$ Hammarstrom, J.M., Zientek, M.L., Parks, H.L., Dicken, C.L., and the U.S. Geological Survey Global Copper Mineral Resource Assessment Team, 2019, Assessment of undiscovered copper resources of the world, 2015 (ver.1.1, May 24, 2019): U.S. Geological Survey Scientific Investigations Report 2018-5160, 619 p., https://doi.org/10.3133/sir20185160.
} 


\section{DIAMOND (INDUSTRIAL) ${ }^{1}$}

\section{(Data in million carats unless otherwise noted)}

Domestic Production and Use: In 2020, total domestic primary production of manufactured industrial diamond bort, grit, and dust and powder was estimated to be 110 million carats with a value of $\$ 44$ million, a slight decrease from that in 2019. No diamond stone was produced domestically. One firm with facilities in Florida and Ohio and a second firm in Pennsylvania accounted for all of the production. At least four firms produced polycrystalline diamond from diamond powder. At least two companies recovered used industrial diamond material from used diamond drill bits, diamond tools, and other diamond-containing wastes for recycling. The major consuming sectors of industrial diamond are computer chip production; construction; drilling for minerals, natural gas, and oil; machinery manufacturing; stone cutting and polishing; and transportation (infrastructure and vehicles). Highway building, milling, and repair and stone cutting consumed most of the industrial diamond stone. About $99 \%$ of U.S. industrial diamond apparent consumption was synthetic industrial diamond because its quality can be controlled and its properties can be customized.

Salient Statistics-United States:

Bort, grit, and dust and powder; natural and synthetic:

Production: Manufactured diamonde Secondary

Imports for consumption

Exports

Consumption, apparent ${ }^{2}$

Price, value of imports, dollars per carat

Net import reliance ${ }^{3}$ as a percentage of apparent consumption

Stones, natural and synthetic:

Production: Manufactured diamonde Secondary

Imports for consumption

Exports

Consumption, apparent ${ }^{2}$

Price, value of imports, dollars per carat

Net import reliance ${ }^{3}$ as a percentage of apparent consumption

$\begin{array}{rrrrr}\mathbf{2 0 1 6} & \underline{\mathbf{2 0 1 7}} & \underline{\mathbf{2 0 1 8}} & \underline{\mathbf{2 0 1 9}} & \underline{\underline{\mathbf{2 0 2 0}}} \\ & & & & \\ 42 & 41 & 184 & 114 & 110 \\ 66 & 11 & 32 & 36 & 35 \\ 216 & 399 & 574 & 312 & 220 \\ 134 & 161 & 139 & 114 & 91 \\ 190 & 290 & 651 & 348 & 270 \\ 0.23 & 0.16 & 0.12 & 0.14 & 0.18 \\ & & & & \\ 43 & 79 & 67 & 57 & 47 \\ & & & & \\ 83 & 87 & -\overline{13} & 0.10 & 0.10 \\ 0.36 & 0.39 & 0.55 \\ 1.37 & 1.23 & 2.52 & 1.61 & 0.55 \\ -\overline{8} & - & - & \left({ }^{4}\right) & 0.03 \\ 84.9 & 89.0 & 2.7 & 1.7 & 0.6 \\ 13.6 & 12.9 & 2.9 & 3.9 & 7.4 \\ & & & & \\ 2 & 1 & 95 & 94 & 84\end{array}$

Recycling: In 2020, the amount of diamond bort, grit, and dust and powder recycled was estimated to be 35 million carats with an estimated value of $\$ 5.5$ million. It was estimated that 98,000 carats of diamond stone was recycled with an estimated value of $\$ 150,000$.

Import Sources (2016-19): Bort, grit, and dust and powder; natural and synthetic: China, 80\%; Ireland, 7\%; the Republic of Korea, 6\%; Russia, 3\%; and other, 4\%. Stones, primarily natural: South Africa, 22\%; India, 20\%; Botswana, 15\%; Congo (Kinshasa), 13\%; and other, 30\%.

\section{Tariff: Item}

Industrial Miners' diamonds, carbonados

Industrial Miners' diamonds, other

Industrial diamonds, simply sawn, cleaved, or bruted

Industrial diamonds, not worked

Grit or dust and powder of natural diamonds, 80 mesh or finer

Grit or dust and powder of natural diamonds, over 80 mesh

Grit or dust and powder of synthetic diamonds, coated with metal

Grit or dust and powder of synthetic diamonds, not coated with metal, 80 mesh or finer

Grit or dust and powder of synthetic diamonds, not coated with metal, over 80 mesh
Number

7102.21 .1010

7102.21 .1020

7102.21 .3000

7102.21 .4000

7105.10.0011

7105.10 .0015

7105.10 .0020

7105.10 .0030

7105.10.0050
Normal Trade Relations

12-31-20

Free.

Free.

Free.

Free.

Free.

Free.

Free.

Free.

Free. 
Depletion Allowance: $14 \%$ (domestic and foreign).

Government Stockpile: None.

Events, Trends, and Issues: Most natural industrial diamond is produced as a byproduct of mining gem-quality diamond. Global natural industrial diamond production decreased slightly during 2020. This decrease was due to mine closures and lower output as mines approach the ends of their mine life. The world's largest diamond mines have matured and are past their peak production levels, and several of the largest diamond mines are expected to close by the end of 2025. As these mines are depleted, global production is expected to continue to decline in quantity, and the global supply of crude natural diamond (including gem-quality and industrial diamond) is forecasted to steadily decrease to about 120 million carats in 2030 .

Worldwide diamond exploration spending has increased over the past few years. The success rate in diamond exploration has been estimated to be less than $1 \%$, and no major deposit has been discovered in more than 20 years.

In 2020, U.S. synthetic-industrial-diamond producers did not manufacture any diamond stone, and industrial diamond stone apparent consumption decreased. Domestic and global demand for synthetic diamond grit and powder is expected to remain greater than that for natural diamond material. In 2020, China was the leading producing country of synthetic industrial diamond, followed by the United States, Russia, Ireland, and South Africa, in descending order of quantity. These five countries produced about $99 \%$ of the world's synthetic industrial diamond. Synthetic diamond accounted for more than $99 \%$ of global industrial diamond production and consumption. Worldwide production of manufactured industrial diamond totaled more than 14.6 billion carats.

The United States is likely to continue to be one of the world's leading markets for industrial diamond into the next decade and is expected to remain a significant producer and exporter of synthetic industrial diamond as well. U.S. demand for industrial diamond is likely to be strong in the construction sector as the United States continues building, milling, and repairing the Nation's highway system. Industrial diamond coats the cutting edge of saws used to cut concrete in highway construction and repair work.

World Natural Industrial Diamond Mine Production and Reserves: Reserves for Australia, Botswana, and South Africa were revised based on Government and company information.

\begin{tabular}{lrrr} 
& \multicolumn{2}{c}{ Mine production } & Reserves $^{\mathbf{5}}$ \\
United States & $\underline{\mathbf{2 0 1 9}}$ & $\underline{\mathbf{2 0 2 0 ^ { \mathbf { e } }}}$ & NA \\
Australia & $\overline{13}$ & $\overline{2}$ & 625 \\
Botswana & 7 & 5 & 310 \\
Congo (Kinshasa) & 11 & 12 & 150 \\
Russia & 20 & 19 & 650 \\
South Africa & 1 & 3 & 130 \\
Zimbabwe & 2 & 2 & NA \\
Other countries & 1 & $\frac{1}{54}$ & 120 \\
$\quad$ World total (rounded) & 55 & 5,400
\end{tabular}

World Resources: 5 Natural diamond deposits have been discovered in more than 35 countries. Natural diamond accounts for about $1 \%$ of all industrial diamond used; synthetic diamond accounts for the remainder. At least 15 countries have the technology to produce synthetic diamond.

Substitutes: Materials that can compete with industrial diamond in some applications include manufactured abrasives, such as cubic boron nitride, fused aluminum oxide, and silicon carbide. Globally, synthetic diamond, rather than natural diamond, is used for about $99 \%$ of industrial applications.

\footnotetext{
eEstimated. NA Not available. - Zero.

${ }^{1}$ See Gemstones for information on gem-quality diamond.

${ }^{2}$ Defined as manufactured diamond production + secondary diamond production + imports - exports.

${ }^{3}$ Defined as imports - exports.

${ }^{4}$ Less than $1 / 2$ unit.

${ }^{5}$ See Appendix $\mathrm{C}$ for resource and reserve definitions and information concerning data sources.

${ }^{6}$ In Australia, Joint Ore Reserves Committee-compliant reserves were 25 million carats.
} 


\section{DIATOMITE}

(Data in thousand metric tons unless otherwise noted)

Domestic Production and Use: In 2020, production of diatomite was estimated to be 770,000 tons with an estimated processed value of $\$ 260$ million, free on board (f.o.b.) plant. Six companies produced diatomite at 12 mining areas and 9 processing facilities in California, Nevada, Oregon, and Washington. Approximately $60 \%$ of diatomite is used in filtration products. The remaining $40 \%$ is used in absorbents, fillers, lightweight aggregates, and other applications. A small amount, less than 1\%, is used for specialized pharmaceutical and biomedical purposes. The unit value of diatomite varied widely in 2020 , from approximately $\$ 10$ per ton when used as a lightweight aggregate in portland cement concrete to more than $\$ 1,000$ per ton for limited specialty markets, including art supplies, cosmetics, and deoxyribonucleic acid (DNA) extraction.

\begin{tabular}{|c|c|c|c|c|c|}
\hline Salient Statistics-United States: & $\underline{2016}$ & $\underline{2017}$ & $\underline{2018}$ & $\underline{2019}$ & $\underline{2020^{e}}$ \\
\hline$\overline{\text { Production }^{1}}$ & $\overline{686}$ & $\overline{768}$ & 957 & $\overline{768}$ & 770 \\
\hline Imports for consumption & 8 & 9 & 9 & 10 & 16 \\
\hline Exports & 66 & 87 & 68 & 68 & 67 \\
\hline Consumption, apparent ${ }^{2}$ & 628 & 690 & 898 & 710 & 720 \\
\hline Price, average value, f.o.b. plant, dollars per ton & 280 & 360 & 330 & 340 & 340 \\
\hline Employment, mine and plant, numbere & 350 & 360 & 370 & 370 & 370 \\
\hline $\begin{array}{l}\text { Net import reliance }{ }^{3} \text { as a percentage } \\
\text { of apparent consumption }\end{array}$ & $E$ & E & $\mathrm{E}$ & $\mathrm{E}$ & $E$ \\
\hline
\end{tabular}

Recycling: None.

Import Sources (2016-19): Canada, 72\%; Mexico, 11\%; Germany, 10\%; Argentina, 2\%; and other, 5\%.

Tariff: Item

Siliceous fossil meals, including diatomite

Depletion Allowance: $14 \%$ (domestic and foreign).
Number

2512.00.0000

\author{
Normal Trade Relations \\ 12-30-20 \\ Free.
}

\section{Government Stockpile: None.}

Events, Trends, and Issues: The amount of domestically produced diatomite sold or used by producers in 2020 remained essentially the same compared with that of 2019. Apparent domestic consumption increased slightly in 2020 to an estimated 720,000 tons; exports were estimated to have decreased slightly. The United States remained the leading global producer and consumer of diatomite. Filtration (including the purification of beer, liquors, and wine and the cleansing of greases and oils) continued to be the leading end use for diatomite, also known as diatomaceous earth. An important application for diatomite is the removal of microbial contaminants, such as bacteria, protozoa, and viruses in public water systems. Other applications for diatomite include filtration of human blood plasma, pharmaceutical processing, and use as a nontoxic insecticide. Domestically, diatomite used in the production of cement was the second-ranked use. Despite disruptions caused by the global COVID-19 pandemic, the production of diatomite through the second quarter of 2020 remained consistent with that of 2019. 


\section{DIATOMITE}

In 2020, the United States accounted for an estimated 35\% of total world production, followed by Denmark with 17\%, Turkey with $8 \%$, China with $7 \%$, Peru with $5 \%$, and Mexico with $4 \%$. Smaller quantities of diatomite were mined in 22 additional countries.

World Mine Production and Reserves:

\begin{tabular}{|c|c|c|}
\hline \multicolumn{2}{|r|}{ Mine production } & \multirow[t]{2}{*}{ Reserves $^{4}$} \\
\hline & $\underline{2019 \quad 2020^{e}}$ & \\
\hline United States ${ }^{1}$ & 770 & 250,000 \\
\hline Argentina & 70 & NA \\
\hline China & 150 & 110,000 \\
\hline Denmark $^{5}$ (processed) & 370 & NA \\
\hline France & 75 & NA \\
\hline Germany & 52 & NA \\
\hline Japan & 40 & NA \\
\hline Korea, Republic of & 41 & NA \\
\hline Mexico & 96 & NA \\
\hline New Zealand & 40 & NA \\
\hline Peru & 110 & NA \\
\hline Russia & 51 & NA \\
\hline Spain & 50 & NA \\
\hline Turkey & 170 & 44,000 \\
\hline Other countries & 170 & NA \\
\hline World total (rounded) & 2,200 & Large \\
\hline
\end{tabular}

World Resources: ${ }^{4}$ Diatomite deposits form from an accumulation of amorphous hydrous silica cell walls of dead diatoms in oceanic and fresh waters. Diatomite is also known as kieselguhr (Germany), tripolite (after an occurrence near Tripoli, Libya), and moler (an impure Danish form). Because U.S. diatomite occurrences are at or near Earth's surface, recovery from most deposits is achieved through low-cost, open pit mining. Outside the United States, however, underground mining is fairly common owing to deposit location and topographic constraints. World resources of crude diatomite are adequate for the foreseeable future.

Substitutes: Many materials can be substituted for diatomite. However, the unique properties of diatomite assure its continued use in many applications. Expanded perlite and silica sand compete for filtration. Filters made from manufactured materials, notably ceramic, polymeric, or carbon membrane filters and filters made with cellulose fibers, are becoming competitive as filter media. Alternate filler materials include clay, ground limestone, ground mica, ground silica sand, perlite, talc, and vermiculite. For thermal insulation, materials such as various clays, exfoliated vermiculite, expanded perlite, mineral wool, and special brick can be used. Transportation costs will continue to determine the maximum economic distance that most forms of diatomite may be shipped and still remain competitive with alternative materials.

\footnotetext{
${ }^{e}$ Estimated. E Net exporter. NA Not available.

${ }^{1}$ Processed ore sold or used by producers.

${ }^{2}$ Defined as production + imports - exports.

${ }^{3}$ Defined as imports - exports.

${ }^{4}$ See Appendix $\mathrm{C}$ for resource and reserve definitions and information concerning data sources.

${ }^{5}$ Include sales of moler production.
} 


\section{FELDSPAR AND NEPHELINE SYENITE}

(Data in thousand metric tons unless otherwise noted)

Domestic Production and Use: U.S. feldspar production in 2020 had an estimated value of $\$ 45$ million. Three leading companies mined and processed about $80 \%$ of production; four other companies supplied the remainder. The five leading producing States, in alphabetical order, were California, Idaho, North Carolina, Oklahoma, and Virginia. Feldspar processors reported joint product recovery of mica and silica sand. Nepheline syenite produced in the United States was not included in production figures because the material was not considered to be marketable as a flux and was mostly used in construction applications.

Feldspar is ground to about 20 mesh for glassmaking and to 200 mesh or finer for most ceramic and filler applications. It was estimated that domestically produced feldspar was transported by ship, rail, or truck to at least 30 States and to foreign destinations, including Canada and Mexico. In pottery and glass, feldspar and nepheline syenite function as a flux. The estimated 2020 end-use distribution of domestic feldspar and nepheline syenite was glass, about $65 \%$, and ceramic tile, pottery, and other uses, $35 \%$.

\begin{tabular}{|c|c|c|c|c|c|}
\hline$\frac{\text { Salient Statistics_-United States: }}{\text { Production, marketable }^{1}}$ & $\frac{2016}{480}$ & $\frac{2017}{440}$ & $\frac{2018}{550}$ & $\frac{2019}{450}$ & $\frac{2020^{\mathrm{e}}}{420}$ \\
\hline \multicolumn{6}{|l|}{ Imports for consumption: } \\
\hline Feldspar & 37 & 290 & 181 & 64 & 68 \\
\hline Nepheline syenite & 572 & 1,460 & 1,070 & 508 & 500 \\
\hline Exports, feldspar & 6 & 5 & 4 & 4 & 3 \\
\hline \multicolumn{6}{|l|}{ Consumption, apparent:1, 2} \\
\hline Feldspar only & 510 & 730 & 730 & 510 & 490 \\
\hline Feldspar and nepheline syenite & 1,100 & 2,200 & 1,800 & 1,000 & 990 \\
\hline \multicolumn{6}{|l|}{ Price, average value, dollars per ton: } \\
\hline Feldspar only, marketable production & 69 & 64 & 97 & 107 & 110 \\
\hline Nepheline syenite, import value & 128 & 61 & 76 & 156 & 160 \\
\hline $\begin{array}{l}\text { Employment, mine, preparation plant, } \\
\text { and office, numbere }\end{array}$ & 250 & 240 & 240 & 240 & 240 \\
\hline \multicolumn{6}{|l|}{$\begin{array}{l}\text { Net import reliance }{ }^{3} \text { as a percentage } \\
\text { of apparent consumption: }\end{array}$} \\
\hline $\begin{array}{l}\text { Feldspar } \\
\text { Nepheline syenite }\end{array}$ & $\begin{array}{r}6 \\
100\end{array}$ & $\begin{array}{r}39 \\
100\end{array}$ & $\begin{array}{r}24 \\
100\end{array}$ & $\begin{array}{r}12 \\
100\end{array}$ & $\begin{array}{r}13 \\
100\end{array}$ \\
\hline
\end{tabular}

Recycling: Feldspar and nepheline syenite are not recycled by producers; however, glass container producers use cullet (recycled container glass), thereby reducing feldspar and nepheline syenite consumption.

Import Sources (2016-19): Feldspar: Turkey, 98\%; and other, 2\%. Nepheline syenite: Canada, 100\%.

Tariff: Item

Feldspar

Nepheline syenite
Number

2529.10 .0000

2529.30.0010
Normal Trade Relations

12-31-20

Free.

Free.

Depletion Allowance: $14 \%$ (domestic and foreign).

Government Stockpile: None.

Events, Trends, and Issues: In 2020, domestic production and sales of feldspar decreased by almost $7 \%$, and the average unit value of sales was about the same as that of 2019. When compared to 2019, imports of feldspar increased by about $6 \%$ and nepheline syenite imports decreased slightly in 2020. Imports of nepheline syenite reported by the U.S. Census Bureau in 2017 and 2018 were unusually high.

Domestic feldspar consumption has been gradually shifting toward glass from ceramics. A growing segment in the glass industry was solar glass, used in the production of solar panels. Glass-including beverage containers (more than one-half of the feldspar consumed by the glass industry), plate glass, and fiberglass insulation for housing and building construction-continued to be the leading end use of feldspar in the United States. 
In the United States, residential construction, in which feldspar is a raw material commonly used in the manufacture of plate glass, ceramic tiles and sanitaryware, and insulation, increased by $5 \%$ during the first 10 months of 2020 compared with the same period in 2019. Production and sales of feldspar are expected to increase over the next few years, owing in part to low mortgage interest rates and increased demand for single-family homes as the global COVID-19 pandemic made multifamily homes less desirable.

A company based in Canada continued development of a feldspar-quartz-kaolin project in Idaho that contained highgrade potassium feldspar. Production was expected to be about 30,000 tons per year of potassium feldspar during a 25-year mine life. For several years, the operation has produced a low-iron and trace-element feldspathic sand product from old mine tailings, which was sold to ceramic tile producers.

World Feldspar Mine Production and Reserves: ${ }^{4}$ Reserves data for the Republic of Korea were revised based on Government information.

United States ${ }^{1}$
Brazil (beneficiated marketable)
China
Czechia
Egypt
Germany
India
Iran
Italy
Korea, Republic of
Malaysia
Mexico
Russia
Saudi Arabia
Spain (includes pegmatites)
Thailand
Turkey
Other countries
$\quad$ World total (rounded)

United States ${ }^{1}$

China

Czechia

India

Iran

Italy

Malaysia

Rexico

Saudi Arabia

Spain (includes pegmatites)

Thailand

World total (rounded)

\begin{tabular}{|c|c|}
\hline Mine & uctio \\
\hline 2019 & $2020^{\mathrm{e}}$ \\
\hline 450 & 420 \\
\hline 300 & 00 \\
\hline 2,000 & 2,00 \\
\hline 441 & 4 \\
\hline 400 & 40 \\
\hline 260 & \\
\hline 4,000 & 4,0 \\
\hline 750 & 1,300 \\
\hline 4,000 & 4,000 \\
\hline 620 & 400 \\
\hline 202 & 20 \\
\hline 210 & 210 \\
\hline 290 & 290 \\
\hline 210 & \\
\hline 800 & \\
\hline 1,200 & 1,200 \\
\hline 5,500 & 5,000 \\
\hline 1,320 & 1,50 \\
\hline 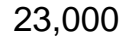 & \\
\hline
\end{tabular}

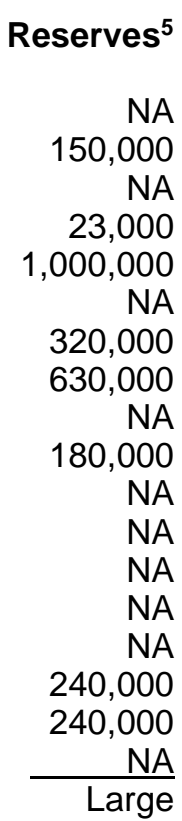

World Resources: ${ }^{5}$ Identified and undiscovered resources of feldspar are more than adequate to meet anticipated world demand. Quantitative data on resources of feldspar existing in feldspathic sands, granites, and pegmatites generally have not been compiled. Ample geologic evidence indicates that resources are large, although not always conveniently accessible to the principal centers of consumption.

Substitutes: Imported nepheline syenite was the major alternative material for feldspar. Feldspar can be replaced in some of its end uses by clays, electric furnace slag, feldspar-silica mixtures, pyrophyllite, spodumene, or talc.

\footnotetext{
eEstimated. NA Not available.

${ }^{1}$ Rounded to two significant digits to avoid disclosing company proprietary data.

${ }^{2}$ Defined as production + imports - exports.

${ }^{3}$ Defined as imports - exports.

${ }^{4}$ Feldspar only.

${ }^{5}$ See Appendix $\mathrm{C}$ for resource and reserve definitions and information concerning data sources.
} 


\section{FLUORSPAR}

(Data in thousand metric tons unless otherwise noted)

Domestic Production and Use: In 2020, minimal fluorspar (calcium fluoride, $\mathrm{CaF}_{2}$ ) was produced in the United States. One company sold fluorspar from stockpiles produced as a byproduct of its limestone quarrying operation in Cave-in-Rock, IL, and continued development on its fluorspar mine in Kentucky. After acquiring a fluorspar mine in Utah, a second company continued a drilling program to further define the mineral resource and facilitate development of a mine plan. An estimated 29,000 tons of fluorosilicic acid (FSA), equivalent to about 47,000 tons of fluorspar grading $100 \%$, was recovered from five phosphoric acid plants processing phosphate rock, which was primarily used in water fluoridation. The U.S. Department of Energy continued to produce aqueous hydrofluoric acid (HF) as a byproduct of the conversion of depleted uranium hexafluoride to depleted uranium oxide at plants in Paducah, KY, and Portsmouth, $\mathrm{OH}$.

U.S. fluorspar consumption was satisfied primarily by imports. Domestically, production of HF in Louisiana and Texas was by far the leading use for acid-grade fluorspar. Hydrofluoric acid is the primary feedstock for the manufacture of virtually all fluorine-bearing chemicals, particularly refrigerants and fluoropolymers, and is also a key ingredient in the processing of aluminum and uranium. Fluorspar was also used in cement production, in enamels, as a flux in steelmaking, in glass manufacture, in iron and steel casting, and in welding rod coatings.

\begin{tabular}{|c|c|c|c|c|c|}
\hline \multirow{2}{*}{\multicolumn{6}{|c|}{$\begin{array}{l}\text { Salient Statistics-United States: } \\
\text { Production: }\end{array}$}} \\
\hline & & & & & \\
\hline Finished, metallurgical grade & NA & NA & NA & NA & NA \\
\hline Fluorosilicic acid from phosphate rock & 44 & 40 & 33 & 29 & 29 \\
\hline \multicolumn{6}{|l|}{ Imports for consumption: } \\
\hline Acid grade & 328 & 331 & 381 & 317 & 320 \\
\hline Metallurgical grade & 55 & 70 & 78 & 59 & 70 \\
\hline Total fluorspar imports & $\overline{383}$ & $\overline{401}$ & $\overline{459}$ & $\overline{376}$ & $\overline{390}$ \\
\hline Hydrofluoric acid & 126 & 123 & 122 & 124 & 110 \\
\hline Aluminum fluoride & 20 & 21 & 26 & 37 & 22 \\
\hline Cryolite & 16 & 10 & 17 & 21 & 24 \\
\hline Exports, fluorspar, all grades ${ }^{1}$ & 12 & 11 & 9 & 8 & 8 \\
\hline \multicolumn{6}{|l|}{ Consumption: } \\
\hline Apparent ${ }^{2}$ & 371 & 390 & 450 & 368 & 380 \\
\hline Reported & W & W & W & W & W \\
\hline \multicolumn{6}{|c|}{$\begin{array}{l}\text { Price, average value of imports, cost, insurance, and } \\
\text { freight dollars per ton: }\end{array}$} \\
\hline Acid grade & 273 & 267 & 276 & 324 & 320 \\
\hline Metallurgical grade & 233 & 237 & 258 & 292 & 160 \\
\hline Stocks, consumer and dealer ${ }^{3}$ yearend & $\mathrm{e} 147$ & NA & NA & NA & NA \\
\hline Employment, mine, numbere & 13 & 16 & 16 & 16 & 19 \\
\hline $\begin{array}{l}\text { Net import reliance } 4 \text { as a percentage of } \\
\text { apparent consumption }\end{array}$ & 100 & 100 & 100 & 100 & 100 \\
\hline
\end{tabular}

Recycling: Synthetic fluorspar may be produced from neutralization of waste in the enrichment of uranium, petroleum alkylation, and stainless-steel pickling; however, undesirable impurities constrain use. Primary aluminum producers recycle HF and fluorides from smelting operations.

Import Sources (2016-19): Mexico, 70\%; Vietnam, 9\%; China, 8\%; South Africa, 7\%; and other, 6\%.

\section{Tariff: Item}

Metallurgical grade (less than $97 \% \mathrm{CaF}_{2}$ )

Acid grade $\left(97 \%\right.$ or more $\left.\mathrm{CaF}_{2}\right)$

Natural cryolite

Hydrogen fluoride (hydrofluoric acid)

Aluminum fluoride

Synthetic cryolite
Number

2529.21 .0000

2529.22.0000

2530.90.1000

2811.11.0000

2826.12.0000

2826.30.0000
Normal Trade Relations

12-31-20

Free.

Free.

Free.

Free.

Free.

Free.

Depletion Allowance: 22\% (domestic), 14\% (foreign).

Government Stockpile: None. 


\section{FLUORSPAR}

Events, Trends, and Issues: The global availability of fluorspar was estimated to have increased in 2020 owing to decreased consumption in some downstream applications and continued rampup of new mines in Canada and South Africa. On the consumption side, an increasing number of new projects continued to focus on developing alternatives to fluorspar in the manufacture of HF. Hydrofluoric acid was produced from FSA at four plants in China and a fifth plant was ramping up production in 2020. In June, a leading domestic fluorochemical producer and leading phosphoric acid producer announced a partnership to construct a 40,000-ton-per-year anhydrous HF plant in Aurora, NC, using FSA feedstock. The new plant, expected to begin production in 2022, would be the first plant of its kind outside of China, although similar projects were reportedly being evaluated in other countries. The agreement established a long-term HF supply agreement which would support production of fluorogases and fluoropolymers in Calvert City, KY. The capacity of existing U.S. HF plants that use fluorspar as a feedstock was 220,000 tons per year.

World Mine Production and Reserves: Reserves for Morocco were revised based on company-reported information but were only available for one producer.

\begin{tabular}{lrrr} 
& \multicolumn{2}{c}{ Mine production } & Reserves \\
& $\underline{\mathbf{2 0 1 9}}$ & \\
United States & $\mathrm{NA}$ & $\frac{\mathbf{2 0 2}}{\mathrm{NA}}$ & 4,000 \\
Burma & 53 & 53 & $\mathrm{NA}$ \\
Canada & 80 & 100 & $\mathrm{NA}$ \\
China & 7,300 & 74,300 & 42,000 \\
Germany & 50 & 50 & $\mathrm{NA}$ \\
Iran & 55 & 55 & 3,400 \\
Kazakhstan & 88 & 77 & $\mathrm{NA}$ \\
Mexico & 1,230 & 1,200 & 68,000 \\
Mongolia & 718 & 720 & 22,000 \\
Morocco & 88 & 88 & 210 \\
Pakistan & 100 & 100 & $\mathrm{NA}$ \\
South Africa & 210 & 320 & 41,000 \\
Spain & 139 & 140 & 10,000 \\
Vietnam & 238 & 240 & 5,000 \\
Other countries & 107 & 110 & 120,000 \\
$\quad$ World total (rounded) & 7,460 & 7,600 & 320,000
\end{tabular}

World Resources: ${ }^{5}$ Large quantities of fluorine are present in phosphate rock. Current U.S. reserves of phosphate rock are estimated to be 1 billion tons, containing about 72 million tons of $100 \%$ fluorspar equivalent assuming an average fluorine content of $3.5 \%$ in the phosphate rock. World reserves of phosphate rock are estimated to be 71 billion tons, equivalent to about 5 billion tons of $100 \%$ fluorspar equivalent.

Substitutes: FSA is used to produce aluminum fluoride $\left(\mathrm{AlF}_{3}\right)$ and $\mathrm{HF}$. Because of differing physical properties, $\mathrm{AlF}_{3}$ produced from FSA is not readily substituted for $\mathrm{AlF}_{3}$ produced from fluorspar. Aluminum smelting dross, borax, calcium chloride, iron oxides, manganese ore, silica sand, and titanium dioxide have been used as substitutes for fluorspar fluxes.

\footnotetext{
EEstimated. NA Not available. W Withheld to avoid disclosing company proprietary data. ${ }^{1}$ Includes data for the following Schedule B codes: 2529.21.0000 and 2829.22.0000.

${ }^{2}$ Defined as total fluorspar imports - exports.

${ }^{3}$ Industry stocks for leading consumers and fluorspar distributors.

${ }^{4}$ Defined as imports - exports.

${ }^{5}$ See Appendix $\mathrm{C}$ for resource and reserve definitions and information concerning data sources.

${ }^{6}$ Measured as $100 \%$ calcium fluoride.

${ }^{7}$ As reported by China's Ministry of Natural Resources. Likely excludes production from operations that did not meet the Government's minimum mining and processing requirements. The China Non-Metallic Minerals Industry Association estimated that actual production was closer to 6 million tons.
} 


\section{GALLIUM}

(Data in kilograms of gallium content unless otherwise noted)

Domestic Production and Use: No domestic primary (low-purity, unrefined) gallium has been recovered since 1987. Globally, primary gallium is recovered as a byproduct of processing bauxite and zinc ores. One company in Utah recovered and refined high-purity gallium from imported primary low-purity gallium metal and new scrap. Imports of gallium metal and gallium arsenide (GaAs) wafers were valued at about $\$ 1$ million and $\$ 150$ million, respectively. GaAs was used to manufacture integrated circuits (ICs) and optoelectronic devices, which include laser diodes, lightemitting diodes (LEDs), photodetectors, and solar cells. Gallium nitride (GaN) principally was used to manufacture optoelectronic devices. ICs accounted for $72 \%$ of domestic gallium consumption, optoelectronic devices accounted for $25 \%$, and research and development accounted for $3 \%$. About $80 \%$ of the gallium consumed in the United States was contained in $\mathrm{GaAs}$, GaN, and gallium phosphide (GaP) wafers. Gallium metal, triethyl gallium, and trimethyl gallium, used in the epitaxial layering process to fabricate epiwafers for the production of LEDs and ICs, accounted for most of the remainder. Optoelectronic devices were used in aerospace applications, consumer goods, industrial equipment, medical equipment, and telecommunications equipment. Uses of ICs included defense applications, highperformance computers, and telecommunications equipment.

\section{Salient Statistics-United States:}

Production, primary

Imports for consumption:

Metal

Gallium arsenide wafers (gross weight)

Exports

Consumption, reported

Price, imports, dollars per kilogram:

High-purity, refined ${ }^{1}$

Low-purity, primary ${ }^{2}$

Stocks, consumer, yearend

Net import reliance ${ }^{3}$ as a percentage

of reported consumption

$\begin{array}{rrrrr}\frac{\mathbf{2 0 1 6}}{-} & \underline{\mathbf{2 0 1 7}} & \underline{\mathbf{2 0 1 8}} & \underline{\mathbf{2 0 1 9}} & \frac{\mathbf{2 0 2 0}}{-} \\ 10,500 & 20,200 & 32,000 & 5,740 & 4,600 \\ 1,290,000 & 803,000 & 444,000 & 272,000 & 190,000 \\ \text { NA } & \text { NA } & \text { NA } & \text { NA } & \text { NA } \\ 18,100 & 17,900 & 15,000 & 14,900 & 15,000 \\ & & & & \\ 690 & 477 & 508 & 570 & 570 \\ 125 & 124 & 185 & 150 & 170 \\ 2,720 & 2,840 & 2,920 & 2,850 & 2,700 \\ 100 & 100 & 100 & 100 & 100\end{array}$

Recycling: Old scrap, none. Substantial quantities of new scrap generated in the manufacture of GaAs-based devices were reprocessed to recover high-purity gallium at one facility in Utah.

Import Sources (2016-19): Metal: China, ${ }^{4}$ 55\%; the United Kingdom, 11\%; Germany, 10\%; and other, $24 \%$.

Tariff: Item

Gallium arsenide wafers, doped

Gallium metal
Number

3818.00.0010

8112.92.1000
Normal Trade Relations

12-31-20

Free.

$3.0 \%$ ad val.

Depletion Allowance: 14\% (domestic and foreign).

Government Stockpile: None.

Events, Trends, and Issues: Imports of gallium metal and GaAs wafers continued to account for all U.S. consumption of gallium. In 2020, gallium metal imports decreased by an estimated $20 \%$ from those of 2019 , most likely owing to higher import tariffs on gallium from China that began in 2019 . This followed a $300 \%$ increase of gallium metal imports from China in 2018 before the tariffs were introduced. In 2019, gallium metal imports from China decreased by $97 \%$ from those of 2018.

Primary low-purity (99.99\%-pure) gallium prices in China increased by an estimated $32 \%$ in 2020 owing mostly to reduced production in China. The price for primary low-purity gallium in China increased to $\$ 185$ per kilogram in September 2020 from approximately $\$ 140$ per kilogram at yearend 2019. China's primary low-purity gallium production capacity has been approximately 600,000 kilograms per year since 2016, following an expansion from 140,000 kilograms per year in 2010 . China accounted for more than $80 \%$ of worldwide low-purity gallium capacity.

The remaining primary low-purity gallium producers outside of China most likely restricted output owing to a large surplus of primary gallium that began in 2012. These producers included Japan, the Republic of Korea, and Russia. Germany and Kazakhstan ceased primary production in 2016 and 2013, respectively. Hungary and Ukraine were thought to have ceased primary production in 2015 and 2019, respectively. 
High-purity refined gallium production in 2020 was estimated to be about 220,000 kilograms, a $5 \%$ increase from that of 2019. China, Japan, Slovakia, and the United States were the known principal producers of high-purity refined gallium. The United Kingdom ceased high-purity refined gallium production in 2018. Gallium was recovered from new scrap in Canada, China, Germany, Japan, Slovakia, and the United States. World primary low-purity gallium production capacity in 2020 was estimated to be 724,000 kilograms per year; high-purity refined gallium production capacity, 325,000 kilograms per year; and secondary high-purity gallium production capacity, 273,000 kilograms per year.

In 2019, the value of worldwide radio frequency (RF) GaAs device consumption decreased by $4 \%$ to $\$ 8.6$ billion owing primarily to a decline in third- and fourth-generation (3G and 4G) "smartphone" shipments. In 2020, worldwide $\mathrm{RF}$ GaAs device consumption was expected to decrease by $4 \%$ from that of 2019 owing to the impacts of the COVID-19 pandemic and a United States-China trade dispute that resulted in higher ad valorem tariffs on imports from China. Global GaAs wafer consumption by volume was estimated to have increased by $14 \%$ in 2020 , with an estimated $48 \%, 32 \%$, and $20 \%$ of wafers used in LED, RF, and photonics applications, respectively. Countries within the Asia and the Pacific region dominated the GaAs wafer market.

Owing to their large power-handling capabilities, high-switching frequencies, and higher voltage capabilities, GaN-based products, which historically have been used in defense applications, are used in fifth-generation (5G) networks, cable television transmission, commercial wireless infrastructure, power electronics, and satellite markets. The value of the GaN RF device market was estimated to be $\$ 940$ million in 2020, an increase of $22 \%$ from the revised $\$ 770$ million in 2019 . The global high-power LED market was estimated to be $\$ 14$ billion in 2020 , an increase of $5.3 \%$ from that in 2019 .

\section{World Production and Reserves:}

United States
China
Japan
Korea, Republic of
Russia
Ukraine
$\quad$ World total (rounded)

World Resources: ${ }^{5}$ Gallium occurs in very small concentrations in ores of other metals. Most gallium is produced as a byproduct of processing bauxite, and the remainder is produced from zinc-processing residues. The average gallium content of bauxite is 50 parts per million. U.S. bauxite deposits consist mainly of subeconomic resources that are not generally suitable for alumina production owing to their high silica content. Some domestic zinc ores contain up to 50 parts per million gallium and could be a significant resource, although no gallium is currently recovered from domestic ores. Gallium contained in world resources of bauxite is estimated to exceed 1 million tons, and a considerable quantity could be contained in world zinc resources. However, less than $10 \%$ of the gallium in bauxite and zinc resources is potentially recoverable.

Substitutes: Liquid crystals made from organic compounds are used in visual displays as substitutes for LEDs. Silicon-based complementary metal-oxide semiconductor power amplifiers compete with GaAs power amplifiers in midtier $3 G$ cellular handsets. Indium phosphide components can be substituted for GaAs-based infrared laser diodes in some specific-wavelength applications, and helium-neon lasers compete with GaAs in visible laser diode applications. Silicon is the principal competitor with GaAs in solar-cell applications. In many defense-related applications, GaAs-based ICs are used because of their unique properties, and no effective substitutes exist for GaAs in these applications. In heterojunction bipolar transistors, GaAs is being replaced in some applications by silicongermanium.

\footnotetext{
eEstimated. NA Not available. - Zero.

${ }^{1}$ Estimated based on the average values of U.S. imports for $99.9999 \%$ - and $99.99999 \%$-pure gallium.

${ }^{2}$ Estimated based on the average values of U.S. imports for $99.99 \%$-pure gallium.

${ }^{3}$ Defined as imports - exports. Excludes gallium arsenide wafers.

${ }^{4}$ Includes Hong Kong.

${ }^{5}$ See Appendix $\mathrm{C}$ for resource and reserve definitions and information concerning data sources.
}

U.S. Geological Survey, Mineral Commodity Summaries, January 2021 


\section{GARNET (INDUSTRIAL) ${ }^{1}$}

(Data in metric tons of garnet unless otherwise noted)

Domestic Production and Use: In 2020, garnet for industrial use was mined by four firms-one in Idaho, one in Montana, and two in New York. One processing facility operated in Oregon and another operated in Pennsylvania. The estimated value of crude garnet production was about $\$ 23$ million, and refined material sold or used had an estimated value of $\$ 65$ million. The major end uses of garnet were, in descending percentage of consumption, for abrasive blasting, water-filtration media, water-jet-assisted cutting, and other end uses, such as in abrasive powders, nonslip coatings, and sandpaper. Domestic industries that consume garnet include aircraft and motor vehicle manufacturers, ceramics and glass producers, electronic component manufacturers, filtration plants, glass polishing, the petroleum industry, shipbuilders, textile stonewashing, and wood-furniture-finishing operations.

\begin{tabular}{|c|c|c|c|c|c|}
\hline Salient Statistics-United Sta & $\underline{2016}$ & $\underline{2017}$ & $\underline{2018}$ & $\underline{2019}$ & $\underline{2020}$ \\
\hline \multicolumn{6}{|l|}{ Production: } \\
\hline Crude & 81,300 & 92,900 & 101,000 & 104,000 & 110,000 \\
\hline Refined, sold or used & 46,600 & 84,100 & 166,000 & 147,000 & 150,000 \\
\hline Imports for consumptione, 2 & 156,000 & 54,200 & 254,000 & 208,000 & 120,000 \\
\hline Exports ${ }^{e}$ & 10,100 & 17,700 & 14,200 & 12,600 & 20,000 \\
\hline Consumption, apparente, 3 & 227,000 & 129,000 & 341,000 & 300,000 & 210,000 \\
\hline Price, average import value, dollars per ton & 201 & 305 & 215 & 214 & 270 \\
\hline Employment, mine and mill, number & 110 & 140 & 170 & 160 & 130 \\
\hline Net import reliance 4 as a percentage & & & & & \\
\hline & 64 & 8 & 70 & 65 & \\
\hline
\end{tabular}

Recycling: Garnet was recycled at a plant in Oregon with a recycling capacity of 16,000 tons per year and at a plant in Pennsylvania with a recycling capacity of 25,000 tons per year. Garnet can be recycled multiple times without degradation of its quality. Most recycled garnet is from blast cleaning and water-jet-assisted cutting operations.

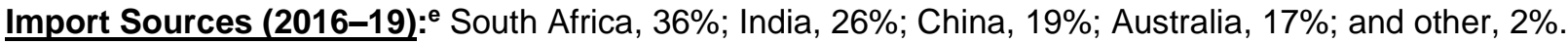

Tariff: Item

Emery, natural corundum, natural garnet, and other natural abrasives, crude

Emery, natural corundum, natural garnet, and other natural abrasives, other than crude
Number

2513.20.1000

2513.20.9000
Normal Trade Relations 12-31-20

Free.

Free.

Depletion Allowance: 14\% (domestic and foreign).

Government Stockpile: None.

Events, Trends, and Issues: During 2020, estimated domestic production of crude garnet concentrates increased by $6 \%$ compared with production in 2019. This increase was due to higher production levels from a mine in Montana, although all other U.S. garnet mines produced less compared with that in 2019. U.S. garnet production was estimated to be about $10 \%$ of total global garnet production. The 2020 estimated domestic sales or use of refined garnet were essentially unchanged compared with sales in 2019. 


\section{GARNET (INDUSTRIAL)}

Garnet imports in 2020 were estimated to have decreased by $42 \%$ compared with those in 2019 . Most of the decrease was attributed to a lack of imports of garnet from South Africa, owing to the Pennsylvania processing facility reaching its storage capacity. In 2020, the average unit value of garnet imports was $\$ 270$ per ton, an increase of $24 \%$ compared with the average unit value in 2019. In the United States, most domestically produced crude garnet concentrate was priced at about $\$ 210$ per ton. U.S. exports in 2020 were estimated to have increased by $59 \%$.

During 2020, the United States consumed about 210,000 metric tons of garnet. This was a $30 \%$ decrease from that of 2019.

The U.S. natural gas and petroleum industry is one of the leading garnet-consuming industries, using garnet for cleaning drill pipes and well casings. Natural gas and petroleum producers also use garnet as a reservoir-fracturing proppant, alone or mixed with other proppants. During 2020, the number of drill rigs operating in the United States was 804 rigs at the beginning of the year, decreasing through the year to 255 rigs at the end of September, likely indicating that less garnet was consumed in well drilling.

The garnet market is very competitive. To increase profitability and remain competitive with imported material, production may be restricted to only high-grade garnet ores or as a byproduct of other salable mineral products that occur with garnet, such as kyanite, marble, metallic ores, mica minerals, sillimanite, staurolite, or wollastonite.

\section{World Mine Production and Reserves:}

United States

Australia

China

India

South Africa

Other countries

World total (rounded)

\begin{tabular}{rr}
\multicolumn{2}{c}{ Mine production } \\
$\mathbf{2 0 1 9}$ & $\underline{\mathbf{2 0 2 0}}$ \\
104,000 & 110,000 \\
352,000 & 360,000 \\
310,000 & 310,000 \\
120,000 & 130,000 \\
179,000 & 140,000 \\
60,000 & 60,000 \\
\hline $1,120,000$ & $\frac{1,100,000}{}$
\end{tabular}

Reserves $^{5}$

$5,000,000$

Moderate to large

Moderate to large

$13,000,000$

NA

$6,500,000$

Moderate to large

World Resources: ${ }^{5}$ World resources of garnet are large and occur in a wide variety of rocks, particularly gneisses and schists. Garnet also occurs in contact-metamorphic deposits in crystalline limestones, pegmatites, serpentinites, and vein deposits. In addition, alluvial garnet is present in many heavy-mineral sand and gravel deposits throughout the world. Large domestic resources of garnet also are concentrated in coarsely crystalline gneiss near North Creek, NY; other significant domestic resources of garnet occur in Idaho, Maine, Montana, New Hampshire, North Carolina, and Oregon. In addition to those in the United States, major garnet deposits exist in Australia, Canada, China, India, and South Africa, where they are mined for foreign and domestic markets; deposits in Russia and Turkey also have been mined in recent years, primarily for internal markets. Additional garnet resources are in Chile, Czechia, Pakistan, Spain, Thailand, and Ukraine; small mining operations have been reported in most of these countries.

Substitutes: Other natural and manufactured abrasives can substitute to some extent for all major end uses of garnet. In many cases, however, using the substitutes would entail sacrifices in quality or cost. Fused aluminum oxide and staurolite compete with garnet as a sandblasting material. IImenite, magnetite, and plastics compete as filtration media. Corundum, diamond, and fused aluminum oxide compete for lens grinding and for many lapping operations. Emery is a substitute in nonskid surfaces. Fused aluminum oxide, quartz sand, and silicon carbide compete for the finishing of plastics, wood furniture, and other products.

\footnotetext{
eEstimated. NA Not available.

${ }^{1}$ Excludes gem and synthetic garnet.

${ }^{2}$ Source: U.S. Census Bureau and Trade Mining, LLC; adjusted by the U.S. Geological Survey.

${ }^{3}$ Defined as crude production + imports - exports.

${ }^{4}$ Defined as imports - exports.

${ }^{5}$ See Appendix $\mathrm{C}$ for resource and reserve definitions and information concerning data sources.
} 


\section{GEMSTONES ${ }^{1}$}

(Data in million dollars unless otherwise noted)

Domestic Production and Use: The combined value of U.S. natural and synthetic gemstone output in 2020 was an estimated $\$ 99$ million, a $4 \%$ decrease compared with that of 2019. Domestic gemstone production included agate, beryl, coral, diamond, garnet, jade, jasper, opal, pearl, quartz, sapphire, shell, topaz, tourmaline, turquoise, and many other gem materials. In descending order of production value, Arizona, Oregon, California, Nevada, Montana, Maine, Arkansas, Colorado, Utah, Idaho, Tennessee, North Carolina, and New York produced $95 \%$ of U.S. natural gemstones. Synthetic gemstones were manufactured by five companies in California, North Carolina, New York, Maryland, and Arizona, in decreasing order of production value. U.S. synthetic gemstone production decreased by $4 \%$ compared with that in 2019. Major gemstone end uses were carvings, gem and mineral collections, and jewelry.

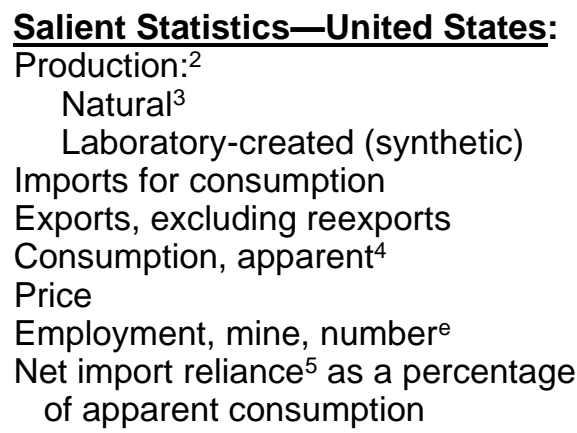

\begin{tabular}{rrrrr}
$\mathbf{2 0 1 6}$ & $\underline{\mathbf{2 0 1 7}}$ & $\underline{\mathbf{2 0 1 8}}$ & $\underline{\mathbf{2 0 1 9}}$ & $\underline{\mathbf{2 0 2 0}}$ \\
11.7 & 9.2 & 9.5 & 9.2 & 8.8 \\
54.9 & 55.1 & 65 & 94 & 90 \\
25,200 & 24,900 & 27,700 & 24,400 & 17,000 \\
2,940 & 2,440 & 1,850 & 1,050 & 1,500 \\
22,300 & 22,500 & 25,900 & 23,500 & 16,000 \\
\multicolumn{4}{l}{ Variable, depending } & on size, type, and quality \\
1,120 & 1,120 & 1,120 & 1,120 & 1,120 \\
99 & 99 & 99 & 99 & 99
\end{tabular}

Recycling: Gemstones are often recycled by being resold as estate jewelry, reset, or recut, but this report does not account for those stones.

Import Sources (2016-19, by value): Diamond: India, 39\%; Israel, 32\%; Belgium, 13\%; South Africa, 4\%; and other, $12 \%$. Diamond imports accounted for an average of $90 \%$ of the total value of gem imports.

Tariff: Item

Coral and similar materials, unworked Imitation gemstones

Pearls, imitation, pearl beads, not strung

Imitation gemstones, glass beads

Pearls, natural, graded and temporarily strung

Pearls, natural, other

Pearls, cultured

Diamonds, unworked or sawn

Diamonds, $1 / 2$ carat or less

Diamonds, cut, more than $1 / 2$ carat

Other nondiamond gemstones, unworked

Other nondiamond gemstones, uncut

Rubies, cut

Sapphires, cut

Emeralds, cut

Other nondiamond gemstones, cut

Other nondiamond gemstones, worked

Synthetic gemstones, cut but not set

Synthetic gemstones, other
Number

0508.00 .0000

3926.90 .4000

7018.10 .1000

7018.10 .2000

7101.10 .3000

7101.10 .6000

7101.21 .0000

7102.31 .0000

7102.39 .0010

7102.39 .0050

7103.10 .2000

7103.10 .4000

7103.91 .0010

7103.91 .0020

7103.91 .0030

7103.99 .1000

7103.99 .5000

7104.90 .1000

7104.90 .5000

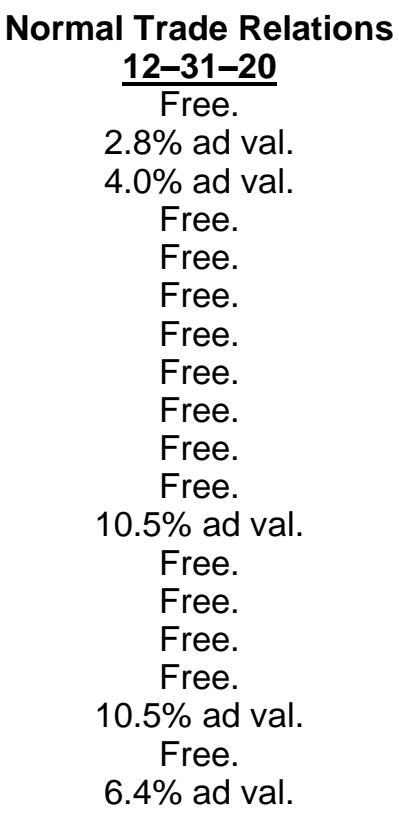

Depletion Allowance: 14\% (domestic and foreign).

Government Stockpile: None.

Events, Trends, and Issues: During 2020, the global COVID-19 pandemic affected the U.S. gemstone and jewelry industries. As the restrictions, lockdowns, and store closings were imposed, many jewelry stores initially saw reduced sales but later in the year successfully shifted sales to their websites. Monthly U.S. gemstone imports declined from March through August, with the largest decrease year-on-year of $96 \%$ happening in April. U.S. apparent consumption of gemstones decreased by $32 \%$. All major U.S. gemstone trade shows were canceled from March through August. 


\section{GEMSTONES}

In 2020 , U.S. imports for consumption of gem-quality diamonds were estimated to be about $\$ 15$ billion, which was a $31 \%$ decrease compared with $\$ 21.7$ billion in 2019. U.S. imports for consumption of natural, nondiamond gemstones were estimated to be about $\$ 2.1$ billion, which was a $22 \%$ decrease compared with $\$ 2.7$ billion in 2019 . Despite the COVID-19 pandemic, the United States was once again the leading global market in terms of consumer demand. The United States is expected to continue to dominate global gemstone demand.

During 2020, the COVID-19 pandemic affected the global diamond industry with temporary diamond mine closings around the world and disruptions of the supply chain. Demand for diamonds plummeted during the pandemic, halting sales. Only demand for large, high-quality diamonds remained stable, and their prices increased steadily during the year. The pandemic forced mining companies to cancel or delay sales, and major diamond trade shows were canceled owing to health and travel restrictions. Rough diamond prices declined by between $15 \%$ and $27 \%$ at the few sales that took place, and the rough diamond market was not operating normally during the second quarter. In India, where about $80 \%$ of the world's diamonds are polished, cutting centers experienced major disruptions as gem workers contracted the virus. Imports of rough diamonds in India decreased from $\$ 1.5$ billion in February to $\$ 1$ million in April. Antwerp experienced a $20 \%$ drop in rough imports and a $46 \%$ decline in exports of polished diamonds. Worldwide, many temporary mine closures resulting from the pandemic, had yet to reopen and were at risk of becoming permanent. Many mining companies sought credit protection or were restructuring their credit. The global diamond jewelry market had an estimated value of $\$ 80$ billion in 2019 and was expected to decline by $19 \%$ in 2020 .

Total world diamond production during 2020 decreased by $10 \%$ from 2019 levels. This decline was attributed to pandemic mine closures and mines becoming depleted.

\section{World Gem Diamond Mine Production and Reserves:}

\begin{tabular}{lrr} 
& \multicolumn{2}{c}{ Mine production } \\
& $\underline{\mathbf{2 0 1 9}}$ & $\underline{\mathbf{2 0 2 0}}$ \\
United States & $\mathbf{-}$ & $-\overline{-}$ \\
Angola & 260 & 8,000 \\
Australia & 16,600 & 13,000 \\
Botswana & 166 & 100 \\
Brazil & 18,600 & 17,000 \\
Canada & 2,670 & 3,000 \\
Congo (Kinshasa) & 183 & 150 \\
Guinea & 1,110 & 1,000 \\
Lesotho & 2,020 & 1,900 \\
Namibia & 25,400 & 24,000 \\
Russia & 649 & 550 \\
Sierra Leone & 5,740 & 4,000 \\
South Africa & 313 & 300 \\
Tanzania & 211 & 200 \\
Zimbabwe & 224 & 230 \\
Other countries & 82,400 & 74,000
\end{tabular}

\section{Reserves $^{7}$}

World reserves of diamond-bearing deposits are substantial. No reserves data are available for other gemstones.

World Resources: ${ }^{7}$ Most diamond ore bodies have a diamond content that ranges from less than 1 carat per ton to about 6 carats per ton of ore. The major diamond reserves are in southern Africa, Australia, Canada, and Russia.

Substitutes: Glass, plastics, and other materials are substituted for natural gemstones. Synthetic gemstones (manufactured materials that have the same chemical and physical properties as natural gemstones) are common substitutes. Simulants (materials that appear to be gems but differ in chemical and physical characteristics) also are frequently substituted for natural gemstones.

\footnotetext{
eEstimated. - Zero.

${ }^{1}$ Excludes industrial diamond and industrial garnet. See Diamond (Industrial) and Garnet (Industrial).

${ }^{2}$ Estimated minimum production.

${ }^{3}$ Includes production of freshwater shell.

${ }^{4}$ Defined as production (natural and synthetic) + imports - exports (excluding reexports).

${ }^{5}$ Defined as imports - exports (excluding reexports).

${ }^{6}$ Data in thousands of carats of gem diamond.

${ }^{7}$ See Appendix $C$ for resource and reserve definitions and information concerning data sources.
} 


\section{GERMANIUM}

(Data in kilograms of germanium content unless otherwise noted)

Domestic Production and Use: In 2020, zinc concentrates containing germanium were produced at mines in Alaska and Tennessee. Germanium-containing concentrates in Alaska were exported to a refinery in Canada for processing and germanium recovery. A zinc smelter in Clarksville, TN, produced and exported germanium leach concentrates recovered from processing zinc concentrates from the Middle Tennessee Mines. Germanium in the form of compounds and metal was imported into the United States for further processing by industry. A company in Utah produced germanium wafers for solar cells used in satellites from imported and recycled germanium. A refinery in Oklahoma recovered germanium from industry-generated scrap and produced germanium tetrachloride for the production of fiber optics. Although the consumption quantity was estimated to have remained level in 2020 compared with that in 2019, the estimated value of germanium consumed in 2020, based on the annual average germanium metal price, was $\$ 30$ million, about 19\% less than that in 2019 .

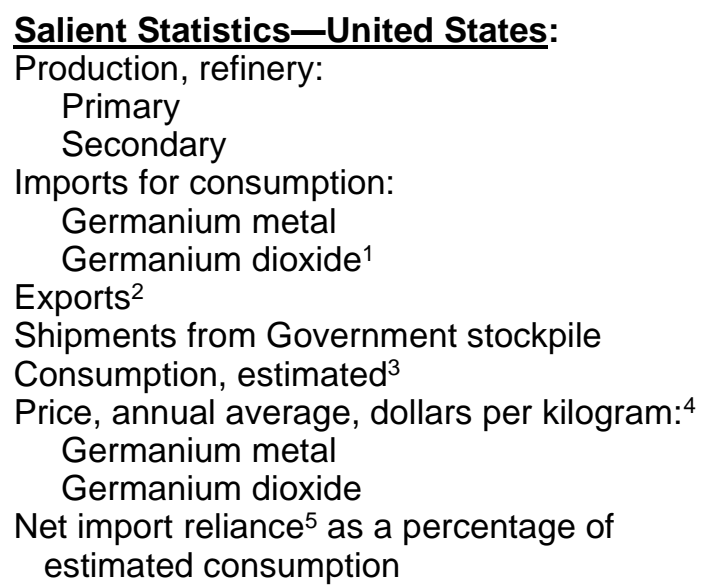

$\begin{array}{rrrrr}\underline{\mathbf{2 0 1 6}} & \underline{\mathbf{2 0 1 7}} & \underline{\mathbf{2 0 1 8}} & \underline{\mathbf{2 0 1 9}} & \underline{\mathbf{2 0 2 0}} \\ \overline{\mathrm{W}} & \overline{\mathrm{W}} & \overline{\mathrm{W}} & \overline{\mathrm{W}} & \overline{\mathrm{W}} \\ 11,000 & 11,100 & 11,900 & 14,100 & 16,000 \\ 15,200 & 12,000 & 12,200 & 21,000 & 10,000 \\ 4,780 & 3,670 & 4,880 & 4,600 & 8,000 \\ 30,0 \overline{-} & 30,000 & 30,000 & 30,000 & 30,000 \\ 1,087 & 1,082 & 1,543 & 1,236 & 1,000 \\ 830 & 731 & 1,084 & 913 & 720 \\ >50 \% & >50 \% & >50 \% & >50 \% & >50 \%\end{array}$

Recycling: Worldwide, about $30 \%$ of the total germanium consumed is produced from recycled materials. During the manufacture of most optical devices, more than $60 \%$ of the germanium metal used is routinely recycled as new scrap. Germanium scrap is also recovered from the windows in decommissioned tanks and other military vehicles. The United States has the capability to recycle new and old scrap.

Import Sources (2016-19): ${ }^{6}$ Germanium metal: China, 58\%; Belgium, 21\%; Germany, 10\%; Russia, 8\%; and other, $3 \%$.

Tariff: Item

Germanium oxides and zirconium dioxide

Metal, unwrought

Metal, powder

Metal, wrought
Number

2825.60.0000

8112.92 .6000

8112.92 .6500

8112.99 .1000
Normal Trade Relations

12-31-20

$3.7 \%$ ad val.

$2.6 \%$ ad val.

$4.4 \%$ ad val.

$4.4 \%$ ad val.

Depletion Allowance: $14 \%$ (domestic and foreign).

\section{Government Stockpile:"7}

\section{Material}

Germanium metal

Germanium scrap (gross weight)

Germanium wafers (each)

Inventory
as of $\mathbf{9 - 3 0 - 2 0}$
14,004
3,794
68,671

FY 2020

$\begin{array}{cc}\begin{array}{c}\text { Potential } \\ \text { acquisitions }\end{array} & \begin{array}{c}\text { Potential } \\ \text { disposals }\end{array} \\ - & - \\ - & 3,000\end{array}$

FY 2021

$\begin{array}{cc}\begin{array}{c}\text { Potential } \\ \text { acquisitions } \\ -\end{array} & \begin{array}{c}\text { Potential } \\ \text { disposals }\end{array} \\ - & 3,000 \\ - & -\end{array}$


Events, Trends, and Issues: The major global end uses for germanium were electronics and solar applications, fiber-optic systems, infrared optics, polymerization catalysts, and other uses (such as chemotherapy, metallurgy, and phosphors). Germanium-containing infrared optics were primarily for military use, but the commercial applications for thermal-imaging devices that use germanium lenses have increased during the past few years.

Demand for fiber-optic cable in the United States reportedly decreased during 2020 owing to decreasing demand from related industrial end use markets as a result of the COVID-19 pandemic. However, this decrease was partially offset by Federal funding to increase broadband infrastructure in rural communities and a nationwide increase in remote work. Domestic demand for fiber-optic cable was still expected to increase as wireless carriers continue to expand and upgrade their networks.

The government of Yunnan Province, a significant area of nonferrous and minor metals production in China, created a stimulus plan directing companies to purchase and stockpile nonferrous metals in response to lower demand caused by the COVID-19 pandemic. Under the plan, the government had targeted a "commercial" stockpile of about 800,000 tons of metals, including 20 tons of germanium, and set aside $\$ 141$ million to subsidize the interest on any loans taken out by companies to stockpile these metals. China's germanium exports in January through August 2020 increased by $18 \%$ compared with those in the same period of 2019 . A leading Chinese producer of processed germanium products, based in Yunnan Province, reported that production of germanium wafers for satellites in January through June 2020 was more the seven times higher than wafer production in the first half of 2019 as production ramped up at its new germanium wafer production line.

\section{World Refinery Production and Reserves: ${ }^{8}$}

\begin{tabular}{lrrr} 
& \multicolumn{2}{c}{ Refinery production } & Reserves $^{9}$ \\
United States & $\underline{\mathbf{2 0 1 9}}$ & $\underline{\mathbf{2 0 2 0}}$ & \\
China & 85,700 & 86,000 & Data on the recoverable germanium \\
Russia & 5,000 & 5,000 & content of zinc ores are not available. \\
Other countries $^{10}$ & $\frac{40,000}{131,000}$ & $\frac{40,000}{130,000}$ & \\
$\quad$ World total (rounded) & ${ }^{11}$ & 13,000 &
\end{tabular}

World Resources: ${ }^{9}$ The available resources of germanium are associated with certain zinc and lead-zinc-copper sulfide ores. Substantial U.S. reserves of recoverable germanium are contained in zinc deposits in Alaska, Tennessee, and Washington. Based on an analysis of zinc concentrates, U.S. reserves of zinc may contain as much as 2,500 tons of germanium. Because zinc concentrates are shipped globally and blended at smelters, however, the recoverable germanium in zinc reserves cannot be determined. On a global scale, as little as 3\% of the germanium contained in zinc concentrates is recovered. Significant amounts of germanium are contained in ash and flue dust generated in the combustion of certain coals for power generation.

Substitutes: Silicon can be a less-expensive substitute for germanium in certain electronic applications. Some metallic compounds can be substituted in high-frequency electronics applications and in some light-emitting-diode applications. Zinc selenide and germanium glass substitute for germanium metal in infrared applications systems, but often at the expense of performance. Antimony and titanium are substitutes for use as polymerization catalysts.

\footnotetext{
eEstimated. W Withheld to avoid disclosing company proprietary data. - Zero.

${ }^{1}$ Data has been adjusted to exclude low-value shipments, then multiplied by $69 \%$ to account for germanium content.

${ }^{2}$ Includes Schedule B numbers: 8112.92.6100, 8112.99.1000, and 2825.60.0000. Data have been adjusted to exclude low-value shipments. Oxide data have been multiplied by $69 \%$ to account for germanium content.

${ }^{3}$ Estimated consumption of germanium contained in metal and germanium dioxide.

${ }^{4}$ Average European price for minimum 99.999\% purity. Source: Argus Media group-Argus Metals International.

${ }^{5}$ Defined as imports - exports + adjustments for Government stock changes.

${ }^{6}$ Import sources are based on gross weight of wrought and unwrought germanium metal and germanium metal powders.

${ }^{7}$ See Appendix $B$ for definitions.

${ }^{8}$ Includes primary and secondary production.

${ }^{9}$ See Appendix $C$ for resource and reserve definitions and information concerning data sources.

${ }^{10}$ Includes Belgium, Canada, Germany, Japan, and Ukraine.

${ }^{11}$ Excludes U.S. production.
} 


\section{GOLD}

(Data in metric tons ${ }^{1}$ of gold content unless otherwise noted)

Domestic Production and Use: In 2020, domestic gold mine production was estimated to be about 190 tons, $5 \%$ less than that in 2019, and the value was estimated to be about $\$ 11$ billion. Gold was produced in 11 States (gold mining in Montana ceased in 2019) at more than 40 lode mines, at several large placer mines in Alaska, and numerous smaller placer mines (mostly in Alaska and in the Western States). About 7\% of domestic gold was recovered as a byproduct of processing domestic base-metal ores, chiefly copper ores. The top 26 operations yielded about $99 \%$ of the mined gold produced in the United States. Commercial-grade gold was produced at about 15 refineries. A few dozen companies, out of several thousand companies and artisans, dominated the fabrication of gold into commercial products. U.S. jewelry manufacturing was heavily concentrated in the New York, NY, and Providence, RI, areas, with lesser concentrations in California, Florida, and Texas. Estimated global consumption was gold-based exchange-traded funds, 34\%; jewelry, 30\%; physical bar, $12 \%$; official coins and medals and imitation coins, $9 \%$; central banks and other institutions, $7 \%$; electrical and electronics, $6 \%$; and other, $2 \%$.

\begin{tabular}{|c|c|c|c|c|c|}
\hline \multirow{2}{*}{\multicolumn{6}{|c|}{$\begin{array}{l}\text { Salient Statistics-United States: } \\
\text { Production: }\end{array}$}} \\
\hline & & & & & \\
\hline Mine & 232 & 237 & 226 & 200 & 190 \\
\hline \multicolumn{6}{|l|}{ Refinery: } \\
\hline Primary & 242 & 207 & 205 & 205 & 200 \\
\hline Secondary (new and old scrap) & 220 & 119 & 117 & 116 & 120 \\
\hline Imports for consumption ${ }^{2}$ & 374 & 255 & 213 & 199 & 610 \\
\hline Exports $^{2}$ & 393 & 461 & 474 & 359 & 270 \\
\hline Consumption, reported ${ }^{3}$ & 210 & 159 & 154 & 151 & 160 \\
\hline Stocks, Treasury, yearend ${ }^{4}$ & 8,140 & 8,140 & 8,140 & 8,140 & 8,140 \\
\hline Price, dollars per troy ounce 5 & 1,252 & 1,261 & 1,272 & 1,395 & 1,770 \\
\hline Employment, mine and mill, number 6 & 11,600 & 11,900 & 12,200 & 12,500 & 12,200 \\
\hline $\begin{array}{l}\text { Net import reliance }{ }^{7} \text { as a percentage of } \\
\text { apparent consumption }\end{array}$ & $E$ & $\mathrm{E}$ & 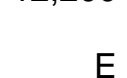 & $1,-, 000$ & 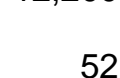 \\
\hline
\end{tabular}

Recycling: In 2020, an estimated 120 tons of new and old scrap was recycled, equivalent to about $75 \%$ of reported consumption. The domestic supply of gold from recycling increased slightly compared with that of 2019.

Import Sources (2016-19): ${ }^{2}$ Ores and concentrates: Greece, 44\%; Canada, 30\%; Ireland, 26\%; and other, $<1 \%$. Dore: Mexico, 42\%; Peru, 16\%; Colombia, 12\%; Canada, 6\%; and other, 24\%. Bullion: Canada, 41\%; Switzerland, 20\%; Peru, 9\%; Brazil and Mexico, 7\% each; and other, 16\%. Combined total: Mexico, 27\%; Canada, 21\%; Peru, $13 \%$; Colombia, $8 \%$; and other, $31 \%$.

Tariff: Item

Precious metal ore and concentrates:

Gold content of silver ores

Gold content of other ores

Gold bullion

Gold dore

Gold scrap
Number

2616.10.0080

2616.90 .0040

7108.12 .1013

7108.12.1020

7112.91 .0000

\section{Normal Trade Relations 12-31-20}

$0.8 \mathrm{c} / \mathrm{kg}$ on lead content.

$1.7 \mathrm{c} / \mathrm{kg}$ on lead content.

Free.

Free.

Free.

Depletion Allowance: 15\% (domestic), 14\% (foreign).

Government Stockpile: The U.S. Department of the Treasury maintains stocks of gold (see salient statistics above), and the U.S. Department of Defense administers a Governmentwide secondary precious-metals recovery program.

Events, Trends, and Issues: The United States was not a net exporter of gold in 2020 for the first time since 2010 owing to a significant increase in imports of high-purity gold bullion. The estimated gold price in 2020 was $26 \%$ higher than the price in 2019 , and $5 \%$ higher than the previous record-high annual price in 2012 . The Engelhard daily price of gold in 2020 fluctuated through several cycles. Early in the year the gold price was about of $\$ 1,580$ per troy ounce before decreasing in March and increasing to an allime high of about $\$ 2,060$ per troy ounce in August. During this time, several factors were reported to have caused the increase in price: gold demand increased to safe-haven buying as a result of the global COVID-19 pandemic and global investor uncertainty; the U.S. Federal Reserve Board cut interest rates; and trade negotiations halted between the United States and China. The price started a downward trend in October and November. 
The $5 \%$ decrease in domestic mine production in 2020 was attributed to the COVID-19 pandemic. In 2020, worldwide gold mine production was estimated to be $3 \%$ less than that in 2019. Mine production remained unchanged in Argentina, China, Mali, and Sudan, and was slightly less in Australia, Canada, Ghana, and Russia compared with that of 2019.

In the first 9 months of 2020, global consumption in physical bars decreased by about $16 \%$, in jewelry by $41 \%$, and in industrial applications by 10\%; however, gold consumption in official coins and medals and imitation coins increased by $33 \%$ compared with that of the first 9 months of 2019. Global investments in gold-based exchange-traded funds increased by almost $168 \%$, while gold holdings in central banks decreased by about $58 \%$ during the same period.

World Mine Production and Reserves: Reserves for Canada, Papua New Guinea, Peru, Russia, and South Africa were revised based on Government and (or) industry reports.

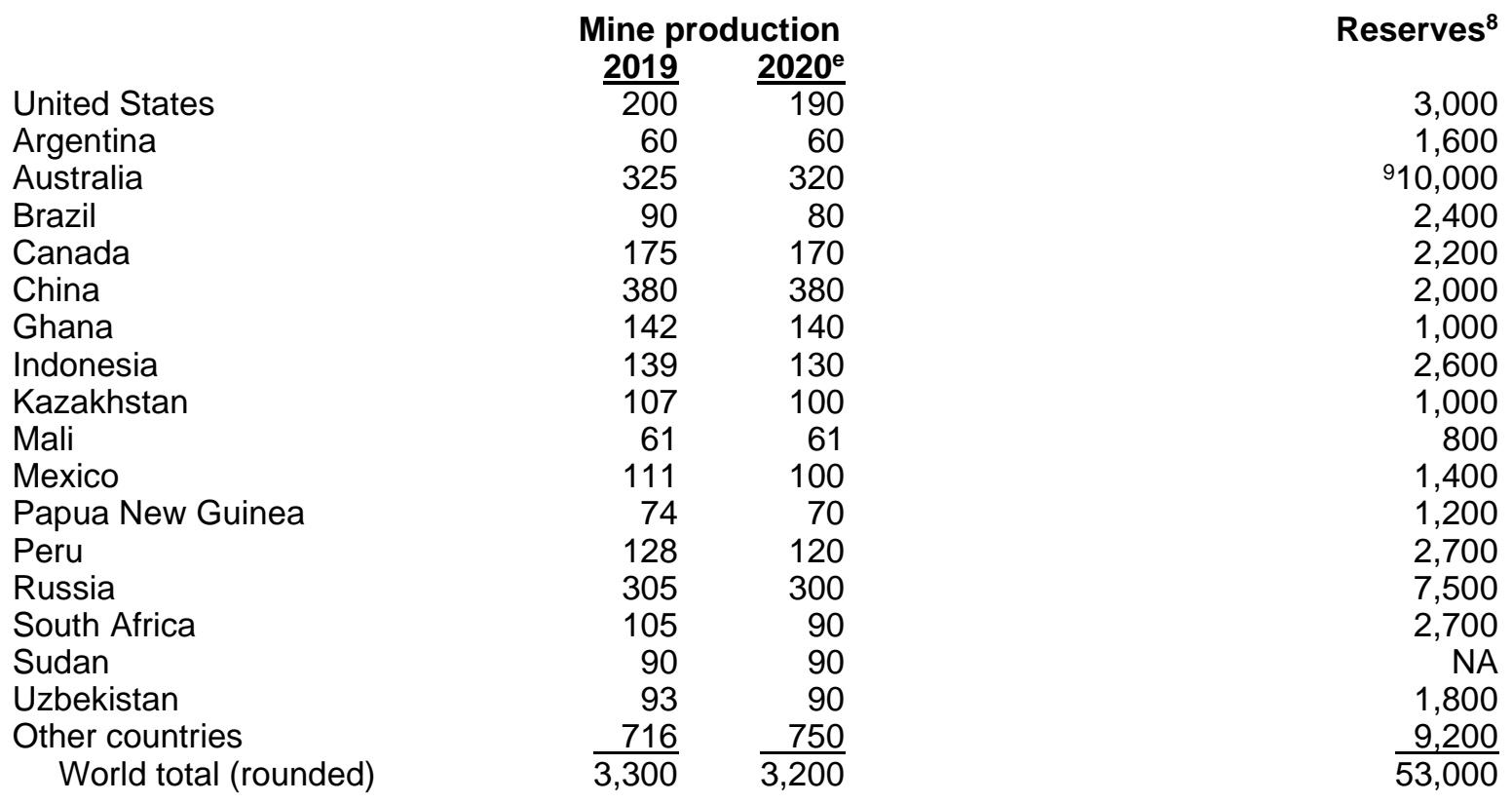

World Resources: ${ }^{8}$ An assessment of U.S. gold resources indicated 33,000 tons of gold in identified (15,000 tons) and undiscovered (18,000 tons) resources. 10 Nearly one-quarter of the gold in undiscovered resources was estimated to be contained in porphyry copper deposits. The gold resources in the United States, however, are only a small portion of global gold resources.

Substitutes: Base metals clad with gold alloys are widely used in electrical and electronic products, and in jewelry to economize on gold; many of these products are continually redesigned to maintain high-utility standards with lower gold content. Generally, palladium, platinum, and silver may substitute for gold.

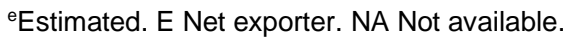

${ }^{1}$ One metric ton $(1,000$ kilograms $)=32,150.7$ troy ounces.

${ }^{2}$ Includes refined bullion, dore, ores, concentrates, and precipitates. Excludes waste and scrap, official monetary gold, gold in fabricated items, gold in coins, and net bullion flow (in tons) to market from foreign stocks at the New York Federal Reserve Bank.

${ }^{3}$ Includes gold used in the production of consumer purchased bar, coins, and jewelry. Excludes gold as an investment (except consumer purchased bar and coins). Source: World Gold Council.

${ }^{4}$ Includes gold in Exchange Stabilization Fund. Stocks were valued at the official price of $\$ 42.22$ per troy ounce.

${ }^{5}$ Engelhard's average gold price quotation for the year. In 2020, the price was estimated by the U.S. Geological Survey based on data from January through November.

${ }^{6}$ Data from the Mine Safety and Health Administration.

${ }^{7}$ Defined as imports - exports.

${ }^{8}$ See Appendix $\mathrm{C}$ for resource and reserve definitions and information concerning data sources.

${ }^{9}$ For Australia, Joint Ore Reserves Committee-compliant reserves were 4,000 tons.

${ }^{10}$ U.S. Geological Survey National Mineral Resource Assessment Team, 2000, 1998 assessment of undiscovered deposits of gold, silver, copper, lead, and zinc in the United States: U.S. Geological Survey Circular 1178, 21 p.
} 


\section{GRAPHITE (NATURAL)}

(Data in metric tons unless otherwise noted)

Domestic Production and Use: In 2020, natural graphite was not produced in the United States; however, approximately 95 U.S. firms, primarily in the Great Lakes and Northeastern regions and Alabama and Tennessee, consumed 35,000 tons valued at an estimated $\$ 21$ million. The major uses of natural graphite were batteries, brake linings, lubricants, powdered metals, refractory applications, and steelmaking. During 2020, U.S. natural graphite imports were an estimated 41,000 tons, which were about $71 \%$ flake and high-purity, $28 \%$ amorphous, and $1 \%$ lump and chip graphite.

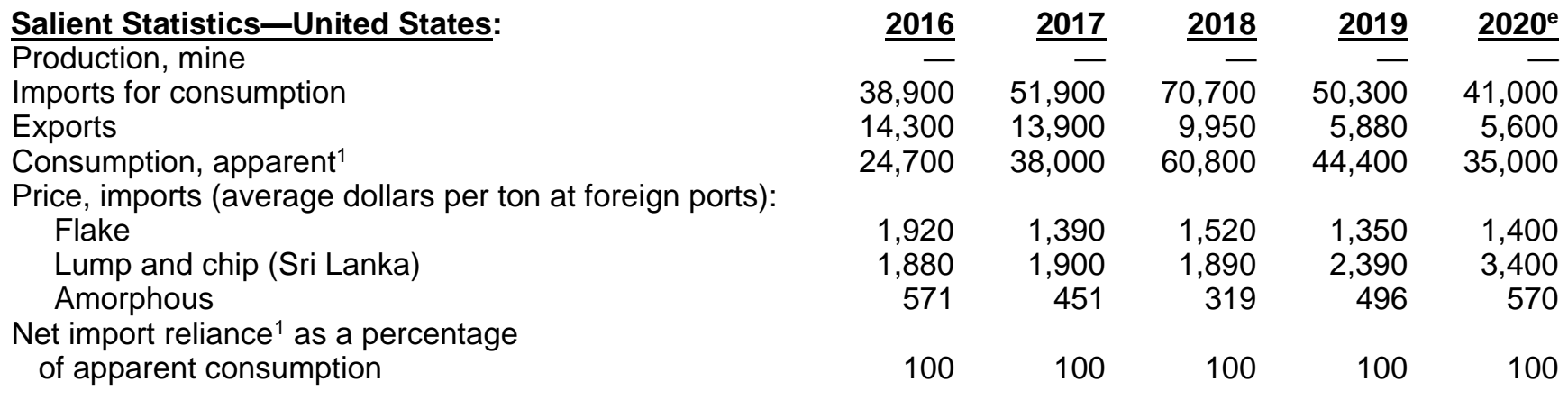

Recycling: Refractory brick and linings, alumina-graphite refractories for continuous metal castings, magnesiagraphite refractory brick for basic oxygen and electric arc furnaces, and insulation brick led the way in the recycling of graphite products. The market for recycled refractory graphite material is expanding, with material being recycled into products such as brake linings and thermal insulation. Recovering high-quality flake graphite from steelmaking kish is technically feasible, but currently not practiced. The abundance of graphite in the world market inhibits increased recycling efforts. Information on the quantity and value of recycled graphite is not available.

Import Sources (2016-19): China, 33\%; Mexico, 23\%; Canada, 17\%; India, 9\%; and other, 18\%.

Tariff: Item

Crystalline flake (not including flake dust)

Powder

Other
Number

2504.10.1000

2504.10.5000

2504.90.0000
Normal Trade Relations 12-31-20

Free.

Free.

Free.

Depletion Allowance: 22\% (domestic lump and amorphous), 14\% (domestic flake), and 14\% (foreign).

Government Stockpile: None.

Events, Trends, and Issues: U.S. natural graphite exports decreased each year from 2016 to 2020, with an overall $61 \%$ decline over the 5-year period. U.S. imports for consumption and apparent consumption increased each year from 2016 to 2018, when imports and consumption peaked, and declined each year during 2019 and 2020.

Restrictions put in place in response to the COVID-19 pandemic caused the 2020 U.S. imports to decrease by $18 \%$, which in turn caused a $21 \%$ decrease in U.S. apparent consumption.

In 2020, principal United States import sources of natural graphite were, in descending order of tonnage, China, Mexico, Canada, Madagascar, Mozambique, Brazil, the United Kingdom, Hong Kong, Austria, and Belgium, which combined accounted for $99 \%$ of the tonnage and $96 \%$ of the value of total United States imports. China and Mexico provided most of the amorphous graphite, and Sri Lanka provided all the lump and chip dust variety.

During 2020, China was the world's leading graphite producer, producing an estimated $62 \%$ of total world output. Approximately $40 \%$ of production in China was amorphous graphite and about $60 \%$ was flake. China produced some large flake graphite, but much of its flake graphite production is very small, in the +200 -mesh range. China also processed most of the world's spherical graphite. Globally, during the first 6 months of 2020, the COVID-19 pandemic had some effect on graphite supplies, but mostly to operations outside of China. Most areas in China important for natural graphite flake production were far from the initial coronavirus occurrences. The impact was limited in these areas and the recovery was quick, which was demonstrated by China's pattern of exports. Chinese producers quickly increased production after a few months of closures in 2020. This allowed China to gain a more dominant position in the market and slow down the diversification of the supply chain. 
North America produced only $2 \%$ of the world's graphite supply with production in Canada and Mexico. No production of natural graphite was reported in the United States, but two companies were developing graphite projects-one in Alabama and one in Alaska.

Large graphite deposits were being developed in Madagascar, northern Mozambique, Namibia, and south-central Tanzania. A graphite mine in Mozambique in a high-grade graphite deposit was reportedly the largest natural graphite mine globally. The mine was expected to operate for about 50 years.

A U.S. automaker continued building a large plant to manufacture lithium-ion electric vehicle batteries. The automaker reported that the plant was about $30 \%$ completed. The completed portion of the plant was operational, and it produced battery cells, battery packs, drive units, and energy storage products. At full capacity, the plant was expected to require 35,200 tons per year of spherical graphite for use as anode material for lithium-ion batteries.

New thermal technology and acid-leaching techniques have enabled the production of higher purity graphite powders that are likely to lead to development of new applications for graphite in high-technology fields. Innovative refining techniques have made the use of graphite possible in carbon-graphite composites, electronics, foils, friction materials, and specialty lubricant applications. Flexible graphite product lines are likely to be the fastest growing market. Largescale fuel-cell applications are being developed that could consume as much graphite as all other uses combined.

World Mine Production and Reserves: Reserves for Brazil, Madagascar, Sri Lanka, and Tanzania were revised based on information reported by graphite-producing companies and the Governments of those countries.

\begin{tabular}{lrrr} 
& \multicolumn{2}{c}{ Mine production } & Reserves $^{\mathbf{2}}$ \\
United States & $\mathbf{2 0 1 9}$ & $\mathbf{2 0 2 0}$ & $(3)$ \\
Austria & 1,000 & 1,000 & $(3)$ \\
Brazil & 96,000 & 95,000 & $70,000,000$ \\
Canada & 11,000 & 10,000 & $(3)$ \\
China & 700,000 & 650,000 & $73,000,000$ \\
Germany & 800 & 800 & $(3)$ \\
India & 35,000 & 34,000 & $8,000,000$ \\
Korea, North & 6,000 & 5,000 & $2,000,000$ \\
Madagascar & 48,000 & 47,000 & $26,000,000$ \\
Mexico & 9,000 & 8,000 & $3,100,000$ \\
Mozambique & 107,000 & 120,000 & $25,000,000$ \\
Norway & 16,000 & 15,000 & 600,000 \\
Pakistan & 14,000 & 13,000 & $(3)$ \\
Russia & 25,100 & 24,000 & $(3)$ \\
Sri Lanka & 4,000 & 3,500 & $1,500,000$ \\
Tanzania & 150 & 150 & $17,000,000$ \\
Turkey & 2,000 & 1,500 & $90,000,000$ \\
Ukraine & 20,000 & 19,000 & $(3)$ \\
Uzbekistan & 100 & 100 & $7,600,000$ \\
Vietnam & 5,000 & 4,500 & $(3)$ \\
$\quad$ World total (rounded) & $1,100,000$ & $1,100,000$ & $320,000,000$
\end{tabular}

World Resources: ${ }^{2}$ Domestic resources of graphite are relatively small, but the rest of the world's inferred resources exceed 800 million tons of recoverable graphite.

Substitutes: Synthetic graphite powder, scrap from discarded machined shapes, and calcined petroleum coke compete for use in iron and steel production. Synthetic graphite powder and secondary synthetic graphite from machining graphite shapes compete for use in battery applications. Finely ground coke with olivine is a potential competitor in foundry-facing applications. Molybdenum disulfide competes as a dry lubricant but is more sensitive to oxidizing conditions.

\footnotetext{
eEstimated. - Zero.

${ }^{1}$ Defined as imports - exports.

${ }^{2}$ See Appendix $\mathrm{C}$ for resource and reserve definitions and information concerning data sources.

${ }^{3}$ Included with "World total."
} 


\section{GYPSUM}

(Data in thousand metric tons unless otherwise noted)

Domestic Production and Use: In 2020, domestic production of crude gypsum was estimated to be 22 million tons with a value of about $\$ 190$ million. The leading crude gypsum-producing States were estimated to be lowa, Kansas, Nevada, Oklahoma, and Texas. Overall, 47 companies produced or processed gypsum in the United States at 52 mines in 16 States. The majority of domestic consumption, which totaled approximately 41 million tons, was used by agriculture, cement production, and manufacturers of wallboard and plaster products. Small quantities of highpurity gypsum, used in a wide range of industrial processes, accounted for the remaining tonnage. At the beginning of 2020, the production capacity of 63 operating gypsum panel manufacturing plants in the United States was about 34.1 billion square feet ${ }^{1}$ per year. Total wallboard sales were estimated to be 26.0 billion square feet.

\begin{tabular}{|c|c|c|c|c|c|}
\hline Salient Statistics-United States: & $\underline{2016}$ & $\underline{2017}$ & $\underline{2018}$ & $\underline{2019}$ & $\underline{2020^{\circ}}$ \\
\hline \multicolumn{6}{|l|}{ Production: } \\
\hline Crude & 19,800 & 20,700 & 21,100 & 21,200 & 22,000 \\
\hline Synthetic ${ }^{2}$ & 16,700 & 20,700 & 16,600 & 14,400 & 13,000 \\
\hline Calcined $^{3}$ & 17,900 & 17,800 & 17,500 & 17,500 & 17,000 \\
\hline Wallboard products sold, million square feet ${ }^{1}$ & 24,400 & 25,000 & 23,700 & 25,200 & 26,000 \\
\hline Imports, crude, including anhydrite & 4,340 & 4,800 & 5,210 & 6,140 & 5,900 \\
\hline Exports, crude, not ground or calcined & 43 & 36 & 36 & 37 & 32 \\
\hline Consumption, apparent ${ }^{4}$ & 40,800 & 46,200 & 42,900 & 41,700 & 40,900 \\
\hline \multicolumn{6}{|l|}{ Price, average, dollars per metric ton: } \\
\hline Crude, free on board (f.o.b.) mine & 8 & 7.5 & 8.2 & 8.6 & 8.6 \\
\hline Calcined, f.o.b. plant & 30 & 30 & 32 & 35 & 35 \\
\hline Employment, mine and calcining plant, numbere & 4,500 & 4,500 & 4,500 & 4,500 & 4,500 \\
\hline \multicolumn{6}{|l|}{ Net import reliance ${ }^{5}$ as a percentage } \\
\hline of apparent consumption & 11 & 10 & 12 & 15 & 14 \\
\hline
\end{tabular}

Recycling: Approximately 700,000 tons of gypsum scrap that was generated by wallboard manufacturing was recycled onsite. The recycling of wallboard from new construction and demolition sources also took place, although those amounts are unknown. Recycled gypsum was used primarily for agricultural purposes and feedstock for the manufacture of new wallboard. Other potential markets for recycled gypsum include athletic field marking, cement production (as a stucco additive), grease absorption, sludge drying, and water treatment.

Import Sources (2016-19): Mexico, 38\%; Spain, 31\%; Canada, 28\%; and other, 3\%.

Tariff: Item

Gypsum; anhydrite
Number

2520.10 .0000

\section{Normal Trade Relations 12-31-20 \\ Free.}

Depletion Allowance: $14 \%$ (domestic and foreign).

\section{Government Stockpile: None.}

Events, Trends, and Issues: U.S. gypsum production increased by $4 \%$ compared with that of 2019. Apparent consumption decreased slightly compared with that of 2019. U.S. gypsum imports decreased by an estimated $4 \%$ compared with those of 2019. Exports, although very low compared with imports and often subject to wide fluctuations, decreased by $14 \%$.

Demand for gypsum depends principally on construction industry activity, particularly in the United States, where the majority of gypsum consumed is used for agriculture, building plasters, the manufacture of portland cement, and wallboard products. The construction of wallboard manufacturing plants designed to use synthetic gypsum from coal flue gas desulfurization (FGD) units as feedstock has resulted in less mining of natural gypsum. The availability of inexpensive natural gas, however, has limited the additional construction of FGD units and, therefore, the use of synthetic gypsum in wallboard. Despite disruptions caused by the COVID-19 pandemic, the production of gypsum through the second quarter of 2020 was not affected. 


\section{GYPSUM}

The United States, the world's leading crude gypsum producer, produced an estimated 22 million tons. Iran was the second-leading producer with an estimated 16 million tons of crude production, followed by China with 16 million tons. Increased use of wallboard in Asia, coupled with new gypsum product plants, spurred increased production in that region. As wallboard becomes more widely used, worldwide gypsum production is expected to increase.

World Mine Production and Reserves: Reserves for Brazil, France, and Pakistan were revised based on Government and other public data.

\begin{tabular}{lrrr} 
& \multicolumn{2}{c}{ Mine production } & Reserves $^{\mathbf{6}}$ \\
United States & $\mathbf{2 0 1 9}$ & $\underline{\mathbf{2 0 2 0}}$ & 700,000 \\
Algeria & 21,200 & 22,000 & $\mathrm{NA}$ \\
Brazil & 2,500 & 2,500 & 450,000 \\
Canada & 3,000 & 3,200 & 450,000 \\
China & 3,000 & 3,000 & $\mathrm{NA}$ \\
France & 15,500 & 16,000 & 350,000 \\
Germany & 3,000 & 3,000 & $\mathrm{NA}$ \\
India & 3,300 & 3,200 & 37,000 \\
Iran & 2,700 & 2,700 & $\mathrm{NA}$ \\
Japan & 16,000 & 16,000 & $\mathrm{NA}$ \\
Mexico & 4,300 & 4,700 & $\mathrm{NA}$ \\
Oman & 5,400 & 5,400 & $\mathrm{NA}$ \\
Pakistan & 9,100 & 11,000 & 6,000 \\
Russia & 1,670 & 2,200 & $\mathrm{NA}$ \\
Saudi Arabia & 5,500 & 3,800 & $\mathrm{NA}$ \\
Spain & 3,300 & 3,300 & $\mathrm{NA}$ \\
Thailand & 7,000 & 7,000 & 1,700 \\
Turkey & 9,790 & 9,300 & 200,000 \\
Other countries & 10,000 & 10,000 & $\mathrm{NA}$ \\
$\quad$ World total (rounded) & 22,000 & 22,000 & Large
\end{tabular}

World Resources: ${ }^{6}$ Reserves are large in major producing countries, but data for most are not available. Domestic gypsum resources are adequate but unevenly distributed. Large imports from Canada augment domestic supplies for wallboard manufacturing in the United States, particularly in the eastern and southern coastal regions. Imports from Mexico supplement domestic supplies for wallboard manufacturing along portions of the United States western seaboard. Large gypsum deposits occur in the Great Lakes region, the midcontinent region, and several Western States. Foreign resources are large and widely distributed; 78 countries were thought to produce gypsum in 2020.

Substitutes: In such applications as stucco and plaster, cement and lime may be substituted for gypsum; brick, glass, metallic or plastic panels, and wood may be substituted for wallboard. Gypsum has no practical substitute in the manufacturing of portland cement. Synthetic gypsum generated by various industrial processes, including FGD of smokestack emissions, is very important as a substitute for mined gypsum in wallboard manufacturing, cement production, and agricultural applications (in descending order by tonnage). In 2020, synthetic gypsum was estimated to account for about $40 \%$ of the total domestic gypsum supply.

\footnotetext{
eEstimated. NA Not available.

${ }^{1}$ The standard unit used in the U.S. wallboard industry is square feet; multiply square feet by $9.29 \times 10^{-2}$ to convert to square meters. Source: The Gypsum Association.

${ }^{2}$ Synthetic gypsum used; the majority of these data were obtained from the American Coal Ash Association.

${ }^{3}$ From domestic crude and synthetic gypsum.

${ }^{4}$ Defined as domestic crude production + synthetic used + imports - exports.

${ }^{5}$ Defined as imports - exports.

${ }^{6}$ See Appendix $\mathrm{C}$ for resource and reserve definitions and information concerning data sources.
} 


\section{HELIUM}

(Data in million cubic meters of contained helium gas ${ }^{1}$ unless otherwise noted)

Domestic Production and Use: The estimated value of Grade-A helium (99.997\% or greater) extracted during 2020 by private industry was about $\$ 322$ million. Fourteen plants (one in Arizona, two in Colorado, five in Kansas, one in Oklahoma, four in Texas, and one in Utah) extracted helium from natural gas and produced crude helium that ranged from $50 \%$ to $99 \%$ helium. One plant in Colorado and another in Wyoming extracted helium from natural gas and produced Grade-A helium. Three plants in Kansas and one in Oklahoma accepted crude helium from other producers and the Bureau of Land Management (BLM) pipeline and purified it to Grade-A helium. In 2020, estimated domestic apparent consumption of Grade-A helium was 40 million cubic meters (1.4 billion cubic feet), and it was used for magnetic resonance imaging, lifting gas, analytical and laboratory applications, welding, engineering and scientific applications, leak detection and semiconductor manufacturing, and various other minor applications.

\section{Salient Statistics-United States:}

Helium extracted from natural gas ${ }^{2}$

Withdrawn from storage ${ }^{3}$

Grade-A helium sales

Imports for consumption

Exports

Consumption, apparent ${ }^{4}$

Net import reliance ${ }^{5}$ as a percentage

of apparent consumption

$\begin{array}{rrr}\frac{2016}{66} & \quad 2017 \\ 23 & 63 \\ 89 & 28 \\ 23 & 91 \\ 62 & 19 \\ 50 & 74 \\ & 36\end{array}$

E $\quad$ E

\begin{tabular}{r}
2018 \\
\hline 64 \\
26 \\
90 \\
8 \\
84 \\
40
\end{tabular}

E

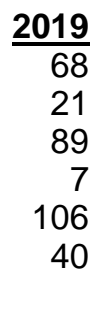

E $2020^{e}$

61

13

75

100

40

E

In fiscal year (FY) 2020, the price for crude helium to Government users was $\$ 3.10$ per cubic meter ( $\$ 86.00$ per thousand cubic feet) and to nongovernment users was $\$ 4.29$ per cubic meter ( $\$ 119.00$ per thousand cubic feet). The last year helium prices were posted by the Federal Government was in 2018. The estimated price for private industry's Grade-A helium was about $\$ 7.57$ per cubic meter ( $\$ 210$ per thousand cubic feet), with some producers posting surcharges to this price.

Recycling: In the United States, helium used in large-volume applications is seldom recycled. Some low-volume or liquid boil-off recovery systems are used. In the rest of the world, helium recycling is practiced more often.

Import Sources (2016-19): Qatar, 75\%; Canada, 9\%; Algeria, 7\%; Portugal, 5\%; and other, 4\%.

Tariff: Item

Helium
Number

2804.29.0010
Normal Trade Relations

12-31-20

$3.7 \%$ ad val.

Depletion Allowance: Allowances are applicable to natural gas from which helium is extracted, but no allowance is granted directly to helium.

Government Stockpile: Under the Helium Stewardship Act of 2013, the BLM manages the Federal Helium Program, which includes all operations of the Cliffside Field helium storage reservoir, in Potter County, TX, and the Government's crude helium pipeline system. Private firms that sell Grade-A helium to Federal agencies are required to purchase a like amount of (in-kind) crude helium from the BLM. The law mandated that the BLM sell at auction Federal Conservation helium stored in Bush Dome at the Cliffside Field. The last auction was completed in the summer of 2018. The remaining conservation helium is less than 83.2 million cubic meters ( 3 billion cubic feet). The Helium Stewardship Act requires that the BLM dispose of all helium assets including the Cliffside Field helium storage reservoir and pipeline system. The BLM will continue to make in-kind helium available to Federal customers. In fiscal year (FY) 2020, privately owned companies purchased about 5.83 million cubic meters (210 million cubic feet) of in-kind crude helium. During FY 2020, the BLM's Amarillo Field Office, Helium Operations, accepted about 0.59 million cubic meters (21 million cubic feet) of private helium for storage and redelivered nearly 1.5 million cubic meters (54 million cubic feet). As of September 30, 2020, about 62.4 million cubic meters (2.25 billion cubic feet) of privately owned helium remained in storage at Cliffside Field.

\section{Stockpile Status-9-30-206}

$\begin{array}{ccc}\text { Material } & \text { Inventory } & \begin{array}{c}\text { Authorized } \\ \text { for disposal }\end{array} \\ \text { Helium } & 68.9 & 52.3\end{array}$

Disposal plan
FY 2021
17.4
Disposal plan
FY 2022
17.4

17.4 


\section{HELIUM}

Events, Trends, and Issues: Helium production in 2020 decreased in the United States and worldwide in response to the COVID-19 pandemic. In April, the BLM announced plans for disposal of the remaining Federal helium inventory and assets by September 2021, after which the General Services Administration would complete the disposal process. Federal in-kind users would continue to have access to helium until September 30, 2022. In Russia, a company was building a 60-million-cubic-meter-per-year helium processing plant that was expected to be completed by late 2024 .

World Mine Production and Reserves: ${ }^{8}$ Reserves for Poland and Qatar were revised based on Government and industry sources.

\begin{tabular}{|c|c|c|}
\hline \multirow{2}{*}{\multicolumn{2}{|c|}{ Mine production }} & \multirow[t]{2}{*}{ Reserves $^{9}$} \\
\hline & & \\
\hline United States (extracted from natural gas) & 68 & 3,900 \\
\hline United States (from Cliffside Field) & 13 & $(10)$ \\
\hline Algeria & 14 & 1,800 \\
\hline Australia & 4 & NA \\
\hline Canada & $<1$ & $\mathrm{~N}$ \\
\hline China & NA & NA \\
\hline Poland & 1 & 23 \\
\hline Qatar & 45 & Large \\
\hline Russia & 5 & 1,700 \\
\hline World total (rounded) & $\overline{140}$ & NA \\
\hline
\end{tabular}

World Resources: ${ }^{9}$ Section 16 of Public Law 113-40 requires the U.S. Geological Survey (USGS) to complete a national helium gas assessment. The USGS and the BLM coordinated efforts to complete this assessment. The USGS results are expected to be published in 2021. The BLM plans to publish an update to its report of the Helium Resources of the United States by midyear 2021. Until then, the following estimates are still the best available.

As of December 31, 2006, the total helium reserves and resources of the United States were estimated to be 20.6 billion cubic meters ( 744 billion cubic feet). This includes 4.25 billion cubic meters (153 billion cubic feet) of measured reserves, 5.33 billion cubic meters (192 billion cubic feet) of probable resources, 5.93 billion cubic meters (214 billion cubic feet) of possible resources, and 5.11 billion cubic meters (184 billion cubic feet) of speculative resources. Measured reserves include 670 million cubic meters (24.2 billion cubic feet) of helium stored in the Cliffside Field Government Reserve and 65 million cubic meters (2.3 billion cubic feet) of helium contained in Cliffside Field native gas. The Cliffside (Texas), Hugoton (Kansas, Oklahoma, and Texas), Panhandle West (Texas), Panoma (Kansas), and Riley Ridge (Wyoming) Fields are the depleting fields from which most U.S.-produced helium is extracted. These fields contained an estimated 3.9 billion cubic meters (140 billion cubic feet) of helium.

Helium resources of the world, exclusive of the United States, were estimated to be about 31.3 billion cubic meters (1.13 trillion cubic feet). The locations and volumes of the major deposits, in billion cubic meters, are Qatar, 10.1; Algeria, 8.2; Russia, 6.8; Canada, 2.0; and China, 1.1. As of December 31, 2020, the BLM had analyzed about 22,700 gas samples from 26 countries and the United States, in a program to identify world helium resources.

Substitutes: There is no substitute for helium in cryogenic applications if temperatures below $-429^{\circ} \mathrm{F}$ are required. Argon can be substituted for helium in welding, and hydrogen can be substituted for helium in some lighter-than-air applications in which the flammable nature of hydrogen is not objectionable. Hydrogen is also being investigated as a substitute for helium in deep-sea diving applications below 305 meters (1,000 feet).

\footnotetext{
eEstimated. E Net exporter. NA Not available.

${ }^{1}$ Measured at 101.325 kilopascals absolute (14.696 psia) and $15^{\circ} \mathrm{C} ; 27.737$ cubic meters of helium $=1,000$ cubic feet of helium at $70{ }^{\circ} \mathrm{F}$ and 14.7 psia. ${ }^{2}$ Both Grade-A and crude helium.

${ }^{3}$ Extracted from natural gas in prior years.

${ }^{4}$ Grade-A helium. Defined as Grade-A helium sales + imports - exports. However, substantial increases in exports reported in 2018, 2019, and 2020 suggest that domestic consumption declined, although no significant decline in U.S. helium consumption is thought to have taken place. For that reason, apparent consumption for 2018-2020 was estimated to have remained at about 40 million cubic meters.

${ }^{5}$ Defined as imports - exports.

${ }^{6}$ See Appendix B for definitions.

${ }^{7}$ Supervisory General Engineer, Helium Resources Division, Bureau of Land Management, Amarillo Field Office, Helium Operations, Amarillo, TX. ${ }^{8}$ Production and reserves outside of the United States are estimated.

${ }^{9}$ See Appendix $\mathrm{C}$ for resource and reserve definitions and information concerning data sources.

${ }^{10}$ Included in United States (extracted from natural gas) reserves.
} 


\section{INDIUM}

(Data in metric tons unless otherwise noted)

Domestic Production and Use: Indium was not recovered from ores in the United States in 2020. Several companies produced indium products-including alloys, compounds, high-purity metal, and solders-from imported indium metal. Production of indium tin oxide (ITO) continued to account for most of global indium consumption. ITO thin-film coatings were primarily used for electrically conductive purposes in a variety of flat-panel displaysmost commonly liquid crystal displays (LCDs). Other indium end uses included alloys and solders, compounds, electrical components and semiconductors, and research. Based on an average of recent annual import levels, estimated domestic consumption of refined indium was 100 tons in 2020 . The estimated value of refined indium consumed domestically in 2020, based on the average New York dealer price, was about $\$ 40$ million.

\begin{tabular}{|c|c|c|c|c|c|}
\hline Salient Statistics-United States: & $\underline{2016}$ & $\underline{2017}$ & $\underline{2018}$ & $\underline{2019}$ & $\underline{2020^{\mathrm{e}}}$ \\
\hline Production, refinery & 二 & 二 & 二 & 二 & - \\
\hline Imports for consumption & 160 & 127 & 125 & 95 & 100 \\
\hline Exports & NA & NA & NA & NA & NA \\
\hline Consumption, estimated ${ }^{1}$ & 160 & 127 & 125 & 95 & 100 \\
\hline Price, annual average, dollars per kilogram: & & & & & \\
\hline New York dealer ${ }^{2}$ & 345 & 363 & 375 & 390 & 400 \\
\hline Duties unpaid in warehouse, Rotterdam ${ }^{3}$ & 240 & 225 & 291 & 185 & 150 \\
\hline $\begin{array}{l}\text { Net import reliance } 4 \text { as a percentage of } \\
\text { estimated consumption }\end{array}$ & 100 & 100 & 100 & 100 & 100 \\
\hline
\end{tabular}

Recycling: Indium is most commonly recovered from ITO scrap in Japan and the Republic of Korea. A significant quantity of scrap was recycled domestically; however, data on the quantity of secondary indium recovered from scrap were not available.

Import Sources (2016-19): China, 34\%; Canada, 22\%; the Republic of Korea, 15\%; and other, 29\%.

\section{Tariff: Item}

Unwrought indium, including powders, waste, and scrap

Depletion Allowance: $14 \%$ (domestic and foreign).

\section{Number}

8112.92.3000
Normal Trade Relations

12-31-20

Free.

Government Stockpile: None.

Events, Trends, and Issues: The estimated average New York dealer price of indium was $\$ 400$ per kilogram in 2020 , a slight increase from that of 2019. The average monthly price was $\$ 390$ per kilogram from January through April, and it increased to an average monthly price of $\$ 400$ per kilogram from May through September. The 2020 estimated average duties unpaid in the warehouse, Rotterdam price of indium was $\$ 150$ per kilogram, $19 \%$ less than in 2019. The average duties unpaid in the warehouse, Rotterdam price began the year at \$138 per kilogram and increased throughout the year to an average of $\$ 162$ per kilogram in September. 
On January 18, the Yunnan Provincial government sold 3,609 tons of indium that was held by the Fanya Metal Exchange that closed in 2015. The lot was offered by an auction process between January 17 and 18 . The lot was purchased by the sole bidder for $\$ 416$ million (2.65 billion yuan). The 3,609 tons of indium that was sold was equivalent to 4 years of global primary indium production.

The leading producer of tin in China announced the launch of a production line for high-purity indium with a capacity of 5 tons per year. The line has the capacity to produced $6 \mathrm{~N}$ - and $7 \mathrm{~N}$-grade metal. The company is also ramping up its indium tin oxide production after completing small-scale operations.

\section{World Refinery Production and Reserves:}

\begin{tabular}{|c|c|c|}
\hline & Refiner & uction \\
\hline & 2019 & $\underline{2020^{\mathrm{e}}}$ \\
\hline United States & 二 & - \\
\hline Belgium & 20 & 20 \\
\hline Canada & 61 & 50 \\
\hline China & 535 & 500 \\
\hline France & 40 & 50 \\
\hline Japan & 70 & 65 \\
\hline Korea, Republic of & 225 & 200 \\
\hline Peru & 12 & 10 \\
\hline Russia & 5 & - \\
\hline World total (rounded) & $\overline{968}$ & $\overline{90}$ \\
\hline
\end{tabular}

\author{
Reserves $^{5}$ \\ Quantitative estimates of reserves \\ are not available.
}

World Resources: $: 5$ Indium is most commonly recovered from the zinc-sulfide ore mineral sphalerite. The indium content of zinc deposits from which it is recovered ranges from less than 1 part per million to 100 parts per million. Although the geochemical properties of indium are such that it occurs in trace amounts in other base-metal sulfidesparticularly chalcopyrite and stannite-most deposits of these minerals are subeconomic for indium recovery.

Substitutes: Antimony tin oxide coatings have been developed as an alternative to ITO coatings in LCDs and have been successfully annealed to LCD glass; carbon nanotube coatings have been developed as an alternative to ITO coatings in flexible displays, solar cells, and touch screens; poly(3,4-ethylene dioxythiophene) (PEDOT) has also been developed as a substitute for ITO in flexible displays and organic light-emitting diodes; and copper or silver nanowires have been explored as a substitute for ITO in touch screens. Graphene has been developed to replace ITO electrodes in solar cells and also has been explored as a replacement for ITO in flexible touch screens.

Researchers have developed a more adhesive zinc oxide nanopowder to replace ITO in LCDs. Hafnium can replace indium in nuclear reactor control rod alloys.

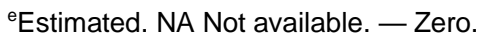

${ }^{1}$ Estimated to equal imports.

${ }^{2}$ Price is based on $99.99 \%$-minimum-purity indium; delivered duty paid U.S. buyers; in minimum lots of 50 kilograms. Source: S\&P Global Platts Metals Week.

${ }^{3}$ Price is based on 99.99\%-minimum-purity indium, duties unpaid in warehouse (Rotterdam). Sources: Metal Bulletin (2016-17) and Argus Media group-Argus Metals International (2018-20).

${ }^{4}$ Defined as imports - exports.

${ }^{5}$ See Appendix $\mathrm{C}$ for resource and reserve definitions and information concerning data sources.
} 


\section{IODINE}

(Data in metric tons of elemental iodine unless otherwise noted)

Domestic Production and Use: lodine was produced from brines in 2020 by three companies operating in Oklahoma. U.S. iodine production in 2020 was withheld to avoid disclosing company proprietary data. The average annual cost, insurance, and freight value of iodine imports in 2020 was estimated to be $\$ 31$ per kilogram, about a $17 \%$ increase from that of 2019.

Because domestic and imported iodine was used by downstream manufacturers to produce many intermediate iodine compounds, it was difficult to establish an accurate end-use pattern. Crude iodine and inorganic iodine compounds were thought to account for more than $50 \%$ of domestic iodine consumption in 2020 . Worldwide, the leading uses of iodine and its compounds were x-ray contrast media, pharmaceuticals, liquid crystal displays (LCDs), and iodophors, in descending order of quantity consumed.

\section{Salient Statistics-United States:}

Production

Imports for consumption

Exports

Consumption:

Apparent ${ }^{1}$

Reported

Price, crude iodine, average value of imports (cost, insurance, and freight), dollars per kilogram

Employment, numbere

Net import reliance ${ }^{2}$ as a percentage

of reported consumption

$\begin{array}{rrrrr}\frac{\mathbf{2 0 1 6}}{W} & \frac{\mathbf{2 0 1 7}}{W} & \frac{\mathbf{2 0 1 8}}{W} & \frac{\mathbf{2 0 1 9}}{W} & \frac{\mathbf{2 0 2 0}}{W} \\ 4,320 & 4,170 & 4,930 & 4,300 & 4,300 \\ 1,050 & 1,230 & 1,190 & 1,230 & 1,300 \\ W & W & W & W & W \\ W & W & W & 4,000 & 4,000 \\ 4,610 & 4,500 & 4,620 & & \\ 22.71 & 19.55 & 22.46 & 26.38 & 31 \\ 60 & 60 & 60 & 60 & 60 \\ >50 & >50 & >50 & >50 & >50\end{array}$

Recycling: Small amounts of iodine were recycled.

Import Sources (2016-19): Chile, 88\%; Japan, 11\%; and other, $1 \%$.

\section{Tariff: Item}

Number

lodine, crude

Depletion Allowance: 14\% (domestic and foreign).

\section{Normal Trade Relations \\ 12-31-20}

Free.

Government Stockpile: None. 


\section{IODINE}

Events, Trends, and Issues: According to trade publications, spot prices for iodine crystal averaged about $\$ 37$ per kilogram during the first 9 months of 2020. Although this was an increase from the 2019 annual average of about $\$ 30$ per kilogram, prices were still considerably less than the historically high levels of $\$ 65$ to $\$ 85$ per kilogram in late 2012 and early 2013.

As in recent years, Chile was the world's leading producer of iodine, followed by Japan and the United States. Excluding production in the United States, Chile accounted for about two-thirds of world production in 2020. Most of the world's iodine supply comes from three areas: the Chilean desert nitrate mines, the gasfields and oilfields in Japan, and the iodine-rich brine wells in northwestern Oklahoma.

Domestic and international iodine production was not considerably affected by the global COVID-19 pandemic during the first half of 2020. However, market demand was expected to decrease in the second half of 2020 and will likely affect iodine prices in the latter half of the year.

World Mine Production and Reserves: China and Iran also produce crude iodine, but output is not officially reported.

\begin{tabular}{|c|c|c|}
\hline \multicolumn{2}{|r|}{ Mine production } & Reserves $^{3}$ \\
\hline & $\underline{2019}$ & \\
\hline United States & $\bar{W}$ & 250,000 \\
\hline Azerbaijan & 190 & 170,000 \\
\hline Chile & 20,200 & 610,000 \\
\hline Indonesia & 40 & 100,000 \\
\hline Japan & 9,100 & $4,900,000$ \\
\hline Russia & 2 & 120,000 \\
\hline Turkmenistan & 600 & 70,000 \\
\hline World total (rounded) & $\overline{430.100}$ & $6,200,000$ \\
\hline
\end{tabular}

World Resources: ${ }^{3}$ Seawater contains 0.06 part per million iodine, and the oceans are estimated to contain approximately 90 billion tons of iodine. Seaweeds of the Laminaria family are able to extract and accumulate up to $0.45 \%$ iodine on a dry basis. Although not as economical as the production of iodine as a byproduct of gas, nitrates, and oil, the seaweed industry represented a major source of iodine prior to 1959 and remains a large resource.

Substitutes: No comparable substitutes exist for iodine in many of its principal applications, such as in animal feed, catalytic, nutritional, pharmaceutical, and photographic uses. Bromine and chlorine could be substituted for iodine in biocide, colorant, and ink, although they are usually considered less desirable than iodine. Antibiotics can be used as a substitute for iodine biocides.

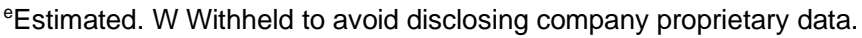

${ }^{1}$ Defined as production + imports - exports.

${ }^{2}$ Defined as imports - exports.

${ }^{3}$ See Appendix $\mathrm{C}$ for resource and reserve definitions and information concerning data sources.

${ }^{4}$ Excludes U.S. production.
} 


\section{IRON AND STEEL ${ }^{1}$}

(Data in million metric tons of metal unless otherwise noted)

Domestic Production and Use: The U.S. iron and steel industry produced raw steel in 2020 with an estimated value of about $\$ 91$ billion, an 12\% decrease from $\$ 104$ billion in 2019 and $\$ 103$ billion in 2018 . Pig iron and raw steel was produced by three companies operating integrated steel mills in 11 locations. Raw steel was produced by 51 companies at 98 minimills. Combined production capacity was about 110 million tons. Indiana accounted for an estimated $26 \%$ of total raw steel production, followed by Ohio, $12 \%$; Michigan, $5 \%$; and Pennsylvania, $5 \%$, with no other State having more than $5 \%$ of total domestic raw steel production. Construction accounted for an estimated $46 \%$ of total domestic shipments by market classification, followed by transportation (predominantly automotive), 26\%; machinery and equipment, 8\%; energy, 6\%; appliances, 5\%; and other applications, $9 \%$.

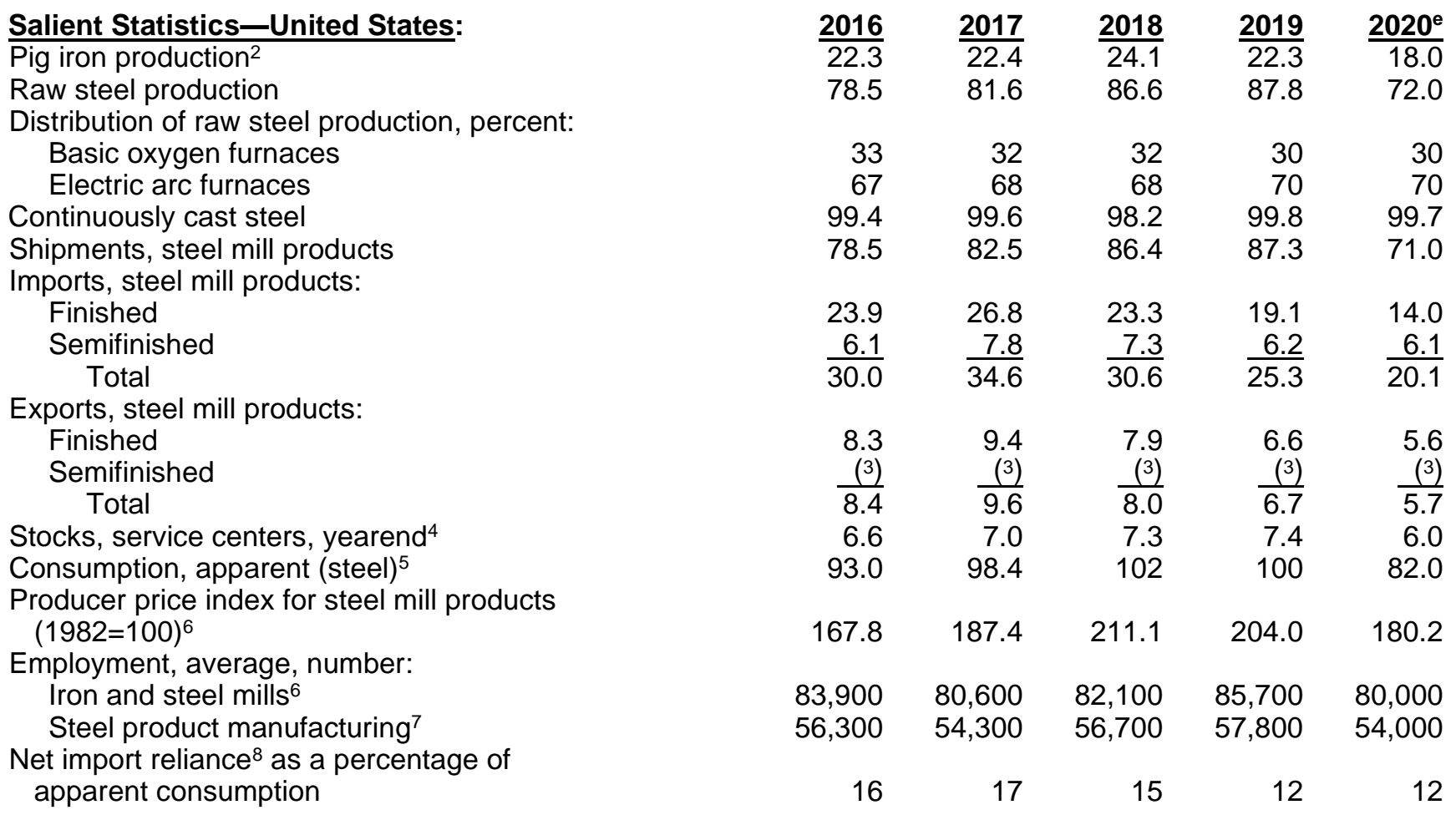

Recycling: See Iron and Steel Scrap and Iron and Steel Slag.

Import Sources (2016-19): Canada, 18\%; Brazil, 14\%; Mexico, 11\%; the Republic of Korea, 10\%; and other, 47\%.

\section{Tariff: Item}

Carbon steel:

Semifinished

Flat, hot-rolled

Flat, cold-rolled

Galvanized

Bars and rods, hot-rolled

Structural shapes

Stainless steel:

Semifinished

Flat-rolled sheets

Bars and rods
Number

7207.00 .0000

7208.00 .0000

7209.00 .0000

7210.00 .0000

7213.00 .0000

7216.00 .0000

7218.00 .0000

7219.00 .0000

7222.00 .0000
Normal Trade Relations

12-31-20

Free.

Free.

Free.

Free.

Free.

Free.

Free.

Free.

Free.

Depletion Allowance: Not applicable.

Government Stockpile: None. 
Events, Trends, and Issues: The World Steel Association ${ }^{9}$ forecast global finished steel consumption to decrease by $2.4 \%$ in 2020 as a result of the impacts related to reduced consumption and demand of manufactured products, new construction, and other consumable goods owing to the global COVID-19 pandemic. On a monthly basis, global steel demand reached its lowest point in April; however, the rate of economic recovery in various countries has been variable owing to differences in containment strategies, the domestic industry structure, and economic measures to combat slowing economic growth. A rebound in steel demand later in the year following easing of restrictions was not enough to offset early losses in consumption.

In April, multiple U.S.-based blast furnaces were idled owing to the reduced steel demand resulting from the COVID-19 pandemic; however, they all reopened in the second half of 2020. In August, one iron ore and iron metallics company announced it had entered into a definitive agreement to purchase two iron ore mines, six steelmaking facilities, eight finishing facilities, and three coal and cokemaking operations from another domestic iron and steel production company, making it the largest manufacturer of flat-rolled steel in North America.

\section{World Production:}

\begin{tabular}{|c|c|c|c|c|}
\hline & & & & teel \\
\hline & 2019 & $2020^{e}$ & 2019 & $\underline{2020^{e}}$ \\
\hline United States & 22 & 18 & 88 & 72 \\
\hline Brazil & 26 & 23 & 32 & 28 \\
\hline China & 809 & 830 & 996 & 1,000 \\
\hline Germany & 25 & 21 & 40 & 33 \\
\hline India & 74 & 56 & 111 & 84 \\
\hline Iran & 3 & 3 & 32 & 35 \\
\hline Italy & 5 & 4 & 23 & 19 \\
\hline Japan & 75 & 61 & 99 & 81 \\
\hline Korea, Republic of & 48 & 43 & 71 & 65 \\
\hline Mexico & 4 & 3 & 19 & 15 \\
\hline Russia & 50 & 49 & 72 & 69 \\
\hline Taiwan & 15 & 14 & 22 & 21 \\
\hline Turkey & 10 & 10 & 34 & 33 \\
\hline Ukraine & 20 & 19 & 21 & 19 \\
\hline Vietnam & 8 & 9 & 14 & 15 \\
\hline Other countries & 86 & 85 & 190 & 210 \\
\hline World total (rounded) & 1,280 & 1,200 & $\overline{1,860}$ & $\overline{1,800}$ \\
\hline
\end{tabular}

World Resources: Not applicable. See Iron Ore and Iron and Steel Scrap for steelmaking raw-material resources.

Substitutes: Iron is the least expensive and most widely used metal. In most applications, iron and steel compete either with less expensive nonmetallic materials or with more expensive materials that have a performance advantage. Iron and steel compete with lighter materials, such as aluminum and plastics, in the motor vehicle industry; aluminum, concrete, and wood in construction; and aluminum, glass, paper, and plastics in containers.

\footnotetext{
eEstimated.

${ }^{1}$ Production and shipments data source is the American Iron and Steel Institute; see also Iron and Steel Scrap and Iron Ore.

${ }^{2}$ More than $95 \%$ of iron made is transported in molten form to steelmaking furnaces located at the same site.

${ }^{3}$ Less than $1 / 2$ unit.

${ }^{4}$ Steel mill products. Source: Metals Service Center Institute.

${ }^{5}$ Defined as steel shipments + imports of finished steel mill products - exports of steel mill products + adjustments for industry stock changes.

${ }^{6}$ Source: U.S. Department of Labor, Bureau of Labor Statistics, North American Industry Classification System Code 331100.

${ }^{7}$ Source: U.S. Department of Labor, Bureau of Labor Statistics, North American Industry Classification System Code 331200.

${ }^{8}$ Defined as imports of finished steel mill products - total exports + adjustments for industry stock changes.

${ }^{9}$ World Steel Association, 2020, Short range outlook October 2020: Brussels, Belgium, World Steel Association press release, October 15, 7 p.
} 


\section{IRON AND STEEL SCRAP 1}

(Data in million metric tons of metal unless otherwise noted)

Domestic Production and Use: In 2020, the total value of domestic purchases of iron and steel scrap (receipts of ferrous scrap by all domestic consumers from brokers, dealers, and other outside sources) and exports was estimated to be $\$ 13$ billion, approximately $20 \%$ less than the $\$ 16.3$ billion in 2019 and $38 \%$ less than the $\$ 21.1$ billion in 2018. U.S. apparent steel consumption, the leading end use for iron and steel scrap was estimated to have decreased by $18 \%$ to 82 million tons in 2020 from 100 million tons in 2019. Manufacturers of pig iron, raw steel, and steel castings accounted for about $93 \%$ of scrap consumption by the domestic steel industry, using scrap together with pig iron and direct-reduced iron to produce steel products for the appliance, construction, container, machinery, oil and gas, transportation, and various other consumer industries. The ferrous castings industry consumed most of the remaining scrap to produce cast iron and steel products. Relatively small quantities of steel scrap were used for producing ferroalloys, for the precipitation of copper, and by the chemical industry; these uses collectively totaled less than 1 million tons.

During 2020, raw steel production was an estimated 72 million tons, down $18 \%$ from 87.8 million tons in 2019 . Net shipments of steel mill products were an estimated 71 million tons, down 19\% from 87.3 million tons in 2019.

\begin{tabular}{|c|c|c|c|c|c|}
\hline \multirow{2}{*}{\multicolumn{6}{|c|}{$\begin{array}{l}\text { Salient Statistics-United States: } \\
\text { Production: }\end{array}$}} \\
\hline & & & & & \\
\hline Home scrap & 5.9 & 5.6 & 5.8 & 5.7 & 4.4 \\
\hline Purchased scrap ${ }^{2}$ & 53 & 55 & 59 & 57 & 54 \\
\hline Imports for consumption ${ }^{3}$ & 3.9 & 4.6 & 5.0 & 4.3 & 4.0 \\
\hline Exports $^{3}$ & 13 & 15 & 17 & 18 & 17 \\
\hline \multicolumn{6}{|l|}{ Consumption: } \\
\hline Reported & 50 & 51 & 51 & 50 & 46 \\
\hline Apparent $^{4}$ & 50 & 50 & 52 & 51 & 46 \\
\hline \multicolumn{6}{|l|}{ Price, average, delivered, No. 1 Heavy Melting } \\
\hline composite price, dollars per ton & 196 & 265 & 3 & 249 & 213 \\
\hline Stocks, consumer, yearend & 4.3 & 4.5 & 5.1 & 3.9 & 3.2 \\
\hline Employment, dealers, brokers, processors, numbere & 27,000 & 27,000 & 27,000 & 26,000 & 22,000 \\
\hline $\begin{array}{l}\text { Net import reliance } 5 \text { as a percentage of } \\
\text { reported consumption }\end{array}$ & $E$ & $E$ & $E$ & $E$ & $E$ \\
\hline
\end{tabular}

Recycling: Recycled iron and steel scrap is a vital raw material for the production of new steel and cast iron products. The steel and foundry industries in the United States have been structured to recycle scrap and, as a result, are highly dependent upon scrap. One ton of steel that is recycled conserves 1.1 tons of iron ore, 0.6 ton of coking coal, and 0.05 ton of limestone.

Overall, the scrap recycling rate in the United States has averaged between $80 \%$ and $90 \%$ during the past decade, with automobiles making up the primary source of old steel scrap. Recycling of automobiles is nearly $100 \%$ each year, with rates fluctuating slightly owing to the rate of new vehicle production and general economic trends. More than 15 million tons of steel is recycled from automobiles annually, the equivalent of approximately 12 million cars, from more than 7,000 vehicle dismantlers and 350 car shredders in North America. The recycling of steel from automobiles is estimated to save the equivalent energy necessary to power 18 million homes every year.

Recycling rates, which fluctuate annually, were estimated to be $98 \%$ for structural steel from construction, $88 \%$ for appliances, $71 \%$ for rebar and reinforcement steel, and $70 \%$ for steel packaging. The recycling rates for appliance, can, and construction steel are expected to increase in the United States and in emerging industrial countries at an even greater rate. Public interest in recycling continues, and recycling is becoming more profitable and convenient as environmental regulations for primary production increase.

Recycling of scrap plays an important role in the conservation of energy because the remelting of scrap requires much less energy than the production of iron or steel products from iron ore. Also, consumption of iron and steel scrap by remelting reduces the burden on landfill disposal facilities and prevents the accumulation of abandoned steel products in the environment. Recycled scrap consists of approximately $58 \%$ post-consumer (old, obsolete) scrap, $24 \%$ prompt scrap (produced in steel-product manufacturing plants), and $18 \%$ home scrap (recirculating scrap from current operations). 
Import Sources (2016-19): Canada, 70\%; Mexico, 10\%; the United Kingdom, 7\%; Sweden, 5\%; and other, 8\%.

\section{Tariff: Item}

Ferrous waste and scrap:

Stainless steel

Turnings, shavings, chips, milling waste, sawdust,

filings, trimmings, and stampings:

No. 1 bundles

No. 2 bundles

Borings, shovelings, and turnings

Other

Other:

No. 1 heavy melting

No. 2 heavy melting

Cut plate and structural

Shredded

Remelting scrap ingots

Powders, of pig iron, spielgeleisen, iron, or steel:

Alloy steel

Other
Number

7204.21 .0000

7204.41 .0020

7204.41 .0040

7204.41 .0060

7204.41 .0080

7204.49 .0020

7204.49 .0040

7204.49 .0060

7204.49 .0070

7204.50 .0000

7205.21 .0000

7205.29 .0000
Normal Trade Relations

12-31-20

Free.

Free.

Free.

Free.

Free.

Free.

Free.

Free.

Free.

Free.

Free.

Free.

Depletion Allowance: Not applicable.

Government Stockpile: None.

Events, Trends, and Issues: In 2020, steel mill production capacity utilization reached its lowest monthly rate since July 2009 , reaching $54.6 \%$ in May 2020, with the rate declining during the year from $81.7 \%$ in January to its lowest point in May before rebounding to $68.6 \%$ in September 2020. Composite prices published for No. 1 Heavy Melting steel scrap delivered averaged about $\$ 214$ per ton during the first 8 months of 2020 , a $14 \%$ decrease from $\$ 249$ per ton in 2019. The average monthly prices during this time fluctuated between a high of $\$ 249.61$ per ton in January and a low of $\$ 194.01$ per ton in July. In the first 8 months of 2020, Turkey was the primary destination for exports of ferrous scrap, by tonnage, accounting for $26 \%$ of total exports, followed by Malaysia, Mexico, and Taiwan (10\% each). The value of exported scrap decreased to an estimated $\$ 4.4$ billion in 2020 from $\$ 5.3$ billion in 2019 .

The World Steel Association ${ }^{6}$ forecast global finished steel consumption to decrease by $2.4 \%$ in 2020 as a result of the impacts related to reduced consumption and demand of manufactured products, new construction, and other consumable goods owing to the global COVID-19 pandemic. On a monthly basis, global steel demand reached its lowest point in April; however, the rate of economic recovery in various countries has been variable owing to differences in containment strategies, the domestic industry structure, and economic measures to combat slowing economic growth. A rebound in steel demand later in the year following easing of restrictions was not enough to offset early losses in consumption.

World Mine Production and Reserves: Not applicable. See Iron and Steel and Iron Ore.

World Resources: Not applicable. See Iron and Steel and Iron Ore.

Substitutes: An estimated 2.2 million tons of direct-reduced iron was consumed in the United States in 2020 as a substitute for iron and steel scrap, down from 2.5 million tons in 2019.

\footnotetext{
eEstimated. E Net exporter.

${ }^{1}$ See also Iron and Steel and Iron Ore.

${ }^{2}$ Defined as net receipts + exports - imports.

${ }^{3}$ Excludes used rails for rerolling and other uses, and ships, boats, and other vessels for scrapping.

${ }^{4}$ Defined as home scrap + purchased scrap + imports - exports + adjustments for industry stock changes.

${ }^{5}$ Defined as imports - exports + adjustments for industry stock changes.

${ }^{6}$ World Steel Association, 2020, Short range outlook October 2020: Brussels, Belgium, World Steel Association press release, October 15, 7 p.
} 


\section{IRON AND STEEL SLAG}

(Data in million metric tons unless otherwise noted)

Domestic Production and Use: Iron and steel (ferrous) slags are formed by the combination of slagging agents and impurities during the production of crude (or pig) iron and crude steel. The slags are tapped separately from the metals, cooled and processed, and primarily used in the construction industry. Data are unavailable on actual U.S. ferrous slag production, but domestic slag sales ${ }^{1}$ in 2020 were estimated to be 14 million tons valued at about $\$ 380$ million. Blast furnace slag was about $50 \%$ of the tonnage sold and accounted for $88 \%$ of the total value of slag, most of which was granulated. Steel slag produced from basic oxygen and electric arc furnaces accounted for the remainder of sales. Slag was processed by 28 companies servicing active iron and steel facilities or reprocessing old slag piles at about 129 processing plants (including some iron and steel plants with more than one slag-processing facility) in 33 States, including facilities that import and grind unground slag to sell as ground granulated blast furnace slag (GGBFS).

Air-cooled iron slag and steel slag are used primarily as aggregates in concrete (air-cooled iron slag only); asphaltic paving, fill, and road bases; both slag types also can be used as a feed for cement kilns. Almost all GGBFS is used as a partial substitute for portland cement in concrete mixes or in blended cements. Pelletized slag is generally used for lightweight aggregate but can be ground into material similar to GGBFS. Actual prices per ton ranged from a few cents for some steel slags at a few locations to about $\$ 120$ or more for some GGBFS in 2020. Owing to low unit values, most slag types can be shipped only short distances by truck, but rail and waterborne transportation allow for greater travel distances. Because much higher unit values make it economical to ship GGBFS longer distances, much of the GGBFS consumed in the United States is imported.

\section{Salient Statistics-United States:}

Production (sales) ${ }^{1,2}$

Imports for consumption ${ }^{3}$

Exports

Consumption, apparent ${ }^{5}$

Price, average value, free on board plant, dollars per ton ${ }^{6}$

Employment, numbere

Net import reliance ${ }^{7}$ as a percentage of

apparent consumption

\begin{tabular}{r}
2016 \\
\hline 15.7 \\
1.8 \\
$\left({ }^{4}\right)$ \\
15.7 \\
22.00 \\
1,600
\end{tabular}

11

\begin{tabular}{r}
$\mathbf{2 0 1 7}$ \\
\hline 16.2 \\
2.1 \\
$\left({ }^{4}\right)$ \\
16.2 \\
24.50 \\
1,500
\end{tabular}

13

$\frac{2018}{16.8}$
2.2
$(4)$
16.8
26.50
1,500

13

$\begin{array}{rr}\frac{\mathbf{2 0 1 9}}{\mathrm{e} 17} & \frac{\mathbf{2 0 2 0}}{14} \\ 1.8 & 2.0 \\ (4) & \left({ }^{\mathrm{e}}\right) \\ \mathrm{e} 17 & 14 \\ 27.50 & 27.00 \\ 1,500 & 1,500\end{array}$

10
14

Recycling: Following removal of entrained metal, slag can be returned to the blast and steel furnaces as ferrous and flux feed, but data on these returns are incomplete. Entrained metal, particularly in steel slag, is routinely recovered during slag processing for return to the furnaces and is an important revenue source for slag processors; data on metal returns are unavailable.

Import Sources (2016-19): Japan, 29\%; Brazil, 18\%; Canada, 14\%; Italy, 12\%; and other, 27\%.

Tariff: Item

Granulated slag

Slag, dross, scalings, and other waste from manufacture of iron and steel:

Ferrous scale

Other
Number

2618.00 .0000

2619.00.3000

2619.00.9000
Normal Trade Relations 12-31-20

Free.

Free.

Free. 
Depletion Allowance: Not applicable.

\section{Government Stockpile: None.}

Events, Trends, and Issues: In April, several domestic blast furnaces were idled owing to the reduced steel demand resulting from the global COVID-19 pandemic. Demand increased later in the year, and all the blast furnaces idled in 2020 reopened. In recent years, U.S. blast furnaces have been closed or idled, contributing to the reduction in the domestic supply of new blast furnace slag. However, many sites have large slag stockpiles, which can allow for processing to continue for several years after the furnaces are closed or idled. The majority of U.S steel slag production is from electric arc furnaces.

During 2020, domestic GGBFS remained in limited supply because granulation cooling was available at only two active U.S. blast furnaces. It remained unclear if new granulation cooling installations at additional blast furnace sites would be economic. Another plant produced a limited supply of pelletized slag, but it was uncertain if additional pelletizing capacity would be added. Grinding of granulated blast furnace slag was only done domestically by cement companies. Supply constraints appear to have limited domestic consumption of GGBFS in recent years. Although prices have increased, sales of GGBFS have not correlated with the increases in the quantity of cement sold since 2010.

The domestic supply of fly ash, which is used as an additive in concrete production, has decreased, owing to new restrictions of mercury and carbon dioxide $\left(\mathrm{CO}_{2}\right)$ emissions at coal-fired powerplants, powerplant closures, and conversion of powerplants to natural gas. Mercury emission restrictions on cement plants, enacted in 2015, may reduce the demand for fly ash as a raw material in clinker manufacture, and air-cooled and steel slags could be used as substitute raw materials. Demand for GGBFS is likely to increase because its use in cement yields a superior product in many applications and reduces the unit $\mathrm{CO}_{2}$ emissions in the production of the cement.

World Mine Production and Reserves: Because slag is not mined, the concept of reserves does not apply. World production data for slag were unavailable, but iron slag from blast furnaces may be estimated to be $25 \%$ to $30 \%$ of crude (pig) iron production and steel furnace slag may be estimated to be $10 \%$ to $15 \%$ of raw steel production. In 2020, world iron slag production was estimated to be between 310 million and 380 million tons, and steel slag production was estimated to be between 180 million and 270 million tons.

\section{World Resources: Not applicable.}

Substitutes: In the construction sector, ferrous slags compete with natural aggregates (crushed stone and construction sand and gravel) but are far less widely available than the natural materials. As a cementitious additive in blended cements and concrete, GGBFS mainly competes with fly ash, metakaolin, and volcanic ash pozzolans. In this respect, GGBFS reduces the amount of portland cement per ton of concrete, thus allowing more concrete to be made per ton of portland cement. Slags (especially steel slag) can be used as a partial substitute for limestone and some other natural raw materials for clinker (cement) manufacture and compete in this use with fly ash and bottom ash. Some other metallurgical slags, such as copper slag, can compete with ferrous slags in some specialty markets, such as a ferrous feed in clinker manufacture, but are generally in much more restricted supply than ferrous slags.

\footnotetext{
eEstimated.

${ }^{1}$ Processed slag sold during the year, excluding entrained metal.

${ }^{2}$ Data include sales of imported granulated blast furnace slag and exclude sales of pelletized slag.

${ }^{3}$ U.S. Census Bureau data adjusted by the U.S. Geological Survey to remove nonslag materials (such as cenospheres, fly ash, and silica fume) and slags or other residues of other metallurgical industries (especially copper slag), whose unit values are outside the range expected for granulated slag. In some years, tonnages may be underreported.

${ }^{4}$ Less than 0.05 million tons.

${ }^{5}$ Defined as total sales of slag - exports.

${ }^{6}$ Rounded to the nearest $\$ 0.50$ per ton.

${ }^{7}$ Defined as imports - exports.
} 


\section{IRON ORE'}

(Data in thousand metric tons, usable ore, unless otherwise noted)

Domestic Production and Use: In 2020, mines in Michigan and Minnesota shipped $98 \%$ of the usable iron ore products, which were consumed in the steel industry in the United States with an estimated value of $\$ 4.1$ billion, a decrease from $\$ 4.4$ billion in 2019 . The remaining $2 \%$ of domestic iron ore was produced for nonsteel end uses. Seven open pit iron ore mines (each with associated concentration and pelletizing plants), and three iron metallic plants-one direct-reduced iron (DRI) plant in Louisiana and two hot-briquetted iron (HBI) plants in Indiana and Texas-operated during the year to supply steelmaking raw materials. The United States was estimated to have produced $1.5 \%$ and consumed $1.1 \%$ of the world's iron ore output.

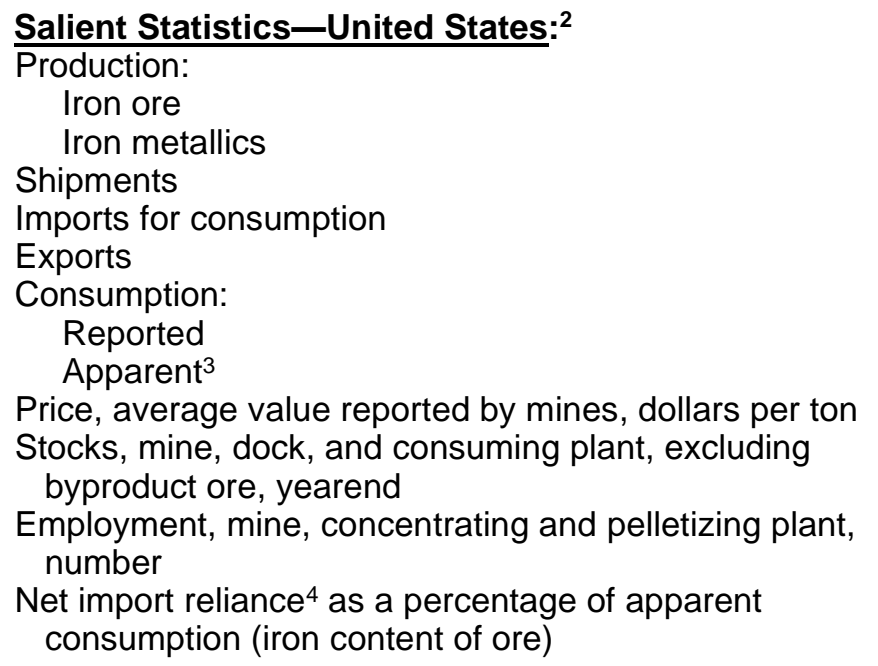

$\begin{array}{rrrrr}\underline{\mathbf{2 0 1 6}} & \underline{\mathbf{2 0 1 7}} & \underline{\mathbf{2 0 1 8}} & \underline{\mathbf{2 0 1 9}} & \underline{\mathbf{2 0 2 0 ^ { e }}} \\ 41,800 & 47,900 & 49,500 & 46,900 & 37,000 \\ 2,070 & 3,250 & 3,560 & 3,660 & 3,400 \\ 46,600 & 46,900 & 50,400 & 47,000 & 34,000 \\ 3,010 & 3,720 & 3,810 & 3,980 & 2,900 \\ 8,710 & 10,600 & 12,700 & 11,400 & 10,000 \\ 34,500 & 34,400 & 36,600 & 34,800 & 27,000 \\ 37,900 & 40,100 & 41,400 & 39,100 & 33,000 \\ 73.11 & 78.54 & 93.00 & 92.94 & 108.00 \\ 2,990 & 3,930 & 3,100 & 3,500 & 1,100 \\ 4,660 & 4,630 & 4,860 & 4,960 & 4,700 \\ E & E & E & E & E\end{array}$

Recycling: None. See Iron and Steel Scrap.

Import Sources (2016-19): Brazil, 58\%; Canada, 21\%; Sweden, 7\%, Chile, 4\%; and other, 10\%.

Tariff: Item

Iron ores and concentrates:

Concentrates

Coarse ores

Other ores

Pellets

Briquettes

Sinter

Roasted iron pyrites

\section{Number}

2601.11 .0030

2601.11.0060

2601.11.0090

2601.12.0030

2601.12.0060

2601.12.0090

2601.20 .0000
Normal Trade Relations 12-31-20

Free.

Free.

Free.

Free.

Free.

Free.

Free.

Depletion Allowance: $15 \%$ (domestic), 14\% (foreign).

Government Stockpile: None.

Events, Trends, and Issues: Significant decreases in production, shipments, and trade in 2020 were due to the ongoing effects of the COVID-19 pandemic, which lowered steel production and consumption globally. Domestic iron ore production was estimated to be 37 million tons in 2020, 21\% lower than 46.9 million tons in 2019, owing to the closure of multiple iron ore plants. Total raw steel production was estimated to have decreased to 69 million tons in 2020 from 87.8 million tons in 2019. The share of steel produced by basic oxygen furnaces, the process that uses iron ore, continued to decline from $37.3 \%$ in 2015 to an estimated $30 \%$ in 2020 owing to increased use of electric arc furnaces because of their energy efficiency, reduced environmental impacts, and the ready supply of scrap.

Overall, global prices trended upwards to an average value of $\$ 97.96$ per ton in the first 8 months of 2020 , a $4 \%$ increase from the 2019 annual average of $\$ 93.85$ per ton and a $40 \%$ increase from the 2018 annual average of $\$ 69.75$ per ton. Based on reported prices for iron ore fines (62\% iron content) imported into China (cost and freight into Tianjin Port), the highest monthly average price during the first 8 months of 2020 was $\$ 121.07$ per ton in August compared with the high of $\$ 120.24$ per ton in July 2019 . The lowest monthly average price during the same period in 
2020 was $\$ 84.73$ per ton in April compared with the low of $\$ 76.16$ per ton in January 2019 . The prices trended upwards owing to a reduced supply of higher grade iron ore products, spurred partially by closures of pelletizing plants in Brazil. One company in Brazil cut guidance for pellet sales in 2020 by 25 million to 30 million tons based on first-quarter projections following 302 million tons of iron ore production in 2019, a decrease from 385 million tons produced in 2018, owing to a tailings dam collapse that idled operations at the collocated mine.

In August, one company expected to begin production at a hot-briquetted iron plant under construction in Ohio in late 2020, and announced it had entered into a definitive agreement to purchase two iron ore mines, six steelmaking facilities, eight finishing facilities, and three coal and cokemaking operations from another domestic iron and steel production company. In the first half of 2020, five domestic iron ore mines were idled with only four restarting in the second half of the year. One mine continued to remain idle with no plans to restart as of October. Globally, iron ore production in 2020 was expected to decrease slightly from that of 2019. Global finished steel consumption was forecast by the World Steel Association ${ }^{5}$ to decrease by $2.4 \%$ in 2020 and increase by $4.1 \%$ in 2021 .

World Mine Production and Reserves: Reserves for Australia, Brazil, and South Africa were revised based on Government and industry sources.

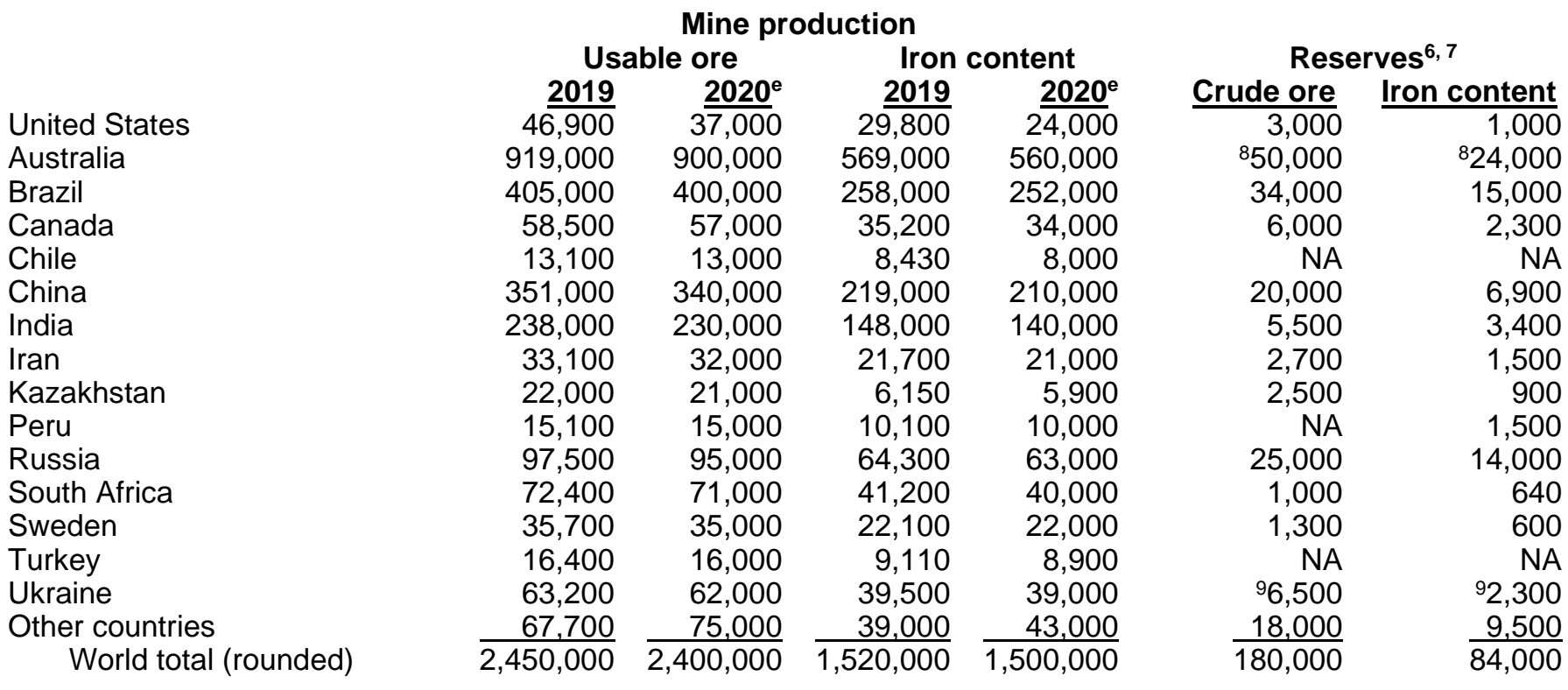

World Resources: ${ }^{6}$ U.S. resources are estimated to be 110 billion tons of iron ore containing about 27 billion tons of iron. U.S. resources are mainly low-grade taconite-type ores from the Lake Superior district that require beneficiation and agglomeration prior to commercial use. World resources are estimated to be greater than 800 billion tons of crude ore containing more than 230 billion tons of iron.

Substitutes: The only source of primary iron is iron ore, used directly as direct-shipping ore or converted to briquettes, concentrates, DRI, iron nuggets, pellets, or sinter. DRI, iron nuggets, and scrap are extensively used for steelmaking in electric arc furnaces and in iron and steel foundries. Technological advancements have been made, which allow hematite to be recovered from tailings basins and pelletized.

\footnotetext{
eEstimated. E Net exporter. NA Not available.

${ }^{1}$ Data are for iron ore used as a raw material in steelmaking unless otherwise noted. See also Iron and Steel and Iron and Steel Scrap.

${ }^{2}$ Except where noted, salient statistics are for all forms of iron ore used in steelmaking, and do not include iron metallics, which include DRI, hot-briquetted iron, and iron nuggets.

${ }^{3}$ Defined as production + imports - exports + adjustments for industry stock changes.

${ }^{4}$ Defined as imports - exports + adjustments for industry stock changes.

${ }^{5}$ World Steel Association, 2020, Short range outlook October 2020: Brussels, Belgium, World Steel Association press release, October 15, 7 p.

${ }^{6}$ See Appendix $C$ for resource and reserve definitions and information concerning data sources.

${ }^{7}$ Million metric tons.

${ }^{8}$ For Australia, Joint Ore Reserves Committee-compliant reserves were 23 billion tons for crude ore and 11 billion tons for iron content.

${ }^{9}$ For Ukraine, reserves consist of the A and B categories of the Soviet reserves classification system.
} 


\section{IRON OXIDE PIGMENTS}

(Data in metric tons unless otherwise noted)

Domestic Production and Use: Iron oxide pigments (IOPs) were mined domestically by two companies in Alabama and Georgia. Mine production, which was withheld to avoid disclosing company proprietary data, decreased in 2020 from that of 2019. Five companies, including the two producers of natural IOPs, processed and sold about 26,000 tons of finished natural and synthetic IOPs with an estimated value of $\$ 15$ million. About $46 \%$ of natural and synthetic finished IOPs were used in concrete and other construction materials; $13 \%$ for foundry sands and other foundry uses; $6 \%$ each in animal feed and industrial coatings; $5 \%$ for paint and coatings; $3 \%$ each in plastics, and glass and ceramics; and the remaining $18 \%$ in other uses.

\section{Salient Statistics-United States:}

Mine production, crude

Sold or used, finished natural and synthetic IOPs

Imports for consumption

Exports, pigment grade

Consumption, apparent ${ }^{1}$

Price, average value, dollars per kilogram²

Employment, mine and mill, number

Net import reliance ${ }^{3}$ as a percentage of:

Apparent consumption

Reported consumption

$\begin{array}{rrrrr}\frac{\mathbf{2 0 1 6}}{W} & \frac{\mathbf{2 0 1 7}}{W} & \frac{\mathbf{2 0 1 8}}{W} & \frac{\mathbf{2 0 1 9}}{W} & \frac{\mathbf{2 0 2 0}}{W} \\ 48,500 & 47,300 & 48,200 & 19,200 & 26,000 \\ 179,000 & 179,000 & 179,000 & 159,000 & 180,000 \\ 15,800 & 13,500 & 11,100 & 11,200 & 10,000 \\ 212,000 & 213,000 & 216,000 & 167,000 & 200,000 \\ 1.46 & 1.46 & 1.58 & 0.69 & 0.58 \\ 60 & 60 & 60 & 55 & 47 \\ 77 & 78 & 78 & 89 & 87 \\ >75 & >75 & >75 & >75 & >75\end{array}$

Recycling: None.

Import Sources (2016-19): Natural: Spain, 43\%; Cyprus, 33\%; France, 11\%; Austria, 10\%; and other, 3\%. Synthetic: China, 48\%; Germany, 32\%; Brazil, 7\%; and other, 13\%. Total: China, 47\%; Germany, 31\%; Brazil, 7\%; and other, $15 \%$.

\section{Tariff: Item}

Natural:

Micaceous iron oxides

Earth colors

Iron oxides and hydroxides containing

$70 \%$ or more by weight $\mathrm{Fe}_{2} \mathrm{O}_{3}$ :

Synthetic:

Black

Red

Yellow

Other

Earth colors
Number

2530.90 .2000

2530.90 .8015

2821.10.0010

2821.10 .0020

2821.10.0030

2821.10 .0040

2821.20 .0000
Normal Trade Relations

12-31-20

$2.9 \%$ ad val.

Free.

Depletion Allowance: 14\% (domestic and foreign).

Government Stockpile: None.

$3.7 \%$ ad val.

$3.7 \%$ ad val.

$3.7 \%$ ad val.

$3.7 \%$ ad val.

$5.5 \%$ ad val. 
Events, Trends, and Issues: In 2020, domestic mine production of crude natural IOPs decreased compared with 2019 production owing to a major producer closing down multiple facilities. Production and sales of finished natural and synthetic IOPs increased by about $35 \%$ compared with those of 2019 . Production and sales of synthetic IOPs also increased in 2020, owing in part to low mortgage interest rates and increased demand for single-family homes as the global COVID-19 pandemic made multifamily homes less desirable. In the United States, residential construction, in which IOPs are commonly used to color concrete block and brick, ready-mixed concrete, and roofing tiles, increased slightly during the first 9 months of 2020 compared with that of the same period in 2019 . Housing starts increased by about $5 \%$ in 2020 compared with those of 2019 .

Exports of pigment-grade IOPs decreased by about $8 \%$ during the first 9 months of 2020 compared with those during the same period in 2019, mostly owing to a significant decrease in exports to Argentina, South Africa, and Spain. About $53 \%$ of pigment-grade IOPs went to Mexico, China, Thailand, Germany, Belgium, Chile, India, and Brazil, in descending order of quantity. Exports of other grades of iron oxides and hydroxides decreased by about $29 \%$ during the first 9 months of 2020 compared with those of the same period in 2019 . About $92 \%$ of exports of other grades of iron oxides and hydroxides went to Germany, Colombia, Vietnam, and Canada, in descending order of quantity. Total imports of natural and synthetic IOPs increased by 13\% in 2020 compared with those in 2019.

\section{World Mine Production and Reserves:}

\begin{tabular}{|c|c|c|c|}
\hline & Mine $\mathrm{p}$ & luction & Reserves $^{4}$ \\
\hline & 2019 & $2020^{e}$ & \\
\hline United States & $\bar{W}$ & $\bar{W}$ & Moderate \\
\hline Austria (micaceous IOPs) & NA & NA & NA \\
\hline Cyprus (umber) & 3,013 & 3,500 & Moderate \\
\hline France & 8,000 & 8,000 & $\mathrm{~N}$ \\
\hline Germany 5 & 360,000 & 360,000 & Moderat \\
\hline India (ocher) & $2,500,000$ & $2,500,000$ & $37,000,00$ \\
\hline Italy & 9,000 & 9,000 & $\mathrm{~N}$ \\
\hline Pakistan (ocher) & 70,000 & 50,000 & 100,000 \\
\hline Spain (ocher and red iron oxide) & 10,000 & 10,000 & Larg \\
\hline World total & ${ }^{6} \mathrm{NA}$ & ${ }^{6} \mathrm{NA}$ & Larg \\
\hline
\end{tabular}

World Resources: ${ }^{4}$ Domestic and world resources for production of IOPs are adequate. Adequate resources are available worldwide for the manufacture of synthetic IOPs.

Substitutes: Milled IOPs are thought to be the most commonly used natural minerals for pigments. Because IOPs are color stable, low cost, and nontoxic, they can be economically used for imparting black, brown, red, and yellow coloring in large and relatively low-value applications. Other minerals may be used as colorants, but they generally cannot compete with IOPs because of their higher costs and more limited availability. Synthetic IOPs are widely used as colorants and compete with natural IOPs in many color applications. Organic colorants are used for some colorant applications, but many of the organic compounds fade over time from exposure to sunlight.

\footnotetext{
${ }^{e}$ Estimated. NA Not available. W Withheld to avoid disclosing company proprietary data.

${ }^{1}$ Defined as sold or used finished natural and synthetic iron oxide pigments + imports - exports.

${ }^{2}$ Average unit value for finished iron oxide pigments sold or used by U.S. producers.

${ }^{3}$ Defined as imports - exports.

${ }^{4}$ See Appendix $\mathrm{C}$ for resource and reserve definitions and information concerning data sources.

${ }^{5}$ Includes natural and synthetic iron oxide pigments.

${ }^{6} \mathrm{~A}$ significant number of other countries, including Azerbaijan, Brazil, China, Honduras, Iran, Kazakhstan, Lithuania, Paraguay, Russia, South Africa, Turkey, Ukraine, and the United Kingdom, are thought to produce iron oxide pigments, but output was not reported and no basis was available to make reliable estimates of production.
} 


\section{KYANITE AND RELATED MINERALS}

(Data in metric tons unless otherwise noted)

Domestic Production and Use: In Virginia, one firm with integrated mining and processing operations produced an estimated 85,000 tons of kyanite worth $\$ 30$ million from two hard-rock open pit mines and synthetic mullite by calcining kyanite. Two other companies, one in Alabama and another in Georgia, produced synthetic mullite from materials mined from four sites; each company sourced materials from one site in Alabama and one site in Georgia. Synthetic mullite production data are withheld to avoid disclosing company proprietary data. Commercially produced synthetic mullite is made by sintering or fusing such feedstock materials as kyanite, kaolin, bauxite, or bauxitic kaolin. Natural mullite occurrences typically are rare and not economical to mine. Of the kyanite-mullite output, $90 \%$ was estimated to have been used in refractories and $10 \%$ in other uses, including abrasive products, such as motor vehicle brake shoes and pads and grinding and cutting wheels; ceramic products, such as electrical insulating porcelains, sanitaryware, and whiteware; foundry products and precision casting molds; and other products. An estimated $60 \%$ to $70 \%$ of the refractory use was by the iron and steel industries, and the remainder was by industries that manufacture cement, chemicals, glass, nonferrous metals, and other materials. Andalusite was commercially mined from an andalusite-pyrophyllite-sericite deposit in North Carolina and processed as a blend of primarily andalusite for use by producers of refractories in making firebrick.

\begin{tabular}{|c|c|c|c|c|c|}
\hline \multirow{2}{*}{\multicolumn{6}{|c|}{$\begin{array}{l}\text { Salient Statistics-United States: } \\
\text { Production: }\end{array}$}} \\
\hline & & & & & \\
\hline $\begin{array}{l}\text { Kyanite, mine } \\
\text { Synthetic mullite }\end{array}$ & $\begin{array}{r}179,700 \\
W\end{array}$ & 191,300 & ${ }^{1} 89,200$ & 191,300 & 85,000 \\
\hline Imports for consumption (andalusite) & 2,510 & $\begin{array}{r}W \\
7.420\end{array}$ & 8,590 & $\begin{array}{r}W \\
6.960\end{array}$ & $\begin{array}{r}W \\
1,000\end{array}$ \\
\hline Exports (kyanite) & 37,100 & 42,300 & 43,000 & 40,100 & 37,000 \\
\hline Consumption, apparent ${ }^{2}$ & W & W & W & W & W \\
\hline \multicolumn{6}{|c|}{ Price, average, kyanite,$^{3}$ dollars per metric ton: } \\
\hline Raw concentrate & 270 & 270 & NA & NA & NA \\
\hline Calcined & 420 & 420 & NA & NA & NA \\
\hline \multicolumn{6}{|l|}{ Employment, number:e } \\
\hline Kyanite, mine, office, and plant & 150 & 140 & 150 & 150 & 140 \\
\hline Synthetic mullite, office and plant & 210 & 200 & 200 & 200 & 200 \\
\hline $\begin{array}{l}\text { Net import reliance }{ }^{4} \text { as a percentage } \\
\text { apparent consumption }\end{array}$ & $E$ & $E$ & $E$ & $E$ & $E$ \\
\hline \multicolumn{6}{|l|}{ Recycling: Insignificant. } \\
\hline \multicolumn{6}{|c|}{ Import Sources (2016-19): 5 South Africa, 79\%; Peru, 11\%; France, 6\%; United Kingdom, 3\%; and other, 1\%. } \\
\hline Tariff: Item & Number & & & $\begin{array}{r}\text { mal Trac } \\
12-3 \\
\end{array}$ & $\begin{array}{l}\text { Relations } \\
2 \underline{20}\end{array}$ \\
\hline $\begin{array}{l}\text { Andalusite, kyanite, and sillimanite } \\
\text { Mullite }\end{array}$ & $\begin{array}{l}2508.50 .000 \\
2508.60 .000\end{array}$ & & & $\begin{array}{l}\text { Fre } \\
\text { Fre }\end{array}$ & \\
\hline
\end{tabular}


Depletion Allowance: 22\% (domestic), 14\% (foreign).

\section{Government Stockpile: None.}

Events, Trends, and Issues: Crude steel production in the United States, which ranked fourth in the world, decreased by about $20 \%$ in the first 8 months of 2020 compared with that of the same period in 2019 , indicating a similar change in consumption of kyanite-mullite refractories. Total world steel production decreased by about $4 \%$ during the first 8 months of 2020 compared with that of the same period in 2019. The decrease in world steel production during the first 8 months of 2020 was the result of economic disruptions owing to the global COVID-19 pandemic. The steel industry continued to be the largest market for refractories.

In March 2020, mines in India, Peru, and South Africa were temporarily closed in response to national lockdowns imposed to limit the spread of COVID-19. Mines gradually reopened as restrictions eased, but production recovery efforts were complicated by logistical issues as well as new health and safety guidelines implemented to help protect workers. The resulting loss of industrial output may correspond with reduced global demand in 2020.

\section{World Mine Production and Reserves:}

\begin{tabular}{lrrr} 
& \multicolumn{2}{c}{ Mine production } & Reserves $^{\mathbf{6}}$ \\
United States (kyanite) & $\mathbf{2 0 1 9}$ & $\underline{\mathbf{2 0 2 0}}$ & Large \\
India (kyanite and sillimanite) & 191,300 & 85,000 & $7,200,000$ \\
Peru (andalusite) & 72,700 & 69,000 & NA \\
South Africa (andalusite) & 40,000 & 37,000 & NA \\
$\quad$ World total (rounded) & $\frac{190,000}{7 \mathrm{NA}}$ & $\frac{180,000}{7 \mathrm{NA}}$ & NA
\end{tabular}

World Resources: ${ }^{6}$ Large resources of kyanite and related minerals are known to exist in the United States. The chief resources are in deposits of micaceous schist and gneiss, mostly in the Appalachian Mountains and in Idaho. Other resources are in aluminous gneiss in southern California. These resources are not economical to mine at present. The characteristics of kyanite resources in the rest of the world are thought to be similar to those in the United States. Significant resources of andalusite are known to exist in China, France, Peru, and South Africa; kyanite resources have been identified in Brazil, India, and Russia; and sillimanite has been identified in India.

Substitutes: Two types of synthetic mullite (fused and sintered), superduty fire clays, and high-alumina materials are substitutes for kyanite in refractories. Principal raw materials for synthetic mullite are bauxite, kaolin and other clays, and silica sand.

\footnotetext{
${ }^{e}$ Estimated. E Net exporter. NA Not available. W Withheld to avoid disclosing company proprietary data.

${ }^{1}$ Source: Virginia Department of Mines, Minerals and Energy.

${ }^{2}$ Defined as production + imports - exports.

${ }^{3}$ Source: Industrial Minerals (Fastmarkets IM), average yearend price.

${ }^{4}$ Defined as imports - exports.

${ }^{5}$ Includes data for the following Harmonized Tariff Schedule of the United States code: 2508.50 .0000$.

${ }^{6}$ See Appendix $C$ for resource and reserve definitions and information concerning data sources.

${ }^{7}$ In addition to the countries listed, France continued production of andalusite, and Cameroon and China produced kyanite and related minerals.

Output was not reported quantitatively, and no reliable basis was available for estimation of output levels.
} 
Domestic Production and Use: Six lead mines in Missouri, plus four mines in Alaska and Idaho that produced lead as a principal product or byproduct, accounted for all domestic lead mine production. One mine in Washington closed after the current reserves were exhausted in 2019. The value of the lead in concentrates mined in 2020, based on the average North American Market price for refined lead, was about \$574 million. Nearly all lead mine production has been exported since the last primary refinery closed in 2013. The 12 secondary refineries in 10 States accounted for more than $95 \%$ of the secondary lead produced in 2020 . It was estimated that the lead-acid battery industry accounted for about $92 \%$ of reported U.S. lead consumption during 2020 . Lead-acid batteries were primarily used as starting-lighting-ignition (SLI) batteries for automobiles, as industrial-type batteries for standby power for computer and telecommunications networks, and for motive power. During the first 7 months of 2020, 73 million lead-acid automotive batteries were shipped by North American producers, essentially unchanged from those shipped in the same period of 2019.

\begin{tabular}{|c|c|c|c|c|c|}
\hline Salient Statistics_-United States: & $\underline{2016}$ & $\underline{2017}$ & $\underline{2018}$ & $\underline{2019}$ & $\underline{2020^{\mathrm{e}}}$ \\
\hline \multicolumn{6}{|l|}{ Production: } \\
\hline Mine, lead in concentrates & 346 & 310 & 280 & 274 & 290 \\
\hline Primary refinery & - & - & - & - & - \\
\hline Secondary refinery, old scrap & 1,110 & 1,140 & 1,140 & 1,170 & 1,100 \\
\hline \multicolumn{6}{|l|}{ Imports for consumption: } \\
\hline Lead in concentrates & - & $\left({ }^{1}\right)$ & - & $\left({ }^{1}\right)$ & - \\
\hline Refined metal, unwrought (gross weight) & 533 & 658 & 563 & 501 & 370 \\
\hline \multicolumn{6}{|l|}{ Exports: } \\
\hline Lead in concentrates & 341 & 269 & 251 & 259 & 270 \\
\hline Refined metal, unwrought (gross weight) & 43 & 24 & 70 & 25 & 17 \\
\hline Consumption, apparent ${ }^{2}$ & 1,600 & 1,770 & 1,630 & 1,650 & 1,500 \\
\hline \multicolumn{6}{|l|}{ Price, average, cents per pound: ${ }^{3}$} \\
\hline North American market & 94.4 & 114.5 & 110.9 & 99.9 & 89.8 \\
\hline London Metal Exchange (LME), cash & 84.8 & 105.1 & 101.8 & 91.0 & 81.5 \\
\hline Employment, mine and mill (average), number 4 & 1,970 & 1,890 & 1,860 & 1,790 & 1,900 \\
\hline $\begin{array}{l}\text { Net import reliance } 5 \text { as a percentage of } \\
\text { apparent consumption, refined metal }\end{array}$ & 31 & 36 & 30 & 29 & 24 \\
\hline
\end{tabular}

Recycling: In 2020, about 1.1 million tons of secondary lead was produced, an amount equivalent to $73 \%$ of apparent domestic consumption. Nearly all secondary lead was recovered from old scrap, mostly lead-acid batteries.

Import Sources (2016-19): Refined metal: Canada, 44\%; the Republic of Korea, 18\%; Mexico, 18\%; India, 5\%; and other, $15 \%$.

Tariff: Item

Lead ores and concentrates, lead content

Refined lead

Antimonial lead

Alloys of lead

Other unwrought lead
Number

2607.00 .0020

7801.10 .0000

7801.91 .0000

7801.99 .9030

7801.99 .9050
Normal Trade Relations 12-31-20

$1.1 \mathrm{c} / \mathrm{kg}$ on lead content.

$2.5 \%$ on the value of the lead content. $2.5 \%$ on the value of the lead content.

$2.5 \%$ on the value of the lead content.

$2.5 \%$ on the value of the lead content.

Depletion Allowance: $22 \%$ (domestic), 14\% (foreign).

Government Stockpile: None. 
Events, Trends, and Issues: During the first 10 months of 2020, the average LME cash price for lead was 81.5 cents per pound, $10 \%$ less than the average price in 2019. Global stocks of lead in LME-approved warehouses were 124,000 tons in October 2020, which was 88\% more than those at yearend 2019.

In 2020, domestic mine production was estimated to have increased by $6 \%$ from that in the previous year. However, domestic production of secondary lead decreased by $6 \%$ from that in the previous year. U.S. apparent consumption of refined lead decreased by $9 \%$ from that in the previous year. In the first 9 months of 2020, 19.7 million spent SLI lead-acid batteries were exported, slightly less than that in the same time period in 2019.

According to the International Lead and Zinc Study Group, ${ }^{6}$ global refined lead production in 2020 decreased by $4 \%$ to 11.7 million tons, and metal consumption decreased by $7 \%$ to 11.4 million tons. In 2020, the quarantine-related restrictions imposed as a result of the global COVID-19 pandemic affected the mining industry in several countries, especially Bolivia, Kazakhstan, Mexico, and Peru. ${ }^{7}$ Consequently, world mine production fell by $7 \%$ in 2020 compared with the previous year.

World Mine Production and Reserves: Reserves estimates for Peru and Russia were revised based on new information from Government reports.

\begin{tabular}{lrrr} 
& \multicolumn{2}{c}{ Mine production } & Reserves $^{8}$ \\
United States & $\frac{\mathbf{2 0 1 9}}{274}$ & $\frac{\mathbf{2 0 2 0}^{\mathbf{e}}}{290}$ & \\
Australia & 509 & 480 & 5,000 \\
Bolivia & 88 & 65 & 936,000 \\
China & 2,000 & 1,900 & 1,600 \\
India & 200 & 210 & 18,000 \\
Kazakhstan & 56 & 30 & 2,500 \\
Mexico & 259 & 240 & 2,000 \\
Peru & 308 & 240 & 5,600 \\
Russia & 230 & 220 & 6,000 \\
Sweden & 69 & 70 & 4,000 \\
Tajikistan & 65 & 65 & 1,100 \\
Turkey & 71 & 72 & $\mathrm{NA}$ \\
Other countries & 591 & 520 & 860 \\
$\quad$ World total (rounded) & 4,720 & 4,400 & 5,000 \\
\hline
\end{tabular}

World Resources: ${ }^{8}$ Identified world lead resources total more than 2 billion tons. In recent years, significant lead resources have been identified in association with zinc and (or) silver or copper deposits in Australia, China, Ireland, Mexico, Peru, Portugal, Russia, and the United States (Alaska).

Substitutes: Substitution by plastics has reduced the use of lead in cable covering and cans. Tin has replaced lead in solder for potable water systems. The electronics industry has moved toward lead-free solders and flat-panel displays that do not require lead shielding. Steel and zinc are common substitutes for lead in wheel weights.

\footnotetext{
eEstimated. NA Not available. — Zero.

${ }^{1}$ Less than $1 / 2$ unit.

${ }^{2}$ Defined as primary refined production + secondary refined production (old scrap) + refined imports - refined exports.

${ }^{3}$ Source: S\&P Global Platts Metals Week.

${ }^{4}$ Includes lead and zinc-lead mines for which lead was either a principal product or significant byproduct. Data from the Mine Safety and Health Administration.

${ }^{5}$ Defined as imports - exports.

${ }^{6}$ International Lead and Zinc Study Group, 2020, ILZSG session/forecasts: Lisbon, Portugal, International Lead and Zinc Study Group news release, October 16.

${ }^{7}$ International Lead and Zinc Study Group, 2020, ILZSG session/forecasts: Lisbon, Portugal, International Lead and Zinc Study Group press release, October 21.

${ }^{8}$ See Appendix $C$ for resource and reserve definitions and information concerning data sources.

${ }^{9}$ For Australia, Joint Ore Reserves Committee-compliant reserves were 12 million tons.
} 


\section{LIME1}

(Data in thousand metric tons unless otherwise noted)

Domestic Production and Use: In 2020, an estimated 16 million tons of quicklime and hydrate was produced (excluding independent commercial hydrators ${ }^{2}$ ), valued at about $\$ 2.2$ billion. At yearend, 28 companies were producing lime, which included 18 companies with commercial sales and 10 companies that produced lime strictly for internal use (for example, sugar companies). These companies had 74 primary lime plants (plants operating quicklime kilns) in 28 States and Puerto Rico. One lime plant was idle in 2020. Five of the 28 companies operated only hydrating plants in 9 States. In 2020, the five leading U.S. lime companies produced quicklime or hydrate in 22 States and accounted for about $72 \%$ of U.S. lime production. Principal producing States were, in alphabetical order, Alabama, Kentucky, Missouri, Ohio, and Texas. Major markets for lime were, in descending order of consumption, steelmaking, chemical and industrial applications (such as the manufacture of fertilizer, glass, paper and pulp, and precipitated calcium carbonate, and in sugar refining), flue gas treatment, construction, water treatment, and nonferrous mining.

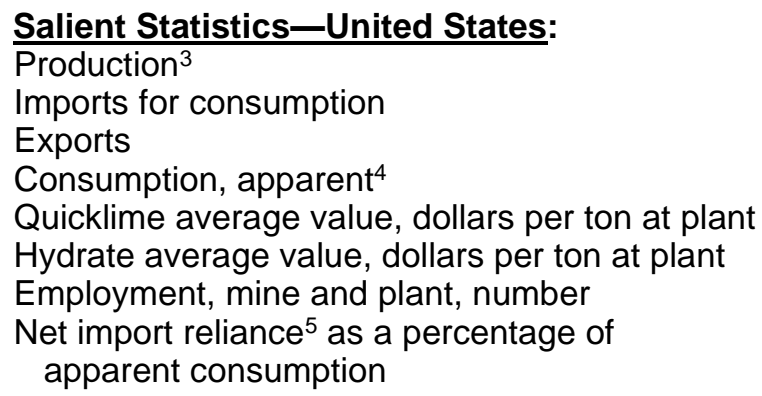

$\begin{array}{rrrrr}\mathbf{2 0 1 6} & \mathbf{2 0 1 7} & \mathbf{2 0 1 8} & \mathbf{2 0 1 9} & \underline{\mathbf{2 0 2 0}} \\ 17,300 & 17,600 & 18,000 & 16,900 & 16,000 \\ 376 & 367 & 370 & 342 & 310 \\ 329 & 391 & 424 & 347 & 260 \\ 17,300 & 17,600 & 18,000 & 16,900 & 16,000 \\ 119.7 & 120.8 & 125.2 & 128.3 & 128 \\ 145.4 & 147.1 & 151.6 & 154.6 & 154 \\ \text { NA } & \text { NA } & \text { NA } & \text { NA } & \text { NA } \\ & & & & \\ <1 & \text { E } & \mathrm{E} & \mathrm{E} & <1\end{array}$

Recycling: Large quantities of lime are regenerated by paper mills. Some municipal water-treatment plants regenerate lime from softening sludge. Quicklime is regenerated from waste hydrated lime in the carbide industry. Data for these sources were not included as production in order to avoid duplication.

Import Sources (2016-19): Canada, 92\%; Mexico, 7\%; and other, 1\%.

\section{Tariff: Item}

Calcined dolomite

Quicklime

Slaked lime

Hydraulic lime
Number

2518.20.0000

2522.10.0000

2522.20.0000

2522.30.0000
Normal Trade Relations

12-31-20

$3 \%$ ad val.

Free.

Free.

Free.

Depletion Allowance: Limestone produced and used for lime production, 14\% (domestic and foreign).

Government Stockpile: None.

Events, Trends, and Issues: In 2020, domestic lime production was estimated to have decreased by $5 \%$ from that of 2019. A decline in lime production was a result of plants temporarily closing as a result of the global COVID-19 pandemic. In San Bernardino County, CA, plans were underway to a construct a new quicklime plant using crushed limestone transported to the site from a nearby quarry. In Texas, one company planned to expand lime production capacity at two separate plants by 2021 . One plant was adding a new vertical kiln to meet increasing steel industry demand for high-purity dolomitic lime products. The other plant was adding a new energy-efficient lime kiln to produce high-calcium lime products to meet the increasing demand from the steel and construction industries. The total number of operating quicklime plants was 73 in 2020 along with 10 hydrating plants. Hydrated lime is a dry calcium hydroxide powder made from reacting quicklime with a controlled amount of water in a hydrator. It is used in chemical and industrial, construction, and environmental applications. 
World Lime Production and Limestone Reserves:

\begin{tabular}{lrr} 
& \multicolumn{2}{c}{ Production $^{\mathbf{6}}$} \\
United States & $\underline{\mathbf{2 0 1 9}}$ & $\mathbf{2 0 2 \mathbf { e } ^ { \mathbf { e } }}$ \\
Australia & 16,900 & 16,000 \\
Belgium & 1,980 & 2,000 \\
Brazil & 1,560 & 1,500 \\
Bulgaria & 8,100 & 8,100 \\
Canada (shipments) & 1,460 & 1,500 \\
China & 1,710 & 1,700 \\
France & 310,000 & 300,000 \\
Germany & 2,600 & 2,600 \\
India & 7,100 & 7,100 \\
Iran & 16,000 & 16,000 \\
Italy & 3,450 & 3,300 \\
Japan (quicklime only) & 3,500 & 3,500 \\
Korea, Republic of & 7,320 & 7,300 \\
Malaysia & 5,200 & 5,200 \\
Poland (hydrated and quicklime) & 1,600 & 1,600 \\
Romania & 2,700 & 2,700 \\
Russia (industrial and construction) & 1,960 & 1,900 \\
Slovenia & 11,000 & 11,000 \\
South Africa & 1,190 & 1,100 \\
Spain & 1,300 & 1,300 \\
Turkey & 1,800 & 1,800 \\
Ukraine & 4,600 & 4,600 \\
United Kingdom & 2,250 & 2,200 \\
Other countries & 1,500 & 1,500 \\
$\quad$ World total (rounded) & 15,500 & 15,000 \\
nation & 432,000 & 420,000
\end{tabular}

World Resources: ${ }^{7}$ Domestic and world resources of limestone and dolomite suitable for lime manufacture are very large.

Substitutes: Limestone is a substitute for lime in many applications, such as agriculture, fluxing, and sulfur removal. Limestone, which contains less reactive material, is slower to react and may have other disadvantages compared with lime, depending on the application; however, limestone is considerably less expensive than lime. Calcined gypsum is an alternative material in industrial plasters and mortars. Cement, cement kiln dust, fly ash, and lime kiln dust are potential substitutes for some construction uses of lime. Magnesium hydroxide is a substitute for lime in $\mathrm{pH}$ control, and magnesium oxide is a substitute for dolomitic lime as a flux in steelmaking.

\footnotetext{
EEstimated. E Net exporter. NA Not available.

${ }^{1}$ Data are for quicklime, hydrated lime, and refractory dead-burned dolomite. Includes Puerto Rico.

${ }^{2}$ To avoid double counting quicklime production, excludes independent commercial hydrators that purchase quicklime for hydration.

${ }^{3}$ Sold or used by producers.

${ }^{4}$ Defined as production + imports - exports. Includes some double counting based on nominal, undifferentiated reporting of company export sales as U.S. production.

${ }^{5}$ Defined as imports - exports.

${ }^{6}$ Only countries that produced 1 million tons of lime or more are listed separately.

${ }^{7}$ See Appendix $\mathrm{C}$ for resource and reserve definitions and information concerning data sources.

${ }^{8}$ Includes hydraulic lime.
} 


\section{LITHIUM}

(Data in metric tons of lithium content unless otherwise noted)

Domestic Production and Use: The only lithium production in the United States was from a brine operation in Nevada. Two companies produced a wide range of downstream lithium compounds in the United States from domestic or imported lithium carbonate, lithium chloride, and lithium hydroxide. Domestic production data were withheld to avoid disclosing company proprietary data.

Although lithium markets vary by location, global end-use markets are estimated as follows: batteries, $71 \%$; ceramics and glass, $14 \%$; lubricating greases, $4 \%$; continuous casting mold flux powders, $2 \%$; polymer production, $2 \%$; air treatment, $1 \%$; and other uses, $6 \%$. Lithium consumption for batteries has increased significantly in recent years because rechargeable lithium batteries are used extensively in the growing market for portable electronic devices and increasingly are used in electric tools, electric vehicles, and grid storage applications. Lithium minerals were used directly as ore concentrates in ceramics and glass applications.

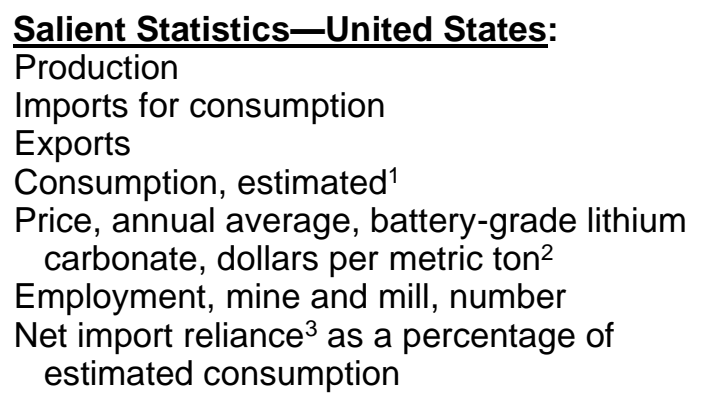

$\begin{array}{rrrrr}\frac{\mathbf{2 0 1 6}}{W} & \frac{\mathbf{2 0 1 7}}{W} & \frac{\mathbf{2 0 1 8}}{W} & \frac{\mathbf{2 0 1 9}}{W} & \frac{\mathbf{2 0 2 0}}{W} \\ 3,140 & 3,330 & 3,420 & 2,620 & 2,900 \\ 1,520 & 1,960 & 1,660 & 1,680 & 1,400 \\ 3,000 & 3,000 & 3,000 & 2,000 & 2,000 \\ & & & & \\ 8,650 & 15,000 & 17,000 & 12,700 & 8,000 \\ 70 & 70 & 70 & 70 & 70 \\ >50 & >50 & >50 & >25 & >50\end{array}$

Recycling: One domestic company has recycled lithium metal and lithium-ion batteries since 1992 at its facility in British Columbia, Canada. In 2015, the company began operating the first U.S. recycling facility for lithium-ion vehicle batteries in Lancaster, $\mathrm{OH}$. Seven other companies located in Canada and the United States have begun recycling, or intend to begin recycling, lithium metal and lithium-ion batteries to some degree.

Import Sources (2016-19): Argentina, 55\%; Chile, 36\%; China, 5\%; Russia, 2\%; and other, 2\%.

\section{Tariff: Item}

Other alkali metals

Lithium oxide and hydroxide

Lithium carbonate:

U.S. pharmaceutical grade

Other

Depletion Allowance: 22\% (domestic), 14\% (foreign).

Number
2805.19 .9000
2825.20 .0000
2836.91 .0010
2836.91 .0050

2836.91 .0050

\author{
Normal Trade Relations \\ 12-31-20 \\ $5.5 \%$ ad val. \\ $3.7 \%$ ad val. \\ $3.7 \%$ ad val. \\ $3.7 \%$ ad val.
}

\section{Government Stockpile: ${ }^{4}$}

\section{Material}

Lithium cobalt oxide (kilograms, gross weight)

Lithium nickel cobalt aluminum oxide (kilograms, gross weight)

Lithium-ion precursors (kilograms, gross weight)
FY 2020

Inventory
as of $9-30-20$

Potential acquisitions

\section{Potential disposals}

\author{
750 \\ 2,700
}

\begin{abstract}
Potential Potential acquisitions disposals
\end{abstract}

Events, Trends, and Issues: Excluding U.S. production, worldwide lithium production in 2020 decreased by $5 \%$ to 82,000 tons of lithium content from 86,000 tons of lithium content in 2019 in response to lithium production exceeding consumption and decreasing lithium prices. Global consumption of lithium in 2020 was estimated to be 56,000 tons of lithium content, about the same as that of 2019. During the first half of 2020, the economic impact of the global COVID-19 pandemic was reported to have been a substantial factor in the reduction of customer demand. The second half of 2020 saw lithium demand increase owing primarily to strong growth in the lithium-ion battery market. 


\section{LITHIUM}

Spot lithium carbonate prices in China decreased from approximately $\$ 7,100$ per ton at the beginning of the year to about $\$ 6,200$ per ton in November. For large fixed contracts, the annual average U.S. lithium carbonate price was $\$ 8,000$ per metric ton in 2020 , a $37 \%$ decrease from that of 2019 . Spot lithium hydroxide prices in China decreased from approximately $\$ 7,800$ per ton at the beginning of the year to about $\$ 7,000$ per ton in November. Spot lithium metal $(99.9 \%$ lithium) prices in China decreased from approximately $\$ 83,000$ per ton at the beginning of the year to about $\$ 71,000$ per ton in November.

Five mineral operations in Australia, two brine operations each in Argentina and Chile, and two brine and one mineral operation in China accounted for the majority of world lithium production. Owing to overproduction and decreased prices, several established lithium operations postponed capacity expansion plans. Junior mining operations in Australia and Canada ceased production altogether.

Lithium supply security has become a top priority for technology companies in the United States and Asia. Strategic alliances and joint ventures among technology companies and exploration companies continued to be established to ensure a reliable, diversified supply of lithium for battery suppliers and vehicle manufacturers. Brine-based lithium sources were in various stages of development in Argentina, Bolivia, Chile, China, and the United States; mineral-based lithium sources were in various stages of development in Australia, Austria, Brazil, Canada, China, Congo (Kinshasa), Czechia, Finland, Germany, Mali, Namibia, Peru, Portugal, Serbia, Spain, and Zimbabwe; and lithium-clay sources were in various stages of development in Mexico and the United States.

World Mine Production and Reserves: Reserves for Argentina, Australia, Canada, Chile, China, the United States, Zimbabwe, and other countries were revised based on new information from Government and industry sources.

United States

Argentina

Australia

Brazil

Canada

Chile

China

Portugal

Zimbabwe

Other countries ${ }^{7}$ World total (rounded)

\begin{tabular}{rr}
\multicolumn{3}{c}{ Mine production } \\
2019 & $\frac{\mathbf{2 0 2 0}}{W}$ \\
W & 6,200 \\
6,300 & 6,2000 \\
45,000 & 40,000 \\
2,400 & 1,900 \\
200 & - \\
19,300 & 18,000 \\
10,800 & 14,000 \\
900 & 900 \\
1,200 & 1,200 \\
$\frac{-}{886,000}$ & $\frac{-}{882,000}$
\end{tabular}

$$
\begin{array}{r}
\text { Reserves }^{5} \\
\\
750,000 \\
1,900,000 \\
64,700,000 \\
95,000 \\
530,000 \\
9,200,000 \\
1,500,000 \\
60,000 \\
220,000 \\
2,100,000 \\
\hline 21,000,000
\end{array}
$$

World Resources: ${ }^{5}$ Owing to continuing exploration, identified lithium resources have increased substantially worldwide and total about 86 million tons. Lithium resources in the United States-from continental brines, geothermal brines, hectorite, oilfield brines, and pegmatites-are 7.9 million tons. Lithium resources in other countries have been revised to 78 million tons. Lithium resources are Bolivia, 21 million tons; Argentina, 19.3 million tons; Chile, 9.6 million tons; Australia, 6.4 million tons; China, 5.1 million tons; Congo (Kinshasa), 3 million tons; Canada, 2.9 million tons; Germany, 2.7 million tons; Mexico, 1.7 million tons; Czechia, 1.3 million tons; Serbia, 1.2 million tons; Peru, 880,000 tons; Mali, 700,000 tons; Zimbabwe, 500,000 tons; Brazil, 470,000 tons; Spain, 300,000 tons; Portugal, 270,000 tons; Ghana, 90,000 tons; and Austria, Finland, Kazakhstan, and Namibia, 50,000 tons each.

Substitutes: Substitution for lithium compounds is possible in batteries, ceramics, greases, and manufactured glass. Examples are calcium, magnesium, mercury, and zinc as anode material in primary batteries; calcium and aluminum soaps as substitutes for stearates in greases; and sodic and potassic fluxes in ceramics and glass manufacture.

\footnotetext{
eEstimated. W Withheld to avoid disclosing company proprietary data. - Zero.

${ }^{1}$ Defined as production + imports - exports + adjustments for Government and industry stock changes. Rounded to one significant digit to avoid disclosing company proprietary data.

${ }^{2}$ Source: Industrial Minerals (Fastmarkets IM), lithium carbonate, large contracts, delivered continental United States.

${ }^{3}$ Defined as imports - exports + adjustments for Government and industry stock changes.

${ }^{4}$ See Appendix B for definitions.

${ }^{5}$ See Appendix $C$ for resource and reserve definitions and information concerning data sources.

${ }^{6}$ For Australia, Joint Ore Reserves Committee-compliant reserves were 2.8 million tons.

${ }^{7}$ Other countries with reported reserves include Austria, Congo (Kinshasa), Czechia, Finland, Germany, Mali, and Mexico.

${ }^{8}$ Excludes U.S. production.
} 


\section{MAGNESIUM COMPOUNDS 1}

[Data in thousand metric tons of magnesium oxide $(\mathrm{MgO})$ content unless otherwise noted] ${ }^{2}$

Domestic Production and Use: Seawater and natural brines accounted for about $70 \%$ of U.S. magnesium compound production in 2020. The value of shipments of all types of magnesium compounds was estimated to be $\$ 360$ million, essentially unchanged from the revised value in 2019. Magnesium oxide and other compounds were recovered from seawater by one company in California and another company in Delaware, from well brines by one company in Michigan, and from lake brines by two companies in Utah. Magnesite was mined by one company in Nevada. One company in Washington processed olivine that was mined previously for use as foundry sand. About $67 \%$ of the magnesium compounds consumed in the United States was used in agricultural, chemical, construction, deicing, environmental, and industrial applications in the form of caustic-calcined magnesia, magnesium chloride, magnesium hydroxide, and magnesium sulfates. The remaining $33 \%$ was used for refractories in the form of deadburned magnesia, fused magnesia, and olivine.

\begin{tabular}{|c|c|c|c|c|c|}
\hline Salient Statistics-United States: & $\underline{2016}$ & $\underline{2017}$ & $\underline{2018}$ & $\underline{2019}$ & $\underline{2020^{\mathrm{e}}}$ \\
\hline Production (shipments) & 408 & 438 & 405 & 376 & 350 \\
\hline Shipments (gross weight) & 579 & 616 & 610 & 563 & 530 \\
\hline Imports for consumption & 370 & 436 & 551 & 564 & 480 \\
\hline Exports & 88 & 103 & 116 & 88 & 70 \\
\hline Consumption, apparent ${ }^{3}$ & 690 & 771 & 840 & 852 & 760 \\
\hline Employment, plant, number & 260 & 260 & 270 & 270 & 270 \\
\hline $\begin{array}{l}\text { Net import reliance }{ }^{4} \text { as a percentage } \\
\text { of apparent consumption }\end{array}$ & 41 & 43 & 52 & 56 & 54 \\
\hline
\end{tabular}

Recycling: Some magnesia-based refractories are recycled, either for reuse as refractory material or for use as construction aggregate.

Import Sources (2016-19): Caustic-calcined magnesia: China, 69\%; Canada, 21\%; Australia, 5\%; Israel, 3\%; and other, 2\%. Crude magnesite: China, 84\%; Singapore, 12\%; and other 4\%. Dead-burned and fused magnesia: China, 66\%; Brazil, 10\%; Turkey, 6\%; Mexico, 4\%; and other, 14\%. Magnesium chloride: Israel, $63 \%$; the Netherlands, $24 \%$; China, 5\%; India, 3\%; and other, 5\%. Magnesium hydroxide: Mexico, 53\%; the Netherlands, 15\%; Israel, $12 \%$;

Austria, 10\%; and other, 10\%. Magnesium sulfates: China, 55\%; Germany, 13\%; India, $11 \%$; Canada, $8 \%$; and other, 13\%. Total imports: China, 44\%; Israel, 15\%; Brazil, 14\%; the Netherlands, 7\%; and other, $20 \%$.

\section{Tariff: Item}

Crude magnesite

Dead-burned and fused magnesia

Caustic-calcined magnesia

Kieserite

Epsom salts

Magnesium hydroxide and peroxide

Magnesium chloride

Magnesium sulfate (synthetic)

\section{Number}

2519.10.0000

2519.90 .1000

2519.90.2000

2530.20.1000

2530.20.2000

2816.10.0000

2827.31.0000

2833.21.0000
Normal Trade Relations

12-31-20

Free.

Free.

Free.

Free.

Free.

$3.1 \%$ ad val.

$1.5 \%$ ad val.

$3.7 \%$ ad val.

Depletion Allowance: Brucite, 10\% (domestic and foreign); dolomite, magnesite, and magnesium carbonate, 14\% (domestic and foreign); magnesium chloride (from brine wells), 5\% (domestic and foreign); and olivine, 22\% (domestic) and $14 \%$ (foreign).

\section{Government Stockpile: None.}

Events, Trends, and Issues: Consumption of dead-burned and fused magnesia in the United States decreased by $11 \%$ in 2020 compared with that in 2019. Global consumption of dead-burned and fused magnesia decreased by about $3 \%$ during the first 9 months of 2020 compared with that in the same period of 2019. Top domestic consumption of magnesium compounds, in descending order, were water treatment, deicing, chemical, and agriculture. The leading magnesium compounds consumed, in descending order, were magnesium oxide (causticcalcined magnesia, dead burned magnesia, and fused magnesia), magnesium hydroxide, and magnesium chloride. 
The global COVID-19 pandemic and efforts to mitigate the spread of the disease caused disruptions in many of the mining and manufacturing industries across the United States and around the world. Overall demand for magnesium compounds was lower in the first half of the year, rebounding to January levels by the third quarter as global lockdowns were eased.

China remains the leading producer of magnesia and magnesite. Policy changes, coupled with the impacts of the global COVID-19 pandemic, have resulted in inconsistent supplies and restricted availability of all grades of magnesia in the world market. Pandemic-related closures of mining and manufacturing activities and reduced demand from downstream industries in early 2020 caused decreased steel production, a major consumer of refractory-grade magnesia. Air pollution controls scheduled to be imposed in major steel-producing Provinces during the autumn and winter months will further reduce consumption of refractory grade magnesia. Liaoning Province, a major source of Chinese magnesite, implemented a 6 -month ban on the use of explosives that began on July 1 . New open pit mines were banned as well. Export prices for dead-burned and fused magnesia from China decreased by about $13 \%$ from the start of the year to the end of September, which was likely caused by a decrease in demand owing to the impact of the global pandemic.

World Magnesite Mine Production and Reserves: ${ }^{5}$ In addition to magnesite, vast reserves exist in well and lake brines and seawater from which magnesium compounds can be recovered. Reserves for Austria, Brazil, Slovakia, and Turkey were revised based on new information from Government and industry sources.

\begin{tabular}{|c|c|c|c|}
\hline & Mine p & ction & Reserves $^{6}$ \\
\hline & $\underline{2019}$ & $2020^{e}$ & \\
\hline United States & W & $W$ & 35,000 \\
\hline Australia & 320 & 310 & 7320,000 \\
\hline Austria & 780 & 760 & 49,000 \\
\hline Brazil & 1,500 & 1,500 & 200,000 \\
\hline China & 19,000 & 18,000 & $1,000,000$ \\
\hline Greece & 530 & 500 & 280,000 \\
\hline India & 150 & 150 & 82,000 \\
\hline Russia & 1,500 & 1,500 & $2,300,000$ \\
\hline Slovakia & 475 & 460 & 370,000 \\
\hline Spain & 570 & 600 & 35,000 \\
\hline Turkey & 1,500 & 1,100 & 205,000 \\
\hline Other countries & 700 & 680 & $2,700,000$ \\
\hline World total (rounded) & 827,100 & $8 \overline{26,000}$ & $\overline{7,600,000}$ \\
\hline
\end{tabular}

World Resources: ${ }^{6}$ Resources from which magnesium compounds can be recovered range from large to virtually unlimited and are globally widespread. Identified world magnesite and brucite resources total 12 billion tons and several million tons, respectively. Resources of dolomite, forsterite, magnesium-bearing evaporite minerals, and magnesia-bearing brines are estimated to constitute a resource of billions of tons. Magnesium hydroxide can be recovered from seawater. Serpentine could be used as a source of magnesia but global resources, including in tailings of asbestos mines, have not been quantified but are thought to be very large.

Substitutes: Alumina, chromite, and silica substitute for magnesia in some refractory applications.

\footnotetext{
eEstimated. W Withheld to avoid disclosing company proprietary data.

${ }^{1}$ See also Magnesium Metal.

${ }^{2}$ Previously reported as magnesium content. Based on input from consumers, producers, and others involved in the industry, it was determined that reporting magnesium compound data in terms of contained magnesium oxide was more useful than reporting in terms of magnesium content. Calculations were made using the following magnesium oxide $(\mathrm{MgO})$ contents: magnesite, $47.8 \%$; magnesium chloride, $42.3 \%$; magnesium hydroxide, $69.1 \%$; and magnesium sulfate, $33.5 \%$.

${ }^{3}$ Defined as production + imports - exports.

${ }^{4}$ Defined as imports - exports.

${ }^{5}$ Gross weight of magnesite (magnesium carbonate) in thousand tons.

${ }^{6}$ See Appendix $C$ for resource and reserve definitions and information concerning data sources.

${ }^{7}$ For Australia, Joint Ore Reserves Committee-compliant reserves were 37 million tons.

${ }^{8}$ Excludes U.S. production.
} 


\section{MAGNESIUM METAL ${ }^{1}$}

(Data in thousand metric tons unless otherwise noted)

Domestic Production and Use: In 2020, primary magnesium was produced by one company in Utah at an electrolytic process plant that recovered magnesium from brines from the Great Salt Lake. Secondary magnesium was recovered from scrap at plants that produced magnesium ingot and castings and from aluminum alloy scrap at secondary aluminum smelters. Primary magnesium production in 2020 was estimated to have decreased from that of 2019. Information regarding U.S. primary magnesium production was withheld to avoid disclosing company proprietary data. The leading use for primary magnesium metal, which accounted for $47 \%$ of reported consumption, was in castings, principally used for the automotive industry. Aluminum-base alloys that were used for packaging, transportation, and other applications accounted for $33 \%$ of primary magnesium metal consumption; desulfurization of iron and steel, $16 \%$; and all other uses, $4 \%$. About $33 \%$ of the secondary magnesium was consumed for structural uses, and about $67 \%$ was used in aluminum alloys.

\begin{tabular}{|c|c|c|c|c|c|}
\hline Salient Statistics-United States: & $\underline{2016}$ & 2017 & $\underline{2018}$ & 2019 & $\underline{2020^{\circ}}$ \\
\hline \multicolumn{6}{|l|}{ Production: } \\
\hline Primary & W & W & W & W & W \\
\hline Secondary (new and old scrap) & 101 & 112 & 109 & 101 & 90 \\
\hline Imports for consumption & 45 & 42 & 47 & 59 & 61 \\
\hline Exports & 19 & 14 & 12 & 10 & 12 \\
\hline \multicolumn{6}{|l|}{ Consumption: } \\
\hline Reported, primary & 69 & 65 & 51 & 55 & 50 \\
\hline Apparent $^{2}$ & W & W & W & W & W \\
\hline \multicolumn{6}{|l|}{ Price, annual average: ${ }^{3}$} \\
\hline U.S. spot Western, dollars per pound & 2.15 & 2.15 & 2.17 & 2.45 & 2.50 \\
\hline European free market, dollars per metric ton & 2,190 & 2,265 & 2,550 & 2,425 & 2,100 \\
\hline Stocks, producer, yearend & W & W & W & W & W \\
\hline Employment, numbere & 420 & 400 & 400 & 400 & 400 \\
\hline $\begin{array}{l}\text { Net import reliance } 4 \text { as a percentage of } \\
\text { apparent consumption }\end{array}$ & $<25$ & $<25$ & $<50$ & $<50$ & $<50$ \\
\hline
\end{tabular}

Recycling: In 2020, about 25,000 tons of secondary magnesium was recovered from old scrap and 65,000 tons was recovered from new scrap. Aluminum-base alloys accounted for about $55 \%$ of the secondary magnesium recovered, and magnesium-based castings, ingot, and other materials accounted for about $45 \%$.

Import Sources (2016-19): Canada, 23\%; Israel, 20\%; Mexico, 11\%; Russia, 8\%; and other, 38\%.

\section{Tariff: Item}

Unwrought metal

Unwrought alloys

Scrap

Powders and granules

Wrought metal
Number

8104.11 .0000

8104.19 .0000

8104.20 .0000

8104.30 .0000

8104.90 .0000
Normal Trade Relations

12-31-20

$8.0 \%$ ad val.

$6.5 \%$ ad val.

Free.

$4.4 \%$ ad val.

$14.8 \% / \mathrm{kg}$ on $\mathrm{Mg}$ content $+3.5 \%$ ad val.

Depletion Allowance: Dolomite, 14\% (domestic and foreign); magnesium chloride (from brine wells), $5 \%$ (domestic and foreign).

\section{Government Stockpile: None.}

Events, Trends, and Issues: The sole U.S. producer of primary magnesium temporarily shut down some capacity at the end of 2016 citing the shutdown of a titanium sponge plant that had been a major customer, and this capacity was not expected to restart in the foreseeable future.

Prices and demand for magnesium fluctuated during much of the year in response to the COVID-19 pandemic. The price in Europe spiked in February compared with the price at the end of January but then declined by mid-March. The price increase in Europe in February and early March was attributed to concerns that shutdowns of smelters in China would cause shortages of magnesium. During January and February, producers in China shut down some capacity citing travel and work restrictions, less demand because of the pandemic, and heavy snowfall in the northwest part of China. But as many secondary aluminum smelters and diecasters in Europe temporarily shut down production in February and March, magnesium consumption decreased. Prices in Europe decreased during April and May, on decreased demand, but increased in June. Decreased production in China during the summer months was 
cited for increased magnesium prices in Europe. In September, prices in Europe declined. In the United States, spot sales of magnesium declined dramatically in April and May, causing the price to drop. Diecasters producing parts for the automobile industry as well as secondary aluminum smelters decreased magnesium consumption in response to shutdowns of automobile assembly lines, aluminum extruders, and aluminum rolling mills. By midyear, consumption of magnesium by aluminum smelters and diecasters stabilized but prices remained at lower levels in the United States and dropped again in August.

Producers in China dominate global magnesium metal production, but several projects were under development to increase primary magnesium metal capacity elsewhere and in China. In the United States, one company obtained a location to build a pilot plant to test magnesium production from a dolomite deposit in Nevada. A company in Quebec, Canada, started construction of a secondary magnesium smelter with completion expected by midyear 2021. Then the company planned to construct a primary magnesium smelter to produce magnesium from serpentine-bearing asbestos tailings. A company in Australia was planning to start construction in 2021 on a 3,000-ton-per-year plant to recover magnesium from coal fly ash with completion expected to take 18 months.

The use of magnesium in automobile parts continued to increase as automobile manufacturers sought to decrease vehicle weight in response to consumer desires for increased fuel efficiency. Magnesium castings have substituted for aluminum, iron, and steel in some automobiles. The substitution of aluminum for steel in automobile sheet was expected to increase consumption of magnesium in aluminum alloy sheet. Although some magnesium sheet applications have been developed for automobiles, these were generally limited to expensive sports cars and luxury vehicles, automobiles where the higher price of magnesium is not a deterrent to its use.

\section{World Primary Production and Reserves:}

\begin{tabular}{lrr} 
& \multicolumn{2}{c}{ Smelter production } \\
& $\underline{\mathbf{2 0 1 9}}$ & $\underline{\mathbf{2 0 2 0 ^ { e }}}$ \\
United States & 22 & W \\
Brazil & 970 & 20 \\
China & 21 & 200 \\
Israel & 25 & 20 \\
Kazakhstan & 67 & 60 \\
Russia & 7 & 11 \\
Turkey & 8 & $\mathbf{5}$ \\
Ukraine & $\mathbf{1 , 1 2 0}$ & $\mathbf{1 , 0 0 0}$
\end{tabular}

\section{Reserves $^{5}$}

Magnesium metal can be derived from seawater, natural brines, dolomite, serpentine, and other minerals. The reserves for this metal are sufficient to supply current and future requirements.

World Resources: ${ }^{5}$ Resources from which magnesium may be recovered range from large to virtually unlimited and are globally widespread. Resources of dolomite, serpentine, and magnesium-bearing evaporite minerals are enormous. Magnesium-bearing brines are estimated to constitute a resource in the billions of tons, and magnesium could be recovered from seawater along world coastlines.

Substitutes: Aluminum and zinc may substitute for magnesium in castings and wrought products. The relatively light weight of magnesium is an advantage over aluminum and zinc in castings and wrought products in most applications; however, its high cost is a disadvantage relative to these substitutes. For iron and steel desulfurization, calcium carbide may be used instead of magnesium. Magnesium is preferred to calcium carbide for desulfurization of iron and steel because calcium carbide produces acetylene in the presence of water.

\footnotetext{
eEstimated. W Withheld to avoid disclosing company proprietary data.

${ }^{1}$ See also Magnesium Compounds.

${ }^{2}$ Defined as primary production + secondary production from old scrap + imports - exports + adjustments for industry stock changes.

${ }^{3}$ Source: S\&P Global Platts Metals Week.

${ }^{4}$ Defined as imports - exports + adjustments for industry stock changes.

${ }^{5}$ See Appendix $\mathrm{C}$ for resource and reserve definitions and information concerning data sources.

${ }^{6}$ Excludes U.S. production.
} 


\section{MANGANESE}

(Data in thousand metric tons gross weight unless otherwise noted)

Domestic Production and Use: Manganese ore containing $20 \%$ or more manganese has not been produced domestically since 1970. Manganese ore was consumed mainly by six firms with plants principally in the East and Midwest. Most ore consumption was related to steel production, either directly in pig iron manufacture or indirectly through upgrading the ore to ferroalloys. Manganese ferroalloys were produced at two plants. Additional quantities of ore were used for such nonmetallurgical purposes as production of dry cell batteries, in fertilizers and animal feed, and as a brick colorant.

\begin{tabular}{|c|c|c|c|c|c|}
\hline Salient Statistics-United States: ${ }^{1}$ & $\underline{2016}$ & $\underline{2017}$ & $\underline{2018}$ & $\underline{2019}$ & $\underline{2020^{\mathrm{e}}}$ \\
\hline Production, mine & 二 & 二 & 二 & - & 二 \\
\hline \multicolumn{6}{|l|}{ Imports for consumption: } \\
\hline Manganese ores and concentrates & 281 & 297 & 440 & 434 & 310 \\
\hline Ferromanganese & 229 & 331 & 427 & 332 & 240 \\
\hline Silicomanganese $^{2}$ & 264 & 351 & 412 & 351 & 240 \\
\hline \multicolumn{6}{|l|}{ Exports: } \\
\hline Manganese ores and concentrates & 1 & 1 & 3 & 1 & 1 \\
\hline Ferromanganese & 7 & 9 & 10 & 5 & 4 \\
\hline Silicomanganese & 2 & 8 & 4 & 2 & 2 \\
\hline \multicolumn{6}{|l|}{ Shipments from Government stockpile: ${ }^{3}$} \\
\hline Manganese ore & - & - & - & - & - \\
\hline Ferromanganese & 44 & 9 & 10 & 8 & 21 \\
\hline \multicolumn{6}{|l|}{ Consumption, reported: } \\
\hline Manganese ore ${ }^{4}$ & 410 & 378 & 370 & e370 & 330 \\
\hline Ferromanganese & 342 & 345 & 348 & 336 & 300 \\
\hline Silicomanganese ${ }^{2}$ & 139 & 141 & 139 & 143 & 130 \\
\hline Consumption, apparent, manganese ${ }^{5}$ & 545 & 714 & 793 & e 780 & 520 \\
\hline \multicolumn{6}{|l|}{ Price, average, $44 \% \mathrm{Mn}$ metallurgical ore, } \\
\hline dollars per metric ton unit ${ }^{6}$ & 4.34 & 5.97 & 7.16 & 5.63 & 4.72 \\
\hline \multicolumn{6}{|l|}{ Stocks, producer and consumer, yearend: } \\
\hline Manganese ore ${ }^{4}$ & 207 & 148 & 185 & e190 & 190 \\
\hline Ferromanganese & 21 & 17 & 27 & 16 & 16 \\
\hline Silicomanganese & 10 & 11 & 21 & 11 & 11 \\
\hline $\begin{array}{l}\text { Net import reliance }{ }^{7} \text { as a percentage of } \\
\text { apparent consumption }\end{array}$ & 100 & 100 & 100 & 100 & 100 \\
\hline
\end{tabular}

Recycling: Manganese was recycled incidentally as a constituent of ferrous and nonferrous scrap; however, scrap recovery specifically for manganese was negligible. Manganese is recovered along with iron from steel slag.

Import Sources (2016-19): Manganese ore: Gabon, 69\%; South Africa, 17\%; Mexico, 8\%; Australia, 4\%; and other, 2\%. Ferromanganese: Australia, 21\%; South Africa, 21\%; Norway, 16\%; the Republic of Korea, 12\%; and other, $30 \%$. Silicomanganese: Georgia, 26\%; South Africa, 22\%; Australia, 20\%; and other, 32\%. Manganese contained in principal manganese imports: ${ }^{8}$ Gabon, 20\%; South Africa, 19\%; Australia, 15\%; Georgia, $10 \%$; and other, 36\%.

\section{Tariff: Item}

Ores and concentrates

Manganese dioxide

High-carbon ferromanganese

Ferrosilicon manganese (silicomanganese)

Metal, unwrought
Number

2602.00.0040, 2602.00.0060

2820.10 .0000

7202.11 .5000

7202.30 .0000

$8111.00 .4700,8111.00 .4900$
Normal Trade Relations

12-31-20

Free.

$4.7 \%$ ad val.

$1.5 \%$ ad val.

$3.9 \%$ ad val.

$14 \%$ ad val.

Depletion Allowance: $22 \%$ (domestic), 14\% (foreign). 


\section{Government Stockpile: ${ }^{9}$}

\section{Material}

Manganese ore, metallurgical grade

Ferromanganese, high-carbon

Manganese metal, electrolytic

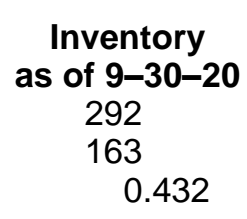

FY 2020

$\begin{array}{cc}\begin{array}{c}\text { Potential } \\ \text { acquisitions }\end{array} & \begin{array}{c}\text { Potential } \\ \text { disposals } \\ -\end{array} \\ \overline{5} & 292 \\ - & 45\end{array}$

FY 2021

$\begin{array}{cc}\begin{array}{c}\text { Potential } \\ \text { acquisitions }\end{array} & \begin{array}{c}\text { Potential } \\ \text { disposals }\end{array} \\ - & 292 \\ - & 45 \\ 5 & -\end{array}$

Events, Trends, and Issues: Steel production, the leading use of manganese, decreased across the globe in 2020 compared with production in 2019 owing to reduced demand attributed to the global COVID-19 pandemic. Global production of manganese ore was estimated to be about $6 \%$ less than that in 2019 . The leading countries for manganese ore production were, in descending order on a contained-weight basis, South Africa, Australia, and Gabon. Total U.S. manganese imports were estimated to have decreased by approximately $30 \%$ in 2020 compared with those in 2019. By September 2020, average spot market prices for manganese ore from China had decreased by $16 \%$ compared with the annual average spot price in 2019 .

World Mine Production and Reserves (manganese content): Reserves for Australia, Brazil, and South Africa were revised based on Government and industry sources.

\begin{tabular}{|c|c|c|c|}
\hline \multirow[b]{3}{*}{ United States } & \multicolumn{2}{|c|}{ Mine production } & \multirow[t]{2}{*}{ Reserves $^{10}$} \\
\hline & $\underline{2019}$ & $2020^{\mathrm{e}}$ & \\
\hline & & & \\
\hline Australia & 3,180 & 3,300 & 11230,000 \\
\hline Brazil & 1,740 & 1,200 & 270,000 \\
\hline Burma & 430 & 400 & NA \\
\hline China & 1,330 & 1,300 & 54,000 \\
\hline Côte d'Ivoire & 482 & 460 & NA \\
\hline Gabon & 2,510 & 2,800 & 61,000 \\
\hline Georgia & 116 & 150 & NA \\
\hline Ghana & 1,550 & 1,400 & 13,000 \\
\hline India & 801 & 640 & 34,000 \\
\hline Kazakhstan, concentrate & 140 & 130 & 5,000 \\
\hline Malaysia & 390 & 350 & NA \\
\hline Mexico & 202 & 190 & 5,000 \\
\hline South Africa & 5,800 & 5,200 & 520,000 \\
\hline Ukraine, concentrate & 500 & 550 & 140,000 \\
\hline Vietnam & 158 & 150 & NA \\
\hline Other countries & 270 & 270 & Small \\
\hline World total (rounded) & $\overline{19,600}$ & $\overline{18,500}$ & $\overline{1,300,000}$ \\
\hline
\end{tabular}

World Resources: ${ }^{10}$ Land-based manganese resources are large but irregularly distributed; those in the United States are very low grade and have potentially high extraction costs. South Africa accounts for about $40 \%$ of the world's manganese reserves, and Brazil accounts for about $20 \%$.

Substitutes: Manganese has no satisfactory substitute in its major applications.

eEstimated. NA Not available. - Zero.

${ }^{1}$ Manganese content typically ranges from $35 \%$ to $54 \%$ for manganese ore and from $74 \%$ to $95 \%$ for ferromanganese.

${ }^{2}$ Imports more nearly represent amount consumed than does reported consumption.

${ }^{3}$ Defined as stockpile shipments - receipts, thousand tons, manganese content. If net receipts, a negative quantity is shown.

${ }^{4}$ Exclusive of ore consumed directly at iron and steel plants and associated yearend stocks.

${ }^{5}$ Defined as imports - exports + adjustments for Government and industry stock changes, thousand tons, manganese content. Based on estimates of average content for all significant components—including ore, manganese dioxide, ferromanganese, silicomanganese, and manganese metalexcept imports, for which content is reported.

${ }^{6}$ For average metallurgical-grade ore containing $44 \%$ manganese, as reported by CRU Group.

${ }^{7}$ Defined as imports - exports + adjustments for Government and industry stock changes, thousand tons, manganese content.

${ }^{8}$ Includes imports of ferromanganese, manganese ore, silicomanganese, synthetic manganese dioxide, and unwrought manganese metal.

${ }^{9}$ See Appendix B for definitions.

${ }^{10}$ See Appendix $C$ for resource and reserve definitions and information concerning data sources.

${ }^{11}$ For Australia, Joint Ore Reserves Committee-compliant reserves were 76 million tons gross weight. 


\section{MERCURY}

(Data in metric tons of mercury content unless otherwise noted)

Domestic Production and Use: Mercury has not been produced as a principal mineral commodity in the United States since 1992. In 2020, mercury was recovered as a byproduct from processing gold-silver ore at several mines in Nevada; however, production data were not reported. Secondary, or recycled, mercury was recovered from batteries, compact and traditional fluorescent lamps, dental amalgam, medical devices, and thermostats, as well as mercury-contaminated soils. The U.S. Environmental Protection Agency (EPA) reported that domestic production of mercury was 33 tons in 2018 (the last year for which data were available), and about 70 tons of mercury was stored by manufactures or producers. The reported domestic consumption of mercury and mercury in compounds in products was 9 tons. The leading domestic end uses of mercury were dental amalgam (47\%); relays, sensors, switches, and valves (45\%); formulated products (buffers, catalysts, fixatives, and vaccination uses) (9\%); bulbs, lamps, and lighting (8\%); and batteries (1\%). A large quantity of mercury (about 245 tons) is used in manufacturing processes such as catalysts or as a cathode in the chlorine-caustic soda (chloralkali) process. Almost all of the mercury is reused in the process. The leading manufacturing processes that use mercury are mercury-cell chloralkali plants. In 2020, only one mercury-cell chloralkali plant operated in the United States. Until December 31, 2012, domestic- and foreign-sourced mercury was refined and then exported for global use, primarily for small-scale gold mining in many parts of the world. Beginning January 1, 2013, export of elemental mercury from the United States was banned, with some exceptions, under the Mercury Export Ban Act of 2008. Effective January 1, 2020, exports of five mercury compounds were added to that ban.

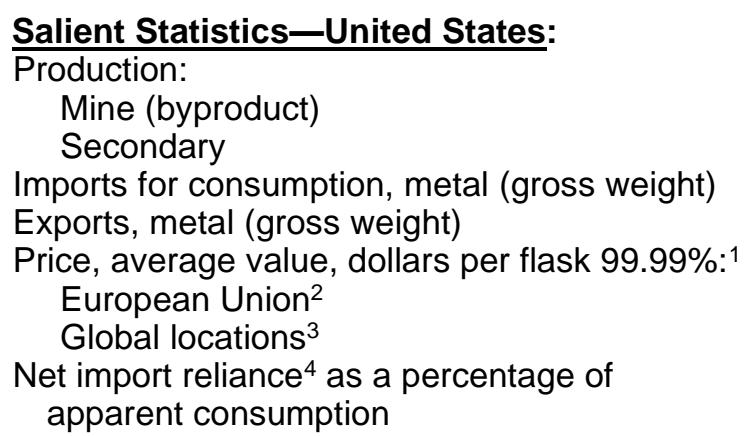

$\begin{array}{rrrrr}\mathbf{2 0 1 6} & \underline{\mathbf{2 0 1 7}} & \underline{\mathbf{2 0 1 8}} & \underline{\mathbf{2 0 1 9}} & \underline{\underline{\mathbf{2 0 2 0}}} \\ \text { NA } & \text { NA } & \text { NA } & \text { NA } & \text { NA } \\ \text { NA } & \text { NA } & \text { NA } & \text { NA } & \text { NA } \\ 24 & 20 & 6 & 9 & - \\ - & - & - & - & - \\ 1,402 & 1,041 & 1,100 & \text { NA } & \text { NA } \\ 1,275 & 1,273 & 2,709 & 2,550 & \text { NA } \\ \text { NA } & \text { NA } & \text { NA } & \text { NA } & -\end{array}$

Recycling: In 2020, eight facilities operated by six companies in the United States accounted for the majority of secondary mercury produced and were authorized by the U.S. Department of Energy (DOE) to temporarily store mercury until the DOE's long-term facility opens. Mercury-containing automobile convenience switches, barometers, compact and traditional fluorescent bulbs, computers, dental amalgam, medical devices, and thermostats were collected by smaller companies and shipped to the refining companies for retorting to reclaim the mercury. In addition, many collection companies recovered mercury when retorting was not required. With the rapid phasing out of compact and traditional fluorescent lighting for light-emitting-diode (LED) lighting, an increased quantity of mercury was being recycled.

Import Sources (2016-19): Canada, 53\%; France, 29\%; China, 10\%; Switzerland, 7\%; and other, 1\%.

Tariff: Item

Mercury

Amalgams
Number

2805.40 .0000

2843.90.0000

\section{Normal Trade Relations} 12-31-20

$1.7 \%$ ad val.

$3.7 \%$ ad val.

Depletion Allowance: $22 \%$ (domestic), 14\% (foreign).

Government Stockpile: ${ }^{5}$ The Defense Logistics Agency Strategic Materials held and managed an inventory of 4,437 tons of mercury in storage at the Hawthorne Army Depot in Hawthorne, NV. On December 3, 2019, the DOE selected a site near Andrews, TX, to store up to 6,800 tons of mercury. Sales of mercury from the stockpiles remained suspended.

\section{Material}

Mercury
FY 2020

$\begin{array}{ccc}\begin{array}{c}\text { Inventory } \\ \text { as of 9-30-20 }\end{array} & \begin{array}{c}\text { Potential } \\ \text { acquisitions }\end{array} & \begin{array}{c}\text { Potential } \\ \text { disposals }\end{array} \\ 4,437 & - & -\end{array}$

FY 2021

$\begin{array}{cc}\begin{array}{c}\text { Potential } \\ \text { acquisitions }\end{array} & \begin{array}{c}\text { Potential } \\ \text { disposals }\end{array}\end{array}$


Events, Trends, and Issues: Owing to mercury toxicity and concerns for the environment and human health, overall mercury use has declined in the United States and worldwide. Mercury continues to be released to the environment from numerous sources, including mercury-containing car switches when automobiles (those produced prior to 2003) are scrapped without recovering the switches for recycling, coal-fired powerplant emissions, incineration of mercurycontaining medical devices, and naturally occurring sources. Mercury is no longer used in most batteries and paints manufactured in the United States. Some button-type batteries, cleansers, fireworks, folk medicines, grandfather clocks, pesticides, and skin-lightening creams and soaps may still contain mercury. Mercury compounds were used as catalysts in the coal-based manufacture of vinyl chloride monomer in China. In some parts of the world, mercury was used in the recovery of gold in artisanal and small-scale mining operations. Conversion to nonmercury technology for chloralkali production and the ultimate closure of the world's mercury-cell chloralkali plants may release a large quantity of mercury to the global market for recycling, sale, or, owing to export bans in Europe and the United States, long-term storage.

Byproduct mercury production is expected to continue from large-scale domestic and foreign gold-silver mining and processing, as is secondary production of mercury from an ever-diminishing supply of mercury-containing products. Domestic mercury consumption will continue to decline owing to increased use of LED lighting and consequent reduced use of conventional fluorescent tubes and compact fluorescent bulbs and continued substitution of nonmercury-containing products in control, dental, and measuring applications.

\section{World Mine Production and Reserves:}

$\begin{array}{lrr}\text { United States } & \frac{\mathbf{2 0 1 9}}{\mathrm{NA}} & \frac{\mathbf{2 0 2 0}}{\mathrm{NA}} \\ \text { Argentina } & 50 & 50 \\ \text { China } & 3,600 & 3,400 \\ \text { Kyrgyzstan } & 15 & 15 \\ \text { Mexico (net exports) } & 63 & 60 \\ \text { Norway } & 20 & 20 \\ \text { Peru (exports) } & 40 & 40 \\ \text { Tajikistan } & 100 & 100 \\ \text { Other countries } & 12 & 20 \\ \quad \text { World total (rounded) } & 3,900 & 3,700\end{array}$

\section{Reserves $^{6}$}

Quantitative estimates of reserves are not available. China, Kyrgyzstan, and Peru are thought to have the largest reserves.

World Resources: ${ }^{6}$ China, Kyrgyzstan, Mexico, Peru, Russia, Slovenia, Spain, and Ukraine have most of the world's estimated 600,000 tons of mercury resources. Mexico reclaims mercury from Spanish colonial silver-mining waste. In Spain, once a leading producer of mercury, mining at its centuries-old Almaden Mine stopped in 2003. In the United States, mercury occurrences are in Alaska, Arkansas, California, Nevada, and Texas. The declining consumption of mercury, except for small-scale gold mining, indicates that these resources are sufficient for centuries of use.

Substitutes: Ceramic composites substitute for the dark-gray mercury-containing dental amalgam. "Galinstan," an alloy of gallium, indium, and tin, replaces the mercury used in traditional mercury thermometers, and digital thermometers have replaced traditional thermometers. At chloralkali plants around the world, mercury-cell technology is being replaced by newer diaphragm and membrane-cell technology. LEDs that contain indium substitute for mercury-containing fluorescent lamps. Lithium, nickel-cadmium, and zinc-air batteries replace mercury-zinc batteries in the United States; indium compounds substitute for mercury in alkaline batteries; and organic compounds are being used instead of mercury fungicides in latex paint.

\footnotetext{
eEstimated. NA Not available. - Zero.

${ }^{1}$ Some international data and dealer prices are reported in flasks. One metric ton $(1,000$ kilograms $)=29.0082 \mathrm{flasks}$, and $1 \mathrm{flask}=76$ pounds, or 34.47 kilograms, or 0.03447 ton.

${ }^{2}$ Average annual price of minimum 99.99\% mercury. Source: Argus Media group_Argus Metals International. Price discontinued on May $1,2018$.

${ }^{3}$ Average midpoint of free market $99.99 \%$ mercury in warehouse, global locations, price published by Metal Bulletin. Price discontinued on December 1, 2019.

${ }^{4}$ Defined as imports - exports + adjustments for Government stock changes.

${ }^{5}$ See Appendix $B$ for definitions.

${ }^{6}$ See Appendix $C$ for resource and reserve definitions and information concerning data source.
} 


\section{MICA (NATURAL)}

(Data in metric tons unless otherwise noted)

Domestic Production and Use: Scrap and flake mica production, excluding low-quality sericite, was estimated to be 35,000 tons valued at \$4.3 million. Mica was mined in Georgia, North Carolina, and South Dakota. Scrap mica was recovered principally from mica and sericite schist and as a byproduct from feldspar, industrial sand beneficiation, and kaolin. Eight companies produced an estimated 57,000 tons of ground mica valued at about \$22 million from domestic and imported scrap and flake mica. Most of the domestic production was processed into small-particle-size mica by either wet or dry grinding. Primary uses were joint compound, oil-well-drilling additives, paint, roofing, and rubber products.

A minor amount of sheet mica has been produced as incidental production from feldspar mining in North Carolina in the past several years. Data on sheet mica production were not available in 2020. The domestic consuming industry was dependent on imports to meet demand for sheet mica. Most sheet mica was fabricated into parts for electrical and electronic equipment.

\section{Salient Statistics-United States:}

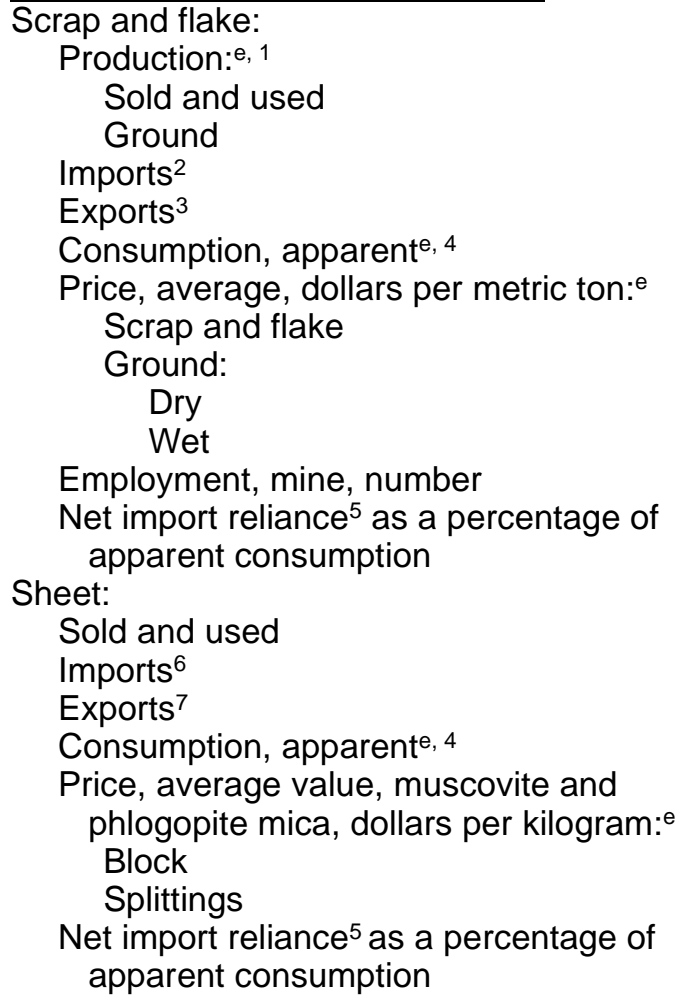

Recycling: None.

Import Sources (2016-19): Scrap and flake: Canada, 44\%; China, 32\%; India, 9\%; Finland, 4\%; and other, 11\%. Sheet: China, 56\%; Brazil, 16\%; Belgium, 6\%; India, 4\%; and other, 18\%.

\section{Tariff: Item}

Split block mica

Mica splittings

Unworked, other

Mica powder

Mica waste

Plates, sheets, and strips of agglomerated or reconstituted mica

Worked mica and articles of mica, other
Number

2525.10.0010

2525.10.0020

2525.10.0050

2525.20.0000

2525.30.0000

6814.10 .0000

6814.90 .0000

\section{Normal Trade Relations 12-31-20 \\ Free. \\ Free. \\ Free. \\ Free. \\ Free.}

$2.7 \%$ ad val. $2.6 \%$ ad val. 
Depletion Allowance: 22\% (domestic), 14\% (foreign).

\section{Government Stockpile: None.}

Events, Trends, and Issues: Domestic production of scrap and flake mica was estimated to have decreased by $13 \%$ in 2020. Apparent consumption of scrap and flake mica decreased by $17 \%$. Apparent consumption of sheet mica was estimated to have decreased by $6 \%$ in 2020 . The economic effects of the COVID-19 pandemic had a significant impact on some of industries that use mica, primarily oil-well-drilling fluid and plastics for automobiles. No environmental concerns are associated with the manufacture and use of mica products. Supplies of sheet mica for United States consumption were expected to continue to be from imports, primarily from Belgium, Brazil, China, and India.

World Mine Production and Reserves: World production of sheet mica has remained steady; however, reliable production numbers for some countries that may influence that world total were unavailable. Reserves for the Republic of Korea were revised based on official Government data.

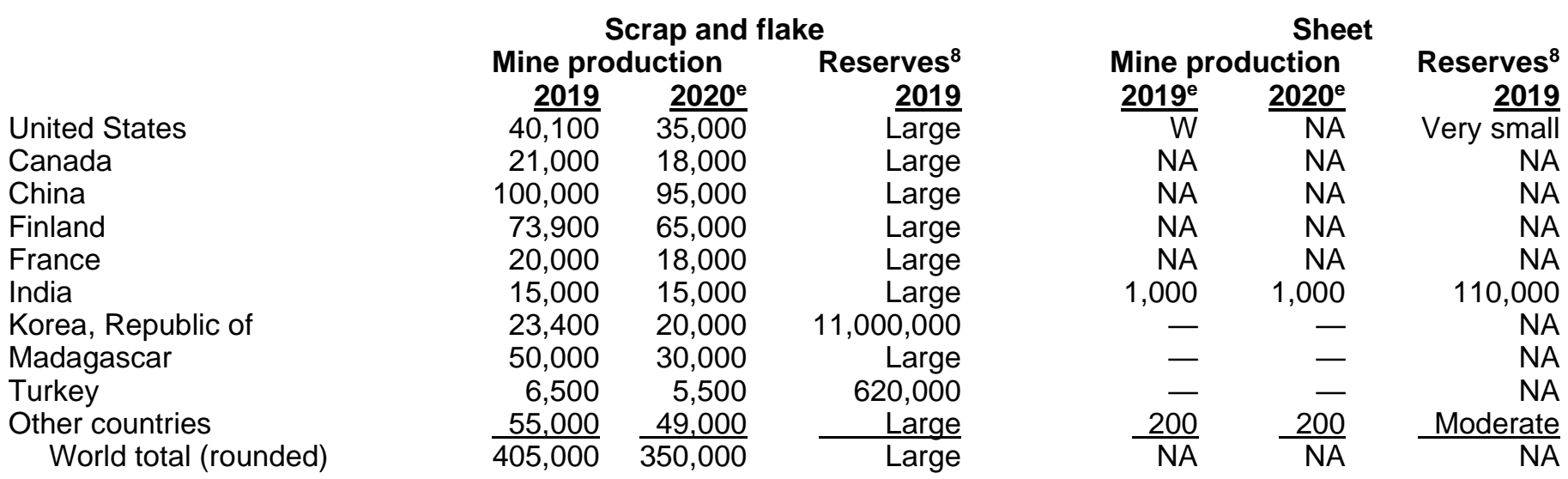

World Resources: ${ }^{8}$ Resources of scrap and flake mica are available in clay deposits, granite, pegmatite, and schist, and are considered more than adequate to meet anticipated world demand in the foreseeable future. World resources of sheet mica have not been formally evaluated because of the sporadic occurrence of this material. Large deposits of mica-bearing rock are known to exist in countries such as Brazil, India, and Madagascar. Limited resources of sheet mica are available in the United States. Domestic resources are not economical because of the high cost of the hand labor required to mine and process sheet mica from pegmatites.

Substitutes: Some lightweight aggregates, such as diatomite, perlite, and vermiculite, may be substituted for ground mica when used as filler. Ground synthetic fluorophlogopite, a fluorine-rich mica, may replace natural ground mica for uses that require the thermal and electrical properties of mica. Many materials can be substituted for mica in numerous electrical, electronic, and insulation uses. Substitutes include acrylic, cellulose acetate, fiberglass, fishpaper, nylatron, nylon, phenolics, polycarbonate, polyester, styrene, polyvinyl chloride, and vulcanized fiber. Mica paper made from scrap mica can be substituted for sheet mica in electrical and insulation applications.

\footnotetext{
EEstimated. NA Not available. W Withheld to avoid disclosing company proprietary data. — Zero.

${ }^{1}$ Excludes low-quality sericite used primarily for brick manufacturing.

${ }^{2}$ Includes data for the following Harmonized Tariff Schedule of the United States codes: 2525.10.0050, <\$6.00/kg; 2525.20.0000; and

2525.30.0000.

${ }^{3}$ Includes data for the following Schedule B codes: 2525.10.0000, <\$6.00/kg; 2525.20.0000; and 2525.30.0000.

${ }^{4}$ Defined as sold or used by producing companies + imports - exports.

${ }^{5}$ Defined as imports - exports.

${ }^{6}$ Includes data for the following Harmonized Tariff Schedule of the United States codes: 2525.10.0010; 2525.10.0020; 2525.10.0050, >\$6.00/kg; 6814.10.0000; and 6814.90.0000.

${ }^{7}$ Includes data for the following Schedule B codes: $2525.10 .0000,>\$ 6.00 / \mathrm{kg} ; 6814.10 .0000$; and 6814.90.0000.

${ }^{8}$ See Appendix $\mathrm{C}$ for resource and reserve definitions and information concerning data sources.
} 


\section{MOLYBDENUM}

(Data in metric tons of molybdenum content unless otherwise noted)

Domestic Production and Use: U.S. mine production of molybdenum in 2020 increased by $13 \%$ to 49,000 tons compared with the previous year. Molybdenum ore was produced as a primary product at two mines - both in Colorado-whereas seven copper mines (four in Arizona and one each in Montana, Nevada, and Utah) recovered molybdenite concentrate as a byproduct. Three roasting plants converted molybdenite concentrate to molybdic oxide, from which intermediate products, such as ferromolybdenum, metal powder, and various chemicals, were produced. Metallurgical applications accounted for more than $88 \%$ of the total molybdenum consumed.

\begin{tabular}{|c|c|c|c|c|c|}
\hline Salient Statistics-United States: & $\underline{2016}$ & $\underline{2017}$ & $\underline{2018}$ & $\underline{2019}$ & $\underline{2020^{e}}$ \\
\hline$\overline{\text { Production, mine }}$ & 36,200 & $40, \overline{700}$ & $4 \overline{1,400}$ & $4 \overline{3,600}$ & $4 \overline{9,000}$ \\
\hline Imports for consumption & 22,800 & 36,000 & 37,500 & 34,200 & 26,000 \\
\hline Exports & 31,200 & 43,200 & 48,400 & 67,200 & 62,000 \\
\hline \multicolumn{6}{|l|}{ Consumption: } \\
\hline Reported 1 & 15,800 & 17,400 & 16,700 & 16,500 & 14,000 \\
\hline Apparent ${ }^{2}$ & 27,900 & 34,100 & 31,300 & 10,500 & 13,000 \\
\hline Price, average value, dollars per kilogram ${ }^{3}$ & 14.40 & 18.06 & 27.04 & 26.50 & 20 \\
\hline Stocks, consumer materials & 1,910 & 2,010 & 1,940 & 1,980 & 2,100 \\
\hline Employment, mine and plant, number & 920 & 940 & 940 & 950 & 950 \\
\hline $\begin{array}{l}\text { Net import reliance }{ }^{4} \text { as a percentage of } \\
\text { apparent consumption }\end{array}$ & $E$ & $E$ & $\mathrm{E}$ & $E$ & $\mathrm{E}$ \\
\hline
\end{tabular}

Recycling: Molybdenum is recycled as a component of catalysts, ferrous scrap, and superalloy scrap. Ferrous scrap consists of revert, new, and old scrap. Revert scrap refers to remnants manufactured in the steelmaking process. New scrap is generated by steel mill customers and recycled by scrap collectors and processors. Old scrap is largely molybdenum-bearing alloys recycled after serving their useful life. The amount of molybdenum recycled as part of new and old steel and other scrap may be as much as 30\% of the apparent supply of molybdenum. There are no processes for the separate recovery and refining of secondary molybdenum from its alloys. Molybdenum is not recovered separately from recycled steel and superalloys, but the molybdenum content of the recycled alloys is significant, and the molybdenum content is reused. Recycling of molybdenum-bearing scrap will continue to be dependent on the markets for the principal alloy metals in which molybdenum is contained, such as iron, nickel, and chromium.

Import Sources (2016-19): Ferromolybdenum: Chile, 54\%; the Republic of Korea, 38\%; Canada, 4\%; and other, 4\%. Molybdenum ores and concentrates: Peru, 57\%; Chile, 22\%; Canada, 12\%; Mexico, 8\%; and other, $1 \%$.

\section{Tariff: Item}

Molybdenum ore and concentrates, roasted

Molybdenum ore and concentrates, other

Molybdenum chemicals:

Molybdenum oxides and hydroxides

Molybdates of ammonium

Molybdates, all others

Molybdenum pigments, molybdenum orange

Ferroalloys, ferromolybdenum

Molybdenum metals:

Powders

Unwrought

Wrought bars and rods

Wrought plates, sheets, strips, etc.

Wire

Waste and scrap

Other

\section{Number}

2613.10.0000

2613.90.0000

2825.70 .0000

2841.70 .1000

2841.70 .5000

3206.20 .0020

7202.70 .0000

8102.10 .0000

8102.94 .0000

8102.95 .3000

8102.95 .6000

8102.96 .0000

8102.97 .0000

8102.99 .0000
Normal Trade Relations 12-31-20

$12.8 \phi / \mathrm{kg}+1.8 \%$ ad val. $17.8 \mathrm{c} / \mathrm{kg}$.

$3.2 \%$ ad val.

$4.3 \%$ ad val.

$3.7 \%$ ad val.

$3.7 \%$ ad val.

$4.5 \%$ ad val.

$9.1 \mathrm{c} / \mathrm{kg}+1.2 \%$ ad val.

$13.9 \% / \mathrm{kg}+1.9 \%$ ad val.

$6.6 \%$ ad val.

$6.6 \%$ ad val.

$4.4 \%$ ad val.

Free.

$3.7 \%$ ad val.

Depletion Allowance: 22\% (domestic), 14\% (foreign).

Government Stockpile: None. 
Events, Trends, and Issues: In 2020, the estimated average molybdic oxide price decreased by $25 \%$ compared with that of 2019, and U.S. estimated mine output of molybdenum increased by $13 \%$ from that of 2019 . The increase in production was mainly the result of one byproduct mine in Utah increasing its production by more than $60 \%$. This increase in production in Utah offset the production delays caused by the global COVID-19 pandemic at other molybdenum producers. Byproduct molybdenum production continued at the Bagdad, Morenci, Pinto Valley, and Sierrita Mines in Arizona; the Continental Pit Mine in Montana; the Robinson Mine in Nevada; and the Bingham Canyon Mine in Utah. Primary molybdenum production continued at the Climax and Henderson Mines in Colorado. The Thompson Creek Mine in Idaho continued to be on care-and-maintenance status in 2020.

Estimated U.S. imports for consumption decreased by $24 \%$ compared with those of 2019. U.S. exports decreased by $8 \%$ from those of 2019. Apparent consumption increased by 26\% compared with that of 2019.

Global molybdenum production in 2020 increased slightly compared with 2019. In descending order of production, China, Chile, the United States, Peru, and Mexico provided more than $90 \%$ of total global production.

World Mine Production and Reserves: The reserves estimates for Canada, Mongolia, Peru, and Turkey were revised based on new information from company and Government reports.

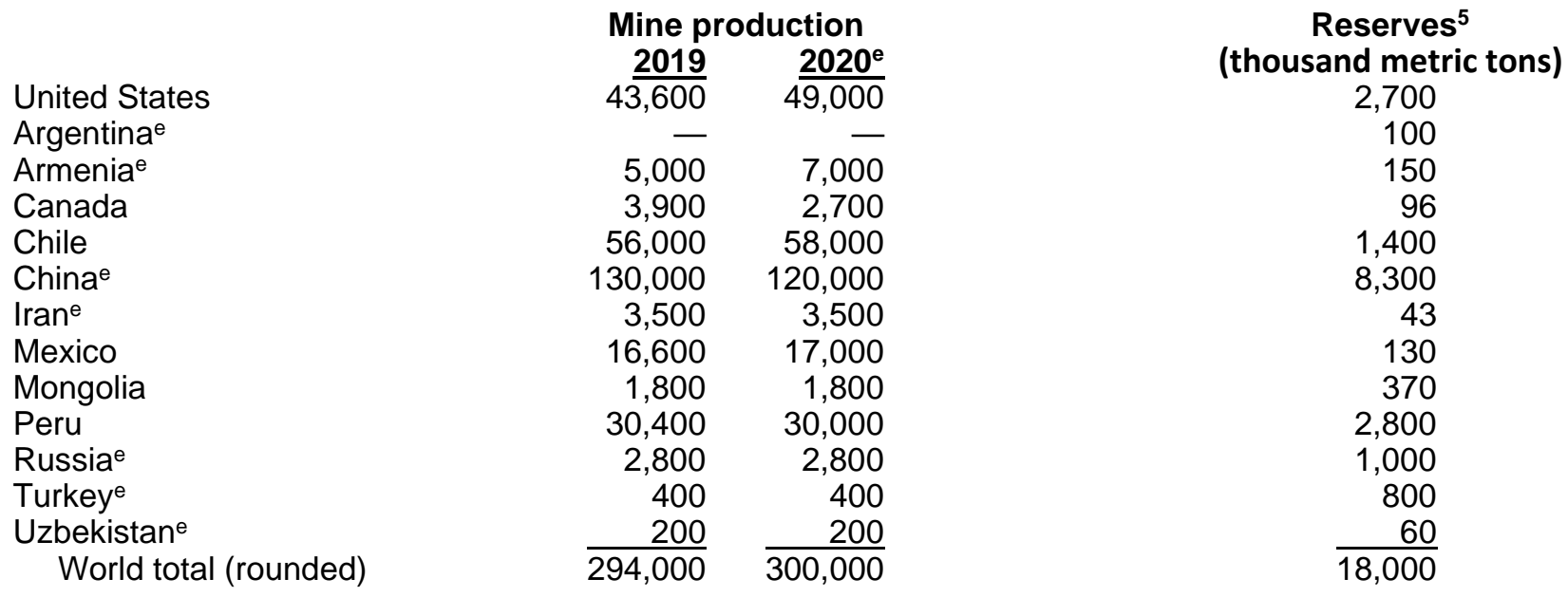

World Resources: ${ }^{5}$ Identified resources of molybdenum in the United States are about 5.4 million tons, and in the rest of the world, about 20 million tons. Molybdenum occurs as the principal metal sulfide in large low-grade porphyry molybdenum deposits and as an associated metal sulfide in low-grade porphyry copper deposits. Resources of molybdenum are adequate to supply world needs for the foreseeable future.

Substitutes: There is little substitution for molybdenum in its major application in steels and cast irons. In fact, because of the availability and versatility of molybdenum, industry has sought to develop new materials that benefit from its alloying properties. Potential substitutes include boron, chromium, niobium (columbium), and vanadium in alloy steels; tungsten in tool steels; graphite, tantalum, and tungsten for refractory materials in high-temperature electric furnaces; and cadmium-red, chrome-orange, and organic-orange pigments for molybdenum orange.

\footnotetext{
eEstimated. E Net exporter. - Zero.

${ }^{1}$ Reported consumption of primary molybdenum products.

${ }^{2}$ Defined as production + imports - exports + adjustments for concentrate, consumer, and product producer stock changes.

${ }^{3}$ Time-weighted average price per kilogram of molybdenum contained in technical-grade molybdic oxide, as reported by CRU Group.

${ }^{4}$ Defined as imports - exports + adjustments for industry stock changes.

${ }^{5}$ See Appendix $\mathrm{C}$ for resource and reserve definitions and information concerning data sources.
} 


\section{NICKEL}

(Data in metric tons of nickel content unless otherwise noted)

Domestic Production and Use: In 2020, the underground Eagle Mine in Michigan produced approximately 16,000 tons of nickel in concentrate, which was exported to smelters in Canada and overseas. A company in Missouri recovered metals, including nickel, from mine tailings as part of the Superfund Redevelopment Initiative. Nickel in crystalline sulfate was produced as a byproduct of smelting and refining platinum-group-metal ores mined in Montana.

In the United States, the leading uses for primary nickel are stainless and alloy steels, nonferrous alloys and superalloys, electroplating, and other uses including catalysts and chemicals. Stainless and alloy steel and nickelcontaining alloys typically account for more than $85 \%$ of domestic consumption.

\begin{tabular}{|c|c|c|c|c|c|}
\hline Salient Statistics_-United States: & $\underline{2016}$ & 2017 & $\underline{2018}$ & $\underline{2019}$ & $\underline{2020^{\circ}}$ \\
\hline \multicolumn{6}{|l|}{ Production: } \\
\hline Mine & 24,100 & 22,100 & 17,600 & 13,500 & 16,000 \\
\hline Refinery, byproduct & W & W & W & W & W \\
\hline \multicolumn{6}{|l|}{ Imports: } \\
\hline Ores and concentrates & $(1)$ & 64 & 3 & 4 & 120 \\
\hline Primary & 111,000 & 150,000 & 144,000 & 119,000 & 110,000 \\
\hline Secondary & 32,300 & 38,100 & 45,100 & 37,700 & 32,000 \\
\hline \multicolumn{6}{|l|}{ Exports: } \\
\hline Ores and concentrates & 22,400 & 20,000 & 18,000 & 14,700 & 13,000 \\
\hline Primary & 10,300 & 11,000 & 9,780 & 12,800 & 11,000 \\
\hline Secondary & 63,700 & 51,500 & 59,400 & 51,100 & 34,000 \\
\hline \multicolumn{6}{|l|}{ Consumption: } \\
\hline Reported, primary metal & 97,800 & 105,000 & 107,000 & 105,000 & 85,000 \\
\hline Reported, secondary, purchased scrap & 131,000 & 133,000 & 123,000 & 111,000 & 100,000 \\
\hline Apparent, primary metal ${ }^{2}$ & 104,000 & 140,000 & 136,000 & 106,000 & 99,000 \\
\hline Apparent, total ${ }^{3}$ & 235,000 & 273,000 & 259,000 & 217,000 & 200,000 \\
\hline \multicolumn{6}{|c|}{ Price, average annual, London Metal Exchange (LME): } \\
\hline Cash, dollars per metric ton & 9,594 & 10,403 & 13,114 & 13,903 & 14,000 \\
\hline Cash, dollars per pound & 4.352 & 4.719 & 5.948 & 6.306 & 6.40 \\
\hline \multicolumn{6}{|l|}{ Stocks, yearend: } \\
\hline Consumer & 15,100 & 14,600 & 16,300 & 13,400 & 13,000 \\
\hline LME U.S. warehouses & 5,232 & 3,780 & 2,268 & 1,974 & 2,000 \\
\hline $\begin{array}{l}\text { Net import reliance }{ }^{4} \text { as a percentage of to } \\
\text { apparent consumption }\end{array}$ & 44 & 51 & 52 & 49 & 50 \\
\hline
\end{tabular}

Recycling: Nickel in alloyed form was recovered from the processing of nickel-containing waste, including flue dust, grinding swarf, mill scale, and shot blast generated during the manufacturing of stainless steel; filter cakes, plating solutions, spent catalysts, spent pickle liquor, sludges, and all types of spent nickel-containing batteries. Nickelcontaining alloys and stainless-steel scrap were also melted and used to produce new alloys and stainless steel. The U.S. Department of Energy's ReCell Center continued to investigate methods to more effectively recover raw materials, including nickel, from recycled batteries. In 2020, recycled nickel in all forms accounted for approximately $50 \%$ of apparent consumption.

Import Sources (2016-19): Nickel contained in ferronickel, metal, oxides, and salt: Canada, 42\%; Norway, 10\%; Finland, 9\%; Russia, 8\%; and other, 31\%. Nickel-containing scrap, including nickel content of stainless-steel scrap: Canada, 38\%; Mexico, 27\%; United Kingdom, 9\%; and other, 26\%.

\section{Tariff: Item}

Nickel ores and concentrates, nickel content

Ferronickel

Unwrought nickel, not alloyed

Nickel waste and scrap

Nickel powders

Nickel flakes

\section{Number}

2604.00.0040

7202.60 .0000

7502.10 .0000

7503.00 .0000

7504.00 .0010

7504.00 .0050
Normal Trade Relations

12-31-20

Free.

Free.

Free.

Free.

Free.

Free.

Depletion Allowance: 22\% (domestic), 14\% (foreign). 
Government Stockpile: ${ }^{5}$ The U.S. Department of Energy is holding nickel ingot contaminated by low-level radioactivity at Paducah, KY, and shredded nickel scrap at Oak Ridge, TN. Ongoing decommissioning activities at former nuclear defense sites were expected to generate additional nickel in scrap. See the Lithium chapter for statistics on lithium-nickel-cobalt-aluminum oxide.

\begin{tabular}{|c|c|c|c|c|c|}
\hline \multirow[b]{2}{*}{$\begin{array}{l}\text { Material } \\
\text { Nickel alloys, gross weight }\end{array}$} & \multirow[b]{2}{*}{$\begin{array}{c}\text { Inventory } \\
\text { as of 9-30-20 } \\
609\end{array}$} & \multicolumn{2}{|c|}{ FY 2020} & \multicolumn{2}{|c|}{ FY 2021} \\
\hline & & $\begin{array}{c}\text { Potential } \\
\text { acquisitions }\end{array}$ & $\begin{array}{c}\text { Potential } \\
\text { disposals } \\
272\end{array}$ & $\begin{array}{c}\text { Potential } \\
\text { acquisitions }\end{array}$ & $\begin{array}{l}\text { Potential } \\
\text { disposals }\end{array}$ \\
\hline
\end{tabular}

Events, Trends, and Issues: Domestic reported consumption of primary nickel decreased by an estimated $20 \%$ in 2020 , owing primarily to reduced demand related to the global COVID-19 pandemic. Approximately $70 \%$ of the decrease was attributed to reduced consumption of nickel alloys, primarily those used in the aviation and oil and gas sectors. Domestic production of stainless steel and related nickel consumption decreased substantially in the first half of 2020, but most of the leading domestic stainless-steel producers reported relatively robust recovery in the third quarter. Total domestic production of stainless steel in 2020 was estimated to have decreased by approximately $10 \%$.

Globally, nickel mine production was estimated to have decreased by $5 \%$. Although stainless-steel production in most leading producing countries and (or) localities decreased, these were mostly offset by a rapid recovery in China's production of nickel-bearing stainless-steel grades after the first quarter, and the continued rampup of nickel pig iron and stainless-steel projects in Indonesia.

World Mine Production and Reserves: Reserves for Brazil, Canada, and the United States were revised based on new information from company and (or) Government reports

\begin{tabular}{lrrr} 
& \multicolumn{2}{c}{ Mine production } & Reserves $^{\mathbf{6}}$ \\
United States & $\mathbf{2 0 1 9}$ & $\underline{\mathbf{2 0 2 0}}$ & 100,000 \\
Australia & 13,500 & 16,000 & $720,000,000$ \\
Brazil & 159,000 & 170,000 & $16,000,000$ \\
Canada & 60,600 & 73,000 & $2,800,000$ \\
China & 181,000 & 150,000 & $2,800,000$ \\
Cuba & 120,000 & 120,000 & $5,500,000$ \\
Dominican Republic & 49,200 & 49,000 & $\mathrm{NA}$ \\
Indonesia & 56,900 & 47,000 & $21,000,000$ \\
New Caledonia & 853,000 & 760,000 & $\mathrm{NA}$ \\
Philippines & 208,000 & 200,000 & $4,800,000$ \\
Russia & 323,000 & 320,000 & $6,900,000$ \\
Other countries & 279,000 & 280,000 & $14,000,000$ \\
$\quad$ World total (rounded) & 310,000 & $\underline{290,000}$ & $94,000,000$
\end{tabular}

World Resources: ${ }^{6}$ Identified land-based resources averaging approximately $0.5 \%$ nickel or greater contain at least 300 million tons of nickel, with about $60 \%$ in laterites and $40 \%$ in sulfide deposits. Extensive nickel resources also are found in manganese crusts and nodules on the ocean floor.

Substitutes: Low-nickel, duplex, or ultrahigh-chromium stainless steels have been substituted for austenitic grades in construction. Nickel-free specialty steels are sometimes used in place of stainless steel in the power-generating and petrochemical industries. Titanium alloys can substitute for nickel metal or nickel-base alloys in corrosive chemical environments. Lithium-ion batteries may be used instead of nickel metal hydride batteries in certain applications.

\footnotetext{
eEstimated. NA Not available. W Withheld to avoid disclosing company proprietary data. — Zero.

${ }^{1}$ Less than $1 / 2$ unit.

${ }^{2}$ Defined as primary imports - primary exports + adjustments for industry stock changes, excluding secondary consumer stocks.

${ }^{3}$ Defined as apparent primary metal consumption + reported secondary consumption.

${ }^{4}$ Defined as imports - exports + adjustments for consumer stock changes.

${ }^{5}$ See Appendix $B$ for definitions.

${ }^{6}$ See Appendix $C$ for resource and reserve definitions and information concerning data sources.

${ }^{7}$ For Australia, Joint Ore Reserves Committee-compliant reserves were 6.2 million tons.

${ }^{8}$ Overseas Territory of France.
} 


\section{NIOBIUM (COLUMBIUM)}

(Data in metric tons of niobium content unless otherwise noted)

Domestic Production and Use: Significant U.S. niobium mine production has not been reported since 1959. Companies in the United States produced niobium-containing materials from imported niobium concentrates, oxides, and ferroniobium. Niobium was consumed mostly in the form of ferroniobium by the steel industry and as niobium alloys and metal by the aerospace industry. In 2020, there was a decrease in reported consumption of niobium for high-strength low-alloy steel and superalloy applications. Major end-use distribution of reported niobium consumption was as follows: steels, about $81 \%$, and superalloys, about $19 \%$. The estimated value of niobium consumption was $\$ 280$ million, as measured by the value of imports.

\begin{tabular}{|c|c|c|c|c|c|}
\hline Salient Statistics_-United Sta & 2016 & 2017 & 2018 & 2019 & $2020^{e}$ \\
\hline Production, mine & & & & & \\
\hline Imports for consumption ${ }^{1}$ & 8,250 & 9,330 & 11,200 & 10,100 & 7,500 \\
\hline Exports $^{1}$ & 1,480 & 1,490 & 955 & 668 & 520 \\
\hline Shipments from Government stockpile & - & - & - & - & - \\
\hline \multicolumn{6}{|l|}{ Consumption:e } \\
\hline Apparent $^{2}$ & 6,730 & 7,780 & 10,100 & 9,370 & 6,900 \\
\hline Reported $^{3}$ & 7,370 & 7,640 & 6,850 & 6,880 & 5,500 \\
\hline Price, unit value, ferroniobium, dollars per kilogram ${ }^{4}$ & 21 & 20 & 21 & 23 & 24 \\
\hline $\begin{array}{l}\text { Net import reliance }{ }^{2} \text { as a percentage of } \\
\text { apparent consumption }\end{array}$ & 100 & 100 & 100 & 100 & 100 \\
\hline
\end{tabular}

Recycling: Niobium was recycled when niobium-bearing steels and superalloys were recycled; scrap recovery, specifically for niobium content, was negligible. The amount of niobium recycled is not available, but it may be as much as $20 \%$ of apparent consumption.

Import Sources (2016-19): Niobium and tantalum ores and concentrates: Rwanda, 36\%; Australia, 25\%; Brazil, 14\%; Congo (Kinshasa), 7\%; and other, 18\%. Niobium oxide: Brazil, 54\%; Russia, 19\%; Thailand, 11\%; Estonia, 7\%; and other, 9\%. Ferroniobium and niobium metal: Brazil, 68\%; Canada, 25\%; Germany, 5\%, Russia, 1\%; and other, 1\%. Total imports: Brazil, 66\%; Canada, 22\%; Germany, 4\%; Russia, 3\%; and other, $5 \%$. Of the U.S. niobium material imports (by contained weight), $76 \%$ was ferroniobium, $14 \%$ was niobium metal, $9 \%$ was niobium oxide, and $1 \%$ was niobium ores and concentrates.

\section{Tariff: Item}

Synthetic tantalum-niobium concentrates

Niobium ores and concentrates

Niobium oxide

Ferroniobium:

Less than $0.02 \% \mathrm{P}$ or $\mathrm{S}$, or less than $0.4 \% \mathrm{Si}$

Other

Niobium:

Waste and scrap $^{5}$

Powders and unwrought metal

Niobium, other ${ }^{5}$

\section{Number}

2615.90.3000

2615.90.6030

2825.90.1500

7202.93 .4000

7202.93 .8000

8112.92 .0600

8112.92 .4000

8112.99 .9000

\author{
Normal Trade Relations \\ 12-31-20 \\ Free. \\ Free.
}

$3.7 \%$ ad val.

$5 \%$ ad val.

$5 \%$ ad val.

Free.

$4.9 \%$ ad val.

$4 \%$ ad val.

Depletion Allowance: $22 \%$ (domestic), 14\% (foreign).

\section{Government Stockpile: ${ }^{6}$}

Material

Ferroniobium (gross weight)

Niobium metal (gross weight)

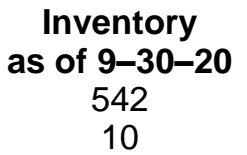

FY 2020

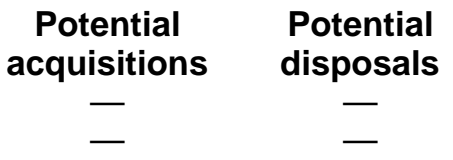

FY 2021

$\begin{array}{cc}\begin{array}{c}\text { Potential } \\ \text { acquisitions }\end{array} & \begin{array}{c}\text { Potential } \\ \text { disposals }\end{array}\end{array}$


Events, Trends, and Issues: Niobium principally was imported in the form of ferroniobium. Based on data through August 2020, U.S. niobium apparent consumption (measured in contained niobium) for 2020 was estimated to be 6,900 tons, a $26 \%$ decrease from that of 2019 . Brazil continued to be the world's leading niobium producer with $91 \%$ of global production, followed by Canada with $8 \%$. Significant production decreases by major aircraft manufacturers reduced niobium consumption for superalloys. Global niobium production and consumption was thought to have decreased in 2020 owing to a decrease in steel production in most countries caused by the COVID-19 pandemic. A significant decrease in ferrovanadium prices in 2020 was also a factor in reduced ferroniobium consumption. In 2019, consumption of ferroniobium, especially in China, had increased in part because it was used as a substitute for ferrovanadium by some producers of high-strength low-alloy steel owing to the supply deficit and high price volatility of ferrovanadium. In the first 9 months of 2020, China's imports of ferrovanadium increased by $700 \%$ while ferroniobium imports decreased by $36 \%$ compared with those in the same period of 2019 , suggesting that some reverse substitution was taking place. Total exports of ferroniobium to all countries from Brazil, the leading producing country, decreased by 35\% during the first 9 months of 2020 compared with exports during the same period of 2019.

One domestic company developing its Elk Creek project in Nebraska announced that it had secured options to purchase all the land needed for the mine and processing facility. The company received its construction air permit from the State of Nebraska in June. The project would be the only niobium mine and primary niobium processing facility in the United States, with construction to begin after financing was obtained.

A leading niobium producer in Brazil was in the process of increasing its annual ferroniobium production capacity by $50 \%$ to 150,000 tons per year (approximately 98,000 tons per year of contained niobium). Originally expected by the end of 2020, the expansion was to be completed in 2021.

World Mine Production and Reserves: ${ }^{7}$ The reserves data for Brazil were revised based on information reported by the Government of Brazil, and reserves data for the United States were revised based on company reports.

\begin{tabular}{lrrr} 
& \multicolumn{2}{c}{ Mine production } & Reserves $^{\mathbf{2}}$ \\
United States & $\underline{\mathbf{2 0 1 9}}$ & $\underline{\mathbf{2 0 2 0 ^ { \mathrm { e } }}}$ & 170,000 \\
Brazil & 88,900 & 71,000 & $16,000,000$ \\
Canada & 6,800 & 6,200 & $1,600,000$ \\
Other countries & 1,250 & $\frac{1,000}{N, 000}$ & NA \\
$\quad$ World total (rounded) & $\underline{97,000}$ & 78,000 & $>17,000,000$
\end{tabular}

World Resources: ${ }^{7}$ World resources of niobium are more than adequate to supply projected needs. Most of the world's identified resources of niobium occur as pyrochlore in carbonatite (igneous rocks that contain more than $50 \%$-by-volume carbonate minerals) deposits and are outside the United States.

Substitutes: The following materials can be substituted for niobium, but a performance loss or higher cost may ensue: ceramic matrix composites, molybdenum, tantalum, and tungsten in high-temperature (superalloy) applications; molybdenum, tantalum, and titanium as alloying elements in stainless and high-strength steels; and molybdenum and vanadium as alloying elements in high-strength low-alloy steels.

\footnotetext{
eEstimated. NA Not available. - Zero.

${ }^{1}$ Imports and exports include the estimated niobium content of ferroniobium, niobium and tantalum ores and concentrates, niobium oxide, and niobium powders and unwrought metal.

${ }^{2}$ Defined as imports - exports + adjustments for Government stock changes.

${ }^{3}$ Only includes ferroniobium and nickel niobium.

${ }^{4}$ Unit value is weighted average unit value of gross weight of U.S. ferroniobium trade. (Trade is imports plus exports.)

${ }^{5}$ This category includes niobium-containing material and other material.

${ }^{6}$ See Appendix B for definitions.

${ }^{7}$ See Appendix $\mathrm{C}$ for resource and reserve definitions and information concerning data sources.
} 
Domestic Production and Use: Ammonia was produced by 16 companies at 35 plants in 16 States in the United States during 2020; 2 additional plants were idle for the entire year. About $60 \%$ of total U.S. ammonia production capacity was in Louisiana, Oklahoma, and Texas because of their large reserves of natural gas, the dominant domestic feedstock for ammonia. In 2020 , U.S. producers operated at about $85 \%$ of rated capacity. The United States was one of the world's leading producers and consumers of ammonia. Urea, ammonium nitrate, nitric acid, ammonium phosphates, and ammonium sulfate were, in descending order of importance, the major derivatives of ammonia produced in the United States.

Approximately $88 \%$ of apparent domestic ammonia consumption was for fertilizer use, including anhydrous ammonia for direct application, urea, ammonium nitrates, ammonium phosphates, and other nitrogen compounds. Ammonia also was used to produce explosives, plastics, synthetic fibers and resins, and numerous other chemical compounds.

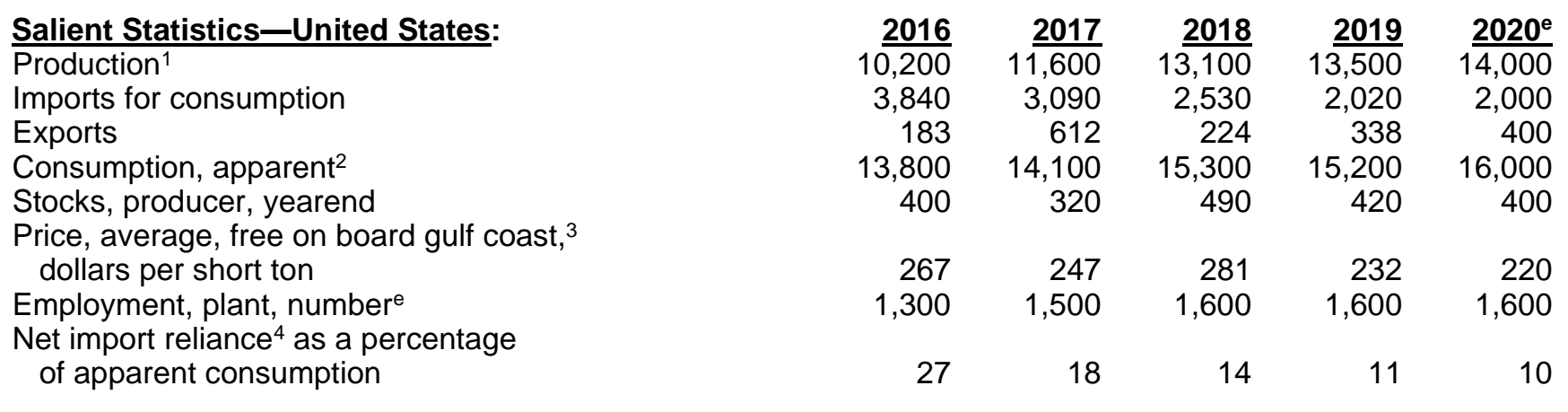

Recycling: None.

Import Sources (2016-19): Trinidad and Tobago, 65\%; Canada 30\%; Venezuela, 3\%; and other, 2\%.

Tariff: Item

Ammonia, anhydrous

Urea

Ammonium sulfate

Ammonium nitrate
Number

2814.10.0000

3102.10 .0000

3102.21 .0000

3102.30 .0000
Normal Trade Relations

12-31-20

Free.

Free.

Free.

Free.

Depletion Allowance: Not applicable.

Government Stockpile: None.

Events, Trends, and Issues: The Henry Hub spot natural gas price ranged between $\$ 1.34$ and $\$ 2.52$ per million British thermal units for most of the year, with an average of about $\$ 2.07$ per million British thermal units. Natural gas prices in 2020 were lower than those in 2019-a result of mild weather that decreased demand for natural gas for heating in early 2020 and reduced manufacturing activity. The U.S. Department of Energy, Energy Information Administration, projected that Henry Hub natural gas spot prices would average higher than $\$ 3.00$ per million British thermal units in 2021.

The weekly average gulf coast ammonia price was $\$ 220$ per short ton at the beginning of 2020 , decreased to $\$ 205$ per short ton in mid-June, and then increased to \$228 per short ton in early October. The average ammonia price for 2020 was estimated to be $\$ 220$ per short ton. In 2020, low natural gas prices resulted in lower ammonia prices.

A long period of stable and low natural gas prices in the United States has made it economical for companies to upgrade existing ammonia plants and construct new nitrogen facilities. The additional capacity has reduced ammonia imports. Expansion in the ammonia industry took place throughout the past 5 years; however, no additional ammonia plants are expected to be commissioned before 2022. 
Global ammonia capacity is expected to increase by a total of $4 \%$ during the next 4 years. Capacity additions are expected in Africa and south Asia; however, ongoing plant closures will decrease capacity in east Asia and Latin America. Demand for ammonia is expected to increase in all regions with the largest increases expected in Africa, central Asia, and Eastern Europe.

Large corn plantings maintain the continued demand for nitrogen fertilizers. According to the U.S. Department of Agriculture, U.S. corn growers planted 37.2 million hectares of corn in the 2020 crop-year (July 1, 2019, through June 30, 2020), which was 3\% greater than the area planted in crop-year 2019. Corn acreage in the $2021 \mathrm{crop}-y e a r$ is expected to increase because of anticipated higher returns for corn compared with those of other crops.

In 2020, the fertilizer industry was considered part of the critical chemical sector by the U.S. Department of Homeland Security. The COVID-19 pandemic stay-at-home orders issued in March 2020 did not affect the fertilizer industry, and U.S. ammonia plants maintained full operations.

\section{World Ammonia Production and Reserves:}

\begin{tabular}{lrr} 
& \multicolumn{2}{c}{ Plant production } \\
United States & $\mathbf{2 0 1 9}$ & $\mathbf{2 0 2 0}$ \\
Algeria & 13,500 & 14,000 \\
Australia & 2,200 & 2,200 \\
Canada & 1,300 & 1,300 \\
China & 3,940 & 3,900 \\
Egypt & 38,000 & 38,000 \\
Germany & 4,200 & 4,500 \\
India & 2,420 & 2,400 \\
Indonesia & 12,200 & 13,000 \\
Iran & 5,000 & 5,000 \\
Netherlands & 3,500 & 3,500 \\
Oman & 2,200 & 2,200 \\
Pakistan & 1,700 & 1,700 \\
Poland & 3,100 & 3,100 \\
Qatar & 2,200 & 2,200 \\
Russia & 3,150 & 3,200 \\
Saudi Arabia & 15,000 & 15,000 \\
Trinidad and Tobago & 4,000 & 4,000 \\
Ukraine & 4,480 & 4,300 \\
Uzbekistan & 1,500 & 1,500 \\
Vietnam & 1,100 & 1,100 \\
Other countries & 1,100 & 1,100 \\
$\quad$ World total (rounded) & 16,400 & 17,000 \\
\hline
\end{tabular}

\section{Reserves $^{5}$}

Available atmospheric nitrogen and sources of natural gas for production of ammonia are considered adequate for all listed countries.

World Resources: ${ }^{5}$ The availability of nitrogen from the atmosphere for fixed nitrogen production is unlimited. Mineralized occurrences of sodium and potassium nitrates, such as those found in the Atacama Desert of Chile, contribute minimally to the global nitrogen supply.

Substitutes: Nitrogen is an essential plant nutrient that has no substitute. No practical substitutes for nitrogen explosives and blasting agents are known.

\footnotetext{
eEstimated.

${ }^{1}$ Source: The Fertilizer Institute; data adjusted by the U.S. Geological Survey.

${ }^{2}$ Defined as production + imports - exports + adjustments for industry stock changes.

${ }^{3}$ Source: Green Markets.

${ }^{4}$ Defined as imports - exports + adjustments for industry stock changes.

${ }^{5}$ See Appendix $\mathrm{C}$ for resource and reserve definitions and information concerning data sources.
} 
(Data in thousand metric tons unless otherwise noted)

Domestic Production and Use: The estimated free on board (f.o.b.) mine value of sold marketable peat production in the conterminous United States was $\$ 13$ million in 2020. Peat was harvested and processed by 30 companies in 12 conterminous States. Florida, Michigan, and Minnesota were the leading producing States, in order of quantity harvested. Reed-sedge peat accounted for approximately $93 \%$ of the total volume produced, followed by sphagnum moss with $3 \%$. Domestic peat applications included earthworm culture medium, golf course construction, mixed fertilizers, mushroom culture, nurseries, packing for flowers and plants, seed inoculants, and vegetable cultivation. In the industrial sector, peat was used as an oil absorbent and as an efficient filtration medium for the removal of waterborne contaminants in mine waste streams, municipal storm drainage, and septic systems.

\section{Salient Statistics_United States:}

Production

Sales by producers

Imports for consumption

Exports

Consumption, apparent ${ }^{1}$

Price, average value, f.o.b. mine, dollars per ton

Stocks, producer, yearend

Employment, mine and plant, number

Net import reliance ${ }^{2}$ as a percentage of apparent consumption

$\begin{array}{rr}\frac{\mathbf{2 0 1 6}}{441} & \underline{\mathbf{2 0 1 7}} \\ 443 & 515 \\ 1,130 & 1,150 \\ 30 & 30 \\ 1,590 & 1,520 \\ 31.97 & 27.55 \\ 125 & 222 \\ 550 & 540\end{array}$

72
Number

2703.00.0000

\begin{tabular}{rrr}
$\mathbf{2 0 1 8}$ & $\underline{\mathbf{2 0 1 9}}$ & $\underline{\mathbf{2 0 2 0}}$ \\
\hline 477 & 456 & 430 \\
545 & 556 & 540 \\
1,200 & 1,160 & 1,400 \\
37 & 46 & 50 \\
1,670 & 1,480 & 1,800 \\
25.88 & 24.59 & 24.60 \\
196 & 280 & 250 \\
540 & 540 & 530 \\
71 & 69 & 76
\end{tabular}

Normal Trade Relations 12-31-20 Free.

Peat

Depletion Allowance: $5 \%$ (domestic and foreign).

Government Stockpile: None.

Events, Trends, and Issues: Peat is an important component of plant-growing media, and the demand for peat generally follows that of horticultural applications. In the United States, the short-term outlook is for production to average about 430,000 tons per year, and imported peat from Canada is expected to continue to account for more than $70 \%$ of domestic consumption. Imports for 2020 were estimated to have increased to 1.4 million tons from 1.2 million tons in 2019, and exports were estimated to have increased to about 50,000 tons from 46,000 tons in 2019. Peat stocks were estimated to have decreased in 2020 owing to a wet peat-harvesting season causing a decrease in peat production in some parts of the country. Based on estimated world production for 2020, the world's leading peat producers were, in descending order of production, Finland, Germany, Belarus, Sweden, Ireland, and Latvia. 
In other parts of the world, concerns about climate change prompted several countries to plan to decrease or eliminate the use of peat, owing to peatland's ability to act as a carbon sink. Ireland's peat production was expected to decrease over the coming years owing to its transition to alternative fuel sources. The country was aiming to have at least $80 \%$ of its fossil fuel sector employment transitioned to the renewable energy sector by 2025 . Ireland planned to stop all peat harvesting by 2028, 2 years ahead of the previously announced schedule. In 2020, Finland continued to work toward its goal of becoming carbon neutral by 2035. To achieve this, peat production will be phased out in favor for other forms of noncarbon energy. Presently, about $40 \%$ of Finland's energy consumption is supplied by peat and other fossil fuels. Several European countries, including Belarus, Ireland, and Sweden, were planning or implementing peatland restoration projects to help combat greenhouse-gas emissions and restore wildlife habitats. These initiatives were expected to decrease peat production across Europe in the future.

World Mine Production and Reserves: Reserves for countries that reported by volume only and had insufficient data for conversion to tons were combined and included with "Other countries." Reserves for Estonia and Latvia were revised based on information from company reports.

\begin{tabular}{|c|c|c|}
\hline \multirow{2}{*}{\multicolumn{2}{|c|}{ Mine production }} & \multirow[t]{2}{*}{ Reserves $^{3}$} \\
\hline & $2019 \quad 2020^{\mathrm{e}}$ & \\
\hline United States & 456 & 150,000 \\
\hline Belarus & 2,600 & $2,600,000$ \\
\hline Canada & 1,300 & 720,000 \\
\hline Estonia & 900 & 59,000 \\
\hline Finland & 11,800 & $6,000,000$ \\
\hline Germany & 4,200 & $(4)$ \\
\hline Ireland & 2,000 & $(4)$ \\
\hline Latvia & 1,900 & 220,000 \\
\hline Lithuania & 500 & 210,000 \\
\hline Poland & 700 & (4) \\
\hline Russia & 800 & $1,000,000$ \\
\hline Sweden & 2,500 & $(4)$ \\
\hline Ukraine & 680 & (4) \\
\hline Other countries ${ }^{\mathrm{e}}$ & 730 & $1,400,000$ \\
\hline World total (rounded) & $\overline{31,900}$ & $\overline{12,000,000}$ \\
\hline
\end{tabular}

World Resources: ${ }^{3}$ Peat is a renewable resource, continuing to accumulate on $60 \%$ of global peatlands. However, the volume of global peatlands has been decreasing at a rate of $0.05 \%$ annually owing to harvesting and land development. Many countries evaluate peat resources based on volume or area because the variations in densities and thickness of peat deposits make it difficult to estimate tonnage. Volume data have been converted using the average bulk density of peat produced in each of those countries. More than $50 \%$ of the U.S. peat resources are located in undisturbed areas of Alaska.

Substitutes: Natural organic materials, such as composted yard waste and coir (coconut fiber), compete with peat in horticultural applications. Shredded paper and straw are used to hold moisture for some grass-seeding applications. The superior water-holding capacity and physiochemical properties of peat limit substitution alternatives in most applications.

\footnotetext{
eEstimated.

${ }^{1}$ Defined as production + imports - exports + adjustments for industry stock changes.

${ }^{2}$ Defined as imports - exports + adjustments for industry stock changes.

${ }^{3}$ See Appendix $\mathrm{C}$ for resource and reserve definitions and information concerning data sources.

${ }^{4}$ Included with "Other countries."
} 


\section{PERLITE}

(Data in thousand metric tons unless otherwise noted)

Domestic Production and Use: In 2020, the quantity of domestic processed crude perlite sold and used was estimated to be 440,000 tons with a value of $\$ 28$ million. Crude ore production was from eight mines operated by six companies in five Western States. New Mexico and Oregon continued to be the leading producing States. Processed crude perlite was expanded at 57 plants in 28 States. Domestic apparent consumption was estimated to be 610,000 tons. The applications for expanded perlite were building construction products, 53\%; fillers, $16 \%$; horticultural aggregate, 16\%; filter aid, $12 \%$; and other, $3 \%$. Other applications included specialty insulation and miscellaneous uses.

Salient Statistics_United States:

Mine production, crude ore

Exports ${ }^{1}$

Consumption, apparent ${ }^{2}$

Price, average value, free on board mine, dollars per ton

Employment, mine and mill, number

Net import reliance ${ }^{3}$ as a percentage of apparent consumption
Sold and used, processed crude perlite

Imports for consumption ${ }^{1}$

$\begin{array}{rrrrr}\frac{\mathbf{2 0 1 6}}{521} & \frac{\mathbf{2 0 1 7}}{570} & \frac{\mathbf{2 0 1 8}}{494} & \frac{\mathbf{2 0 1 9}}{526} & \frac{\mathbf{2 0 2 0}}{520} \\ 437 & 479 & 444 & 416 & 440 \\ 199 & 171 & 204 & 183 & 190 \\ 16 & 18 & 16 & 19 & 22 \\ 620 & 632 & 632 & 580 & 610 \\ 65 & 73 & 72 & 64 & 64 \\ 135 & 139 & 130 & 140 & 140 \\ 30 & 24 & 30 & 28 & 28\end{array}$

Recycling: Not available.

\section{Tariff: Item}

Vermiculite, perlite and chlorites, unexpanded

Depletion Allowance: $10 \%$ (domestic and foreign).

\section{Number}

2530.10 .0000

\author{
Normal Trade Relations \\ 12-31-20 \\ Free.
}

\section{Government Stockpile: None.}

Events, Trends, and Issues: Perlite is a siliceous volcanic glass that expands up to 20 times its original volume when rapidly heated. In horticultural uses, expanded perlite is used to provide moisture retention and aeration without compaction when added to soil. Owing primarily to cost, some commercial greenhouse growers in the United States have recently switched to a wood fiber material over perlite. Perlite, however, remained a preferred soil amendment for segments of greenhouse growers because it does not degrade or compact over lengthy growing times and is inert. Construction applications for expanded perlite are numerous because it is lightweight, fire resistant, and an excellent insulator. Novel and small markets for perlite have increased during the past 10 years; cosmetics, environmental remediation, and personal care products have become increasing markets for perlite. A major producer with operations in Arizona and New Mexico acquired another producer with a mine in Oregon during the year. Project planning progressed at a perlite deposit in Nevada that could be developed as a potential supplier of crude perlite ore for industrial and household applications. 
Domestic perlite mining generally takes place in remote areas, and its environmental impact is not severe. The mineral fines, overburden, and reject ore produced during ore mining and processing are used to reclaim the minedout areas, and, therefore, little waste remains. Airborne dust is captured by baghouses, and virtually no runoff contributes to water pollution.

Despite economic disruptions owing to the global COVID-19 pandemic, the value of total construction put in place in the United States increased by about 4\% during the first 8 months of 2020 compared with that of the same period in 2019 , indicating a similar change in consumption of perlite. Construction products remained the largest domestic market for perlite. Increased interest in home gardening may also correspond to increased consumption of horticultural-grade perlite.

Based on estimated world production for 2020, the world's leading producers were, in descending order of production, China, Greece, Turkey, and the United States, with about 38\%, 21\%, 19\%, and 15\%, respectively, of world production. Although China was the leading producer, most of its perlite production was thought to be consumed internally. Greece and Turkey remained the leading exporters of perlite.

World Perlite Production and Reserves: Reserves for Iran were revised based on industry information.

\begin{tabular}{lrrr} 
& \multicolumn{2}{c}{ Production } & Reserves $^{\mathbf{4}}$ \\
United States & $\frac{\mathbf{2 0 1 9}}{5526}$ & $\frac{\mathbf{2 0 2 0}}{5520}$ & 50,000 \\
Argentina & 19 & 19 & NA \\
China & 1,300 & 1,300 & NA \\
Greece & 719 & 700 & 120,000 \\
Hungary & 71 & 70 & 49,000 \\
Iran & 72 & 70 & 73,000 \\
Mexico & 20 & 20 & NA \\
New Zealand & 17 & 17 & NA \\
Slovakia & 40 & 40 & NA \\
Turkey & 650 & 640 & 57,000 \\
Other countries & 29 & 29 & NA \\
$\quad$ World total (rounded) & 3,460 & 3,400 & NA
\end{tabular}

World Resources: ${ }^{4}$ Perlite occurrences in Arizona, Idaho, Nevada, New Mexico, and Oregon are thought to contain large resources. Significant deposits have been reported in China, Greece, Hungary, and Turkey, and a few other countries. Insufficient information is available to make reliable estimates of resources in many perlite-producing countries.

Substitutes: In construction applications, diatomite, expanded clay and shale, pumice, and slag can be substituted for perlite. For horticultural uses, vermiculite, coco coir, wood pulp, and pumice are alternative soil additives and are sometimes used in conjunction with perlite.

\footnotetext{
eEstimated. NA Not available.

${ }^{1}$ Exports and imports were estimated by the U.S. Geological Survey from U.S. Census Bureau combined data for vermiculite, perlite, and chlorites, unexpanded.

${ }^{2}$ Defined as sold or used processed perlite + imports - exports.

${ }^{3}$ Defined as imports - exports.

${ }^{4}$ See Appendix $\mathrm{C}$ for resource and reserve definitions and information concerning data sources.

${ }^{5}$ Mine production of crude ore.
} 


\section{PHOSPHATE ROCK}

(Data in thousand metric tons unless otherwise noted)

Domestic Production and Use: In 2020, phosphate rock ore was mined by five firms at 10 mines in four States and processed into an estimated 24 million tons of marketable product, valued at $\$ 1.7$ billion, free on board (f.o.b.) mine. Florida and North Carolina accounted for more than $75 \%$ of total domestic output; the remainder was produced in Idaho and Utah. Marketable product refers to beneficiated phosphate rock with phosphorus pentoxide $\left(\mathrm{P}_{2} \mathrm{O}_{5}\right)$ content suitable for phosphoric acid or elemental phosphorus production. More than $95 \%$ of the phosphate rock mined in the United States was used to manufacture wet-process phosphoric acid and superphosphoric acid, which were used as intermediate feedstocks in the manufacture of granular and liquid ammonium phosphate fertilizers and animal feed supplements. Approximately $50 \%$ of the wet-process phosphoric acid produced was exported in the form of upgraded granular diammonium phosphate (DAP) and monoammonium phosphate (MAP) fertilizer, and merchant-grade phosphoric acid. The balance of the phosphate rock mined was for the manufacture of elemental phosphorus, which was used to produce phosphorus compounds for industrial applications, primarily glyphosate herbicide.

\section{Salient Statistics-United States:}

Production, marketable

Sold or used by producers

Imports for consumption

Consumption, apparent ${ }^{1}$

Price, average value, f.o.b. mine,$^{2}$ dollars per ton

Stocks, producer, yearend

Employment, mine and beneficiation plant, number ${ }^{\mathrm{e}}$

Net import reliance ${ }^{3}$ as a percentage of

apparent consumption

Recycling: None.

Import Sources (2016-19): Peru, 85\%; Morocco, 15\%.

Tariff: Item

Number

Natural calcium phosphates:

Unground

Ground

$\begin{array}{rrrrr}\mathbf{2 0 1 6} & \mathbf{2 0 1 7} & \underline{\mathbf{2 0 1 8}} & \mathbf{2 0 1 9} & \underline{\mathbf{2 0 2 0}} \\ 27,100 & 27,900 & 25,800 & 23,300 & 24,000 \\ 26,700 & 26,300 & 23,300 & 23,400 & 24,000 \\ 1,590 & 2,470 & 2,770 & 2,140 & 2,300 \\ 28,200 & 28,800 & 26,000 & 25,500 & 26,000 \\ 76.90 & 73.67 & 70.77 & 67.98 & 70.00 \\ 7,450 & 8,440 & 10,600 & 9,940 & 9,500 \\ 2,000 & 2,000 & 2,000 & 2,000 & 2,000 \\ 4 & 5 & 2 & 11 & 10\end{array}$

Normal Trade Relations 12-31-20

Free.

Free.
2510.10 .0000

2510.20 .0000 $2020^{\mathrm{e}}$

4,000

2,300

70.00

9,500

10

Depletion Allowance: $14 \%$ (domestic and foreign).

Government Stockpile: None.

Events, Trends, and Issues: The COVID-19 pandemic did not have a major effect on the domestic phosphate rock market in 2020. The fertilizer industry and related agricultural businesses were considered essential industries in the United States and most other countries. U.S. consumption and production of phosphate rock were estimated to have increased slightly in 2020, owing to a slight increase in phosphoric acid and combined DAP and MAP production.

The U.S. Department of the Interior, Bureau of Land Management, and the U.S. Department of Agriculture, Forest Service, approved an expansion to the largest phosphate rock mine in Idaho. The expansion will allow the operating company to continue mining at the site for about 10 years, after which it will shift mining to a new mine that is under development in the same area.

A new phosphate rock mine began operation near Spanish Forks, UT, in July 2020. The operating company will market its phosphate rock for direct application to soil for organic farming. Production initially was to be about 5,000 tons per year, eventually increasing to 48,000 tons per year after 5 years. The mine site was developed in the early 1980s by another company, but the project was cancelled after 2 years.

According to industry analysts, the rated capacity of global phosphate rock mines was projected to increase to 261 million tons in 2024 from 238 million tons in 2020, including production of marketable phosphate rock in China of between 80 million and 85 million tons per year, compared with official production statistics of 90 million to 95 million tons per year that included some crude ore production. Most of the increases in production capacity were planned for Africa and the Middle East, where major expansion projects were in progress in Algeria, Egypt, Guinea Bissau, Morocco, Senegal, and Togo. 
PHOSPHATE ROCK

World consumption of $\mathrm{P}_{2} \mathrm{O}_{5}$ contained in fertilizer and industrial uses was projected to increase to 49 million tons in 2024 from 47 million tons in 2020. Asia and South America are projected to be the leading regions of growth. U.S. consumption of contained $\mathrm{P}_{2} \mathrm{O}_{5}$ has remained steady at about 4 million tons per year over the past decade.

World Mine Production and Reserves: Reserves for Australia, Brazil, Israel, and Jordan were revised based on company or Government reports. Reserves for Egypt were revised based on information from an independent research organization.

\begin{tabular}{lrrr} 
& \multicolumn{2}{c}{ Mine production } & Reserves \\
& $\mathbf{2 0 1 9}$ & $\mathbf{2 0 2 \mathbf { S } ^ { \mathbf { e } }}$ & \\
United States & 23,300 & 24,000 & $1,000,000$ \\
Algeria & 1,300 & 1,300 & $2,200,000$ \\
Australia & 2,700 & 2,700 & $51,100,000$ \\
Brazil & 4,700 & 5,500 & $1,600,000$ \\
China & 95,000 & 90,000 & $3,200,000$ \\
Egypt & 5,000 & 5,000 & $2,800,000$ \\
Finland & 995 & 1,000 & $1,000,000$ \\
India & 1,480 & 1,500 & 46,000 \\
Israel & 2,810 & 2,800 & 57,000 \\
Jordan & 9,220 & 9,200 & 800,000 \\
Kazakhstan & 1,500 & 1,500 & 260,000 \\
Mexico & 558 & 600 & 30,000 \\
Morocco and Western Sahara & 35,500 & 37,000 & $50,000,000$ \\
Peru & 4,000 & 4,000 & 210,000 \\
Russia & 13,100 & 13,000 & 600,000 \\
Saudi Arabia & 6,500 & 6,500 & $1,400,000$ \\
Senegal & 3,420 & 3,500 & 50,000 \\
South Africa & 2,100 & 2,100 & $1,400,000$ \\
Syria & 2,000 & 360 & $1,800,000$ \\
Togo & 800 & 800 & 30,000 \\
Tunisia & 4,110 & 4,000 & 100,000 \\
Uzbekistan & 900 & 900 & 100,000 \\
Vietnam & 4,650 & 4,700 & 30,000 \\
Other countries & 1,140 & 1,100 & 840,000 \\
$\quad$ World total (rounded) & 227,000 & 223,000 & $71,000,000$
\end{tabular}

World Resources: ${ }^{4}$ Some world reserves were reported only in terms of ore tonnage and grade. Phosphate rock resources occur principally as sedimentary marine phosphorites. The largest sedimentary deposits are found in northern Africa, China, the Middle East, and the United States. Significant igneous occurrences are found in Brazil, Canada, Finland, Russia, and South Africa. Large phosphate resources have been identified on the continental shelves and on seamounts in the Atlantic Ocean and the Pacific Ocean. World resources of phosphate rock are more than 300 billion tons. There are no imminent shortages of phosphate rock.

Substitutes: There are no substitutes for phosphorus in agriculture.

\footnotetext{
eEstimated.

${ }^{1}$ Defined as phosphate rock sold or used by producers + imports. U.S. producers stopped exporting phosphate rock in 2003.

${ }^{2}$ Marketable phosphate rock, weighted value, all grades.

${ }^{3}$ Defined as imports + adjustments for industry stock changes.

${ }^{4}$ See Appendix $\mathrm{C}$ for resource and reserve definitions and information concerning data sources.

${ }^{5}$ For Australia, Joint Ore Reserves Committee-compliant reserves were 113 million tons.

${ }^{6}$ Production data for large mines only, as reported by the National Bureau of Statistics of China.
} 


\title{
PLATINUM-GROUP METALS
}

\author{
(Palladium, platinum, iridium, osmium, rhodium, and ruthenium) \\ (Data in kilograms of platinum-group-metal content unless otherwise noted)
}

Domestic Production and Use: One company in Montana produced approximately 18,000 kilograms of platinumgroup metals (PGMs) with an estimated value of about $\$ 1.1$ billion. Small quantities of primary PGMs also were recovered as byproducts of copper-nickel mining in Michigan; however, this material was sold to foreign companies for refining. The leading domestic use for PGMs was in catalytic converters to decrease harmful emissions from automobiles. PGMs are also used in catalysts for bulk-chemical production and petroleum refining; dental and medical devices; electronic applications, such as in computer hard disks, hybridized integrated circuits, and multilayer ceramic capacitors; glass manufacturing; investment; jewelry; and laboratory equipment.

\begin{tabular}{|c|c|c|c|c|c|}
\hline$\frac{\text { Salient Statistics-United States: }}{\text { Mine production }-1}$ & $\underline{2016}$ & $\underline{2017}$ & $\underline{2018}$ & $\underline{2019}$ & $\underline{2020^{\mathrm{e}}}$ \\
\hline \multicolumn{6}{|l|}{ Mine production: ${ }^{1}$} \\
\hline Palladium & 13,100 & 14,000 & 14,300 & 14,300 & 14,000 \\
\hline Platinum & 3,890 & 4,000 & 4,160 & 4,150 & 4,000 \\
\hline \multicolumn{6}{|l|}{ Imports for consumption: ${ }^{2}$} \\
\hline Palladium & 80,400 & 86,000 & 92,900 & 84,300 & 78,000 \\
\hline Platinum & 42,300 & 53,200 & 58,500 & 42,300 & 60,000 \\
\hline PGM waste and scrap & 154,000 & 354,000 & 40,700 & 54,300 & 130,000 \\
\hline Iridium & 1,300 & 1,420 & 1,020 & 875 & 1,300 \\
\hline Osmium & 27 & 856 & 25 & $\left({ }^{3}\right)$ & - \\
\hline Rhodium & 10,700 & 11,600 & 14,500 & 15,000 & 20,000 \\
\hline Ruthenium & 8,410 & 14,600 & 17,900 & 11,200 & 11,000 \\
\hline \multicolumn{6}{|l|}{ Exports: 4} \\
\hline Palladium & 17,500 & 52,300 & 52,900 & 55,500 & 36,000 \\
\hline Platinum & 14,000 & 16,700 & 18,900 & 17,400 & 18,000 \\
\hline PGM waste and scrap & 48,100 & 37,200 & 31,700 & 20,800 & 29,000 \\
\hline Rhodium & 794 & 844 & 2,010 & 1,210 & 1,300 \\
\hline Other PGMs & 736 & 939 & 2,500 & 1,330 & 1,400 \\
\hline \multicolumn{6}{|l|}{ Consumption, apparent:5, 6} \\
\hline Palladium & 118,000 & 89,700 & 96,200 & 96,100 & 110,000 \\
\hline Platinum & 43,200 & 51,600 & 53,700 & 37,100 & 53,000 \\
\hline \multicolumn{6}{|l|}{ Price, dollars per troy ounce: ${ }^{7}$} \\
\hline Palladium & 617.39 & 874.30 & $1,036.43$ & $1,544.31$ & $2,100.00$ \\
\hline Platinum & 989.52 & 951.23 & 882.66 & 866.94 & 850.00 \\
\hline Iridium & 586.90 & 908.35 & $1,293.27$ & $1,485.80$ & $1,600.00$ \\
\hline Rhodium & 696.84 & $1,112.59$ & $2,225.30$ & $3,918.78$ & $9,200.00$ \\
\hline Ruthenium & 42.00 & 76.86 & 244.41 & 262.59 & 260.00 \\
\hline Employment, mine, number ${ }^{1}$ & 1,432 & 1,513 & 1,628 & 1,789 & 1,600 \\
\hline \multicolumn{6}{|c|}{$\begin{array}{l}\text { Net import reliance } 6,8 \text { as a percentage of } \\
\text { apparent consumption: }\end{array}$} \\
\hline Palladium & 53 & 38 & 42 & 30 & 40 \\
\hline Platinum & 66 & 71 & 74 & 67 & 79 \\
\hline
\end{tabular}

Recycling: About 102,000 kilograms of palladium and platinum was recovered globally from new and old scrap in 2020, including about 57,000 kilograms recovered from automobile catalytic converters in the United States.

Import Sources (2016-19): Palladium: Russia, 38\%; South Africa, 33\%; Germany, 8\%; United Kingdom, 5\%; and other, 16\%. Platinum: South Africa, 43\%; Germany, 21\%; Italy, 7\%; Switzerland, 6\%; and other, 23\%.

Tariff: All unwrought and semimanufactured forms of PGMs are imported duty free. See footnotes for specific Harmonized Tariff Schedule of the United States codes.

Depletion Allowance: 22\% (domestic), 14\% (foreign). 


\section{Government Stockpile: ${ }^{9}$}

$\begin{array}{lc}\text { Material } & \begin{array}{c}\text { Inventory } \\ \text { as of } \mathbf{9 - 3 0 - 2 0}\end{array} \\ \text { Iridium } & 15 \\ \text { Platinum } & 261\end{array}$
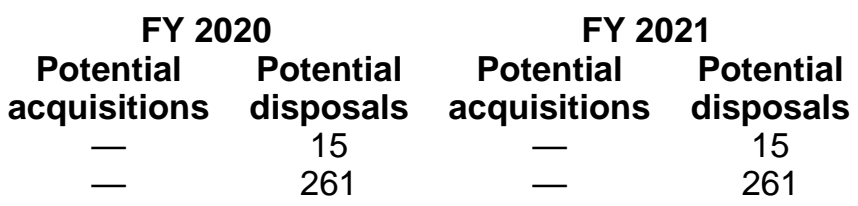

Events, Trends, and Issues: Progress continued at a domestic mine expansion project; full production from the project was expected by late 2021. Production of PGMs in South Africa, the world's leading supplier of mined material, decreased by $11 \%$ compared with that of 2019 owing to temporary lockdowns related to the COVID-19 pandemic as well as increased labor costs, increased costs for electricity, an unreliable supply of electricity, and challenges related to deep-level mining.

The estimated annual average prices of iridium, palladium, rhodium, and ruthenium increased by $5 \%, 38 \%, 136 \%$, and slightly, respectively, compared with those of 2019. The estimated average annual price of platinum decreased slightly compared with that of 2019 , continuing a 5-year trend of declining prices. The price of palladium remained higher than that of platinum in 2020, with palladium prices exceeding a previous high of $\$ 1,977.00$ in December 2019 .

\section{World Mine Production and Reserves:}

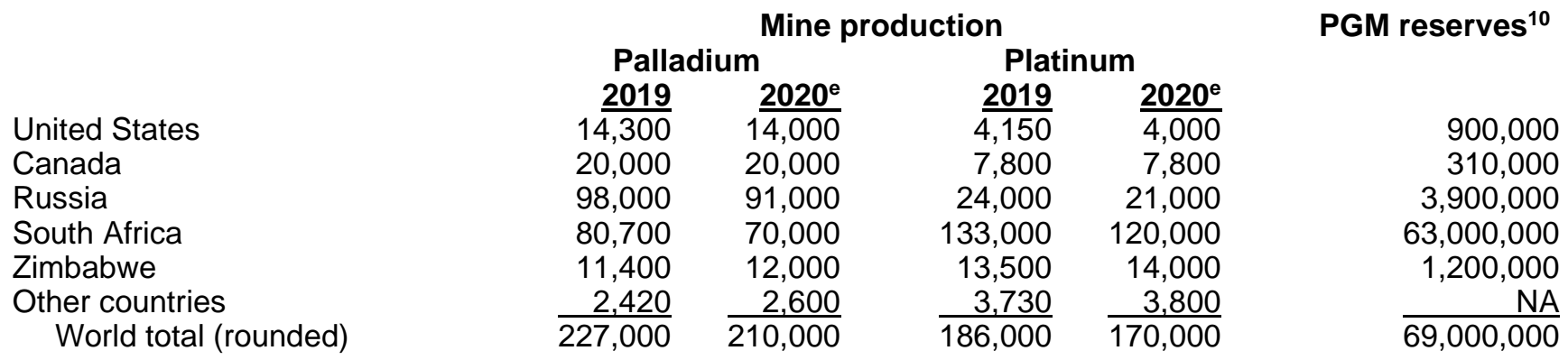

World Resources: ${ }^{10}$ World resources of PGMs are estimated to total more than 100 million kilograms. The largest reserves are in the Bushveld Complex in South Africa.

Substitutes: Palladium has been substituted for platinum in most gasoline-engine catalytic converters because of the historically lower price for palladium relative to that of platinum. About $25 \%$ of palladium can routinely be substituted for platinum in diesel catalytic converters; the proportion can be as much as $50 \%$ in some applications. For some industrial end uses, one PGM can substitute for another, but with losses in efficiency.

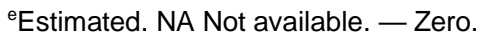

${ }^{1}$ Estimated from published sources.

${ }^{2}$ Includes data for the following Harmonized Tariff Schedule of the United States codes: 7110.11.0010, 7110.11.0020, 7110.11.0050,

$7110.19 .0000,7110.21 .0000,7110.29 .0000,7110.31 .0000,7110.39 .0000,7110.41 .0010,7110.41 .0020,7110.41 .0030,7110.49 .0010$,

7112.92.0000, and 7118.90.0020.

${ }^{3}$ Less than $1 / 2$ unit.

${ }^{4}$ Includes data for the following Schedule B codes: 7110.11.0000, 7110.19.0000, 7110.21.0000, 7110.29.0000, 7110.31.0000, 7110.39.0000,

7110.41.0000, 7110.49.0000, and 7112.92.0000.

${ }^{5}$ Defined as primary production + secondary production + imports - exports.

${ }^{6}$ Excludes imports and (or) exports of waste and scrap.

${ }^{7}$ Engelhard Corp. unfabricated metal.

${ }^{8}$ Defined as imports - exports.

${ }^{9}$ See Appendix B for definitions.

${ }^{10}$ See Appendix $\mathrm{C}$ for resource and reserve definitions and information concerning data sources.
} 


\section{POTASH}

(Data in thousand metric tons of $\mathrm{K}_{2} \mathrm{O}$ equivalent unless otherwise noted)

Domestic Production and Use: In 2020, the estimated sales value of marketable potash, free on board (f.o.b.) mine, was $\$ 430$ million, which was $10 \%$ higher than that in 2019. Potash denotes a variety of mined and manufactured salts that contain the element potassium in water-soluble form. In agriculture, the term potash refers to potassic fertilizers, which are potassium chloride (KCl), potassium sulfate or sulfate of potash (SOP), and potassium magnesium sulfate (SOPM) or langbeinite. Muriate of potash (MOP) is an agriculturally acceptable mix of $\mathrm{KCl}(95 \%$ pure or greater) and sodium chloride for fertilizer use. The majority of U.S. production was from southeastern New Mexico, where two companies operated two underground mines and one deep-well solution mine. Sylvinite and langbeinite ores in New Mexico were beneficiated by flotation, dissolution-recrystallization, heavy-media separation, solar evaporation, and (or) combinations of these processes, and accounted for about $50 \%$ of total U.S. producer sales. In Utah, two companies operated three facilities. One company extracted underground sylvinite ore by deep-well solution mining. Solar evaporation crystallized the sylvinite ore from the brine solution, and a flotation process separated the MOP from byproduct sodium chloride. The firm also processed subsurface brines by solar evaporation and flotation to produce MOP at its other facility. Another company processed brine from the Great Salt Lake by solar evaporation to produce SOP and other byproducts.

The fertilizer industry used about $85 \%$ of U.S. potash sales, and the remainder was used for chemical and industrial applications. About $65 \%$ of the potash produced was SOPM and SOP, which are required to fertilize certain chloridesensitive crops. The remaining $35 \%$ of production was MOP and was used for agricultural and chemical applications.

\begin{tabular}{|c|c|c|c|c|c|}
\hline Salient Statistics-United States: & $\underline{2016}$ & $\underline{2017}$ & $\underline{2018}$ & $\underline{2019}$ & $\underline{2020^{\circ}}$ \\
\hline 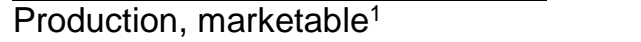 & 510 & 480 & 520 & 510 & 470 \\
\hline Sales by producers, marketable ${ }^{1}$ & 600 & 490 & 520 & 480 & 520 \\
\hline Imports for consumption & 4,550 & 5,870 & 5,710 & 4,940 & 5,100 \\
\hline Exports & 96 & 128 & 105 & 145 & 140 \\
\hline Consumption, apparent ${ }^{1,2}$ & 5,100 & 6,200 & 6,100 & 5,300 & 5,500 \\
\hline $\begin{array}{l}\text { Price, average, all products, f.o.b. mine, }{ }^{3} \\
\text { dollars per ton of } \mathrm{K}_{2} \mathrm{O}\end{array}$ & 680 & 770 & 750 & 820 & 830 \\
\hline $\begin{array}{l}\text { Price, average, muriate, f.o.b. mine, } \\
\text { dollars per ton of } \mathrm{K}_{2} \mathrm{O}\end{array}$ & 350 & 410 & 440 & 480 & 500 \\
\hline Employment, mine and mill, number & 1,150 & 900 & 900 & 900 & 900 \\
\hline $\begin{array}{l}\text { Net import reliance }{ }^{4} \text { as a percentage of } \\
\text { apparent consumption }\end{array}$ & 88 & 92 & 92 & 90 & 90 \\
\hline
\end{tabular}

Recycling: None.

Import Sources (2016-19): Canada, 83\%; Belarus and Russia, 6\% each; and other, 5\%.

Tariff: Item

Potassium nitrate

Potassium chloride

Potassium sulfate

Potassic fertilizers, other
Number

2834.21 .0000

3104.20 .0000

3104.30 .0000

3104.90 .0100
Normal Trade Relations

12-31-20

Free.

Free.

Free.

Free.

Depletion Allowance: $14 \%$ (domestic and foreign).

\section{Government Stockpile: None.}

Events, Trends, and Issues: The COVID-19 pandemic had a minimal effect on the domestic potash market. Potash is an essential plant nutrient and fertilizers were designated as essential products in most countries. Financial assistance was provided to farmers and agribusinesses in the United States and other countries. Domestic potash consumption was estimated to have increased by about $4 \%$ from that of 2019 , owing to fertilizer application rates recovering after unfavorable weather conditions in 2019 affected the spring planting season. Industrial potash use was lower, primarily for oil- and gas-well-drilling additives because those industries were affected severely by the economic downturn caused by the COVID-19 pandemic. Domestic potash production was lower because of higher than average inventories carried over from 2019 and lower production in the first half because of lower evaporation rates at some solar evaporation facilities. 
The company that was developing the Sevier Playa SOP project, which is about 225 kilometers southwest of Salt Lake City, UT, was unable to secure financing because of economic conditions caused by the COVID-19 pandemic. The project, which had planned to begin construction in 2020, was expected to be put on hold. Production was scheduled to begin in 2022 at 30,000 tons per year of SOP with rampup to full capacity of 372,000 tons per year of SOP in 2025.

World potash production increased, owing to increased output in Canada and Russia. World potash consumption was estimated to have been about the same as in 2019 at about 41 million tons of $\mathrm{K}_{2} \mathrm{O}$. Asia and South America were the leading consuming regions. World consumption of potash was projected to increase slightly in 2021, with Asia and South America as the leading regions for growth.

World potash capacity was projected to increase to 69 million tons in 2024 from 64 million tons in 2020. Most of the increase would be MOP from new mines and expansion projects in Belarus, Canada, and Russia. Other projects that were ongoing included new SOP mines in Australia, China, and Eritrea and new MOP mines in Brazil, Ethiopia, and Spain. The startup for some of the other projects was likely to be delayed to beyond 2025 because of unfavorable economic conditions.

World Mine Production and Reserves: Reserves for Brazil and Canada were revised with information reported by the producing companies. Reserves for Laos were revised with official Government data.

\begin{tabular}{|c|c|c|c|c|}
\hline & Mine $\mathrm{p}$ & duction & Rese & ves $^{5}$ \\
\hline & $\underline{2019}$ & $\underline{2020^{e}}$ & Recoverable ore & $\underline{\mathrm{K}_{2}} \mathrm{O}$ equivalent \\
\hline United States ${ }^{1}$ & 510 & 470 & 970,000 & 220,000 \\
\hline Belarus & 7,350 & 7,300 & $3,300,000$ & 750,000 \\
\hline Brazil & 247 & 250 & 10,000 & 2,300 \\
\hline Canada & 12,300 & 14,000 & $4,500,000$ & $1,100,000$ \\
\hline Chile & 840 & 900 & NA & 100,000 \\
\hline China & 5,000 & 5,000 & NA & 350,000 \\
\hline Germany & 3,000 & 3,000 & NA & 150,000 \\
\hline Israel & 2,040 & 2,000 & NA & ${ }^{6}$ Large \\
\hline Jordan & 1,520 & 1,500 & NA & ${ }^{6}$ Large \\
\hline Laos & 400 & 400 & 500,000 & 75,000 \\
\hline Russia & 7,340 & 7,600 & NA & 600,000 \\
\hline Spain & 500 & 470 & NA & 68,000 \\
\hline Other countries & 310 & 300 & $\underline{1,500,000}$ & 300,000 \\
\hline World total (rounded) & $\overline{41,300}$ & $\overline{43,000}$ & $\overline{\mathrm{NA}}$ & $>3,700,000$ \\
\hline
\end{tabular}

World Resources: ${ }^{5}$ Estimated domestic potash resources total about 7 billion tons. Most of these lie at depths between 1,800 and 3,100 meters in a 3,110-square-kilometer area of Montana and North Dakota as an extension of the Williston Basin deposits in Manitoba and Saskatchewan, Canada. The Paradox Basin in Utah contains resources of about 2 billion tons, mostly at depths of more than 1,200 meters. The Holbrook Basin of Arizona contains resources of about 0.7 to 2.5 billion tons. A large potash resource lies about 2,100 meters under central Michigan and contains more than 75 million tons. Estimated world resources total about 250 billion tons.

Substitutes: No substitutes exist for potassium as an essential plant nutrient and as an essential nutritional requirement for animals and humans. Manure and glauconite (greensand) are low-potassium-content materials that can be profitably transported only short distances to crop fields.

\footnotetext{
eEstimated. NA Not available.

${ }^{1}$ Data are rounded to no more than two significant digits to avoid disclosing company proprietary data.

${ }^{2}$ Defined as sales + imports - exports.

${ }^{3}$ Includes MOP, SOP, and SOPM. Does not include other chemical compounds that contain potassium.

${ }^{4}$ Defined as imports - exports.

${ }^{5}$ See Appendix $C$ for resource and reserve definitions and information concerning data sources.

${ }^{6}$ Israel and Jordan recover potash from the Dead Sea, which contains nearly 2 billion tons of potassium chloride.
} 


\section{PUMICE AND PUMICITE}

(Data in thousand metric tons unless otherwise noted)

Domestic Production and Use: In 2020, 10 operations in five States produced pumice and pumicite. Estimated production ${ }^{1}$ was 480,000 tons with an estimated processed value of about $\$ 13$ million, free on board (f.o.b.) plant. That represented decreases of $15 \%$ in quantity and $18 \%$ in value from the 2019 reported production of 565,000 tons valued at $\$ 15.9$ million. Pumice and pumicite were mined in California, Idaho, Kansas, New Mexico, and Oregon. The porous, lightweight properties of pumice are well suited for its main uses. Mined pumice was used in the production of abrasives, concrete admixtures and aggregates, lightweight building blocks, horticultural purposes, and other uses, including absorbent, filtration, laundry stone washing, and road use.

\begin{tabular}{|c|c|c|c|c|c|}
\hline Salient Statistics-United States: & $\underline{2016}$ & $\underline{2017}$ & $\underline{2018}$ & $\underline{2019}$ & $\underline{2020^{e}}$ \\
\hline$\overline{\text { Production, }_{\text {mine }}{ }^{1}}$ & $\overline{374}$ & $\overline{383}$ & $\overline{496}$ & $\overline{565}$ & 480 \\
\hline Imports for consumption & 170 & 166 & 159 & 136 & 48 \\
\hline Exportse & 10 & 12 & 11 & 11 & 7 \\
\hline Consumption, apparent ${ }^{2}$ & 534 & 537 & 644 & 690 & 520 \\
\hline Price, average value, f.o.b. mine or mill, dollars per ton & 38 & 39 & 32 & 28 & 28 \\
\hline Employment, mine and mill, number & 140 & 140 & 140 & 140 & 140 \\
\hline $\begin{array}{l}\text { Net import reliance }{ }^{3} \text { as a percentage of } \\
\text { apparent consumption }\end{array}$ & 30 & 29 & 23 & 18 & 8 \\
\hline
\end{tabular}

Recycling: Little to no known recycling.

Import Sources (2016-19): Greece, 93\%; Iceland, 5\%; and Mexico, 2\%.

Tariff: Item

Pumice, crude or in irregular pieces, including crushed

Pumice, other

\section{Number}

2513.10.0010

2513.10.0080

\section{Normal Trade Relations} $\underline{12-31-20}$

Free. Free.

Depletion Allowance: $5 \%$ (domestic and foreign).

\section{Government Stockpile: None.}

Events, Trends, and Issues: The amount of domestically produced pumice and pumicite sold or used in 2020 was estimated to be $15 \%$ less than that in 2019 . Owing to disruptions likely caused by the COVID-19 pandemic during the first 6 months of 2020, mine production decreased by approximately 15\% compared with the same period of 2019. Imports and exports were estimated to have decreased substantially compared with those of 2019. Since 2015, apparent consumption of pumice and the quantity of pumice that was sold or used followed an upward trend until 2020. Almost all imported pumice originated from Greece in 2020 and primarily supplied markets in the eastern and gulf coast regions of the United States. Although the domestic mill price for pumice was approximately $\$ 28$ per ton, the average imported value of pumice was approximately $\$ 98$ per ton.

Pumice and pumicite are plentiful in the Western United States, but legal challenges and public land designations could limit access to known deposits. Pumice and pumicite production is sensitive to mining and transportation costs. Although unlikely in the short term, an increase in fuel prices would likely lead to increases in production costs, making imports and competing materials attractive substitutes for domestic products.

All known domestic pumice and pumicite mining in 2020 was accomplished through open pit methods, generally in remote areas, away from major population centers. Although the generation and disposal of reject fines in mining and milling may result in local dust issues at some operations, such environmental impacts are thought to be restricted to relatively small geographic areas. 


\section{PUMICE AND PUMICITE}

World production of pumice and related material was estimated to be 21 million tons in 2020 , which was $7 \%$ more than that of 2019. Turkey, followed by Ethiopia, was the leading global producer of pumice and pumicite. Pumice is used more extensively as a building material outside the United States, which explained the large global production of pumice relative to that of the United States. In Europe, basic home construction uses stone and concrete as the preferred building materials. Prefabricated lightweight concrete walls, which may contain pumice as lightweight aggregate, are often produced and shipped to construction locations. Because of their cementitious properties, light weight, and strength, pumice and pumicite perform well in European-style construction.

\section{World Mine Production and Reserves:}

\begin{tabular}{|c|c|c|}
\hline & Mine & luction \\
\hline & 2019 & $\underline{2020^{e}}$ \\
\hline United States ${ }^{1}$ & 565 & 480 \\
\hline Algeria $^{5}$ & 900 & 900 \\
\hline Cameroon $^{5}$ & 300 & 1,000 \\
\hline Chile $^{5}$ & 800 & 800 \\
\hline Ecuador $^{5}$ & 800 & 600 \\
\hline Ethiopia & 2,400 & 2,400 \\
\hline France $^{5}$ & 280 & 300 \\
\hline Greece ${ }^{5}$ & 1,020 & 1,000 \\
\hline Guadeloupe & 200 & 200 \\
\hline Guatemala & 570 & 600 \\
\hline Indonesia & 200 & 770 \\
\hline Jordan & 900 & 900 \\
\hline New Zealand & 220 & 220 \\
\hline Saudi Arabia 5 & 560 & 550 \\
\hline Spain & 200 & 200 \\
\hline Syria ${ }^{5}$ & 200 & 200 \\
\hline Tanzania & 263 & 260 \\
\hline Turkey & 7,800 & 7,800 \\
\hline Uganda & 880 & 1,000 \\
\hline Other countries ${ }^{5}$ & 640 & 640 \\
\hline World total (rounded) & $\overline{19,700}$ & $\overline{21,000}$ \\
\hline
\end{tabular}

World Resources: ${ }^{4}$ The identified U.S. resources of pumice and pumicite, estimated to be more than 25 million tons, are concentrated in the Western States. The estimated total resources (identified and undiscovered) in the Western and Great Plains States are at least 250 million tons and may total more than 1 billion tons. Large resources of pumice and pumicite have been identified on all continents.

Substitutes: The costs of transportation determine the maximum economic distance pumice and pumicite can be shipped and still remain competitive with alternative materials. Competitive materials that may be substituted for pumice and pumicite include crushed aggregates, diatomite, expanded shale and clay, and vermiculite.

\footnotetext{
eEstimated.

${ }^{1}$ Quantity sold and used by producers.

${ }^{2}$ Defined as production + imports - exports.

${ }^{3}$ Defined as imports - exports.

${ }^{4}$ See Appendix $C$ for resource and reserve definitions and information concerning data sources.

${ }^{5}$ Includes pozzolan and (or) volcanic tuff.
} 


\section{QUARTZ CRYSTAL (INDUSTRIAL)}

(Data in kilograms unless otherwise noted)

Domestic Production and Use: Industrial cultured quartz crystal is electronic-grade quartz crystal that is manufactured, not mined. In the past, cultured quartz crystal was primarily produced using lascas ${ }^{1}$ as raw quartz feed material. Lascas mining and processing in Arkansas ended in 1997. In 2020, production of cultured quartz crystal was reported and evidence indicated that two companies produced cultured quartz crystal in the United States. However, production data was withheld in order to avoid disclosing company proprietary data. In addition to lascas, these companies may use cultured quartz crystal that has been rejected during the manufacturing process, owing to crystallographic imperfections, as feed material. The companies may use a mix of cultured quartz and imported lascas as feed material. In the past several years, cultured quartz crystal has been increasingly produced overseas, primarily in Asia. Electronic applications accounted for most industrial uses of quartz crystal; other uses included special optical applications.

Virtually all quartz crystal used for electronics was cultured, rather than natural, crystal. Electronic-grade quartz crystal is used to make frequency filters, frequency controls, and timers in electronic circuits employed for a wide range of products, such as communications equipment, computers, and many consumer goods, such as electronic games and television receivers.

Salient Statistics_United States:

Production:

Mine (lascas)

Cultured quartz crystal

Imports for consumption:

Quartz (lascas)

Piezoelectric quartz, unmounted

Exports:

Quartz (lascas)

Piezoelectric quartz, unmounted

Price, dollars per kilogram:

As-grown cultured quartz

Lumbered quartz ${ }^{2}$

Net import reliance ${ }^{3}$ as a percentage

of apparent consumption

$\begin{array}{rrrrr}\underline{\mathbf{2 0 1 6}} & \underline{\mathbf{2 0 1 7}} & \underline{\mathbf{2 0 1 8}} & \underline{\mathbf{2 0 1 9}} & \underline{\mathbf{2 0 2 0}} \\ \overline{\mathrm{W}} & \overline{\mathrm{W}} & \overline{\mathrm{W}} & \overline{\mathrm{W}} & \overline{\mathrm{W}} \\ \mathrm{NA} & \mathrm{NA} & \mathrm{NA} & \mathrm{NA} & \mathrm{NA} \\ 6,280 & 6,760 & 16,100 & 54,600 & 95,000 \\ \mathrm{NA} & \mathrm{NA} & \mathrm{NA} & \mathrm{NA} & \mathrm{NA} \\ 60,500 & 55,300 & 43,400 & 40,900 & 42,000 \\ 280 & 280 & 300 & 200 & 200 \\ 890 & 300 & 500 & 500 & 500 \\ \mathrm{NA} & \mathrm{NA} & \mathrm{NA} & \mathrm{NA} & \mathrm{NA}\end{array}$

Recycling: An unspecified amount of rejected cultured quartz crystal was used as feed material for the production of cultured quartz crystal.

Import Sources (2016-19): Import statistics specific to lascas are not available because they are combined with other types of quartz. Cultured quartz crystal (piezoelectric quartz, unmounted): China, 76\%; Japan, 11\%; Switzerland and Russia, $2 \%$ each; and other, $9 \%$.

\section{Tariff: Item}

Quartz (including lascas)

Piezoelectric quartz, unmounted
Number

2506.10.0050

7104.10 .0000
Normal Trade Relations

12-31-20

Free.

$3 \%$ ad val.

Depletion Allowance: 22\% (domestic), 14\% (foreign). 
Government Stockpile: ${ }^{5}$ As of September 30, 2020, the National Defense Stockpile (NDS) contained 7,148 kilograms of natural quartz crystal. The stockpile has 11 weight classes for natural quartz crystal that range from 0.2 kilograms to more than 10 kilograms. The stockpiled crystals, however, are primarily in the larger weight classes. The larger pieces are suitable as seed crystals, which are very thin crystals cut to exact dimensions, to produce cultured quartz crystal. In addition, many of the stockpiled crystals could be of interest to the specimen and gemstone industry. Little, if any, of the stockpiled material is likely to be used in the same applications as cultured quartz crystal. No natural quartz crystal was sold from the NDS in 2020. Previously, the only individual crystals from the stockpile that were sold were those that weighed 10 kilograms or more and that could be used as seed material.

\begin{tabular}{lccccc} 
& \multicolumn{2}{c}{ FY 2020 } & \multicolumn{2}{c}{ FY 2021 } \\
Inventory & Potential & Potential & Potential & $\begin{array}{c}\text { Potential } \\
\text { Material }\end{array}$ \\
as of $9-30-20$ & acquisitions & disposals & acquisitions & disposals
\end{tabular}

Events, Trends, and Issues: Rising imports of piezoelectric quartz in the past several years are likely the result of increased demand for vibration sensors such as accelerometers, which are utilized in aerospace and automotive applications. Demand for cultured quartz crystal for frequency-control oscillators and frequency filters in a variety of electronic devices is expected to remain stable. Growth of the consumer electronics market, for products such as personal computers, electronic games, and tablet computers, is likely to continue to sustain global production of cultured quartz crystal.

World Mine Production and Reserves: ${ }^{6}$ This information is unavailable, but the global reserves for lascas are thought to be large.

World Resources: ${ }^{6}$ Limited resources of natural quartz crystal suitable for direct electronic or optical use are available throughout the world. World dependence on these resources will continue to decline because of the increased acceptance of cultured quartz crystal as an alternative material. Additionally, techniques using rejected cultured quartz crystal as feed material could mean a decreased dependence on lascas for growing cultured quartz.

Substitutes: Silicon is increasingly being used as a substitute for quartz crystal for frequency-control oscillators in electronic circuits. Other materials, such as aluminum orthophosphate (the very rare mineral berlinite), langasite, lithium niobate, and lithium tantalate, which have larger piezoelectric coupling constants, have been studied and used. The cost competitiveness of these materials, as opposed to cultured quartz crystal, is dependent on the type of application that the material is used for and the processing required.

\footnotetext{
eEstimated. NA Not available. W Withheld to avoid disclosing company proprietary data. - Zero.

${ }^{1}$ Lascas is a nonelectronic-grade quartz used as a feedstock for growing cultured quartz crystal and for production of fused quartz.

${ }^{2}$ As-grown cultured quartz that has been processed by sawing and grinding.

${ }^{3}$ Defined as imports - exports.

${ }^{4}$ Deceased.

${ }^{5}$ See Appendix $B$ for definitions.

${ }^{6}$ See Appendix $C$ for resource and reserve definitions and information concerning data sources.
} 


\section{RARE EARTHS 1}

[Data in metric tons of rare-earth-oxide (REO) equivalent content unless otherwise noted]

Domestic Production and Use: Rare earths were mined domestically in 2020. Bastnaesite (or bastnäsite), a rareearth fluorocarbonate mineral, was mined as a primary product at a mine in Mountain Pass, CA. Monazite, a phosphate mineral, was produced as a separated concentrate or included as an accessory mineral in heavy-mineral concentrates. The estimated value of rare-earth compounds and metals imported by the United States in 2020 was $\$ 110$ million, a significant decrease from $\$ 160$ million in 2019. The estimated distribution of rare earths by end use was as follows: catalysts, $75 \%$; ceramics and glass, $6 \%$; polishing, $5 \%$; metallurgical applications and alloys, $4 \%$; and other, $10 \%$.

Salient Statistics_-United States:

Production, bastnaesite and monazite concentrates ${ }^{e}$ Imports:e, 2

Compounds

Metals:

Ferrocerium, alloys

Rare-earth metals, scandium, and yttrium

Exports:e, 2

Ores and compounds

Metals:

Ferrocerium, alloys

Rare-earth metals, scandium, and yttrium

Consumption, apparent ${ }^{3}$

Price, average, dollars per kilogram: 4

Cerium oxide, $99.5 \%$ minimum

Dysprosium oxide, $99.5 \%$ minimum

Europium oxide, $99.99 \%$ minimum

Lanthanum oxide, $99.5 \%$ minimum

Mischmetal, 65\% cerium, 35\% lanthanum

Neodymium oxide, $99.5 \%$ minimum

Terbium oxide, $99.99 \%$ minimum

Employment, mine and mill, annual average, number

Net import reliance ${ }^{5}$ as a percentage of apparent consumption: 6

Compounds and metals

Mineral concentrates

\begin{tabular}{|c|c|c|c|c|}
\hline$\frac{2016}{-}$ & $\frac{2017}{-}$ & $\frac{2018}{14,000}$ & $\begin{array}{r}\frac{2019}{28,000}\end{array}$ & $\frac{2020^{e}}{38,000}$ \\
\hline 11,800 & 11,000 & 10,800 & 12,300 & 6,700 \\
\hline $\begin{array}{l}268 \\
404\end{array}$ & $\begin{array}{l}309 \\
524\end{array}$ & $\begin{array}{l}298 \\
526\end{array}$ & $\begin{array}{l}332 \\
627\end{array}$ & 260 \\
\hline 590 & 1,740 & 17,900 & 28,200 & 38,000 \\
\hline $\begin{array}{r}943 \\
103 \\
10.500\end{array}$ & $\begin{array}{r}982 \\
55 \\
9.060\end{array}$ & $\begin{array}{r}1,250 \\
28 \\
6.520\end{array}$ & $\begin{array}{r}1,290 \\
83 \\
11,700\end{array}$ & $\begin{array}{r}630 \\
27 \\
7.800\end{array}$ \\
\hline 2 & 2 & 2 & 2 & 2 \\
\hline 198 & 187 & 179 & 239 & 258 \\
\hline 74 & 77 & 53 & 35 & 31 \\
\hline 2 & 2 & 2 & 2 & 2 \\
\hline 5 & 6 & 6 & 6 & 5 \\
\hline 40 & 50 & 50 & 45 & 47 \\
\hline 415 & 501 & 455 & 507 & 628 \\
\hline - & 24 & 190 & 202 & 180 \\
\hline $\begin{array}{l}100 \\
X X\end{array}$ & $\begin{array}{r}100 \\
X X\end{array}$ & 100 & 100 & 100 \\
\hline
\end{tabular}

Recycling: Limited quantities of rare earths are recovered from batteries, permanent magnets, and fluorescent lamps.

Import Sources (2016-19): Rare-earth compounds and metals: China, 80\%; Estonia, 5\%; Japan and Malaysia, 4\% each; and other, 7\%. Compounds and metals imported from Estonia, Japan, and Malaysia were derived from mineral concentrates and chemical intermediates produced in Australia, China, and elsewhere.

Tariff: Item

Rare-earth metals

Cerium compounds

Other rare-earth compounds:

Oxides or chlorides

Carbonates

Ferrocerium and other pyrophoric alloys
Number

2805.30.0000

2846.10.0000

2846.90.2000

2846.90 .8000

3606.90 .3000

\section{Normal Trade Relations} 12-31-20

$5.0 \%$ ad val. $5.5 \%$ ad val.

Free.

$3.7 \%$ ad val. $5.9 \%$ ad val.

Depletion Allowance: Monazite, $22 \%$ on thorium content and $14 \%$ on rare-earth content (domestic), $14 \%$ (foreign); bastnäsite and xenotime, 14\% (domestic and foreign). 
Government Stockpile: ${ }^{7}$ In the addition to the materials listed below, the FY 2021 potential acquisitions include neodymium, 600 tons; praseodymium, 70 tons; and samarium-cobalt alloy, 50 tons.

Material

Cerium

Dysprosium

Europium

Ferrodysprosium

Lanthanum

Rare-earth-magnet feedstock

Yttrium
FY 2020

Inventory
as of $9-30-20$

Potential
acquisitions
900

0.2

20.9

0.5

-

25

\section{Potential disposals}

$\overline{-}$
$\overline{-}$
$\overline{-}$
FY 2021

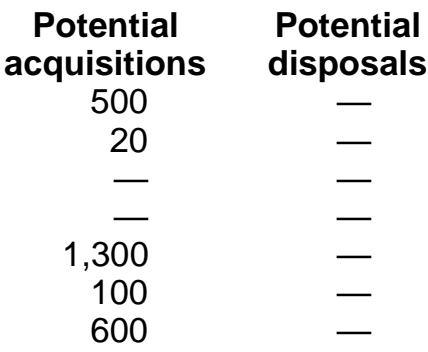

Events, Trends, and Issues: Global mine production was estimated to have increased to 240,000 tons of rare-earthoxide equivalent. According to China's Ministry of Industry and Information Technology, the mine production quota for 2020 was 140,000 tons with 120,850 tons allocated to light rare earths and 19,150 tons allocated to ion-adsorption clays.

World Mine Production and Reserves: Reserves for Brazil and the United States were revised based on information from Government and industry reports.

\begin{tabular}{lrrr} 
& \multicolumn{2}{c}{ Mine production } & Reserves $^{8}$ \\
United States & $\mathbf{2 0 1 9}$ & $\mathbf{2 0 2 \mathbf { O } ^ { \mathbf { 2 } }}$ & $1,500,000$ \\
Australia & 28,000 & 38,000 & $94,100,000$ \\
Brazil & 20,000 & 17,000 & $21,000,000$ \\
Burma & 710 & 1,000 & $\mathrm{NA}$ \\
Burundi & 25,000 & 30,000 & $\mathrm{NA}$ \\
Canada & 200 & 500 & 830,000 \\
China & - & - & $44,000,000$ \\
Greenland & 10132,000 & 10140,000 & $1,500,000$ \\
India & - & - & $6,900,000$ \\
Madagascar & 2,900 & 3,000 & $\mathrm{NA}$ \\
Russia & 4,000 & 8,000 & $12,000,000$ \\
South Africa & 2,700 & 2,700 & 790,000 \\
Tanzania & - & - & 890,000 \\
Thailand & - & - & $\mathrm{NA}$ \\
Vietnam & 1,900 & 2,000 & $22,000,000$ \\
Other countries & 1,300 & 1,000 & 310,000 \\
$\quad$ World total (rounded) & 66 & 100 & $120,000,000$
\end{tabular}

World Resources: ${ }^{8}$ Rare earths are relatively abundant in the Earth's crust, but minable concentrations are less common than for most other mineral commodities. In North America, measured and indicated resources of rare earths were estimated to include 2.7 million tons in the United States and more than 15 million tons in Canada.

Substitutes: Substitutes are available for many applications but generally are less effective.

\footnotetext{
eEstimated. E Net exporter. NA Not available. XX Not applicable. — Zero.

${ }^{1}$ Data include lanthanides and yttrium but exclude most scandium. See also Scandium and Yttrium.

${ }^{2}$ REO equivalent or content of various materials were estimated. Source: U.S. Census Bureau.

${ }^{3}$ Defined as production + imports - exports.

${ }^{4}$ Source: Argus Media group-Argus Metals International.

${ }^{5}$ Defined as imports - exports.

${ }^{6}$ In 2018-2020, all domestic production of mineral concentrates was exported, and all compounds and metals consumed were assumed to be imported material.

${ }^{7}$ Gross weight. See Appendix B for definitions.

${ }^{8}$ See Appendix $\mathrm{C}$ for resource and reserve definitions and information concerning data sources.

${ }^{9}$ For Australia, Joint Ore Reserves Committee-compliant reserves were 2.8 million tons.

${ }^{10}$ Production quota; does not include undocumented production.
} 


\section{RHENIUM}

(Data in kilograms of rhenium content unless otherwise noted)

Domestic Production and Use: During 2020, rhenium-containing products including ammonium perrhenate (APR), metal powder, and perrhenic acid were produced as byproducts from roasting molybdenum concentrates from porphyry copper-molybdenum deposits in Arizona and Montana. U.S. primary production was approximately 7,800 kilograms in 2020, a 6\% decrease from the previous year. The United States continued to be a leading producer of secondary rhenium, recovering rhenium from nickel base superalloy scrap, spent oil-refining catalysts, and foundry revert. The major uses of rhenium were in superalloys used in high-temperature turbine engine components and in petroleum-reforming catalysts, representing an estimated $80 \%$ and $15 \%$, respectively, of end uses. Bimetallic platinum-rhenium catalysts were used in petroleum reforming for the production of high-octane hydrocarbons, which are used in the production of lead-free gasoline. Rhenium improves the high-temperature $\left(>1,000^{\circ} \mathrm{C}\right)$ strength properties of some nickel-base superalloys. Rhenium alloys were used in crucibles, electrical contacts, electromagnets, electron tubes and targets, heating elements, ionization gauges, mass spectrographs, metallic coatings, semiconductors, temperature controls, thermocouples, vacuum tubes, and other applications. The value of rhenium consumed in 2020 was about $\$ 35$ million as measured by the value of imports of rhenium metal and APR.

\begin{tabular}{|c|c|c|c|c|c|}
\hline Salient Statistics-United S & $\underline{2016}$ & $\underline{2017}$ & $\underline{2018}$ & 2019 & $2020^{\mathrm{e}}$ \\
\hline Production ${ }^{1}$ & 8,440 & 8,200 & 8,220 & 8,360 & $\overline{7,800}$ \\
\hline Imports for consumption² & 31,900 & 34,500 & 39,400 & 44,300 & 24,000 \\
\hline Exports & NA & NA & NA & NA & NA \\
\hline Consumption, apparent ${ }^{3}$ & 40,300 & 42,700 & 47,600 & 52,600 & 32,000 \\
\hline \multicolumn{6}{|l|}{$\begin{array}{l}\text { Price, average value, gross weight, } \\
\text { dollars per kilogram: } 4\end{array}$} \\
\hline Metal pellets, $99.99 \%$ pure & 2,030 & 1,550 & 1,470 & 1,300 & 1,000 \\
\hline Ammonium perrhenate & 2,510 & 1,530 & 1,410 & 1,300 & 1,100 \\
\hline Employment, number & Small & Small & Small & Small & Small \\
\hline $\begin{array}{l}\text { Net import reliance } 5 \text { as a percentage of } \\
\text { apparent consumption }\end{array}$ & 79 & 81 & 83 & 84 & 76 \\
\hline
\end{tabular}

Recycling: Nickel-base superalloy scrap and scrapped turbine blades and vanes continued to be recycled hydrometallurgically to produce rhenium metal for use in new superalloy melts. The scrapped parts were also processed to generate engine revert-a high-quality, lower cost superalloy meltstock - by an increasing number of companies, mainly in the United States, Canada, Estonia, France, Germany, Japan, Poland, and Russia. Rheniumcontaining catalysts were also recycled.

Import Sources (2016-19): Ammonium perrhenate: Kazakhstan, 23\%; Germany, 18\%; Canada, 16\%; Poland, 14\%; and other, 29\%. Rhenium metal powder: Chile, 82\%; Germany, 7\%; Canada, 5\%; Poland, 3\%; and other, 3\%. Total imports: Chile, 60\%; Germany, 10\%; Canada, 8\%; Kazakhstan, 7\%; and other, $15 \%$.

\section{Tariff: Item}

Salts of peroxometallic acids, other, ammonium perrhenate

Rhenium (and other metals), waste and scrap

Rhenium, unwrought and powders

Rhenium (and other metals), wrought
Number

2841.90.2000

8112.92 .0600

8112.92 .5000

8112.99 .9000

\section{Normal Trade Relations}

12-31-20

3.1\% ad val.

Free.

$3 \%$ ad val.

$4 \%$ ad val.

Depletion Allowance: $14 \%$ (domestic and foreign).

\section{Government Stockpile: None.}

Events, Trends, and Issues: In 2020, rhenium production in the United States decreased by $6 \%$ compared with that in 2019. A rhenium recovery facility in Utah was closed in 2019; however, the company announced the possibility of reopening the facility in the near future. During 2020, the United States continued to rely on imports for much of its supply of rhenium. Canada, Chile, Germany, and Kazakhstan supplied most of the imported rhenium. Imports of APR decreased by $16 \%$ in 2020 compared with the previous year. Imports of rhenium metal decreased by $57 \%$ in 2020 compared with the previous year. This large decrease in rhenium metal imports was attributed in part to lower consumption by the aerospace industry owing to travel lockdown measures in response to the COVID-19 pandemic and reduced production of airplanes. Additionally, mine production of rhenium-containing feedstocks was lower in 2020. 
The United States and Germany continued to be the leading secondary rhenium producers. Secondary rhenium production also took place in Canada, Estonia, France, Japan, Poland, and Russia. According to industry sources, approximately 20 to 25 tons of rhenium was recycled worldwide in 2020. For the ninth year in a row, rhenium metal and catalytic-grade APR prices decreased. In 2020, catalytic-grade APR prices averaged $\$ 1,100$ per kilogram, a $12 \%$ decrease from the annual average price in 2019. Rhenium metal pellet prices averaged $\$ 1,000$ per kilogram in 2020 , a 20\% decrease from the annual average price in 2019.

There were no primary rhenium projects in 2020 that were expected to significantly contribute to rhenium availability in the near future. Continued low prices of rhenium as well as the global COVID-19 pandemic caused many rhenium recyclers as well as primary-rhenium production facilities to stop recycling or producing rhenium to focus on a more profitable market. The major aerospace companies were expected to continue testing superalloys that contain one-half the quantity of rhenium used in engine blades as currently designed, as well as testing rhenium-free alloys for other engine components.

\section{World Mine Production and Reserves:}

\begin{tabular}{|c|c|c|}
\hline \multicolumn{2}{|r|}{ Mine production 6} & \multirow[t]{2}{*}{ Reserves $^{7}$} \\
\hline & $2020^{e}$ & \\
\hline United States & $\overline{7,800}$ & 400,000 \\
\hline Armenia & 280 & 95,000 \\
\hline Canada & - & 32,000 \\
\hline Chile $^{8}$ & 30,000 & $1,300,000$ \\
\hline China & 2,500 & NA \\
\hline Kazakhstan & 1,000 & 190,000 \\
\hline Korea, Republic of & 2,700 & NA \\
\hline Peru & - & 45,000 \\
\hline Poland & 8,300 & NA \\
\hline Russia & NA & 310,000 \\
\hline Uzbekistan & 460 & NA \\
\hline World total (rounded) & $\overline{53,000}$ & $2,400,000$ \\
\hline
\end{tabular}

World Resources: ${ }^{7}$ Most rhenium occurs with molybdenum in porphyry copper deposits. Identified U.S. resources are estimated to be about 7 million kilograms. Rhenium also is associated with copper minerals in sedimentary deposits in Armenia, Kazakhstan, Poland, Russia, and Uzbekistan, where ore is processed for copper recovery and the rhenium-bearing residues are recovered at copper smelters.

Substitutes: Substitutes for rhenium in platinum-rhenium catalysts are being evaluated continually. Iridium and tin have achieved commercial success in one such application. Other metals being evaluated for catalytic use include gallium, germanium, indium, selenium, silicon, tungsten, and vanadium. The use of these and other metals in bimetallic catalysts might decrease rhenium's share of the existing catalyst market; however, this would likely be offset by rhenium-bearing catalysts being considered for use in several proposed gas-to-liquid projects. Materials that can substitute for rhenium in various end uses are as follows: cobalt and tungsten for coatings on copper $\mathrm{x}$-ray targets, rhodium and rhodium-iridium for high-temperature thermocouples, tungsten and platinum-ruthenium for coatings on electrical contacts, and tungsten and tantalum for electron emitters.

\footnotetext{
eEstimated. NA Not available. - Zero.

${ }^{1}$ Based on $80 \%$ recovery of estimated rhenium contained in molybdenum disulfide concentrates. Secondary rhenium production is not included. ${ }^{2}$ Does not include wrought forms or waste and scrap. The rhenium content of ammonium perrhenate is $69.42 \%$.

${ }^{3}$ Defined as production + imports - exports.

${ }^{4}$ Average price per kilogram of rhenium in pellets or catalytic-grade ammonium perrhenate. Source: Argus Media group—Argus Metals International. ${ }^{5}$ Defined as imports - exports.

${ }^{6}$ Estimated amount of rhenium recovered in association with copper and molybdenum production. Secondary rhenium production not included.

${ }^{7}$ See Appendix $\mathrm{C}$ for resource and reserve definitions and information concerning data sources.

${ }^{8}$ Estimated rhenium recovered from roaster residues from Belgium, Chile, Mexico, and Peru.
} 


\section{RUBIDIUM}

(Data in metric tons of rubidium oxide unless otherwise noted)

Domestic Production and Use: In 2020, no rubidium was mined in the United States; however, occurrences of rubidium-bearing minerals are known in Alaska, Arizona, Idaho, Maine, South Dakota, and Utah. Rubidium is also associated with some evaporate mineral occurrences in other States. Rubidium is not a major constituent of any mineral. Rubidium concentrate is produced as a byproduct of pollucite (cesium) and lepidolite (lithium) mining and is imported from other countries for processing in the United States.

Applications for rubidium and its compounds include biomedical research, electronics, specialty glass, and pyrotechnics. Specialty glasses are the leading market for rubidium; rubidium carbonate is used to reduce electrical conductivity, which improves stability and durability in fiber optic telecommunications networks. Biomedical applications include rubidium salts used in antishock agents and the treatment of epilepsy and thyroid disorder; rubidium-82, a radioactive isotope used as a blood-flow tracer in positron emission tomographic imaging; and rubidium chloride, used as an antidepressant. Rubidium atoms are used in academic research, including the development of quantum-mechanics-based computing devices, a future application with potential for relatively high consumption of rubidium. Quantum computing research uses ultracold rubidium atoms in a variety of applications. Quantum computers, which have the ability to perform more complex computational tasks than traditional computers by calculating in two quantum states simultaneously, were expected to be in prototype phase within 10 years.

Rubidium's photoemissive properties make it useful for electrical-signal generators in motion-sensor devices, nightvision devices, photoelectric cells (solar panels), and photomultiplier tubes. Rubidium is used as an atomic resonance-frequency-reference oscillator for telecommunications network synchronization, playing a vital role in global positioning systems. Rubidium-rich feldspars are used in ceramic applications for spark plugs and electrical insulators because of their high dielectric constant. Rubidium hydroxide is used in fireworks to oxidize mixtures of other elements and produce violet hues. The U.S. military frequency standard, the United States Naval Observatory (USNO) timescale, is based on 48 weighted atomic clocks, including 4 USNO rubidium fountain clocks.

Salient Statistics_-United States: Consumption, export, and import data are not available. Some concentrate was imported to the United States for further processing. Industry information during the past decade suggests a domestic consumption rate of approximately 2,000 kilograms per year. The United States was $100 \%$ import reliant for rubidium minerals.

In 2020 , one company offered 1-gram ampoules of $99.75 \%$-grade rubidium (metal basis) for $\$ 89.00$, a slight increase from $\$ 87.80$ in 2019 , and 100-gram ampoules of the same material for $\$ 1,608.00$, a slight increase from $\$ 1,592.00$ in 2019. The price for 1 -gram ampoules of $99.8 \%$ rubidium formate hydrate (metal basis) was $\$ 34.70$, unchanged from 2019.

In 2020 , the prices for 10 grams of $99.8 \%$ (metal basis) rubidium acetate, rubidium bromide, rubidium carbonate, rubidium chloride, and rubidium nitrate were $\$ 50.60, \$ 67.00, \$ 56.80, \$ 61.30$, and $\$ 47.20$, respectively. The price for a rubidium-plasma standard solution (10,000 micrograms per milliliter) was $\$ 49.50$ for 50 milliliters and $\$ 80.80$ for 100 milliliters, a 5\% decrease, each, from those of 2019.

Recycling: None.

Import Sources (2016-19): No reliable data have been available to determine the source of rubidium ore imported by the United States since 1988. Prior to 2016, Canada was thought to be the primary supplier of rubidium ore. 


\section{RUBIDIUM}

Tariff: Item

Alkali metals, other

Chlorides, other

Bromides, other

lodides, other

Sulfates, other

Nitrates, other

Carbonates, other
Number

2805.19.9000

2827.39.9000

2827.59.5100

2827.60.5100

2833.29.5100

2834.29.5100

2836.99.5000
Normal Trade Relations

12-31-20

$5.5 \%$ ad val.

$3.7 \%$ ad val.

$3.6 \%$ ad val.

$4.2 \%$ ad val.

$3.7 \%$ ad val.

$3.5 \%$ ad val.

$3.7 \%$ ad val.

Depletion Allowance: $14 \%$ (domestic and foreign).

Government Stockpile: None.

Events, Trends, and Issues: Domestic rubidium occurrences will remain uneconomic unless market conditions change, such as the development of new end uses or increased consumption for existing end uses, which in turn could lead to increased prices. No known human health issues are associated with exposure to naturally occurring rubidium, and its use has minimal environmental impact.

During 2020, no rubidium production was reported globally. Production of rubidium from all countries, excluding China, ceased within the past two decades. Production in Namibia ceased in the early 2000s, followed by the Tanco Mine in Canada shutting down and later being sold after a mine collapse in 2015. The Bikita Mine in Zimbabwe was depleted of pollucite ore reserves in 2018, and the Sinclair Mine in Australia completed the mining and shipments of all economically recoverable pollucite ore in 2019. Recent reports indicate that with current processing rates, the world's stockpiles of rubidium ore, excluding those in China, will be depleted by 2022.

The primary processing plant of rubidium compounds globally, located in Germany, has reportedly operated far below capacity for the past few years. A company completed an updated mineral resource estimate for the Karibib project in Namibia, reporting 8.9 million metric tons of measured and indicated resources containing $0.23 \%$ rubidium and 302 parts per million cesium. Located in the Karibib Pegmatite Belt, lithium would be the primary product, with cesium, potassium, and rubidium as potential byproducts.

World Mine Production and Reserves: ${ }^{1}$ There were no official sources for rubidium production data in 2020. Lepidolite and pollucite, the principal rubidium-containing minerals in global rubidium reserves, can contain up to $3.5 \%$ and $1.5 \%$ rubidium oxide, respectively. Rubidium-bearing mineral resources are found in zoned pegmatites. Mineral resources exist globally, but extraction and concentration are mostly cost prohibitive. No reliable data are available to determine reserves for specific countries; however, Australia, Canada, China, Namibia, and Zimbabwe were thought to have reserves totaling less than 200,000 tons.

World Resources: ${ }^{1}$ Significant rubidium-bearing pegmatite occurrences have been identified in Afghanistan, Australia, Canada, China, Denmark, Germany, Japan, Kazakhstan, Namibia, Peru, Russia, the United Kingdom, the United States, and Zambia. Minor quantities of rubidium are reported in brines in northern Chile and China and in evaporites in the United States (New Mexico and Utah), France, and Germany.

Substitutes: Rubidium and cesium can be used interchangeably in many applications because they have similar physical properties and atomic radii. Cesium, however, is more electropositive than rubidium, making it a preferred material for some applications.

${ }^{1}$ See Appendix $C$ for resource and reserve definitions and information concerning data sources. 
(Data in thousand metric tons unless otherwise noted)

Domestic Production and Use: Domestic production of salt was estimated to have decreased by $7 \%$ in 2020 to 39 million tons. The total value of salt sold or used was estimated to be about $\$ 2.4$ billion. Twenty-six companies operated 63 plants in 16 States. The top producing States were, in alphabetical order, Kansas, Louisiana, Michigan, New York, Ohio, Texas, and Utah. These seven States produced about 95\% of the salt in the United States in 2020. The estimated percentage of salt sold or used was, by type, rock salt, $43 \%$; salt in brine, $40 \%$; vacuum pan salt, $10 \%$; and solar salt, $7 \%$.

Highway deicing accounted for about $43 \%$ of total salt consumed. The chemical industry accounted for about $38 \%$ of total salt sales, with salt in brine accounting for $90 \%$ of the salt used for chemical feedstock. Chlorine and caustic soda manufacturers were the main consumers within the chemical industry. The remaining markets for salt were distributors, $9 \%$; food processing, 4\%; agricultural, $2 \%$; and general industrial and primary water treatment, $1 \%$ each. The remaining $2 \%$ was other uses combined with exports.

\begin{tabular}{|c|c|c|c|c|c|}
\hline Salient Statistics-United States: ${ }^{1}$ & 2016 & 2017 & 2018 & $\underline{2019}$ & $\underline{2020^{\mathrm{e}}}$ \\
\hline Production & $4 \longdiv { 1 , 7 0 0 }$ & 39,600 & $\mathrm{e} 42,000$ & $\mathrm{e} 42,000$ & $3 \overline{9,000}$ \\
\hline Sold or used by producers & 39,900 & 38,200 & $\mathrm{e} 41,000$ & $\mathrm{e} 41,000$ & 38,000 \\
\hline Imports for consumption & 12,100 & 12,600 & 17,900 & 18,600 & 16,000 \\
\hline Exports & 729 & 1,120 & 986 & 1,020 & 1,200 \\
\hline \multicolumn{6}{|l|}{ Consumption: } \\
\hline Apparent $^{2}$ & 51,300 & 49,700 & e 58,000 & e 58,000 & 53,000 \\
\hline Reported & 47,800 & 45,500 & e 48,000 & e 49,000 & 43,000 \\
\hline \multicolumn{6}{|c|}{$\begin{array}{l}\text { Price, average value of bulk, pellets and packaged salt, } \\
\text { f.o.b. mine and plant, dollars per ton: }\end{array}$} \\
\hline Vacuum and open pan salt & 197.78 & 211.71 & e220.00 & e215.00 & 215.00 \\
\hline Solar salt & 99.69 & 115.88 & e120.00 & e120.00 & 120.00 \\
\hline Rock salt & 56.75 & 60.41 & e58.00 & e58.00 & 57.00 \\
\hline Salt in brine & 8.68 & 9.49 & eg.00 & eg.00 & 9.00 \\
\hline Employment, mine and plant, numbere & 4,000 & 4,100 & 4,100 & 4,100 & 4,000 \\
\hline $\begin{array}{l}\text { Net import reliance }{ }^{3} \text { as a percentage of } \\
\text { apparent consumption }\end{array}$ & 22 & 23 & 29 & 30 & 27 \\
\hline
\end{tabular}

Recycling: None.

Import Sources (2016-19): Chile, 33\%; Canada, 24\%; Mexico, 13\%; Egypt, 9\%; and other, 21\%.

\section{Tariff: Item}

Salt (sodium chloride)
Number

2501.00 .0000
Normal Trade Relations 12-31-20 Free.

Depletion Allowance: $10 \%$ (domestic and foreign).

Government Stockpile: None.

Events, Trends, and Issues: The global COVID-19 pandemic affected production and consumption of salt throughout the world in 2020. The most significant impact was felt in the chloroalkali industry because international trade declined, but the entire salt sector was negatively affected to varying degrees. The chloralkali industry was also disrupted by severe weather events, mainly hurricanes, in the primary production areas of Louisiana and Texas.

The 2019-20 winter was slightly milder than average after several years of average or below average winter temperatures and more winter weather events than usual. The number of winter weather events including freezing rain, sleet, and snow is a better predictor of demand for rock salt than total snow fall. Several low snowfall or icing events will usually require more salt for highway deicing than a single large snowfall event. Rock salt production and imports in 2020 decreased compared with those of 2019 because demand from many local and State transportation departments decreased. Most local and State governments in regions that experienced a less intense winter season reportedly had remaining stockpiles and therefore less need to replenish supplies of rock salt for the winter of 2020-21. 
For the winter of 2020-21, the National Oceanic and Atmospheric Administration predicted a moderate to strong La Niña weather pattern. A strong La Niña historically favors an average to warmer temperature pattern, but a moderate La Niña favors a colder winter. Based on several factors, the forecasts slightly favored a wetter than normal winter. A warmer and drier pattern was predicted for the southern areas of the United States, but the northwestern and northern plains were more likely to have below average temperatures and elevated precipitation. Areas from the mid-Atlantic to New England were thought to have a better than average chance for warmer temperatures and average precipitation. These forecasts would indicate that demand for rock salt could increase in the Midwest and decrease in the northeastern United States from Maine through Virginia.

Demand for salt brine used in the chloralkali industry was expected to rebound in 2021 as demand for caustic soda increases globally, especially in Asia. Exports from Australia and especially India increased to meet the increasing demand for caustic soda in China, but tensions between China and both countries could affect trade.

\section{World Production and Reserves:}

\begin{tabular}{|c|c|c|}
\hline & Mine pr & uction ${ }^{\mathrm{e}}$ \\
\hline & 2019 & 2020 \\
\hline United States ${ }^{1}$ & 42,000 & $39 \overline{9,000}$ \\
\hline Australia & 13,000 & 12,000 \\
\hline Belarus & 3,300 & 3,000 \\
\hline Brazil & 7,400 & 7,200 \\
\hline Canada & 11,000 & 10,000 \\
\hline Chile & 10,000 & 10,000 \\
\hline China & 59,000 & 60,000 \\
\hline Djibouti & 3,800 & 3,500 \\
\hline France & 5,600 & 5,500 \\
\hline Germany & 14,300 & 14,000 \\
\hline India & 29,000 & 28,000 \\
\hline Iran & 3,000 & 3,000 \\
\hline Italy & 4,200 & 4,000 \\
\hline Mexico & 9,000 & 9,000 \\
\hline Netherlands & 5.910 & 5,000 \\
\hline Pakistan & 3,700 & 3,000 \\
\hline Poland & 4,480 & 4,000 \\
\hline Russia & 6,700 & 6,000 \\
\hline Spain & 4,200 & 4,000 \\
\hline Turkey & 6,500 & 6,400 \\
\hline United Kingdom & 4,100 & 4,000 \\
\hline Other countries & 33,000 & 30,000 \\
\hline World total (rounded) & $\overline{283,000}$ & $\overline{270,000}$ \\
\hline
\end{tabular}

Reserves $^{4}$

Large. Economic and subeconomic deposits of salt are substantial in principal salt-producing countries. The oceans contain a virtually inexhaustible supply of salt.

World Resources: ${ }^{4}$ World continental resources of salt are vast, and the salt content in the oceans is nearly unlimited. Domestic resources of rock salt and salt from brine are primarily in Kansas, Louisiana, Michigan, New York, Ohio, and Texas. Saline lakes and solar evaporation salt facilities are in Arizona, California, Nevada, New Mexico, Oklahoma, and Utah. Almost every country in the world has salt deposits or solar evaporation operations of various sizes.

Substitutes: No economic substitutes or alternatives for salt exist in most applications. Calcium chloride and calcium magnesium acetate, hydrochloric acid, and potassium chloride can be substituted for salt in deicing, certain chemical processes, and food flavoring, but at a higher cost.

\footnotetext{
eEstimated.

${ }^{1}$ Excludes production from Puerto Rico.

${ }^{2}$ Defined as sold or used by producers + imports - exports.

${ }^{3}$ Defined as imports - exports.

${ }^{4}$ See Appendix $\mathrm{C}$ for resource and reserve definitions and information concerning data sources.
} 


\section{SAND AND GRAVEL (CONSTRUCTION) ${ }^{1}$}

(Data in million metric tons unless otherwise noted)

Domestic Production and Use: In 2020, 960 million tons of construction sand and gravel valued at \$9.2 billion was produced by an estimated 3,870 companies operating 6,800 pits and 340 sales and distribution yards in 50 States. Leading producing States were, in order of decreasing tonnage, California, Texas, Arizona, Minnesota, Michigan, Utah, Ohio, Washington, Colorado, and New York, which together accounted for about $53 \%$ of total output. It is estimated that about $46 \%$ of construction sand and gravel was used as portland cement concrete aggregates, $21 \%$ for road base and coverings and road stabilization, $13 \%$ for construction fill, $12 \%$ for asphaltic concrete aggregate and for other bituminous mixtures, and $4 \%$ for other miscellaneous uses. The remaining $4 \%$ was used for concrete products, filtration, golf course maintenance, plaster and gunite sands, railroad ballast, road stabilization, roofing granules, and snow and ice control.

The estimated output of construction sand and gravel in the United States shipped for consumption in the first 9 months of 2020 was 719 million tons, a slight decrease compared with that of the same period of 2019. Third quarter shipments for consumption decreased by $4 \%$ compared with those of the same period of 2019. Additional production information by quarter for each State, geographic region, and the United States is published by the U.S. Geological Survey in its quarterly Mineral Industry Surveys for crushed stone and sand and gravel.

\section{Salient Statistics-United States:}

Production

Imports for consumption

Exports

Consumption, apparent ${ }^{3}$

Price, average value, dollars per metric ton

Employment, mine and mill, number ${ }^{4}$

Net import reliance ${ }^{5}$ as a percentage of

apparent consumption

\begin{tabular}{r}
2016 \\
\hline 887 \\
3 \\
$(2)$ \\
891 \\
8.41 \\
35,300
\end{tabular}

(2)

2017
880
7
$(2)$
886
8.83
36,500

1

\begin{tabular}{r}
2018 \\
\hline 937 \\
6 \\
$(2)$ \\
943 \\
9.14 \\
38,600
\end{tabular}

1

\begin{tabular}{r}
2019 \\
\hline 962 \\
5 \\
$(2)$ \\
967 \\
9.32 \\
39,600
\end{tabular}

1 $2020^{\mathrm{e}}$

960

5

(2)

965

9.59

36,300

1

Import Sources (2016-19): Canada, 95\%; Mexico, 3\%; and other, 2\%.

Tariff: Item

Number

Sand, other

Pebbles and gravel

Depletion Allowance: Common varieties, 5\% (domestic and foreign).

Government Stockpile: None.

\author{
Normal Trade Relations \\ 12-31-20 \\ Free. \\ Free.
}


Events, Trends, and Issues: Construction sand and gravel production was about 960 million tons in 2020, a slight decrease compared with that of 2019. Apparent consumption also decreased slightly to 965 million tons. Demand for construction sand and gravel decreased in 2020 because of measures instituted to mitigate the spread of the global COVID-19 pandemic that caused disruptions in the mining and construction industries. Usually commercial and heavy-industrial construction activity, infrastructure funding, new single-family housing unit starts, and weather affect growth in sand and gravel production and consumption. Long-term increases in construction aggregates demand will be influenced by activity in the public and private construction sectors, as well as by construction work related to security measures being implemented around the Nation. The underlying factors that would support a rise in prices of construction sand and gravel are expected to be present in 2021, especially in and near metropolitan areas.

The construction sand and gravel industry remained concerned with environmental, health, permitting, safety, and zoning regulations. Movement of sand and gravel operations away from densely populated regions was expected to continue where regulations and local sentiment discouraged them. Resultant regional shortages of construction sand and gravel would result in higher-than-average price increases in industrialized and urban areas.

\section{World Mine Production and Reserves:}

\begin{tabular}{|c|c|c|}
\hline & \multicolumn{2}{|c|}{ Mine production } \\
\hline & $\underline{2019}$ & $\underline{2020^{\circ}}$ \\
\hline United States & 962 & 960 \\
\hline Other countries ${ }^{7}$ & NA & NA \\
\hline World total & $\overline{\mathrm{NA}}$ & $\overline{\mathrm{N}}$ \\
\hline
\end{tabular}

\section{Reserves $^{6}$}

Reserves are controlled largely by land use and (or) environmental concerns.

World Resources: ${ }^{6}$ Sand and gravel resources are plentiful throughout the world. However, because of environmental regulations, geographic distribution, and quality requirements for some uses, sand and gravel extraction is uneconomical in some cases. The most important commercial sources of sand and gravel have been glacial deposits, river channels, and river flood plains. Use of offshore deposits in the United States is mostly restricted to beach erosion control and replenishment. Other countries routinely mine offshore deposits of aggregates for onshore construction projects.

Substitutes: Crushed stone, the other major construction aggregate, is often substituted for natural sand and gravel, especially in more densely populated areas of the Eastern United States. Crushed stone remains the dominant choice for construction aggregate use. Increasingly, recycled asphalt and portland cement concretes are being substituted for virgin aggregate, although the percentage of total aggregate supplied by recycled materials remained very small in 2020.

\footnotetext{
eEstimated. NA Not available.

${ }^{1}$ See also Sand and Gravel (Industrial) and Stone (Crushed).

${ }^{2}$ Less than $1 / 2$ unit.

${ }^{3}$ Defined as production + imports - exports.

${ }^{4}$ Including office staff. Source: Mine Safety and Health Administration.

${ }^{5}$ Defined as imports - exports.

${ }^{6}$ See Appendix $C$ for resource and reserve definitions and information concerning data sources.

${ }^{7} \mathrm{No}$ reliable production information is available for most countries owing to the wide variety of ways in which countries report their sand and gravel production. Some countries do not report production for this mineral commodity. Production information for some countries is available in the U.S. Geological Survey Minerals Yearbook, volume III, Area Reports-International.
} 
Domestic Production and Use: In 2020, industrial sand and gravel valued at about $\$ 3.2$ billion was produced by about 180 companies from about 280 operations in 34 States. The value of production of industrial sand and gravel in 2020 decreased by $40 \%$ compared with that of the previous year, owing primarily to reduced demand for hydraulicfracturing sand and metallurgical uses. Demand declined as a result of restrictions put in place in response to the global COVID-19 pandemic coupled with ongoing weak demand from the oil and gas sector. Leading producing States were Texas, Wisconsin, Illinois, Missouri, Minnesota, Oklahoma, Mississippi, North Carolina, Louisiana, and lowa, in descending order of tonnage produced. Combined production from these States accounted for about $81 \%$ of total domestic sales and use. About $58 \%$ of the U.S. tonnage was used as hydraulic-fracturing sand and well-packing and cementing sand; as glassmaking sand and as other whole-grain silica, $12 \%$ each; as foundry sand, $4 \%$; as ceramics, whole-grain fillers for building products, and recreational sand, $3 \%$ each; and as other ground silica, $2 \%$. Abrasives, chemicals, fillers, filtration sand, metallurgical flux, roofing granules, silica gravel, and traction sand, combined, accounted for the remaining $3 \%$ of industrial sand and gravel end uses.

\begin{tabular}{|c|c|c|c|c|c|}
\hline Salient Statistics-United S & 2016 & $\underline{2017}$ & $\underline{2018}$ & $\underline{2019}$ & $2020^{\mathrm{e}}$ \\
\hline Sold or used & 79,400 & 103,000 & 123,000 & $11 \overline{4,000}$ & $7 \overline{1,000}$ \\
\hline Imports for consumption & 281 & 366 & 392 & 389 & 380 \\
\hline Exports & 2,780 & 4,680 & 6,550 & 5,620 & 3,700 \\
\hline Consumption, apparent ${ }^{2}$ & 76,900 & 98,700 & 117,000 & 109,000 & 68,000 \\
\hline Price, average value, dollars per ton & 35.40 & 52.00 & 56.40 & 47.30 & 45.00 \\
\hline Employment, quarry and mill, numbere & 3,500 & 4,000 & 4,000 & 3,500 & 2,000 \\
\hline $\begin{array}{l}\text { Net import reliance }{ }^{3} \text { as a percentage } \\
\text { of apparent consumption }\end{array}$ & $\mathrm{E}$ & $E$ & $E$ & $\mathrm{E}$ & $E$ \\
\hline
\end{tabular}

Recycling: Some foundry sand is recycled, and recycled cullet (pieces of glass) represents a significant proportion of reused silica. About $34 \%$ of glass containers are recycled.

Import Sources (2016-19): Canada, 85\%; Taiwan and Vietnam, 3\% each; and other, 9\%.

Tariff: Item

Sand containing $95 \%$ or more silica

and not more than $0.6 \%$ iron oxide
Number

Normal Trade Relations 12-31-20

2505.10.1000

Free.

Depletion Allowance: Industrial sand or pebbles, 14\% (domestic and foreign).

Government Stockpile: None.

Events, Trends, and Issues: U.S. apparent consumption of industrial sand and gravel was estimated to be 68 million tons in 2020, a 38\% decrease from that of the previous year. The primary causes of the decline were decreased natural gas and petroleum well drilling in North America and oil well completion activity. These decreases were exacerbated by COVID-19 pandemic restrictions, which resulted in a significant decline in consumption of petroleum products, which in turn prompted a decrease in demand for hydraulic-fracturing sand in 2020 compared with that of the previous year. Imports of industrial sand and gravel in 2020 were about 380,000 tons-slightly less than those of 2019. Imports of silica are generally of two types - small shipments of very high-purity silica or a few large shipments of lower grade silica shipped only under special circumstances (for example, very low freight rates). The United States remained a net exporter of industrial sand and gravel, although U.S. exports of industrial sand and gravel decreased by $34 \%$ in 2020 compared with those of 2019 , also a result of the global pandemic.

The United States was the world's leading producer and consumer of industrial sand and gravel based on estimated world production figures. It is difficult to collect definitive data on industrial sand and gravel (sometimes also referred to as silica sand and gravel) production in most nations because of the wide range of terminology and specifications used by different countries. The United States remained a major exporter of industrial sand and gravel, shipping it to almost every region of the world. High global demand for U.S. industrial sand and gravel can be attributed to the high quality and advanced processing techniques used in the United States for many grades of industrial sand and gravel, meeting specifications for virtually any use. 


\section{SAND AND GRAVEL (INDUSTRIAL)}

The duration and outcome of the COVID-19 pandemic remains uncertain, but it is likely that the performance of the industrial sand and gravel industry will continue to be negatively affected, although natural gas and petroleum well drilling activity began to recover in the latter part of the year, indicating that demand for hydraulic-fracturing sand may increase also. The effects of the pandemic were felt throughout the industry with employment declining in the industry and several companies filing for Chapter 11 bankruptcy protection during the year.

Additionally, the industrial sand and gravel industry continued to be concerned with safety and health regulations and environmental restrictions in 2020, especially those concerning crystalline silica exposure. In 2016, the Occupational Safety and Health Administration (OSHA) finalized regulations to further restrict exposure to crystalline silica at quarry sites and in other industries that use materials containing it. Phased implementation of the new regulations was scheduled to take effect through 2021, affecting various industries that use materials containing silica. Local shortages of industrial sand and gravel were expected to continue to increase owing to land development priorities, local zoning regulations, and logistical issues, including ongoing development and permitting of operations producing hydraulic-fracturing sand. Natural gas and petroleum operations that use hydraulic fracturing may also undergo increased scrutiny. These factors may result in future sand and gravel operations being located farther from highpopulation centers.

\section{World Mine Production and Reserves:}

\begin{tabular}{lrr} 
& \multicolumn{2}{c}{ Mine production } \\
United States & $\underline{\mathbf{2 0 1 9}}$ & $\underline{\mathbf{2 0 2 0}}$ \\
Australia & 11,000 & 71,000 \\
Bulgaria & 3,000 & 2,900 \\
Canada & 7,650 & 7,300 \\
France & 2,800 & 2,700 \\
Germany & 9,310 & 8,800 \\
India & 7,500 & 7,100 \\
Indonesia & 11,900 & 11,000 \\
Italy & 5,540 & 2,600 \\
Japan & 14,000 & 13,000 \\
Korea, Republic of & 2,270 & 2,200 \\
Malaysia & 4,250 & 1,300 \\
Mexico & 10,000 & 9,500 \\
Netherlands & 2,360 & 2,300 \\
New Zealand & 54,000 & 51,000 \\
Poland & 1,620 & 1,500 \\
South Africa & 5,110 & 4,800 \\
Spain & 2,300 & 1,900 \\
Turkey & 35,500 & 34,000 \\
United Kingdom & 9,100 & 8,600 \\
Other countries & 4,000 & 3,800 \\
$\quad$ World total (rounded) & 18,900 & 18,000 \\
\hline Wan & 325,000 & 265,000
\end{tabular}

World Resources: ${ }^{5}$ Sand and gravel resources of the world are large. However, because of their geographic distribution, environmental restrictions, and quality requirements for some uses, extraction of these resources is sometimes uneconomic. Quartz-rich sand and sandstone, the main sources of industrial silica sand, occur throughout the world.

Substitutes: Alternative materials that can be used for glassmaking and for foundry and molding sands are chromite, olivine, staurolite, and zircon sands. Although costlier and mostly used in deeper wells, alternative materials that can be used as proppants are sintered bauxite and kaolin-based ceramic proppants.

\footnotetext{
eEstimated. E Net exporter.

${ }^{1}$ See also Sand and Gravel (Construction).

${ }^{2}$ Defined as production (sold or used) + imports - exports.

${ }^{3}$ Defined as imports - exports.

${ }^{4}$ Deceased.

${ }^{5}$ See Appendix $\mathrm{C}$ for resource and reserve definitions and information concerning data sources.
} 


\section{SCANDIUM1}

(Data in metric tons of scandium oxide equivalent unless otherwise noted)

Domestic Production and Use: Domestically, scandium was neither mined nor recovered from process streams or mine tailings in 2020. Previously, scandium was produced domestically primarily from the scandium-yttrium silicate mineral thortveitite and from byproduct leach solutions from uranium operations. Limited capacity to produce ingot and distilled scandium metal existed at facilities in Ames, IA; Tolleson, AZ; and Urbana, IL. The principal uses for scandium in 2020 were in aluminum-scandium alloys and solid oxide fuel cells (SOFCs). Other uses for scandium included ceramics, electronics, lasers, lighting, and radioactive isotopes.

\begin{tabular}{|c|c|c|c|c|c|}
\hline \multirow{2}{*}{\multicolumn{6}{|c|}{ Salient Statistics-United States: }} \\
\hline & & & & & \\
\hline Acetate, $99.9 \%$ purity, 5 -gram lot size 2 & 44 & 44 & 44 & 45 & 45 \\
\hline Chloride, $99.9 \%$ purity, 5 -gram lot size 2 & 126 & 124 & 125 & 129 & 133 \\
\hline Fluoride, $99.9 \%$ purity, 1 - to 5 -gram lot size 3 & 270 & 277 & 206 & 209 & 214 \\
\hline lodide, $99.999 \%$ purity, 5 -gram lot size ${ }^{2}$ & 149 & 183 & 165 & 157 & 161 \\
\hline Oxide, $99.99 \%$ purity, 5 -kilogram lot size 4 & 4.6 & 4.6 & 4.6 & 3.9 & 3.8 \\
\hline Metal: & & & & & \\
\hline $\begin{array}{l}\text { Scandium, distilled dendritic, 2-gram lot size, }{ }^{2} \\
\text { dollars per gram }\end{array}$ & 228 & 226 & 226 & 233 & 233 \\
\hline Scandium, ingot, 5-gram lot size, ${ }^{2}$ & & & & & \\
\hline dollars per gram & 107 & 132 & 132 & 134 & 134 \\
\hline $\begin{array}{l}\text { Scandium-aluminum alloy, 1-kilogram lot size, }{ }^{4} \\
\text { dollars per kilogram }\end{array}$ & 340 & 350 & 360 & 300 & 340 \\
\hline $\begin{array}{l}\text { Net import reliance } 5 \text { as a percentage of } \\
\text { apparent consumption }\end{array}$ & 100 & 100 & 100 & 100 & 100 \\
\hline
\end{tabular}

Recycling: None.

Import Sources (2016-19): Although no definitive data exist listing import sources, imported material is mostly from Europe, China, Japan, and Russia.

\section{Tariff: Item}

Rare-earth metals, unspecified, not intermixed or interalloyed

Compounds of rare-earth metals:

Mixtures of oxides of yttrium or scandium as the predominant metal

Mixtures of chlorides of yttrium or scandium as the predominant metal

Mixtures of other rare-earth carbonates, including scandium

Mixtures of other rare-earth compounds, including scandium

\section{Number}

2805.30.0050

2846.90.2015

2846.90.2082

2846.90 .8075

2846.90.8090

\section{Normal Trade Relations} 12-31-20

$5.0 \%$ ad val.

Free.

Free.

$3.7 \%$ ad val.

$3.7 \%$ ad val.

Depletion Allowance: $14 \%$ (domestic and foreign).

Government Stockpile: None.

Events, Trends, and Issues: The global supply and consumption of scandium oxide was estimated to be about 15 to 25 tons per year. Scandium was recovered from titanium, zirconium, cobalt, and nickel process streams. China, the Philippines, and Russia were the leading producers. Prices quoted for scandium oxide in the United States decreased slightly compared with those in 2019. Owing in part to low capacity utilization, China's ex-works prices for scandium oxide were significantly less than United States quoted prices. Although global exploration and development projects continued, the COVID-19 pandemic slowed the development of new projects. 


\section{SCANDIUM}

In the United States, environmental and construction permits were approved by the State of Nebraska on the polymetallic Elk Creek project; however, construction was pending additional financing. Probable reserves were estimated to be 36 million tons containing 65.7 parts per million (2,400 tons) scandium. Plans for the project included downstream production of ferroniobium, titanium dioxide, and scandium oxide. The Bokan project in Alaska and the Round Top project in Texas also included scandium recovery in their process plans. In addition, research continued on the development of methods to separate scandium from coal and coal byproducts.

A global mining and polymetallic metal producer announced that it had developed a method to recover scandium from byproduct streams at its titanium slag operations in Sorel-Tracy, Quebec, Canada. The same company was piloting production of aluminum-scandium alloys. In Australia, several polymetallic projects were under development and seeking permitting, financing, and offtake agreements. Projects included the Owendale and Sunrise projects in New South Wales and the SCONI project in Queensland. In the Philippines, a commercial plant designed to recover scandium at the Taganito high-pressure acid-leach nickel operation entered its second year of operation. In the first half of 2020, production of scandium oxalate was reported to be about 5.7 tons. In Russia, feasibility studies for making scandium oxide as a byproduct of alumina refining in the Ural Mountains were ongoing. The pilot plant was reported to have produced scandium oxide with purity greater than $99 \%$. Based on pilot-plant test results, plans were in place for a 3-ton-per-year scandium oxide plant. In Dalur, Kurgan region, development of scandium recovery as a byproduct of uranium production continued, and production capacity included scandium oxide (570 kilograms per year) and aluminum-scandium alloy (24.5 tons per year). In the European Union, recovery methods were being developed to produce scandium compounds and aluminum-scandium alloys from byproducts of aluminum and titanium mining and processing. In Turkey, a pilot plant produced scandium from byproducts of a nickel and cobalt operation in Gordes; however, the plant produced less than one kilogram of ammonium-scandium-hexafluoride. Globally, several projects were underway to commercialize new aluminum-scandium alloys for casting and additive manufacturing.

World Mine Production and Reserves: ${ }^{6}$ No scandium was recovered from mining operations in the United States. As a result of its low concentration, scandium is produced exclusively as a byproduct during processing of various ores or recovered from previously processed tailings or residues. Historically scandium was produced as byproduct material in China (iron ore, rare earths, titanium, and zirconium), Kazakhstan (uranium), the Philippines (nickel), Russia (apatite and uranium), and Ukraine (uranium). Foreign mine production data for 2020 were not available.

World Resources: ${ }^{6}$ Resources of scandium are abundant. Scandium's crustal abundance is greater than that of lead. Scandium lacks affinity for the common ore-forming anions; therefore, it is widely dispersed in the lithosphere and forms solid solutions with low concentrations in more than 100 minerals. Scandium resources have been identified in Australia, Canada, China, Finland, Guinea, Kazakhstan, Madagascar, Norway, South Africa, the Philippines, Russia, Ukraine, and the United States.

Substitutes: Titanium and aluminum high-strength alloys as well as carbon-fiber materials may substitute in highperformance scandium-alloy applications. Under certain conditions, light-emitting diodes may displace mercury-vapor high-intensity lamps that contain scandium iodide. In some applications that rely on scandium's unique properties, substitution is not possible.

\footnotetext{
eEstimated.

${ }^{1}$ See also Rare Earths. Scandium is one of the 17 rare-earth elements.

2Source: Alfa Aesar, a Johnson Matthey company.

${ }^{3}$ Source: Sigma-Aldrich, a part of Millipore Sigma.

${ }^{4}$ Source: Stanford Materials Corp.

${ }^{5}$ Defined as imports - exports. Quantitative data are not available.

${ }^{6}$ See Appendix $\mathrm{C}$ for resource and reserve definitions and information concerning data sources.
} 


\section{SELENIUM}

(Data in metric tons of selenium content unless otherwise noted)

Domestic Production and Use: In 2020, primary selenium was refined from anode slimes recovered from the electrolytic refining of copper at one facility in Texas. Two other electrolytic copper refineries, operating in Arizona and Utah, did not recover selenium domestically, but did produce selenium-bearing anode slimes. U.S. selenium production and consumption data were withheld to avoid disclosing company proprietary data.

Estimates for end uses in global consumption were, in descending order, metallurgy (including manganese production), glass manufacturing, agriculture, chemicals and pigments, electronics, and other uses.

Selenium is used in blasting caps to control delays; in catalysts to enhance selective oxidation; in copper, lead, and steel alloys to improve machinability; in the electrolytic production of manganese to increase yields; in glass manufacturing to decolorize the green tint caused by iron impurities in container glass and other soda-lime silica glass; in gun bluing to improve cosmetic appearance and provide corrosion resistance; in plating solutions to improve appearance and durability; in rubber compounding chemicals to act as a vulcanizing agent; and in thin-film photovoltaic copper-indium-gallium-diselenide (CIGS) solar cells.

Selenium is an essential micronutrient and is used as a human dietary supplement, a dietary supplement for livestock, and as a fertilizer additive to enrich selenium-poor soils. Selenium is also used as an active ingredient in antidandruff shampoos.

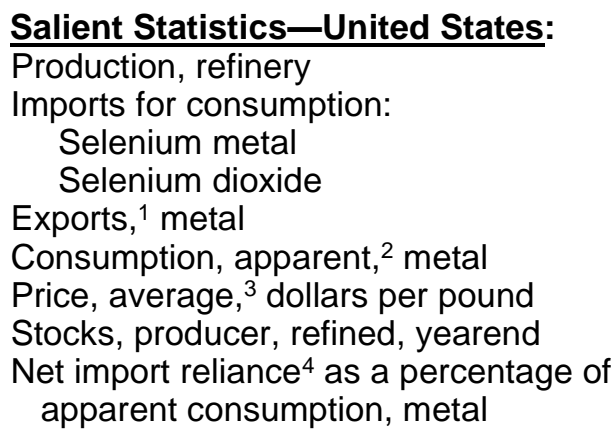

$\begin{array}{rrrrr}\frac{\mathbf{2 0 1 6}}{\text { W }} & \frac{\mathbf{2 0 1 7}}{\mathrm{W}} & \frac{\mathbf{2 0 1 8}}{\mathrm{W}} & \frac{\mathbf{2 0 1 9}}{\mathrm{W}} & \frac{\mathbf{2 0 2 0}}{\mathrm{W}} \\ & & & & \\ 411 & 450 & 445 & 496 & 340 \\ 21 & 19 & 12 & 5 & 13 \\ 150 & 242 & 158 & 361 & 160 \\ \text { W } & \text { W } & \text { W } & \text { W } & \text { W } \\ 23.69 & 10.78 & 18.97 & 20.00 & 20.00 \\ \text { W } & \text { W } & W & W & \text { W } \\ \text { E } & \text { E } & <25 & <25 & <50\end{array}$

Recycling: Domestic production of secondary selenium was estimated to be very small because most scrap from older plain paper photocopiers and electronic materials was exported for recovery of the contained selenium.

Import Sources (2016-19): Selenium metal: China, 20\%; the Philippines, 19\%; Mexico, 14\%; Germany, 13\%; and other, 34\%. Selenium dioxide: China, 27\%; the Republic of Korea, 25\%; Germany, 22\%; Canada, 13\%; and other, $13 \%$.

\section{Tariff: Item}

Selenium metal

Selenium dioxide

\section{Number}

2804.90.0000

2811.29.2000

\author{
Normal Trade Relations \\ 12-31-20 \\ Free. \\ Free.
}

Depletion Allowance: $14 \%$ (domestic and foreign).

Government Stockpile: None.

Events, Trends, and Issues: The supply of selenium is directly affected by the supply of the materials from which it is a byproduct-copper and, to a lesser extent, nickel—and it is directly affected by the number of facilities that recover selenium. The estimated annual average price for selenium was $\$ 20.00$ per pound in 2020 , unchanged from that in 2019. Average monthly prices have remained steady since November 2018. 
Electrolytic manganese production was the main metallurgical end use for selenium in China, where selenium dioxide was used in the electrolytic process to increase current efficiency and the metal deposition rate. Selenium consumption in China was thought to have increased in recent years, owing to higher manganese metal production. In January, Chinese production of selenium dioxide was temporarily halted owing to the COVID-19 pandemic, but production resumed in late February. Later in the year, Chinese importers of selenium had decreased their intakes owing to adequate stocks from previous purchases, reduced demand from the manganese, glassmaking, and ceramics sectors, and sufficient feedstock from domestic copper producers who sold crude selenium to selenium powder and selenium dioxide producers.

\section{World Refinery Production and Reserves:}

\begin{tabular}{|c|c|c|}
\hline & Refinery production 5 & Reserves $^{6}$ \\
\hline & $\underline{2019} \quad 2020^{\mathrm{e}}$ & \\
\hline United States & $\overline{\mathrm{W}}$ & 10,000 \\
\hline Belgium & 200 & - \\
\hline Canada & 57 & 6,000 \\
\hline China & 1,100 & 26,000 \\
\hline Finland & 115 & - \\
\hline Germany & 300 & - \\
\hline Japan & 740 & - \\
\hline Peru & 40 & 13,000 \\
\hline Poland & 64 & 3,000 \\
\hline Russia & 150 & 20,000 \\
\hline Sweden & 19 & - \\
\hline Turkey & 50 & - \\
\hline Other countries ${ }^{7}$ & 45 & 22,000 \\
\hline World total (rounded) & $\overline{72,880}$ & 100,000 \\
\hline
\end{tabular}

World Resources: ${ }^{6}$ Reserves for selenium are based on identified copper deposits and average selenium content. Coal generally contains between 0.5 and 12 parts per million selenium, or about 80 to 90 times the average for copper deposits. The recovery of selenium from coal fly ash, although technically feasible, does not appear likely to be economical in the foreseeable future.

Substitutes: Silicon is the major substitute for selenium in low- and medium-voltage rectifiers. Organic pigments have been developed as substitutes for cadmium sulfoselenide pigments. Other substitutes include cerium oxide as either a colorant or decolorant in glass; tellurium in pigments and rubber; bismuth, lead, and tellurium in freemachining alloys; and bismuth and tellurium in lead-free brasses. Sulfur dioxide can be used as a replacement for selenium dioxide in the production of electrolytic manganese metal, but it is not as energy efficient.

The selenium-tellurium photoreceptors used in some plain paper copiers and laser printers have been replaced by organic photoreceptors in newer machines. Amorphous silicon and cadmium telluride are the two principal competitors with CIGS in thin-film photovoltaic solar cells.

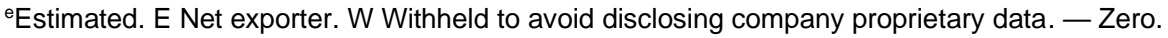

${ }^{1}$ There was no exclusive Schedule B number for selenium dioxide exports.

${ }^{2}$ Defined as production + imports - exports + adjustments for industry stock changes.

${ }^{3}$ U.S. spot market price for selenium metal powder, minimum 99.5\% purity, in 5-ton lots. Source: S\&P Global Platts Metals Week.

${ }^{4}$ Defined as imports - exports + adjustments for industry stock changes; export data are incomplete for common forms of selenium, which may be exported under unexpected or misidentified forms, such as copper slimes, copper selenide, or zinc selenide.

${ }^{5}$ Insofar as possible, data relate to refinery output only; thus, countries that produced selenium contained in blister copper, copper concentrates, copper ores, and (or) refinery residues but did not recover refined selenium from these materials indigenously were excluded to avoid double counting.

${ }^{6}$ See Appendix $\mathrm{C}$ for resource and reserve definitions and information concerning data sources.

${ }^{7}$ Excludes U.S. production. Australia, Iran, Kazakhstan, Mexico, the Philippines, and Uzbekistan are known to produce refined selenium, but output was not reported, and information was inadequate to make reliable production estimates.
} 


\section{SILICON}

(Data in thousand metric tons of silicon content unless otherwise noted)

Domestic Production and Use: Six companies produced silicon materials in 2020, all east of the Mississippi River. Most ferrosilicon was consumed in the ferrous foundry and steel industries, predominantly in the Eastern United States, and was sourced primarily from domestic quartzite (silica). The main consumers of silicon metal were producers of aluminum alloys and the chemical industry, in particular for the manufacture of silicones. The semiconductor and solar energy industries, which manufacture chips for computers and photovoltaic cells from highpurity silicon, respectively, also consumed silicon metal.

\section{Salient Statistics-United States:}

Production, ferrosilicon ${ }^{1}$ and silicon metal ${ }^{2}$

Imports for consumption:

Ferrosilicon, all grades

Silicon metal

Exports:

Ferrosilicon, all grades

Silicon metal

Consumption, apparent, ${ }^{3}$ ferrosilicon ${ }^{1}$ and silicon metal ${ }^{2}$

Price, average, cents per pound of silicon:

Ferrosilicon, $50 \% \mathrm{Si}^{4}$

Ferrosilicon, $75 \% \mathrm{Si}^{5}$

Silicon metal ${ }^{2,5}$

Stocks, producer, ferrosilicon ${ }^{1}$ and silicon metal, ${ }^{2}$

yearend

Net import reliance ${ }^{6}$ as a percentage

of apparent consumption:

Ferrosilicon, all grades

Silicon metal ${ }^{2}$

Total

$\begin{array}{rrrrr}\frac{2016}{384} & \frac{2017}{415} & \frac{2018}{430} & \frac{2019}{310} & \frac{2020^{e}}{290} \\ 155 & 147 & 140 & 127 & 120 \\ 122 & 136 & 116 & 124 & 95\end{array}$

$\begin{array}{llll}122 & 136 & 116 & 124\end{array}$

$\begin{array}{rrrrr}7 & 11 & 12 & 8 & 4 \\ 60 & 71 & 45 & 40 & 31 \\ 601 & 616 & 637 & 517 & 470\end{array}$

$\begin{array}{rrrrr}83 & 94 & 104 & 102 & 104 \\ 71 & 87 & 108 & 89 & 88 \\ 91 & 117 & 134 & 106 & 96\end{array}$

$\begin{array}{lllll}26 & 26 & 19 & 15 & 16\end{array}$

$>50<50 \quad<50 \quad<50 \quad<50$

$<50<50 \quad<50 \quad<50 \quad<50$

$\begin{array}{lllll}36 & 33 & 32 & 40 & 38\end{array}$

Recycling: Insignificant.

Import Sources (2016-19): Ferrosilicon: Russia, 37\%; Canada, 14\%; Brazil, 11\%; and other, 38\%. Silicon metal: Brazil, 30\%; Canada, 20\%; Norway, 12\%; and other, 38\%. Total: Brazil, 20\%; Russia, 20\%; Canada, 16\%; and other, $44 \%$.

\section{Tariff: Item}

Silicon, more than $99.99 \% \mathrm{Si}$

Silicon, $99.00 \%-99.99 \% \mathrm{Si}$

Silicon, other

Ferrosilicon, $55 \%-80 \% \mathrm{Si}$ :

More than $3 \% \mathrm{Ca}$

Other

Ferrosilicon, 80\%-90\% Si

Ferrosilicon, more than $90 \% \mathrm{Si}$

Ferrosilicon, other:

More than 2\% Mg

Other

\section{Number}

2804.61.0000

2804.69.1000

2804.69.5000

7202.21 .1000

7202.21 .5000

7202.21 .7500

7202.21 .9000

7202.29 .0010

7202.29 .0050

Normal Trade Relations
$\frac{\mathbf{1 2 - 3 1 - 2 0}}{\text { Free. }}$
$5.3 \%$ ad val.
$5.5 \%$ ad val.
$1.1 \%$ ad val.
$1.5 \%$ ad val.
$1.9 \%$ ad val.
$5.8 \%$ ad val.
Free.
Free.

Depletion Allowance: Quartzite, 14\% (domestic and foreign); gravel, 5\% (domestic and foreign).

Government Stockpile: None. 
Events, Trends, and Issues: Combined domestic ferrosilicon and silicon metal production in 2020, expressed in terms of contained silicon, decreased from that of 2019. One producer shut down its ferrosilicon production facility on July 1 owing to decreased demand and lower prices-in part because of the global COVID-19 pandemic, as well as competition from lower priced imported ferrosilicon. Domestic production during the first 8 months of 2020 was about $11 \%$ less, on a contained-weight basis, than that during the same period in 2019. By August 2020, average U.S. ferrosilicon spot market prices had increased slightly for $50 \%$-grade ferrosilicon and decreased slightly for $75 \%$-grade ferrosilicon compared with those in 2019; the average silicon metal spot market price had decreased by $10 \%$ compared with the annual average spot price in 2019.

Excluding the United States, ferrosilicon accounted for about $64 \%$ of world silicon production on a silicon-content basis in 2020. The leading countries for ferrosilicon production were, in descending order and on a contained-weight basis, China, Russia, and Norway. For silicon metal, the leading producers were China, Brazil, Norway, and France. China accounted for approximately $68 \%$ of total global estimated production of silicon materials in 2020 . Global production of silicon materials, on a contained weight basis, was estimated to be about 5\% less than that in 2019 .

Steel production, the leading use of ferrosilicon, decreased across the globe in 2020 compared with production in 2019 owing to reduced demand attributed to the global COVID-19 pandemic.

\section{World Production and Reserves:}

\begin{tabular}{|c|c|c|}
\hline & Pro & ion 7 \\
\hline & 2019 & $\underline{2020^{\mathrm{e}}}$ \\
\hline United States & 310 & 290 \\
\hline Bhutan $^{9}$ & 90 & 85 \\
\hline Brazil & 340 & 340 \\
\hline Canada & 57 & 57 \\
\hline China & 5,700 & 5,400 \\
\hline France & 130 & 130 \\
\hline Iceland & 88 & 87 \\
\hline India 9 & 60 & 55 \\
\hline Malaysia $^{9}$ & 150 & 130 \\
\hline Norway & 375 & 330 \\
\hline Russia & 610 & 540 \\
\hline South Africa & 96 & 96 \\
\hline Spain & 66 & 66 \\
\hline Ukraine $^{9}$ & 63 & 60 \\
\hline Other countries & 278 & 290 \\
\hline World total (rounded) & $\overline{8,410}$ & 8,000 \\
\hline
\end{tabular}

\section{Reserves $^{8}$}

The reserves in most major producing countries are ample in relation to demand. Quantitative estimates are not available.

World Resources: ${ }^{8}$ World and domestic resources for making silicon metal and alloys are abundant and, in most producing countries, adequate to supply world requirements for many decades. The source of the silicon is silica in various natural forms, such as quartzite.

Substitutes: Aluminum, silicon carbide, and silicomanganese can be substituted for ferrosilicon in some applications. Gallium arsenide and germanium are the principal substitutes for silicon in semiconductor and infrared applications.

\footnotetext{
eEstimated. W Withheld to avoid disclosing company proprietary data.

${ }^{1}$ Ferrosilicon grades include the two standard grades of ferrosilicon—50\% and $75 \%$ silicon—plus miscellaneous silicon alloys.

${ }^{2}$ Metallurgical-grade silicon metal.

${ }^{3}$ Defined as production + imports - exports + adjustments for industry stock changes.

${ }^{4}$ Source: CRU Group, transaction prices based on weekly averages.

${ }^{5}$ Source: S\&P Global Platts Metals Week, mean import prices based on monthly averages.

${ }^{6}$ Defined as imports - exports + adjustments for industry stock changes.

${ }^{7}$ Production quantities are the silicon content of combined totals for ferrosilicon and silicon metal, except as noted.

${ }^{8}$ See Appendix $\mathrm{C}$ for resource and reserve definitions and information concerning data sources.

${ }^{9}$ Silicon content of ferrosilicon only.
} 


\section{SILVER}

(Data in metric tons ${ }^{1}$ of silver content unless otherwise noted)

Domestic Production and Use: In 2020, U.S. mines produced approximately 1,000 tons of silver with an estimated value of $\$ 670$ million. Silver was produced at 4 silver mines and as a byproduct or coproduct from 33 domestic base- and precious-metal operations. Alaska continued as the country's leading silver-producing State, followed by Nevada. There were 24 U.S. refiners that reported production of commercial-grade silver with an estimated total output of 2,000 tons from domestic and foreign ores and concentrates and from new and old scrap. The physical properties of silver include high ductility, electrical conductivity, malleability, and reflectivity. In 2020 , the estimated domestic uses for silver were electrical and electronics, 28\%; jewelry and silverware, 26\%; coins and medals, 19\%; photography, 3\%; and other, $24 \%$. Other applications for silver include use in antimicrobial bandages, clothing, pharmaceuticals, and plastics; batteries; bearings; brazing and soldering; catalytic converters in automobiles; electroplating; inks; mirrors; photovoltaic solar cells; water purification; and wood treatment. Mercury and silver, the main components of dental amalgam, are biocides, and their use in amalgam inhibits recurrent decay.

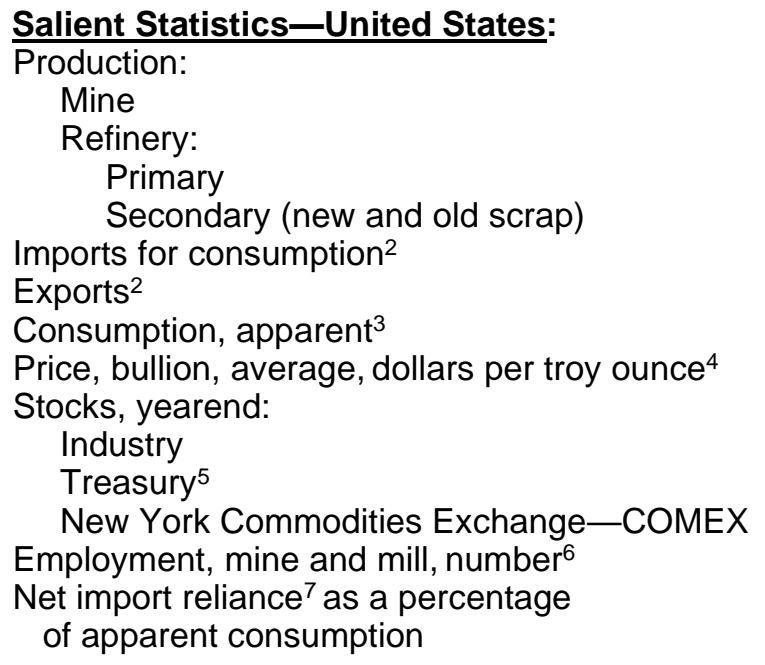

$\begin{array}{rrrrr}\underline{\mathbf{2 0 1 6}} & \underline{\mathbf{2 0 1 7}} & \underline{\mathbf{2 0 1 8}} & \underline{\mathbf{2 0 1 9}} & \underline{\underline{\mathbf{2 0 2 0}}} \\ 1,150 & 1,030 & 934 & 977 & 1,000 \\ 1,530 & 1,420 & 1,420 & 1,420 & 1,400 \\ 866 & 490 & 632 & 643 & 640 \\ 6,160 & 5,040 & 4,830 & 4,760 & 6,500 \\ 289 & 157 & 603 & 220 & 130 \\ 7,890 & 6,420 & 5,790 & 6,160 & 8,000 \\ 17.20 & 17.07 & 15.75 & 17.17 & 20.00 \\ & & & & \\ 63 & 45 & 51 & 52 & 50 \\ 498 & 498 & 498 & 498 & 498 \\ 5,710 & 7,570 & 9,150 & 9,860 & 12,000 \\ 1,050 & 805 & 823 & 869 & 1,100 \\ 74 & 76 & 73 & 74 & 80\end{array}$

Recycling: In 2020, approximately 640 tons of silver was recovered from new and old scrap, about $8 \%$ of apparent consumption.

Import Sources (2016-19):: Mexico, 50\%; Canada, 27\%; Peru, 4\%; Poland, 4\%; and other, 15\%.

Tariff: Item

Silver ores and concentrates, silver content

Bullion, silver content

Dore, silver content

\section{Number}

2616.10.0040

7106.91 .1010

7106.91 .1020
Normal Trade Relations

12-31-20

$0.8 \$ / \mathrm{kg}$ on lead content.

Free.

Free.

Depletion Allowance: 15\% (domestic), 14\% (foreign).

Government Stockpile: The U.S. Department of the Treasury maintains stocks of silver (see salient statistics above).

Events, Trends, and Issues: The estimated average silver price in 2020 was $\$ 20.00$ per troy ounce, $16 \%$ higher than the average price in 2019 . The price began the year at $\$ 17.98$ per troy ounce, then decreased to a low of $\$ 12.13$ per troy ounce on March 18. The price of silver increased to a high of $\$ 28.99$ per troy ounce- in August, because the COVID-19 pandemic caused an increase in investor demand as well as in industrial demand. The price was the highest since March 2013; however, it trended downward through November.

In 2020, global consumption of silver was estimated to have decreased slightly from that of 2019. Coin and bar consumption increased for the fourth year in a row. Consumption for industrial uses was estimated to have decreased in the first half of 2020 owing to lockdown restrictions in response to the COVID-19 pandemic, supply chain disruptions, lowered inventory replenishment, and reduced labor forces within factories. Jewelry and silverware consumption of silver was estimated to have decreased by $23 \%$ and $34 \%$, respectively. In 2020 , there was increased physical investment in silver, reaching an estimated 7,370 tons (236.8 million troy ounces) compared with 5,820 tons (187 million troy ounces) in 2019. Global holdings reached a reported 28,800 tons (925 million troy ounces) compared with 30,890 tons (993 million troy ounces) in $2019 .{ }^{8}$

\section{Prepared by C. Schuyler Anderson [(703) 648-4985, csanderson@usgs.gov]}


World silver mine production decreased by $6 \%$ in 2020 to an estimated 25,000 tons, principally as a result of decreased production from mines in China, Mexico, and Peru, primarily owing to shutdowns in the first half of the year in response to the COVID-19 pandemic. Domestic silver mine production increased slightly in 2020 compared with that in 2019 principally from increased production at mining operations in Alaska. The COVID-19 pandemic did affect silver production in the United States; however, the ending of the strike at the Lucky Friday Mine in January offset the production losses.

World Mine Production and Reserves: Reserves for Australia, Peru, Poland, and the United States were revised based on information from Government and industry sources.

$\begin{array}{lrrr} & \text { Mine production } & \text { Reserves }^{\mathbf{9}} \\ \text { United States } & \frac{\mathbf{2 0 1 9}}{977} & \frac{\mathbf{2 0 2 0}}{1,000} & 26,000 \\ \text { Argentina } & 1,080 & 1,000 & \mathrm{NA} \\ \text { Australia } & 1,330 & 1,300 & 1088,000 \\ \text { Bolivia } & 1,160 & 1,100 & 22,000 \\ \text { Chile } & 1,350 & 1,300 & 26,000 \\ \text { China } & 3,440 & 3,200 & 41,000 \\ \text { Mexico } & 5,920 & 5,600 & 37,000 \\ \text { Peru } & 3,860 & 3,400 & 91,000 \\ \text { Poland } & 1,470 & 1,300 & 70,000 \\ \text { Russia } & 2,000 & 1,800 & 45,000 \\ \text { Other countries } & 3,920 & \frac{3,500}{5,000} & 57,000 \\ \quad \text { World total (rounded) } & 26,500 & 25,000 & 500,000\end{array}$

World Resources: ${ }^{9}$ Although silver was a principal product at several mines, silver was primarily obtained as a byproduct from lead-zinc mines, copper mines, and gold mines, in descending order of production. The polymetallic ore deposits from which silver was recovered account for more than two-thirds of U.S. and world resources of silver. Most recent silver discoveries have been associated with gold occurrences; however, copper and lead-zinc occurrences that contain byproduct silver will continue to account for a significant share of reserves and resources in the future.

Substitutes: Digital imaging, film with reduced silver content, silverless black-and-white film, and xerography substitute for traditional photographic applications for silver. Surgical pins and plates may be made with stainless steel, tantalum, and titanium in place of silver. Stainless steel may be substituted for silver flatware. Nonsilver batteries may replace silver batteries in some applications. Aluminum and rhodium may be used to replace silver that was traditionally used in mirrors and other reflecting surfaces. Silver may be used to replace more costly metals in catalytic converters for off-road vehicles.

\footnotetext{
eEstimated. NA Not available.

${ }^{1}$ One metric ton $(1,000$ kilograms $)=32,150.7$ troy ounces.

${ }^{2}$ Silver content of base metal ores and concentrates, refined bullion, and dore; excludes coinage, and waste and scrap material.

${ }^{3}$ Defined as mine production + secondary production + imports - exports + adjustments for Government and industry stock changes.

${ }^{4}$ Engelhard's industrial bullion quotations. Source: S\&P Global Platts Metals Week.

${ }^{5}$ Source: U.S. Mint. Balance in U.S. Mint only; includes deep storage and working stocks.

${ }^{6}$ Source: U.S. Department of Labor, Mine Safety and Health Administration (MSHA). Only includes mines where silver is the primary product. In 2020, MSHA changed the Mine Employment values in their publicly available database.

${ }^{7}$ Defined as imports - exports + adjustments for Government and industry stock changes.

${ }^{8}$ DiRienzo, Michael, and Newman, Philip, 2020, Key components of silver market affected by pandemic in 2020-Global demand and mine supply impacted, while physical silver investment expected to surge to a 5-year high: Silver Institute and Metal Focus, November 19, 2 p.

${ }^{9}$ See Appendix $\mathrm{C}$ for resource and reserve definitions and information concerning data sources.

${ }^{10}$ For Australia, Joint Ore Reserves Committee-compliant reserves were 25,000 tons.
} 


\section{SODA ASH}

(Data in thousand metric tons unless otherwise noted)

Domestic Production and Use: The total value of domestic natural soda ash (sodium carbonate) produced in 2020 was estimated to be about $\$ 1.5$ billion, ${ }^{1}$ and the quantity produced was 9.7 million tons, about $17 \%$ less than that of the previous year. The U.S. soda ash industry comprised four companies in Wyoming operating five plants and one company in California operating one plant. The five producing companies have a combined annual nameplate capacity of 13.9 million tons (15.3 million short tons). Borax, salt, and sodium sulfate were produced as coproducts of sodium carbonate production in California. Chemical caustic soda, sodium bicarbonate, and sodium sulfite were manufactured as coproducts at several of the Wyoming soda ash plants. Sodium bicarbonate was produced at an operation in Colorado using soda ash feedstock shipped from the company's Wyoming facility.

Based on 2020 quarterly reports, the estimated distribution of soda ash by end use was glass, 48\%; chemicals, 28\%; miscellaneous uses, $8 \%$; soap and detergents, $6 \%$; distributors, $5 \%$; flue gas desulfurization, $3 \%$; pulp and paper, $1 \%$; and water treatment, $1 \%$.

\begin{tabular}{|c|c|c|c|c|c|}
\hline Salient Statistics-United Stat & 2016 & 2017 & 2018 & $\underline{2019}$ & $\underline{2020^{\circ}}$ \\
\hline Production $^{2}$ & 11,800 & 12,000 & $1 \overline{1,900}$ & $1 \overline{1,700}$ & 9,700 \\
\hline Imports for consumption & 35 & 19 & 51 & 115 & 90 \\
\hline Exports & 6,760 & 6,990 & 6,960 & 7,020 & 5,700 \\
\hline \multicolumn{6}{|l|}{ Consumption: } \\
\hline Apparent ${ }^{3}$ & 5,030 & 5,040 & 4,980 & 4,830 & 4,100 \\
\hline Reported & 5,120 & 4,910 & 4,850 & 4,720 & 4,400 \\
\hline \multicolumn{6}{|c|}{$\begin{array}{l}\text { Price, average sales value (natural source), free on } \\
\text { board (f.o.b.) mine or plant: }\end{array}$} \\
\hline Dollars per metric ton & 149.83 & 146.26 & 148.69 & 153.24 & 154 \\
\hline Dollars per short ton & 135.92 & 132.68 & 134.89 & 139.02 & 140 \\
\hline Stocks, producer, yearend & 336 & 293 & 297 & 289 & 320 \\
\hline Employment, mine and plant, numbere & 2,500 & 2,600 & 2,600 & 2,600 & 2,500 \\
\hline Net import reliance 4 as a percentage & & & & & \\
\hline of apparent consumption & $\mathrm{E}$ & $\mathrm{E}$ & $\mathrm{E}$ & $\mathrm{E}$ & $\mathrm{E}$ \\
\hline
\end{tabular}

Recycling: No soda ash was recycled by producers; however, glass container producers use cullet glass, thereby reducing soda ash consumption.

Import Sources (2016-19): Turkey, 62\%; Germany, 9\%; Italy, 7\%; Bulgaria, 5\%; and other, 17\%.

Tariff: Item

Disodium carbonate
Number

2836.20.0000
Normal Trade Relations

12-31-20

$1.2 \%$ ad val.

Depletion Allowance: Natural, 14\% (domestic and foreign).

Government Stockpile: None.

Events, Trends, and Issues: Primarily owing to the global COVID-19 pandemic, U.S. soda ash consumption, exports, imports, production, and sales significantly decreased in 2020 from those of 2019. More than one-half of U.S. production of soda ash was exported, and exports were estimated to have decreased by $19 \%$ compared with those in 2019. Domestic consumption reported by producers decreased by about $7 \%$ in 2020 compared with that of 2019 , and apparent consumption in 2020 decreased by about 15\% compared with that of 2019.

Relatively low production costs and lower environmental impacts provide natural soda ash producers some advantage over producers of synthetic soda ash. The production of synthetic soda ash normally consumes more energy and releases more carbon dioxide than that of natural soda ash. In recent years, U.S. producers of natural soda ash were able to expand their markets when several synthetic soda ash plants were closed or idled in other parts of the world. 
After increasing capacity during the past 3 years, total production capacity in Turkey is estimated to be between 4 million and 5 million tons per year, and soda ash shipments, especially for export, are expected to increase during the next few years. Total United States imports, mostly from Turkey, have recently been about 100,000 tons per year, which is more than double the average amount of annual imports during the past decade.

Three groups dominate production and have become the world's leading suppliers of soda ash-American National Soda Ash Corp., which represented three of the five domestic producers in 2020; multiple producers in China; and Solvay S.A. of Belgium. Increasing soda ash exports from Turkey may affect sales from these three groups. The United States likely will remain competitive with producers in China and Turkey for markets elsewhere in Asia. Asia and South America remain the most likely areas for increased soda ash consumption in the near future.

World Production and Reserves: Reserves for Turkey were revised based on Government and industry reports.

\begin{tabular}{|c|c|c|c|}
\hline \multirow{3}{*}{ Natural: } & \multicolumn{2}{|c|}{ Mine production } & \multirow[t]{2}{*}{ Reserves $^{5,6}$} \\
\hline & $\underline{2019}$ & $\underline{2020^{\mathrm{e}}}$ & \\
\hline & & & \\
\hline United States & 11,700 & 9,700 & $723,000,000$ \\
\hline Botswana & 290 & 250 & 400,000 \\
\hline Ethiopia & 18 & 20 & 400,000 \\
\hline Kenya & 330 & 300 & 7,000 \\
\hline Turkey & 3,500 & 3,400 & $1,650,000$ \\
\hline Other countries & NA & NA & 280,000 \\
\hline World total, natural (rounded) & $\overline{15,800}$ & $\overline{14,000}$ & $\overline{26,000,000}$ \\
\hline World total, synthetic (rounded) & $\underline{41,000}$ & $\underline{38,000}$ & $X X$ \\
\hline World total (rounded) & $\overline{56,800}$ & 52,000 & $\overline{X X}$ \\
\hline
\end{tabular}

World Resources: ${ }^{6}$ Natural soda ash is obtained from trona and sodium carbonate-rich brines. The world's largest deposit of trona is in the Green River Basin of Wyoming. About 47 billion tons of identified soda ash resources could be recovered from the 56 billion tons of bedded trona and the 47 billion tons of interbedded or intermixed trona and halite, which are in beds more than 1.2 meters thick. Underground room-and-pillar mining, using conventional and continuous mining, is the primary method of mining Wyoming trona ore. This method has an average $45 \%$ mining recovery, whereas average recovery from solution mining is 30\%. Improved solution-mining techniques, such as horizontal drilling to establish communication between well pairs, could increase this extraction rate and enable companies to develop some of the deeper trona beds. Wyoming trona resources are being depleted at the rate of about 15 million tons per year (8.3 million tons of soda ash). Searles Lake and Owens Lake in California contain an estimated 815 million tons of soda ash reserves. At least 95 natural sodium carbonate deposits have been identified in the world, the resources of only some of which have been quantified. Although soda ash can be manufactured from salt and limestone, both of which are practically inexhaustible, synthetic soda ash is costlier to produce and generates environmental wastes.

Substitutes: Caustic soda can be substituted for soda ash in certain uses, particularly in the pulp and paper, water treatment, and certain chemical sectors. Soda ash, soda liquors, or trona can be used as feedstock to manufacture chemical caustic soda, which is an alternative to electrolytic caustic soda.

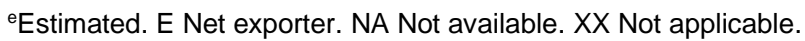

${ }^{1}$ Does not include values for soda liquors and mine waters.

${ }^{2}$ Natural only.

${ }^{3}$ Defined as production + imports - exports + adjustments for industry stock changes.

${ }^{4}$ Defined as imports - exports + adjustments for industry stock changes.

${ }^{5}$ The reported quantities are sodium carbonate only. About 1.8 tons of trona yield 1 ton of sodium carbonate.

${ }^{6}$ See Appendix $C$ for resource and reserve definitions and information concerning data sources.

${ }^{7}$ From trona, nahcolite, and dawsonite deposits.
} 


\section{STONE (CRUSHED) ${ }^{1}$}

(Data in million metric tons unless otherwise noted)

Domestic Production and Use: In 2020, 1.46 billion tons of crushed stone valued at more than $\$ 17.8$ billion was produced by an estimated 1,410 companies operating 3,440 quarries and 180 sales and (or) distribution yards in 50 States. Leading States were, in descending order of production, Texas, Missouri, Florida, Pennsylvania, Ohio, Georgia, Virginia, Illinois, North Carolina, and Kentucky, which combined accounted for more than one-half of the total crushed stone output. Of the total domestic crushed stone produced in 2020 , about $70 \%$ was limestone and dolomite; $15 \%$, granite; $6 \%$, traprock; $5 \%$, miscellaneous stone; $3 \%$, sandstone and quartzite; and the remaining $1 \%$ was divided, in descending order of tonnage, among marble, volcanic cinder and scoria, calcareous marl, slate, and shell. It is estimated that of the 1.5 billion tons of crushed stone consumed in the United States in $2020,72 \%$ was used as construction aggregate, mostly for road construction and maintenance; $16 \%$ for cement manufacturing; $8 \%$ for lime manufacturing; $2 \%$ for agricultural uses; and the remainder for other chemical, special, and miscellaneous uses and products.

The estimated output of crushed stone in the United States shipped for consumption in the first 9 months of 2020 was 1.10 billion tons, a decrease of $3 \%$ compared with that of the same period of 2019 . Third quarter shipments for consumption decreased by $6 \%$ compared with those of the same period of 2019 . Additional production information, by quarter for each State, geographic division, and the United States, is reported in the U.S. Geological Survey quarterly Mineral Industry Surveys for Crushed Stone and Sand and Gravel.

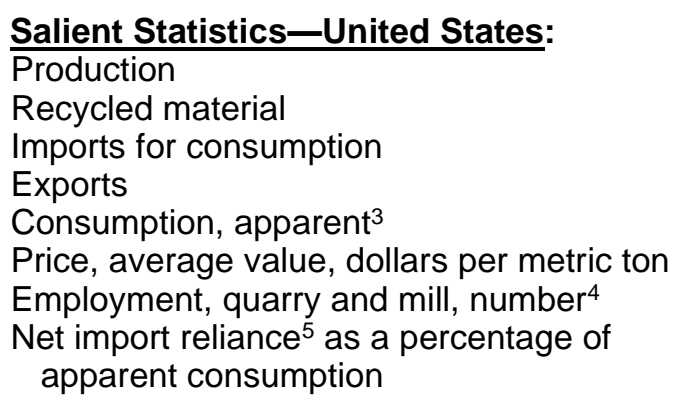

\begin{tabular}{|c|c|c|c|c|}
\hline 2016 & 2017 & 2018 & 2019 & $2020^{\mathrm{e}}$ \\
\hline$\overline{1,360}$ & $\overline{1,370}$ & $\overline{1,390}$ & $\overline{1,490}$ & $\overline{1,460}$ \\
\hline 49 & 43 & 38 & 38 & 38 \\
\hline 20 & 19 & 21 & 24 & 21 \\
\hline 1 & 1 & ${ }^{(2)}$ & $\left(^{2}\right)$ & $\left.{ }^{2}\right)$ \\
\hline 1,430 & 1,430 & 1,450 & 1,550 & 1,520 \\
\hline 11.06 & 11.36 & 11.64 & 11.96 & 12.19 \\
\hline 68,100 & 68,600 & 68,500 & 69,000 & 67,000 \\
\hline 1 & 1 & 1 & 2 & 1 \\
\hline
\end{tabular}

Recycling: Road surfaces made of asphalt concrete and portland cement concrete surface layers, which contain crushed stone aggregate, were recycled on a limited but increasing basis in most States. In 2020, asphalt and portland cement concrete road surfaces were recycled in all 50 States.

Import Sources (2016-19): Mexico, 56\%; Canada, 27\%; The Bahamas, 11\%; Honduras, 5\%; and Jamaica, $1 \%$.

Tariff: Item

Chalk:

Crude

Other

Limestone, except pebbles and gravel

Crushed or broken stone

Marble granules, chippings and powder

Stone granules, chippings and powders

Limestone flux; limestone and other calcareous stone
Number

2509.00.1000

2509.00.2000

2517.10.0020

2517.10.0055

2517.41.0000

2517.49.0000

2521.00 .0000
Normal Trade Relations 12-31-20

Free.

Free.

Free.

Free.

Free.

Free.

Free.

Depletion Allowance: (domestic) 14\% for some special uses; $5 \%$, if used as ballast, concrete aggregate, riprap, road material, and similar purposes.

Government Stockpile: None. 


\section{STONE (CRUSHED)}

Events, Trends, and Issues: Crushed stone production was about 1.46 billion tons in 2020, a slight decrease compared with 1.49 billion tons in 2019. Apparent consumption also decreased slightly to about 1.52 billion tons. Consumption of crushed stone decreased in 2020 because of measures instituted to mitigate the spread of the global COVID-19 pandemic that caused disruptions in the mining and construction industries. Usually commercial and heavy industrial construction activity, infrastructure funding, new single-family housing unit starts, and weather, affect growth in crushed stone production and consumption. Long-term increases in construction aggregates demand are influenced by activity in the public and private construction sectors, as well as by construction work related to security measures being implemented around the Nation. The underlying factors that would support a rise in prices of crushed stone are expected to be present in 2021, especially in and near metropolitan areas.

The crushed stone industry continued to be concerned with environmental, health, and safety regulations. Shortages in some urban and industrialized areas are expected to continue to increase owing to local zoning regulations and land-development alternatives. These issues are expected to continue and to cause new crushed stone quarries to be located away from large population centers.

\section{World Mine Production and Reserves:}

\begin{tabular}{|c|c|c|}
\hline & Mine production & Reserves $^{6}$ \\
\hline United States & $\frac{2019}{1.490} \quad \frac{20 \angle U}{1.460}$ & Adequate, except where special \\
\hline Other countries ${ }^{7}$ & NA & types are needed or where local \\
\hline World total & NA & shortages exist. \\
\hline
\end{tabular}

World Resources: ${ }^{6}$ Stone resources are plentiful throughout the world. Supply of high-purity limestone and dolomite suitable for specialty uses is limited in many geographic areas. The largest resources of high-purity limestone and dolomite in the United States are in the central and eastern parts of the country.

Substitutes: Crushed stone substitutes for roadbuilding include sand and gravel, and iron and steel slag. Substitutes for crushed stone used as construction aggregates include construction sand and gravel, iron and steel slag, sintered or expanded clay or shale, perlite, or vermiculite. Increasingly, recycled asphalt and portland cement concretes are being substituted for virgin aggregate, although the percentage of total aggregate supplied by recycled materials remained very small in 2020.

\footnotetext{
eEstimated. NA Not available.

${ }^{1}$ See also Sand and Gravel (Construction) and Stone (Dimension).

${ }^{2}$ Less than $1 / 2$ unit.

${ }^{3}$ Defined as production + recycled material + imports - exports.

${ }^{4}$ Including office staff. Source: Mine Safety and Health Administration.

${ }^{5}$ Defined as imports - exports.

${ }^{6}$ See Appendix $\mathrm{C}$ for resource and reserve definitions and information concerning data sources.

${ }^{7}$ Consistent production information is not available for other countries owing to the wide variety of ways in which countries report their crushed stone production. Some countries do not report production for this mineral commodity. Production information for some countries is available in the U.S. Geological Survey Minerals Yearbook, volume III, Area Reports-International.
} 


\section{STONE (DIMENSION) ${ }^{1}$}

(Data in thousand metric tons unless otherwise noted)

Domestic Production and Use: Approximately 2.6 million tons of dimension stone, valued at $\$ 400$ million, was sold or used by U.S. producers in 2020. Dimension stone was produced by around 200 companies operating 250 quarries in 34 States. Leading producing States were, in descending order by tonnage, Texas, Wisconsin, Indiana, Vermont, and New York. These five States accounted for about $71 \%$ of the production quantity and contributed about $61 \%$ of the value of domestic production. Approximately $50 \%$, by tonnage, of dimension stone sold or used was limestone, followed by sandstone $(19 \%)$, granite $(17 \%)$, dolomite $(4 \%)$, miscellaneous stone $(3 \%)$, and the remaining $7 \%$ was divided, in descending order of tonnage, among slate, marble, quartzite, and traprock. By value, the leading sales or uses were for limestone $(46 \%)$, followed by granite $(25 \%)$, sandstone $(11 \%)$, slate $(5 \%)$, marble $(4 \%)$, dolomite $(4 \%)$, and the remaining $5 \%$ was divided, in descending order of total value, among quartzite, traprock, and miscellaneous stone. Rough stone represented $54 \%$ of the tonnage and $47 \%$ of the value of all the dimension stone sold or used by domestic producers, including exports. The leading uses and distribution of rough stone, by tonnage, were in building and construction (53\%) and in irregular-shaped stone (35\%). The leading uses and distribution of dressed stone, by tonnage, were in ashlars and partially squared pieces (41\%), slabs and blocks for building and construction (12\%), and curbing (11\%).

\begin{tabular}{|c|c|c|c|c|c|}
\hline $\begin{array}{l}\text { Salient Statistics-United States: } \\
\text { Sold or used by producers: }{ }^{2}\end{array}$ & $\underline{2016}$ & $\underline{2017}$ & $\underline{2018}$ & $\underline{2019}$ & $\underline{2020^{e}}$ \\
\hline Quantity & 2,960 & 2,880 & 2,660 & 2,520 & 2,600 \\
\hline Value, million dollars & 448 & 453 & 437 & 415 & 400 \\
\hline Imports for consumption, value, million dollars & 2,180 & 2,120 & 2,090 & 1,900 & 1,610 \\
\hline Exports, value, million dollars & 65 & 69 & 70 & 59 & 47 \\
\hline Consumption, apparent, value, million dollars ${ }^{3}$ & 2,560 & 2,510 & 2,460 & 2,260 & 1,970 \\
\hline Price & \multicolumn{5}{|c|}{ Variable, depending on type of product } \\
\hline Employment, quarry and mill, number ${ }^{4}$ & 4,000 & 3,900 & 3,900 & 3,900 & 3,900 \\
\hline $\begin{array}{l}\text { Net import reliance } 5 \text { as a percentage of } \\
\text { apparent consumption (based on value) }\end{array}$ & 83 & 82 & 82 & 82 & 79 \\
\hline \multicolumn{6}{|l|}{ Granite only, sold or used by producers: } \\
\hline Quantity & 593 & 526 & 484 & 430 & 400 \\
\hline nillion dollars & 130 & 115 & 108 & 105 & 99 \\
\hline Imports, value, million dollars & 1,120 & 1,020 & 915 & 863 & 720 \\
\hline Exports, value, million dollars & 21 & 22 & 19 & 17 & 13 \\
\hline Consumption, apparent, value, million dollars 3 & 1,220 & 1,110 & 1,000 & 950 & 810 \\
\hline Price & \multicolumn{5}{|c|}{ Variable, depending on type of product } \\
\hline Employment, quarry and mill, number ${ }^{4}$ & 880 & 800 & 800 & 800 & 800 \\
\hline $\begin{array}{l}\text { Net import reliance } 5 \text { as a percentage of } \\
\text { apparent consumption (based on value) }\end{array}$ & 89 & 90 & 89 & 89 & 88 \\
\hline
\end{tabular}

Recycling: Small amounts of dimension stone were recycled, principally by restorers of old stone work.

Import Sources (2016-19 by value): All dimension stone: China, 25\%; Brazil, 23\%; Italy, 19\%; India, 12\%; and other, $21 \%$. Granite only: Brazil, 45\%; China, 23\%; India, 17\%; Italy, 7\%; and other, $8 \%$.

Tariff: Dimension stone tariffs ranged from free to $6.5 \%$ ad valorem, according to type, degree of preparation, shape, and size, for countries with normal trade relations in 2020 . Most crude or roughly trimmed stone was imported at $3.7 \%$ ad valorem or less. 


\section{STONE (DIMENSION)}

Depletion Allowance: All dimension stone, 14\% (domestic and foreign); slate used or sold as sintered or burned lightweight aggregate, $7.5 \%$ (domestic and foreign); dimension stone used for rubble and other nonbuilding purposes, $5 \%$ (domestic and foreign).

\section{Government Stockpile: None.}

Events, Trends, and Issues: The United States remained one of the world's leading markets for dimension stone. In 2020 , total imports of dimension stone decreased in value by about $15 \%$ compared with the value in 2019 . In 2020, increased demand for dimension stone for construction and refurbishment used in residential markets helped offset decreases in commercial markets. Both markets were affected because of the measures instituted to mitigate the spread of the global COVID-19 pandemic. These measures also led to increases in the home remodeling sector, with companies reporting a $40 \%$ to $50 \%$ increase in demand for remodeling projects. Dimension stone exports decreased to about $\$ 47$ million. Apparent consumption, by value, was estimated to be $\$ 2.0$ billion in 2020 -a $13 \%$ decrease compared with that of 2019.

The dimension stone industry continued to be concerned with safety and health regulations and environmental restrictions in 2020, especially those concerning crystalline silica exposure. Beginning in 2016, the Occupational Safety and Health Administration (OSHA) finalized new regulations to further restrict exposure to crystalline silica at quarry sites and other industries that use materials containing it. Phased implementation of the new regulations was scheduled to take effect through 2021, affecting various industries that use materials containing silica. Most provisions of the new regulations became enforceable on June 23,2018 , for general industry and maritime operations.

\section{World Mine Production and Reserves:}

\begin{tabular}{|c|c|c|c|}
\hline \multicolumn{3}{|c|}{ Mine production } & \multirow[t]{2}{*}{ Reserves $^{6}$} \\
\hline & & $2020^{\circ}$ & \\
\hline United States & $\overline{2,520}$ & $\overline{2,600}$ & $\begin{array}{l}\text { Adequate, except for certain speci } \\
\text { types and local shortages. }\end{array}$ \\
\hline $\begin{array}{l}\text { Other countries } \\
\text { World total }\end{array}$ & $\frac{\mathrm{NA}}{\mathrm{NA}}$ & $\frac{N A}{N A}$ & types and local shortages. \\
\hline
\end{tabular}

World Resources: ${ }^{6}$ Dimension stone resources of the world are sufficient. Resources can be limited on a local level or occasionally on a regional level by the lack of a particular kind of stone that is suitable for dimension purposes.

Substitutes: Substitutes for dimension stone include aluminum, brick, ceramic tile, concrete, glass, plastics, resinagglomerated stone, and steel.

\footnotetext{
eEstimated. NA Not available.

${ }^{1}$ See also Stone (Crushed).

${ }^{2}$ Includes granite, limestone, and other types of dimension stone.

${ }^{3}$ Defined as sold or used (value) + imports (value) - exports (value).

${ }^{4}$ Excludes office staff.

${ }^{5}$ Defined as imports - exports.

${ }^{6}$ See Appendix $\mathrm{C}$ for resource and reserve definitions and information concerning data sources.
} 


\section{STRONTIUM}

(Data in metric tons of strontium content unless otherwise noted)

Domestic Production and Use: Although deposits of strontium minerals occur widely throughout the United States, none have been mined in the United States since 1959. Domestic production of strontium carbonate, the principal strontium compound, ceased in 2006. Virtually all the strontium mineral celestite consumed in the United States since 2006 is thought to have been used as an additive in drilling fluids for oil and natural gas wells. A few domestic companies produced small quantities of downstream strontium chemicals from imported strontium carbonate.

Based on import data, the estimated end-use distribution in the United States for strontium, including celestite and strontium compounds, was, in descending order, ceramic ferrite magnets and pyrotechnics and signals, $27 \%$ each; drilling fluids, 26\%; and electrolytic production of zinc, master alloys, pigments and fillers, and other applications, including glass, $5 \%$ each.

\section{Salient Statistics-United States:}

\section{Production}

Imports for consumption:

Celestite 1

Strontium compounds ${ }^{2}$

Exports, strontium compounds

Consumption, apparent: ${ }^{3}$

Celestite

Strontium compounds Total

Price, average value of celestite imports at port of exportation, dollars per ton

Net import reliance ${ }^{3}$ as a percentage of apparent consumption

$\begin{array}{rrrrr}\frac{\mathbf{2 0 1 6}}{-} & \underline{\mathbf{2 0 1 7}} & \underline{\mathbf{2 0 1 8}} & \underline{\mathbf{2 0 1 9}} & \underline{\mathbf{2 0 2 0}} \\ 4,420 & 11,300 & 16,900 & 7,960 & 1,300 \\ 6,420 & 6,660 & 6,350 & 5,560 & 3,800 \\ 91 & 36 & 32 & 20 & 30 \\ 4,420 & 11,300 & 16,900 & 7,960 & 1,300 \\ \frac{6,330}{10,700} & \frac{6,620}{17,900} & \frac{6,320}{23,200} & \frac{5,540}{13,500} & \frac{3,800}{5,100} \\ 78 & 74 & 78 & 82 & 66 \\ 100 & 100 & 100 & 100 & 100\end{array}$

Recycling: None.

Import Sources (2016-19): Celestite: Mexico, 100\%. Strontium compounds: Mexico, 50\%; Germany, 40\%; China, 6\%; and other, 4\%. Total imports: Mexico, 81\%; Germany, 15\%; China, 2\%; and other, 2\%.

Tariff: Item

Celestite

Strontium compounds:

Strontium metal

Strontium oxide, hydroxide, peroxide

Strontium nitrate

Strontium carbonate
Number

2530.90 .8010

2805.19.1000

2816.40 .1000

2834.29.2000

2836.92.0000
Normal Trade Relations

$\frac{12-31-20}{\text { Freer }}$

Free.

$3.7 \%$ ad val.

$4.2 \%$ ad val.

$4.2 \%$ ad val.

$4.2 \%$ ad val.

Depletion Allowance: 22\% (domestic), 14\% (foreign).

Government Stockpile: None. 


\section{STRONTIUM}

Events, Trends, and Issues: Apparent consumption of strontium declined by $63 \%$ in 2020 compared with that in 2019 because of the economic downturn caused by restrictions imposed worldwide as the result of the global COVID-19 pandemic. Many countries experienced significant industrial declines, and celestite production was estimated to have declined from most sources.

Imports of celestite, the most commonly used strontium mineral, decreased by $84 \%$, likely the result of decreased natural-gas- and oil-drilling activity, which was at least partly caused by the pandemic restrictions. Nearly all celestite imports were from Mexico and were thought to be used as additives in drilling fluids for oil and natural gas exploration and production, which experienced declined activity. For these applications, celestite is ground but undergoes no chemical processing. A small quantity of high-value celestite imports were reported; these were most likely mineral specimens. Although no strontium carbonate was produced in the United States, celestite is the raw material from which strontium carbonate and other strontium compounds are produced.

Strontium carbonate is the most commonly traded strontium compound and is used as the raw material from which other strontium compounds are derived. Strontium carbonate is sintered with iron oxide to produce permanent ceramic ferrite magnets, and strontium nitrate contributes a brilliant red color to fireworks and signal flares. Smaller quantities of these and other strontium compounds were consumed in several other applications, including electrolytic production of zinc, glass production, master alloys, and pigments and fillers. Imports of strontium compounds decreased by $32 \%$ in 2020 .

\section{World Mine Production and Reserves: ${ }^{4}$}

\begin{tabular}{|c|c|c|}
\hline & \multicolumn{2}{|c|}{ Mine production ${ }^{\mathrm{e}}$} \\
\hline & & $\underline{2020}$ \\
\hline United States & - & \\
\hline Argentina & 700 & 670 \\
\hline China & 50,000 & 50,000 \\
\hline Iran & 37,000 & 35,000 \\
\hline Mexico & 40,000 & 38,000 \\
\hline Spain & 90,000 & 86,000 \\
\hline World total (rounded) & $\overline{220,000}$ & 210,000 \\
\hline
\end{tabular}

Reserves $^{5}$

Quantitative estimates of reserves for most countries were not available.

World Resources: ${ }^{5}$ World resources of strontium are thought to exceed 1 billion tons.

Substitutes: Barium can be substituted for strontium in ferrite ceramic magnets; however, the resulting barium composite will have reduced maximum operating temperature when compared with that of strontium composites. Substituting for strontium in pyrotechnics is hindered by difficulty in obtaining the desired brilliance and visibility imparted by strontium and its compounds. In drilling mud, barite is the preferred material, but celestite may substitute for some barite, especially when barite prices are high.

\footnotetext{
EEstimated. - Zero. content.

${ }^{3}$ Defined as imports - exports.

${ }^{4}$ Gross weight of celestite in tons.

${ }^{5}$ See Appendix $\mathrm{C}$ for resource and reserve definitions and information concerning data sources.
}

${ }^{1}$ The strontium content of celestite is $43.88 \%$, assuming an ore grade of $92 \%$, which was used to convert units of celestite to strontium content. ${ }^{2}$ Strontium compounds, with their respective strontium contents, in descending order, include metal (100.00\%); oxide, hydroxide, and peroxide $(70.00 \%)$; carbonate $(59.35 \%)$; and nitrate $(41.40 \%)$. These factors were used to convert gross weight of strontium compounds to strontium 


\section{SULFUR}

(Data in thousand metric tons of sulfur content unless otherwise noted)

Domestic Production and Use: In 2020, recovered elemental sulfur and byproduct sulfuric acid were produced at 95 operations in 27 States. Total shipments were valued at about $\$ 320$ million. Elemental sulfur production was estimated to be 7.6 million tons; Louisiana and Texas accounted for about $50 \%$ of domestic production. Elemental sulfur was recovered, in descending order of tonnage, at petroleum refineries, natural-gas-processing plants, and coking plants by 35 companies at 90 plants in 26 States. Byproduct sulfuric acid, representing about $6 \%$ of production of sulfur in all forms, was recovered at five nonferrous-metal smelters in four States by four companies. Domestic elemental sulfur provided $62 \%$ of domestic consumption, and byproduct sulfuric acid accounted for about $5 \%$. The remaining $33 \%$ of sulfur consumed was provided by imported sulfur and sulfuric acid. About $90 \%$ of sulfur consumed was in the form of sulfuric acid.

\section{Salient Statistics_United States:}

Production:

Recovered elemental

Other forms

Total (rounded)

Shipments, all forms

Imports for consumption:

Recovered elementale

Sulfuric acid, sulfur content

Exports:

Recovered elemental

Sulfuric acid, sulfur content

Consumption, apparent, all forms ${ }^{1}$

Price, reported average value, free on board, mine

and (or) plant, dollars per ton of elemental sulfur

Stocks, producer, yearend

Employment, mine and (or) plant, number

Net import reliance ${ }^{2}$ as a percentage of

apparent consumption

$\begin{array}{rrrrr}\underline{\mathbf{2 0 1 6}} & \underline{\mathbf{2 0 1 7}} & \underline{\mathbf{2 0 1 8}} & \underline{\mathbf{2 0 1 9}} & \underline{\underline{\mathbf{2 0 2}}} \\ 9,070 & 9,070 & 9,000 & 8,110 & 7,600 \\ \frac{673}{9,740} & \frac{560}{9,630} & \frac{672}{9,670} & \frac{596}{8,710} & \frac{520}{8,100} \\ 9,750 & 9,680 & 9,690 & 8,700 & 8,100 \\ & & & & \\ 1,810 & 1,850 & 2,230 & 1,850 & 2,100 \\ 1,050 & 954 & 997 & 971 & 1,200 \\ 2,060 & 2,340 & 2,390 & 2,200 & 1,500 \\ 59 & 80 & 112 & 72 & 70 \\ 10,500 & 10,100 & 10,400 & 9,240 & 9,800 \\ 37.88 & 46.39 & 81.16 & 51.08 & 40.00 \\ 142 & 124 & 118 & 124 & 110 \\ 2,500 & 2,400 & 2,400 & 2,400 & 2,400 \\ 7 & & & & \\ 7 & 4 & 7 & 6 & 17\end{array}$

Recycling: Typically, between 2.5 million tons and 5 million tons of spent sulfuric acid is reclaimed from petroleum refining and chemical processes during any given year.

Import Sources (2016-19): Elemental: Canada, 75\%; Russia, 12\%; Kazakhstan, 6\%; and other, 7\%. Sulfuric acid: Canada, 64\%; Mexico, 17\%; Spain, 6\%; and other, 13\%. Total sulfur imports: Canada, 71\%; Russia 8\%; Mexico, 7\%; Kazakhstan, 4\%; and other, $10 \%$.

\section{Tariff: Item}

Sulfur, crude or unrefined

Sulfur, all kinds, other

Sulfur, sublimed or precipitated

Sulfuric acid
Number

2503.00.0010

2503.00.0090

2802.00.0000

2807.00.0000
Normal Trade Relations

12-31-20

Free.

Free.

Free.

Free.

Depletion Allowance: 22\% (domestic and foreign).

\section{Government Stockpile: None.}

Events, Trends, and Issues: Total U.S. sulfur production in 2020 was estimated to have decreased by $7 \%$ from that of 2019, and shipments also decreased by $7 \%$ from those of 2019. Domestic production of elemental sulfur from petroleum refineries and recovery from natural gas operations decreased by $6 \%$. Sulfur production decreased because of a decline in refinery capacity utilization as a result of decreased demand for refinery products owing to the global COVID-19 pandemic and processing of more sweet crude oil. Domestically, refinery sulfur production is expected to remain low as long as COVID-19 restrictions remain in place. Domestic byproduct sulfuric acid is expected to remain relatively constant, unless one or more of the remaining nonferrous-metal smelters close. 
Domestic phosphate rock consumption in 2020 was estimated to have remained the same as that in 2019 , which resulted in the same consumption of sulfur to process the phosphate rock into phosphate fertilizers.

World sulfur production was slightly less than it was in 2019 as a result of decreased demand resulting from global COVID-19 pandemic restrictions, but production is likely to increase steadily for the foreseeable future. New sulfur demand associated with phosphate fertilizer projects is expected mostly in Africa, but sulfur demand likely will increase in Asia and Eastern Europe. A major change for 2020 was the implementation of new international standards limiting sulfur oxide emissions from ocean-going ships on January 1,2020. The global sulfur content limit of marine fuels was reduced to $0.5 \%$ from $3.5 \%$, which is likely to lead to increased sulfur recovery from fuels in North America, Asia, and Europe.

Contract sulfur prices in Tampa, FL, began 2020 at around $\$ 46$ per long ton. The sulfur price decreased to $\$ 36$ per long ton in mid-April, and then increased to $\$ 58$ per long ton by the end of September. Fourth-quarter 2020 prices were set at $\$ 69$ per long ton. The fourth-quarter price increase was a result of the decreased availability of sulfur owing to reduced output from natural gas and crude oil refining. In the past few years, sulfur prices have been variable, a result of the volatility in the demand for sulfur.

\section{World Production and Reserves:}

\begin{tabular}{|c|c|c|}
\hline & Producti & forms \\
\hline & $\underline{2019}$ & $2020^{\mathrm{e}}$ \\
\hline United States & $\overline{8,710}$ & $\overline{8,100}$ \\
\hline Australia & 900 & 900 \\
\hline Brazil & 500 & 500 \\
\hline Canada & 6,940 & 6,300 \\
\hline Chile & 1,500 & 1,500 \\
\hline China $^{4}$ & 17,500 & 17,000 \\
\hline Finland & 766 & 770 \\
\hline Germany & 670 & 670 \\
\hline India & 3,600 & 3,600 \\
\hline Iran & 2,200 & 2,200 \\
\hline Italy & 550 & 550 \\
\hline Japan & 3,400 & 3,400 \\
\hline Kazakhstan & 3,500 & 3,500 \\
\hline Korea, Republic of & 3,080 & 3,100 \\
\hline Kuwait & 850 & 850 \\
\hline Netherlands & 510 & 510 \\
\hline Poland & 1,190 & 1,200 \\
\hline Qatar & 1,800 & 1,800 \\
\hline Russia & 7,560 & 7,500 \\
\hline Saudi Arabia & 6,500 & 6,500 \\
\hline United Arab Emirates & 3,300 & 3,300 \\
\hline Other countries & 4,500 & 4,300 \\
\hline World total (rounded) & $\overline{80,000}$ & $\overline{78,000}$ \\
\hline
\end{tabular}

\section{Reserves $^{3}$}

Reserves of sulfur in crude oil, natural gas, and sulfide ores are large. Because most sulfur production is a result of the processing of fossil fuels, supplies are expected to be adequate for the foreseeable future. Because petroleum and sulfide ores can be processed long distances from where they are produced, sulfur production may not be in the country to which the reserves were attributed. For instance, sulfur from Saudi Arabian oil may be recovered at refineries in the United States.

World Resources: ${ }^{3}$ Resources of elemental sulfur in evaporite and volcanic deposits, and sulfur associated with natural gas, petroleum, tar sands, and metal sulfides, total about 5 billion tons. The sulfur in gypsum and anhydrite is almost limitless, and 600 billion tons of sulfur is contained in coal, oil shale, and shale that is rich in organic matter. Production from these sources would require development of low-cost methods of extraction. The domestic sulfur resource is about one-fifth of the world total.

Substitutes: Substitutes for sulfur at present or anticipated price levels are not satisfactory; some acids, in certain applications, may be substituted for sulfuric acid, but usually at a higher cost.

\footnotetext{
eEstimated.

${ }^{1}$ Defined as shipments + imports - exports.

${ }^{2}$ Defined as imports - exports + adjustments for industry stock changes.

${ }^{3}$ See Appendix $C$ for resource and reserve definitions and information concerning data sources.

${ }^{4}$ Sulfur production in China includes byproduct elemental sulfur recovered from natural gas and petroleum, the estimated sulfur content of byproduct sulfuric acid from metallurgy, and the sulfur content of sulfuric acid from pyrite.
} 


\section{TALC AND PYROPHYLLITE1}

(Data in thousand metric tons unless otherwise noted)

Domestic Production and Use: Three companies operated five talc producing mines in three States during 2020, and domestic production of crude talc was estimated to have decreased by $12 \%$ to 510,000 tons valued at almost $\$ 21$ million. Talc was mined in Montana, Texas, and Vermont. Total sales (domestic and export) of talc by U.S. producers were estimated to be 430,000 tons valued at about $\$ 100$ million, a $17 \%$ decrease from those in 2019 . Talc produced and sold in the United States was used in ceramics (including automotive catalytic converters) (22\%), paint $(19 \%)$, paper (17\%), plastics $(11 \%)$, rubber $(4 \%)$, roofing (3\%), and cosmetics $(2 \%)$. The remaining $22 \%$ was for agriculture, export, insecticides, and other miscellaneous uses.

One company in North Carolina mined and processed pyrophyllite in 2020. Domestic production was withheld to avoid disclosing company proprietary data and was estimated to have decreased from that in 2019. Pyrophyllite was sold for refractory, paint, and ceramic products.

\begin{tabular}{|c|c|c|c|c|c|}
\hline Salient Statistics-United States: & $\underline{2016}$ & $\underline{2017}$ & $\underline{2018}$ & $\underline{2019}$ & $\underline{2020^{e}}$ \\
\hline Production, mine & $\overline{578}$ & $\overline{610}$ & 648 & 578 & 510 \\
\hline Sold by producers & 528 & 528 & 547 & 515 & 430 \\
\hline Imports for consumption & 378 & 336 & 313 & 281 & 210 \\
\hline Exports & 239 & 220 & 273 & 234 & 180 \\
\hline Consumption, apparent ${ }^{2}$ & 667 & 644 & 586 & 562 & 459 \\
\hline Price, average, milled, dollars per metric ton ${ }^{3}$ & 197 & 214 & 227 & 240 & 240 \\
\hline \multicolumn{6}{|l|}{ Employment, mine and mill, number: 4} \\
\hline Talc & 223 & 206 & 208 & 202 & 185 \\
\hline Pyrophyllite & 30 & 31 & 30 & 31 & 31 \\
\hline $\begin{array}{l}\text { Net import reliance } 5 \text { as a percentage of } \\
\text { apparent consumption }\end{array}$ & 21 & 18 & 7 & 8 & 6 \\
\hline \multicolumn{6}{|l|}{ Recycling: Insignificant. } \\
\hline \multicolumn{6}{|c|}{$\begin{array}{l}\text { Import Sources (2016-19): Pakistan, } 42 \% \text {; Canada, 27\%; China, 18\%; and other, } 13 \% \text {. Large quantities of crude } \\
\text { talc are thought to have been mined in Afghanistan before being milled in and exported from Pakistan. }\end{array}$} \\
\hline Tariff: Item & Number & & \multicolumn{3}{|c|}{$\begin{array}{l}\text { Normal Trade Relations } \\
\underline{12-31-20}\end{array}$} \\
\hline \multicolumn{6}{|l|}{ Natural steatite and talc: } \\
\hline Not crushed, not powdered & 2526.10.0000 & & & Fre & \\
\hline Crushed or powdered & 2526.20 .0000 & & & Fre & \\
\hline Talc, steatite, and soapstone; cut or sawed & 6815.99 .2000 & & & Fre & \\
\hline
\end{tabular}

Depletion Allowance: Block steatite talc: 22\% (domestic), 14\% (foreign). Other talc and pyrophyllite: 14\% (domestic and foreign).

Government Stockpile: None. 
Events, Trends, and Issues: Canada, China, and Pakistan were the principal sources for United States talc imports in recent years. Imports from Pakistan have increased in recent years, and imports from China have stayed at about one-third of previous levels. Canada and Mexico continued to be the primary destinations for United States talc exports, collectively receiving about one-half of exports. Imports and exports of talc and related materials are estimated to have decreased by at least $20 \%$ in 2020 compared with those of 2019 . Primarily owing to the global COVID-19 pandemic, U.S. talc consumption, production, and sales decreased in 2020 from those of 2019.

Ceramic tile and sanitaryware formulations and the technology for firing ceramic tile changed over recent decades, reducing the amount of talc required for the manufacture of some ceramic products. For paint, the industry shifted its focus to production of water-based paint (a product for which talc is not well suited because it is hydrophobic) from oil-based paint in order to reduce volatile emissions. Paper manufacturing began to decrease beginning in the 1990s, and some talc used for pitch control was replaced by chemical agents. For cosmetics, manufacturers of body dusting powders shifted some of their production from talc-based to corn-starch-based products. The paper industry has traditionally been the largest consumer of talc worldwide; however, plastics are expected to overtake paper as the predominant end use within the next several years, as papermakers in Asia make greater use of talc substitutes and as the use of talc in automobile plastics increases.

World Mine Production and Reserves: Reserves for India and the Republic of Korea were revised based on Government and industry sources.

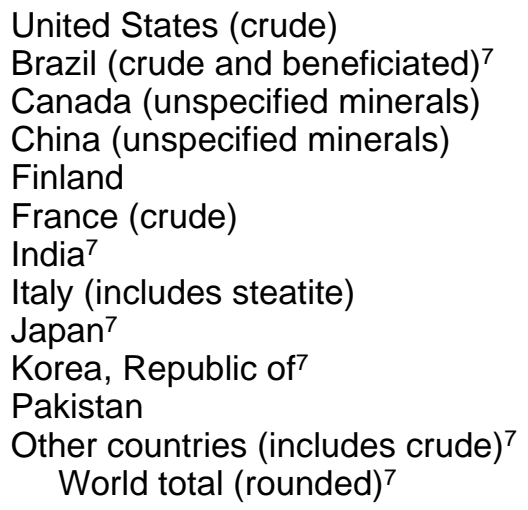

\begin{tabular}{|c|c|}
\hline \multicolumn{2}{|c|}{ Mine production } \\
\hline 2019 & $2020^{\mathrm{e}}$ \\
\hline 578 & 510 \\
\hline 660 & 650 \\
\hline 240 & 220 \\
\hline 1,400 & 1,300 \\
\hline 330 & 320 \\
\hline 450 & 430 \\
\hline 920 & 900 \\
\hline 165 & 150 \\
\hline 160 & 150 \\
\hline 330 & 320 \\
\hline 183 & 170 \\
\hline 728 & 700 \\
\hline 6,140 & 80 \\
\hline
\end{tabular}

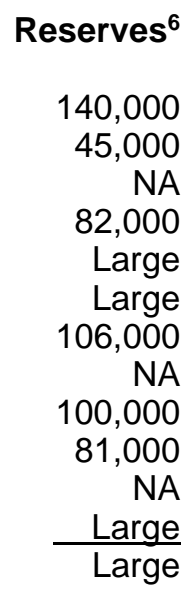

World Resources: ${ }^{6}$ The United States is self-sufficient in most grades of talc and related minerals, but lower priced imports have replaced domestic minerals for some uses. Talc occurs in the United States from New England to Alabama in the Appalachian Mountains and the Piedmont region, as well as in California, Montana, Nevada, Texas, and Washington. Domestic and world identified resources are estimated to be approximately five times the quantity of reserves.

Substitutes: Substitutes for talc include bentonite, chlorite, feldspar, kaolin, and pyrophyllite in ceramics; chlorite, kaolin, and mica in paint; calcium carbonate and kaolin in paper; bentonite, kaolin, mica, and wollastonite in plastics; and kaolin and mica in rubber.

\footnotetext{
eEstimated. NA Not available.

${ }^{1}$ All statistics exclude pyrophyllite unless otherwise noted.

${ }^{2}$ Defined as sold by producers + imports - exports.

${ }^{3}$ Average ex-works unit value of milled talc sold by U.S. producers, based on data reported by companies.

${ }^{4}$ Includes only companies that mine talc or pyrophyllite. Excludes office workers and mills that process imported or domestically purchased material.

${ }^{5}$ Defined as imports - exports.

${ }^{6}$ See Appendix $\mathrm{C}$ for resource and reserve definitions and information concerning data sources.

${ }^{7}$ Includes pyrophyllite.
} 


\section{TANTALUM}

(Data in metric tons of tantalum content unless otherwise noted)

Domestic Production and Use: Significant U.S. tantalum mine production has not been reported since 1959. Domestic tantalum resources are of low grade, some are mineralogically complex, and most are not commercially recoverable. Companies in the United States produced tantalum alloys, capacitors, carbides, compounds, and tantalum metal from imported tantalum ores and concentrates and tantalum-containing materials. Tantalum metal and alloys were recovered from foreign and domestic scrap. Domestic tantalum consumption was not reported by consumers. Major end uses for tantalum included alloys for gas turbines used in the aerospace and oil and gas industries; tantalum capacitors for automotive electronics, mobile phones, and personal computers; tantalum carbides for cutting and boring tools; and tantalum oxide $\left(\mathrm{Ta}_{2} \mathrm{O}_{5}\right)$ was used in glass lenses to make lighter weight camera lenses that produce a brighter image. The value of tantalum consumed in 2020 was estimated to exceed $\$ 210$ million as measured by the value of imports.

\begin{tabular}{|c|c|c|c|c|c|}
\hline \multirow{2}{*}{\multicolumn{6}{|c|}{$\begin{array}{l}\text { Salient Statistics-United States: } \\
\text { Production: }\end{array}$}} \\
\hline & & & & & \\
\hline & - & - & - & - & - \\
\hline Secondary & NA & NA & NA & NA & NA \\
\hline Imports for consumption ${ }^{1}$ & 1,060 & 1,460 & 1,660 & 1,380 & 1,300 \\
\hline Exports $^{1}$ & 604 & 549 & 681 & 423 & 400 \\
\hline Shipments from Government stockpile & - & - & - & - & 2 \\
\hline Consumption, apparent ${ }^{2}$ & 460 & 907 & 975 & 957 & 900 \\
\hline Price, tantalite, dollars per kilogram of $\mathrm{Ta}_{2} \mathrm{O}_{5}$ content $^{3}$ & 193 & 193 & 214 & 161 & 158 \\
\hline Net import reliance 4 as a percentage & 100 & 100 & 100 & 100 & 100 \\
\hline Imption & & 100 & 100 & 100 & 100 \\
\hline
\end{tabular}

Recycling: Tantalum was recycled mostly from new scrap that was generated during the manufacture of tantalumcontaining electronic components and from tantalum-containing cemented carbide and superalloy scrap. The amount of tantalum recycled was not available, but it may be as much as $30 \%$ of apparent consumption.

Import Sources (2016-19): Tantalum ores and concentrates: Rwanda, 36\%; Australia, 25\%; Brazil, 14\%; Congo (Kinshasa), 7\%; and other, 18\%. Tantalum metal and powder: China, 38\%; Germany, 21\%; Thailand, 13\%;

Kazakhstan, 12\%; and other, 16\%. Tantalum waste and scrap: Indonesia, 15\%; China, 13\%; Japan, 13\%; Mexico, 10\%; and other, 49\%. Total: China, 26\%; Germany, 11\%; Australia, 10\%; Indonesia, 10\%, and other, 43\%.

Tariff: Item

Synthetic tantalum-niobium concentrates

Tantalum ores and concentrates

Tantalum oxide 5

Potassium fluorotantalate 5

Tantalum, unwrought:

Powders

Alloys and metal

Tantalum, waste and scrap

Tantalum, other
Number

2615.90.3000

2615.90.6060

2825.90.9000

2826.90.9000

8103.20.0030

8103.20 .0090

8103.30 .0000

8103.90 .0000
Normal Trade Relations 12-31-20

Free.

Free.

$3.7 \%$ ad val.

$3.1 \%$ ad val.

$2.5 \%$ ad val

$2.5 \%$ ad val.

Free.

$4.4 \%$ ad val.

Depletion Allowance: 22\% (domestic), 14\% (foreign).

\section{Government Stockpile: ${ }^{6}$}

\section{Material}

Tantalum carbide powder

Tantalum niobium concentrate (gross weight)

Tantalum metal ${ }^{7}$ (gross weight)

Tantalum alloy (gross weight)

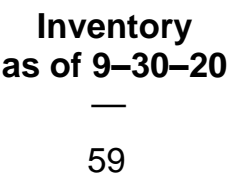

0.084

0.0015
FY 2020

$\begin{array}{cc}\begin{array}{c}\text { Potential } \\ \text { acquisitions }\end{array} & \begin{array}{c}\text { Potential } \\ \text { disposals }\end{array} \\ - & 1.71\end{array}$

15.4

$-$
0.09

15.4

0.09 
Events, Trends, and Issues: U.S. tantalum apparent consumption (measured in contained tantalum) was estimated to have decreased by $6 \%$ from that of 2019 . Most of the tantalum imported was in the form of scrap followed by a slightly lesser quantity of metal and powder; imports of ores and concentrates decreased by almost 20\% from that in 2019 . Globally, consumption of tantalum decreased because of disruptions in transportation and electronics manufacturing supply chains caused by the global COVID-19 pandemic; a leading end use for tantalum was in capacitors. Significant production decreases by major aircraft manufacturers reduced tantalum consumption for superalloys.

World production was lower in part because of temporary mine closures in Brazil and Rwanda caused by the COVID-19 pandemic. Continued low prices for tantalum was also a factor. In Australia, lithium mines that had produced tantalum as a byproduct in 2019 remained on care-and-maintenance status in 2020 because of continued low prices for lithium. Production in Congo (Kinshasa) was estimated to have increased in 2020 based on reported ore production through August 2020; China was the main export destination. Brazil, Congo (Kinshasa), and Rwanda accounted for $77 \%$ of estimated global tantalum mine production in 2020 .

The U.S. Department of Defense issued an interim rule effective October 1, 2020, amending the Defense Federal Acquisition Regulation Supplement to implement a section of the National Defense Authorization Act for Fiscal Year 2020 that prohibits the acquisition of tantalum metal and alloys from China, Iran, North Korea, and Russia.

World Mine Production and Reserves: Reserves for Australia and Brazil were revised based on Government and industry information.

\begin{tabular}{|c|c|c|c|}
\hline \multicolumn{3}{|c|}{ Mine production } & Reserves $^{8}$ \\
\hline United States & $\underline{2019}$ & $\frac{20<0}{-}$ & - \\
\hline Australia & 67 & 30 & 999,000 \\
\hline Brazil & 430 & 370 & 40,000 \\
\hline Burundi & 38 & 30 & NA \\
\hline China & 76 & 70 & NA \\
\hline Congo (Kinshasa) & 580 & 670 & NA \\
\hline Ethiopia & 70 & 60 & NA \\
\hline Nigeria & 180 & 160 & NA \\
\hline Russia & 26 & 26 & NA \\
\hline Rwanda & 336 & 270 & NA \\
\hline Other countries & 45 & 35 & NA \\
\hline World total (rounded) & $\overline{1,850}$ & $\overline{1,700}$ & 140,000 \\
\hline
\end{tabular}

World Resources: ${ }^{8}$ Identified world resources of tantalum, most of which are in Australia, Brazil, and Canada, are considered adequate to supply projected needs. The United States has about 55,000 tons of tantalum resources in identified deposits, most of which were considered uneconomical at 2020 prices for tantalum.

Substitutes: The following materials can be substituted for tantalum, but a performance loss or higher costs may ensue: niobium and tungsten in carbides; aluminum, ceramics, and niobium in electronic capacitors; glass, molybdenum, nickel, niobium, platinum, stainless steel, titanium, and zirconium in corrosion-resistant applications; and hafnium, iridium, molybdenum, niobium, rhenium, and tungsten in high-temperature applications.

\footnotetext{
eEstimated. NA Not available. - Zero.

${ }^{1}$ Imports and exports include the estimated tantalum content of niobium and tantalum ores and concentrates, unwrought tantalum alloys and powder, tantalum waste and scrap, and other tantalum articles. Synthetic concentrates and niobium ores and concentrates were assumed to contain $32 \% \mathrm{Ta}_{2} \mathrm{O}_{5}$. Tantalum ores and concentrates were assumed to contain $37 \% \mathrm{Ta}_{2} \mathrm{O}_{5} . \mathrm{Ta}_{2} \mathrm{O}_{5}$ is $81.897 \% \mathrm{Ta}$.

${ }^{2}$ Defined as production + imports - exports + adjustments for Government stock changes.

${ }^{3}$ Price is annual average price reported by CRU Group. The estimate for 2020 includes data available through October 2020.

${ }^{4}$ Defined as imports - exports + adjustments for Government stock changes.

${ }^{5}$ This category includes tantalum-containing material and other material.

${ }^{6}$ See Appendix B for definitions.

${ }^{7}$ Potential acquisitions are for unspecified tantalum materials; potential disposals are for tantalum scrap in the Government stockpile.

${ }^{8}$ See Appendix $\mathrm{C}$ for resource and reserve definitions and information concerning data sources.

${ }^{9}$ For Australia, Joint Ore Reserves Committee-compliant reserves were 44,400 tons.
} 


\section{TELLURIUM}

(Data in metric tons unless otherwise noted)

Domestic Production and Use: In 2020, tellurium was recovered in the United States. One company in Texas was thought to export copper anode slimes to Mexico for recovery of commercial-grade tellurium. Downstream companies further refined imported commercial-grade metal to produce tellurium dioxide, high-purity tellurium, and tellurium compounds for specialty applications.

Tellurium was predominantly used in the production of cadmium telluride (CdTe) for thin-film solar cells. Another important end use was for the production of bismuth telluride (BiTe), which is used in thermoelectric devices for both cooling and energy generation. Other uses were as an alloying additive in steel to improve machining characteristics, as a minor additive in copper alloys to improve machinability without reducing conductivity, in lead alloys to improve resistance to vibration and fatigue, in cast iron to help control the depth of chill, and in malleable iron as a carbide stabilizer. It was used in the chemical industry as a vulcanizing agent and accelerator in the processing of rubber and as a component of catalysts for synthetic fiber production. Other uses included those in photoreceptor and thermoelectric devices, blasting caps, and as a pigment to produce various colors in glass and ceramics.

Global consumption estimates of tellurium by end use are solar, $40 \%$; thermoelectric production, $30 \%$; metallurgy, $15 \%$; rubber applications, $5 \%$; and other, $10 \%$.

\begin{tabular}{|c|c|c|c|c|c|}
\hline Salient Statistics-United States: & $\underline{2016}$ & $\underline{2017}$ & $\underline{2018}$ & $\underline{2019}$ & $\underline{2020^{e}}$ \\
\hline Production, refinery & $\bar{W}$ & $\bar{W}$ & $\bar{W}$ & $\bar{W}$ & $\overline{\mathrm{W}}$ \\
\hline Imports for consumption & 73 & 163 & 192 & 59 & 7 \\
\hline Exports & 3 & 2 & 4 & 1 & 118 \\
\hline Consumption, apparent ${ }^{2}$ & W & W & W & W & W \\
\hline Price, ${ }^{3}$ dollars per kilogram & 36 & 38 & 73 & 60 & 55 \\
\hline Stocks, producer, refined, yearend & W & W & W & W & W \\
\hline $\begin{array}{l}\text { Net import reliance }{ }^{4} \text { as a percentage of } \\
\text { apparent consumption }\end{array}$ & $>95$ & $>95$ & $>95$ & $>95$ & $>95$ \\
\hline
\end{tabular}

Recycling: For traditional metallurgical and chemical uses, there was little or no old scrap from which to extract secondary tellurium because these uses of tellurium are highly dispersive or dissipative. A very small amount of tellurium was recovered from scrapped selenium-tellurium photoreceptors employed in older plain-paper copiers in Europe. A plant in the United States recycled tellurium from CdTe solar cells; however, the amount recycled was limited because most CdTe solar cells were relatively new and had not reached the end of their useful life.

Import Sources (2016-19): Canada, 57\%; China, 21\%; Germany, 17\%; the Philippines, 3\%; and other, 2\%.

Tariff: Item

Tellurium
Number

2804.50 .0020
Normal Trade Relations

12-31-20

Free.

Depletion Allowance: 14\% (domestic and foreign).

Government Stockpile: None.

Events, Trends, and Issues: In 2020, domestic tellurium content in anode slimes was estimated to have remained essentially unchanged from that in 2019. One domestic producer of anode slimes shipped at least a portion of its anode slimes to Mexico for treatment and refining. In 2020, the domestic average monthly price of tellurium generally decreased in the first 8 months of the year, from around $\$ 65$ per kilogram in January to $\$ 55$ per kilogram in August, after which the prices recovered to around $\$ 60$ per kilogram in September.

Domestic imports of tellurium were estimated to have decreased by about $89 \%$ in 2020 from those of 2019 , mostly as a result of a significant decrease in imports from Germany and Canada. During the first 8 months of 2020, the United States imported 0.025 ton (25 kilograms) of tellurium from Germany and 1 ton of tellurium from Canada. During the same period of 2019, the United States imported 22 tons of tellurium from Germany and 2 tons of tellurium from Canada. Domestic exports of tellurium had increased significantly in 2020 which may include misclassified exports. 
World production of tellurium was estimated to be about 490 tons. China was the leading producer of refined tellurium, recovering tellurium from copper anode slimes and from residues generated during the lead, nickel, precious metals, and zinc smelting processes. In late 2019, the Yunnan Provincial government in China announced an auction of 170 tons of tellurium from the defunct Fanya Metal Exchange with a starting price of $\$ 43$ per kilogram (306 yuan per kilogram), or a total lot bid of $\$ 7.34$ million (51.95 million yuan), and the tellurium was sold in December 2019. Demand in China for CdTe for solar panels increased in 2020 owing to increased investment in solar production projects. Production of tellurium increased at a Chinese firm to 6 tons per month, up from 1 to 2 tons per month in the previous year. Exports of CdTe from China also rose in the first 6 months of 2020, rising by $6 \%$ to over 300 tons.

A Canadian company announced in August that it would expand production of ultra-high purity (99.99999\%) tellurium for semiconductor technologies, such as solid-state radiation detectors. Solid-state radiation detectors produce highly accurate images, and are used in healthcare, security, and military systems.

World Refinery Production and Reserves: The figures shown for reserves include only tellurium contained in copper reserves. These estimates assume that more than one-half of the tellurium contained in unrefined copper anodes is recoverable.

\begin{tabular}{|c|c|c|c|}
\hline \multirow[b]{3}{*}{ United States } & \multicolumn{2}{|c|}{ Refinery production } & \multirow{2}{*}{ Reserves $^{5}$} \\
\hline & 2019 & $2020^{e}$ & \\
\hline & $\mathrm{W}$ & $\mathrm{W}$ & 3,500 \\
\hline Bulgaria & e4 & 5 & NA \\
\hline Canada & $\mathrm{e} 40$ & 35 & 800 \\
\hline China & е 325 & 300 & 6,600 \\
\hline Japan & e50 & 50 & - \\
\hline Russia & 52 & 50 & NA \\
\hline South Africa & e8 & 5 & - \\
\hline Sweden & 41 & 40 & 670 \\
\hline Other countries 6 & $\mathrm{NA}$ & $\mathrm{NA}$ & $\underline{19,000}$ \\
\hline World total (rounded) & 520 & 490 & 31,000 \\
\hline
\end{tabular}

World Resources: ${ }^{5}$ Data on tellurium resources were not available. More than $90 \%$ of tellurium has been produced from anode slimes collected from electrolytic copper refining, and the remainder was derived from skimmings at lead refineries and from flue dusts and gases generated during the smelting of bismuth, copper, and lead-zinc ores. Potential sources of tellurium include bismuth telluride and gold telluride ores.

Substitutes: Several materials can replace tellurium in most of its uses, but usually with losses in efficiency or product characteristics. Bismuth, calcium, lead, phosphorus, selenium, and sulfur can be used in place of tellurium in many free-machining steels. Several of the chemical process reactions catalyzed by tellurium can be carried out with other catalysts or by means of noncatalyzed processes. In rubber compounding, sulfur and (or) selenium can act as vulcanization agents in place of tellurium. The selenides and sulfides of niobium and tantalum can serve as electricalconducting solid lubricants in place of tellurides of those metals.

The selenium-tellurium photoreceptors used in some plain paper photocopiers and laser printers have been replaced by organic photoreceptors in newer devices. Amorphous silicon and copper indium gallium selenide were the two principal competitors of CdTe in thin-film photovoltaic solar cells. Bismuth selenide and organic polymers can be used to substitute for some BiTe thermal devices.

\footnotetext{
eEstimated. NA Not available. W Withheld to avoid disclosing company proprietary data. — Zero.

${ }^{1}$ Includes material that may have been misclassified.

${ }^{2}$ Defined as production + imports - exports + adjustments for industry stock changes.

${ }^{3}$ Average annual price. Source: Argus Media group_Argus Metals International for $99.95 \%$ tellurium, in warehouse, Rotterdam.

${ }^{4}$ Defined as imports - exports + adjustments for industry stock changes. For 2020, exports were not included in the calculation.

${ }^{5}$ See Appendix $\mathrm{C}$ for resource and reserve definitions and information concerning data sources.

${ }^{6}$ In addition to the countries listed, Australia, Belgium, Chile, Colombia, Germany, Kazakhstan, Mexico, the Philippines, and Poland produced refined tellurium, but output was not reported and available information was inadequate to make reliable production estimates.
} 


\section{THALLIUM}

(Data in kilograms unless otherwise noted)

Domestic Production and Use: Small quantities of thallium are consumed annually, but variations in pricing and value data make it difficult to estimate the value of consumption. The primary end uses included the following: radioisotope thallium-201 used for medical purposes in cardiovascular imaging; thallium as an activator (sodium iodide crystal doped with thallium) in gamma radiation detection equipment; thallium-barium-calcium-copper-oxide high-temperature superconductors used in filters for wireless communications; thallium in lenses, prisms, and windows for infrared detection and transmission equipment; thallium-arsenic-selenium crystal filters for light diffraction in acousto-optical measuring devices; and thallium in mercury alloys for low-temperature measurements. Other uses include as an additive in glass to increase its refractive index and density, a catalyst for organic compound synthesis, and a component in high-density liquids for gravity separation of minerals.

\section{Salient Statistics-United States:}

Production, refinery

Imports for consumption:

Unwrought metal and metal powders

Waste and scrap

Other articles

Exports:

Unwrought metal and powders

Waste and scrap

Other articles

Consumption, estimated ${ }^{2}$

Price, metal,,${ }^{3}$ dollars per kilogram

Net import reliance ${ }^{4}$ as a percentage of

estimated consumption

$\begin{array}{rrrrr}\frac{\mathbf{2 0 1 6}}{-} & \underline{\mathbf{2 0 1 7}} & \underline{\mathbf{2 0 1 8}} & \underline{\mathbf{2 0 1 9}} & \frac{\mathbf{2 0 2 0}}{-} \\ - & - & - & - & 57 \\ \overline{1} & - & 23 & 27 & - \\ & - & 41 & 38 & - \\ 56 & 34 & 100 & 290 & 300 \\ 286 & 364 & 853 & 133 & 320 \\ 973 & 1,560 & 131,400 & 179,000 & 500 \\ 193 & - & 64 & 65 & 57 \\ 7,400 & \text { NA } & \text { NA } & 7,600 & 8,200 \\ \text { NA } & \text { NA } & \text { NA } & \text { NA } & \text { NA }\end{array}$

Recycling: None.

Import Sources (2016-19): Germany, 60\%; China, 24\%; Norway, 8\%; and the United Kingdom, 8\%.

Tariff: Item

Unwrought and powders

Waste and scrap

Other
Number

8112.51 .0000

8112.52 .0000

8112.59 .0000
Normal Trade Relations

12-31-20

$4.0 \%$ ad val.

Free.

$4.0 \%$ ad val.

Depletion Allowance: 14\% (domestic and foreign).

Government Stockpile: None. 
Events, Trends, and Issues: In 2020, imports of thallium unwrought metal and powder was 57 kilograms. Exports of unwrought thallium and powders were higher in 2020 compared with those of 2019. All exports of unwrought thallium and powders left the Cleveland, $\mathrm{OH}$, and New Orleans, LA, customs districts and went to Taiwan. All exports of thallium waste and scrap left from the Laredo, TX, customs district and went to Mexico in 2020, the same as in 2019. Exports of other thallium articles (Schedule B number 8112.59.0000) returned to lower levels. In 2018 and 2019 , reported exports of thallium articles were unusually high in quantity; these exports likely were misclassified material.

Demand for thallium for use in cardiovascular-imaging applications has declined owing to superior performance and availability of alternatives, such as the medical isotope technetium-99. A global shortage of technetium-99 from 2009 to 2011 had contributed to an increase in thallium consumption during that time period. Since 2011, consumption of thallium has declined significantly. Small quantities of thallium are used for research.

The leading global uses for thallium were gamma radiation detection equipment, high-temperature superconductors, infrared optical materials, low-melting glasses, photoelectric cells, and radioisotopes. Producers of these products were in China, Japan, the Republic of Korea, and the United States.

Thallium metal and its compounds are highly toxic materials and are strictly controlled to prevent harm to humans and the environment. Thallium and its compounds can be absorbed into the human body by skin contact, ingestion, or inhalation of dust or fumes. Under its national primary drinking water regulations for public water supplies, the U.S. Environmental Protection Agency has set an enforceable Maximum Contaminant Level of 2 parts per billion thallium in drinking water.

World Refinery Production and Reserves: ${ }^{5}$ Thallium is produced commercially in only a few countries as a byproduct in the roasting of copper, lead, and zinc ores and is recovered from flue dust. Because most producers withhold thallium production data, global production data are limited. In 2020, global production of thallium was estimated to be less than 8,000 kilograms. China, Kazakhstan, and Russia were thought to be leading producers of primary thallium. Since 2005, substantial thallium-rich deposits have been identified in Brazil, China, North Macedonia, and Russia. Quantitative estimates of reserves are not available, owing to the difficulty in identifying deposits where thallium can be extracted economically. Previous estimates of reserves were based on the thallium content of zinc ores.

World Resources: ${ }^{5}$ Although thallium is reasonably abundant in the Earth's crust, estimated at about 0.7 part per million, it exists mostly in association with potassium minerals in clays, granites, and soils, and it is not generally considered to be commercially recoverable from those materials. The major source of recoverable thallium is the trace amounts found in copper, lead, zinc, and other sulfide ores. World resources of thallium contained in identified zinc resources could be as much as 17 million kilograms; most are in Europe, Canada, and the United States. World identified resources of coal contain an estimated 630 million kilograms of thallium.

Substitutes: Although other materials and formulations can substitute for thallium in gamma radiation detection equipment and optics used for infrared detection and transmission, thallium materials are presently superior and more cost effective for these very specialized uses. The medical isotope technetium-99 can be used in cardiovascularimaging applications instead of thallium.

Nonpoisonous substitutes, such as tungsten compounds, are being marketed as substitutes for thallium in highdensity liquids for gravity separation of minerals.

\footnotetext{
eEstimated. NA Not available. - Zero.

${ }^{1}$ Includes material that may have been misclassified.

${ }^{2}$ Estimated to be equal to imports.

${ }^{3}$ Estimated price of $99.99 \%$-pure granules in 100 -gram lots.

${ }^{4}$ Defined as imports - exports. Consumption and exports of unwrought thallium were from imported material or from a drawdown in unreported inventories.

${ }^{5}$ See Appendix $\mathrm{C}$ for resource and reserve definitions and information concerning data sources.
} 


\section{THORIUM}

(Data in kilograms, gross weight, unless otherwise noted)

Domestic Production and Use: The world's primary source of thorium is the rare-earth and thorium phosphate mineral monazite. In 2020, monazite may have been produced as a separated concentrate or included as an accessory mineral in heavy-mineral concentrates. Essentially, all thorium compounds and alloys consumed by the domestic industry were derived from imports. The number of companies that processed or fabricated various forms of thorium for commercial use was not available. Thorium's use in most products was generally limited because of concerns over its naturally occurring radioactivity. Imports of thorium compounds are sporadic owing to changes in consumption and fluctuations in consumer inventory levels. The estimated value of thorium compounds imported for consumption by the domestic industry in 2020 was $\$ 55,000$, compared with $\$ 213,000$ in 2019.

\begin{tabular}{|c|c|c|c|c|c|}
\hline Salient Statistics_-United States: & $\frac{2016}{N A}$ & $\frac{2017}{N A}$ & $\begin{array}{r}\mathbf{2 0 1 8} \\
2520,000\end{array}$ & $21,700,000$ & ${ }^{2} 60 \overline{2020}^{\mathrm{e}}$ \\
\hline \multicolumn{6}{|l|}{ Imports for consumption: } \\
\hline Ore and concentrates (monazite) & 16,000 & - & 1,000 & - & \\
\hline Compounds (oxide, nitrate, etc.) & 3,120 & 8,510 & 9,000 & 4,000 & 1,900 \\
\hline \multicolumn{6}{|l|}{ Exports: } \\
\hline Ore and concentrates (monazite) & NA & NA & 520,000 & $1,700,000$ & 600,000 \\
\hline Compounds (oxide, nitrate, etc.) ${ }^{3}$ & 6,000 & 6,100 & 3,000 & 3,200 & 400 \\
\hline \multicolumn{6}{|l|}{ Consumption, apparent: ${ }^{4}$} \\
\hline Ore and concentrates (monazite) & 16,000 & — & 1,000 & - & \\
\hline Compounds (oxide, nitrate, etc.) & $\left({ }^{5}\right)$ & 2,410 & 6,000 & 800 & 1,500 \\
\hline \multirow{2}{*}{\multicolumn{6}{|c|}{$\begin{array}{l}\text { Price, average value, compounds, India, }{ }^{6} \\
\text { dollars per kilogram }\end{array}$}} \\
\hline & 65 & 73 & 72 & 72 & NA \\
\hline $\begin{array}{l}\text { Net import reliance }{ }^{7} \text { as a percentage of } \\
\text { apparent consumption }\end{array}$ & NA & NA & NA & NA & NA \\
\hline
\end{tabular}

Recycling: None.

Import Sources (2016-19): Monazite: Canada, 100\%. Thorium compounds: India, 82\%; France, 17\%; and the United Kingdom, $1 \%$.

\section{Tariff: Item}

Thorium ore and concentrates (monazite)

Thorium compounds

\section{Number}

2612.20.0000

2844.30.1000
Normal Trade Relations

12-31-20

Free.

$5.5 \%$ ad val.

Depletion Allowance: Monazite, $22 \%$ on thorium content, and $14 \%$ on rare-earth and yttrium content (domestic); $14 \%$ (foreign).

Government Stockpile: None. 


\section{THORIUM}

Events, Trends, and Issues: Domestic demand for thorium alloys, compounds, and metals was limited. In addition to research purposes, various commercial uses of thorium included catalysts, high-temperature ceramics, magnetrons in microwave ovens, metal-halide lamps, nuclear medicine, optical coatings, tungsten filaments, and welding electrodes.

Exports of unspecified thorium compounds were estimated to be 400 kilograms in 2020 . Because $99 \%$ of the exports were reported to have a unit value of less than $\$ 50$ per kilogram, those quantities were not included in the total export estimate because it is likely that they were misclassified. Owing to potentially misclassified material and variations in the type and purity of thorium compounds, the unit value of exports varied widely by month and by exporting customs district.

Globally, monazite was produced primarily for its rare-earth-element content, and only a small fraction of the byproduct thorium produced was consumed. India was the leading producer of monazite. Thorium consumption worldwide is relatively small compared with that of most other mineral commodities. In international trade, China was the leading importer of monazite; Brazil, Madagascar, Thailand, and Vietnam were China's leading import sources. The United States exported monazite to China and Hong Kong. Operators of the Eneabba mineral sands project (Australia), the Kvanefjeld project (Greenland), and the Steenkrampskraal Mine (South Africa) plan to start producing within the next year.

Several companies and countries were active in the pursuit of commercializing thorium as a fuel material for a new generation of nuclear reactors. Thorium-based nuclear research and development programs have been or are underway in Australia, Belgium, Brazil, Canada, China, Czechia, Denmark, Finland, France, Germany, India, Israel, Italy, Japan, the Netherlands, Norway, the Republic of Korea, Russia, the United Kingdom, and the United States.

World Refinery Production and Reserves: ${ }^{8}$ Production and reserves are associated with the recovery of monazite in heavy-mineral-sand deposits. Without demand for the rare earths, monazite would probably not be recovered for its thorium content under current market conditions.

World Resources: ${ }^{8}$ The world's leading thorium resources are found in placer, carbonatite, and vein-type deposits. Thorium is found in several minerals, including monazite, thorite, and thorianite. According to the Organisation for Economic Co-operation and Development's Nuclear Energy Agency, worldwide identified thorium resources were estimated to total 6.4 million tons of thorium. Thorium resources are found throughout the world, most notably in Australia, Brazil, India, and the United States. India has the largest resources (850,000 tons), followed by Brazil (630,000 tons) and Australia and the United States (600,000 tons each).

Substitutes: Nonradioactive substitutes have been developed for many applications of thorium. Yttrium compounds have replaced thorium compounds in incandescent lamp mantles. A magnesium alloy containing lanthanides, yttrium, and zirconium can substitute for magnesium-thorium alloys in aerospace applications. Cerium and lanthanum can substitute for thorium in welding electrodes. Several replacement materials are in use as optical coatings instead of thorium fluoride.

\footnotetext{
eEstimated. NA Not available. - Zero.

${ }^{1}$ Monazite may have been produced as a separate concentrate or included as an accessory mineral in heavy-mineral concentrates.

${ }^{2}$ Estimates based on exports.

${ }^{3}$ Excludes estimates of material that may have been misclassified.

${ }^{4}$ Defined as production + imports - exports. Shown separately for ore and concentrates and for compounds. Production is only for ore and concentrates.

${ }^{5}$ The apparent consumption calculation yields negative values for thorium compounds in 2016.

${ }^{6}$ Based on U.S. Census Bureau customs data.

${ }^{7}$ Defined as imports - exports; however, a meaningful net import reliance could not be calculated owing to uncertainties in the classification of material being imported and exported.

${ }^{8}$ See Appendix $\mathrm{C}$ for resource and reserve definitions and information concerning data sources.
} 
(Data in metric tons of tin content unless otherwise noted)

Domestic Production and Use: Tin has not been mined or smelted in the United States since 1993 and 1989, respectively. Twenty-five firms accounted for over $90 \%$ of the primary tin consumed domestically in 2020 . The major uses for tin in the United States were tinplate, 21\%; chemicals, 18\%; solder, 15\%; alloys, 10\%; babbitt, brass and bronze, and tinning, 10\%; and other, 26\%. Based on the average S\&P Global Platts Metals Week New York dealer price for tin, the estimated value of imported refined tin in 2020 was $\$ 557$ million, and the estimated value of tin recovered from old scrap domestically in 2020 was $\$ 174$ million.

\begin{tabular}{|c|c|c|c|c|c|}
\hline \multirow{2}{*}{\multicolumn{6}{|c|}{$\frac{\text { Salient Statistics-United States: }}{\text { Production, secondary: }}$}} \\
\hline & & & & & \\
\hline Old scrap & 10,000 & 10,000 & 9,900 & 9,900 & 10,000 \\
\hline New scrap & 8,000 & 8,000 & 8,000 & 8,000 & 8,000 \\
\hline \multicolumn{6}{|l|}{ Imports for consumption: } \\
\hline Tin, refined & 32,200 & 34,300 & 36,800 & 34,100 & 32,000 \\
\hline Tin, alloys, gross weight & 1,910 & 1,550 & 1,430 & 1,020 & 700 \\
\hline Tin, waste and scrap, gross weight & 27,200 & 52,100 & 47,700 & 30,400 & 23,000 \\
\hline \multicolumn{6}{|l|}{ Exports: } \\
\hline Tin, refined & 1,150 & 1,560 & 941 & 1,300 & 500 \\
\hline Tin, alloys, gross weight & 1,040 & 966 & 885 & 1,200 & 1,100 \\
\hline Tin, waste and scrap, gross weight & 4,570 & 3,460 & 5,980 & 2,470 & 1,300 \\
\hline Shipments from Government stockpile, gross weight & - & 2 & 13 & 1 & - \\
\hline Consumption, apparent, refined ${ }^{1}$ & 41,800 & 42,400 & 42,300 & 42,600 & 41,000 \\
\hline \multicolumn{6}{|l|}{ Price, average, cents per pound:2 } \\
\hline New York dealer & 839 & 937 & 936 & 868 & 790 \\
\hline London Metal Exchange (LME), cash & 815 & 911 & 914 & 846 & 770 \\
\hline Stocks, consumer and dealer, yearend & 6,370 & 6,660 & 10,100 & 10,200 & 11,000 \\
\hline $\begin{array}{l}\text { Net import reliance }{ }^{3} \text { as a percentage of } \\
\text { apparent consumption, refined }\end{array}$ & 76 & 76 & 77 & 77 & 75 \\
\hline
\end{tabular}

Recycling: About 18,000 tons of tin from old and new scrap was estimated to have been recycled in 2020 . Of this, about 10,000 tons was recovered from old scrap at 2 detinning plants and about 75 secondary nonferrous metalprocessing plants, accounting for $24 \%$ of apparent consumption.

Import Sources (2016-19): Refined tin: Indonesia, 24\%; Malaysia, 21\%; Peru, 20\%; Bolivia, 17\%; and other, 18\%. Waste and scrap: Canada, $99 \%$; and other, $1 \%$.

\section{Tariff: Item}

Unwrought tin:

Tin, not alloyed

Tin alloys, containing, by weight:

$5 \%$ or less lead

More than $5 \%$ but not more than $25 \%$ lead

More than $25 \%$ lead

Tin waste and scrap
Number

8001.10 .0000

8001.20 .0010

8001.20 .0050

8001.20 .0090

8002.00 .0000
Normal Trade Relations 12-31-20

Free.

Free.

Free.

Free.

Free.

Depletion Allowance: $22 \%$ (domestic), 14\% (foreign).

\section{Government Stockpile: ${ }^{4}$}

Material

Tin (gross weight)

Inventory
as of $9-30-20$
4,015
Potential acquisitions 40

FY 2020 Potential
disposals
FY 2021

$\begin{array}{cc}\begin{array}{c}\text { Potential } \\ \text { acquisitions }\end{array} & \begin{array}{c}\text { Potential } \\ \text { disposals }\end{array} \\ - & 4,034\end{array}$


Events, Trends, and Issues: The estimated amount of tin recycled in 2020 remained essentially unchanged compared with that in 2019. Estimated annual average tin prices based on the first 11 months in 2020 were 790 and 770 cents per pound for the New York dealer price and LME cash price, respectively - a 9\% decrease for both prices compared with those in 2019. In 2020, the monthly average New York dealer tin price peaked in November at 856 cents per pound, from a low monthly average price of 705 cents per pound in April.

Decline in global tin use began in 2019 and continued through 2020, likely exacerbated by the global COVID-19 pandemic that has caused disruptions in mining and manufacturing industries around the world. Solder remains the largest global use of tin. Owing to pandemic-related consumption of canned foods, tinplate usage is expected to increase despite years of stagnation. The use of tin in chemicals and tin alloys is expected to decline from that in 2019, matching the overall decline in demand for many durable goods in 2020.

Chinese demand for tin in the third quarter of 2020 reached 2019 levels, despite pandemic-related declines in the first half of 2020. China struggled to source an adequate supply of tin as global mine production only partially recovered in the third quarter. In Burma, further issues with mine flooding and border restrictions imposed because of the COVID-19 pandemic have tightened traditional tin ore sources. In late 2020, China's Yunnan Tin Company Limited began operations at a new smelter in Yunnan Province. The new smelter will replace an existing, and soon-to-be decommissioned, facility in the same Province.

World Mine Production and Reserves: Reserves for Australia, Brazil, Congo (Kinshasa), Malaysia, Peru, and Russia were revised based on information from company and Government reports.

\begin{tabular}{|c|c|c|c|}
\hline & Mine $p$ & Juction & Reserves $^{5}$ \\
\hline & $\underline{2019}$ & $\underline{2020^{\mathrm{e}}}$ & \\
\hline United States & - & & 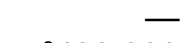 \\
\hline Australia & 7,740 & 6,800 & 6430,000 \\
\hline Bolivia $^{e}$ & 17,000 & 15,000 & 400,000 \\
\hline Brazil & 14,000 & 13,000 & 420,000 \\
\hline Burma & 42,000 & 33,000 & 100,000 \\
\hline China & 84,500 & 81,000 & $1,100,000$ \\
\hline Congo (Kinshasa)e & 12,200 & 17,000 & 160,000 \\
\hline Indonesia & 77,500 & 66,000 & 800,000 \\
\hline $\operatorname{Laos}^{e}$ & 1,400 & 1,200 & NA \\
\hline Malaysia & 3,610 & 3,300 & 150,000 \\
\hline Nigeriae & 5,800 & 6,000 & NA \\
\hline Peru & 19,900 & 18,000 & 140,000 \\
\hline Russia & 1,800 & 2,500 & 280,000 \\
\hline Rwanda & 2,300 & 1,200 & NA \\
\hline Vietnam & 5,500 & 4,900 & 11,000 \\
\hline Other countries & 549 & 400 & 350,000 \\
\hline World total (rounded) & 296,000 & 270,000 & $4,300,000$ \\
\hline
\end{tabular}

World Resources: ${ }^{5}$ Identified resources of tin in the United States, primarily in Alaska, were insignificant compared with those of the rest of the world. World resources, principally in western Africa, southeastern Asia, Australia, Bolivia, Brazil, Indonesia, and Russia, are extensive and, if developed, could sustain recent annual production rates well into the future.

Substitutes: Aluminum, glass, paper, plastic, or tin-free steel substitute for tin content in cans and containers. Other materials that substitute for tin are epoxy resins for solder; aluminum alloys, alternative copper-base alloys, and plastics for bronze; plastics for bearing metals that contain tin; and compounds of lead and sodium for some tin chemicals.

\footnotetext{
eEstimated. NA Not available. - Zero.

${ }^{1}$ Defined as production (old scrap) + refined tin imports - refined tin exports + adjustments for Government and industry stock changes. Excludes imports and exports of alloys, and waste and scrap.

${ }^{2}$ Source: S\&P Global Platts Metals Week.

${ }^{3}$ Defined as imports - exports + adjustments for Government and industry stock changes, excluding imports and exports of waste and scrap.

${ }^{4}$ See Appendix B for definitions.

${ }^{5}$ See Appendix $C$ for resource and reserve definitions and information concerning data sources.

${ }^{6}$ For Australia, Joint Ore Reserves Committee-compliant reserves were 250,000 tons.
} 


\section{TITANIUM AND TITANIUM DIOXIDE'1}

(Data in metric tons unless otherwise noted)

Domestic Production and Use: Titanium sponge metal was produced by two operations in Nevada and Utah. Production data were withheld to avoid disclosing company proprietary data. The facility in Salt Lake City, UT, with an estimated capacity of 500 tons per year, produced titanium that was further refined for use in electronics. Sponge operations in Henderson, NV, with an estimated capacity of 12,600 tons per year, were idled at yearend owing to market conditions. A third operation, in Rowley, UT, with an estimated capacity of 10,900 tons per year, remained on care-and-maintenance status since 2016.

Although detailed 2020 consumption data were withheld to avoid disclosing proprietary data, the majority of titanium metal was used in aerospace applications, and the remainder was used in armor, chemical processing, marine hardware, medical implants, power generation, consumer, and other applications. The value of imported sponge was about \$206 million, a 24\% decrease compared with imports in 2019.

In 2020, titanium dioxide $\left(\mathrm{TiO}_{2}\right)$ pigment production, by four companies operating five facilities in four States, was valued at about $\$ 3$ billion. The estimated end-use distribution of $\mathrm{TiO}_{2}$ pigment consumption was paints (including lacquers and varnishes), $60 \%$; plastics, $20 \%$; paper, $5 \%$; and other, $15 \%$. Other uses of $\mathrm{TiO}_{2}$ included catalysts, ceramics, coated fabrics and textiles, floor coverings, printing ink, and roofing granules.

\begin{tabular}{|c|c|c|c|c|c|}
\hline Salient Statistics-United States: & $\underline{2016}$ & $\underline{2017}$ & $\underline{2018}$ & $\underline{2019^{e}}$ & $\underline{2020^{e}}$ \\
\hline \multicolumn{6}{|l|}{ Titanium sponge metal: } \\
\hline Production & W & W & W & W & W \\
\hline Imports for consumption & 16,200 & 24,100 & 23,700 & 30,000 & 24,000 \\
\hline Exports & 724 & 3,090 & 533 & 869 & 910 \\
\hline Consumption, reported & 34,100 & 37,400 & 35,200 & W & W \\
\hline Price, dollars per kilogram, yearend & 9.50 & 9.10 & 9.20 & 6.85 & 6.90 \\
\hline Stocks, industry, yearende & 25,100 & 13,200 & 10,700 & W & W \\
\hline Employment, numbere & 150 & 150 & 150 & 150 & 150 \\
\hline \multicolumn{6}{|l|}{ Net import reliance ${ }^{2}$ as a percentage of } \\
\hline reported consumption & 45 & 88 & 73 & $>50$ & $>50$ \\
\hline \multicolumn{6}{|l|}{ Titanium dioxide pigment: } \\
\hline Production & $1,240,000$ & $1,260,000$ & $1,150,000$ & $1,150,000$ & $1,000,000$ \\
\hline Imports for consumption & 247,000 & 240,000 & 269,000 & 226,000 & 270,000 \\
\hline Exports & 651,000 & 634,000 & 528,000 & 411,000 & 370,000 \\
\hline Consumption, apparent ${ }^{3}$ & 840,000 & 870,000 & 893,000 & 965,000 & 900,000 \\
\hline Producer price index $(1982=100)$, yearend 4 & 175 & 205 & 205 & NA & NA \\
\hline Employment, numbere & 3,110 & 3,110 & 3.050 & 3.050 & 3,100 \\
\hline $\begin{array}{l}\text { Net import reliance }{ }^{2} \text { as a percentage of } \\
\text { apparent consumption }\end{array}$ & $\mathrm{E}$ & $E$ & $\mathrm{E}$ & $\mathrm{E}$ & . \\
\hline
\end{tabular}

Recycling: About 45,000 tons of titanium scrap metal was consumed in $2020-35,000$ tons by the titanium industry, 8,000 tons by the steel industry, less than 500 tons by the superalloy industry, and the remainder in other industries.

Import Sources (2016-19): Sponge metal: Japan, 90\%; Kazakhstan, 7\%; Ukraine, 2\%; and other, 1\%. Titanium dioxide pigment: Canada, 38\%; China, 22\%; Germany, 9\%; Belgium, 4\%; and other, 27\%.

Tariff: Item

Titanium oxides (unfinished $\mathrm{TiO}_{2}$ pigments)

$\mathrm{TiO}_{2}$ pigments, $80 \%$ or more $\mathrm{TiO}_{2}$

$\mathrm{TiO}_{2}$ pigments, other

Ferrotitanium and ferrosilicon titanium

Unwrought titanium metal

Titanium waste and scrap metal

Other titanium metal articles

Wrought titanium metal

\section{Number}

2823.00.0000

3206.11 .0000

3206.19 .0000

7202.91 .0000

8108.20 .0010

8108.30 .0000

8108.90 .3000

8108.90 .6000
Normal Trade Relations

12-31-20

$5.5 \%$ ad val.

$6.0 \%$ ad val.

$6.0 \%$ ad val.

$3.7 \%$ ad val.

$15.0 \%$ ad val.

Free.

$5.5 \%$ ad val.

$15.0 \%$ ad val. 
Depletion Allowance: Not applicable.

Government Stockpile: None.

Events, Trends, and Issues: Owing to airline travel concerns and restrictions implemented to limit the spread of the global COVID-19 pandemic, domestic consumption of titanium sponge in 2020 decreased significantly compared with that of 2019. U.S. producers of titanium ingot continued to rely heavily on imports of titanium sponge and scrap.

Imports of titanium sponge decreased by about $20 \%$, and exports increased moderately. Japan (88\%) and Kazakhstan (10\%) were the leading import sources for titanium sponge in 2020. U.S. imports of titanium waste and scrap were about 18,000 tons. Germany (19\%), Japan (18\%), the United Kingdom (14\%), and France (11\%) were the leading import sources for titanium waste and scrap in 2020. At yearend, plans to idle the 12,600-ton-per-year sponge plant in Henderson, NV, left the 500-ton-per-year Salt Lake City, UT, plant as the only active domestic producer of titanium sponge. The U.S. Department of Commerce led investigations under section 232 of the Trade Expansion Act of 1962 that determined titanium sponge imports into the United States threatened to impair national security. In 2020, a working group was formed to explore measures to ensure access to titanium sponge in the United States for use for national defense and in critical industries during an emergency. In China, production of titanium sponge increased significantly in 2020, and projects to increase titanium sponge and titanium pigment capacity were expected in 2021.

Domestic production of $\mathrm{TiO}_{2}$ pigment in 2020 was estimated to be about 1 million tons. Although heavily reliant on imports of titanium mineral concentrates, the United States was a net exporter of $\mathrm{TiO}_{2}$ pigments. Following a record high of 743,000 tons in 2011, exports of titanium dioxide have followed a declining trend. Since 2011, an increasing percentage of domestic production has been used domestically in lieu of being exported.

\section{World Sponge Metal Production and Sponge and Pigment Capacity:}

\begin{tabular}{|c|c|c|c|c|}
\hline & Sponge & ductione & Capa & $2020^{5}$ \\
\hline & $\underline{2019}$ & 2020 & Sponge & Pigment \\
\hline United States & $\overline{\mathrm{W}}$ & $\bar{W}$ & 13,100 & $\overline{1,370,000}$ \\
\hline Australia & - & - & - & 260,000 \\
\hline Canada & - & - & - & 104,000 \\
\hline China & 85,000 & 110,000 & 158,000 & $4,000,000$ \\
\hline Germany & - & - & - & 472,000 \\
\hline India & 250 & 250 & 500 & 108,000 \\
\hline Japan & 49,000 & 50,000 & 68,800 & 314,000 \\
\hline Kazakhstan & 16,000 & 15,000 & 26,000 & 1,000 \\
\hline Mexico & - & - & - & 300,000 \\
\hline Russia & 44,000 & 33,000 & 46,500 & 55,000 \\
\hline Saudi Arabia & 100 & 500 & 15,600 & 210,000 \\
\hline Ukraine & 8,000 & 6,000 & 12,000 & 120,000 \\
\hline United Kingdom & - & - & - & 315,000 \\
\hline Other countries & - & $=$ & - & 784,000 \\
\hline World total (rounded) & 200,000 & $\overline{6210,000}$ & $\overline{341,000}$ & $\overline{8,400,000}$ \\
\hline
\end{tabular}

World Resources: ${ }^{7}$ Reserves and resources of titanium minerals are discussed in the Titanium Mineral Concentrates chapter.

Substitutes: Few materials possess titanium metal's strength-to-weight ratio and corrosion resistance. In highstrength applications, titanium competes with aluminum, composites, intermetallics, steel, and superalloys. Aluminum, nickel, specialty steels, and zirconium alloys may be substituted for titanium for applications that require corrosion resistance. Ground calcium carbonate, precipitated calcium carbonate, kaolin, and talc compete with titanium dioxide as a white pigment.

\footnotetext{
eEstimated. E Net exporter. NA Not Available. W Withheld to avoid disclosing company proprietary data. — Zero.

${ }^{1}$ See also Titanium Mineral Concentrates.

${ }^{2}$ Defined as imports - exports.

${ }^{3}$ Defined as production + imports - exports.

${ }^{4}$ U.S. Department of Labor, Bureau of Labor Statistics.

${ }^{5}$ Yearend operating capacity.

${ }^{6}$ Excludes U.S. production.

${ }^{7}$ See Appendix $\mathrm{C}$ for resource and reserve definitions and information concerning data sources.
} 


\title{
TITANIUM MINERAL CONCENTRATES ${ }^{1}$
}

\author{
(Data in thousand metric tons of $\mathrm{TiO}_{2}$ content unless otherwise noted)
}

Domestic Production and Use: In 2020, one company was recovering ilmenite and rutile concentrates from its surface-mining operations near Nahunta, GA, and Starke, FL. A second company processed existing mineral sands mine tailings in Florida and South Carolina. Based on reported data through October 2020, the estimated value of titanium mineral and synthetic concentrates imported into the United States was $\$ 520$ million. Abrasive sands, monazite, and zircon were coproducts of domestic mining operations. About $90 \%$ of titanium mineral concentrates were consumed by domestic titanium dioxide $\left(\mathrm{TiO}_{2}\right)$ pigment producers. The remaining $10 \%$ was used in welding-rod coatings and for manufacturing carbides, chemicals, and titanium metal.

\begin{tabular}{|c|c|c|c|c|c|}
\hline Salient Statistics_-United States: & $\underline{2016}$ & $\underline{2017}$ & $\underline{2018}$ & $\underline{2019^{e}}$ & $\underline{2020^{\mathrm{e}}}$ \\
\hline$\overline{\text { Production }^{2}}$ & 100 & 100 & 100 & 100 & 100 \\
\hline Imports for consumption & 1,020 & 1,170 & 1,100 & 1,160 & 780 \\
\hline Exports, all forms ${ }^{\mathrm{e}}$ & 5 & 6 & 32 & 8 & 19 \\
\hline Consumption, apparent ${ }^{3}$ & 1,100 & 1,300 & 1,200 & 1,300 & 900 \\
\hline \multicolumn{6}{|l|}{ Price, dollars per metric ton: } \\
\hline Rutile, bulk, minimum $95 \% \mathrm{TiO}_{2}$, f.o.b. Australia 4 & 740 & 740 & 1,025 & 1,125 & 1,200 \\
\hline Ilmenite, bulk, minimum $54 \% \mathrm{TiO}_{2}$, f.o.b. Australia 4 & 105 & 173 & NA & NA & NA \\
\hline Ilmenite, import & 142 & 172 & 219 & 186 & 210 \\
\hline Slag, $80 \%-95 \% \mathrm{TiO}_{2} 5$ & $612-682$ & $621-700$ & $699-738$ & 742-897 & $640-1,020$ \\
\hline Employment, mine and mill, number & 155 & 286 & 299 & 310 & 260 \\
\hline $\begin{array}{l}\text { Net import reliance }{ }^{6} \text { as a percentage of } \\
\text { apparent consumption }\end{array}$ & 91 & 92 & 91 & 92 & 88 \\
\hline
\end{tabular}

Recycling: None.

Import Sources (2016-19): South Africa, 39\%; Australia, 20\%; Madagascar, 10\%; Mozambique, 9\%; and other, $22 \%$.

Tariff: Item

Synthetic rutile

Ilmenite and ilmenite sand

Rutile concentrate

Titanium slag

\section{Number}

2614.00.3000

2614.00.6020

2614.00.6040

2620.99 .5000

\author{
Normal Trade Relations \\ 12-31-20 \\ Free. \\ Free. \\ Free. \\ Free.
}

Depletion Allowance: Ilmenite and rutile, 22\% (domestic) and 14\% (foreign).

Government Stockpile: None.

Events, Trends, and Issues: Consumption of titanium mineral concentrates is tied to production of $\mathrm{TiO}_{2}$ pigments that are primarily used in paint, paper, and plastics. Demand for these primary uses are tied to changes in the gross domestic product. Demand in the first half of 2020 decreased sharply owing to restrictions implemented to limit the spread of the COVID-19 virus. In the second half of 2020, titanium producers reported that demand was recovering, led by demand for $\mathrm{TiO}_{2}$ in paints and coatings. Domestic apparent consumption of titanium mineral concentrates in 2020 was estimated to have decreased by about 30\% from that of 2019; however, inventory changes were not included in this calculation. Although small compared with apparent consumption, exports of titanium mineral concentrates increased substantially from those in the previous year owing to increased exports to China, India, and the Netherlands.

Australia, China, and South Africa were the leading producers of titanium mineral concentrates. China continued to be both the leading producer and consumer of titanium mineral concentrates. In 2020, China's imports of titanium mineral concentrates were about 3 million tons in gross weight, an increase of 19\% compared with those in 2019. In Guangdong Province, capacity to produce up to 200,000 tons per year of synthetic rutile was being commissioned. As of October, Mozambique (36\%), Australia (14\%), Vietnam (11\%), and Kenya (11\%) were the leading sources of titanium mineral concentrates to China. In Saudi Arabia, owing to technical problems and COVID-19 pandemic concerns, commissioning of a project to produce up to 500,000 tons per year of titanium slag was delayed until 2021. Other projects were being developed in Australia, China, Malawi, Mozambique, Norway, Senegal, and Tanzania. 
TITANIUM MINERAL CONCENTRATES

World Mine Production and Reserves: Reserves for Australia, Kenya, Madagascar, Mozambique, and South Africa were revised based on Government or industry reports.

\begin{tabular}{|c|c|c|}
\hline \multirow[b]{2}{*}{ Ilmenite: } & Mine production & \multirow{2}{*}{ Reserves $^{7}$} \\
\hline & $\underline{2020^{\circ}}$ & \\
\hline United States 2,8 & 100 & 2.000 \\
\hline Australia & 800 & 9150,000 \\
\hline Brazil & 25 & 43,000 \\
\hline Canada ${ }^{10}$ & 680 & 31.000 \\
\hline China & 2,300 & 230,000 \\
\hline India & 160 & 85,000 \\
\hline Kenya & 190 & 440 \\
\hline Madagascar ${ }^{10}$ & 300 & 23,000 \\
\hline Mozambique & 600 & 26,000 \\
\hline Norway & 400 & 37,000 \\
\hline Senegal & 310 & NA \\
\hline South Africa ${ }^{10}$ & 1,000 & 35,000 \\
\hline Ukraine & 470 & 5,900 \\
\hline Vietnam & 160 & 1,600 \\
\hline Other countries & 70 & 26,000 \\
\hline World total (ilmenite, rounded) 8 & $\overline{7,600}$ & $\overline{700,000}$ \\
\hline \multicolumn{3}{|l|}{ Rutile: } \\
\hline United States & $(8)$ & $(8)$ \\
\hline Australia & 200 & 927,000 \\
\hline India & 11 & 7,400 \\
\hline Kenya & 74 & 170 \\
\hline Mozambique & 6 & 890 \\
\hline Senegal & 9 & NA \\
\hline Sierra Leone & 120 & 490 \\
\hline South Africa & 100 & 6,800 \\
\hline Ukraine & 94 & 2,500 \\
\hline Other countries & 20 & 400 \\
\hline World total (rutile, rounded) 8 & 630 & 46,000 \\
\hline World total (ilmenite and rutile, rounded) & $\overline{8,200}$ & $\overline{740,000}$ \\
\hline
\end{tabular}

World Resources: ${ }^{7}$ IImenite accounts for about $90 \%$ of the world's consumption of titanium minerals. World resources of anatase, ilmenite, and rutile total more than 2 billion tons.

Substitutes: Ilmenite, leucoxene, rutile, slag, and synthetic rutile compete as feedstock sources for producing $\mathrm{TiO}_{2}$ pigment, titanium metal, and welding-rod coatings.

\footnotetext{
eEstimated. NA Not available.

${ }^{1}$ See also Titanium and Titanium Dioxide.

${ }^{2}$ Rounded to the nearest 100,000 tons to avoid disclosing company proprietary data.

${ }^{3}$ Defined as production + imports - exports. Rounded to the nearest 100,000 tons to avoid disclosing company proprietary data.

${ }^{4}$ Source: Industrial Minerals (Fastmarkets IM); average of yearend price. Prices of ilmenite from Australia were discontinued at yearend 2017.

${ }^{5}$ Landed duty-paid value based on U.S. imports for consumption. Data series revised to reflect annual average unit value range of significant importing countries.

${ }^{6}$ Defined as imports - exports.

${ }^{7}$ See Appendix $\mathrm{C}$ for resource and reserve definitions and information concerning data sources.

${ }^{8} \mathrm{U}$.S. rutile production and reserves data are included with ilmenite.

${ }^{9}$ For Australia, Joint Ore Reserves Committee-compliant reserves for ilmenite and rutile were estimated to be 36 million and 8.2 million tons, respectively.

${ }^{10}$ Mine production is primarily used to produce titaniferous slag.
} 


\section{TUNGSTEN}

(Data in metric tons of tungsten content unless otherwise noted)

Domestic Production and Use: There has been no known domestic commercial production of tungsten concentrates since 2015. Approximately six companies in the United States used chemical processes to convert tungsten concentrates, ammonium paratungstate (APT), tungsten oxide, and (or) scrap to tungsten metal powder, tungsten carbide powder, and (or) tungsten chemicals. Nearly $60 \%$ of the tungsten used in the United States was used in cemented carbide parts for cutting and wear-resistant applications, primarily in the construction, metalworking, mining, and oil and gas drilling industries. The remaining tungsten was used to make various alloys and specialty steels; electrodes, filaments, wires, and other components for electrical, electronic, heating, lighting, and welding applications; and chemicals for various applications. The estimated value of apparent consumption in 2020 was approximately $\$ 500$ million.

\section{Salient Statistics_United States:}

Production:

Mine

Secondary

Imports for consumption:

Concentrate

Other forms ${ }^{1}$

Exports:

Concentrate

Other forms ${ }^{2}$

Shipments from Government stockpile:

Concentrate

Other forms

Consumption:

Reported, concentrate

Apparent, ${ }^{3}$ all forms

Price, ${ }^{4}$ concentrate, average U.S. spot market, dollars per metric ton unit of tungsten trioxide ${ }^{5}$

Stocks, industry, concentrate and other forms, yearend

Net import reliance ${ }^{6}$ as a percentage of

apparent consumption

$\begin{array}{rrrrr}\underline{\mathbf{2 0 1 6}} & \underline{\mathbf{2 0 1 7}} & \underline{\mathbf{2 0 1 8}} & \underline{\mathbf{2 0 1 9}} & \underline{\mathbf{2 0 2 0}} \\ \overline{\mathrm{W}} & \overline{\mathrm{W}} & \overline{\mathrm{W}} & \overline{\mathrm{W}} & \overline{\mathrm{W}} \\ 3,580 & 3,920 & 4,050 & 2,760 & 2,000 \\ 6,300 & 9,780 & 10,400 & 11,100 & 9,000 \\ 183 & 532 & 284 & 584 & 300 \\ 3,200 & 3,010 & 3,210 & 2,780 & 2,500 \\ - & 1,460 & 1,180 & 663 & 700 \\ - & - & - & - & 20 \\ \text { W } & \mathrm{W} & \mathrm{W} & \mathrm{W} & \mathrm{W} \\ \mathrm{W} & \mathrm{W} & \mathrm{W} & \mathrm{W} & \mathrm{W} \\ 148 & 245 & 326 & 270 & 270 \\ \mathrm{~W} & \mathrm{~W} & \mathrm{~W} & \mathrm{~W} & \mathrm{~W} \\ >25 & >50 & >50 & >50 & >50\end{array}$

Recycling: The estimated quantity of secondary tungsten produced and the amount consumed from secondary sources by processors and end users in 2020 were withheld to avoid disclosing company proprietary data.

Import Sources (2016-19): Tungsten contained in ores and concentrates, intermediate and primary products, wrought and unwrought tungsten, and waste and scrap: China, 32\%; Bolivia, 9\%; Germany, 9\%; Austria, 5\%; and other, $45 \%$.

Tariff: Item

Ores

Concentrates

Tungsten oxides

Ammonium tungstates

Tungsten carbides

Ferrotungsten

Tungsten powders

Tungsten waste and scrap
Number

2611.00.3000

2611.00 .6000

2825.90.3000

2841.80 .0010

2849.90.3000

7202.80 .0000

8101.10 .0000

8101.97 .0000
Normal Trade Relations 12-31-20 Free.

$37.5 \$ / \mathrm{kg}$ tungsten content. $5.5 \%$ ad val. $5.5 \%$ ad val. $5.5 \%$ ad val. $5.6 \%$ ad val. $7.0 \%$ ad val. $2.8 \%$ ad val.

Depletion Allowance: $22 \%$ (domestic), 14\% (foreign).

\section{Government Stockpile: ${ }^{7}$}

\section{Material}

Metal powder

Ores and concentrates

Tungsten alloys, gross weight ${ }^{8}$
FY 2020

Inventory
as of $\mathbf{9 - 3 0 - 2 0}$
107
7,660
6

$\begin{array}{cc}\begin{array}{c}\text { Potential } \\ \text { acquisitions }\end{array} & \begin{array}{c}\text { Potential } \\ \text { disposals }\end{array} \\ - & 125 \\ - & 1,360 \\ 5 & -\end{array}$

FY 2021

Potential Potential acquisitions disposals 125

Prepared by Kim B. Shedd [(703) 648-4974, kshedd@usgs.gov] 


\section{TUNGSTEN}

Events, Trends, and Issues: World tungsten supply was dominated by production in China and exports from China. China's Government regulated its tungsten industry by limiting the number of mining and export licenses, imposing quotas on concentrate production, and placing constraints on mining and processing. In 2020, production of tungsten concentrate outside China was expected to remain at less than $20 \%$ of world production. Scrap continued to be an important source of raw material for the tungsten industry worldwide.

China was the world's leading tungsten consumer. Analysts forecast global tungsten consumption in 2020 will be less than that in 2019 as a result of the impacts of the global COVID-19 pandemic on the global economy and industrial production, particularly tungsten consuming end-use sectors such as the automotive, commercial aerospace, and oil and gas drilling industries. The decrease in tungsten consumption in 2020 is expected to result in a market surplus. During March and April 2020, most prices of tungsten concentrates and downstream tungsten materials decreased in response to reduced demand; prices then stabilized or gradually trended upward as the year progressed.

World Mine Production and Reserves: Reserves for Mongolia and Russia were revised based on Government reports.

\begin{tabular}{lrrr} 
& \multicolumn{2}{c}{ Mine production } & Reserves $^{\mathbf{9}}$ \\
United States & $\mathbf{2 0 1 9}$ & $\mathbf{2 0 2 \mathbf { e } ^ { \mathbf { e } }}$ & $\mathrm{NA}$ \\
Austria & $\mathbf{-}$ & $\mathbf{-}$ & $\mathbf{-}$ \\
Bolivia & 1,060 & 1,400 & $\mathrm{NA}$ \\
China & 69,000 & 69,000 & $1,900,000$ \\
Korea, North & 1,130 & 500 & 29,000 \\
Mongolia & 1,900 & 1,900 & 4,300 \\
Portugal & 518 & 680 & 3,100 \\
Russia & 2,200 & 2,200 & 400,000 \\
Rwanda & 900 & 1,000 & $\mathrm{NA}$ \\
Spain & 603 & 800 & 54,000 \\
Vietnam & 4,500 & 4,300 & 95,000 \\
Other countries & 1,070 & 1,000 & 880,000 \\
$\quad$ World total (rounded) & 83,800 & 84,000 & $3,400,000$
\end{tabular}

World Resources: ${ }^{9}$ World tungsten resources are geographically widespread. China ranks first in the world in terms of tungsten resources and reserves and has some of the largest deposits. Canada, Kazakhstan, Russia, and the United States also have significant tungsten resources.

Substitutes: Potential substitutes for cemented tungsten carbides include cemented carbides based on molybdenum carbide, niobium carbide, or titanium carbide; ceramics; ceramic-metallic composites (cermets); and tool steels. Most of these options reduce, rather than replace, the amount of tungsten used. Potential substitutes for other applications are as follows: molybdenum for certain tungsten mill products; molybdenum steels for tungsten steels, although most molybdenum steels still contain tungsten; lighting based on carbon nanotube filaments, induction technology, and light-emitting diodes for lighting based on tungsten electrodes or filaments; depleted uranium or lead for tungsten or tungsten alloys in applications requiring high density or the ability to shield radiation; and depleted uranium alloys or hardened steel for cemented tungsten carbides or tungsten alloys in armor-piercing projectiles. In some applications, substitution would result in increased cost or a loss in product performance.

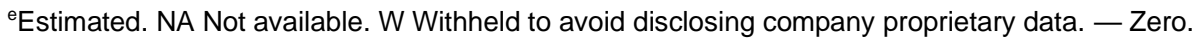

${ }^{1}$ Includes ammonium and other tungstates; ferrotungsten; tungsten carbides; tungsten metal powders; tungsten oxides, chloride, and other tungsten compounds; unwrought tungsten; wrought tungsten forms; and tungsten waste and scrap.

${ }^{2}$ Includes ammonium and other tungstates, ferrotungsten, tungsten carbides, tungsten metal powders, unwrought tungsten, wrought tungsten forms, and tungsten waste and scrap.

${ }^{3}$ Defined as mine production + secondary production + imports - exports + adjustments for Government and industry stock changes.

${ }^{4}$ Source: S\&P Global Platts Metals Week.

${ }^{5} \mathrm{~A}$ metric ton unit of tungsten trioxide contains 7.93 kilograms of tungsten.

${ }^{6}$ Defined as imports - exports + adjustments for Government and industry stock changes.

${ }^{7}$ See Appendix $B$ for definitions.

${ }^{8}$ Inventory includes tungsten alloys and tungsten-rhenium metal; potential acquisitions are tungsten-rhenium metal only.

${ }^{9}$ See Appendix $\mathrm{C}$ for resource and reserve definitions and information concerning data sources.
} 


\section{VANADIUM}

(Data in metric tons of vanadium content unless otherwise noted)

Domestic Production and Use: Byproduct vanadium production in Utah from the mining of uraniferous sandstones on the Colorado Plateau ceased in the first quarter of 2020 owing to decreasing vanadium prices. An estimated 170 tons of contained vanadium with an estimated value of $\$ 1.4$ million was produced in 2020 . Secondary vanadium production continued primarily in Arkansas, Delaware, Ohio, Pennsylvania, and Texas, where processed waste materials (petroleum residues, spent catalysts, utility ash, and vanadium-bearing pig iron slag) were used to produce ferrovanadium, vanadium-bearing chemicals or specialty alloys, vanadium metal, and vanadium pentoxide.

Metallurgical use, primarily as an alloying agent for iron and steel, accounted for about $94 \%$ of domestic reported vanadium consumption in 2020 . Of the other uses for vanadium, the major nonmetallurgical use was in catalysts to produce maleic anhydride and sulfuric acid.

\section{Salient Statistics_-United States:}

Production, mine, mill

Imports for consumption:

Vanadium ores and concentrates

Ferrovanadium

Vanadium pentoxide, anhydride

Oxides and hydroxides, other

Aluminum-vanadium master alloys

Ash and residues

Vanadium chemicals ${ }^{1}$

Vanadium metal ${ }^{2}$

Exports:

Vanadium ores and concentrates

Ferrovanadium

Vanadium pentoxide, anhydride

Oxides and hydroxides, other

Aluminum-vanadium master alloys

Ash and residues

Vanadium metal $^{2}$

Consumption:

Apparent $^{3}$

Reported

Price, average, vanadium pentoxide,$^{4}$ dollars per pound

Stocks, yearend 5

Net import reliance ${ }^{6}$ as a percentage of apparent consumption

$\begin{array}{rrrrr}\frac{\mathbf{2 0 1 6}}{-} & \frac{\mathbf{2 0 1 7}}{-} & \frac{\mathbf{2 0 1 8}}{-} & \frac{\mathbf{2 0 1 9}}{460} & \frac{\mathbf{2 0 2 0}}{170} \\ 18 & 1 & 330 & 108 & 3 \\ 1,590 & 2,810 & 2,970 & 2,280 & 1,600 \\ 2,460 & 3,400 & 4,600 & 3,660 & 2,800 \\ 660 & 148 & 98 & 105 & 140 \\ 157 & 288 & 281 & 222 & 180 \\ 2,820 & 2,540 & 2,810 & 2,120 & 50 \\ 555 & 607 & 515 & 201 & 230 \\ 33 & 54 & 28 & 45 & 1 \\ & & & & \\ 260 & 37 & 29 & 57 & 30 \\ 394 & 229 & 575 & 295 & 200 \\ 5 & 126 & 563 & 423 & 80 \\ 81 & 148 & 53 & 750 & 80 \\ 53 & 132 & 90 & 29 & 30 \\ 123 & 322 & 287 & 256 & 60 \\ 19 & 59 & 39 & 27 & 20 \\ & & & & \\ 7,360 & 8,780 & 9,980 & 7,350 & 4,800 \\ 4,610 & 4,670 & 5,640 & 4,840 & 4,400 \\ 3.38 & 7.61 & 16.4 & 12.2 & 6.7 \\ 207 & 227 & 250 & 257 & 220 \\ 100 & 100 & 100 & 94 & 96\end{array}$

Recycling: The quantity of vanadium recycled from spent chemical process catalysts was significant and may compose as much as $40 \%$ of total vanadium catalysts.

Import Sources (2016-19): Ferrovanadium: Austria, 47\%; Canada, 25\%; Russia, 14\%; Japan, 5\%; and other, 9\%. Vanadium pentoxide: Brazil, 41\%; South Africa, 37\%; China, 11\%; Taiwan, 5\%; and other, 6\%.

\section{Tariff: Item}

Vanadium ores and concentrates

Vanadium bearing ash and residues

Vanadium bearing ash and residues, other

Chemical compounds:

Vanadium pentoxide, anhydride

Vanadium oxides and hydroxides, other

Vanadium sulfates

Vanadates

Hydrides and nitrides of vanadium

Ferrovanadium

Vanadium metal

Vanadium and articles thereof ${ }^{7}$

\section{Number}

2615.90.6090

2620.40 .0030

2620.99.1000

2825.30.0010

2825.30.0050

2833.29.3000

2841.90 .1000

2850.00.2000

7202.92 .0000

8112.92 .7000

8112.99.2000
Normal Trade Relations

12-31-20

Free.

Free.

Free.

$5.5 \%$ ad val.

$5.5 \%$ ad val.

$5.5 \%$ ad val.

$5.5 \%$ ad val.

$5.5 \%$ ad val.

$4.2 \%$ ad val.

$2.0 \%$ ad val.

$2.0 \%$ ad val.

Depletion Allowance: 22\% (domestic), 14\% (foreign).

Prepared by Désirée E. Polyak [(703) 648-4909, dpolyak@usgs.gov] 
Government Stockpile: None.

Events, Trends, and Issues: U.S. apparent consumption of vanadium in 2020 decreased by $35 \%$ from that of 2019. Among the major uses for vanadium, production of carbon, full-alloy, and high-strength low-alloy steels accounted for $18 \%, 45 \%$, and $33 \%$, respectively, of domestic consumption. The estimated average Chinese vanadium pentoxide price in 2020 decreased by $45 \%$ compared with the 2019 price, and the estimated United States ferrovanadium price decreased by $53 \%$ to $\$ 10.40$ per pound in 2020 compared with that in 2019 .

The implementation of the new high-strength rebar standards by the Standardization Administration of China continued to be enforced inconsistently. Larger mills in China began implementation in 2018; however, smaller mills have been slower to implement the new rebar standards. In addition, substitution of ferroniobium for ferrovanadium has caused lasting effects on mills, and mills were unlikely to switch back to using ferrovanadium owing to costly technical changes already incurred.

A vanadium processing facility in South Africa reopened in early 2020 under new management and began processing stockpiled materials. A producer in Brazil that started production in 2014 continued to be on track to reach vanadium production guidance for 2020 despite production delays caused by the global COVID-19 pandemic. However, some vanadium producers have reported that they were unlikely to reach their original anticipated production guidance and were unsure of the continuing effects of the pandemic.

\section{World Mine Production and Reserves:}

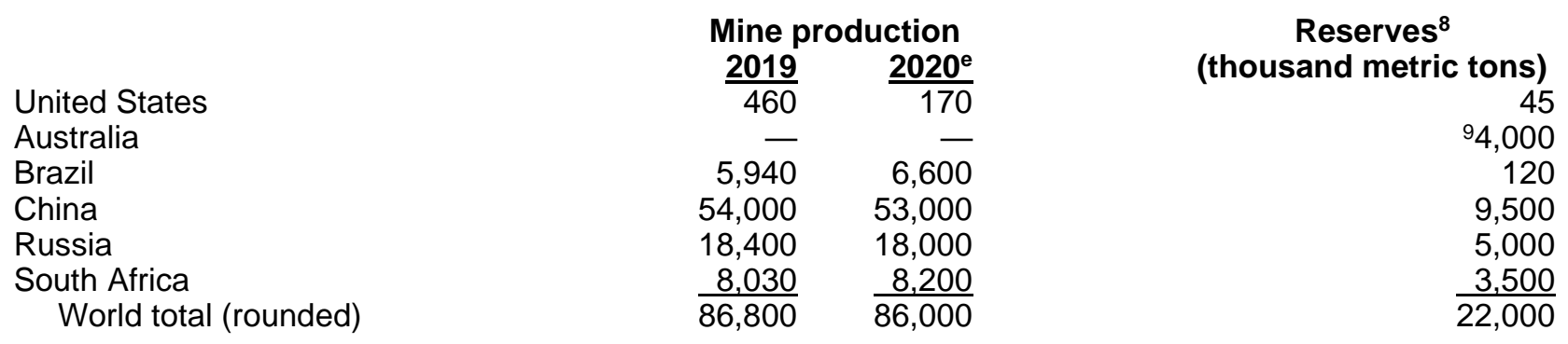

World Resources: ${ }^{8}$ World resources of vanadium exceed 63 million tons. Vanadium occurs in deposits of phosphate rock, titaniferous magnetite, and uraniferous sandstone and siltstone, in which it constitutes less than $2 \%$ of the host rock. Significant quantities are also present in bauxite and carboniferous materials, such as coal, crude oil, oil shale, and tar sands. Because vanadium is typically recovered as a byproduct or coproduct, demonstrated world resources of the element are not fully indicative of available supplies. Although domestic resources and secondary recovery are adequate to supply a large portion of domestic needs, almost all of U.S. demand is currently met by foreign sources.

Substitutes: Steels containing various combinations of other alloying elements can be substituted for steels containing vanadium. Certain metals, such as manganese, molybdenum, niobium (columbium), titanium, and tungsten, are to some degree interchangeable with vanadium as alloying elements in steel. Platinum and nickel can replace vanadium compounds as catalysts in some chemical processes. Currently, no acceptable substitute for vanadium is available for use in aerospace titanium alloys. 


\section{VERMICULITE}

(Data in thousand metric tons unless otherwise noted)

Domestic Production and Use: Two companies with mining and processing facilities in South Carolina and Virginia produced approximately 100,000 tons of vermiculite concentrate; actual data have been rounded to one significant digit to avoid disclosing company proprietary data. Flakes of raw vermiculite concentrate are micaceous in appearance and contain interlayer water in their structure. When the flakes are heated rapidly to a temperature above $870{ }^{\circ} \mathrm{C}$, the water flashes into steam, and the flakes expand into accordionlike particles. This process is called exfoliation or expansion, and the resulting ultralightweight material is chemically inert, fire resistant, and odorless. Most of the vermiculite concentrate produced in the United States was shipped to 17 exfoliating plants in 11 States. The end uses for exfoliated vermiculite were estimated to be agriculture and horticulture, $48 \%$; lightweight concrete aggregates (including cement premixes, concrete, and plaster), 14\%; insulation, 11\%; and other, $27 \%$.

\begin{tabular}{|c|c|c|c|c|c|}
\hline Salient Statistics-United States: & $\underline{2016}$ & $\underline{2017}$ & $\underline{2018}$ & $\underline{2019}$ & $2020^{\mathrm{e}}$ \\
\hline$\overline{\text { Productione, } 1,2}$ & $\overline{100}$ & $\overline{100}$ & 100 & 100 & 100 \\
\hline Imports for consumptione & 36 & 28 & 37 & 39 & 40 \\
\hline Exports & 21 & 16 & 14 & 9 & 10 \\
\hline \multicolumn{6}{|l|}{ Consumption: } \\
\hline Apparent, concentrate 3 & 120 & 110 & 120 & 130 & 130 \\
\hline Reported, exfoliated & 68 & 72 & 76 & 74 & 70 \\
\hline \multicolumn{5}{|l|}{$\begin{array}{l}\text { Price, range of value, concentrate, ex-plant, } \\
\text { dollars per ton }\end{array}$} & NA \\
\hline Employment, numbere & 62 & 63 & 66 & 73 & 73 \\
\hline $\begin{array}{l}\text { Net import reliance }{ }^{4} \text { as a percentage of } \\
\text { apparent consumptione, } 2\end{array}$ & 10 & 10 & 20 & 20 & 20 \\
\hline
\end{tabular}

Recycling: Insignificant.

Import Sources (2016-19): South Africa, 71\%; Brazil, 25\%; Zimbabwe, 2\%; Kenya, 1\%; and other, 1\%.

Tariff: Item

Vermiculite, perlite and chlorites, unexpanded

Exfoliated vermiculite, expanded clays, foamed

slag, and similar expanded materials
Number

2530.10 .0000

6806.20 .0000
Normal Trade Relations 12-31-20 Free.

Free.

Depletion Allowance: 14\% (domestic and foreign).

Government Stockpile: None.

Events, Trends, and Issues: U.S. exports and imports of vermiculite are not collected as a separate category by the U.S. Census Bureau. Despite the global COVID-19 pandemic, U.S. imports were estimated to be about 40,000 tons in 2020, essentially unchanged from those of 2019. Most imports came from South Africa and Brazil in 2020. One company announced price increases for vermiculite in 2020 but did not disclose specific price ranges.

A company in Brazil continued to expand production capacity at its vermiculite mine in central Brazil and continued with the development of another deposit near Brasilia to bring the company's total production capacity to 200,000 tons per year. Companies in China with significant vermiculite resources also were ramping up production, although processing operations continued to be somewhat constrained by increased enforcement of environmental regulations. Specific production data were not available for China.

Coarse-grade vermiculite remained in short supply. Sustained production at the 30,000-ton-per-year Namekara Mine in Uganda provides coarser grades to the market because it is considered to be one of the world's largest vermiculite deposits with significant portions of medium- and coarse-grade material. The Namekara deposit has enough resources for more than 50 years of production at previously announced rates. The company in Uganda pursued mine planning strategies after becoming the $100 \%$ owner of the mine. 
Exploration and development of vermiculite deposits containing medium, large, and premium (coarser) grades (mostly in China and South Africa) are likely to continue because of the higher demand for those grades. Finer grade production has exceeded consumption for several years. However, coarser grade (greater than 5-millimeter particle size) production has not been able to keep up with demand. Producers will continue to investigate ways to increase the use of the finer grades in existing products and in uses that require coarse material. Innovative applications continue to emerge, including the use of vermiculite to combat air pollution and absorb water in mines, replacing zeolites in ion-exchange columns, purifying wastewater, and containing or removing nuclear waste.

\section{World Mine Production and Reserves:}

\begin{tabular}{|c|c|c|c|}
\hline \multirow[b]{3}{*}{ United States } & \multicolumn{2}{|c|}{ Mine production } & \multirow[t]{2}{*}{ Reserves $^{5}$} \\
\hline & 2019 & $\underline{2020^{e}}$ & \\
\hline & $\mathrm{e}, \overline{2100}$ & $\overline{2100}$ & 25,000 \\
\hline Brazil & 50 & 50 & 6,600 \\
\hline Bulgaria & 11 & 10 & NA \\
\hline China & NA & NA & NA \\
\hline Egypt & 8 & 8 & NA \\
\hline India & 2 & 2 & 1,600 \\
\hline Russia & 25 & 25 & NA \\
\hline South Africa & 158 & 140 & 14,000 \\
\hline Uganda & 7 & 7 & NA \\
\hline Zimbabwe & 30 & 30 & NA \\
\hline Other countries & 3 & 3 & NA \\
\hline World total (rounded) 6 & $\overline{390}$ & $\overline{380}$ & $\overline{\mathrm{NA}}$ \\
\hline
\end{tabular}

World Resources: ${ }^{5}$ In addition to the producing mines in South Carolina and Virginia, there are vermiculite occurrences in Colorado, Nevada, North Carolina, Texas, and Wyoming which contain estimated resources of 2 million tons to 3 million tons. Significant deposits have been reported in Australia, China, Russia, Uganda, and some other countries, but reserves and resource information comes from many sources and, in most cases, it is not clear whether the numbers refer to vermiculite alone or vermiculite plus other minerals and host rock and overburden.

Substitutes: Expanded perlite is a substitute for exfoliated vermiculite in lightweight concrete and plaster. Other denser but less costly alternatives in these applications include expanded clay, shale, slag, and slate. Alternate materials for loose-fill fireproofing insulation include fiberglass, perlite, and slag wool. In agriculture, substitutes include bark and other plant materials, peat, perlite, sawdust, and synthetic soil conditioners.

\footnotetext{
eEstimated. NA Not available.

${ }^{1}$ Concentrate sold or used by producers.

${ }^{2}$ Data are rounded to one significant digit to avoid disclosing company proprietary data.

${ }^{3}$ Defined as concentrate sold or used by producers + imports - exports.

${ }^{4}$ Defined as imports - exports.

${ }^{5}$ See Appendix $\mathrm{C}$ for resource and reserve definitions and information concerning data sources.

${ }^{6}$ Excludes China production.
} 


\section{WOLLASTONITE}

(Data in metric tons unless otherwise noted)

Domestic Production and Use: Wollastonite was mined by two companies in New York during 2020. U.S. production of wollastonite (sold or used by producers) was withheld to avoid disclosing company proprietary data but was estimated to have remained essentially unchanged from that of 2019. Economic resources of wollastonite typically form as a result of thermal metamorphism of siliceous limestone during regional deformation or chemical alteration of limestone by siliceous hydrothermal fluids along faults or contacts with magmatic intrusions. Deposits of wollastonite have been identified in Arizona, California, Idaho, Nevada, New Mexico, New York, and Utah; however, New York is the only State where long-term continuous mining has taken place.

The U.S. Geological Survey does not collect consumption statistics for wollastonite, but consumption was estimated to have decreased in 2020, compared with that of 2019. Ceramics (frits, sanitaryware, and tile), friction products (primarily brake linings), metallurgical applications (flux and conditioner), paint (architectural and industrial paints), plastics and rubber markets (thermoplastic and thermoset resins and elastomer compounds), and miscellaneous uses (including adhesives, concrete, glass, and sealants) accounted for wollastonite sales in the United States.

In ceramics, wollastonite decreases shrinkage and gas evolution during firing; increases green and fired strength; maintains brightness during firing; permits fast firing; and reduces crazing, cracking, and glaze defects. In metallurgical applications, wollastonite serves as a flux for welding, a source for calcium oxide, a slag conditioner, and protects the surface of molten metal during the continuous casting of steel. As an additive in paint, it improves the durability of the paint film, acts as a pH buffer, improves resistance to weathering, reduces gloss and pigment consumption, and acts as a flatting and suspending agent. In plastics, wollastonite improves tensile and flexural strength, reduces resin consumption, and improves thermal and dimensional stability at elevated temperatures. Surface treatments are used to improve the adhesion between wollastonite and the polymers to which it is added. As a substitute for asbestos in floor tiles, friction products, insulating board and panels, paint, plastics, and roofing products, wollastonite is resistant to chemical attack, stable at high temperatures, and improves flexural and tensile strength.

Salient Statistics_United States: The United States was thought to be a net exporter of wollastonite in 2020. Comprehensive trade data were not available for wollastonite because it is imported and exported under generic Harmonized Tariff Schedule of the United States and Schedule B codes, respectively, that include multiple mineral commodities. Prices for domestically produced wollastonite were estimated to be between $\$ 360$ to $\$ 390$ per metric ton. Price data for globally produced wollastonite were unavailable. Products with finer grain sizes and acicular (highly elongated) particles sold for higher prices. Surface treatment, when necessary, also increased the selling price. Approximately 60 people were employed at wollastonite mines and mills in 2019 (excluding office workers).

Recycling: None.

Import Sources (2016-19): Comprehensive trade data were not available, but wollastonite was primarily imported from Canada, China, India, and Mexico.

\section{Tariff: Item}

Mineral substances not elsewhere specified or included

Depletion Allowance: 10\% (domestic and foreign).
Number

2530.90 .8050
Normal Trade Relations $\underline{12-31-20}$

Free.

Government Stockpile: None. 


\section{WOLLASTONITE}

Events, Trends, and Issues: Construction starts of new housing units through July 2020, increased by $4.7 \%$ compared with those during the same period in 2019, suggesting that sales of wollastonite to domestic constructionrelated markets, such as adhesives, caulks, cement board, ceramic tile, paints, stucco, and wallboard, might have increased. However, sales of wollastonite to most other major markets in which wollastonite is used were estimated to have decreased. Owing to disruptions caused by the COVID-19 pandemic, production of motor vehicles and parts, which contain wollastonite in friction products and plastic and rubber components, decreased in the first 7 months of 2020; plastics and rubber production decreased by $33 \%$ each; and primary iron and steel production decreased by $19 \%$ compared with those in the same period of 2019.

Globally, ceramics, polymers (such as plastics and rubber), and paint accounted for most wollastonite sales. Lesser global uses for wollastonite included miscellaneous construction products, friction materials, metallurgical applications, and paper. Global sales of wollastonite were estimated to be in the range of 830,000 to 880,000 tons, slightly lower than those in 2019.

World Mine Production and Reserves: More countries than those listed may produce wollastonite; however, many countries do not publish wollastonite production data.

\begin{tabular}{lrr} 
& \multicolumn{2}{c}{ Mine production } \\
United States & $\frac{\mathbf{2 0 1 9}}{W}$ & $\frac{\mathbf{2 0 2 0}}{W}$ \\
Canada & 20,000 & 20,000 \\
China & 890,000 & 890,000 \\
India & 170,000 & 120,000 \\
Mexico & 101,000 & 100,000 \\
Other countries & 17,000 & $\frac{17,000}{\quad \text { World total (rounded) }{ }^{2}}$ \\
$\quad$ & $1,200,000$ & $1,100,000$
\end{tabular}

Reserves $^{1}$

World reserves of wollastonite exceed 100 million tons. Many deposits, however, have not been surveyed, precluding accurate estimates of reserves.

World Resources: ${ }^{1}$ Reliable estimates of wollastonite resources do not exist for most countries. Large deposits of wollastonite have been identified in China, Finland, India, Mexico, and the United States. Smaller, but significant, deposits have been identified in Canada, Chile, Kenya, Namibia, South Africa, Spain, Sudan, Tajikistan, Turkey, and Uzbekistan.

Substitutes: The acicular nature of many wollastonite products allows it to compete with other acicular materials, such as ceramic fiber, glass fiber, steel fiber, and several organic fibers, such as aramid, polyethylene, polypropylene, and polytetrafluoroethylene, in products where improvements in dimensional stability, flexural modulus, and heat deflection are sought. Wollastonite also competes with several nonfibrous minerals or rocks, such as kaolin, mica, and talc, which are added to plastics to increase flexural strength, and such minerals as barite, calcium carbonate, gypsum, and talc, which impart dimensional stability to plastics. In ceramics, wollastonite competes with carbonates, feldspar, lime, and silica as a source of calcium and silica. Its use in ceramics depends on the formulation of the ceramic body and the firing method.

\footnotetext{
eEstimated. W Withheld to avoid disclosing company proprietary data.

${ }^{1}$ See Appendix $C$ for resource and reserve definitions and information concerning data sources.

${ }^{2}$ Excludes U.S. production.
} 


\section{YTTRIUM1}

[Data in metric tons of yttrium-oxide $\left(\mathrm{Y}_{2} \mathrm{O}_{3}\right)$ equivalent content unless otherwise noted]

Domestic Production and Use: Yttrium is one of the rare-earth elements. Bastnaesite (or bastnäsite), a rare-earth fluorocarbonate mineral, was mined in 2020 as a primary product at the Mountain Pass Mine in California, which was restarted in the first quarter of 2018 after being put on care-and-maintenance status in the fourth quarter of 2015. Monazite, a rare-earth phosphate mineral, was produced as a separated concentrate or included as an accessory mineral in heavy-mineral concentrates. Yttrium was estimated to represent about $0.12 \%$ of the rare-earth elements in the Mountain Pass bastnaesite ore. Insufficient information was available to determine the yttrium content of mine production.

The leading end uses of yttrium were in catalysts, ceramics, lasers, metallurgy, and phosphors. In ceramic applications, yttrium compounds were used in abrasives, bearings and seals, high-temperature refractories for continuous-casting nozzles, jet-engine coatings, oxygen sensors in automobile engines, and wear-resistant and corrosion-resistant cutting tools. In metallurgical applications, yttrium was used as a grain-refining additive and as a deoxidizer. Yttrium was used in heating-element alloys, high-temperature superconductors, and superalloys. In electronics, yttrium-iron garnets were components in microwave radar to control high-frequency signals. Yttrium was an important component in yttrium-aluminum-garnet laser crystals used in dental and medical surgical procedures, digital communications, distance and temperature sensing, industrial cutting and welding, nonlinear optics, photochemistry, and photoluminescence. Yttrium was used in phosphor compounds for flat-panel displays and various lighting applications.

\begin{tabular}{|c|c|c|c|c|c|}
\hline$\frac{\text { Salient Statistics-United States: }}{\text { Production mine }}$ & $\underline{2016}$ & $\underline{2017}$ & $\frac{2018}{N A}$ & $\frac{2019}{N A}$ & $\frac{2020^{\mathrm{e}}}{\mathrm{NA}}$ \\
\hline & - & - & & & \\
\hline $\begin{array}{l}\text { Imports for consumption, yttrium, alloys, } \\
\text { compounds, and metale, } 2\end{array}$ & 340 & 380 & 450 & 360 & 600 \\
\hline Exports, compounds ${ }^{e, 3}$ & 2 & 2 & 14 & 6 & 1 \\
\hline Consumption, apparente 4 & 300 & 400 & 500 & 400 & 600 \\
\hline Price, average, dollars per kilogram: 5 & & & & & \\
\hline Yttrium oxide, minimum $99.999 \%$ purity & 4 & 3 & 3 & 3 & 3 \\
\hline Yttrium metal, minimum $99.9 \%$ purity & 35 & 35 & 36 & 34 & 34 \\
\hline $\begin{array}{l}\text { Net import reliance }{ }^{6,7} \text { as a percentage of } \\
\text { apparent consumption }\end{array}$ & 100 & 100 & 100 & 100 & 100 \\
\hline
\end{tabular}

Recycling: Insignificant.

Import Sources (2016-19): ${ }^{8}$ Yttrium compounds: China, 94\%; the Republic of Korea, 2\%; Japan, 1\%; and other, 3\%. Nearly all imports of yttrium metal and compounds are derived from mineral concentrates processed in China. Import sources do not include yttrium contained in value-added intermediates and finished products.

\section{Tariff: Item}

Rare-earth metals, unspecified, whether or not intermixed or interalloyed

Mixtures of rare-earth oxides containing yttrium or scandium as the predominant metal

Mixtures of rare-earth chlorides containing yttrium or scandium as the predominant metal

Yttrium-bearing materials and compounds containing by weight $>19 \%$ to $<85 \% \mathrm{Y}_{2} \mathrm{O}_{3}$

Other rare-earth compounds, including yttrium and other compounds
Number

2805.30.0090

2846.90 .2015

2846.90 .2082

2846.90 .4000

2846.90 .8000

\section{Normal Trade Relations} 12-31-20

$5.0 \%$ ad val.

Free.

Free.

Free.

$3.7 \%$ ad val. 


\section{YTTRIUM}

Depletion Allowance: Monazite, thorium content, 22\% (domestic), 14\% (foreign); yttrium, rare-earth content, 14\% (domestic and foreign); and xenotime, 14\% (domestic and foreign).

\section{Government Stockpile: ${ }^{9}$}

\begin{tabular}{lccccc} 
& \multicolumn{2}{c}{ FY 2020 } & \multicolumn{2}{c}{ FY 2021 } \\
Material & Inventory as of & Potential & Potential & $\begin{array}{c}\text { Potential } \\
\text { acquisitions }\end{array}$ & $\begin{array}{c}\text { Potential } \\
\text { disposals }\end{array}$ \\
Yttrium & $9-30-20$ & acquisitions & disposals & acqual \\
& 25 & - & - & 600 & -
\end{tabular}

Events, Trends, and Issues: China produced most of the world's supply of yttrium from its weathered clay ionadsorption ore deposits in the southern Provinces_-primarily Fujian, Guangdong, and Jiangxi-and from a lesser number of deposits in Guangxi and Hunan Provinces. Yttrium was also produced from similar clay deposits in Burma.

Globally, yttrium was mainly consumed in the form of oxide compounds for ceramics and phosphors. Lesser amounts were consumed in electronic devices, lasers, optical glass, and metallurgical applications. The average prices for yttrium metal and yttrium oxide price were nearly unchanged compared with that of 2019. China's Ministry of Industry and Information Technology raised the rare-earth mining and separation quotas to record highs of 140,000 tons and 135,000 tons of rare-earth-oxide equivalent, respectively. The yttrium content of the production quota was not specified. In 2020, China's exports of yttrium compounds and metal were estimated to be 2,300 tons of yttrium-oxide equivalent, and the leading export destinations were, in descending order, Japan, the United States, Italy, and the Republic of Korea.

World Mine Production and Reserves: ${ }^{10}$ World mine production of yttrium contained in rare-earth mineral concentrates was estimated to be 8,000 to 12,000 tons. Most of this production took place in China and Burma. Global reserves of yttrium oxide were estimated to be more than 500,000 tons. The leading countries for these reserves included Australia, Brazil, Canada, China, and India. Although mine production in Burma was significant, information on reserves in Burma was not available. Global reserves may be adequate to satisfy near-term demand at current rates of production; however, changes in economic conditions, environmental issues, or permitting and trade restrictions could affect the availability of many of the rare-earth elements, including yttrium.

World Resources: ${ }^{10}$ Large resources of yttrium in monazite and xenotime are available worldwide in placer deposits, carbonatites, uranium ores, and weathered clay deposits (ion-adsorption ore). Additional resources of yttrium occur in apatite-magnetite-bearing rocks, deposits of niobium-tantalum minerals, nonplacer monazite-bearing deposits, sedimentary phosphate deposits, and uranium ores.

Substitutes: Substitutes for yttrium are available for some applications but generally are much less effective. In most uses, especially in electronics, lasers, and phosphors, yttrium is generally not subject to direct substitution by other elements. As a stabilizer in zirconia ceramics, yttrium oxide may be substituted with calcium oxide or magnesium oxide, but the substitutes generally impart lower toughness.

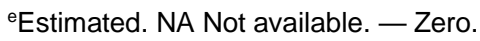

${ }^{1}$ See also Rare Earths; trade data for yttrium are included in the data shown for rare earths.

${ }^{2}$ Estimated from Trade Mining LLC and IHS Markit Ltd. shipping records.

${ }^{3}$ Includes data for the following Schedule B code: 2846.90.2015.

${ }^{4}$ Defined as imports - exports. Rounded to one significant digit. Yttrium consumed domestically was imported or refined from imported materials.

${ }^{5}$ Free on board China. Source: Argus Media group_Argus Metals International, London, United Kingdom.

${ }^{6}$ Defined as imports - exports.

${ }^{7}$ In 2018, 2019, and 2020, domestic production of mineral concentrates was stockpiled or exported. Consumers of compounds and metals were reliant on imports and stockpiled inventory of compounds and metals.

${ }^{8}$ Includes estimated yttrium-oxide equivalent content from the following Harmonized Tariff Schedule of the United States codes: 2846.90 .2015 ,

2846.90.2082, 2846.90.4000, 2846.90.8050, and 2846.90.8060.

${ }^{9}$ See Appendix B for definitions.

${ }^{10}$ See Appendix $\mathrm{C}$ for resource and reserve definitions and information concerning data sources.
} 


\section{ZEOLITES (NATURAL)}

(Data in metric tons unless otherwise noted)

Domestic Production and Use: In 2020, six companies in the United States operated nine zeolite mines and produced an estimated 88,000 tons of natural zeolites, essentially unchanged from that of 2019 . Chabazite was mined in Arizona, and clinoptilolite was mined in California, Idaho, New Mexico, Oregon, and Texas. Minor quantities of erionite, ferrierite, mordenite, and (or) phillipsite also likely were produced. New Mexico was estimated to be the leading natural zeolite-producing State in 2020 . The top three companies accounted for approximately $75 \%$ of total domestic production.

An estimated 77,000 tons of natural zeolites were sold in the United States during 2020, essentially unchanged compared with sales in 2019. Domestic uses were, in decreasing order by estimated quantity, animal feed, odor control, unclassified end uses (such as ice melt, soil amendment, and synthetic turf), water purification, pet litter, wastewater treatment, fungicide or pesticide carrier, oil and grease absorbent, air filtration and gas absorbent, fertilizer carrier, desiccant, and aquaculture. Animal feed, odor control, and water purification applications likely accounted for about $60 \%$ of the domestic sales tonnage.

\section{Salient Statistics-United States:}

Production, mine

Sales, mill

Imports for consumptione

Exports ${ }^{e}$

Consumption, apparent ${ }^{1}$

Price, range of value, dollars per ton²

Employment, mine and mill, numbere, 3

Net import reliance ${ }^{4}$ as a percentage of apparent consumption

$\begin{array}{rrrrr}\mathbf{2 0 1 6} & \mathbf{2 0 1 7} & \mathbf{2 0 1 8} & \mathbf{2 0 1 9} & \underline{\mathbf{2 0 2 0}} \\ 75,200 & 82,400 & 86,100 & 87,800 & 88,000 \\ 71,300 & 81,300 & 80,500 & 77,100 & 77,000 \\ <1,000 & <1,000 & <1,000 & <1,000 & <1,000 \\ <1,000 & <1,000 & <1,000 & <1,000 & <1,000 \\ 71,300 & 81,300 & 80,500 & 77,100 & 77,000 \\ 100-400 & 100-300 & e 50-300 & e 50-300 & 50-300 \\ 115 & 110 & 110 & 120 & 120 \\ \text { E } & \text { E } & \text { E } & \text { E } & \text { E }\end{array}$

Recycling: Zeolites used for desiccation, gas absorbance, wastewater cleanup, and water purification may be reused after reprocessing of the spent zeolites. Information about the quantity of recycled natural zeolites was unavailable.

Import Sources (2016-19): Comprehensive trade data were not available for natural zeolite minerals because they were imported and exported under generic Harmonized Tariff Schedule of the United States and Schedule B codes, respectively, that include multiple mineral commodities or under codes for finished products. Nearly all imports and exports were thought to be synthetic zeolites.

Tariff: Item

Mineral substances not elsewhere specified or included
Number

2530.90 .8050
Normal Trade Relations 12-30-20

Free.

Depletion Allowance: 14\% (domestic and foreign).

Government Stockpile: None. 


\section{ZEOLITES (NATURAL)}

Events, Trends, and Issues: Prior to the 1990s, annual output of natural zeolites in the United States was less than 15,000 tons. Production rose more than sixfold from 1990 through 2020 owing predominantly to increases in sales for animal feed applications, although sales for odor control and water purification also increased significantly. In contrast, sales for pet litter declined substantially during this period as a result of competition from other products. Owing to disruptions likely caused by the global COVID-19 pandemic, mine production during the first 6 months of 2020 was mixed compared with the same period of 2019. Some mines appeared to have cut production and others may have increased production.

World Mine Production and Reserves: Many countries either do not report production of natural zeolites or production is reported with a 2- to 3-year lag time. End uses for natural zeolites in countries that mine large tonnages of zeolite minerals typically include low-value, high-volume construction applications, such as dimension stone, lightweight aggregate, and pozzolanic cement. As a result, production data for some countries may not accurately indicate the quantities of natural zeolites used in the high-value applications that are reflected in the domestic data.

World reserves of natural zeolites have not been estimated. Deposits occur in many countries, but companies rarely publish reserves data. Further complicating estimates of reserves is the fact that much of the reported world production includes altered volcanic tuffs with low to moderate concentrations of zeolites that are typically used in high-volume construction applications. Some deposits should, therefore, be excluded from reserves estimates because it is the rock itself and not its zeolite content that makes the deposit valuable.

\begin{tabular}{lrr} 
& \multicolumn{2}{c}{ Mine production } \\
& $\underline{\mathbf{2 0 1 9}}$ & $\underline{\mathbf{2 0 2 0}}$ \\
United States & 687,800 & 88,000 \\
China & 320,000 & 320,000 \\
Cuba & 653,000 & 53,000 \\
Hungary & 29,000 & 29,000 \\
Indonesia & 130,000 & 130,000 \\
Jordan & 10,000 & 10,000 \\
Korea, Republic of & 6144,000 & 140,000 \\
New Zealand & 100,000 & 100,000 \\
Russia & 35,000 & 35,000 \\
Slovakia & 117,000 & 120,000 \\
Turkey & 60,000 & 60,000 \\
Other countries & 4,120 & 4,000 \\
\cline { 2 - 3 }$\quad$ World total (rounded) & $1,090,000$ & $1,100,000$
\end{tabular}

Reserves $^{5}$

Two of the leading companies in the United States reported combined reserves of 80 million tons in 2020; total U.S. reserves likely are substantially larger. World data are unavailable, but reserves are estimated to be large.

World Resources: ${ }^{5}$ Recent estimates for domestic and global resources of natural zeolites are not available. Resources of chabazite and clinoptilolite in the United States are sufficient to satisfy foreseeable domestic demand.

Substitutes: For pet litter, zeolites compete with other mineral-based litters, such as those manufactured using bentonite, diatomite, fuller's earth, and sepiolite; organic litters made from shredded corn stalks and paper, straw, and wood shavings; and litters made using silica gel. Diatomite, perlite, pumice, vermiculite, and volcanic tuff compete with natural zeolite as lightweight aggregate. Zeolite desiccants compete against such products as magnesium perchlorate and silica gel. Zeolites compete with bentonite, gypsum, montmorillonite, peat, perlite, silica sand, and vermiculite in various soil amendment applications. Activated carbon, diatomite, or silica sand may substitute for zeolites in water-purification applications. As an oil absorbent, zeolites compete mainly with bentonite, diatomite, fuller's earth, sepiolite, and a variety of polymer and natural organic products. In animal feed, zeolites compete with bentonite, diatomite, fuller's earth, kaolin, silica, and talc as anticaking and flow-control agents.

\footnotetext{
EEstimated. E Net exporter.

${ }^{1}$ Defined as mill sales + imports - exports. Information about industry stocks was unavailable.

${ }^{2}$ Range of ex-works mine and mill unit values for individual natural zeolite operations, based on data reported by U.S. producers and U.S.

Geological Survey estimates. Average unit values per ton for the past 5 years were $\$ 140$ in 2016 and 2017, and an estimated $\$ 125$ in 2018 , 2019, and 2020. Prices vary with the percentage of zeolite present in the product, the chemical and physical properties of the zeolite mineral(s), particle size, surface modification and (or) activation, and end use.

${ }^{3}$ Excludes administration and office staff. Estimates based on data from the Mine Safety and Health Administration.

${ }^{4}$ Defined as imports - exports.

${ }^{5}$ See Appendix $\mathrm{C}$ for resource and reserve definitions and information concerning data sources.

${ }^{6}$ Reported figure.
} 
(Data in thousand metric tons of zinc content unless otherwise noted)

Domestic Production and Use: The value of zinc mined in 2020, based on zinc contained in concentrate, was about $\$ 1.6$ billion. Zinc was mined in five States at 14 mines operated by five companies. Three smelter facilities, one primary and two secondary, operated by three companies, produced commercial-grade zinc metal. Of the total reported zinc consumed, most was used in galvanizing, followed by brass and bronze, zinc-based alloys, and other uses.

\begin{tabular}{|c|c|c|c|c|c|}
\hline \multicolumn{6}{|l|}{$\begin{array}{l}\text { Salient Statistics_United States: } \\
\text { Production: }\end{array}$} \\
\hline $\begin{array}{l}\text { Production: } \\
\text { Zinc in ores and concentrates }\end{array}$ & 805 & 774 & 824 & 753 & 670 \\
\hline Refined zinc ${ }^{1}$ & 126 & 132 & 116 & 115 & 150 \\
\hline \multicolumn{6}{|l|}{ Imports for consumption: } \\
\hline Zinc in ores and concentrates & $\left({ }^{2}\right)$ & 7 & $\left({ }^{2}\right)$ & $(2)$ & 4 \\
\hline Refined zinc & 713 & 729 & 775 & 830 & 710 \\
\hline \multicolumn{6}{|l|}{ Exports: } \\
\hline Zinc in ores and concentrates & 597 & 682 & 806 & 796 & 560 \\
\hline Refined zinc & 47 & 33 & 23 & 5 & 2 \\
\hline Shipments from Government stockpile & - & - & - & - & - \\
\hline Consumption, apparent, refined zinc ${ }^{3}$ & 792 & 829 & 868 & 939 & 860 \\
\hline \multicolumn{6}{|l|}{ Price, average, cents per pound: } \\
\hline North American ${ }^{4}$ & 101.4 & 139.3 & 141.0 & 124.1 & 109.0 \\
\hline London Metal Exchange (LME), cash & 94.8 & 131.2 & 132.7 & 115.6 & 101.0 \\
\hline $\begin{array}{l}\text { Stocks, reported producer and consumer, refined zinc, } \\
\text { yearend }\end{array}$ & 79 & 114 & 119 & 116 & 130 \\
\hline \multicolumn{6}{|l|}{ Employment, number: } \\
\hline Mine and mill ${ }^{5}$ & 2,350 & 2,420 & 2,630 & 2,490 & 2,400 \\
\hline Smelter, primary & 246 & 240 & 250 & 250 & 250 \\
\hline \multicolumn{6}{|l|}{$\begin{array}{l}\text { Net import reliance }{ }^{6} \text { as a percentage of apparent } \\
\text { consumption: }\end{array}$} \\
\hline $\begin{array}{l}\text { Ores and concentrates } \\
\text { Refined zinc }\end{array}$ & $\begin{array}{r}E \\
84\end{array}$ & $\begin{array}{r}E \\
84\end{array}$ & $\begin{array}{r}E \\
87\end{array}$ & $\begin{array}{r}E \\
88\end{array}$ & $\begin{array}{r}E \\
83\end{array}$ \\
\hline
\end{tabular}

Recycling: In 2020, an estimated one-third of the refined zinc produced in the United States was recovered from secondary materials at both primary and secondary smelters. Secondary materials included galvanizing residues and crude zinc oxide recovered from electric arc furnace dust.

Import Sources (2016-19): Ores and concentrates: Peru, 98\%; the Republic of Korea, 1\%; other, 1\%. Refined metal: Canada, 64\%; Mexico, 14\%; Peru, 7\%; Spain, 7\%; and other, 8\%. Waste and scrap (gross weight): Canada, $65 \%$; Mexico, 33\%; and other, $2 \%$. Combined total (includes gross weight of waste and scrap): Canada, $64 \%$; Mexico, 14\%; Peru, 8\%; Spain, 7\%; and other, 7\%.

\section{Tariff: Item}

Zinc ores and concentrates, Zn content

Zinc oxide; zinc peroxide

Unwrought zinc, not alloyed:

Containing $99.99 \%$ or more zinc

Containing less than $99.99 \%$ zinc: Casting-grade Other

Zinc alloys

Zinc waste and scrap

\section{Number}

2608.00.0030

2817.00.0000

7901.11 .0000

7901.12 .1000

7901.12 .5000

7901.20 .0000

7902.00 .0000

\section{Normal Trade Relations \\ 12-31-20 \\ Free. \\ Free.}

$1.5 \%$ ad val.

$3 \%$ ad val.

$1.5 \%$ ad val.

$3 \%$ ad val.

Free.

Depletion Allowance: 22\% (domestic), 14\% (foreign).

Government Stockpile: ${ }^{7}$

$\begin{array}{lc}\text { Inventory } \\ \text { Material } & \text { as of } 9-30-20 \\ \text { Zinc } & 7.25\end{array}$

\begin{tabular}{cc}
\multicolumn{2}{c}{ FY 2020} \\
Potential & $\begin{array}{c}\text { Potential } \\
\text { acquisitions }\end{array}$ \\
disposals & 7.25
\end{tabular}

\begin{tabular}{cc}
\multicolumn{2}{c}{ FY 2021 } \\
Potential & $\begin{array}{c}\text { Potential } \\
\text { disposals }\end{array}$ \\
acquisitions & 7.25
\end{tabular}

Prepared by Amy C. Tolcin [(703) 648-4940, atolcin@usgs.gov] 
Events, Trends, and Issues: Global zinc mine production in 2020 was estimated to be 12 million tons, a $6 \%$ decrease from that of 2019. Government-mandated lockdowns and a decrease in zinc prices following the onset of the global COVID-19 pandemic resulted in a decrease in zinc mine production in many countries, particularly in South America.

According to the International Lead and Zinc Study Group, ${ }^{8}$ global refined zinc production in 2020 was estimated to increase slightly to 13.60 million tons, and metal consumption was estimated decrease by $5 \%$ to 12.98 million tons, resulting in a production-to-consumption surplus of about 620,000 tons of refined zinc.

Domestic zinc mine production decreased in 2020, owing partially to the closure of the Pend Oreille Mine in Washington State in 2019 after current reserves were exhausted and a decrease in production at the Red Dog Mine in Alaska related to the mining of lower grade ores after a change in the mine plan to manage water levels at the site. Refined zinc production increased after the reopening of an idled secondary zinc refinery in North Carolina in March. Apparent consumption of refined zinc decreased to an estimated 860,000 tons in 2020 , consistent with a contraction in the domestic steel industry during the year as a result of the pandemic. The estimated annual average North American Special High Grade (SHG) zinc price decreased by 12\% in 2020 from that in 2019 to $\$ 1.09$ per pound.

World Mine Production and Reserves: Reserves for Canada, India, and Peru were revised based on Government or industry reports.

\begin{tabular}{lrrr} 
& \multicolumn{2}{c}{ Mine production } & ( \\
& $\mathbf{2 0 1 9}$ & $\mathbf{2 0 2 0}^{\mathbf{e}}$ & Reserves $^{\mathbf{1 0}}$ \\
United States & 753 & 670 & 11,000 \\
Australia & 1,330 & 1,400 & 1168,000 \\
Bolivia & 520 & 330 & 4,800 \\
Canada & 336 & 280 & 2,300 \\
China & 4,210 & 4,200 & 44,000 \\
India & 720 & 720 & 10,000 \\
Kazakhstan & 304 & 300 & 12,000 \\
Mexico & 677 & 600 & 22,000 \\
Peru & 1,400 & 1,200 & 20,000 \\
Russia & 260 & 260 & 22,000 \\
Sweden & 245 & 220 & 3,600 \\
Other countries & 1,950 & 2,000 & 34,000 \\
$\quad$ World total (rounded) & 12,700 & 12,000 & 250,000
\end{tabular}

World Resources: ${ }^{10}$ Identified zinc resources of the world are about 1.9 billion tons.

Substitutes: Aluminum and plastics substitute for galvanized sheet in automobiles; aluminum alloys, cadmium, paint, and plastic coatings replace zinc coatings in other applications. Aluminum- and magnesium-base alloys are major competitors for zinc-base diecasting alloys. Many elements are substitutes for zinc in chemical, electronic, and pigment uses.

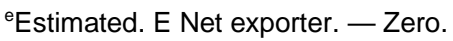

${ }^{1}$ Includes primary and secondary refined production.

${ }^{2}$ Less than $1 / 2$ unit.

${ }^{3}$ Defined as refined production + refined imports - refined exports + adjustments for Government stock changes.

${ }^{4}$ Source: S\&P Global Platts Metals Week, North American Special High Grade (SHG) zinc; based on the LME cash price plus premium.

${ }^{5}$ Includes mine and mill employment at all zinc-producing mines. Source: Mine Safety and Health Administration.

${ }^{6}$ Defined as imports - exports + adjustments for Government stock changes.

${ }^{7}$ See Appendix B for definitions.

${ }^{8}$ International Lead and Zinc Study Group, 2020, ILZSG session/forecasts: Lisbon, Portugal, International Lead and Zinc Study Group press

release, October 21, $5 \mathrm{p}$.

${ }^{9}$ Zinc content of concentrates and direct shipping ores.

${ }^{10}$ See Appendix $\mathrm{C}$ for resource and reserve definitions and information concerning data sources.

${ }^{11}$ For Australia, Joint Ore Reserves Committee-compliant reserves were 24 million tons.
} 


\section{ZIRCONIUM AND HAFNIUM}

(Data in metric tons unless otherwise noted)

Domestic Production and Use: In 2020, one firm recovered zircon (zirconium silicate) from surface-mining operations in Florida and Georgia as a coproduct from the mining of heavy-mineral sands and the processing of titanium and zirconium mineral concentrates, and a second company processed existing mineral sands tailings in Florida. Zirconium metal and hafnium metal were produced from zirconium chemical intermediates by one producer in Oregon and one in Utah. Zirconium and hafnium are typically contained in zircon at a ratio of about 36 to 1 . Zirconium chemicals were produced by the metal producer in Oregon and by at least 10 other companies. Ceramics, foundry sand, opacifiers, and refractories are the leading end uses for zircon. Other end uses of zircon include abrasives, chemicals (predominantly, zirconium basic sulfate and zirconium oxychloride octohydrate as intermediate chemicals), metal alloys, and welding rod coatings. The leading consumers of zirconium metal are the chemical process and nuclear energy industries. The leading use of hafnium metal is in superalloys.

\section{Salient Statistics-United States:}

Production, zirconium ores and concentrates $\left(\mathrm{ZrO}_{2} \text { content }\right)^{1}$ Imports:

Zirconium ores and concentrates $\left(\mathrm{ZrO}_{2} \text { content }\right)^{1}$

Zirconium, unwrought, powder, and waste and scrap

Zirconium, wrought

Hafnium, unwrought, powder, and waste and scrap

Exports:

Zirconium ores and concentrates $\left(\mathrm{ZrO}_{2} \text { content }\right)^{1}$

Zirconium, unwrought, powder, and waste and scrap

Zirconium, wrought

Consumption, apparent, ${ }^{4}$ zirconium ores and concentrates

$\left(\mathrm{ZrO}_{2} \text { content }\right)^{1}$

Price:

Zircon, dollars per metric ton (gross weight):

Australia, free on board ${ }^{5}$

China, cost insurance and freight ${ }^{6}$ Imported $^{7}$

Zirconium, unwrought, import, China, ${ }^{8}$ dollars per kilogram

Hafnium, unwrought, ${ }^{6}$ dollars per kilogram

Net import reliance ${ }^{9}$ as a percentage of apparent

consumption:

Zirconium ores and concentrates

Hafnium

$\begin{array}{rrrrr}\frac{\mathbf{2 0 1 6}}{W} & 250,000 & 3100,000 & 3100,000 & 3<10 \frac{\mathbf{2 0 1 0}}{\mathbf{2 0 1 7}} \\ & & & & \\ 24,900 & 24,300 & 26,400 & 22,600 & 20,000 \\ 1,040 & 899 & 1,880 & 1,820 & 3,000 \\ 195 & 282 & 284 & 289 & 300 \\ 180 & 113 & 41 & 32 & 20 \\ & & & & \\ 3,280 & 31,500 & 77,500 & 40,500 & 14,000 \\ 363 & 627 & 556 & 897 & 780 \\ 788 & 972 & 1,150 & 867 & 850 \\ & & & & \\ W & 250,000 & 3100,000 & 3100,000 & 3<100,000 \\ & & & & \\ 975 & 975 & N A & N A & N A \\ N A & 1,295 & 1,625 & 1,585 & 1,500 \\ 877 & 916 & 1,290 & 1,490 & 1,400 \\ 33 & 12 & 13 & 14 & 6 \\ 930 & 900 & 840 & 780 & 750 \\ & & & & \\ <50 & E & E & E & <25 \\ N A & N A & N A & N A & N A\end{array}$

Recycling: Companies in Oregon and Utah recycled zirconium from new scrap generated during metal production and fabrication and (or) from post-commercial old scrap. Zircon foundry mold cores and spent or rejected zirconia refractories are often recycled. Hafnium metal recycling was insignificant.

Import Sources (2016-19): Zirconium ores and concentrates: South Africa, 55\%; Senegal, 26\%; Australia, 15\%; Russia, 1\%; and other, 3\%. Zirconium, unwrought, including powder: China, 81\%; Germany, 12\%; Japan, 3\%;

France, 2\%; and other, 2\%. Zirconium, wrought: France, 63\%; Germany, 18\%; Belgium, 5\%; Canada, 4\%; and other, 10\%. Hafnium, unwrought: Germany, 45\%; France, 31\%; China, 17\%; the United Kingdom, 5\%; and other, $2 \%$.

Tariff: Item

Zirconium ores and concentrates

Ferrozirconium

Zirconium, unwrought and powder

Zirconium waste and scrap

Other zirconium articles

Hafnium, unwrought, powder, and waste and scrap
Number

2615.10.0000

7202.99 .1000

8109.20 .0000

8109.30 .0000

8109.90 .0000

8112.92.2000
Normal Trade Relations 12-31-20

Free.

$4.2 \%$ ad val.

$4.2 \%$ ad val.

Free.

$3.7 \%$ ad val.

Free.

Depletion Allowance: 22\% (domestic), 14\% (foreign).

Government Stockpile: None. 
Events, Trends, and Issues: The average unit value for imports of zircon concentrates decreased in 2020 after increasing for the past 3 years. Exports of zirconium ores and zircon concentrates decreased by an estimated $65 \%$ in 2020 from those in 2019. In August, new mining and heavy-mineral-processing operations were being commissioned near Jessup, GA.

Global zircon production was estimated to have decreased slightly in 2020 owing to the impact of the COVID-19 pandemic, reduced consumption, and power and labor issues.

During 2020, several large mining projects containing zirconium were in development but construction had not begun on any of them. In Western Australia, two companies announced a potential joint venture that would provide the funding needed for the first stage of construction at the Thunderbird mineral sands project if final agreements and approvals were reached. Regional or national government agencies in Australia indicated that they would provide financial support, such as loans, for the Coburn mineral sands project in Western Australia and the Dubbo polymetallic project in New South Wales.

World Mine Production and Reserves: World primary hafnium production data are not available and quantitative estimates of hafnium reserves are not available. Zirconium reserves for Australia were revised on the basis of Government reports. Zirconium reserves for Kenya and South Africa were revised on the basis of company reports.

\begin{tabular}{|c|c|c|c|}
\hline \multirow[b]{3}{*}{ United States } & \multicolumn{2}{|c|}{$\begin{array}{l}\text { Zirconium ores and zircon } \\
\text { concentrates, mine production } \\
\text { (thousand metric tons, } \\
\text { gross weight) }\end{array}$} & \multirow[t]{2}{*}{$\begin{array}{c}\text { Zirconium reserves } \\
\text { (thousand metric tons, }^{10} \\
\mathrm{ZrO}_{2} \text { content) }\end{array}$} \\
\hline & 2019 & $2020^{\mathrm{e}}$ & \\
\hline & $\overline{3100}$ & $\overline{3<100}$ & 500 \\
\hline Australia & 470 & 480 & 1143,000 \\
\hline China & 140 & 140 & 500 \\
\hline Indonesia & 34 & 60 & NA \\
\hline Kenya & 29 & 25 & 55 \\
\hline Mozambique & 100 & 125 & 1,800 \\
\hline Senegal & 65 & 65 & NA \\
\hline South Africa & 370 & 320 & 6,700 \\
\hline Other countries & 112 & 110 & 11,000 \\
\hline World total (rounded) & $\overline{1,420}$ & $\overline{1,400}$ & $\overline{64,000}$ \\
\hline
\end{tabular}

World Resources: ${ }^{10}$ Resources of zircon in the United States included about 14 million tons associated with titanium resources in heavy-mineral-sand deposits. Phosphate rock and sand and gravel deposits could potentially yield substantial amounts of zircon as a byproduct. World resources of hafnium are associated with those of zircon and baddeleyite. Quantitative estimates of hafnium resources are not available.

Substitutes: Chromite and olivine can be used instead of zircon for some foundry applications. Dolomite and spinel refractories can also substitute for zircon in certain high-temperature applications. Niobium (columbium), stainless steel, and tantalum provide limited substitution in nuclear applications, and titanium and synthetic materials may substitute in some chemical processing plant applications. Silver-cadmium-indium control rods are used in lieu of hafnium at numerous nuclear powerplants. Zirconium can be used interchangeably with hafnium in certain superalloys.

\footnotetext{
eEstimated. E Net Exporter. NA Not available. W Withheld to avoid disclosing company proprietary data.

${ }^{1}$ Calculated $\mathrm{ZrO}_{2}$ content as $65 \%$ of gross production.

${ }^{2}$ Rounded to one significant digit to avoid disclosing company proprietary data.

${ }^{3}$ Rounded to nearest 100,000 to avoid disclosing company proprietary data.

${ }^{4}$ Defined as production + imports - exports.

${ }^{5}$ Source: Industrial Minerals (Fastmarkets IM), average of yearend price. Prices of zircon from Australia were discontinued at yearend 2017.

${ }^{6}$ Source: Argus Media group-Argus Metals International, average of yearend price.

${ }^{7}$ Unit value based on annual United States imports for consumption from Australia, Senegal, and South Africa.

${ }^{8}$ Unit value based on annual United States imports for consumption from China.

${ }^{9}$ Defined as imports - exports.

${ }^{10}$ See Appendix $C$ for resource and reserve definitions and information concerning data sources.

${ }^{11}$ For Australia, Joint Ore Reserves Committee-compliant reserves were 22.1 million tons gross weight.
} 


\section{APPENDIX A}

\section{Abbreviations and Units of Measure}

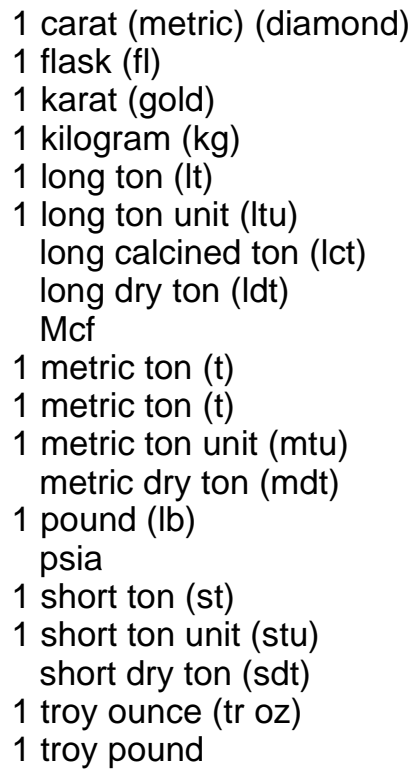

$=200$ milligrams

$=76$ pounds, avoirdupois, or 33.47 kilograms

$=$ one twenty-fourth part

$=2.2046$ pounds, avoirdupois

$=2,240$ pounds, avoirdupois

$=1 \%$ of 1 long ton, or 22.4 pounds, avoirdupois

$=$ excludes water of hydration

$=$ excludes excess free moisture

$=1,000$ cubic feet

$=2,204.6$ pounds, avoirdupois, or 1,000 kilograms

$=1.1023$ short ton

$=1 \%$ of 1 metric ton, or 10 kilograms

$=$ excludes excess free moisture

$=453.6$ grams

$=$ pounds per square inch absolute

$=2,000$ pounds, avoirdupois

$=1 \%$ of 1 short ton, or 20 pounds, avoirdupois

$=$ excludes excess free moisture

$=1.09714$ avoirdupois ounces, or 31.103 grams

$=12$ troy ounces

\section{APPENDIX B}

\section{Definitions of Selected Terms Used in This Report}

\section{Terms Used for Materials in the National Defense Stockpile and Helium Stockpile}

Inventory refers to the quantity of mineral materials held in the National Defense Stockpile or in the Federal Helium Reserve. Nonstockpile-grade materials may be included in the table; where significant, the quantities of these stockpiled materials are specified in the text accompanying the table.

Potential disposals indicate the total amount of a material in the National Defense Stockpile that the U.S. Department of Defense is permitted to dispose of under the Annual Materials Plan approved by Congress for the fiscal year. Congress has authorized disposal over the long term at rates designed to maximize revenue but avoid undue disruption to the usual markets and financial loss to the United States. Fiscal year (FY) 2020 is the period from October 1, 2019, through September 30, 2020. FY 2021 is the period from October 1, 2020, through September 30, 2021. Disposals are defined as any disposal or sale of National Defense Stockpile stock. For mineral commodities that have a disposal plan greater than the inventory, the actual quantity will be limited to the remaining disposal authority or inventory. Note that, unlike the National Defense Stockpile, helium stockpile sales by the Bureau of Land Management under the Helium Privatization Act of 1996 are permitted to exceed disposal plans.

Potential acquisitions indicate the maximum amount of a material that may be acquired by the U.S. Department of Defense for the National Defense Stockpile under the Annual Materials Plan approved by Congress for the fiscal year. FY 2020 is the period from October 1, 2019, through September 30, 2020. FY 2021 is the period from October 1, 2020, through September 30, 2021.

\section{Depletion Allowance}

The depletion allowance is a business tax deduction analogous to depreciation, but which applies to an ore reserve rather than equipment or production facilities. Federal tax law allows this deduction from taxable corporate income, recognizing that an ore deposit is a depletable asset that must eventually be replaced. 


\section{Reserves and Resources}

Reserves data are dynamic. They may be reduced as ore is mined and (or) the feasibility of extraction diminishes, or more commonly, they may continue to increase as additional deposits (known or recently discovered) are developed, or currently exploited deposits are more thoroughly explored and (or) new technology or economic variables improve their economic feasibility. Reserves may be considered a working inventory of mining companies' supplies of an economically extractable mineral commodity. As such, the magnitude of that inventory is necessarily limited by many considerations, including cost of drilling, taxes, price of the mineral commodity being mined, and the demand for it. Reserves will be developed to the point of business needs and geologic limitations of economic ore grade and tonnage. For example, in 1970, identified and undiscovered world copper resources were estimated to contain 1.6 billion metric tons of copper, with reserves of about 280 million tons of copper. Since then, almost 580 million tons of copper have been produced worldwide, but world copper reserves in 2020 were estimated to be 870 million tons of copper, more than triple those of 1970 , despite the depletion by mining of more than the original estimated reserves.

Future supplies of minerals will come from reserves and other identified resources, currently undiscovered resources in deposits that will be discovered in the future, and material that will be recycled from current in-use stocks of minerals or from minerals in waste disposal sites. Undiscovered deposits of minerals constitute an important consideration in assessing future supplies. Mineral-resource assessments have been carried out for small parcels of land being evaluated for land reclassification, for the Nation, and for the world.

\section{Part A-Resource and Reserve Classification for Minerals ${ }^{1}$}

\section{Introduction}

Through the years, geologists, mining engineers, and others operating in the minerals field have used various terms to describe and classify mineral resources, which as defined herein include energy materials. Some of these terms have gained wide use and acceptance, although they are not always used with precisely the same meaning.

The U.S. Geological Survey (USGS) collects information about the quantity and quality of all mineral resources. In 1976, the USGS and the U.S. Bureau of Mines developed a common classification and nomenclature, which was published as USGS Bulletin 1450-A"Principles of the Mineral Resource Classification System of the U.S. Bureau of Mines and U.S. Geological Survey." Experience with this resource classification system showed that some changes were necessary in order to make it more workable in practice and more useful in long-term planning. Therefore, representatives of the USGS and the U.S. Bureau of Mines collaborated to revise Bulletin 1450-A. Their work was published in 1980 as USGS Circular 831"Principles of a Resource/Reserve Classification for Minerals."

Long-term public and commercial planning must be based on the probability of discovering new deposits, on developing economic extraction processes for currently unworkable deposits, and on knowing which resources are immediately available. Thus, resources must be continuously reassessed in the light of new geologic knowledge, of progress in science and technology, and of shifts in economic and political conditions. To best serve these planning needs, known resources should be classified from two standpoints: (1) purely geologic or physical and chemical characteristics-such as grade, quality, tonnage, thickness, and depth-of the material in place; and (2) profitability analyses based on costs of extracting and marketing the material in a given economy at a given time. The former constitutes important objective scientific information of the resource and a relatively unchanging foundation upon which the latter more valuable economic delineation can be based.

The revised classification system, designed generally for all mineral materials, is shown graphically in figures $\mathrm{C} 1$ and $\mathrm{C} 2$; its components and their usage are described in the text. The classification of mineral and energy resources is necessarily arbitrary because definitional criteria do not always coincide with natural boundaries. The system can be used to report the status of mineral and energy-fuel resources for the Nation or for specific areas. ${ }^{1}$

\section{Resource and Reserve Definitions}

A dictionary definition of resource, "something in reserve or ready if needed," has been adapted for mineral and energy resources to comprise all materials, including those only surmised to exist, that have present or anticipated future value.

Resource.-A concentration of naturally occurring solid, liquid, or gaseous material in or on the Earth's crust in such form and amount that economic extraction of a commodity from the concentration is currently or potentially feasible.

Original Resource.-The amount of a resource before production.

Identified Resources.-Resources for which location, grade, quality, and quantity are known or estimated from specific geologic evidence. Identified resources include economic, marginally economic, and subeconomic components. To reflect varying degrees of geologic certainty, these economic divisions can be subdivided into measured, indicated, and inferred. 
Demonstrated.-A term for the sum of measured plus indicated resources.

Measured.-Quantity is computed from dimensions revealed in outcrops, trenches, workings, or drill holes; grade and (or) quality are computed from the results of detailed sampling. The sites for inspection, sampling, and measurements are spaced so closely and the geologic character is so well defined that size, shape, depth, and mineral content of the resource are well established.

Indicated.-Quantity and grade and (or) quality are computed from information similar to that used for measured resources, but the sites for inspection, sampling, and measurements are farther apart or are otherwise less adequately spaced. The degree of assurance, although lower than that for measured resources, is high enough to assume continuity between points of observation.

Inferred.-Estimates are based on an assumed continuity beyond measured and (or) indicated resources, for which there is geologic evidence. Inferred resources may or may not be supported by samples or measurements.

Reserve Base.-That part of an identified resource that meets specified minimum physical and chemical criteria related to current mining and production practices, including those for grade, quality, thickness, and depth. The reserve base is the in-place demonstrated (measured plus indicated) resource from which reserves are estimated. It may encompass those parts of the resources that have a reasonable potential for becoming economically available within planning horizons beyond those that assume proven technology and current economics. The reserve base includes those resources that are currently economic (reserves), marginally economic (marginal reserves), and some of those that are currently subeconomic (subeconomic resources). The term "geologic reserve" has been applied by others generally to the reserve-base category, but it also may include the inferred-reserve-base category; it is not a part of this classification system.

Inferred Reserve Base.-The in-place part of an identified resource from which inferred reserves are estimated. Quantitative estimates are based largely on knowledge of the geologic character of a deposit and for which there may be no samples or measurements. The estimates are based on an assumed continuity beyond the reserve base, for which there is geologic evidence.

Reserves.-That part of the reserve base that could be economically extracted or produced at the time of determination. The term "reserves" need not signify that extraction facilities are in place and operative. Reserves include only recoverable materials; thus, terms such as "extractable reserves" and "recoverable reserves" are redundant and are not a part of this classification system.

Marginal Reserves.-That part of the reserve base which, at the time of determination, borders on being economically producible. Its essential characteristic is economic uncertainty. Included are resources that would be producible, given postulated changes in economic or technological factors.
Economic.-This term implies that profitable extraction or production under defined investment assumptions has been established, analytically demonstrated, or assumed with reasonable certainty.

Subeconomic Resources.-The part of identified resources that does not meet the economic criteria of reserves and marginal reserves.

Undiscovered Resources.-Resources, the existence of which are only postulated, comprising deposits that are separate from identified resources. Undiscovered resources may be postulated in deposits of such grade and physical location as to render them economic, marginally economic, or subeconomic. To reflect varying degrees of geologic certainty, undiscovered resources may be divided into two parts, as follows:

Hypothetical Resources.-Undiscovered resources that are similar to known mineral bodies and that may be reasonably expected to exist in the same producing district or region under analogous geologic conditions. If exploration confirms their existence and reveals enough information about their quality, grade, and quantity, they will be reclassified as identified resources.

Speculative Resources.-Undiscovered resources that may occur either in known types of deposits in favorable geologic settings where mineral discoveries have not been made, or in types of deposits as yet unrecognized for their economic potential. If exploration confirms their existence and reveals enough information about their quantity, grade, and quality, they will be reclassified as identified resources.

Restricted Resources or Reserves.-That part of any resource or reserve category that is restricted from extraction by laws or regulations. For example, restricted reserves meet all the requirements of reserves except that they are restricted from extraction by laws or regulations.

Other Occurrences.-Materials that are too low grade or for other reasons are not considered potentially economic, in the same sense as the defined resource, may be recognized and their magnitude estimated, but they are not classified as resources. A separate category, labeled "other occurrences," is included in figures $\mathrm{C} 1$ and $\mathrm{C} 2$. In figure $\mathrm{C} 1$, the boundary between subeconomic and other occurrences is limited by the concept of current or potential feasibility of economic production, which is required by the definition of a resource. The boundary is obviously uncertain, but limits may be specified in terms of grade, quality, thickness, depth, extractable percentage, or other economic-feasibility variables.

Cumulative Production.-The amount of past cumulative production is not, by definition, a part of the resource. Nevertheless, a knowledge of what has been produced is important in order to understand current resources, in terms of both the amount of past production and the amount of residual or remaining in-place resource. A separate space for cumulative production is shown in figures $\mathrm{C} 1$ and $\mathrm{C} 2$. Residual material left in the ground during current or future extraction should be recorded in the resource category appropriate to its economic-recovery potential. 
Figure C1.-Major Elements of Mineral-Resource Classification, Excluding

Reserve Base and Inferred Reserve Base

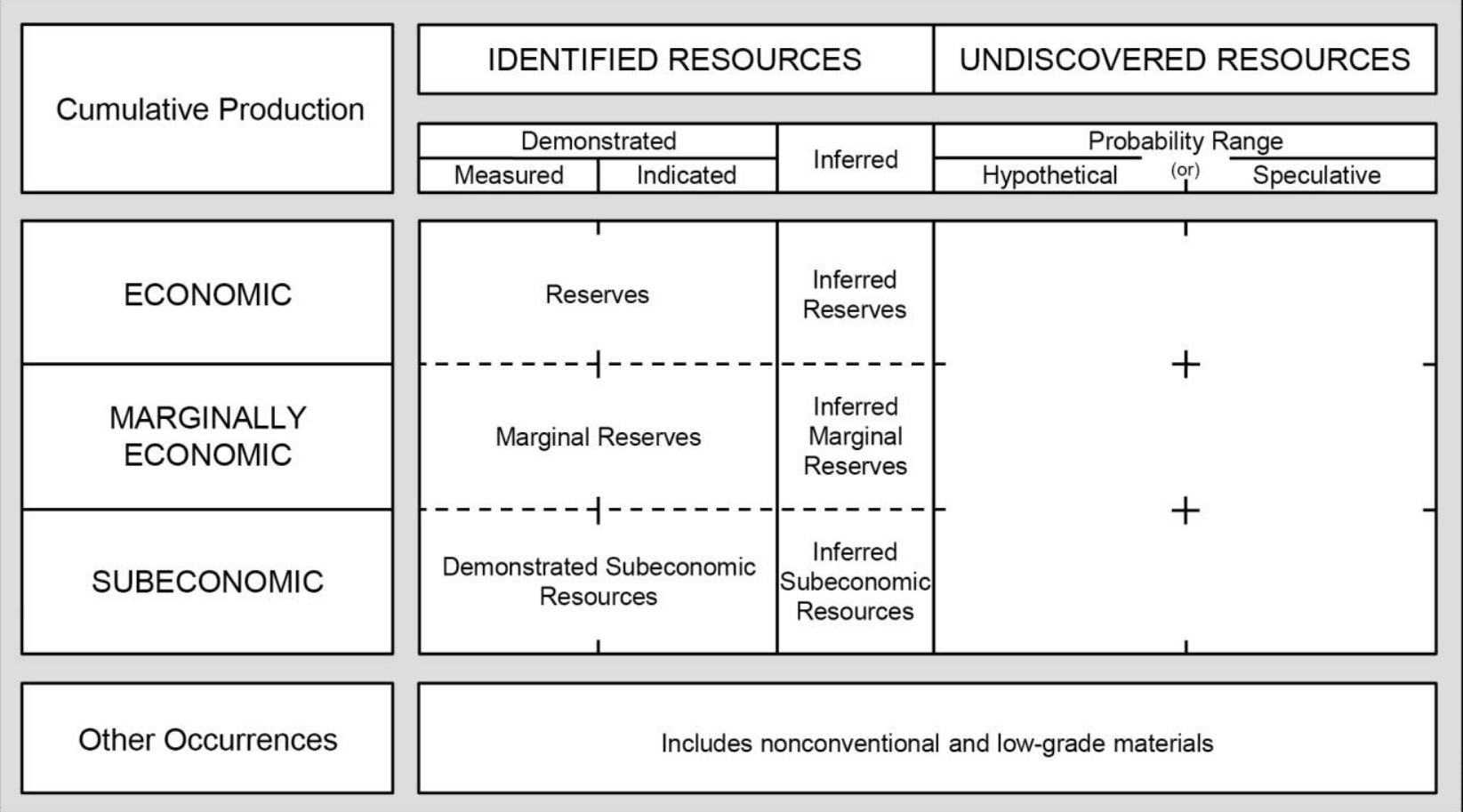

Figure C2.-Reserve Base and Inferred Reserve Base Classification Categories

\begin{tabular}{|c|c|c|c|c|c|c|}
\hline \multirow{3}{*}{ Cumulative Production } & \multicolumn{3}{|c|}{ IDENTIFIED RESOURCES } & \multicolumn{3}{|c|}{ UNDISCOVERED RESOURCES } \\
\hline & \multicolumn{2}{|c|}{ Demonstrated } & \multirow{2}{*}{ Inferred } & \multicolumn{3}{|c|}{ Probability Range } \\
\hline & Measured & Indicated & & Hypothetical & (or) & Speculative \\
\hline \multicolumn{7}{|l|}{ ECONOMIC } \\
\hline $\begin{array}{l}\text { MARGINALLY } \\
\text { ECONOMIC }\end{array}$ & \multicolumn{2}{|c|}{$\begin{array}{l}\text { Reserve } \\
\text { Base }\end{array}$} & $\begin{array}{c}\text { Inferred } \\
\text { Reserve } \\
\text { Base }\end{array}$ & \multicolumn{3}{|c|}{+} \\
\hline \multicolumn{7}{|l|}{ SUBECONOMIC } \\
\hline Other Occurrences & \multicolumn{6}{|c|}{ Includes nonconventional and low-grade materials } \\
\hline
\end{tabular}




\section{Part B-Sources of Reserves Data}

National information on reserves for most mineral commodities found in this report, including those for the United States, is derived from a variety of sources. The ideal source of such information would be comprehensive evaluations that apply the same criteria to deposits in different geographic areas and report the results by country. In the absence of such evaluations, national reserves estimates compiled by countries for selected mineral commodities are a primary source of national reserves information. Lacking national assessment information by governments, sources such as academic articles, company reports, presentations by company representatives, and trade journal articles, or a combination of these, serve as the basis for national information on reserves reported in the mineral commodity sections of this publication.

A national estimate may be assembled from the following: historically reported reserves information carried for years without alteration because no new information is available, historically reported reserves reduced by the amount of historical production, and company-reported reserves. International minerals availability studies conducted by the U.S. Bureau of Mines before 1996 and estimates of identified resources by an international collaborative effort (the International Strategic Minerals Inventory) are the bases for some reserves estimates. The USGS collects some qualitative information about the quantity and quality of mineral resources but does not directly measure reserves or resources, and companies or governments do not directly report information about reserves or resources to the USGS. Reassessment of reserves is a continuing process, and the intensity of this process differs by mineral commodity, country, and time period.

Some countries have specific definitions for reserves data, and reserves for each country are assessed separately, based on reported data and definitions. An attempt is made to make reserves consistent among countries for a mineral commodity and its byproducts. For example, the Australasian Joint Ore Reserves Committee (JORC) established the Australasian Code for Reporting of Exploration Results, Mineral Resources and Ore Reserves (JORC Code) that sets out minimum standards, recommendations, and guidelines for public reporting in Australasia of exploration results, mineral resources, and ore reserves. Companies listed on the Australian Securities Exchange and the New Zealand Stock Exchange are required to report publicly on ore reserves and mineral resources under their control, using the JORC Code.

Data reported for individual deposits by mining companies are compiled in Geoscience Australia's national mineral resources database and used in the preparation of the annual national assessments of Australia's mineral resources. Because of its specific use in the JORC Code, the term "reserves" is not used in the national inventory, where the highest category is "Economic Demonstrated Resources" (EDR). In essence, EDR combines the JORC Code categories "proved reserves" and "probable reserves," plus measured resources and indicated resources. This is considered to provide a reasonable and objective estimate of what is likely to be available for mining in the long term. Accessible Economic Demonstrated Resources represent the resources within the EDR category that are accessible for mining. Reserves for Australia in Mineral Commodity Summaries 2021 are Accessible EDR. For more information, see "Table 3. Australia's Identified Mineral Resources as at December 2018," which can be found at https://www.ga.gov.au/scientific-topics/minerals/mineralresources-and-advice/aimr/mineral-resources.

In Canada, the Canadian Institute of Mining, Metallurgy and Petroleum (CIM) provides definition standards for the classification of mineral resources and mineral reserves estimates into various categories. The category to which a resource or reserves estimate is assigned depends on the level of confidence in the geologic information available on the mineral deposit, the quality and quantity of data available on the deposit, the level of detail of the technical and economic information that has been generated about the deposit, and the interpretation of the data and information. For more information on the CIM definition standards, see https://mrmr.cim.org/en/standards/canadian-mineralresource-and-mineral-reserve-definitions/.

In Russia, reserves for most minerals can appear in a number of sources, although no comprehensive list of reserves is published. Reserves data for a limited set of mineral commodities are available in the annual report "Gosudarstvennyi Doklad o Sostoyanii i Ispol'zovanii Mineral'no-Syryevyh Resursov Rossiyskoy Federatsii" (State Report on the State and Use of Mineral and Raw Materials Resources of the Russian Federation), which is published by Russia's Ministry of Natural Resources and Environment. Reserves data for various minerals appear at times in journal articles, such as those in the journal "Mineral'nyye Resursy Rossii. Ekonomika i Upravleniye" (Mineral Resources of Russia. Economics and Management), which is published by the "OOO RGInform," a subsidiary of Rosgeologiya Holding. It is sometimes not clear if the reserves are being reported in ore or mineral content. It is also in many cases not clear which definition of reserves is being used, because the system inherited from the former Soviet Union has a number of ways in which the term "reserves" is defined, and these definitions qualify the percentage of resources that are included in a specific category. For example, the Soviet reserves classification system, besides the categories $A, B, C 1$, and $\mathrm{C} 2$, which represent progressively detailed knowledge of a mineral deposit based on exploration data, has other subcategories cross imposed upon the system. Under the broad category reserves (zapasy), there are subcategories that include balance reserves (balansovyye zapasy, or economic reserves) and outside-the-balance reserves (zabalansovye zapasy, or subeconomic reserves), as well as categories that include explored, industrial, and proven reserves, and the reserves totals can vary significantly, depending on the specific definition of reserves being reported. 


\section{Country Specialists Directory}

Minerals information country specialists at the U.S. Geological Survey collect and analyze information on the mineral industries of more than 170 nations throughout the world. The specialists are available to answer minerals-related questions concerning individual countries.

\section{Africa and the Middle East}

\begin{tabular}{|c|c|}
\hline Algeria & Mowafa Taib \\
\hline Angola & Meralis Plaza-Toledo \\
\hline Bahrain & Philip A. Szczesniak \\
\hline Benin & Meralis Plaza-Toledo \\
\hline Botswana & Thomas R. Yager \\
\hline Burkina Faso & Alberto A. Perez \\
\hline Burundi & Thomas R. Yager \\
\hline Cabo Verde & Meralis Plaza-Toledo \\
\hline Cameroon & Philip A. Szczesniak \\
\hline Central African Republic & James J. Barry \\
\hline Chad & Philip A. Szczesniak \\
\hline Comoros & James J. Barry \\
\hline Congo (Brazzaville) & James J. Barry \\
\hline Congo (Kinshasa) & Thomas R. Yager \\
\hline Côte d'Ivoire & Alberto A. Perez \\
\hline Djibouti & Thomas R. Yager \\
\hline Egypt & Mowafa Taib \\
\hline Equatorial Guinea & Meralis Plaza-Toledo \\
\hline Eritrea & Thomas R. Yager \\
\hline Eswatini & James J. Barry \\
\hline Ethiopia & Meralis Plaza-Toledo \\
\hline Gabon & Alberto A. Perez \\
\hline The Gambia & Meralis Plaza-Toledo \\
\hline Ghana & Meralis Plaza-Toledo \\
\hline Guinea & Alberto A. Perez \\
\hline Guinea-Bissau & Meralis Plaza-Toledo \\
\hline Iran & Philip A. Szczesniak \\
\hline Iraq & Philip A. Szczesniak \\
\hline Israel & Philip A. Szczesniak \\
\hline Jordan & Mowafa Taib \\
\hline Kenya & Thomas R. Yager \\
\hline Kuwait & Philip A. Szczesniak \\
\hline Lebanon & Mowafa Taib \\
\hline Lesotho & J. Barry \\
\hline Liberia & Meralis Plaza-Toledo \\
\hline Libya & Mowafa Taib \\
\hline Madagascar & Thomas R. Yager \\
\hline Malawi & s R. Yager \\
\hline Mali & Alberto A. Perez \\
\hline Mauritania & Mowafa Taib \\
\hline Mauritius & James J. Barry \\
\hline Morocco and & \\
\hline Western Sahara & Mowafa Taib \\
\hline Mozambique & Meralis Plaza-Toledo \\
\hline Namibia & James J. Barry \\
\hline Niger & Alberto A. Perez \\
\hline Nigeria & Thomas R. Yager \\
\hline Oman & Philip A. Szczesniak \\
\hline Qatar & Philip A. Szczesniak \\
\hline Reunion & James J. Barry \\
\hline Rwanda & Thomas R. Yager \\
\hline & $\Lambda$ \\
\hline
\end{tabular}

Africa and the Middle East-Continued

Saudi Arabia

Senegal

Seychelles

Sierra Leone

Somalia

South Africa

South Sudan

Sudan

Syria

Tanzania

Togo

Tunisia

Uganda

United Arab Emirates

Yemen

Zambia

Zimbabwe

\section{Asia and the Pacific}

Afghanistan
Australia
Bangladesh
Bhutan
Brunei
Burma (Myanmar)
Cambodia
China
Fiji
India
Indonesia
Japan
Korea, North
Korea, Republic of
Laos
Malaysia
Mongolia
Nauru
Nepal
New Caledonia
New Zealand
Pakistan
Papua New Guinea
Philippines
Singapore
Solomon Islands
Sri Lanka
Taiwan
Thailand
Timor-Leste
Vietnam

Mowafa Taib Alberto A. Perez James J. Barry Alberto A. Perez Philip A. Szczesniak Thomas R. Yager Alberto A. Perez Mowafa Taib Mowafa Taib Thomas R. Yager Alberto A. Perez Mowafa Taib Thomas R. Yager Philip A. Szczesniak Mowafa Taib James J. Barry James J. Barry

Karine M. Renaud Spencer D. Buteyn Ji Won Moon Ji Won Moon Spencer D. Buteyn Ji Won Moon Ji Won Moon Sean Xun Spencer D. Buteyn Karine M. Renaud Jaewon Chung Jaewon Chung Jaewon Chung Jaewon Chung Ji Won Moon Spencer D. Buteyn Jaewon Chung Spencer D. Buteyn Ji Won Moon Spencer D. Buteyn Spencer D. Buteyn Ji Won Moon Spencer D. Buteyn Ji Won Moon Spencer D. Buteyn Jaewon Chung Ji Won Moon Jaewon Chung Ji Won Moon Jaewon Chung Ji Won Moon 
Europe and Central Eurasia

Albania
Armenia
Austria
Azerbaijan
Belarus
Belgium
Bosnia and Herzegovina
Bulgaria
Croatia
Cyprus
Czechia
Denmark, Faroe Islands,
and Greenland
Estonia
Finland
France
Georgia
Germany
Greece
Hungary
Iceland
Ireland
Italy
Kazakhstan
Kosovo
Kyrgyzstan
Latvia
Lithuania
Luxembourg
Malta
Moldova
Montenegro
Netherlands
North Macedonia
Norway
Poland
Portugal
Romania
Russia
Serbia
Slovakia
Slovenia
Spain

Jaewon Chung

Elena Safirova

Spencer D. Buteyn

Elena Safirova

Elena Safirova

Loyd M. Trimmer III

Karine M. Renaud

Karine M. Renaud

Karine M. Renaud

Sinan Hastorun

Loyd M. Trimmer III

Joanna Goclawska

Ji Won Moon

Joanna Goclawska

Jaewon Chung

Elena Safirova

Elena Safirova

Sinan Hastorun

Loyd M. Trimmer III

Joanna Goclawska

Joanna Goclawska

Loyd M. Trimmer III

Elena Safirova

Sinan Hastorun

Karine M. Renaud

Ji Won Moon

Ji Won Moon

Spencer D. Buteyn

Jaewon Chung

Elena Safirova

Jaewon Chung

Loyd M. Trimmer III

Karine M. Renaud

Joanna Goclawska

Joanna Goclawska

Joanna Goclawska

Ji Won Moon

Elena Safirova

Karine M. Renaud

Ji Won Moon

Loyd M. Trimmer III

Loyd M. Trimmer III

\section{Europe and Central Eurasia-Continued}

Sweden

Switzerland

Tajikistan

Turkey

Turkmenistan

Ukraine

United Kingdom

Uzbekistan

Joanna Goclawska

Spencer D. Buteyn

Karine M. Renaud

Sinan Hastorun

Karine M. Renaud

Elena Safirova

Jaewon Chung

Elena Safirova

\section{North America, Central America, and the Caribbean}

$\begin{array}{ll}\text { Aruba } & \text { Yadira Soto-Viruet } \\ \text { The Bahamas } & \text { Yadira Soto-Viruet } \\ \text { Belize } & \text { Jesse J. Inestroza } \\ \text { Canada } & \text { James J. Barry } \\ \text { Costa Rica } & \text { Jesse J. Inestroza } \\ \text { Cuba } & \text { Yadira Soto-Viruet } \\ \text { Dominican Republic } & \text { Yadira Soto-Viruet } \\ \text { El Salvador } & \text { Jesse J. Inestroza } \\ \text { Guatemala } & \text { Jesse J. Inestroza } \\ \text { Haiti } & \text { Yadira Soto-Viruet } \\ \text { Honduras } & \text { Jesse J. Inestroza } \\ \text { Jamaica } & \text { Yadira Soto-Viruet } \\ \text { Mexico } & \text { Alberto A. Perez } \\ \text { Nicaragua } & \text { Jesse J. Inestroza } \\ \text { Panama } & \text { Jesse J. Inestroza } \\ \text { Trinidad and Tobago } & \text { Yadira Soto-Viruet }\end{array}$

\section{South America}

Argentina
Bolivia
Brazil
Chile
Colombia
Ecuador
French Guiana
Guyana
Paraguay
Peru
Suriname
Uruguay
Venezuela

Jesse J. Inestroza Yolanda Fong-Sam Yolanda Fong-Sam Yadira Soto-Viruet Jesse J. Inestroza Jesse J. Inestroza Yolanda Fong-Sam Yolanda Fong-Sam Yadira Soto-Viruet Yadira Soto-Viruet Yolanda Fong-Sam Yadira Soto-Viruet Yolanda Fong-Sam

\section{Country specialist}

James J. Barry

Spencer D. Buteyn Jaewon Chung

Yolanda Fong-Sam

Joanna Goclawska

Sinan Hastorun

Jesse J. Inestroza

Ji Won Moon

Alberto A. Perez

Meralis Plaza-Toledo

Karine M. Renaud

Elena Safirova

Yadira Soto-Viruet

Philip A. Szczesniak

Mowafa Taib

Loyd M. Trimmer III

Sean Xun

Thomas R. Yager

\section{Telephone}

(703) 648-7752

(703) 648-7738

(703) 648-4793

(703) 648-7756

(703) 648-7973

(703) 648-7744

(703) 648-7779

(703) 648-7791

(703) 648-7749

(703) 648-7759

(703) 648-7748

(703) 648-7731

(703) 648-4957

(703) 648-7728

(703) 648-4986

(703) 648-4983

(703) 648-7746

(703) 648-7739

\section{E-mail}

jbarry@usgs.gov

sbuteyn@usgs.gov

jchung@usgs.gov

yfong-sam@usgs.gov

jgoclawska@usgs.gov

shastorun@usgs.gov

jinestroza@usgs.gov

jmoon@usgs.gov

aperez@usgs.gov

mplaza-toledo@usgs.gov

krenaud@usgs.gov

esafirova@usgs.gov

ysoto-viruet@usgs.gov

pszczesniak@usgs.gov

mtaib@usgs.gov

Itrimmer@usgs.gov

sxun@usgs.gov

tyager@usgs.gov 